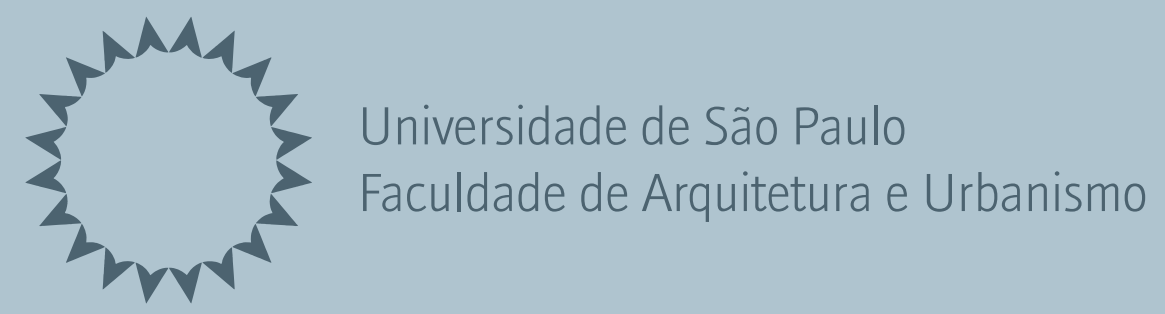

\title{
ACESSIBILIDADE NOS \\ BENS CULTURAIS IMÓVEIS: \\ POSSIBILIDADES E LIMITES \\ NOS MUSEUS E CENTROS CULTURAIS
}

ELISA PRADO DE ASSIS

São Paulo

2012 


\section{ELISA PRADO DE ASSIS}

\section{Acessibilidade nos bens culturais imóveis:}

\section{possibilidades e limites nos museus e centros culturais}

Dissertação apresentada à Faculdade de Arquitetura e Urbanismo da Universidade de São Paulo para obtenção do título de Mestre em Arquitetura e Urbanismo.

Área de concentração: História e Fundamentos da Arquitetura e do Urbanismo

Orientador: Prof. ${ }^{\underline{a}}$ Dr. ${ }^{\underline{a}}$ Maria Lucia Bressan Pinheiro

EXEMPLAR REVISADO E ALTERADO EM RELAÇÃO À VERSÃO ORIGINAL, SOB RESPONSABILIDADE DO AUTOR E ANUÊNCIA DO ORIENTADOR.

$O$ original se encontra na sede do programa.

São Paulo, 19 de junho de 2012. 
AUTORIZO A REPRODUÇÃO E DIVULGAÇÃO TOTAL OU PARCIAL DESTE TRABALHO, POR QUALQUER MEIO CONVENCIONAL OU ELETRÔNICO, PARA FINS DE ESTUDO E PESQUISA, DESDE QUE CITADA A FONTE.

E-MAIL: contato@elisaprado.com.br ; eassis@usp.br

\begin{tabular}{|l}
\hline A848a \\
Assis, Elisa Prado de \\
Acessibilidade nos bens culturais imóveis : possibilidades \\
e limites nos museus e centros culturais / Elisa Prado de \\
Assis. -- São Paulo, 2012. \\
372 p. : il. \\
Dissertação (Mestrado - Área de Concentração : \\
História e Fundamentos da Arquitetura e do Urbanismo) - \\
FAUUSP. \\
Orientadora: Maria Lucia Bressan Pinheiro \\
1. Acessibilidade ao meio físico 2. Desenho universal \\
6. Pessoas com deficiência 4. Bens culturais 5. Museus \\
6. Centros culturais I. Título \\
CDU 72-056.26
\end{tabular}




\section{FOLHA DE APROVAÇÃO}

Elisa Prado de Assis

Acessibilidade nos bens culturais imóveis:

possibilidades e limites nos museus e centros culturais

Dissertação apresentada à Faculdade de Arquitetura e Urbanismo da Universidade de São Paulo para obtenção do título de Mestre em Arquitetura e Urbanismo.

Aprovação em:

\section{Banca examinadora}

Prof. Dr.:

Instituição:

Assinatura:

Prof. Dr.:

Instituição:

Assinatura:

Prof. Dr.:

Instituição:

Assinatura: 


\section{AGRADECIMENTO}

Agradeço:

Primeiramente a Deus.

Ao meu marido, Maneco, por me dar a tranquilidade e paz necessárias para cumprir esta tarefa, por me incentivar a sempre continuar e por ser meu amor.

Aos meus pais, Eliana e Luiz Carlos, por, serem os revisores de todo esse conteúdo e, principalmente, por me criarem crítica e curiosa para poder cumprir esta missão.

Aos meus irmãos, Elói, Laura, Lúcio e Lígia, por entenderem meus longos períodos de reclusão.

À Prof. ${ }^{a}$ Dr. ${ }^{\text {a }}$ Maria Lucia Bressan Pinheiro, por acreditar no meu tema e por ser uma verdadeira parceira nesta empreitada.

Às Prof. ${ }^{a}$ Dr. ${ }^{\text {a }}$ Beatriz Kuhl e Prof. ${ }^{\text {a }}$ Dr. ${ }^{\underline{a}}$ Maria Elisabete Lopes, por me ajudarem a entender o verdadeiro motivo da minha pesquisa.

À Secretaria Municipal da Pessoa com Deficiência e Mobilidade Reduzida por permitir a minha dedicação a este trabalho, que espero que dê frutos para a sociedade.

Aos colegas da Comissão Permanente de Acessibilidade, Eduardo F. Auge, Oswaldo R. Fantini, Silvana S. Cambiaghi, Silvia Gonçalves e Ulysses dos Santos, por toda sua valiosa contribuição. E à Danielle Vale por contribuir com os desenhos da Casa das Rosas.

À querida Valquiria Prates por ser a primeira pessoa a acreditar nesta possibilidade que se completa agora. Ao Odirlei Faria por ser um grande amigo e intérprete de Libras. Aos amigos, Aline Morais, Ariana Chediak, Camila Benvenuto, Lincoln Tavares e Rafael Públio pela cumplicidade.

Ao Ubirajara Giglio, à Mariana Rabelo e à Miriam R. M. Santos pela preciosa contribuição.

Aos novos amigos, Claudia A., Edvaldo P., José Antonio A. e Maria Eliete S., por serem os representantes desta pesquisa.

Às instituições culturais que abriram suas portas para eu realizar minha pesquisa: Casa das Rosas, Centro Cultural Banco do Brasil e Pinacoteca do Estado de São Paulo. E também aos profissionais, das áreas de manutenção e de educação, por serem gentis e solícitos durante minhas visitas e entrevistas.

Ao Centro Cultural São Paulo e às pessoas que trabalham nele por cederam um local para realizar o grupo focal.

E às amigas, Ana Paula, Sarita e Tayana por tornarem coletiva essa experiência. 
"Por um mundo onde sejamos socialmente iguais, humanamente diferentes e totalmente livres."

Rosa Luxemburgo 


\section{RESUMO}

Os bens culturais imóveis são motivo de interesse da população em geral, inclusive das pessoas com deficiência e mobilidade reduzida. O diálogo entre preservação e acessibilidade precisa avançar para dar boas soluções de acesso e circulação e, assim, não inibir a participação de ninguém, quaisquer sejam suas características sensoriais, cognitivas e motoras. Legislações de preservação e de acessibilidade no Brasil pouco falam sobre essa interação e a consequência é a grande dificuldade conceitual e prática para resolver a questão. A finalidade do presente trabalho é demonstrar que as diretrizes de preservação e restauro permitem a convergência para a acessibilidade e que a adequação à acessibilidade pode ser implementada mesmo com as limitações necessárias à preservação do bem. Três etapas foram estabelecidas para averiguar o objetivo proposto. Primeiramente, a análise crítica dos parâmetros existentes, como leis, normas e instruções, que dão suporte para o possível contato entre os campos de preservação e acessibilidade. Posteriormente, a avaliação técnica, relativa à acessibilidade e à preservação, das adaptações feitas em três objetos de estudo (utilizados como museu ou centro cultural) - Casa das Rosas, Centro Cultural Banco do Brasil e Pinacoteca do Estado -, destacando suas qualidades e limitações. Finalmente, a averiguação da percepção do usuário com deficiência, para assim, examinar a eficácia das soluções realizadas.

Palavras chave: Acessibilidade ao meio físico. Desenho Universal. Pessoa com deficiência. Bens culturais. Museus. Centros Culturais. 


\section{ABSTRACT}

Historic buildings are of interest to the wide population, including persons with disabilities or reduced mobility. The dialogue between preservation and accessibility needs to advance to provide good access and circulation solutions, thus allowing anyone to participate, no matter what their sensory, cognitive or motor characteristics may be. Legislation for preservation and accessibility in Brazil hardly mentions an interaction between these fields, creating huge conceptual and practical issues in resolving the matter. The goal of this work is to demonstrate that guidelines for preservation and restoration of these buildings allow for a path towards accessibility, and that accessibility can be implemented respecting the limitations necessary to preserve such an asset.

Three steps have been established to analyze the proposed goal. First, the critical analysis of the existing parameters, such as laws, norms and instructions, which support the connection between preservation and accessibility. Then, a technical evaluation regarding accessibility and preservation of three study objects (used as museums or cultural centers) - Casa das Rosas, Centro Cultural Banco do Brasil and Pinacoteca do Estado -, showcasing their features and limitations. Finally, a look at the perception of disabled users, in order to examine the efficacy of the solutions used.

Keywords: Physical accessibility. Universal Design. Persons with disabilities. Historic heritage. Museums. Cultural Centers. 


\section{LISTA DE FIGURAS}

Figura 1 - Rampa apoiada nos degraus na entrada da Secretaria da Justiça em São Paulo. 2012 ... 63

Figura 2 - Exemplo de adição: bloco de circulação vertical no Museu Reina Sofia - Espanha. 2006. 80

Figura 3 - Exemplo de supressão: plataforma inserida na escadaria da Opéra Nacional de Bordeaux França. Foto: Autoria desconhecida.

Figura 4 - Exemplo de sobreposição: rampa na Igreja do Bonfim - Salvador. Foto: Eduardo Romero. Data: 2010.

Figura 5 - Vista noturna do Teatro Municipal. Foto: Jefferson Pancieri/SPTuris. 86

Figuras 6 e 7 - Plataforma inclinada no acesso lateral do Teatro. Foto: Paula Dias/Acervo PMSP-

CPA. Data: abr. 2004.

Figura 8 - Vista da Biblioteca Mário de Andrade e detalhe da plataforma na lateral da entrada principal. Foto: Piratininga Arquitetos Associados.

Figura 9 - Detalhes do projeto de acessibilidade da Biblioteca Mário de Andrade. Revista AU. Data: jan. 2012.

Figura 10 - Entrada da Biblioteca pela Av. São Luís. Foto: Maíra Acayaba/Revista AU. Data: jan. 2012.

Figura 11 - Plataforma vertical. Foto: Maíra Acayaba/Revista AU. Data: jan. 2012. 89

Figura 12 - Vista da Rua Roberto Simonsen da Casa ํ⒈ 2012. 90

Figura 13 - Entrada. 2012. 91

Figura 14 - Escada de circulação geral. 2012. 91

Figura 15 - Elevador. 2012. 91

Figura 16 - Sanitário acessível. 2012. 91

Figura 17 - Fachada principal do Theatro Municipal do RJ. Foto: Caru Ribeiro 92

Figura 18 - Escadaria na fachada principal da Igreja do Bonfim. 2009. 94

Figura 19 - Rampa de alvenaria na fachada lateral. Foto: Eduardo Romero. Data: 2010. 95

Figura 20 - Rampa metálica para entrada lateral e acesso à parte frontal. 2011 95

Figura 21 - Vista da fachada principal. 2010 96

Figura 22 - Vista posterior com novo bloco inserido. 2010. 97

Figura 23 - Passarela e anexo. 2010. 97

Figura 24 - Mapa indicativo das áreas e serviços acessíveis em Veneza. 98 


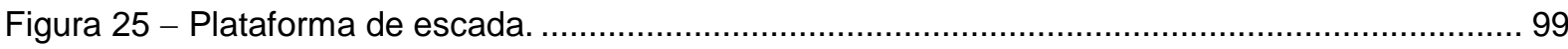

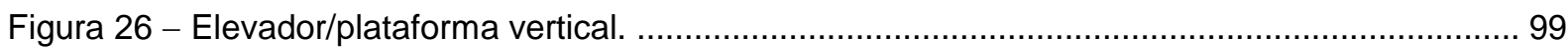

Figura 27 - Rampa móvel na Ponte della Paglia...................................................................... 100

Figura 28 - Rampa na Ponte dei Lavraneri. .......................................................................... 100

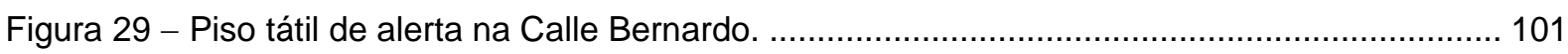

Figura 30 - Portão móvel para prevenção de queda em Campo S. Stefano. ……............................. 101

Figura 31 - Via com acesso perpendicular à ponte................................................................. 102

Figura 32 - Piso tátil direcional orientando percurso à ponte........................................................... 102

Figura 33 - Visão geral da Villa d’Este. Foto: Fabrizio Vescovo.................................................... 102

Figura 34 - Carro elétrico percorre o jardim. Foto: Fabrizio Vescovo. ............................................. 103

Figura 35 - Antes e depois da alteração de um percurso para a passagem do carro elétrico. Foto:

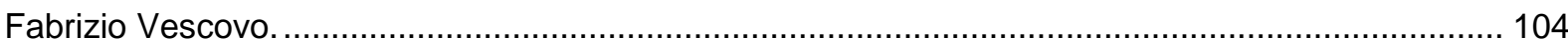

Figura 36 - Projeto alterou a escada com degraus inclinados sobrepondo uma rampa para a passagem do carro elétrico. Desenho: Fabrizio Vescovo................................................................ 104

Figura 37 - Projeto para inserção de um elevador. Foto e desenhos: Fabrizio Vescovo. ................. 105

Figura 38 - Porta do elevador à direita. Foto: Fabrizio Vescovo................................................... 105

Figura 39 - Vista geral do Fórum de Trajano. Foto: http://en.mercatiditraiano.it ............................. 106

Figuras 40 e 41 - Plataforma e escada de acesso ao nível inferior. Foto: Fabrizio Vescovo............ 107

Figura 42 - Vista interior do Grande Salão do Mercado de Trajano. Foto: http://en.mercatiditraiano.it

Figura 43 - Torres de circulação vertical. 2006..................................................................... 108

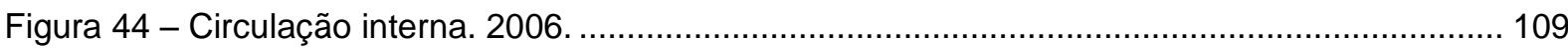

Figura 45 - Mapa de localização. Fonte: Google, 2011........................................................... 114

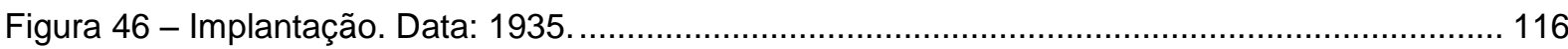

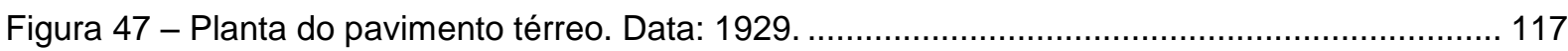

Figura 48 - Planta do pavimento superior (Andar Alto). Data: 1929.......................................... 118

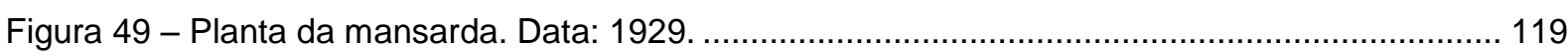

Figura 50 - Planta do porão. Data: [1928 ou 1929] (data não legível)........................................... 120

Figura 51 - Projeto para a fachada voltada à Av. Paulista. Data: 1929. ....................................... 121

Figura 52 - Projeto para a fachada voltada ao jardim. Data: 1928. ............................................... 121 


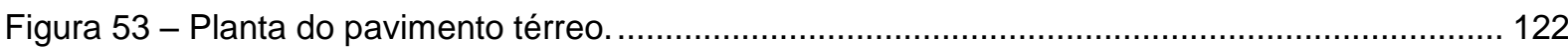

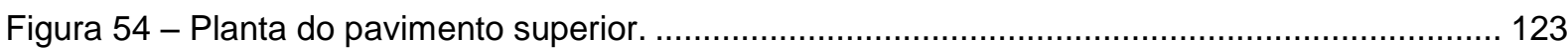

Figura 55 - Plantas dos pavimentos da mansarda e do porão. ................................................... 124

Figura 56 - Plantas dos pavimentos térreo e superior da edícula.................................................... 125

Figura 57 - Foto da residência de Ernesto de Castro na década de 1970 (TOLEDO, 1987)........... 126

Figura 58 - Restauro e construção do edifício Parque Cultural Paulista. Fonte: Laudo técnico do

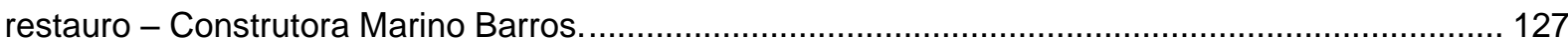

Figura 59 - Casa das Rosas e Edifício Parque Cultural. 2011.................................................... 128

Figura 60 - Rampa colocada para a mostra. Fonte: http: http://www.casaartedesign.com.br ........... 130

Figura 61 - Exemplo de argamassa da fachada com acumulo de poluição atmosférica................... 134

Figura 62 e 63 - Manchas revelam a infiltração na cobertura e/ou condutores................................... 134

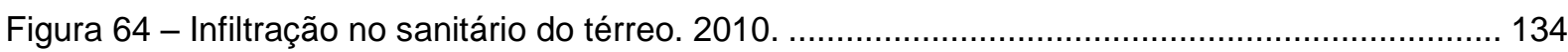

Figura 65 - Carranca que esconde o buzinote e a mancha na fachada, ao lado do condutor de água

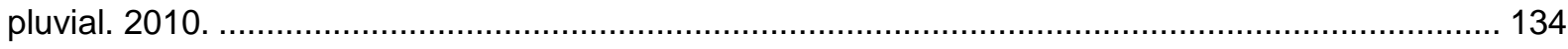

Figura 66 - Manchas amareladas no forro do Salão do térreo. 2010............................................. 135

Figura 67 - Beiral danificado, na fachada para Av. Paulista. 2010 .............................................. 135

Figura 68 - Depósito do porão tomado por infiltrações por capilaridade. 2010 ................................ 135

Figura 69 - Muretas com formação de musgo. 2010 ............................................................. 135

Figura 70 - Passeio da Av. Paulista em frente à Casa das Rosas. 2009........................................ 138

Figura 71 - Calçada revestida em mosaico português da Al. Santos. 2011 ................................... 139

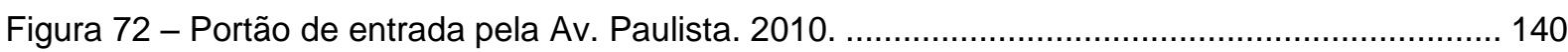

Figuras 73 e 74 - Entrada de pedestres da Al. Santos. 2011. ....................................................... 140

Figura 75 - Área externa em piso de ladrilho hidráulico. 2011 ........................................................ 141

Figura 76 - Área externa do Parque Cultural Paulista em mosaico português. 2011....................... 141

Figura 77 - Degraus em tijolo sem corrimão de apoio. 2009...................................................... 142

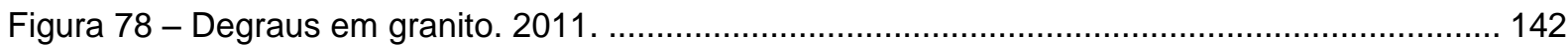

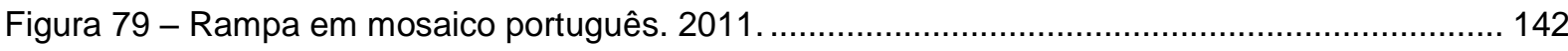

Figura 80 - Exemplo de grelha na circulação externa. 2009.......................................................... 143

Figura 81 - Entrada principal, voltada para o jardim. 2010 …....................................................... 144

Figura 82 - Escada de acesso à área de administrativa. 2010 …................................................. 144 
Figura 83 - Entrada lateral, voltada para Av. Paulista. 2010 ................................................... 144

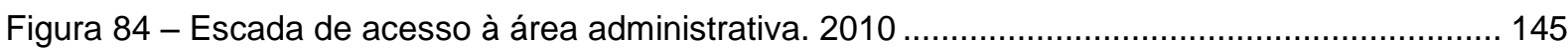

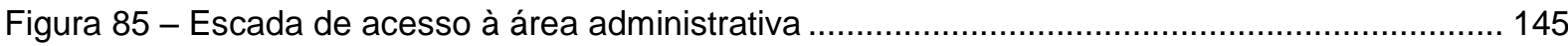

Figura 86 - Entrada dos fundos: porte-cochère. 2011 ................................................................. 145

Figuras 87 e 88 - Sinalização com orientações para o acesso de pessoas com deficiência física.

Figura 89 - Rampa metálica para acesso à Casa das Rosas. 2012 ............................................ 147

Figuras 90 e 91 - Porta da entrada principal (esquerda) e lateral (direita). 2009. ............................ 148

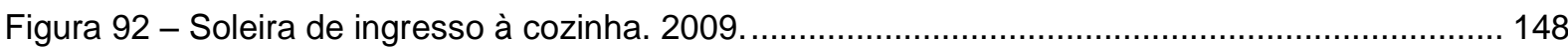

Figura 93 - Circulação no térreo. 2012 ……………......................................................... 149

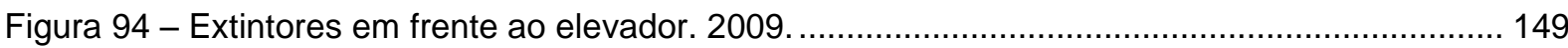

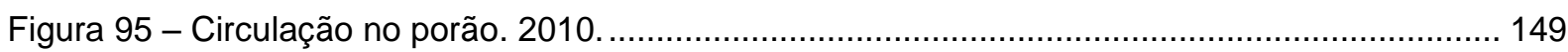

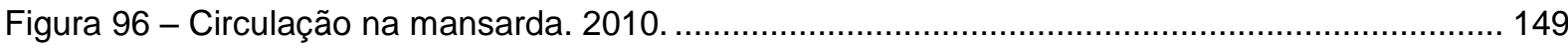

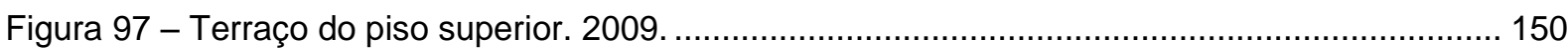

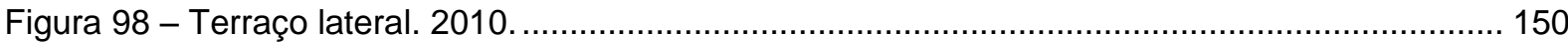

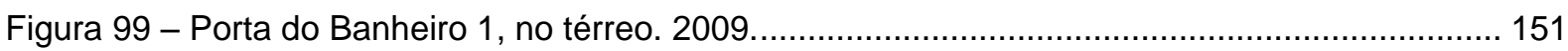

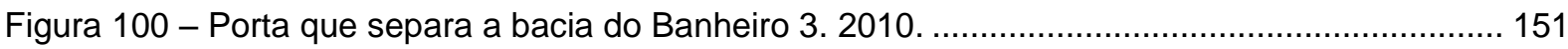

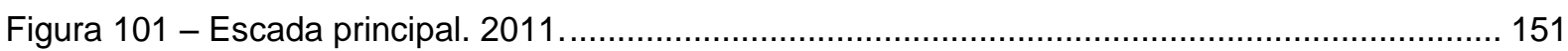

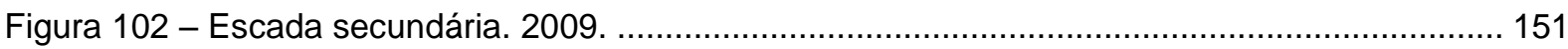

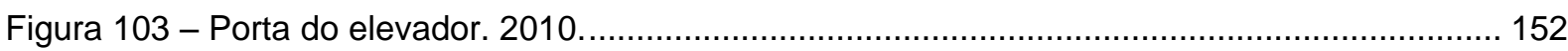

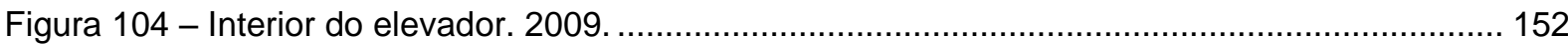

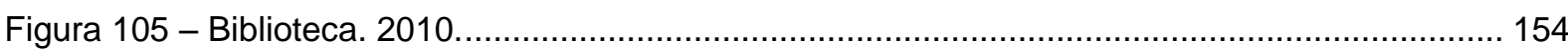

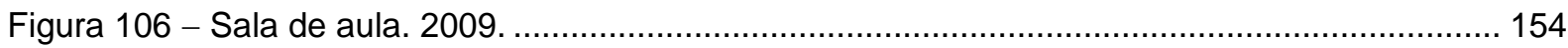

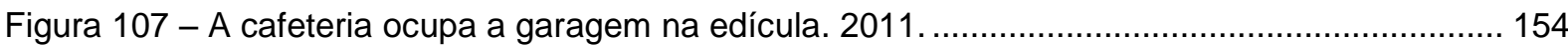

Figura 108 - Acesso ao pavimento superior da edícula. 2010 ....................................................... 155

Figura 109 - Escada e porta de acesso ao pavimento superior da edícula. 2010 ........................... 156

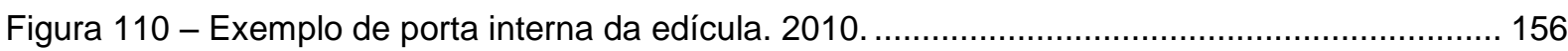

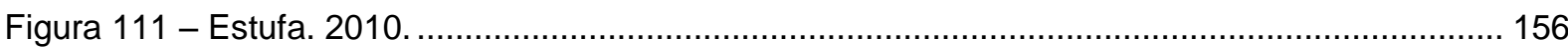

Figura 112 - Lavatório do sanitário do pavimento térreo. 2009.................................................... 158

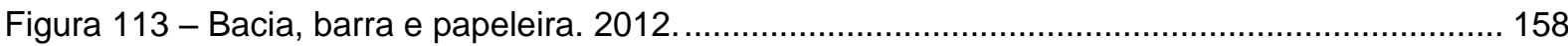


Figura 114 - Balcão de atendimento da biblioteca. 2009........................................................ 160

Figura 115 e 116 - Prateleiras e mesa da biblioteca. 2010 e 2009............................................... 160

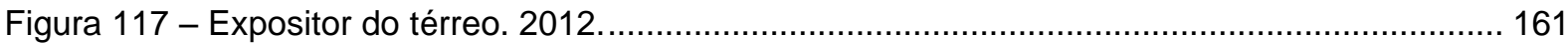

Figura 118 e 119 - Expositores do primeiro andar. 2009 e 2012 ...................................................... 161

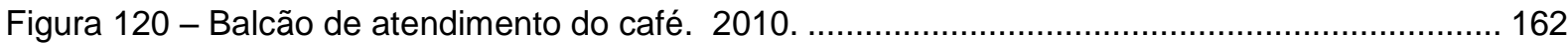

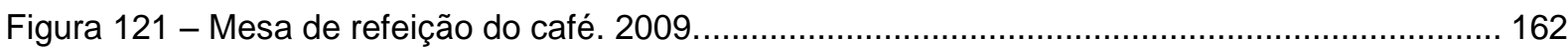

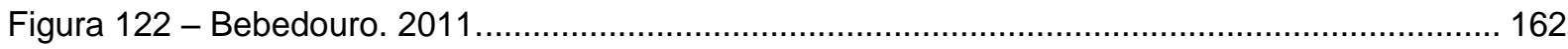

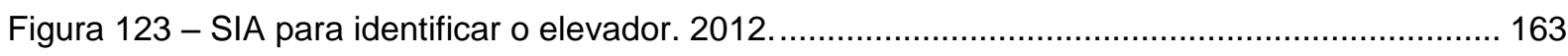

Figura 124 - Piso tátil de alerta em frente à porta do elevador no pav. térreo. 2009........................ 164

Figura 125, 126 e 127 - Exemplos de escadas e degraus sem piso tátil de alerta e faixa contrastante.

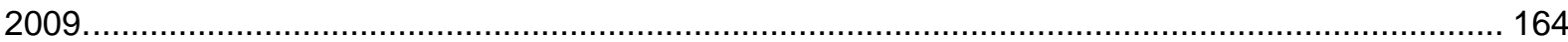

Figura 128 e 129 - Sinalização no sanitário aberto apenas à visitação e detalhe. 2009................... 165

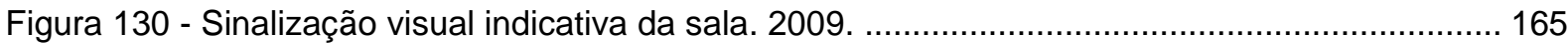

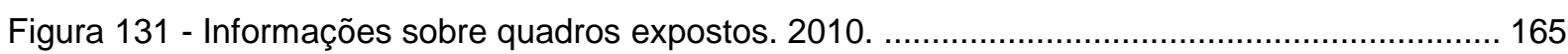

Figura 132 - Abertura original para monta-carga, no subsolo. 2010 .......................................... 174

Figura 133 - Abertura para alçapão no primeiro pavimento. 2010 ………………...................... 175

Figura 134 - Lavatório original do banheiro do térreo. 2010 ................................................... 175

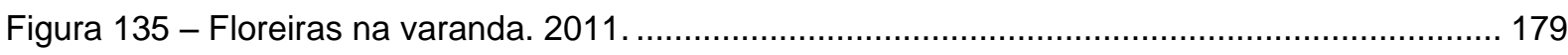

Figura 136 - Vista do Centro Cultural Banco do Brasil. 2011. .................................................... 185

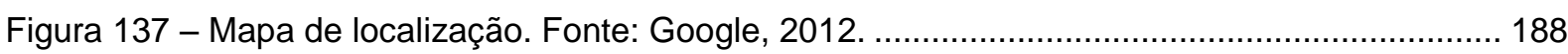

Figura 138 - Planta de situação. Data: 22 jun. 1925. Fonte: Acervo do Condephaat / UPPH. ......... 189

Figura 139 - Planta do pav. térreo de autoria de Pujol Jr. para a agência do Banco do Brasil. Data: 10 dez. 1924. Fonte: Acervo do Condephaat / UPPH. .................................................................... 189

Figura 140 - Planta do 1ำ pav. Data: 10 dez. 1924. Fonte: Acervo do Condephaat / UPPH............ 190

Figura 141 - Corte. Fonte: Revista Finestra/Brasil. ................................................................... 190

Figura 142 - Escada Helicoidal subindo para o mezanino. Data: 2001. Fonte:

http://www.arqbrasil.com.br/_arq/lt_arquitetura/lt_arq_ccbb.htm............................................... 191

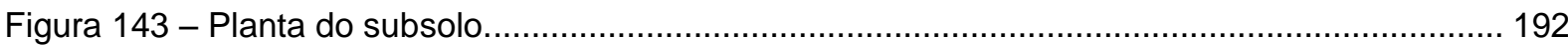

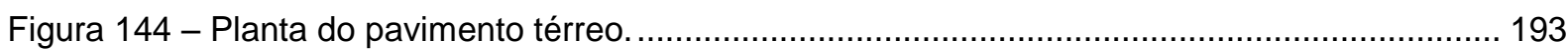

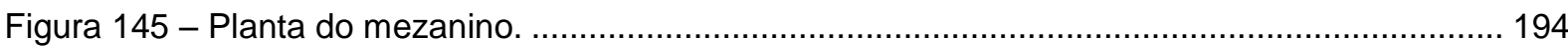

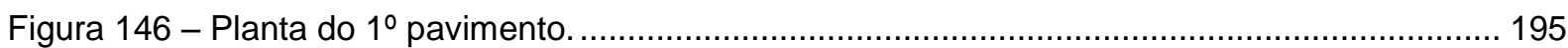




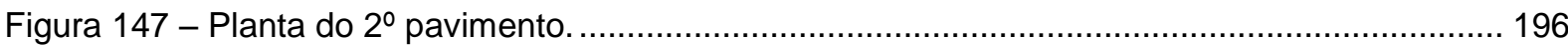

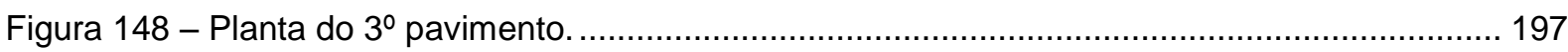

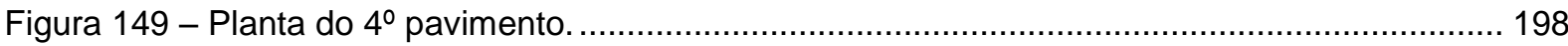

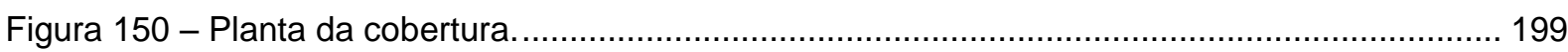

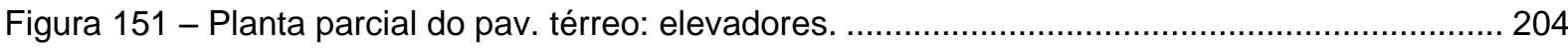

Figuras 152 e 153 - Calçadão das ruas Álvares Penteado e da Quitanda. 2011 .............................. 208

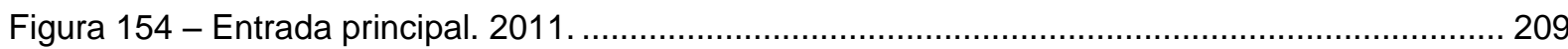

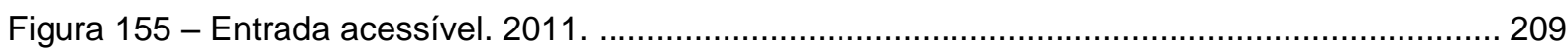

Figura 156 - Entrada de serviço na Rua da Quitanda. 2011 ...................................................... 210

Figura 157 - Entrada de serviço: detalhe para o interfone. 2011 ...................................................... 210

Figura 158 - Exemplo de circulação no pav. térreo. 2011 ............................................................ 211

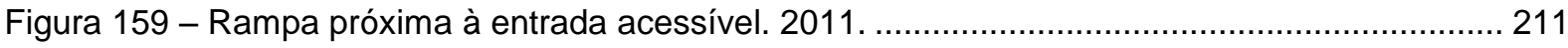

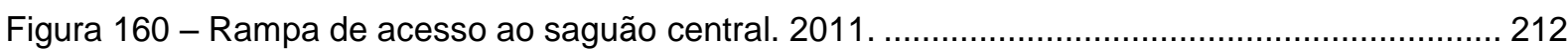

Figura 161 - Plano inclinado no acesso ao banheiro acessível. 2011 ......................................... 212

Figura 162 - Identificação das rampas e planos inclinados no pav. térreo. 2011 ............................. 213

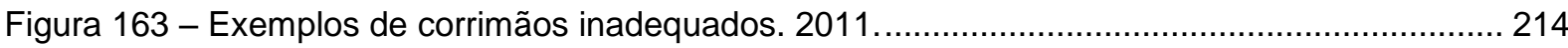

Figura 164 - Escada com prolongamento menor. 2011 .............................................................. 214

Figura 165 - Escada de circulação do público. 2011 ............................................................... 214

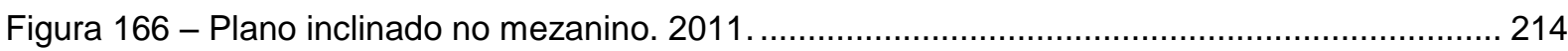

Figura 167 - Elevador de porta pantográfica para acesso ao subsolo. 2011 ................................. 215

Figura 168 - Porta corta-fogo entre elevador e área de exposições. 2011 ...................................... 215

Figura 169 - Piso rampeado em frente às portas do cofre central. 2011 ...................................... 216

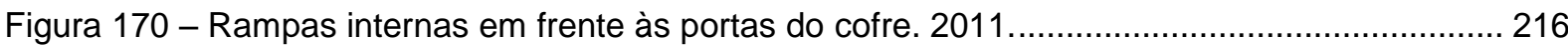

Figura 171 - Entrada para circulação dos sanitários. 2011 …….............................................. 217

Figura 172 - Porta de abertura automática para área expositiva. 2011..................................... 217

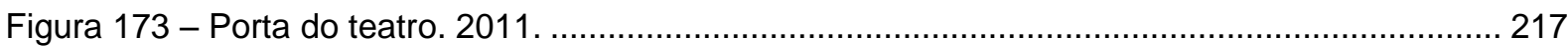

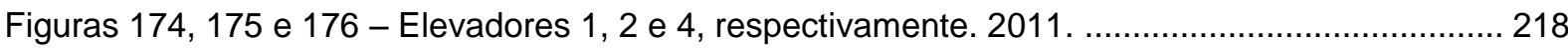

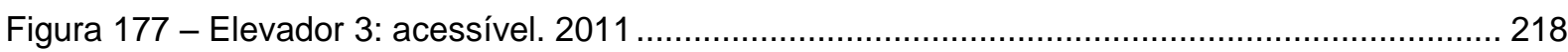

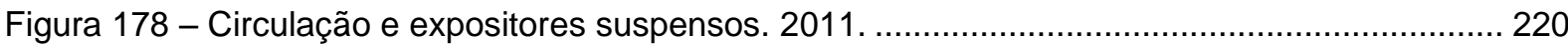

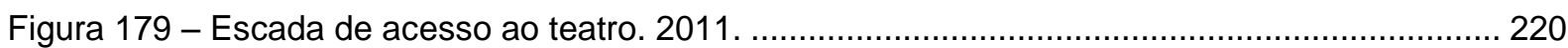




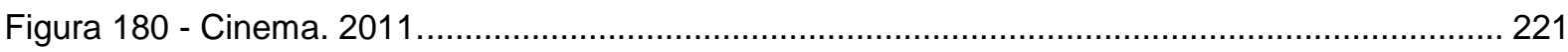

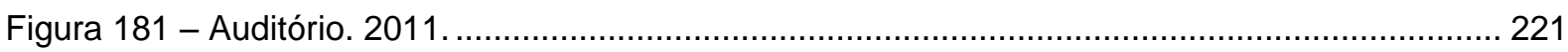

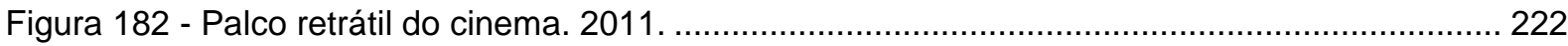

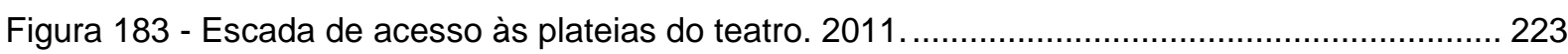

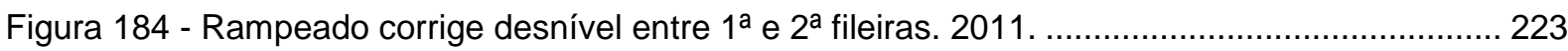

Figuras 185 e 186 - Plateias, inferior e superior, do teatro. 2011 ............................................... 223

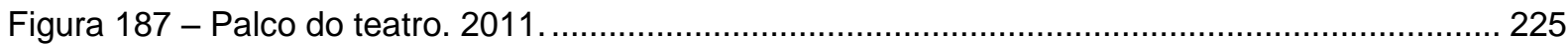

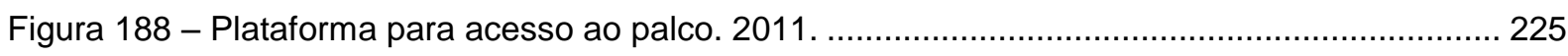

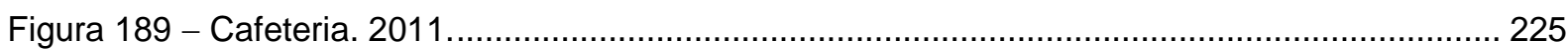

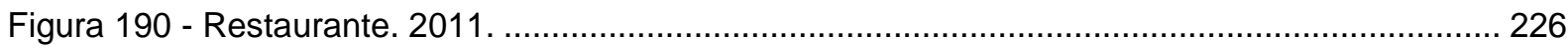

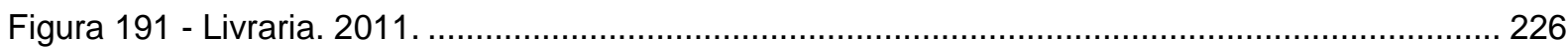

Figuras 192 e 193 - Sanitário acessível no térreo: bacia e lavatório. 2011 ...................................... 229

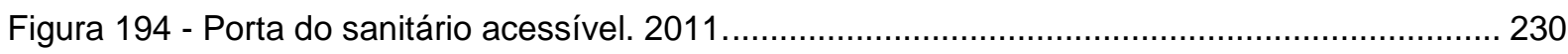

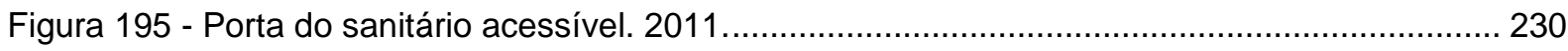

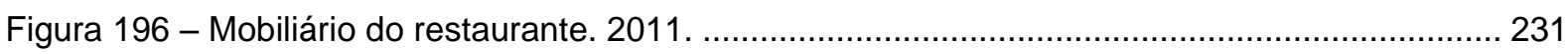

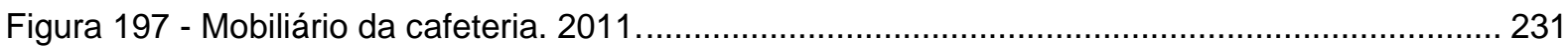

Figura 198 - Mobiliário da cafeteria - externo. 2011 ............................................................. 232

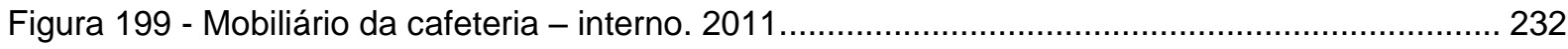

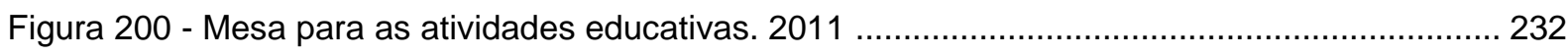

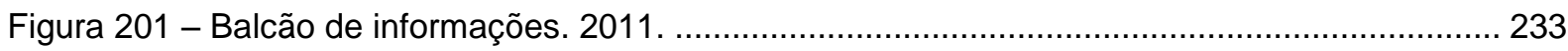

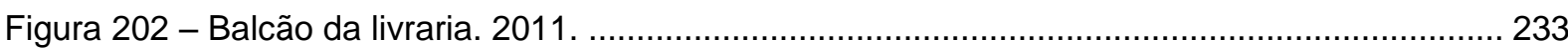

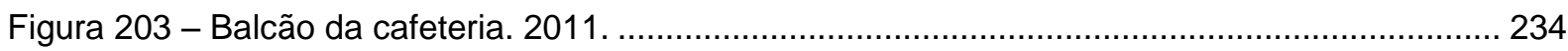

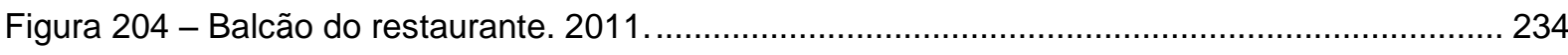

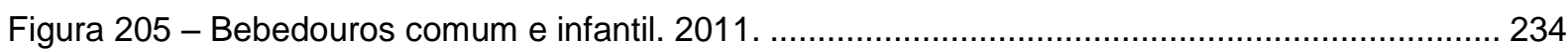

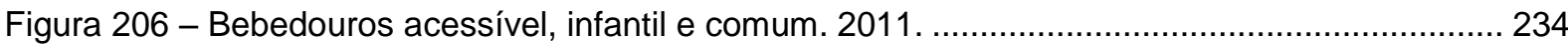

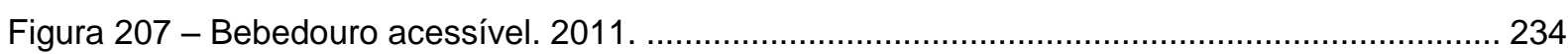

Figuras 208, 209 e 210 - Conjunto de telefones no térreo, telefone para surdos e acessível. 2011. 235

Figura 211 - Suporte de folhetos da programação (esquerda). 2011............................................ 236

Figura 212 - Exemplo de degrau sem piso tátil de alerta, mas sinalizado com faixa contrastante. 2011. 237 
Figura 213 - Exemplo de sinalização visual identificando o ambiente, no alto da porta. 2011 ......... 238

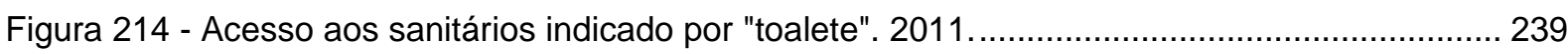

Figura 215 - Indicação direcional com pictograma, mas usa termo "toaletes". 2011 ........................ 239

Figura 216 - Identificação das exposições nos andares. 2011 ................................................... 240

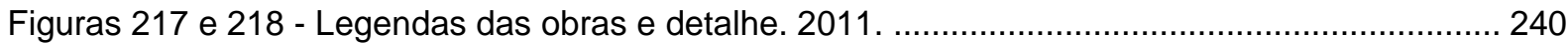

Figura 219 - Sinalização braile no corrimão da escada. 2011 .................................................... 241

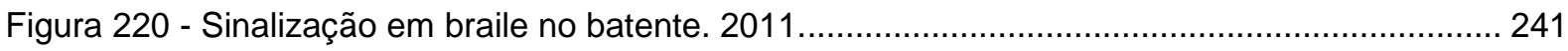

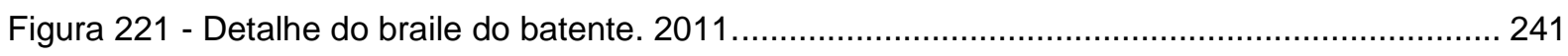

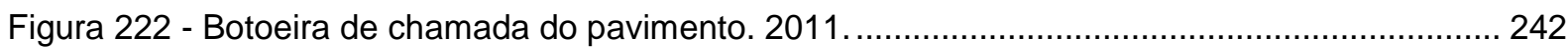

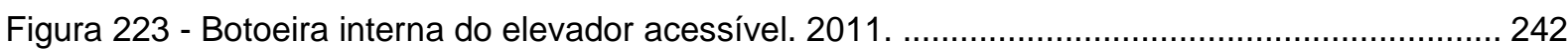

Figura 224 - Espaço entre rampa de entrada e a livraria. 2011 ..................................................... 255

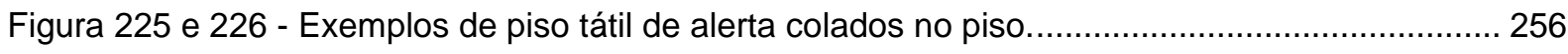

Figura 227 - Vista da Pinacoteca a partir da Estação da Luz. 2011 ................................................ 262

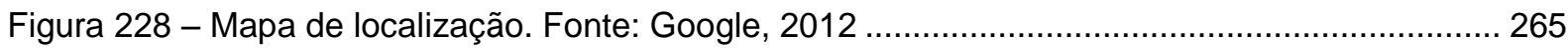

Figura 229 - Planta do pavimento térreo - acervo do Condephaat/ Unidade de Preservação do

Patrimônio Histórico da Secretaria da Cultura do Estado de SP. 266

Figura 230 Planta do 1ำ pavimento - acervo do Condephaat/ Unidade de Preservação do Patrimônio Histórico da Secretaria da Cultura do Estado de SP. 266

Figura 231 - Planta do $2^{\circ}$ pavimento - acervo do Condephaat/ Unidade de Preservação do

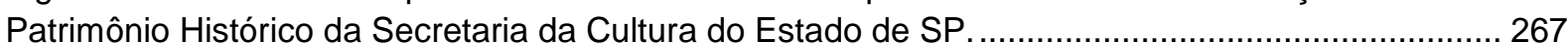

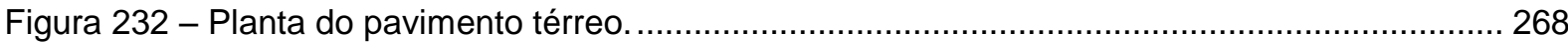

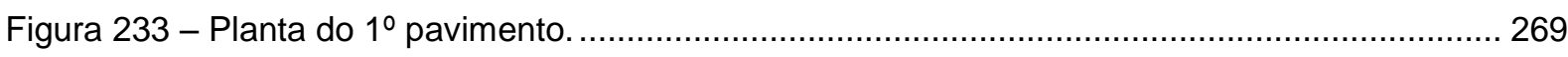

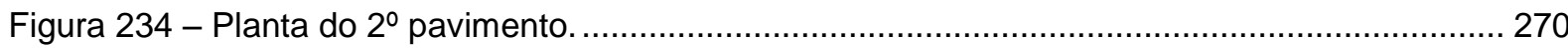

Figura 235 - Carro de apoio com material educativo do Programa Educativo Públicos Especiais da Pinacoteca do Estado. 2011.

Figura 236 - Maquete de montar e relevo da obra Antropofagia da artista Tarsila do Amaral do Programa Educativo Públicos Especiais da Pinacoteca do Estado. 2011.

Figura 237 - Reprodução dos elementos principais da obra em alto contraste do Programa Educativo Públicos Especiais da Pinacoteca do Estado. 2011.

Figura 238 - Galeria Tátil de Esculturas Brasileiras do Programa Educativo Públicos Especiais da Pinacoteca do Estado. 2011.

Figura 239 e 240 - Catálogo (e detalhe) do acervo em dupla leitura e relevo, elaborados pelo Programa Educativo Públicos Especiais da Pinacoteca do Estado. 2011. 
Figura 241 e 242 - Maquetes táteis e detalhe de uma delas, elaboradas pelo Programa Educativo Públicos Especiais da Pinacoteca do Estado. 2011.

Figura 243 - Guia de visitação para o público surdo, elaborado pelo Programa Educativo Públicos Especiais da Pinacoteca do Estado. 2011

Figura 244 - Exemplo de signoguia, utilizado no Museu Nacional d'Art de Catalunya, Espanha. Fonte: sítio MNAC. 279

Figura 245 - Passeio em frente à entrada. 2011 281

Figura 246 - Passeio voltado para a Av. Tiradentes. 2011. 282

Figura 247 - Rebaixamento na travessia. 2011. 283

Figura 248 - Rebaixamento sem piso tátil de alerta e com desnível. 2011. 283

Figura 249 - Travessia elevada em frente à entrada da Praça da Luz. 2011. 284

Figura 250 - Desnível existente no único acesso a partir do passeio. 2011. 285

Figura 251 - Acesso único para carros e pedestres. 2011. 285

Figura 252 - Pavimento inadequado para circulação de pedestres. 2011. 286

Figura 253 - Desnível na ligação entre o mosaico português na área da pinacoteca e o piso de terra no Parque da Luz. 2011. 286

Figura 254 - Vaga com cone. Sinalização apagada. 2011. 287

Figura 255 - Estacionamento. 2011. 287

Figura 256 - Escada na entrada principal. 2009. 288

Figura 257 - Posicionamento da entrada acessível em relação à escada. 2011. 289

Figura 258 - Entrada acessível. 2011. 289

Figura 259 - Porta da entrada acessível. 2011. 289

Figura 260 - Porta automática na entrada principal. 2011 290

Figuras 261 e 262 - Exemplos de circulação no pavimento térreo. 2011 291

Figuras 263 e 264 - Exemplos de circulação no 1ำ pavimento. 2011. 291

Figuras 265 e 266 - Exemplos de circulação no 2o pavimento. 2011. 291

Figuras 267 e 268 - Exemplos de portas de ferro e vidro no pavimento térreo. 2011. 292

Figura 269 - Exemplo de porta da área de exposições do $1^{\circ}$ andar. 2011 293

Figura 270 - Porta automática no acesso ao Belvedere. 2011. 293

Figura 271 - Porta de sala expositiva do $2^{\circ}$ andar. 2011. 294

Figura 272 - Detalhe do puxador. 2011. 294 
Figura 273 e 274 - Rampas metálicas em frente às portas. 2011 ............................................ 295

Figura 275 e 276 - Rampas metálicas nas portas de acesso às varandas. 2011 ........................... 295

Figura 277 - Vão de passagem de acesso ao sanitário do $1^{\circ}$ andar. 2011 ...................................... 295

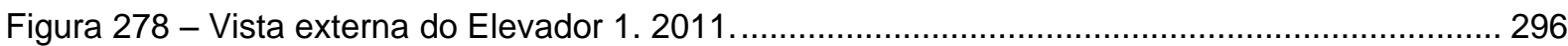

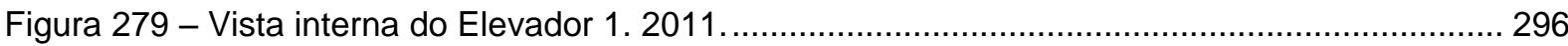

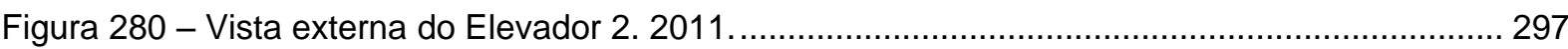

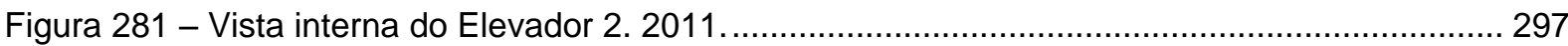

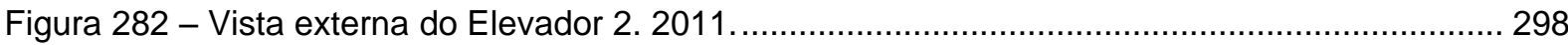

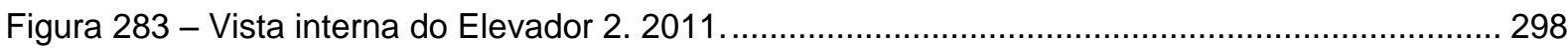

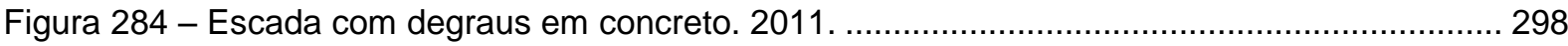

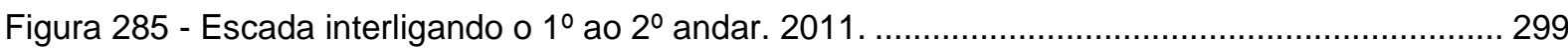

Figura 286 e 287 - Detalhes do corrimão da escada do térreo ao 1ํandar. 2011........................... 299

Figura 288 - Corrimão é interrompido antes de chegar ao pavimento. 2011 .................................. 300

Figura 289 - Aviso pede que se utilize o corrimão para a própria segurança. 2011 .......................... 300

Figura 290 - Saída de uma das passarelas no $1^{\circ}$ a andar. 2011 ....................................................... 300

Figura 291 e 292 - Exemplos das saídas de passarela no 2o andar. 2011..................................... 301

Figura 293 - Circulação rampeada e escada helicoidal no $2^{\circ}$ andar. 2011. ..................................... 301

Figura 294 e 295 - Exemplos de circulação dos espaços expositivos. 2011 ...................................... 302

Figura 296 - Exemplos de expositores que permitem aproximação. 2011 ..................................... 302

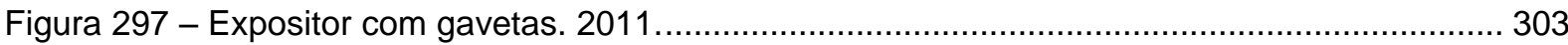

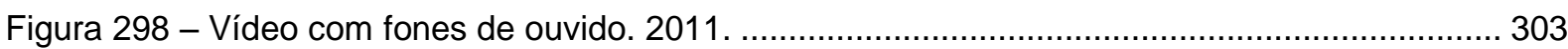

Figura 299 - Detalhe do tamanho da letra nas legendas. 2011 .................................................. 304

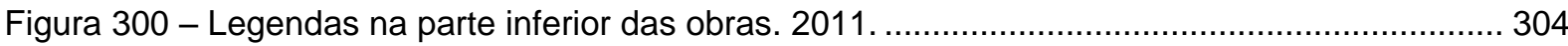

Figura 301 - Exemplo de escultura com legenda em fonte ampliada e braile, fora da Galeria Tátil. 2011

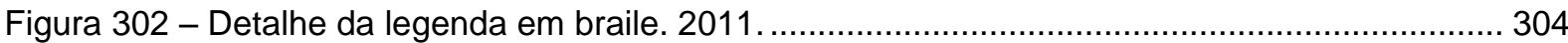

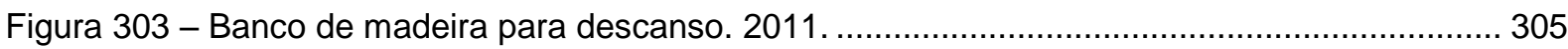

Figura 304 - Áreas livres no térreo para a reunião de grupos. 2011........................................... 305

Figura 305 - Áreas livres no térreo para a reunião de grupos. 2011 .............................................. 306

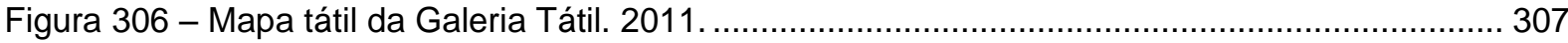




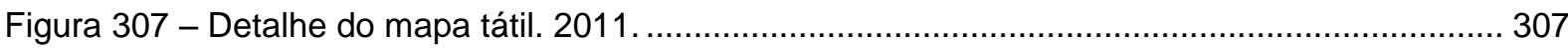

Figura 308 - Rota direcional no percurso da Galeria Tátil. 2011 ................................................ 307

Figura 309 - Detalhe da legenda de escultura exposta na Galeria Tátil. 2011............................... 307

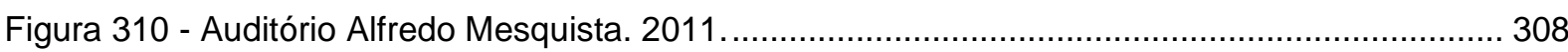

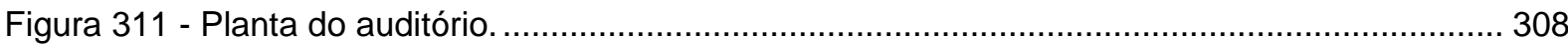

Figura 312 - Palco e degraus de acesso. Início da rampa, no fundo à direita. 2011. ...................... 308

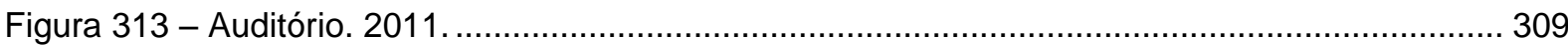

Figura 314 - Espaço no fundo pode acomodar pessoas em cadeiras de rodas. 2011. .................... 310

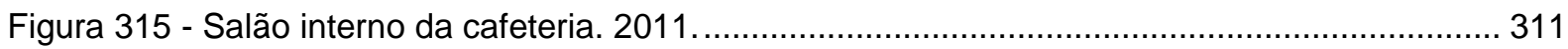

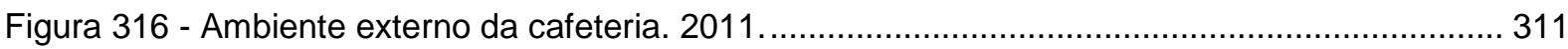

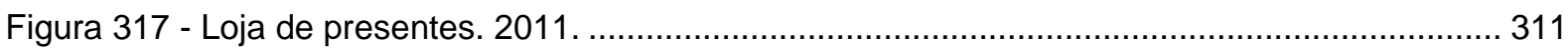

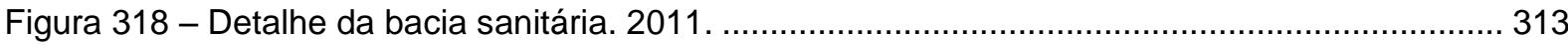

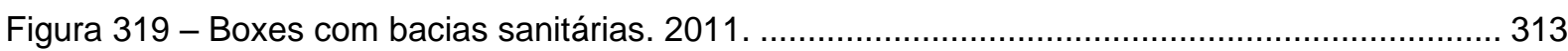

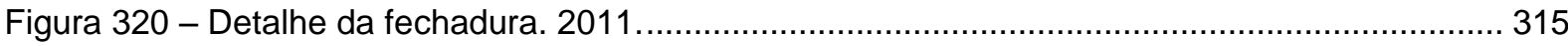

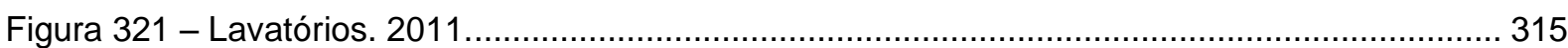

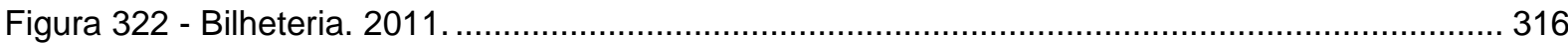

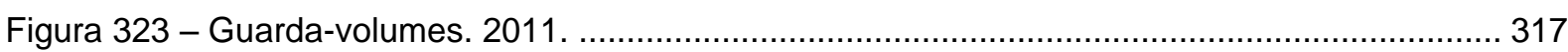

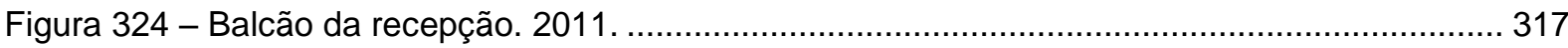

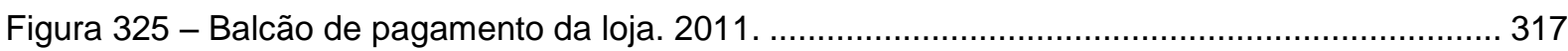

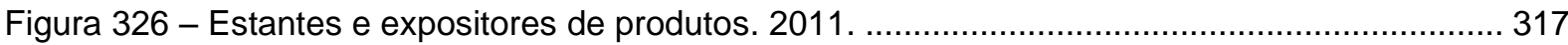

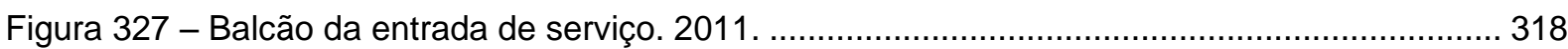

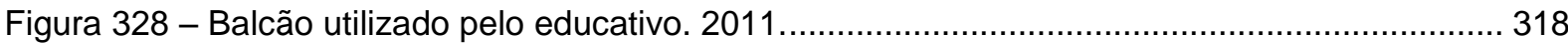

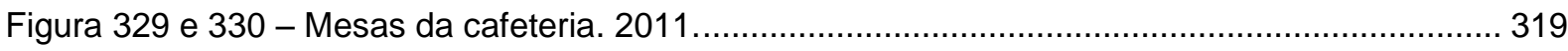

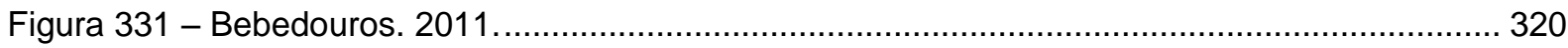

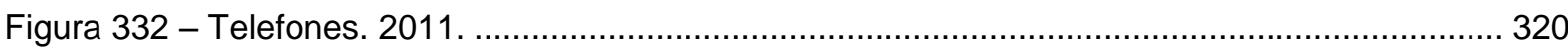

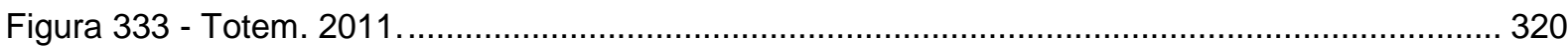

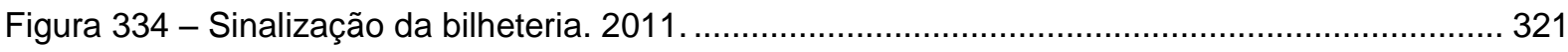

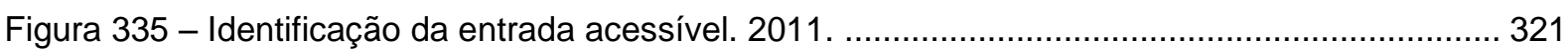

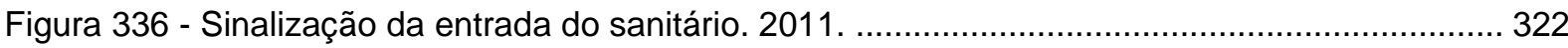

Figura 337 e 338 - Sinalização ambiental com símbolos de circulação e de sanitários. 2011 .......... 322 


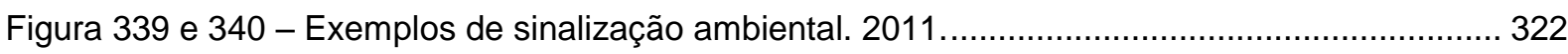

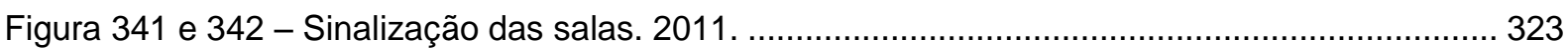

Figura 343 - Sinalização dos pontos de interesse em cada andar. 2011....................................... 324

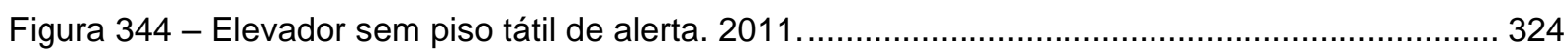

Figura 345 - Botoeira de piso com indicação em braile e relevo. 2011 .......................................... 324

Figura 346 e 347 - Sinalização do Elevador 2 em fonte ampliada e braile. 2011 ............................. 325

Figura 348 - Ausência de sinalização tátil de alerta. 2011 ........................................................... 325

Figura 349 e 350 - Extintores que não precisam de sinalização. 2011 ....................................... 326

Figura 351 - Ausência de piso tátil de alerta na rampa e na escada e de faixa contrastante nos

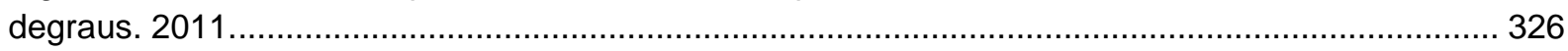

Figura 352 e 353 - Novos elementos: elevador, passarelas e cobertura. 2009. ……..................... 336

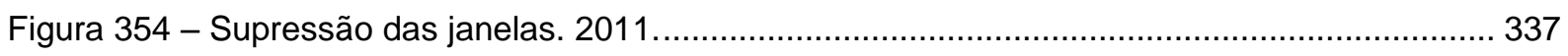

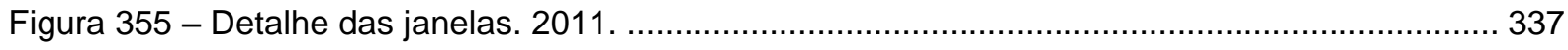

Figura 356 - Local de supressão de uma janela. 2011 ......................................................... 338

Figura 357 - Piso de madeira e rampa metálica, sobrepostos ao piso original. 2011....................... 339 


\section{LISTA DE GRÁFICOS}

Gráfico 1 - Tipos de deficiência. Fonte: IBGE, Censo Demográfico 2010.

\section{LISTA DE TABELAS}

Tabela 1- Promoção da acessibilidade pelo IPHAN 2005-2009: Contratos 67

Tabela 2 - Promoção da acessibilidade pelo IPHAN 2005-2009: Convênios. 67

Tabela 3 - Distribuição de peças sanitárias. 157

Tabela 4 - Distribuição de peças sanitárias para visitantes. 227

Tabela 5 - Distribuição de peças sanitárias para funcionários... 228

Tabela 6 - Distribuição de peças sanitárias destinadas aos visitantes. 312

Tabela 7 - Distribuição de peças sanitárias destinadas aos funcionários. 316 


\section{SUMÁRIO}

INTRODUÇÃO

METODOLOGIA

1 ACESSIBILIDADE E PRESERVAÇÃO

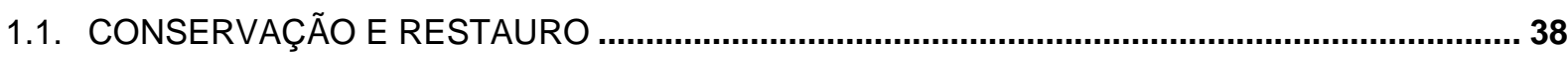

1.2. INCLUSÃO E ACESSIBILIDADE

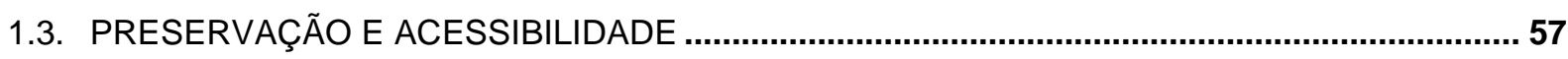

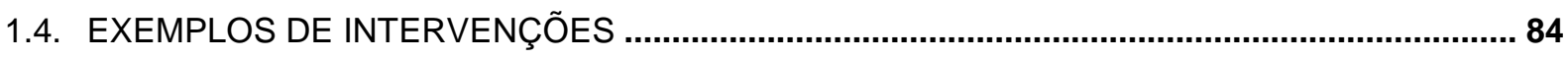

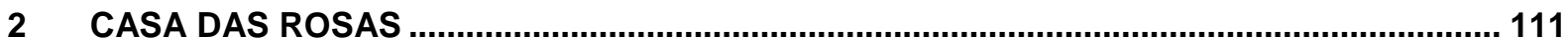

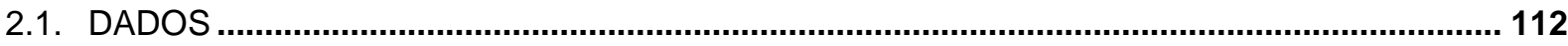

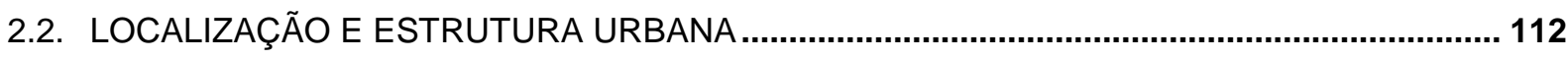

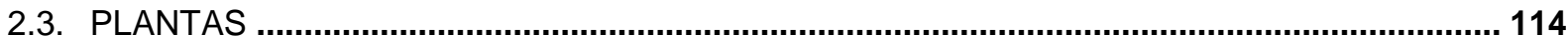

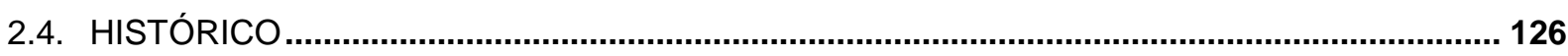

2.5. CARACTERÍSTICAS FÍSICAS ...................................................................................131

2.6. ESTADO DE CONSERVAÇÃO E PRESERVAÇÃO DO PATRIMÔNIO …................................133

2.7. PROGRAMAS DE ATENDIMENTO ÀS PESSOAS COM DEFICIÊNCIA ................................136

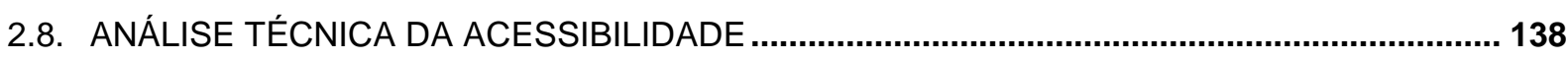

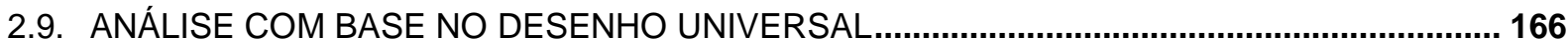

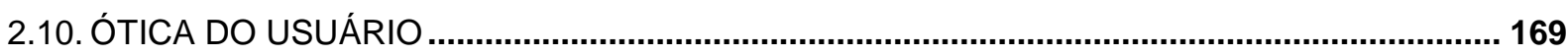

2.11. ANÁLISE DA RELAÇÃO ENTRE PRESERVAÇÃO E ACESSIBILIDADE .............................173

2.12. CONCLUSÕES E RECOMENDAÇÕES DE ADEQUAÇÃO .................................................. 176

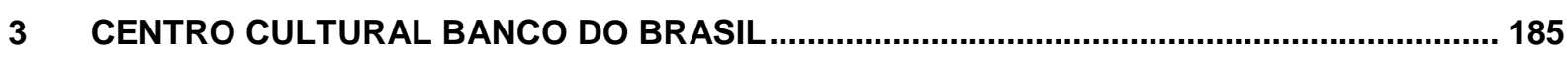

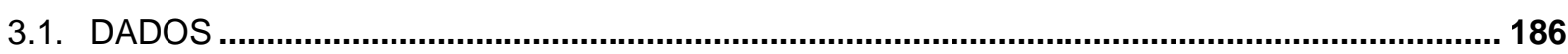

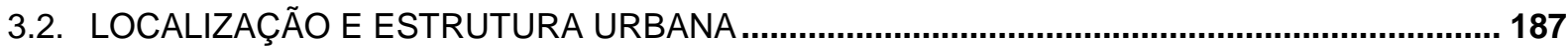

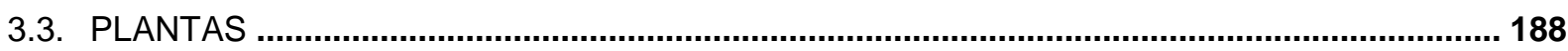

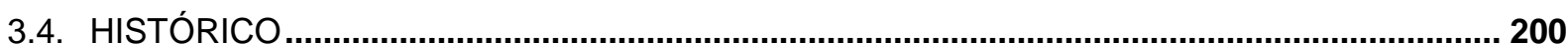

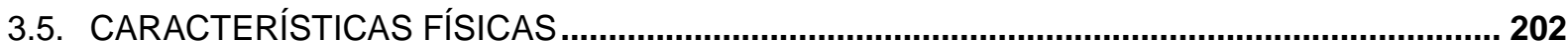

3.6. ESTADO DE CONSERVAÇÃO E PRESERVAÇÃO DO PATRIMÔNIO .................................. 205

3.7. PROGRAMAS DE ATENDIMENTO ÀS PESSOAS COM DEFICIÊNCIA ................................ 205

3.8. ANÁLISE TÉCNICA DA ACESSIBILIDADE

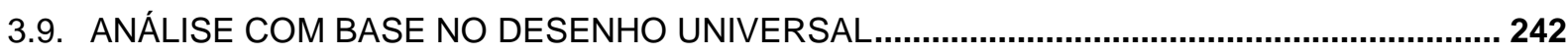

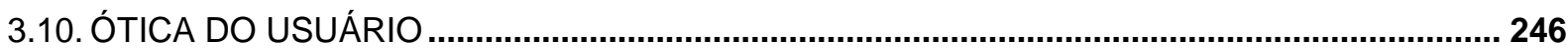


3.11. ANÁLISE DA RELAÇÃO ENTRE PRESERVAÇÃO E ACESSIBILIDADE …............................250

3.12. CONCLUSÃO E RECOMENDAÇÕES DE ADEQUAÇÃO................................................. 253

4 PINACOTECA DO ESTADO DE SÃO PAULO

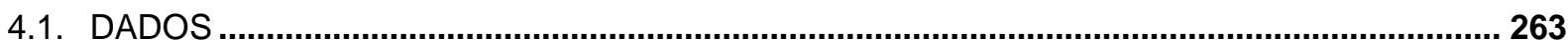

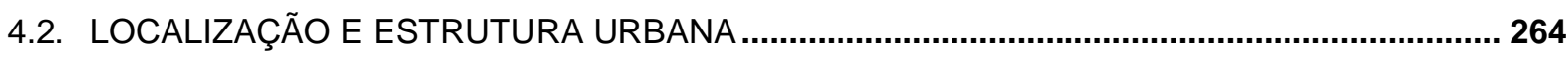

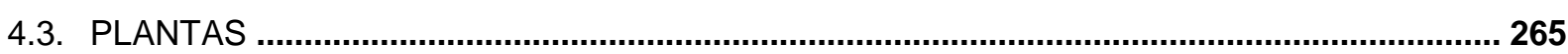

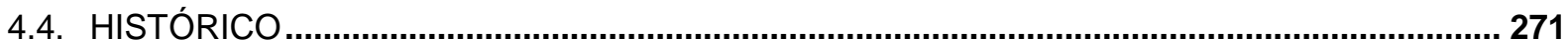

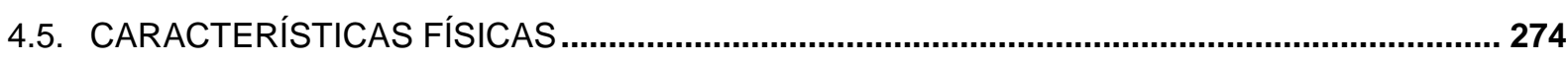

4.6. ESTADO DE CONSERVAÇÃO E PRESERVAÇÃO DO PATRIMÔNIO ...................................274

4.7. PROGRAMAS DE ATENDIMENTO ÀS PESSOAS COM DEFICIÊNCIA …............................. 275

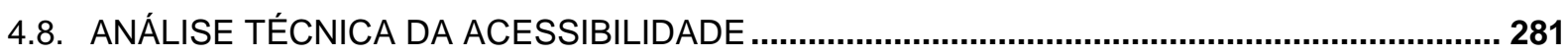

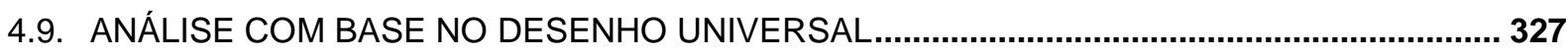

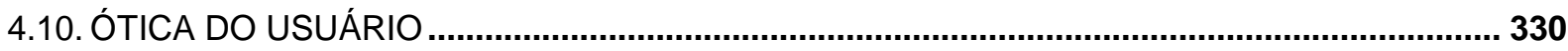

4.11. ANÁLISE DA RELAÇÃO ENTRE PRESERVAÇÃO E ACESSIBILIDADE ..............................335

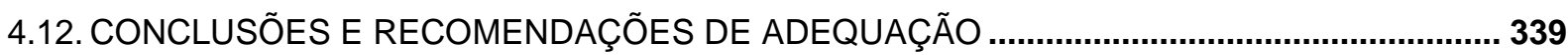

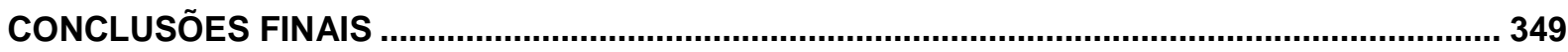

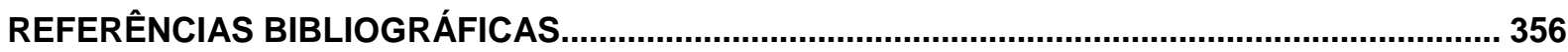




\section{INTRODUÇÃO}

A adaptação de uma edificação existente à acessibilidade, muitas vezes, exige grandes mudanças para conquistar o acesso e circulação de todos. Soluções são possíveis, mas nem sempre se chega ao ideal ou ao mínimo desejável.

Se o objeto de reabilitação ao uso coletivo é um edifício tombado, por seu valor histórico, artístico ou cultural, as barreiras costumam tornar-se mais difíceis de ser vencidas. As características que levaram ao tombamento da edificação devem ser preservadas e as adaptações demandam maior atenção para que não se descaracterize o bem cultural. Mas, muitas vezes, as adequações necessárias para o acesso e circulação de todas as pessoas, que devem incluir as pessoas com deficiência ou mobilidade reduzida, são desprezadas quando se planeja a restauração do edifício para o uso diário.

Os dados preliminares da pesquisa Censo 2010, divulgados pelo Instituto Brasileiro de Geografia e Estatística (IBGE), informam que no Brasil 23,9\% da população declararam ter alguma deficiência. O Gráfico 1, a seguir, demonstra a divisão por tipo de deficiência:

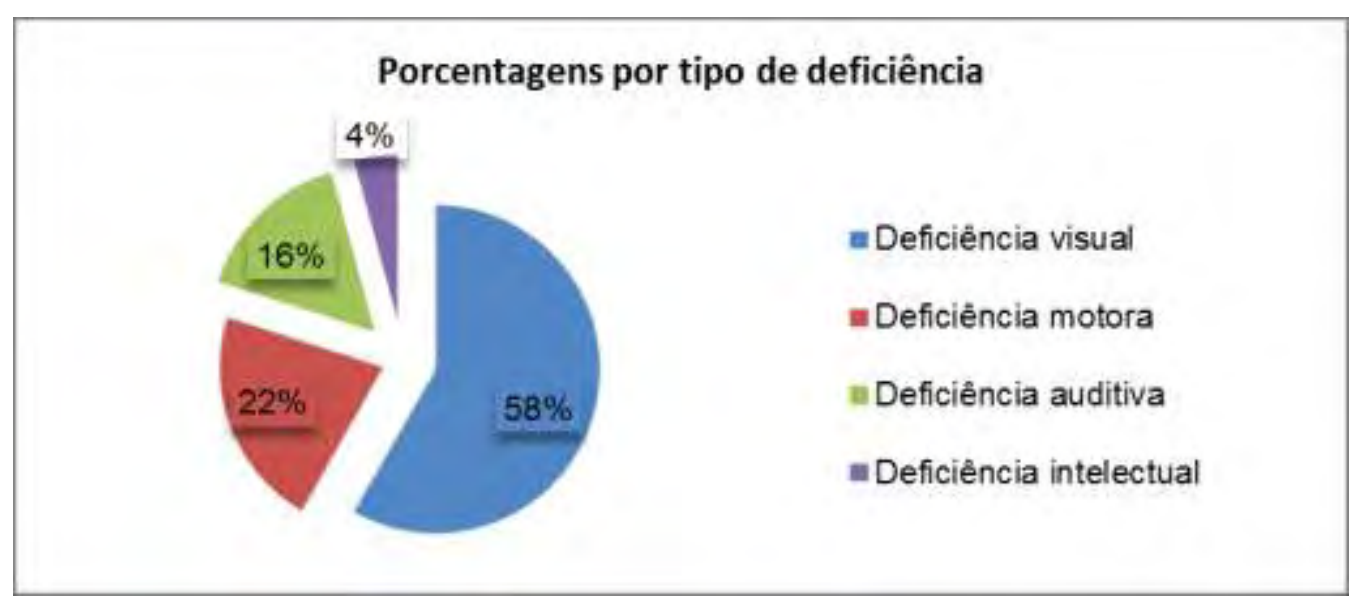

Gráfico 1 - Tipos de deficiência. Fonte: IBGE, Censo Demográfico 2010. 
Os edifícios tombados, muitas vezes tornam-se equipamentos de uso coletivo da população em geral, principalmente para atividades culturais, educativas e recreacionais, e devem dar atendimento igualitário a todas as pessoas.

Estão entre os princípios da Convenção sobre os Direitos das Pessoas com Deficiência da Organização das Nações Unidas ${ }^{1}$, o respeito pela dignidade inerente, a plena e efetiva participação e inclusão na sociedade, a igualdade de oportunidades e a acessibilidade. Segundo o prefácio escrito pelo Secretário Especial dos Direitos Humanos da Presidência da República, Paulo Vannuchi, na publicação sobre a Convenção, o Estado Parte que a ratifica, não pode permitir qualquer prejuízo à pessoa com deficiência (BRASIL, 2007b, p. 6-7, grifo nosso):

Com a Convenção da ONU, se não houver acessibilidade significa que há discriminação, condenável do ponto de vista moral e ético e punível na forma da lei. Cada Estado Parte se obriga a promover a inclusão em bases iguais com as demais pessoas, bem como dar acesso a todas as oportunidades existentes para a população em geral.

Portanto, estes espaços destinados a todos precisam levar em consideração a diversidade humana, e não mais somente padrões "normais", como cita Cambiaghi (2011, p. 40), sobre o processo de trabalho comum a arquitetos, engenheiros e designers nos dias de hoje: "[...] tendência dominante de fazer projetos para um público pretensamente normal, que corresponderia à média da população".

No âmbito da preservação, o Instituto do Patrimônio Histórico e Artístico Nacional (IPHAN) criou uma Instrução Normativa em 2003 com o objetivo de orientar a adequação à acessibilidade aos bens culturais imóveis. Do objetivo da Instrução Normativa $n^{\circ} 1$ do IPHAN, de 25 de novembro de 2003:

\footnotetext{
${ }^{1}$ Esta Convenção foi ratificada pelo Brasil pelo Decreto federal no 6.949 , de 25 de agosto de 2009.
} 
1. Estabelecer diretrizes, critérios e recomendações para a promoção das devidas condições de acessibilidade aos bens culturais imóveis especificados nesta Instrução Normativa, a fim de equiparar as oportunidades de fruição destes bens pelo conjunto da sociedade, em especial pelas pessoas portadoras de deficiência ou com mobilidade reduzida.

A preocupação em tornar os bens culturais imóveis acessíveis, garantindo igualdade de acesso e tornando o espaço democrático é crescente. O debate está aberto, mas as ações ainda são escassas.

No Brasil temos pouca regulamentação com alguma orientação sobre o assunto. O Decreto Federal 5.296/2004, que trata da acessibilidade nas edificações, se restringe apenas ao artigo 30 que, remete à Instrução Normativa $n^{\circ} 1$ do IPHAN. A NBR 9050/2004, norma da Associação Brasileira de Normas Técnicas (ABNT), apresenta a respeito apenas três parágrafos em um de seus capítulos.

Como a NBR 9050/2004 indica que a adequação do espaço deve ser feita seguindo todo o conteúdo da norma, com a ressalva de que o órgão de preservação é que deve aprovar cada adaptação, as efetivas reformas com esse objetivo são escassas. Pois, o discurso da preservação tem mais força, e a acessibilidade fica em segundo plano, por se considerar que pode descaracterizar o bem. E assim temos uma discussão desequilibrada.

Claro que devemos levar em consideração as especificidades impostas pela preservação do bem cultural, uma vez que, as próprias barreiras são resultantes de um processo de ocupação em um momento histórico no qual a acessibilidade e a inclusão não faziam parte das preocupações e prioridades da sociedade.

E o desafio é exatamente este. Promover acessibilidade, dentro das limitações físicas e conceituais que o patrimônio impõe, sem causar mutilações ou 
descaracterizações, dando maior qualidade ao espaço e garantindo o atendimento às atuais necessidades do edifício e seu público.

A acessibilidade deve ter peso igual às outras adaptações necessárias ao novo uso do edifício tombado (CAMBIAGHI, 2004). E acredito que devem ser consideradas de ordem prioritária. Já existe a compreensão de que bens culturais imóveis necessitam receber mudanças por conta de sistemas hidráulicos, elétricos e de segurança, entre outros, a fim de se adequar à visitação pública. Por que será que a acessibilidade encontra tanta resistência, já que ela também está ligada à segurança e principalmente ao direito de ir e vir dos usuários? Possivelmente pela falta de intimidade dos profissionais que atuam nesse campo, com as normas e leis que tratam de acessibilidade para, assim, garantir soluções criativas e eficazes aos edifícios tombados sem causar descaracterização. Este quadro precisa ser modificado para a garantia da equiparação de oportunidades.

A finalidade da presente dissertação é averiguar se as diretrizes de preservação e restauro permitem a convergência para a acessibilidade e se a adequação à acessibilidade pode ser implementada mesmo com as limitações necessárias à preservação do bem, e para isso, três etapas-macro foram estabelecidas.

Primeiramente será realizada revisão bibliográfica e análise crítica dos parâmetros existentes, como leis, normas e instruções, que dão suporte para o possível contato entre os campos de preservação e acessibilidade. Com esse foco, será feita leitura pormenorizada da Instrução Normativa no 1, de 2003, do IPHAN, que se refere à interface conjunta de preservação do patrimônio e acessibilidade, já que este é o único instrumento legal existente atualmente, que claramente envolve os dois temas. As recomendações existentes serão avaliadas à luz das teorias de 
preservação e das cartas patrimoniais, elementos essenciais para análise crítica das adaptações dos estudos de caso.

Em um segundo momento, será avaliada a eficácia da adaptação à acessibilidade para pessoas com deficiência e mobilidade reduzida realizada em bens culturais imóveis, abertos a uso público, e os impactos dessas alterações nos mesmos, sob o ponto de vista da preservação. Para tanto, serão estudadas as adequações feitas em três bens culturais imóveis e, assim, verificar se, de forma efetiva, estas permitem a participação de pessoas com deficiência e mobilidade reduzida nos serviços e atividades propostas aos públicos em geral. E se as adaptações são conflitantes ou não com os elementos que motivaram sua preservação.

Os objetos-concretos são:

- Pinacoteca do Estado de São Paulo;

- Centro Cultural Banco do Brasil;

- Casa das Rosas - Espaço Haroldo de Campos de Poesia e Literatura.

Todos são edifícios paulistanos das primeiras décadas do século XX, tombados em diversas esferas e utilizados hoje como espaços de lazer, cultura e recreação, portanto destinados à visitação do público em geral.

Apesar das semelhanças existentes - a época de construção, o uso atual e de não serem edificações térreas -, os estudos de caso apresentam distinções para servir de comparativo em relação à eficácia da adaptação e da preservação: uso original, área construída, ocupação do lote e gabarito de altura. Pretende-se avaliar se essas diferenças refletem em maior ou menor facilidade de adaptação à acessibilidade, na comparação dos casos estudados. 
Também será avaliado o entorno dos edifícios, a fim de verificar as possibilidades de acesso do transporte público e estacionamento até o ponto de interesse, para conferir como isso influencia ou não a utilização do espaço por pessoas com deficiência e mobilidade reduzida.

Não é objetivo desta dissertação a qualidade da acessibilidade ao acervo ou das propostas lúdico-educativas de mediação, mas este ponto será sim levantado, pois isso acarretará maior ou menor interesse na visitação por parte de pessoas com deficiência, especialmente aquelas com limitações sensoriais e cognitivas.

E complementando a avaliação técnica das características de acessibilidade e preservação, pessoas com deficiência serão convidadas a relatar suas opiniões, percepções e sentimentos em relação aos estudos de caso propostos, em busca de saber se as adaptações ocorridas de fato garantem seus anseios de uso e acesso.

No Capítulo 1, Acessibilidade e Preservação, procura-se entender a interação sobre as duas matérias do título. Primeiramente, se mostrou necessário conhecer cada área isoladamente, seus pontos chave para em seguida realizar uma análise conjunta de sua união.

Leis, normas, textos reguladores e referências bibliográficas, que serão a base da análise dos estudos de caso, passam por revisão crítica, neste capítulo, em busca de entender o momento atual em que a temática se encontra. Nesses pontos, é necessário avançar e fazer considerações pertinentes para melhorar a abordagem e aproximação de uma avaliação similar a outras situações que demandam adequações à acessibilidade. Também são apresentados exemplos de bens culturais, no Brasil e no mundo, que receberam adequações à acessibilidade. 
O Capítulo 2, Casa das Rosas, destina-se ao primeiro estudo de caso proposto para a dissertação. Neste capítulo é apresentado o histórico da edificação, características de sua estrutura física, tipologia, uso, infraestrutura urbana e estado de conservação; análise técnica das exigências legais de acessibilidade, dos princípios do Desenho Universal e das diretrizes de preservação em relação à acessibilidade e vice-versa; e relato resumido da percepção dos usuários, compilados utilizando-se a técnica de grupo focal. Ao final, a união de todas os pontos relatados, resulta em conclusões e recomendações de adequação para o estudo de caso.

Os Capítulos 3, Centro Cultural Banco do Brasil, e Capítulo 4, Pinacoteca do Estado de São Paulo, seguem a mesma estrutura proposta para o Capítulo 2.

Em relação aos capítulos de estudos de caso é importante destacar que o capítulo 2 é mais denso que os demais, e isso se deve ao fato de a Casa das Rosas ter figurado em vários trabalhos das disciplinas cursadas ao longo do programa de mestrado, sendo efetivamente analisado ao logo dos três anos disponíveis para tal. Foi tema de um dos Trabalhos Programados, realizados para a qualificação, no qual foram reunidas informações pesquisadas, em fontes primárias e secundárias, sobre o histórico e a materialidade, para permitir a análise de sua importância e identificação de suas alterações, seja para, atender a acessibilidade ou a outras necessidades. Serviu como base para elaborar a metodologia a ser aplicada nos demais casos.

A síntese dos resultados encontrados na pesquisa, o aprendizado obtido durante o trabalho e a verificação do cumprimento dos objetivos, estão expressos em Conclusões finais. 
A autoria de todas as fotos apresentadas nesta dissertação, quando não indicada, é da autora do presente trabalho. 


\section{METODOLOGIA}

Para atingir os objetivos propostos para esta investigação serão utilizados métodos qualitativos, além de consulta a fontes de dados secundários e primários, a serem desenvolvidos conforme descrito a seguir.

\section{Contextualizacão e análise crítica}

Levantamento teórico dos campos de preservação e acessibilidade teorias, normas, leis e diretrizes, matizando seu processo evolutivo e o debate contemporâneo -, para analisar a possibilidade de convergência dos campos, embasada em suas próprias teorias e referências. Em especial, foram analisadas as diretrizes contidas em cartas patrimoniais e na legislação brasileira reguladora das intervenções em bens culturais tombados, para verificar a viabilidade teórica de convergir preceitos como autonomia, direitos humanos, inclusão, segurança e acessibilidade com preservação, reversibilidade, distinguibilidade e mínima intervenção.

\section{Levantamento de dados}

Esta etapa trouxe dados históricos, dimensionais e construtivos da edificação estudada, sua infraestrutura urbana disponível no entorno e programas educativos realizados pelas instituições culturais que as ocupam; também se buscou exemplos de bens culturais adaptados à acessibilidade.

a. Levantamento histórico: reunião de informações sobre cada edifício e seus elementos que motivaram a preservação pelos órgãos oficiais, por meio de fontes secundárias, tais como 
publicações, literatura específica, revistas e plantas, principalmente nas bibliotecas da Faculdade de Arquitetura e Urbanismo da Universidade São Paulo (USP) dos edifícios Vilanova Artigas e Vila Penteado; processos administrativos dos órgãos de preservação; e consulta aos sítios de internet, para outras publicações.

b. Visitas exploratórias: reunião de dados obtidos por fontes primárias, em visitas exploratórias, registros fotográficos e levantamento do espaço construtivo e das condições de acessibilidade, de cada estudo de caso.

c. Infraestrutura urbana: sistema de transporte disponível a cada um dos estudos de caso, incluindo acesso facilitado por transporte individual ou coletivo, aliado às características do entorno, como passeio público, travessias, sinalização etc. Essas informações revelam possíveis facilitadores e/ou complicadores no acesso de pessoas com restrições sensoriais ou de mobilidade aos locais. Para tanto, foram consultados os bancos de dados das empresas prestadoras de serviço de transporte público (São Paulo Transportes - SPTRANS, Companhia do Metropolitano de São Paulo - Metrô, Companhia Paulista de Trens Metropolitanos CPTM), geralmente disponíveis em seus sítios na Internet. As demais informações foram levantadas in loco, com registro de anotações, dimensões e fotografias, e avaliadas com base nas mesmas normalizações já citadas.

d. Programas educativos: entrevista semiestruturadas ou aplicação de questionários de perguntas abertas direcionadas ao 
representante do programa educativo destinado à pessoa com deficiência de cada uma das instituições culturais; quando realizada pessoalmente foi aplicada entrevista semiestruturada em perguntas e temas; quando por correio eletrônico, utilizou-se questionário com perguntas abertas preenchidas pelo respondente. A disponibilidade da pessoa chave foi a definidora da forma de aplicação.

e. Exemplos de adequação: o método de consulta a fontes primárias também foi utilizado para obter dados de bens culturais imóveis adaptados à acessibilidade, no Brasil e no mundo, a fim de servir como referência para todo o estudo.

\section{Análise técnica}

Esta fase se refere tanto à análise das características de acessibilidade quanto de preservação.

a. Leis e normas técnicas de acessibilidade: Os dados levantados foram processados e avaliados de forma comparativa aos parâmetros técnicos contidos nas normas da Associação Brasileira de Normas Técnicas (ABNT), em especial a ABNT NBR 9050/2004. Os parâmetros legais se baseiam no Decreto federal 5.296, de 2 de dezembro de $2004^{2}$ e demais leis relativas à acessibilidade, que se aplicarem a cada caso; quando necessário foi apontada a legislação/norma técnica vigente à época da execução da

\footnotetext{
${ }^{2}$ O referido decreto traz algumas exigências distintas da ABNT NBR 9050/2004, e ao mesmo tempo designa as normas da ABNT como referencial para os parâmetros técnicos.
} 
adaptação, para um melhor entendimento das tomadas de decisão. Esta análise técnica foi feita de forma restrita aos parâmetros contidos nas regulamentações, sem considerar a condição da edificação como bem cultural tombado, pois isso será relativizado em etapa posterior.

b. Desenho Universal: o atendimento aos princípios do Desenho Universal foram avaliados por meio de lista de verificação adaptada pela autora com base na existente no livro Universal Design Handbook, do governo de Calgary, Canadá (2010). Este tipo de codificação de avaliação de desempenho foi apontada por Preiser (In: ORNSTEIN et al., 2010, p. 19) como não tendo sido suficientemente explorada e desenvolvida: "No atual momento, a avaliação de desempenho com foco no desenho universal pode ser considerada crítica e necessita ser desenvolvida".

c. Preservação: Para análise das alterações à acessibilidade em relação aos elementos que compõem o valor histórico e cultural da edificação preservada, foi levado em conta 0 debate contemporâneo da preservação, contido na Carta de Veneza e no Decreto-lei no 25, de 30 de novembro de 1937. Com base nas visitas exploratórias e nos dados, como fotografias, memoriais e plantas, contidos em processos administrativos dos órgãos de preservação e publicações, foram verificadas alterações, divididas em adições, subtrações, ou sobreposições, que tenham ocorrido para promover a acessibilidade nos espaços. 


\section{Percepcão do usuário:}

Seguindo o lema "Nada sobre nós sem nós", cunhado em 1986 por William Rowland no artigo "Nada Sobre Nós, Sem Nós: algumas reflexões sobre o movimento das pessoas com deficiência na África do Sul" (SASSAKI, 2007a), e amplamente proferido pelos ativistas da inclusão, buscou-se ouvir os protagonistas das adaptações, em torno dos quais e para o quais se constrói e se justifica toda esta pesquisa.

Para dar voz às suas percepções em relação aos estudos de caso, ainda que em pequena amostra, optou-se pela aplicação da técnica de grupo focal. $\mathrm{O}$ objetivo principal é identificar percepções, sentimentos, atitudes e ideias dos participantes a respeito dos estudos de caso, o uso de seus espaços e de suas atividades propostas. Segundo, Zeisel $(1997$, p.137) as entrevistas focadas são particularmente adequadas para pesquisas ambiente-comportamento, onde se busca considerações pessoais do entrevistado em relação a situações complexas. Realizada em grupo, tem a vantagem de estimular discussões e ideias em torno de um tema, o que, possivelmente, não aconteceria em uma entrevista isolada. $\mathrm{Na}$ aplicação da técnica de grupo focal pode haver inibição, por parte dos participantes, em expressar sua opinião em frente às demais pessoas, situação que deve ser contornada pelo moderador, que também tem a função de estimular o diálogo e a participação de todos.

Inicialmente, decidiu-se por um grupo de cinco participantes com diferentes deficiências: um usuário de cadeira de rodas, uma pessoa cega, uma surda, uma com baixa estatura e uma idosa. Foram convidadas pessoas que pudessem participar da pesquisa conforme a caracterização explicitada. No entanto, o convidado com baixa estatura, apesar de responder positivamente ao convite, não 
efetivou sua participação, mesmo após novas solicitações, inclusive de proposta de participação fora do formato de grupo focal, em entrevista ou questionário. Como não foi possível substitui-lo a tempo desta pesquisa, resultou-se, assim, um grupo de quatro pessoas com deficiência.

Cada um dos participantes visitou os três locais de estudo, acompanhados ou não, entre novembro e dezembro de 2011, sob a orientação de que realizassem uma visita espontânea, sem percursos pré-determinados.

Anteriormente à apuração das informações, a autora, no papel de moderadora da discussão, elaborou um roteiro para guiar o debate entre os participantes e estimular a abordagem de determinados temas. Toda a discussão foi registrada em áudio, para permitir a transcrição das informações após a discussão; um intérprete de Libras participou da sessão para possibilitar o registro em áudio dos relatos da pessoa surda. A caracterização de cada participante está descrita a seguir:

a. Pessoa usuária de cadeira de rodas (PCR): homem, 38 anos, trabalha em empresa metalúrgica; deficiência física em decorrência de acidente com arma de fogo.

b. Pessoa com deficiência visual (PDV): homem, 30 anos, formação de nível superior em Letras, trabalha com tecnologia; deficiência visual parcial - vê vultos com o olho esquerdo e menos de $10 \%$ com o direito - e utiliza bengala longa para sua orientação.

c. Pessoa com deficiência auditiva (PS): mulher, 30 anos, formação de nível superior em Artes Visuais, Pedagogia e Letras-Libras, ministra aulas de arte em escolas para surdos, nos níveis Fundamental II e Médio; nasceu ouvinte e com seis meses de idade uma infecção 
causou perda total da audição do lado esquerdo e pequeno resíduo no lado direito; foi oralizada ${ }^{3}$ e somente aos 19 anos aprendeu Língua Brasileira de Sinais (Libras); apesar de ter realizado a visita com acompanhante ouvinte, este não interferiu, simulando condição de surdo, se comunicando em Libras.

d. Pessoa idosa (PI): mulher, 69 anos, aposentada; possui mobilidade reduzida em decorrência da idade e de cirurgias realizadas; tem dificuldade para levantar o braço, o que prejudica, inclusive, no ato de subir escadas.

\footnotetext{
${ }^{3}$ Oralismo é o método de educação voltado às crianças com perda auditiva para tentar moldá-la como pessoa ouvinte. No final do século XIX, o método oral foi escolhido como o melhor para a educação dos surdos e a língua de sinais proibida, em todo o mundo. Somente na década de 60 é que a língua de sinais ganharia referência científica para ser considerada língua com estrutura própria. Em 2002, é reconhecida pelo governo brasileiro como meio legal de comunicação e expressão. Cf. BRASIL, 2010c, p. 41-42.
} 


\section{ACESSIBILIDADE E PRESERVAÇÃO}

As temáticas da acessibilidade e da preservação surgiram em épocas completamente distintas e só atualmente é que a convergência dos temas tem sido discutida em busca de atender adequadamente a ambos. É certo que as questões preservacionistas têm recebido muito mais atenção do que o tema da acessibilidade, esta muito mais recente inclusive no que diz respeito à legislação e à produção teórica.

Para melhor fundamentar a discussão, é importante destacar alguns pontos de cada um dos campos disciplinares para entender como suas trajetórias individuais têm convergido na atualidade.

\subsection{Conservação e Restauro}

O conhecimento teórico e evolutivo dos campos da conservação e do restauro são bastante extensos e complexos para serem expostos aqui, considerando que este não é o objetivo desta dissertação. Diversos autores dedicaram trabalhos completos a esse objetivo e merecem a leitura por quem desejar uma reflexão mais aprofundada e uma visão mais ampla das temáticas. Entre as inúmeras contribuições ao desenvolvimento da teoria da restauração, podemos destacar autores como Boito (2002), Brandi (2005), Riegl (2006), Ruskin (2008) e Viollet-le-Duc (2007). Além de autores que produziram importantes reflexões sobre a trajetória desses: Choay (2006), Kühl (1998, 2005, 2006, 2010), Pinheiro (2011) e Cunha (2004, 2006). Aqui serão expostos os principais conceitos 
que fomentam o debate contemporâneo do campo da preservação e que deram forma aos conceitos de preservação e restauro propostos atualmente.

Neste recorte, o primeiro teórico a ser destacado é Camilo Boito (1836$1914)^{4}$, com sua teoria de restauro filológico ou científico. Foi por volta de 1880, que Boito começou a assumir a postura que o notabilizou, com os critérios de intervenção apontados no Congresso dos Engenheiros e Arquitetos Italianos em Roma em 1883, que se tornaram os sete princípios adotados pelo Ministério de Educação, conforme elencado por Kühl (In: BOITO, 2003, p. 21 e 22):

[...] ênfase no valor documental dos monumentos, que deveriam ser preferencialmente consolidados a reparados e reparados a restaurados; evitar acréscimos e renovações, que, se fossem necessários, deveriam ter caráter diverso do original, mas não poderiam destoar do conjunto; os completamentos de partes deterioradas ou faltantes deveriam, mesmo se seguissem a forma primitiva, ser de material diverso ou ter incisa a data de sua restauração ou, ainda, no caso das restaurações arqueológicas, ter formas simplificadas; as obras de consolidação deveriam limitar-se ao estritamente necessário, evitando-se a perda dos elementos característicos ou, mesmo, pitorescos; respeitar as várias fases do monumento, sendo a remoção de elementos somente admitidas se tivessem qualidade artística manifestamente inferior à do edifício; registrar as obras, apontando-se a utilidade da fotografia para documentar a fase antes, durante e depois da intervenção, devendo o material ser acompanhado de descrições e justificativas e encaminhado ao Ministério da Educação; colocar uma lápide com inscrições para apontar a data e as obras de restauro realizadas.

Os princípios de restauro desenvolvidos por Boito ficaram conhecidos especialmente através de Os Restauradores, transcrição de uma conferência realizada durante a exposição de Turim em 1884, onde ele apresentou convicções advindas de sua experiência. Este documento é base para conceitos contemporâneos de restauração.

\footnotetext{
${ }^{4}$ Camillo Boito nasceu em Roma no ano de 1836. Estudou música e literatura, com o seu irmão Arrigo Boito, e frequentou o curso de Belas Artes em Veneza. Foi arquiteto, engenheiro, professor, teórico, literato, historiador da arte e se dedicou a estudar especialmente o campo da preservação e do restauro. Situava-se justamente entre a modernidade técnica e a apreciação da arte, o que o tornou chave para discutir o campo da preservação.
} 
Boito utilizou como referência obras de Carlos Cattaneo (1801-1869), Giuseppe Mongeri, Giuseppe Fiorelli (1823-1896) e Tito Vespasiano Paravicini (1832-1899). Foi Paravicini quem atentou para o perigo da falsificação e a necessidade de distinguir qualquer intervenção da matéria original. Boito acredita que a conservação constante é sempre o melhor caminho. Essa vertente de restauro instituída por Boito ficou conhecida como filológico, onde o monumento histórico tem valor documental, e a edificação é considerada um documento histórico.

Importante citar a contribuição de Alois Riegl (1858-1905) $)^{5}$ que foi responsável por um profundo trabalho de reflexão no início do século $\mathrm{XX}$, em relação à preservação. Riegl em $O$ Culto Moderno dos Monumentos ${ }^{6}$ adota a postura de observador das várias formas de relacionamento da sociedade com os monumentos históricos, identificando, em categorias de valores, que podem coexistir no mesmo monumento, mesmo sendo contraditórios. Choay (2006, p. 170) aponta que, segundo Riegl, as decisões "[...] dependem de compromissos negociáveis em cada caso particular, em função do estado do monumento e do contexto social e cultural em que se insere". O historiador sinaliza a individualidade dos monumentos históricos e a ausência de fórmulas genéricas. Ele vê maior importância no valor que é concedido ao monumento do que o monumento em si. E esse é o grande diferencial de Riegl, que analisa as relações e as exalta como definidoras dos valores dos monumentos históricos.

Conectado a este pensamento, de que os valores são definidos pela

\footnotetext{
${ }^{5}$ Nascido em Linz, na Áustria, Riegl estudou história e filosofia na Universidade de Viena. Dirigiu por mais de 10 anos o departamento de tecidos do Museu Austríaco de Artes Decorativas, onde adquiriu experiência como conservador. Em 1902 assumiu a presidência da Comissão Austríaca de Monumentos Históricos. O seu livro Culto Moderno dos Monumentos, de 1903, faz parte de um projeto de organização legislativa para a conservação na Áustria.

${ }^{6}$ A. Riegl, Der Moderne Denkmalkultus, Viena, 1903, tradução brasileira de E. Peixoto e A. Vicentine. O culto moderno dos monumentos, Goiânia, Ed. da UCG, 2006.
} 
sociedade $^{7}$, Cesare Brandi (1906-1988) ${ }^{8}$ foi além, e viu na restauração um ato crítico-cultural do presente, relativizando toda ação nesse sentido, de forma a se apoiar na individualidade que deveria ser dada a cada intervenção. Tratando as dimensões formais e documentais ao mesmo tempo, de forma dialética, Brandi procurava com o restauro crítico tirar a subjetividade do ato de preservar e de restaurar.

Como diretor do Instituto Central de Restauração (ICR) de Roma, Cesare Brandi coordenou a restauração de obras de arte destruídas nos bombardeios da Segunda Guerra Mundial, entre outras, e dessa experiência surge sua Teoria da Restauração ${ }^{9}$ em 1963. Segundo Brandi, “a restauração constitui o momento metodológico do reconhecimento da obra de arte, na sua consistência física e na sua dúplice polaridade estética e histórica, com vistas à sua transmissão para o futuro" (2005, p. 30, grifo do autor). Ponto importante da sua definição está na chave metodológica que envolve o restauro; processo crítico e científico que legitima qualquer intervenção e retira o empirismo da ação (BRANDI, 2005, p. 100).

Brandi criou importante base para o desenvolvimento dos preceitos de restauro que vigoram no século $\mathrm{XXI}$, utilizando-se de um ato crítico para embasar a intervenção. Ele apresenta claramente conceitos como distinguibilidade, reversibilidade e ambiência, que devem ser levados em consideração no momento da intervenção.

\footnotetext{
${ }^{7}$ Os valores estão na sociedade, e não nos monumentos históricos, porque depende da sociedade querer ou poder identificar tais valores, para que edificações sejam nomeadas e consequentemente preservadas para as gerações futuras.

${ }^{8}$ Cesare Brandi nasceu em Siena, tendo falecido na mesma cidade. Licenciado em Direito (Siena, 1927) e em História da Arte (Firenze 1928), foi funcionário da Administração de tutela do Ministério da Cultura, entre 1930 e 1960. A partir de 1939 tornou-se diretor do Instituto Central de Restauro, em Roma, onde permaneceu por 20 anos. Ensinou História da Arte na Universidade de Palermo e na de Roma.

${ }^{9}$ BRANDI, C. Teoria da restauração. Tradução de Beatriz Mugayar Kühl. 2ª ${ }^{a}$ ed. Cotia: Ateliê Editorial, 2005. 261 p.
} 
Brandi coloca que "a integração deverá ser sempre e facilmente reconhecível; mas sem que por isto se venha a infringir a própria unidade que se visa a reconstruir" (2005, p. 47). Ou seja, define aí o princípio de distinguibilidade.

Pensando na evolução das técnicas e amadurecimento das ideias, e principalmente que o restauro é um ato do presente, Brandi aponta "que qualquer intervenção de restauro não torne impossível mas, antes, facilite as eventuais intervenções futuras" (2005, p. 48), promovendo a reversibilidade.

E a preservação da ambiência é fundamental, pois o espaço no qual a arquitetura se insere coexiste com o próprio monumento e, portanto sua restauração deve ter isso como guia condutor.

Em 1964, ano seguinte à Teoria da Restauração, é redigida a Carta de Veneza, na qual é possível verificar a permanência desses conceitos. Como aponta Kühl (2010, p. 295), a Carta de Veneza ${ }^{10}$ "é herdeira direta do restauro crítico e, indiretamente, também da teoria brandiana". É na Carta de Veneza ${ }^{11}$ que o conceito de monumento histórico é ampliado, passando a incluir, por exemplo, sítios históricos e edificações rurais. Também ganha ênfase o reconhecimento do valor das diversas camadas, sendo a exclusão de elementos adicionados ao longo da vida da edificação um ato excepcional.

A Declaração de Amsterdã, elaborada em 1975 pelo Congresso do Patrimônio Arquitetônico Europeu, focou em conceitos e diretrizes para abranger no planejamento urbano e regional a conservação de centros históricos. Essa

\footnotetext{
${ }^{10}$ Seu conteúdo foi elaborado no II Congresso Internacional de Arquitetos e de Técnicos de Monumentos Históricos, realizado em Veneza, em maio de 1964.

${ }^{11}$ A Carta de Veneza é uma das cartas patrimoniais, e que segundo Kühl (2010, p. 300) "uma carta é a repercussão do estágio das idéias de um determinado momento", sem a pretensão de ser um ponto final referencial para a restauração e sim um ponto inicial para a metodologia de intervenção, a partir das especificidades do objeto da restauração, e da respectiva realidade cultural.
} 
Declaração propôs o conceito de conservação integrada, onde a preservação do ambiente garantirá melhor compreensão da significação do patrimônio arquitetônico. Faz-se necessário, também, o envolvimento dos valores a serem preservados na vida cotidiana da população, priorizando a utilização do monumento histórico, para fazer perdurar sua riqueza cultural.

Outras cartas, recomendações e convenções foram e continuam a ser elaboradas com o objetivo de fornecer diretrizes universais para a metodologia de restauração de monumentos. Porém cabe ressaltar que as diretrizes contidas na Carta de Veneza permanecem até hoje como referência aos profissionais envolvidos na restauração. Novas linhas teóricas nascem baseadas no histórico da preservação e nas ações tomadas ao longo dos séculos para garantir a transmissão de elementos referenciais da paisagem para as gerações futuras, como parte de sua cultura e de autoconhecimento. De fato não é possível retroceder nas conquistas metodológicas de aproximação e intervenção a que chegamos hoje. Mas, sempre há novas demandas e tecnologias que contribuem para que a discussão mantenha-se ativa e renovada. É o caso, precisamente, do reconhecimento de que, para a fruição dos bens culturais - patrimônio de todos -, são necessárias determinadas condições que devem ser contempladas nos projetos de restauro, utilizando-se das diretrizes preservacionistas para esse propósito.

\subsection{Inclusão e Acessibilidade}

As condições atuais alcançadas pelos militantes da inclusão e dos direitos das pessoas com deficiência nem sempre foram assim. As pessoas com deficiência foram marginalizadas por muito tempo, assim como outros segmentos excluídos da 
sociedade, como mulheres, negros, índios etc. Só com a abertura política no Brasil, na década de 1970, essas camadas tiveram força para exigir o respeito aos seus direitos, dentro da sociedade livre.

As pessoas com deficiência foram por muito tempo vistas como estranhas, monstruosas, assustadoras, místicas, inúteis, repulsivas, doentes, desventuradas, incapazes, pecadoras. Tinham as vidas eliminadas, ou eram retiradas do convívio social e escondidas da vista alheia. Foram tratadas com dó e pena e trancafiadas em instituições de assistência à saúde, e dependiam da caridade, em particular da religiosa.

$\mathrm{Na}$ Roma e na Grécia antigas a prática comum era sacrificar ou abandonar crianças que nascessem com qualquer deficiência. Com o surgimento do cristianismo no Império Romano iniciou-se a prática de caridade (LARAIA, 2009, p. 26), e criaram-se os primeiros hospitais para indigentes e pessoas com deficiência. Na Idade Média, o mais comum é que essas pessoas fossem isoladas e asiladas. Com o Renascimento, na Idade moderna, houve uma evolução das ciências naturais, o que permitiu a melhora da condição de vida das pessoas com deficiência, por meio de tratamentos médicos, porém ainda eram vistos como doentes.

A Revolução Industrial, no século XVIII, as Guerras Mundiais e a Guerra do Vietnã, no século XX, foram momentos que culminaram em avanços para temas como direitos humanos, reabilitação, seguridade social, tecnologia assistiva e acessibilidade, para atender às demandas da grande quantidade de pessoas com deficiência adquirida. No Brasil, a partir da década de 1950 foram inaugurados diversos centros de reabilitação física, motivados pelo surto de poliomielite no 
País ${ }^{12}$, como a Associação Brasileira Beneficente de Reabilitação - $\operatorname{ABBR}^{13}(1954)$ a Associação de Assistência à Criança Defeituosa - $A A C D^{14}$ (1950) e Instituto de Ortopedia e Traumatologia - $10 T^{15}$ do Hospital das Clínicas da Faculdade de Medicina da Universidade de São Paulo (1953), que seguiam de forma geral, como modelo, as técnicas desenvolvidas nos Estados Unidos e na Europa, para a reabilitação pós-guerra ${ }^{16}$.

Até então vigorava o modelo integracionista, em que se buscava tratar a deficiência para atender padrões de normalidade, idealizados a partir de uma média referencial da sociedade. Não era preocupação efetiva a inclusão, o reconhecimento e valorização das diferenças, da diversidade humana, dos direitos humanos, da capacidade de contribuir para a sociedade e de desenvolver-se como cidadão. E assim, toda a carga centrava-se na pessoa com deficiência, única responsável por adequar-se aos padrões.

\footnotetext{
${ }^{12}$ Segundo Brasil (2010, p. 35), a "poliomielite foi observada no início do século XX, no Rio de Janeiro (1907-1911) e em São Paulo (1918). Porém, surtos de considerável magnitude ocorreram na década de 1930, em Porto Alegre (1935), Santos (1937), São Paulo e Rio de Janeiro (1939). A partir de 1950, foram descritos surtos em diversas cidades, com destaque para o de 1953, a maior epidemia já registrada no Brasil, que atingiu o coeficiente de 21,5 casos por 100 mil habitantes, no Rio de Janeiro".

${ }^{13}$ A associação carioca foi idealizada pelo arquiteto Fernando Lemos, cujo filho possuía sequelas de poliomielite. Sua missão é "oferecer serviços integrados de reabilitação física a pessoas de todas as idades com qualidade e responsabilidade social estimulando potencialidades e independência para uma vivência plena e digna na sociedade", segundo informação contida em seu site. Disponível em: < http://www.abbr.org.br/abbr/institucional/home.html>. Acesso em: 23 maio 2011.

${ }^{14}$ Hoje a denominação mudou para Associação de Assistência à Criança Deficiente. A missão da AACD é "promover a prevenção, habilitação e reabilitação de pessoas com deficiência física, especialmente de crianças, adolescentes e jovens, favorecendo a integração social", conforme informações do seu site. Disponível em: http://www.aacd.org.br. Acesso em: 23 maio 2011.

${ }^{15}$ Com a criação do Instituto este recebeu "os casos de Poliomielite Anterior Aguda, em fase de comprometimento respiratório", na década de 1950, durante o surto no país. Hoje sua missão é prestar assistência especializada na área de ortopedia e traumatologia e desenvolver atividades de ensino e pesquisa avançada. Disponível em: <http://www.iothcfmusp.com.br/pt/institucional/quemsomos/>. Acesso em: 23 fev. 2012.

${ }^{16}$ A escola de reabilitação da ABBR para formar fisioterapeutas e terapeutas ocupacionais seguia como modelo o programa curricular da Escola de Reabilitação da Columbia University. A AACD foi criada pelo Dr. Renato da Costa Bomfim que desejava ter no Brasil um centro de reabilitação com a mesma qualidade dos centros que conhecia no exterior.
} 
Conforme Moraes (2007, p. 27), nos Estados Unidos e Europa, a década de 1970 foi muito significativa para as ações de acessibilidade, "uma vez que as leis formuladas aqui [década de 1970] já incluíam aspectos do que Silverstein (2000) chama de novo paradigma da deficiência, que considera as limitações como parte normal e natural da vida humana". Em 1975 a ONU - Organização das Nações Unidas - aprovou a Declaração dos Direitos das Pessoas Deficientes ${ }^{17}$, defendendo o respeito à sua condição humana, o direito de receber o mesmo tratamento que qualquer outro cidadão, e poder usufruir dos direitos fundamentais.

No ano seguinte, a Organização Mundial de Saúde (OMS), adotou a resolução $W H A 29.35^{18}$, na qual aprovou a Classificação Internacional das Deficiências, Incapacidades e Desvantagens (CIDID), em caráter experimental. Tratava-se de uma classificação de deficiências e desvantagens, em um suplemento adicional e não mais como parte integrante da Classificação Internacional de Doenças (CID). Este é um marco extremamente importante, por desvincular "deficiência" de "doença". Após várias revisões e testes, em 2001 seria publicada a resolução WHA54.21 ${ }^{19}$, que atualiza conceitos e institui a Classificação Internacional de Funcionalidade, Incapacidade e Saúde (CIF). Segundo esse modelo (FARIAS; BUCHALLA, 2005, p. 189):

[...] a incapacidade é resultante da interação entre a disfunção apresentada pelo indivíduo (seja orgânica e/ou da estrutura do corpo), a limitação de suas atividades e a restrição na participação social, e dos fatores ambientais que podem atuar como facilitadores ou barreiras para o desempenho dessas atividades e da participação.

Volta-se, portanto, não somente para a pessoa, mas também para o

\footnotetext{
17 Instituído pela Resolução o 3447 de 1975 da Assembleia Geral da ONU. Disponível em: <http://www.centroruibianchi.sp.gov.br/usr/share/documents/Decl_Direitos\%20das\%20Pessoas\%20D eficientes.doc>. Acesso em: 11 maio 2011.

${ }^{18}$ Aprovada em maio de 1976, na 29a Assembleia Mundial de Saúde.

${ }^{19}$ Aprovada em maio de 2001, na 54를 Assembleia Mundial de Saúde.
} 
ambiente no qual está inserida para uma avaliação mais completa ${ }^{20}$.

Mas o ano chave, em âmbito global, para a valorização das pessoas com deficiência, foi 1981, com a instituição do Ano Internacional das Pessoas Deficientes (AIPD) pela ONU ${ }^{21}$, sob o tema "Participação Plena e Igualdade". Foi um momento de grande atenção da mídia e dos governos para motivar ações contínuas voltadas às pessoas com deficiência. Também foi um despertar para as próprias pessoas com deficiência sobre os seus direitos, principalmente para aquelas que ainda não estavam engajadas no debate.

A partir deste marco, leis e normas são estabelecidas no mundo inteiro para promover a acessibilidade e a integração. O Ano Internacional deu origem ao Programa de Ação Mundial para as Pessoas Deficientes $(P A M)^{22}$, o qual definia várias ações para a prevenção da deficiência e a equiparação de oportunidades das pessoas com deficiência em relação às demais pessoas, garantindo sua completa inserção na sociedade.

O PAM alertava que milhões de pessoas com deficiência no mundo viviam em desvantagem, devido às barreiras sociais e físicas impostas, que impediam o pleno usufruto de seus direitos:

[...] é o meio que determina o efeito de uma deficiência ou de uma incapacidade sobre a vida cotidiana da pessoa. A pessoa vê-se

\footnotetext{
20 Segundo a OMS, a CID e a CIF são complementares. A CID fornece informações para padronização de diagnóstico de doenças, distúrbios e outras condições de saúde, e a ClF sobre o nível de funcionalidade. A interação entre as duas ferramentas fornece um quadro mais completo sobre a saúde do indivíduo. Conforme apontado pela OMS, duas pessoas com a mesma doença podem ter diferentes níveis de funcionalidade, e duas pessoas com o mesmo nível de funcionalidade não têm necessariamente a mesma condição de saúde. E a CIF tem aplicação universal, ou seja, aponta a funcionalidade de qualquer pessoa, não sendo voltada exclusivamente às pessoas com deficiência.

${ }^{21}$ Instituído pela Resolução oㅡ 31/123 de 1979 da Assembleia Geral da ONU. Disponível em: < http://daccess-ods.un.org/TMP/9029303.19309235.html>. Acesso em: 11 maio 2011.

22 Instituído pela Resolução no 37/52 de 1982 da Assembleia Geral da ONU. Tradução para o português disponível em: <http://portal.mj.gov.br/corde/progra_acao_mundial.asp>. Acesso em: 05 maio 2011.
} 
relegada à invalidez quando the são negadas as oportunidades de que dispõe, em geral, a comunidade, e que são necessárias aos aspectos fundamentais da vida, inclusive a vida familiar, a educação, o trabalho, a habitação, a segurança econômica e pessoal, a participação em grupos sociais e políticos, as atividades religiosas, os relacionamentos afetivos e sexuais, o acesso às instalações públicas, a liberdade de movimentação e o estilo geral da vida diária.

Como já citado, a movimentação mundial durante a década de 1970 e a instituição do AIPD, em 1981, provocaram um despertar na sociedade para ações voltadas a atender este público até então sem voz ativa para suas demandas. Mundialmente, legislações, políticas públicas, normas e orientações são elaboradas com base nas medidas propostas pelo PAM.

Neste contexto, a Associação Brasileira de Normas Técnicas $(A B N T)^{23}$, em setembro de 1985 , cria a sua primeira norma ${ }^{24}$ para tratar do tema acessibilidade, mesmo sem utilizar tal conceito $^{25}$ : ABNT NBR 9050 - adequação das edificações e do mobiliário urbano à pessoa deficiente. Seu objetivo era: "[fixar] as condições exigíveis, bem como os padrões e as medidas que visam propiciar às pessoas deficientes melhores e mais adequadas condições de acesso aos edifícios de uso público e às vias públicas urbanas".

Um marco importante na história da nação brasileira também trouxe importante avanço na proteção dos direitos humanos das pessoas com deficiência: a

\footnotetext{
${ }^{23}$ Segundo a ABNT (2006, p.84), desde 1954 o processo de elaboração de uma Norma Brasileira é iniciado por manifestação da sociedade. A demanda, se justificada, é repassada a uma Comissão de Estudo (CE) da Associação que, preferencialmente, a elabora com base em normas internacionais, de acordo com o Código de Boas Práticas em Normalização da ISO (International Organization for Standardization) e OMC (Organização Mundial do Comércio). A participação na CE é voluntária e aberta a qualquer interessado no assunto. $O$ projeto é submetido à consulta nacional para receber sugestões e críticas sobre o seu conteúdo, antes de ser publicada como Norma Brasileira e disponibilizada à sociedade.

${ }^{24}$ A ISO define norma técnica como "uma especificação técnica acessível ao público, aprovada por organismos de normalização, estabelecida com a cooperação e com o consenso das partes interessadas embasada nos resultados conjuntos da ciência, da tecnologia e da experiência, tendo como objetivo conseguir benefícios para a comunidade" (apud CAMBIAGHI, 2007, P. 62)

${ }^{25} \mathrm{O}$ termo acessibilidade não aparece na primeira edição da norma, porém, Segundo Moraes (2007, p. 62) um esboço deste conceito já figurava: "[...] propiciar às pessoas deficientes melhor e mais adequadas condições de acesso [...]".
} 
promulgação da Constituição Federal brasileira. "A Assembleia Nacional Constituinte (1987-1988), envolvida no espírito dos novos movimentos sociais, foi a mais democrática da história do Brasil, com canais abertos e legítimos de participação popular" (BRASIL, 2010c, p.47). Durante os debates da Constituinte, os grupos de pessoas com deficiência fizeram suas demandas ser ouvidas, para ter seus direitos garantidos. Foi grande o avanço na legislação, que promoveu a inclusão das pessoas com deficiências nas várias áreas da vida cotidiana, como saúde, educação, transporte e o espaço urbano e edificado.

É também na década de 1980 que surge o conceito do Desenho Universal, criado pelo arquiteto Ron Mace ${ }^{26}$. Em 1985, o arquiteto utilizou pela primeira vez o termo, que significa "criação de produtos e espaços que podem ser usados pela maior quantidade de pessoas possível, sem precisar de adaptação ou projeto especial" (PREISER; OSTROFF, 2001). O conceito de Desenho Universal foi gerado na década de 1950, com os projetos arquitetônicos que visavam a inclusão das pessoas com deficiência. Durante os anos 1970, os governos da Europa e dos EUA começaram a criar normas para o que era chamado de "projeto acessível". Nesta mesma época, o arquiteto norte americano Michael Bednar cria o barrier-free design (projeto livre de barreiras). Neste momento, as barreiras eram algo comum no ato projetual; sua eliminação, segundo Bednar, visava aumentar a capacidade funcional de todos (MORAES, 2007, p. 33).

O conceito pensado por Ron Mace evolui deste ponto, afirmando que os espaços, os equipamentos e a comunicação não precisam ser especialmente

\footnotetext{
${ }^{26}$ Ronaldo L. Mace (1941-1998) formou-se pela Escola de Design da Universidade da Carolina do Norte, em 1966. Aos nove anos contraiu pólio, o que fez com que fosse usuário de cadeira de rodas a maior parte de sua vida. Assim, experimentou pessoalmente o estigma da deficiência, especialmente em relação à concepção dos espaços não preparados para incluí-lo.
} 
pensados para pessoas com deficiência, e sim voltados a todos, valendo-se da diversidade humana para propor as soluções de desenho. Ele desenvolveu sete princípios, que devem ser usados pelos projetistas desde a concepção, ou quando da adaptação de algo existente:

1. Uso equitativo: ambientes ou produtos atendendo a todos os grupos, independente de suas características, como habilidade ou idade, sem segregação ou distinção de uso. Por exemplo, uma porta de abertura automática por sensor, que facilita o acesso de todos, pessoas altas ou baixas, em cadeira de rodas ou não, com ou sem sacolas, etc.;

2. Uso flexível: que garanta maneiras diferentes de uso, a ser definido pelo usuário, suas preferências e habilidades. Por exemplo, uma tesoura que pode ser usada por canhotos ou destros;

3. Uso simples e intuitivo: fácil compreensão do espaço ou de produtos, independente da experiência do usuário, seu nível de formação, conhecimento de idioma ou nível de concentração. Por exemplo, uma sinalização ambiental que se utiliza de pictogramas e outros símbolos de fácil compreensão;

4. Informação fácil e perceptível: comunicação eficaz ao usuário das informações necessárias, independente de sua capacidade sensorial. As informações devem apresentar-se de forma visual, auditiva e tátil, de forma redundante e assim percebida por diferentes pessoas. Por exemplo, um elevador com avisos sonoros 
e visuais, painel e placa em braille e em relevo, todos esses elementos, informando o andar de parada;

5. Tolerância ao erro: minimizar os riscos e consequências de ações acidentais. Se utiliza de avisos de situações de risco, isola elementos que apresentem algum perigo e soluções que minimizam falhas. Por exemplo, barras e banco no boxe do chuveiro como elementos que evitam a queda de pessoas idosas, além de fechamento com cortina que facilita o socorro e minimiza a consequência do acidente, diferente de um boxe fechado por vidro;

6. Baixo esforço físico: uso eficiente e confortável com o mínimo de fadiga muscular do usuário, mantendo uma posição neutra do corpo, e sem necessitar de ações repetitivas. Por exemplo, uma torneira acionada por sensor que não exige sequer mobilidade ou destreza manual para seu funcionamento; ou uma rampa de baixa inclinação longitudinal, que é suavemente transposta;

7. Dimensão e espaço para aproximação e uso: o espaço ou equipamento é dimensionado para permitir sua utilização independente do tamanho do corpo, da postura e da mobilidade do usuário. Por exemplo, um bloqueio no acesso de um edifício, que tem altura confortável para aproximar o cartão de acesso, e largura suficiente de passagem para pessoas em cadeira de rodas, com malas, usuárias de muletas, empurrando carrinho de bebê ou carregando sacolas.

Por todos os princípios norteadores do Desenho Universal, elaborados 
pelo Center for Universal Design ${ }^{27}$ (CUD) da Universidade da Carolina do Norte, fica clara a diferença entre um ambiente ou objeto criado pensando exclusivamente nas características antropométricas de uma pessoa com deficiência, e aquele pensado de forma a atender a uma diversidade humana, trazendo conforto e segurança para todos, inclusive às pessoas com restrições sensoriais, cognitivas ou de mobilidade. Portanto, um espaço acessível é aquele, em que "[...] todos os usuários podem ingressar, circular e utilizar todos os ambientes e não apenas parte deles. [...] Assim o termo acessibilidade representa uma meta ampla de inclusão, não um eufemismo" (CAMBIAGHI, 2011, p. 77). Moraes (2007, p. 39) aponta que o Desenho Universal é um bom investimento, tanto para a qualidade de vida, como em aspectos econômicos, e exemplifica com um estabelecimento comercial que potencialmente irá atrair mais clientes, ao aplicar seus princípios. Na verdade o Desenho Universal vai além, pois costuma-se imaginar que a acessibilidade aumenta os custos; no entanto, requer investimento baixo em relação aos benefícios. Ademais investir em acessibilidade resulta na verdade em economia, se pensarmos na segurança dos usuários no espaço e em sustentabilidade, pois evita-se refazimentos posteriores.

A norma brasileira, que nascia no mesmo ano que o Desenho Universal, não se utilizou deste conceito. Ela estava muito mais voltada para a eliminação de barreiras, em especial para os usuários de cadeiras de rodas, do que para pensar em ambientes para todos. E pouco foi pensado para atender às pessoas que tinham qualquer nível de comprometimento sensorial ou cognitivo. Segundo Prado et al.

\footnotetext{
${ }^{27}$ Centro de pesquisa, informação e desenvolvimento tecnológico para avaliar, desenvolver e promover iniciativas que tenham como meta o desenho universal, em habitações, edifícios, ambientes externos e urbanos e produtos afins. O CUD foi fundado por Ron Mace em 1989. Os princípios foram desenvolvidos e compilados por diversos defensores do Desenho Universal, incluindo Ron Mace, em 1997. Informações obtidas no site do CUD. Disponível em: <http://www.ncsu.edu>. Acesso em: 19 maio 2011.
} 
(2010, p. 12) o Desenho Universal só chegou ao Brasil em meados dos anos 1990, "pelas mãos de profissionais e acadêmicos envolvidos, ainda que de forma incipiente, com as questões de acessibilidade". Foi em 1994, no VI Seminário IberoAmericano de Acessibilidade ao Meio Físico, realizado no Rio de Janeiro, que o arquiteto americano Edward Steinfeld apresentou o conceito de Desenho Universal. Este conceito foi imediatamente adotado pelo grupo que trabalhava na primeira revisão da NBR 9050, que na ocasião estava na redação do texto final.

Em outubro daquele ano era publicada a primeira revisão da NBR 9050, sob o título Acessibilidade de pessoas portadoras de deficiências a edificações, espaços, mobiliários e equipamentos urbanos. Enquanto na primeira edição havia uma denotação de que a deficiência era a causadora da incapacidade ${ }^{28}$, nesta revisão há o início da transposição para o ambiente. Aqui o tema acessibilidade aparece desde o título; e é definido em seu texto como "possibilidade e condição de alcance para utilização, com segurança e autonomia, de edificações, espaço, mobiliário e equipamentos urbanos". Moraes (2007, p. 64) acredita que a nova norma de 1994 ainda carrega a deficiência como fator limitante à pessoa, apesar do avanço citado, pois o ambiente construído não é ressaltado como fator decisivo, como de fato o é.

Em 2000 tem início a nova revisão da NBR 9050, que seria publicada em 2004, com o título Acessibilidade a edificações, mobiliários, espaços e equipamentos urbanos. Reflete-se, já no título, o conceito de Desenho Universal com a supressão do termo "pessoas portadoras de deficiência", buscando assim, tirar o foco de um grupo específico. E atualmente, desde 2008, nova revisão está em andamento para,

\footnotetext{
${ }^{28}$ A edição de 1985 trazia a seguinte definição para as pessoas com deficiência: "Pessoas portadoras de limitações de suas capacidades físicas e/ou mentais".
} 
em breve, ser publicada. Cada revisão traz novos parâmetros técnicos, e procura melhor incorporar as necessidades da diversidade humana.

O início do século XXI traz iniciativas importantes para a defesa dos Direitos Humanos no Brasil, em especial das pessoas com deficiência. O Governo Federal publicou em 2000, duas leis, ainda hoje em vigor, com importantes conquistas para a acessibilidade e inclusão. A lei 10.048, de 8 de novembro de 2000, trata da prioridade de atendimento às pessoas com deficiência, idosos, gestantes, lactantes e pessoas com crianças de colo, e da acessibilidade nos veículos fabricados no país para transporte público. Essa lei demonstra como a inclusão não acontece só com a adaptação do espaço, mas também com o atendimento adequado. No dia 19 de dezembro do mesmo ano é sancionada a lei 10.098, que estabelece normas gerais e os critérios básicos para a promoção da acessibilidade nas edificações públicas ou de uso coletivo, de uso privado, nos sistemas de comunicação e nos transportes públicos.

Essas leis são regulamentadas pelo Decreto 5.296, de 2 de dezembro de 2004, o qual define prazos para adequação das edificações de uso público ou privado. O conceito de Desenho Universal foi incorporado neste decreto com a seguinte definição:

[...] concepção de espaços, artefatos e produtos que visam atender simultaneamente todas as pessoas, com diferentes características antropométricas e sensoriais, de forma autônoma, segura e confortável, constituindo-se nos elementos ou soluções que compõem a acessibilidade.

Importante ressaltar que desde a promulgação das leis, as normas sobre acessibilidade estão incorporadas como parâmetro técnico a ser atendido e, portanto ganham status de obrigatoriedade. 
Dentro desta política do Governo Federal, em 2003 é instituído o Estatuto do Idoso, Lei no 10.741, que garante, àqueles com 60 anos ou mais, o respeito aos direitos inerentes a qualquer pessoa. O ano de 2003 também foi o da criação do Ministério das Cidades, que contribuiu para a divulgação da acessibilidade, com o Programa Brasil Acessível e a publicação, em 2006, de seis cadernos de mesmo nome, com os seguintes temas: Atendimento adequado às pessoas com deficiência e restrição de mobilidade; Construindo a cidade acessível; Implementação do Decreto no 5.296/04; Implantação de políticas municipais de acessibilidade; Implantação de sistemas de transporte acessíveis; e Boas práticas.

No contexto mundial, em dezembro de 2001, a Assembleia Geral das Nações Unidas cria um Comitê Especial ad hoc, por meio da Resolução nº 56/168, para elaborar uma convenção internacional para a proteção dos direitos da pessoa com deficiência. "O objetivo era promover e proteger os direitos e a dignidade das pessoas com deficiência, com base no enfoque holístico das esferas do desenvolvimento social, dos direitos humanos e da não discriminação" (BRASIL, 2010c, p. 110). As discussões sobre o conteúdo da convenção ocorrem de 2002 a 2006. No Brasil foram realizados dois eventos, em 2005 e 2006, para discutir o texto da convenção e dar subsídios para a Delegação Brasileira. "A posição do Governo brasileiro pautou-se por reforçar os Direitos Humanos, dando ênfase à não discriminação e ao tema da acessibilidade" (BRASIL, 2010c, p. 113).

Foi aprovada por consenso na Assembleia Geral das Nações Unidas, em 13 de dezembro de 2006, a Convenção sobre os Direitos das Pessoas com Deficiência e seu Protocolo Facultativo. Por meio da Resolução nº 61/106, a convenção entrou em vigor em 3 de maio de 2008 com a ratificação de 20 Estados 
Membros da ONU.

Em 9 de julho de 2008 foi promulgado, pelo Congresso Nacional, o Decreto Legislativo 186/08, que aprova os textos da Convenção e seu Protocolo Facultativo. Esses documentos foram agregados às normas brasileiras, com equivalência de emenda constitucional. E em 25 de agosto de 2009, o processo se completou com a ratificação do Decreto n- 6.949, atendendo assim, aos direitos de 23,9\% da população brasileira, de acordo com os dados da pesquisa Censo do IBGE, 2010.

Interessante destacar que a definição de pessoas com deficiência, que nas várias revisões da norma falhavam por não abarcar o ambiente como elemento relevante na condição de incapacidade, foi finalmente sanada a partir da Convenção (BRASIL, 2007b, p. 16, grifo nosso):

Pessoas com deficiência são aquelas que têm impedimentos de longo prazo de natureza física, mental, intelectual ou sensorial, os quais, em interação com diversas barreiras, podem obstruir sua participação plena e efetiva na sociedade em igualdades de condições com as demais pessoas.

Se a legislação fosse amplamente atendida teríamos hoje um Brasil inclusivo para as pessoas com deficiência, com condições iguais de direito aos demais cidadãos. No entanto, ainda sobram estranhamento e preconceito no relacionamento com as pessoas com deficiência. Além disso, infelizmente, a Convenção e o Decreto federal 5.296/04 não alcançaram de forma efetiva a sociedade, para que realmente aconteça a mudança pretendida. Falta fiscalização no cumprimento da ampla legislação que temos no Brasil, para que os direitos sejam garantidos. Ademais, as normas técnicas sobre acessibilidade ainda não são amplamente entendidas e atendidas pelos profissionais da construção civil, apesar 
do vasto tempo que elas circulam. Tudo isso resulta em um quadro ainda precário para a mobilidade e inclusão, fazendo com que muitos se contentem com pouco, devido à dificuldade de se ver em a si próprios como detentores de direitos de igualdade.

\subsection{Preservação e Acessibilidade}

Como se pôde verificar, cada um dos temas, preservação e acessibilidade, surgiram em contextos muito diferentes, e sua convergência é algo extremamente recente. E por ser o acesso pleno e em condições de igualdade uma conquista relativamente recente das pessoas com deficiência, é natural que os bens culturais imóveis, geralmente construídos há décadas, não apresentem qualquer condição de acesso e uso por parte dessas pessoas. Essa não era uma preocupação da arquitetura, pois o ato de projetar contemplava (e às vezes ainda contempla) uma média da população considerada pretensamente "normal" (CAMBIAGHI, 2011, p.40), seguindo referenciais, como os traçados por Leonardo da Vinci, Neufert e Le Corbusier. Isso - acrescido a algumas das características desejadas pela arquitetura, como monumentalidade, distanciamento e proteção acabou por tornar as barreiras algo comum nas edificações, nas principais tipologias a serem denominadas como bens culturais imóveis.

Neste assunto deve prevalecer o respeito mútuo pela história e pelos direitos humanos na orientação das ações, que irão impor um desafio ainda maior do que já vivenciam os profissionais das duas áreas.

No art. 23 da Constituição da República Federativa do Brasil de 1988, está determinada a competência comum da União, dos Estados, do Distrito Federal 
e dos Municípios de "proteger os documentos, as obras e outros bens de valor histórico, artístico e cultural, os monumentos, as paisagens naturais notáveis e os sítios arqueológicos", assim como, "proporcionar os meios de acesso à cultura, à educação e à ciência" (BRASIL, 1988). Esse direito reconhecido em nossa Constituição é reforçado na Convenção sobre os Direitos das Pessoas com Deficiência, ratificado pelo Estado Brasileiro com equivalência de emenda constitucional (Decreto federal no 6.949, de 25 de agosto de 2009), que em igualdade de oportunidades com as demais pessoas determina que medidas apropriadas sejam tomadas para que as pessoas com deficiência possam "ter acesso a bens culturais em formatos acessíveis" (BRASIL, 2007b, p. 33). Como preâmbulo, a mesma Convenção, reconhece "[...] a importância da acessibilidade aos meios físico, social, econômico e cultural, à saúde, à educação e à informação e comunicação, para possibilitar às pessoas com deficiência o pleno gozo de todos os direitos humanos e liberdades fundamentais" (BRASIL, 2007b, p. 16).

Como elemento da cultura, o patrimônio é um direito de todos e é esse caráter democrático do patrimônio que a teoria contemporânea do restauro busca garantir, afastando decisões arbitrárias de projeto (mínima intervenção, distinguibilidade, reversibilidade). Assim, acessibilidade e preservação se inserem em um contexto de respeito à pluralidade.

O marco legal no Brasil para a convergência dos temas preservação e acessibilidade é a Lei Federal 10.098, de 19 de dezembro de 2000. Esta legislação que, "Estabelece normas gerais e critérios básicos para a promoção da acessibilidade das pessoas portadoras de deficiência ou com mobilidade reduzida", determina em seu artigo 25 sobre a adaptação à acessibilidade de bens culturais: 
As disposições desta Lei aplicam-se aos edifícios ou imóveis declarados bens de interesse cultural ou de valor histórico-artístico, desde que as modificações necessárias observem as normas específicas reguladoras destes bens.

A exigência atrelada às condições determinadas pelos órgãos de proteção e às características específicas de cada bem cultural resultava em ações escassas e ineficazes, respaldadas pela visão anacrônica de congelamento do patrimônio.

$\mathrm{Na}$ prática as adaptações à acessibilidade não encontravam maiores referências de quais seriam as possibilidades e limites desejáveis, até a publicação da Instrução Normativa n $^{\circ} 01$ de 25 de Novembro de 2003 do Instituto de Patrimônio Histórico e Artístico Nacional - IPHAN - que dispõe sobre a acessibilidade aos bens culturais imóveis acautelados em nível federal, e outras categorias. Visando atender à legislação federal e orientar a relação entre patrimônio e acessibilidade o documento se propõe a criar diretrizes de aproximação a essa demanda. Porém veremos que a Instrução acaba por não resolver o problema inteiramente.

Deve-se observar que, apesar de ser destinada aos bens culturais imóveis acautelados pelo órgão federal, com a promulgação do Decreto Federal 5.296, de 2 de dezembro de 2004, que regulamentou a Lei Federal 10.098/00, ficou determinado no seu artigo $30^{29}$ que as adaptações à acessibilidade devem seguir a Instrução Normativa do IPHAN, sem restrição a que nível de proteção está inserido o bem tombado, ampliando a aplicabilidade da Instrução.

A referida Instrução Normativa do IPHAN indica a ABNT NBR 9050 e a Lei Federal 10.098/2000 como parâmetros. Além disso, apenas duas partes da Instrução

\footnotetext{
29 "Art. 30. As soluções destinadas à eliminação, redução ou superação de barreiras na promoção da acessibilidade a todos os bens culturais imóveis devem estar de acordo com o que estabelece a Instrução Normativa no 1 do Instituto do Patrimônio Histórico e Artístico Nacional - IPHAN, de 25 de novembro de 2003" (grifo nosso).
} 
são destinadas a orientar as adequações à acessibilidade de bens culturais imóveis, estabelecendo, se elencarmos, apenas três premissas e seis critérios. O restante do conteúdo da Instrução refere-se somente a orientações e posturas internas ao órgão, como a exigência de treinamento do quadro funcional, a publicação das ações realizadas para servirem de referência e a necessidade de dispor de recursos para a adequação dos imóveis de propriedade ou administrados pelo órgão federal.

De forma resumida, as premissas presentes no item 1.1 da Instrução Normativa, a serem observadas quando da intervenção à acessibilidade em bens culturais imóveis, são:

1. As intervenções podem ser estruturais e espaciais, e incorporar ajudas técnicas, sinalizações e dispositivos, devendo ser caracterizadas como adições harmônicas do tempo presente;

2. As alterações devem ser estudadas caso a caso levando em consideração as características específicas de cada bem cultural imóvel;

3. O limite de adequação é imposto pelo comprometimento do valor testemunhal e da integridade estrutural.

Apesar da necessidade de equipar oportunidades, na fruição dos bens culturais, estar presente no conteúdo da Instrução ${ }^{30}$, não há entre as premissas citadas qualquer relação com os direitos humanos. Definiram-se, como ponto de partida para a postura metodológica parâmetros unilateralmente relacionados ao

\footnotetext{
${ }^{30}$ No item 1 da Instrução Normativa $n^{\circ} 1 / 2003$ encontramos o objetivo: "Estabelecer diretrizes, critérios e recomendações para a promoção das devidas condições de acessibilidade aos bens culturais imóveis especificados nesta Instrução Normativa, a fim de equiparar as oportunidades de fruição destes bens pelo conjunto da sociedade, em especial pelas pessoas portadoras de deficiência ou com mobilidade reduzida" (grifo nosso).
} 
campo da preservação, que orientam qualquer tipo de intervenção em um bem cultural imóvel. Se como premissas gerais são válidas, no entanto como premissas específicas, para o objetivo desta Instrução, tornam-se insuficientes.

Entre os critérios exigidos para as propostas de adequação para bens culturais imóveis, elencados no item 3 da Instrução Normativa, estão resumidamente que:

1. Deve ser feito o levantamento de dados - histórico, físico, iconográfico e documental;

2. As prioridades e níveis de intervenção devem ser definidos, favorecendo a autonomia, com atenção às características e à destinação do imóvel;

3. As decisões devem favorecer a integração de públicos;

4. A abordagem deve ser global: entorno, entrada, circulação interna e mobiliário, que permitam utilizar todos os serviços e atividades, garantindo-se o acesso às informações sobre o bem e seu acervo, e promovendo soluções alternativas quando não for possível a adequação (maquetes, reproduções, percursos virtuais etc.);

5. A intervenção a ser realizada deve possibilitar a reversibilidade e ser identificada;

6. O local deve dispor de ajudas técnicas e de pessoal treinado para o atendimento, como parte do conjunto de soluções em acessibilidade.

Entre os critérios apresentados fica mais claro como as pessoas com 
deficiência devem ser consideradas nas propostas de adequação, apropriando-se de termos como inclusão, autonomia e abordagem global. Porém, ainda prevalecem critérios relativos à preservação e outros que nada interferem no patrimônio em si, como atendimento. Características como treinamento para atendimento adequado e ajudas técnicas, como dispor de cadeiras de rodas ou outros equipamentos, devem sempre ser considerados pelo administrador do local, e não necessariamente elencados entre os critérios para as propostas de intervenção ${ }^{31}$ a ser aprovada pelo órgão de preservação. A não ser quando, excepcionalmente, a impossibilidade de adaptação a determinadas partes do bem exigir que a proposta de intervenção seja complementada por esses recursos. A Instrução Normativa não esclarece dessa forma, e coloca como se esse critério devesse ser sempre submetido à análise do órgão.

$\mathrm{Na}$ prática este conteúdo torna-se muito escasso para orientar as intervenções. E efetivamente os impedimentos impostos pelo bem cultural imóvel ganham poder sobre o direito de ir e vir, em uma relação caracterizada pela subjetividade, onde sempre quem dá a resposta final é o órgão de preservação.

Como o Decreto-Lei no 25 de 1937, que organiza a proteção do patrimônio histórico e artístico nacional, determina em seu art. 17 "as coisas tombadas não poderão [...] sem prévia autorização especial do Serviço do Patrimônio Histórico e Artístico Nacional, ser reparadas, pintadas ou restauradas", e como a ABNT 9050/2004 e o Decreto federal 5.296/2004 também determinam que os órgãos de preservação devam ser consultados para autorizar as adaptações a

\footnotetext{
31 Não se pretende diminuir a importância da acessibilidade atitudinal ligada ao preparo no atendimento, que é fundamental a inclusão; o objetivo aqui foi demonstrar a falta de organização e clareza ao leitor dos tópicos na Instrução Normativa em questão.
} 
serem realizadas, se faz necessário que os técnicos sejam conscientes da necessidade de se promover acesso às pessoas com deficiência nos bens culturais imóveis, e conheçam tecnicamente a matéria relativa à acessibilidade para melhor avaliar as propostas de intervenção.

A decisão está em grande parte nas mãos dos técnicos dos órgãos de preservação, que geralmente encaram a acessibilidade como algo danoso à preservação, determinando que os bens tombados sejam excetuados das exigências legais. $E$ assim, o resultado dessa postura pode ser a completa falta de acesso para certas pessoas.

Em notícia vinculada no jornal Folha de S. Paulo, de 13 de maio de 1997, Caderno 3, p. 6, sob o título "Secretaria não dá acesso a deficientes", aponta a falta

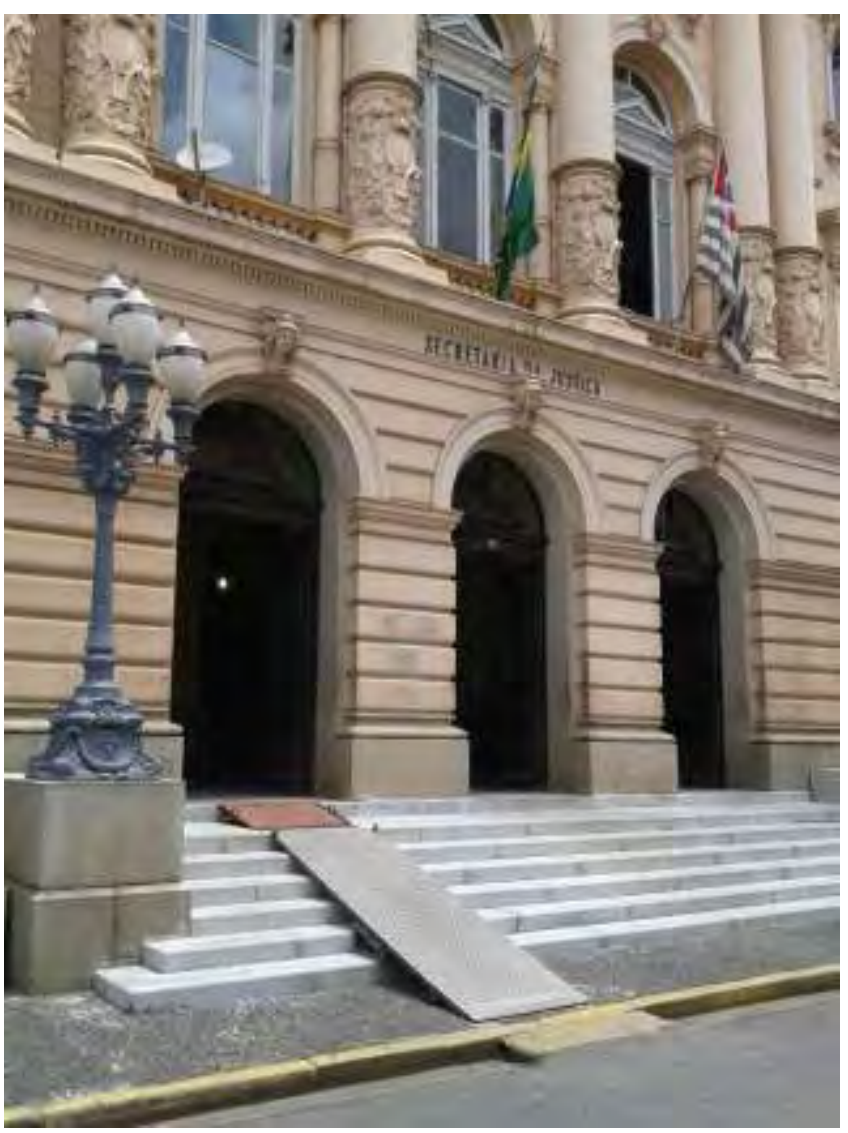

Figura 1 - Rampa apoiada nos degraus na entrada da Secretaria da Justiça em São Paulo. 2012 de acessibilidade ao prédio da Secretaria de Justiça do Estado de São Paulo (localizada no Pátio do Colégio - Centro). O órgão alega que verbalmente 0 Condephaat proibiu a colocação de rampa na entrada por ocasionar alteração da fachada do edifício, que é tombado. Se é verdade ou não a alegação do funcionário da Secretaria de Justiça, não há como saber. Além de que muitos anos se passaram 
e a postura do Conselho pode ter se modificado. Mas o fato é que até hoje a acessibilidade ao prédio é ineficaz e se utiliza de rampa móvel bastante precária, apoiada sobre os degraus da entrada, resultando em inclinação extremamente elevada para permitir a segurança e autonomia no acesso. E justificativas simplórias como essa ainda são dadas hoje em dia.

O objetivo não é medir forças entre acessibilidade e preservação para ver quem sai ganhando, pois com disso, todos perdem: sem acessibilidade a importância do patrimônio não é incorporada plenamente na comunidade, e sem a preservação adequada não há acessibilidade que garanta o usufruto e a fruição dos elementos fundamentais. Do embate propõe-se passar à união de forças, para tornar a vivência da história e da cultura a mais natural possível por todos, independentemente de suas características motoras, cognitivas ou sensoriais. O que se percebe com a Instrução Normativa é um discurso de preservação tentando incorporar acessibilidade sem um profundo diálogo entre as duas partes, ficando sempre em destaque os limites impostos e não as possibilidades existentes.

E não se pode dizer que a "Bíblia" da acessibilidade em sua atual edição, a ABNT NBR 9050/2004, seja mais esclarecedora no que tange a como agir diante da adequação de um bem cultural imóvel ${ }^{32}$. Nos três itens ${ }^{33}$ que tratam do assunto a postura é conservadora e pouco orientativa.

O item 8.1.1 indica que todo o conteúdo da norma pode ser aplicado, desde que respeitando os critérios dos órgãos de preservação. $E$ realmente a avaliação das adequações necessárias deve partir da possibilidade irrestrita de

\footnotetext{
${ }^{32}$ A ABNT NBR 9050/2004 usa o termo "bens tombados".

${ }^{33} \mathrm{O}$ item 8.1 da ABNT NBR 9050/2004, que se divide em 8.1.1, 8.1.2 e 8.1.3, é que trata dos bens tombados.
} 
adaptação com base nas normas de acessibilidade da ABNT, como qualquer outra edificação. Desse modo, pode-se conhecer as inadequações, para então confrontálas com os valores a serem preservados, chegando-se a decisões específicas para cada edificação. Os outros dois itens da ABNT NBR 9050/2004 para bens culturais imóveis, 8.1.2 e 8.1.3, remetem aos casos em que não há possibilidade de adequação, nos quais devem ser ofertadas informações em formato acessível, na busca de suprir a ausência de acesso. Ou seja, nas recomendações da norma pende-se para a impossibilidade e a restrição.

A todo momento as recomendações existentes fazem parecer que os bens culturais imóveis são praticamente intocáveis, como resultado da visão preponderante de congelamento que paira sobre eles; apesar do rol de bens ser bem amplo e variado, e, portanto detentor de inúmeras possibilidades, não sendo possível, consequentemente, colocar a inviabilidade como premissa.

Mais recentemente, no ano de 2010, o IPHAN publicou a Portaria ํㅜ 420, que enumera os procedimentos a serem observados nas intervenções em bens edificados tombados e em suas respectivas áreas de entorno, que necessitam de aprovação previa do órgão. O art. 8ํㅜ remete à Instrução Normativa de 2003, exigindo que os projetos de intervenção devam contemplar a acessibilidade:

Art. 8ำ Para os bens que tenham ou terão destinação pública ou coletiva, cujas intervenções sejam classificadas como Reforma/Construção Nova ou Restauração, o projeto deverá contemplar a acessibilidade universal, obedecendo-se ao previsto na Instrução Normativa Iphan nº 01/2003.

Isso demonstra que a acessibilidade permanece na pauta do órgão federal, cujos procedimentos evidenciam a consideração dos direitos das pessoas com deficiência, apesar dos problemas já apontados na Instrução Normativa. No que 
tange à cidade de São Paulo, tal exigência pode até ser prática informal comum dos órgãos estaduais e municipais pertinentes, mas não há instrução similar para ser citada aqui. Tal situação não oficializada pode causar ruídos de comunicação e de aplicação, principalmente quando há uma mudança na gestão, prejudicando os direitos conquistados.

Entre as políticas públicas do governo federal em prol da melhora de acessibilidade do nosso patrimônio cultural podemos destacar o "Programa Nacional de Mobilidade e Acessibilidade em Áreas Tombadas" lançado em 2009, para as cidades que demandam atenção específica para as questões patrimoniais. Segundo informações do portal do IPHAN na Internet, projetos pilotos e encontros nacionais sobre o tema serão a base para a elaboração do Caderno Técnico de Mobilidade Urbana em Áreas Tombadas, que será o instrumento de orientação nessas questões. Atualmente, quatro projetos piloto estão em fase de elaboração: Ouro Preto, em Minas Gerais, São Francisco do Sul e Laguna, em Santa Catarina, e Paranaguá, no Paraná. O objetivo é melhorar o fluxo de pessoas e veículos nas áreas tombadas visando maior apropriação do espaço público e fruição mais qualificada do conjunto urbanístico. As diretrizes, que estão sendo estabelecidas em um trabalho conjunto entre IPHAN, governo local e população, ajudarão na gestão e no gerenciamento da mobilidade e da acessibilidade nesses espaços ${ }^{34}$.

Em consulta ao site Transparência Pública, do Governo Federal, que traz as despesas realizadas pelos órgãos federais, foi possível obter informações sobre os contratos e convênios realizados pelo IPHAN. No que tange à acessibilidade, verifica-se que, de 2005 (primeiro ano em que são apresentados os dados) até

\footnotetext{
${ }^{34}$ Informações retiradas do sítio do IPHAN: http://portal.iphan.gov.br/
} 
$2009^{35}$, foram poucas as ações. Estes dados foram reunidos na Tabela 1 sobre contratos concluídos ou em andamento, a seguir:

Tabela 1- Promoção da acessibilidade pelo IPHAN 2005-2009: Contratos

\begin{tabular}{|l|c|c|c|c|c|c|}
\hline & \multicolumn{5}{|c|}{ PROMOÇÃO DA ACESSIBILIDADE PELO IPHAN } \\
\cline { 2 - 7 } & $\mathbf{2 0 0 5}$ & $\mathbf{2 0 0 6}$ & $\mathbf{2 0 0 7}$ & $\mathbf{2 0 0 8}$ & $\mathbf{2 0 0 9}$ & TOTAL \\
\hline $\begin{array}{l}\text { TOTAL GERAL DE } \\
\text { CONTRATOS }\end{array}$ & 119 & 190 & 410 & 453 & 107 & 1279 \\
\hline $\begin{array}{l}\text { CONTRATOS EM PROL DA } \\
\text { ACESSIBILIDADE }\end{array}$ & 0 & 1 & 3 & 0 & 2 & 6 \\
\hline $\begin{array}{l}\text { \% DE CONTRATOS EM PROL } \\
\text { DA ACESSIBILIDADE }\end{array}$ & 0 & 0,53 & 0,73 & 0 & 1,87 & 0,47 \\
\hline
\end{tabular}

Fonte: Portal da Transparência - Ministério da Cultural - IPHAN. Acesso em: 28 de jul. de 2009

Quanto a convênios realizados e em andamento pelo IPHAN, no mesmo sentido, os dados estão compilados na Tabela 2:

Tabela 2 - Promoção da acessibilidade pelo IPHAN 2005-2009: Convênios

\begin{tabular}{|l|c|c|c|c|c|c|}
\hline & \multicolumn{5}{|c|}{ PROMOÇÃO DA ACESSIBILIDADE PELO IPHAN } \\
\cline { 2 - 7 } & $\mathbf{2 0 0 5}$ & $\mathbf{2 0 0 6}$ & $\mathbf{2 0 0 7}$ & $\mathbf{2 0 0 8}$ & $\mathbf{2 0 0 9}$ & TOTAL \\
\hline $\begin{array}{l}\text { TOTAL GERAL DE } \\
\text { CONVÊNIOS }\end{array}$ & 23 & 48 & 27 & 45 & 45 & 188 \\
\hline $\begin{array}{l}\text { CONVÊNIOS EM PROL DA } \\
\text { ACESSIBILIDADE }\end{array}$ & 1 & 0 & 1 & 0 & 0 & 2 \\
\hline $\begin{array}{l}\text { \% DE CONVÊNIOS EM PROL } \\
\text { DA ACESSIBILIDADE }\end{array}$ & 4,35 & 0 & 3,7 & 0 & 0 & 1,06 \\
\hline
\end{tabular}

Fonte: Portal da Transparência - Ministério da Cultural - IPHAN. Acesso em: 28 de jul. de 2009

Os dados coletados permitem comprovar a escassez de ações voltadas a garantir acessibilidade aos bens culturais tombados no período. E se olharmos com mais atenção à descrição destes contratos, notamos que apenas os dois que se referem a 2009 dizem respeito à acessibilidade de bens culturais tombados (Ouro

\footnotetext{
${ }^{35}$ Após 2009, a forma de sistematização dos dados sofreu mudanças, o que dificultou a organização das informações na tabela. Portanto, o conteúdo foi restrito aos anos entre 2005 e 2009, que podemos considerar um período relevante para análise.
} 
Preto-MG e São Francisco do Sul-SC - integrantes do Programa Nacional de Mobilidade e Acessibilidade em Áreas Tombadas). Os demais são adequações à acessibilidade das sedes de algumas Superintendências Regionais. Ao que tudo indica, as diretrizes da já citada Instrução Normativa não tiveram resultados expressivos nos primeiros seis anos após sua publicação.

Outro recurso disponível desde 2011 para quem busca melhorias de acessibilidade é utilizar-se do Edital de Modernização de Museus do Instituto Brasileiro de Museus - IBRAM - que visa dar apoio financeiro à modernização de instituições museológicas. Entre as ações que podem ser contempladas com o aporte há a possibilidade de adequar as edificações à acessibilidade. Como é considerável o número de museus e instituições culturais locados em edifícios de interesse histórico e cultural, este edital poderá ser um impulsionador à promoção de acesso nos bens tombados que ainda não possuem ou precisam de melhorias.

Interessante notar que até 2010 o programa disponibilizava recursos para adequações físicas do imóvel, elaboração de projetos para execução de obras e serviços, aquisição de equipamentos de informática, mobiliário expositivo, entre outros objetivos, que poderiam ser aplicados para melhorar o acesso e os recursos de acessibilidade, apesar de não estar explícito. ${ }^{36}$. O edital publicado em 2011 passa a abranger especificamente "serviços para adaptação de espaços e serviços para acessibilidade". Essa mudança reflete a adoção de posturas efetivas pelo próprio governo em relação à exigência do Decreto Federal 5.296/2004, que determina que a aprovação de financiamento com utilização de recursos públicos, deve levar em consideração os critérios básicos para a promoção da acessibilidade contidos no

\footnotetext{
${ }^{36}$ Entre os critérios de desempate do edital, existia a possibilidade de melhor qualificar projetos que contemplassem a democratização do acesso de pessoas com deficiência e idosos.
} 
próprio.

Não obstante todo o aparato legal existente, ainda hoje, mais de uma década depois da promulgação da legislação federal, há grande dificuldade teórica e prática para efetivar a adequação de bens culturais imóveis ao acesso de pessoas com deficiência. Ainda é grande a resistência por parte dos técnicos dos órgãos de preservação, à exceção de poucos casos isolados. Infelizmente, parece ainda predominar o mito de que adaptar à acessibilidade é sinônimo de prejuízo para o bem cultural imóvel. A ausência de adequação deve estar amplamente fundamentada, por questões impostas pelos valores e pela materialidade da edificação e pelas premissas de preservação $^{37}$, e não por uma avaliação superficial de impedimento pelo simples tombamento, como se fosse sinônimo de não intervenção.

Não é condição sine qua non em uma adequação à acessibilidade ser invasiva e/ou descaracterizadora. Essa possibilidade pode acontecer por qualquer objetivo que tiver a intervenção, se não for corretamente embasada nas diretrizes de conservação do patrimônio e se não houver respeito às características essenciais da edificação.

A crença de que as transformações para promover a acessibilidade são obrigatoriamente invasivas e podem trazer danos aos valores que se pretende preservar, costuma levar à inação - a qual infelizmente está entre as opções facultadas pelas leis e normas. Isso quando não são adotadas "soluções" incompletas e incoerentes que causam alterações no bem cultural sem possibilitarem o acesso àqueles que dependem delas, resultando em prejuízos para

\footnotetext{
${ }^{37}$ E essas informações devem estar claramente registradas em processos administrativos dos órgãos de preservação.
} 
todos os envolvidos.

O objetivo é atender às necessidades de acesso e uso sem reduzir a qualidade histórico-artística do bem cultural. O que se pretende investigar aqui é se existe impedimento conceitual na realização de intervenções em bens culturais tombados, com o objetivo de atender à acessibilidade.

Primeiramente, devemos lembrar que como condição intrínseca a arquitetura tem sua função plenamente atendida quando ela é usufruída pelos usuários. Suas fachadas, formas e texturas podem ser contempladas externamente, porém uma experiência corporal-cinestésica completa exige que a arquitetura seja percorrida e sentida internamente, em seus claros e escuros, distâncias e alturas, relevos e planos, temperatura e sons. Só assim o espaço irá ser completamente vivido e reconhecido pelo usuário como parte de si próprio, situação que ninguém pode fazer por ele. A arquitetura de contemplação à distância pode resultar em uma vivência pobre, triste e incompleta.

Acredito que, possibilitar amplo acesso não é só uma necessidade moral da nossa sociedade atual, mas é uma demanda do próprio monumento e de sua existência, para distanciá-lo da "pura contemplação" e salvaguardá-lo como coisa viva e pertencente à atualidade; não para atender a expectativas superficiais de atualização, mas como um bem que se quer manter relevante e presente para a cidade e sua comunidade. A acessibilidade é mais uma forma de criar/ampliar vínculos do passado com o tempo presente. Não aceitar a acessibilidade como um desafio urgente do restauro é adotar uma postura de congelamento do nosso patrimônio; é negar o restauro como ato crítico-cultural do tempo presente, com o objetivo de transmiti-lo ao futuro, conforme afirmado por Cesare Brandi (2005). 
E para garantir sua função inerente, pode ser necessária a adaptação da edificação para melhor atender ao seu público e aos usos propostos. Como afirma a Declaração de Amsterdã, de 1975, "tem sido demonstrado que os edifícios históricos podem receber novas funções que correspondem às necessidades da vida contemporânea". As adequações para atender as novas funções podem ter a mais diversa ordem de necessidades, como alterações de sistemas hidráulicos, elétricos, instalações de rede lógica e de telefonia, sistemas de segurança e estabelecimento de rotas acessíveis. Carbonara ${ }^{38}$ afirma que várias demandas, entre elas a eliminação de barreiras, são colocadas como desafio para o projetista a fim de garantir um uso pleno da edificação:

O projeto é a síntese criativa de diferentes necessidades, no qual o que é feito para remover barreiras assume, como muitas outras necessidades funcionais, o papel da providência ordinária destinada a assegurar, a todos, o melhor uso do bem.

Para que o bem possa atender ao uso diário são necessárias diversas adequações, e não é aceitável que a possibilidade de acesso de algumas pessoas seja deixada em segundo plano, com justificativas insuficientes, por ser tombado ou por não haver recursos.

Como premissa, como determinam as correntes de restauro, cada caso é único, e para a adequação à acessibilidade de um bem cultural imóvel isso também é válido: as decisões estão condicionadas aos valores a ser preservados e exaltados, à sua matéria e às demandas da sociedade. Mas, como afirma Kühl, o "cada caso é um caso" não pode ser traduzido no "fazer o que quiser". Isso vale duplamente para as esferas da preservação e da acessibilidade. As tomadas de

${ }^{38}$ Citação retirada de texto da aula "Adeguamento del patrimonio storico ed archeologico" do prof. Giovani Carbonara durante a $10^{\text {a }}$ edição do curso de pós-graduação "Progettare per tutti senza barriere architettoniche", em Roma, 2002. Disponível em: < http://www.progettarepertutti.org/formazione/lez08_carbonara.pdf>. Acesso em: 11 set. 2011. 
decisão devem ser fruto de árduo trabalho técnico e criativo, dentro daquilo que é funcional e efetivo. Não há receitas prontas, mas diretrizes de aproximação ao objeto.

É possível notar que as diretrizes de preservação e restauro permitem a convergência para a acessibilidade. E a adequação à acessibilidade pode ser implementada mesmo com as limitações necessárias à preservação do bem. Ou seja, estamos falando de uma união possível.

Conforme já visto, acessibilidade, segundo a ABNT NBR 9050/2004 é: "Possibilidade e condição de alcance, percepção e entendimento para a utilização com segurança e autonomia de edificações, espaço, mobiliário, equipamento urbano e elementos". E o conceito de bem cultural, indicado pela Instrução Normativa $n^{\circ} 1$ do IPHAN: "(...) elemento que por sua existência e característica possua significação cultural para a sociedade - valor artístico, histórico, arqueológico, paisagístico, etnográfico - seja individualmente ou em conjunto". Os dois conceitos realmente devem interagir. Pois, se o bem tem significação cultural para a sociedade, ele deve ser acessível para todos, no sentido mais amplo da palavra. Qualquer restrição ou constrangimento que possa existir dificultará a aproximação da sociedade.

E $O$ que se percebe da análise dos dois temas, acessibilidade e preservação, é que eles devem trabalhar de forma harmonizada em vez de contrapor-se, pois apresentam mais semelhanças do que divergências. Cabe mencionar que ambos são temas ainda secundários no curso de graduação em arquitetura, apesar de sua importância e relevância para a prática profissional ${ }^{39}$ e,

${ }^{39} \mathrm{O}$ aumento da lista de edificações e áreas tombadas pelos órgãos de preservação é proporcional à possibilidade dos arquitetos terem de intervir, no mínimo, com a área de entorno de uma edificação tombada, o que faz fundamental um bom convívio com a temática. E, por outro lado, como o decreto federal 5.296/2004 exige a adequação e a concepção das edificações garantindo acesso a todos, 
consequentemente, são vistos pelos próprios profissionais com preconceito. Ambos requerem profissionais especializados, mas frequentemente são implementados por profissionais sem formação específica. Ambos demandam abordagem e intervenção rígida, técnica e contextualizada, porém costumam ser objeto de soluções precipitadas que resultam em novos problemas.

Na verdade, é possível constatar que os dois temas devem se apoiar um no outro para enfrentar as dificuldades em comum, em vez do contrário. Conhecer profundamente os dois temas na hora de intervir trará efetividade e legitimidade, e as alterações, portanto, serão as menos invasivas, pois invasivo será alterar sem ter como resultado o acesso e a preservação.

O artigo 9 da Carta de Veneza diz que qualquer intervenção deve basearse em fatos, e não apenas em suposições. Para a acessibilidade vale o mesmo: adotar soluções não normatizadas, sem qualquer embasamento, resulta em conjecturas sem garantia de efetividade para a funcionalidade pretendida e, consequentemente, para a preservação.

Em "Linee Guida per il superamento delle barriere architettoniche nei luoghi d'interesse culturale"40 (2008, p. 22) são apontados os princípios para o restauro: distinguibilidade, reversibilidade, compatibilidade físico-química e autenticidade expressiva. Esses conceitos são válidos como diretrizes na hora de intervir no bem cultural imóvel e, portanto, são válidos para as tomadas de decisão em relação à promoção da acessibilidade. A distinguibilidade e a reversibilidade são os aspectos aos quais mais devemos ficar atentos quando se trata de atender à este é também um tema que os profissionais devem dominar amplamente.

${ }^{40}$ Manual de orientação, publicado em 2008, elaborado pelo Ministero per i Beni e le Attività Culturali do governo da Itália, para orientar arquitetos e engenheiros e funcionários do governo sobre o tema da acessibilidade dos bens de interesse cultural. 
acessibilidade.

Em outro artigo da Carta de Veneza, a distinguibilidade é definida da seguinte forma (BRASIL, 2004, p. 94):

Art.12 - Os elementos destinados a substituírem as partes que faltem devem integrar-se harmoniosamente no conjunto $e$, simultaneamente, serem distinguíveis do original por forma a que 0 restauro não falsifique o documento artístico ou histórico.

A acessibilidade em geral é um elemento ausente nas edificações de interesse histórico e no momento de sua implantação a distinguibilidade deve ser uma das diretrizes a serem respeitadas. Rampas, elevadores, corrimãos de apoio, sinalizações, não devem tentar parecer parte da edificação como se sempre estivessem estado lá. Em edificações de certa época, fica praticamente óbvio que um elevador não é um elemento original, que possa falsear a percepção, por exemplo, porém em que posição colocá-lo também faz parte da tomada de decisão; portanto são elementos que não merecem causar maior destaque que o bem em si, e a distinguibilidade deve colocar-se de forma harmoniosa e integrada; o que nos leva ao artigo seguinte da Carta de Veneza:

Art.13 - Não é permitida a realização de acrescentos que não respeitem todas as partes importantes do edifício, o equilíbrio da sua composição e a sua relação com o ambiente circundante.

Aqui também entra a autenticidade expressiva, lado a lado com a distinguibilidade: o profissional deve utilizar-se de sua criatividade para propor novas inserções, em harmonia com os elementos significativos, com rigor às regras e respeito à matéria original.

A intervenção em um bem cultural imóvel deve possuir atributos de reversibilidade, quando possível, conforme apontado por Brandi (2005, p. 48): "que qualquer intervenção de restauro não torne impossível mas, antes, facilite as 
eventuais intervenções futuras". O objetivo é a preservação do bem possibilitando reverter determinadas intervenções diante de soluções mais modernas, adequadas e com uso de melhores recursos técnicos e tecnológicos. Porém, é importante não incorrer no erro de traduzir "reversível" em "provisório". Para supostamente atender ao preceito da reversibilidade, muitas vezes, são colocadas, por exemplo, rampas em condições inadequadas e desarmoniosas com o bem cultural. E geralmente essa condição se prolonga e o provisório acaba se tornando permanente, desmotivando e desencorajando a visitação das pessoas com deficiência ao local, que não se sentem benvindas e pertencentes ao espaço. Em "Linee guida per il superamento..." (2008, p. 45) alerta-se para as soluções que, com o temor de deturpar o edifício histórico, recorrem a sistemas postiços e manuais, frequentemente mal projetados, com materiais pobres e fora do contexto em que se inserem.

A compatibilidade físico-química, por sua vez, vai garantir que os novos materiais utilizados no edifício histórico não venham a causar comprometimento do material existente. Os elementos definidos para rampas, pisos táteis e sinalização, por exemplo, em hipótese alguma podem causar prejuízos à integridade da edificação. Se for o caso, materiais alternativos devem ser propostos. Outra compatibilidade a ser considerada também é a de uso. Esta questão deveria ser mais bem discutida, porém foge ao escopo específico da acessibilidade, afetando a preservação efetiva do bem cultural. Trata-se da definição de uso incompatível com o tamanho e/ou a estrutura portante e/ou fragilidade dos materiais construtivos do edifício tombado. Contudo, verificamos que isso ocorre não só com os bens culturais como na mudança de uso de qualquer imóvel existente, parecendo querer passar um cubo por uma abertura redonda, como nos brinquedos de criança.

A já citada Instrução Normativa coloca que pode haver um limite na 
promoção da acessibilidade, decorrente "[...] da avaliação sobre a possibilidade de comprometimento do valor testemunhal e da integridade estrutural resultantes". A visão crítica na hora da intervenção é fundamental. As ações de adequação devem ser fartamente discutidas e fundamentadas para justificar cada intervenção realizada e cada restrição imposta, como ocorre com intervenções de qualquer natureza em um bem cultural imóvel. Talvez nos bens tombados, a acessibilidade esteja mais próxima do conceito de eliminação de barreiras do que da promoção do Desenho Universal. Contudo, isso não quer dizer que seja impossível a acessibilidade plena com autonomia. Esta deve ser sempre a meta inicial, cuja pertinência deve ser avaliada caso a caso.

E o objetivo de eliminação de barreiras arquitetônicas vai além do conceito restrito de obstáculo físico. Conforme definido pelo Decreto Ministerial n. 236/1989, que aponta os requisitos técnicos necessários para garantir a acessibilidade, adaptabilidade e visitabilidade em edifícios privados e públicos na Itália, o conceito de barreira arquitetônica está apoiado em três pilares ("Linee guida per il superamento...", 2008, p. 29):

1. Obstáculos físicos que são fonte de desconforto para todos;

2. Barreiras que restringem ou inibem o uso adequado e seguro de peças, equipamentos ou componentes;

3. Falta de dispositivos e alertas que permitam a orientação e reconhecimento dos lugares e de fontes de perigo (especialmente pessoas cegas e surdas).

Portanto, o conceito de barreira arquitetônica é mais amplo e complexo do que aparenta. Pode estar relacionado com limitações físicas, de percepção ou até 
mesmo de fundo psicológico, que provoquem situações de impedimento, confusão, dependência, fadiga, estresse ou desconforto. Em resumo, são elementos causadores de exclusão, e isso não está relacionado somente às pessoas com deficiência. A eliminação de barreiras visa promover o acolhimento do usuário para uma experiência agradável durante a visita.

É importante perceber que algumas vezes a barreira ambiental é parte integrante da identidade do bem, como as pontes com degraus para atravessar os canais em Veneza, fossos de castelos medievais, escadarias públicas e fortalezas para defesa territorial. Porém, mais uma vez, isto não é sinônimo de inviabilidade para se promover 0 acesso. Não necessariamente as barreiras precisam ser eliminadas, mas sim transpostas. Já há exemplos de soluções para que seja garantido o acesso de todos para muitas destas situações citadas, como se verá dentro deste capítulo.

Para aqueles edifícios que realmente sejam inacessíveis, recomendações de recursos alternativos estão contidas na ABNT NBR 9050/2004 e na Instrução Normativa do IPHAN no 01/2003, além de outras que podem ser desenvolvidas com os avanços tecnológicos e metodológicos. Realmente, não falta empenho em elaborar esses tipos de recomendações. E vale lembrar que as situações de impraticabilidade nem sempre são inacessíveis para todas as deficiências, possibilitando melhorias de acesso e uso para alguns casos específicos. Barreiras e adequação devem ser postos lado a lado para se avaliar possibilidade e limites.

Geralmente acredita-se que para promover a acessibilidade basta ter algumas rampas, um banheiro e, talvez, um elevador; visão limitada causada por um desconhecimento de quem são as pessoas com deficiência, de quais são suas 
necessidades e do que realmente representa a acessibilidade e, principalmente 0 Desenho Universal. Faz-se necessário entender que garantir um ambiente acessível é promover segurança, conforto e qualidade para todos os usuários.

A acessibilidade plena exige uma avaliação mais profunda com base no Desenho Universal. Segundo Preiser (In. Prado et al., 2010, p. 23)

Os princípios [do Desenho Universal] constituem idéias "guardachuva", acompanhados de diretrizes e de recomendações para projetos, bastante genéricas e não qualificáveis. Assim, eles são úteis, pois apontam a direção certa a ser tomada pelo projetista, porém não informam ao projetista o que fazer numa situação especifica.

Os sete princípios serão os norteadores para avaliar as características existentes, quanto às esferas social, cultural, funcional, estética, psicológica e de segurança do ambiente em questão.

E é fundamental propor uma ação integral (abordagem global, como citado na Instrução Normativa do IPHAN) de adequação do bem - caso de qualquer intervenção que objetiva acessibilidade. Um dos grandes erros relativos à acessibilidade são as propostas que não consideram o edifício como um todo, refletindo em situações incoerentes, como por exemplo, sanitários acessíveis em andares inacessíveis. Segundo Cervera (MARTíN et al., 2007, p. 70), "[...] un esfuerzo notable en materia de accesibilidad y supresión de barreras puede resultar inútil, o cuando menos parcial, si se deja en el caminho un sólo obstáculo sin resolver". Ele afirma que, ações fragmentadas e descoordenadas prejudicam a resolução dos problemas (MARTíN et al., 2007, p. 70). Para uma ação integral se faz necessário avaliar o edifício, seus elementos e seu entorno como um todo ${ }^{41}$ e fazer

\footnotetext{
${ }^{41}$ Também não adianta ter acesso da porta para dentro, se a calçada tem problemas; todo o sistema fica prejudicado.
} 
um mapa de problemas. Para cada inadequação deve ser proposta uma solução, com base nas normas e leis. Estabelecer rotas para cada um dos serviços e espaços e até mesmo desenhar isso em planta, facilita verificar se cada espaço foi contemplado com ações de adequação. Ao planejar adequações por etapas, devese ser coerente de forma a eleger ações que vão permitir o uso pleno de certas áreas, mesmo que outras venham a ser adequadas posteriormente.

Apesar de não estar previsto em nossa legislação ou normas, a acessibilidade condicionada pode ser um recurso a ser usado com muita cautela nos bens culturais imóveis. Em "Linee guida per il superamento..." (2008, p. 32) a definição para acessibilidade condicionada é aquela em que há um sistema de chamada para ativar um serviço de apoio para permitir o uso do espaço. Esta possibilidade só deve ser usada como recurso transitório, e deve estar claro para o usuário e para a administração seu início e fim. Por exemplo, enquanto há uma obra, ou enquanto não se inicia uma intervenção mais ampla já projetada. Quando necessária sua utilização, deve estar inserida em um cronograma fechado, com objetivo final de deixar de ser utilizada, no mais curto espaço de tempo possível. Infelizmente esse recurso é usado erroneamente e por tempo indefinido, como se fosse sinônimo de acessibilidade plena, por desconhecimento ou por malícia. É importante frisar que a acessibilidade condicionada fere um dos princípios fundamentais que é a autonomia.

E os edifícios históricos são de fato tão inacessíveis? Essa pergunta foi feita pelo arquiteto peruano Marco Antonio Garcés Desmaison na publicação Accesibilidad Y Patrimonio (MARTíN et al., 2007, p. 17-29). Desmaison considera que, como regra geral, os edifícios eleitos como patrimônio são dotados de 
qualidades, onde "toda buena arquitectura es rica em flexibilidade, texturas, buen trazado y adaptación al médio" (MARTíN et al., 2007, p. 19) - opinião que também compartilhamos. Em resumo, "[...] los edifícios históricos permiten, más que impiden, una razonable adaptación. Y curiosamente, esto es más cierto cuando la antigüedad es mayor". Isto se deve, talvez, às grandes áreas, vãos e recuos, comuns na prática construtiva tradicional, características que nossa arquitetura atual vem perdendo, face à pressão imobiliária, à escassez de terrenos nas grandes cidades e à ganância excessiva. O autor identifica tipologias arquitetônicas e as organiza por maior ou menor possibilidade de adequação; nestas incluem-se, por exemplo, masmorras, minas e criptas e, nas primeiras, palácios, claustros, escolas e hospitais.

É possível perceber que as adequações necessárias para a promoção da acessibilidade geralmente envolvem adições, supressões ou sobreposições.

As adições são blocos construtivos novos, adicionais ao 'corpo' da edificação, como uma torre adicionada para instalação de elevador e escada de emergência.

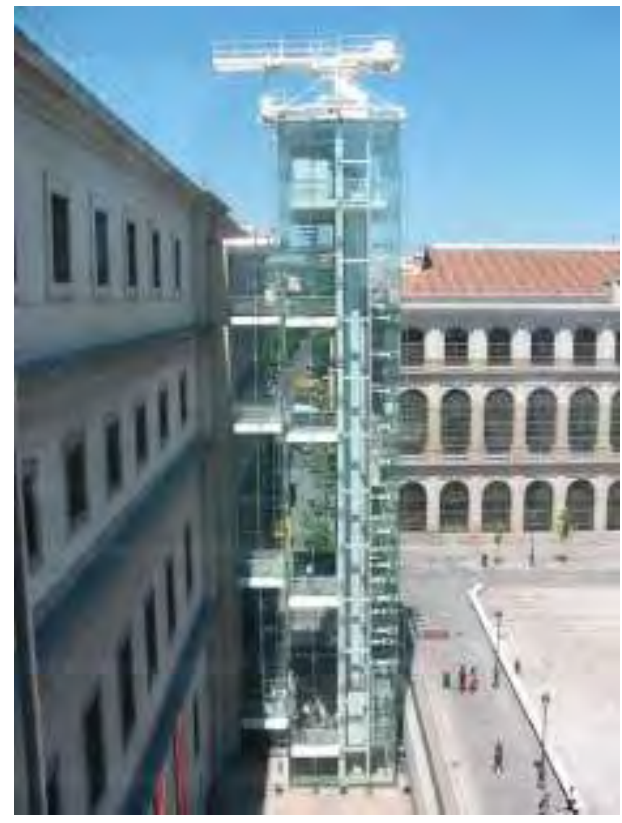

Figura 2 - Exemplo de adição: bloco de circulação vertical no Museu Reina Sofia - Espanha. 2006. 
Supressões são elementos originais que foram retirados para atender a acessibilidade, como uma soleira que é retirada e substituída por uma rampa.

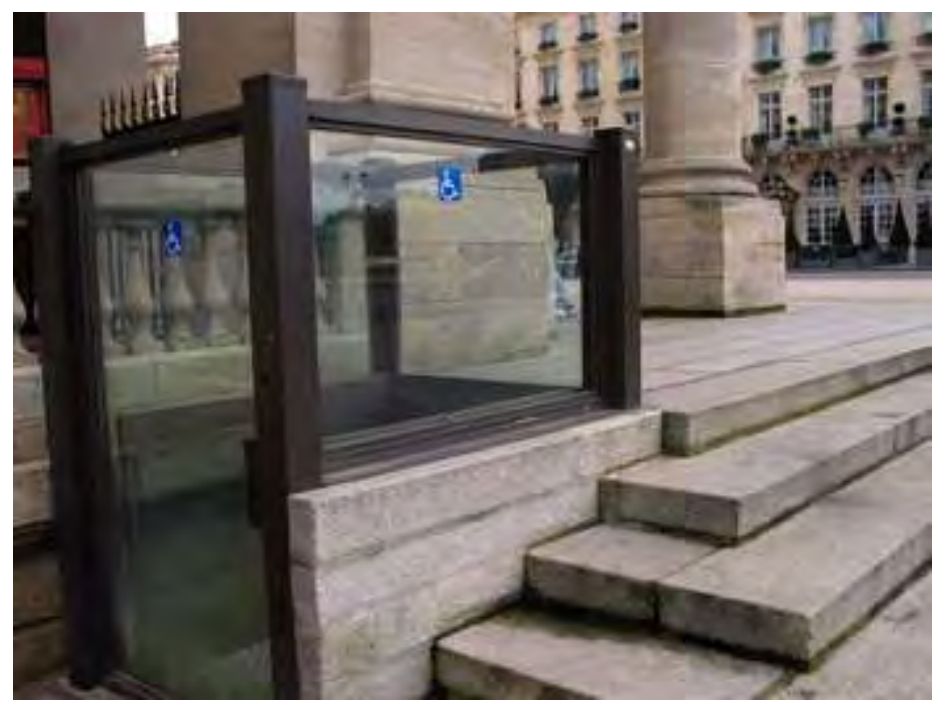

Figura 3 - Exemplo de supressão: plataforma inserida na escadaria da Opéra Nacional de Bordeaux - França. Foto: Autoria desconhecida.

E sobreposições são elementos que são colocados sobre a estrutura existente da edificação, e que podem eventualmente ser retirados, retornando ao estado anterior, como rampas metálicas sobrepostas.

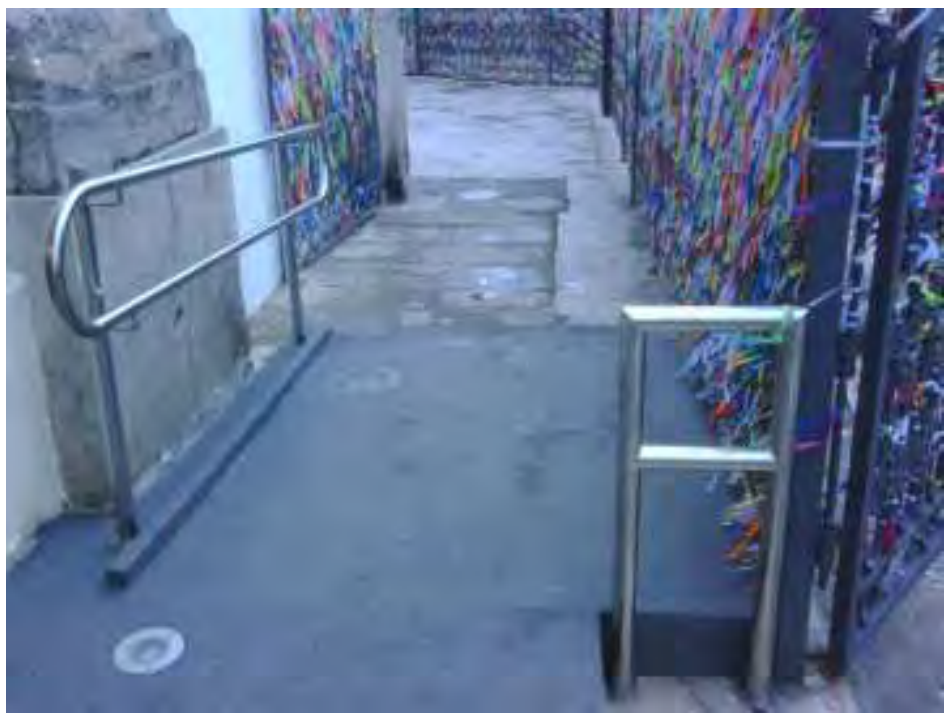

Figura 4 - Exemplo de sobreposição: rampa na Igreja do Bonfim - Salvador. Foto: Eduardo Romero. Data: 2010.

As sobreposições e adições, de forma geral, são preferenciais à 
supressão, pois esta exclui um elemento original da edificação. Porém várias condicionantes devem ser avaliadas na hora de se decidir qual das posturas adotar. E uma mesma edificação pode receber mais de um tipo de alteração, entre as opções apontadas, nas suas diferentes partes.

Qualquer uma das opções propostas pode resultar em prejuízos ao bem cultural imóvel se mal aplicadas ou se definidas sem critério.

Como apontado por Desmaison (MARTíN et al., 2007, p. 18),pode resultar em grande prejuízo também:

[...] la actitud neutra o passiva de quien, simplemente tiene que cumplir com una normativa, cosa que normalmente ocurre cuando los proyectos están acabados y se inicia el duro proceso de adaptar todo lo diseñado a un determinado número de requisitos.

O momento correto de se propor acessibilidade em uma intervenção é na fase de projeto. Pelo fato de ser vista como elemento acessório e pela falta de familiaridade com sua aplicação, geralmente, a preocupação com a acessibilidade ao edifício só aparece após a finalização do projeto - se não mesmo da obra -, prejudicando as possibilidades e a análise integral. $E$ nesse momento a acessibilidade é caracterizada como pesada, prejudicial e desagradável, por não ter participado da concepção do restauro como um todo.

O campo da acessibilidade é muito mais objetivo e exato do que o do restauro. Apesar de o Desenho Universal ser baseado em diretrizes, sem regras prontas, assim como o restauro, hoje, em resumo, a acessibilidade é rígida, fixa, métrica e baseada em regras determinadas em legislações e normas. Portanto, isso faz com que a análise da acessibilidade seja algo taxativo, ou se é ou não, sem meio termo. Por outro lado, a análise da preservação, apesar da legislação disponível, é 
baseada em contexto, costume e referenciais, adquirindo caráter subjetivo, pois pode ter aplicações diferentes de país para país. Na acessibilidade, apesar de poder ter alguma variação de país para país, verifica-se que há grande semelhança conceitual e proximidade métrica. Apesar de conceitualmente ocorrerem bastante semelhanças no campo do restauro mundo afora, isso vem de costumes e conhecimento dos profissionais que atuam e se mantém atualizados ao diálogo mundial, e não por haver uma lista de conduta rígida a ser seguida. Aplicar o Desenho Universal é atender princípios, que podem trazer uma gama variada de soluções, caso se tenha um amplo conhecimento das necessidades, propondo-se um deslocamento seguro e com autonomia. Por facilitar a aplicação e a verificação, e para garantir a qualidade do espaço, o caminho prático, que temos à mão, são as normas.

As equipes multidisciplinares envolvidas na restauração devem incorporar arquitetos com ampla experiência e conhecimento das necessidades das pessoas com deficiência, das normas técnicas e recursos de tecnologia para contribuir na discussão e agregar valor ao objeto de intervenção, desde o início da concepção do projeto.

Devemos lembrar que sempre é possível dar melhores condições de acesso e uso em relação à situação atual e que acessibilidade é uma ação em progresso, que exige constante avaliação em busca de aperfeiçoamento, e não uma meta com fim definido.

Tudo o que foi apresentado aqui pretende ser uma contribuição para o debate que envolve as duas áreas, trazendo reflexões sobre como considerar cada um dos dois lados, criando um viés único de atuação conjunta. A edificação é um 
corpo vivo, que deve ser tocado com cuidado e respeito. A pesquisa, o conhecimento e o reconhecimento são os maiores aliados que o profissional pode ter para as tomadas de decisão. O resultado de um trabalho crítico, fundamentado, conciso, atual e consciente traz riqueza ao patrimônio, tornando-o efetivamente apropriado por todos.

\subsection{Exemplos de intervenções}

Aqui se propõe apresentar brevemente alguns exemplos de bens culturais imóveis, sítios urbanos e arqueológicos, no Brasil e no mundo, que receberam adaptações para garantir o usufruto do patrimônio pelas mais diversas pessoas.

Um estudo detalhado sobre cada uma dessas e de outras intervenções, mostrando os elementos condicionantes das decisões e os resultados obtidos deve ser fruto de publicações, em especial dos órgãos de preservação, de forma a divulgar soluções e caminhos bem sucedidos. Infelizmente, tal compilação, prevista no item 2.5 da Instrução Normativa do IPHAN n $01 / 2003^{42}$, nunca foi feita em âmbito nacional ou regional. Outro ponto da Instrução dá apoio a essa possibilidade:

1.3.1. Os imóveis próprios ou sob a administração do Iphan deverão atender as exigências da LF 10.098/2000, especialmente o estabelecido no art. 23 da referida lei, observando-se as seguintes orientações:

a) Soluções em acessibilidade deverão ser implementadas em curto prazo, tendo em vista proporcionar à comunidade o efeito demonstrativo da ação do Iphan, verificada a disponibilidade imediata

\footnotetext{
42 "2.5. Sistematizar experiências e compilar padrões e critérios, avaliados e aprovados pelas unidades do Iphan, a fim de instruir Manual Técnico destinado a estabelecer parâmetros básicos para acessibilidade aos bens culturais imóveis acautelados em nível federal, e propiciar a atualização permanente dos procedimentos, instrumentos e práticas da Instituição."
} 
de recursos técnicos e financeiros.

b) Os bens culturais imóveis acautelados em nível federal serão adaptados gradualmente, com base nesta Instrução Normativa, em ações propostas pelo Iphan, por seus respectivos Departamentos, Superintendências e Unidades, respeitando-se a disponibilidade orçamentária, os níveis de intervenção estabelecidos pelos responsáveis para cada imóvel, a ordem de relevância cultural e de afluxo de visitantes, bem como a densidade populacional da área no caso de sítios históricos urbanos.

Quase dez anos depois, atendendo a esse item, que exige adequações em curto prazo e de forma gradual, atualmente não faltariam bons exemplos a ser publicados. Essa é uma demanda urgente do órgão e o recurso deve estar previsto anualmente no orçamento, no entanto não se vê o resultado. Portanto, qual será o efeito demonstrativo da ação do IPHAN para a comunidade?

Casos pontuais são divulgados, mas nunca com a riqueza de detalhes que se gostaria e se deveria conhecer para servir de material de consulta de profissionais envolvidos em novas realizações. Tudo isso torna as ações isoladas e o debate inativo.

Desta forma segue-se um conjunto até certo ponto aleatório de exemplos nacionais e internacionais, sem uma avaliação aprofundada, pois a ausência de informações torna difícil realizar uma crítica fundamentada. O que justifica, também, o nível desigual de detalhamento entre os exemplos a seguir.

\section{Theatro Municipal de São Paulo - São Paulo}

O edifício de estilo eclético com influência da Ópera de Paris foi inaugurado em 1911 pelos arquitetos Domiziano Rossi e Cláudio Rossi, do escritório de Ramos de Azevedo, e passou por intervenções nos anos 1950, 1980 e 
novamente agora em 2011, no seu centenário.

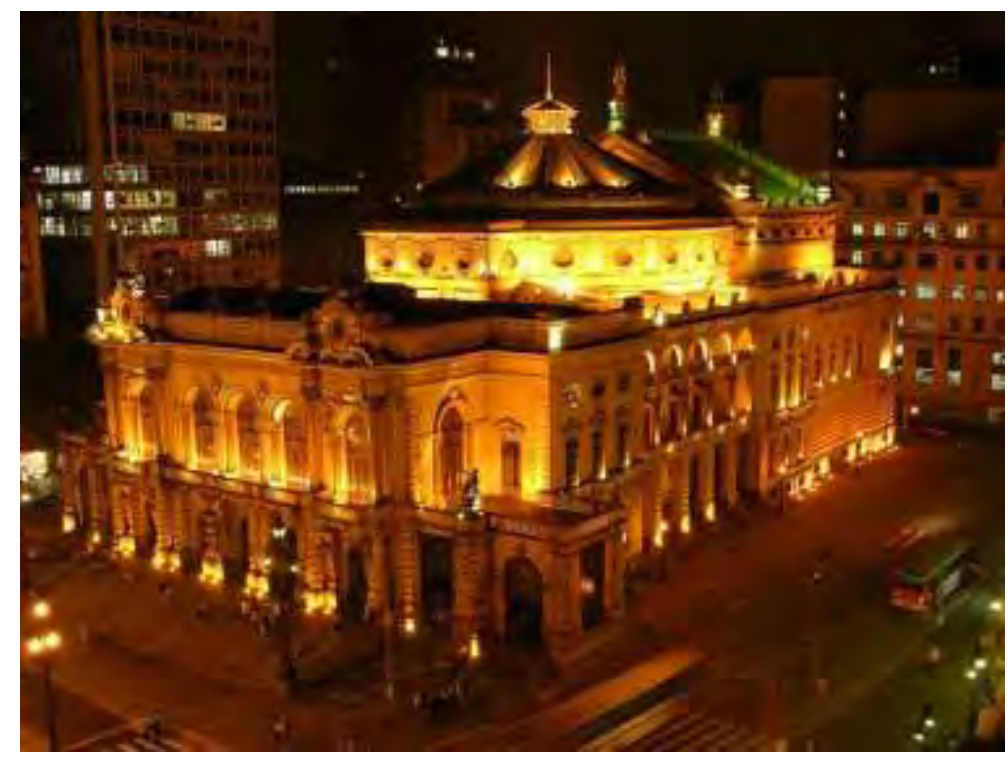

Figura 5 - Vista noturna do Teatro Municipal. Foto: Jefferson Pancieri/SPTuris.
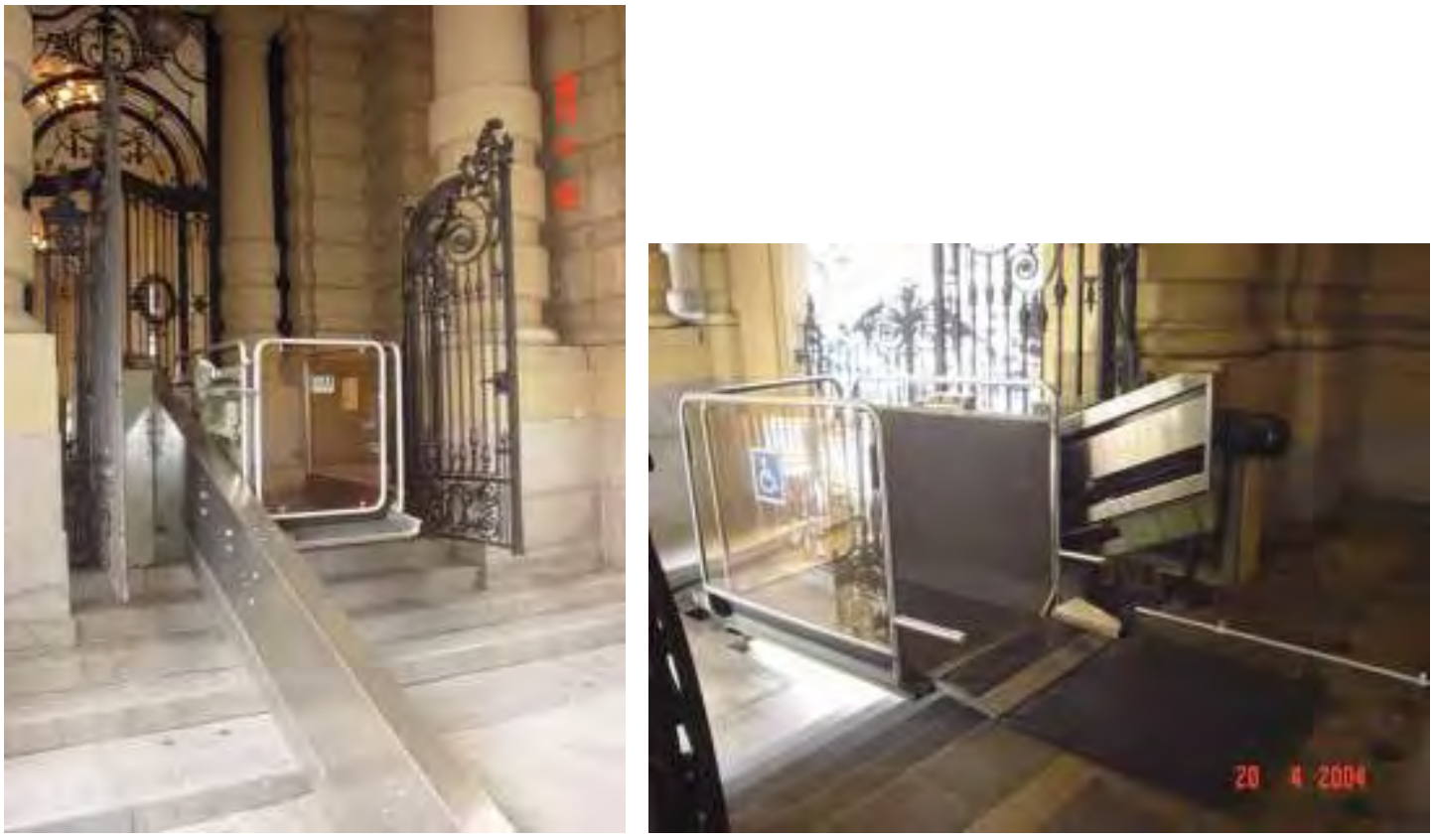

Figuras 6 e 7 - Plataforma inclinada no acesso lateral do Teatro. Foto: Paula Dias/Acervo PMSP-CPA. Data: abr. 2004.

Essa forma de acesso lateral permanece ainda hoje, mesmo após a ampla restauração por que passou o teatro, reinaugurado em 2011. Resta saber, se a manutenção dessa condição, proposta há mais de dez anos, passou por reavaliação ou se o assunto foi ignorado. 


\section{Biblioteca Mario de Andrade - São Paulo}

Além do patrimônio em si que é a construção art déco de 1935 de autoria do arquiteto francês Jacques Pilon, a Biblioteca Mario de Andrade guarda um acervo com mais de 3 milhões de itens, entre livros, periódicos, mapas e materiais audiovisuais, o que torna especialmente importante garantir o acesso de todos à riqueza cultural ali disponibilizada.

A Biblioteca passou por um profundo processo de modernização e restauro a cargo do escritório Piratininga Arquitetos Associados, de 2006 a janeiro de 2011. De forma relutante, como afirma Cambiaghi (2011, p. 219), a acessibilidade foi incorporada ao programa de necessidades durante a elaboração do projeto.
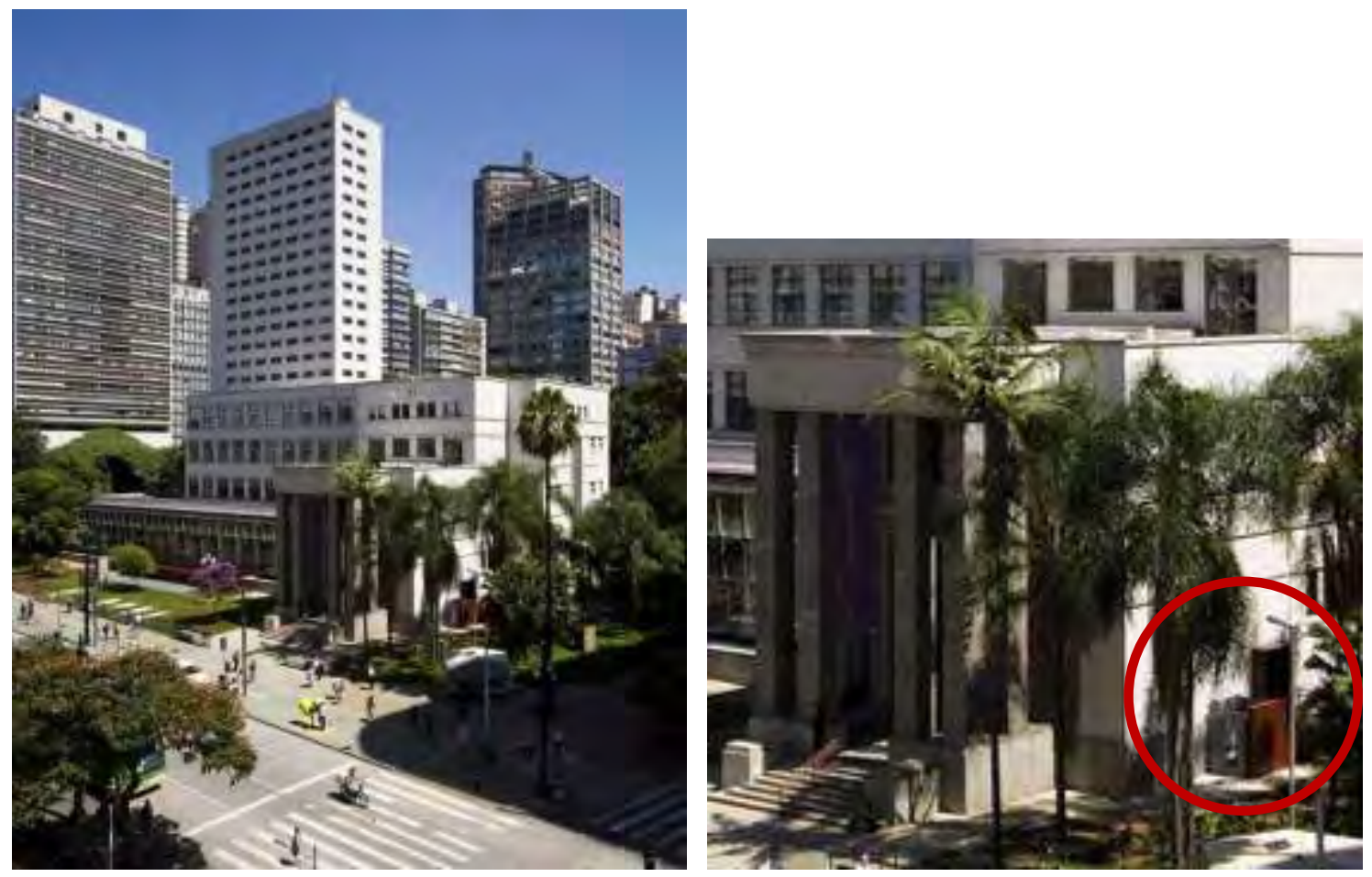

Figura 8 - Vista da Biblioteca Mário de Andrade e detalhe da plataforma na lateral da entrada principal. Foto: Piratininga Arquitetos Associados.

Foi instalada, assim, uma plataforma vertical de acesso, posicionada na lateral do edifício, e bastante próxima da entrada principal. Porém, não há 
sinalização direcional orientando sua localização a partir do acesso principal. A plataforma se torna tão discreta frente à monumentalidade do edifício que não produz qualquer ruído visual para a preservação.
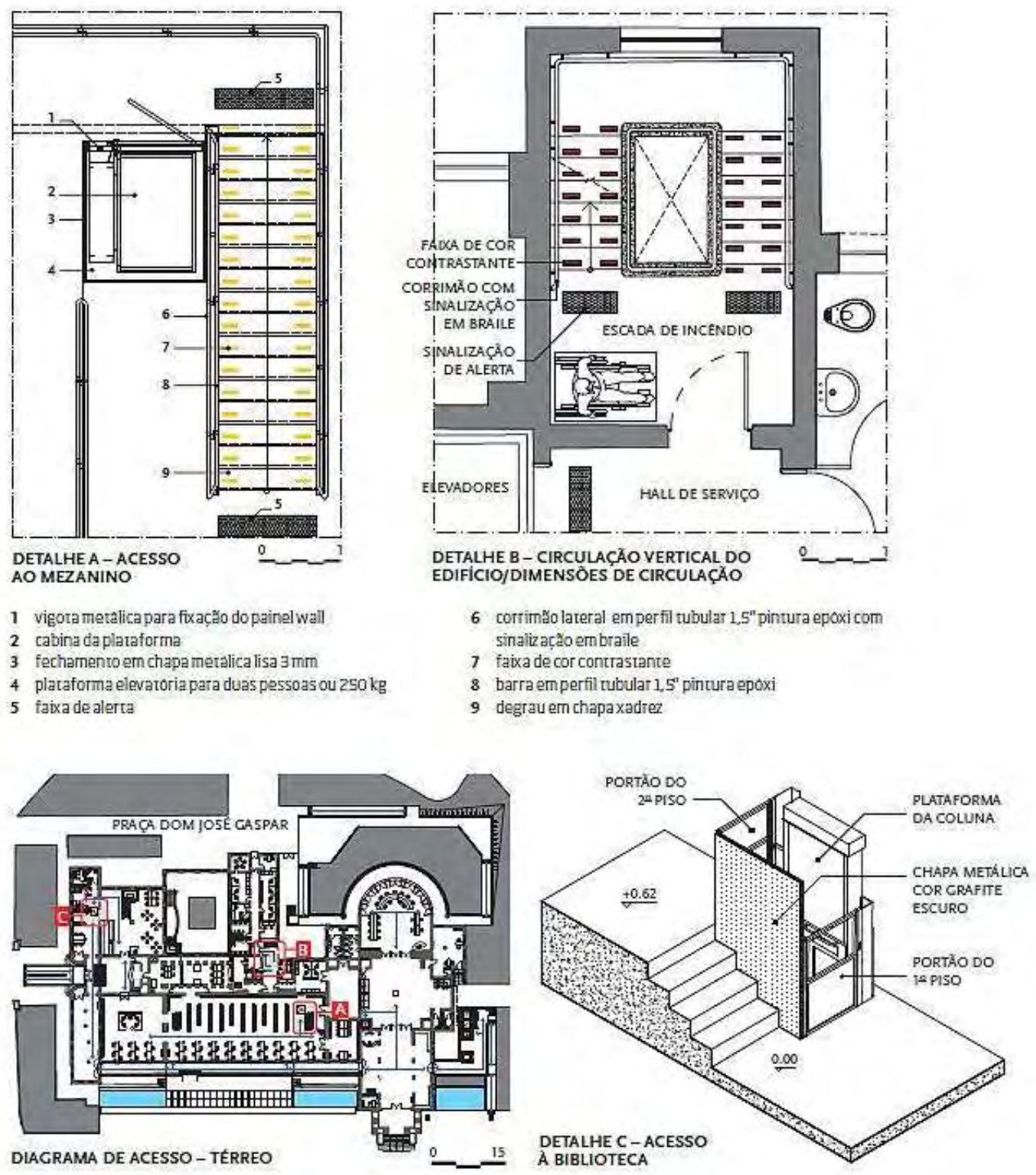

Figura 9 - Detalhes do projeto de acessibilidade da Biblioteca Mário de Andrade. Revista AU. Data: jan. 2012.

Na outra entrada, que fica na Av. São Luís, e é a mais próxima da Biblioteca Circulante, foi colocada uma rampa metálica sobreposta aos degraus para o acesso de todos. Internamente, outra plataforma vertical garante o acesso ao 
mezanino onde fica parte do acervo. No átrio central, um elevador dá acesso a todos os pavimentos. Além disso, há no local sanitários acessíveis, em diversos pavimentos, rampa para o palco no auditório, corrimãos adequados e pisos táteis.

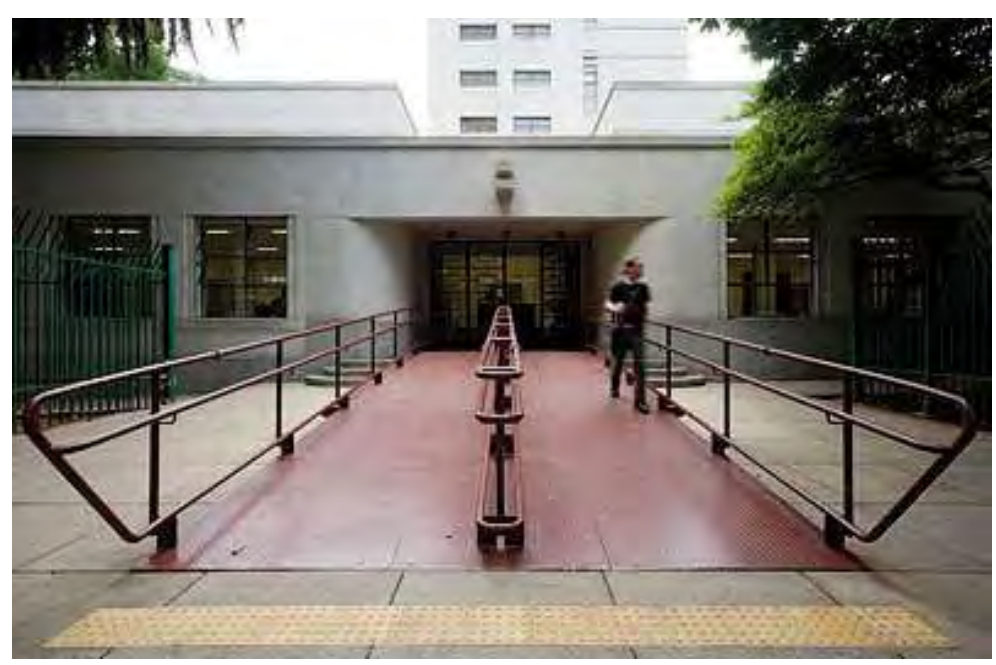

Figura 10 - Entrada da Biblioteca pela Av. São Luís. Foto: Maíra Acayaba/Revista AU. Data: jan. 2012.

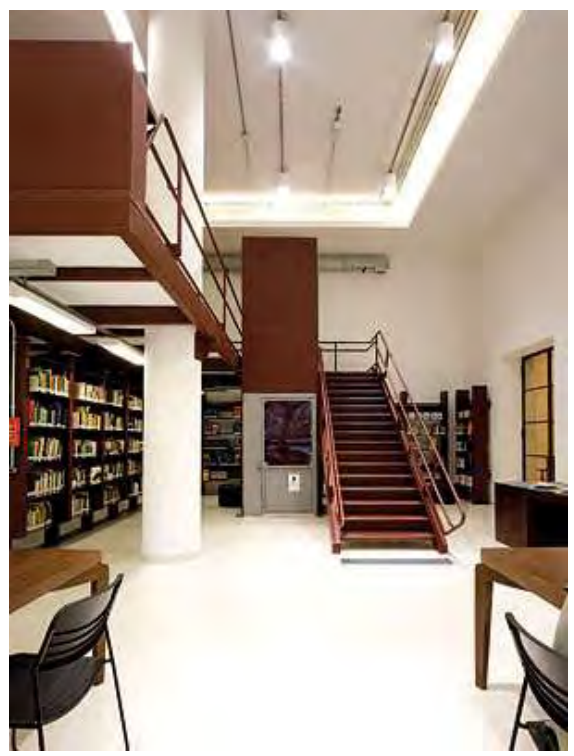

Figura 11 - Plataforma vertical. Foto: Maíra Acayaba/Revista AU. Data: jan. 2012.

O resultado foi uma adaptação eficaz e condizente com as necessidades do público que ainda carecia de forma de participação digna nesse importante patrimônio da cidade.

\section{Casa no 1 - São Paulo}

Conhecida desta forma por situar-se ao no 1 da antiga Rua do Carmo atual Rua Roberto Simonsen nำ136-B - a Casa nำ 1 é um sobrado de três andares com resquícios da casa de taipa de pilão, de 1689, que existiu sob a que está lá hoje de alvenaria de tijolos.

A edificação faz parte dos equipamentos culturais da Prefeitura de São 
Paulo, que compõem o Museu da Cidade de São Paulo, juntamente com outras 12 edificações históricas, para exemplificar a evolução das técnicas construtivas da cidade, representando o uso residencial aristocrático na segunda metade do século XIX

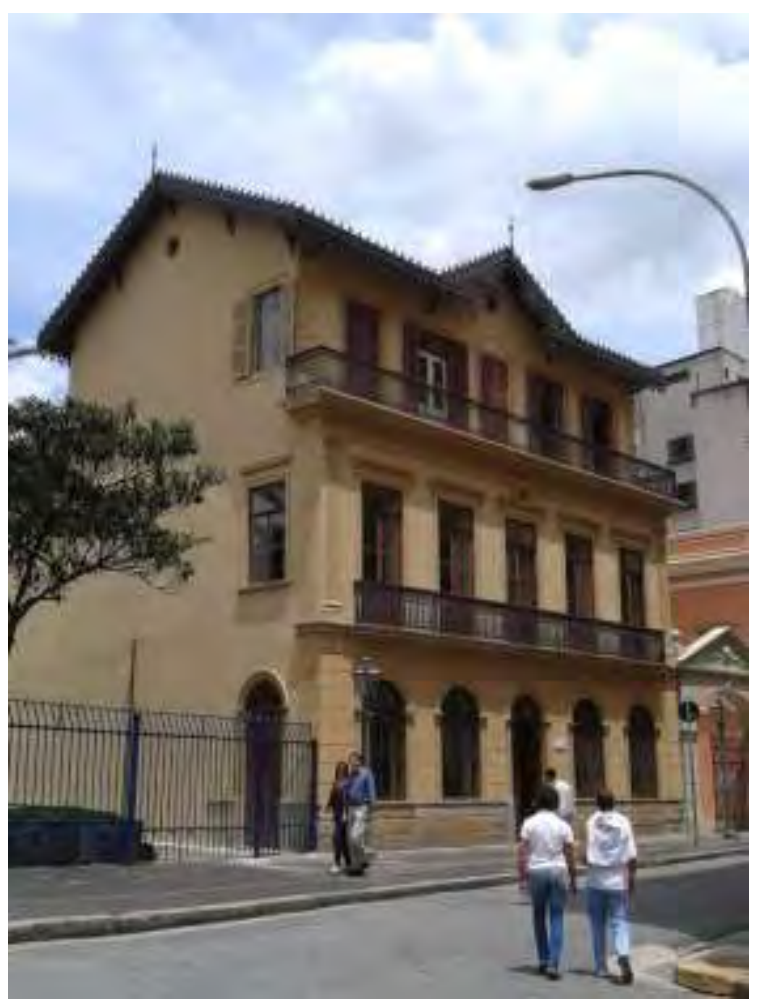

Figura 12 - Vista da Rua Roberto Simonsen da Casa no1. 2012.

Permaneceu fechada de 2008 a 2011, para obras de restauro, que incluíram a reparação integral da parte estrutural, rede de lógica e telefonia, instalação do reservatório para combate a incêndio, intervenções nas pinturas ornamentais internas e adaptação à acessibilidade. Ao ser reaberta recebeu a alcunha de Casa da Imagem e guarda o Acervo Iconográfico municipal, coleção de 710 mil fotografias.

A entrada nivelada com a calçada convida o transeunte a entrar e garante o acesso com autonomia. Internamente, um elevador foi instalado aproveitando o espaço físico de um antigo pátio interno da casa. Pisos táteis de alerta, do tipo placa 
colada, foram colocados em frente à degraus, escadas e elevador, e há um sanitário acessível para uso dos visitantes.

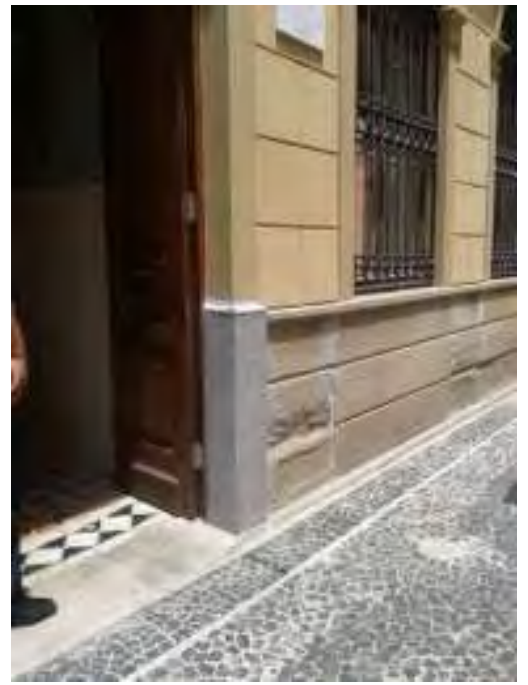

Figura 13 - Entrada. 2012.

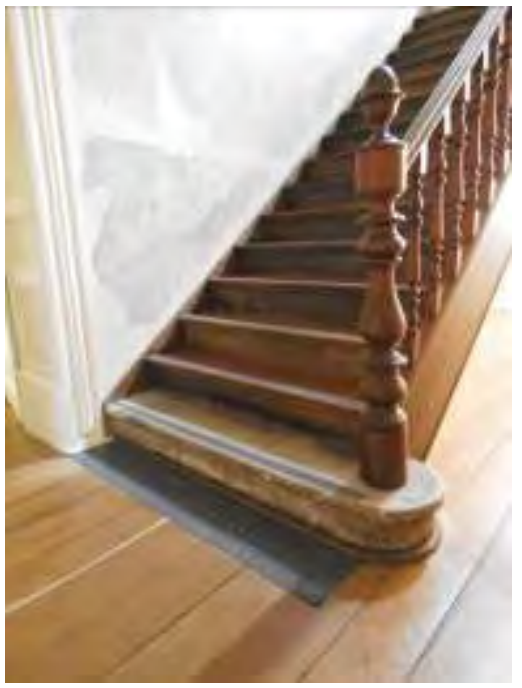

Figura 14 - Escada de circulação geral. 2012.

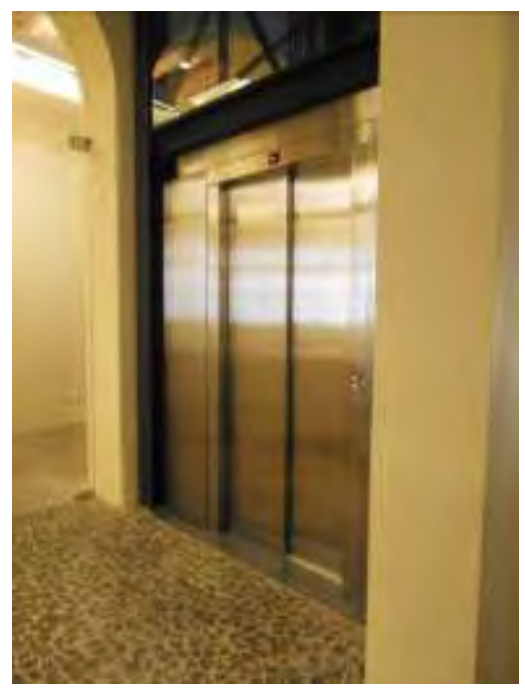

Figura 15 - Elevador. 2012.

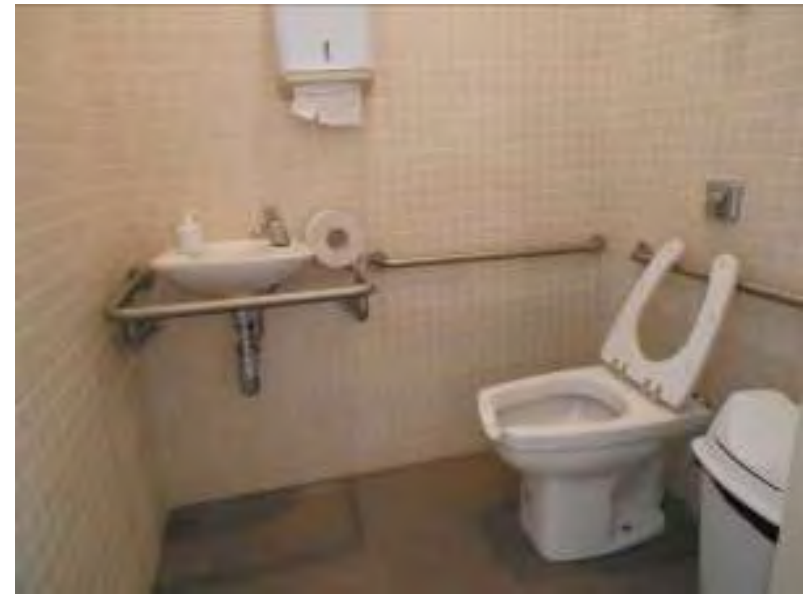

Figura 16 - Sanitário acessível. 2012.

Havendo interesse e compreensão de que um espaço para o público não está pleno se não contemplar o acesso e uso de todos, sempre haverá recursos e soluções para promover a adequação dentro dos limites de preservação. 


\section{Theatro Municipal do Rio de Janeiro - Rio de Janeiro}

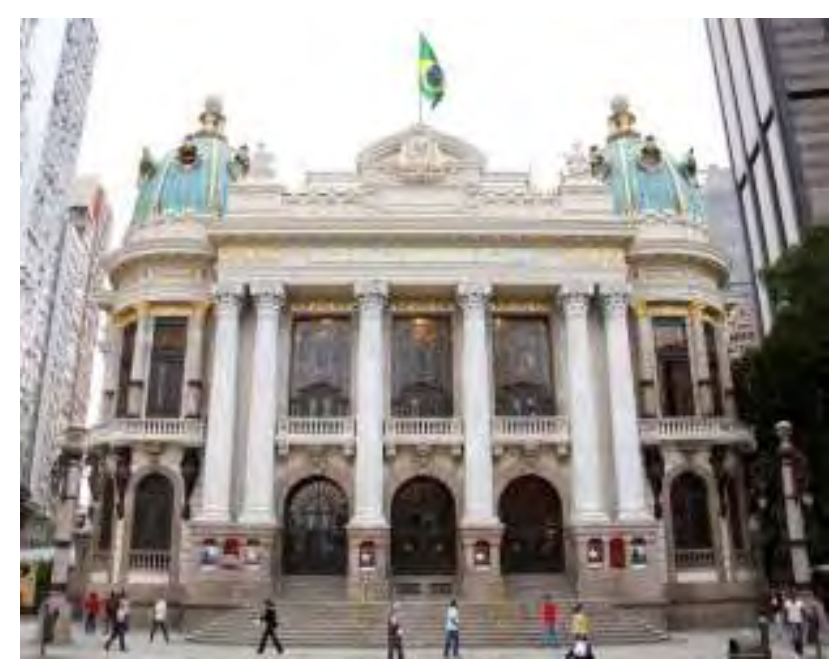

Figura 17 - Fachada principal do Theatro Municipal do RJ. Foto: Caru Ribeiro

Uma das casas de espetáculo mais importantes do Brasil, o Theatro Municipal do Rio de Janeiro, também inspirado na Ópera de Paris, resultou da fusão dos projetos de autoria de Francisco de Oliveira Passos e de Albert Guilbert, que obtiveram $01^{\circ}$ lugar no concurso de projetos para o novo teatro realizado pela prefeitura. Inaugurado em 1909, dois anos antes do teatro paulista, dispunha de mais de 2 mil assentos para seus espetáculos.

De 2009 a 2010 o teatro passou por um restauro como nunca havia sido realizado em seus 100 anos de história. A intervenção incluiu recuperação do telhado, reforma elétrica e hidráulica, restauração de camarins e da sala de espetáculos.

No que se refere à acessibilidade, foi o momento de rever conceitos, já que o local já tinha recebido adequações para garantir o acesso. Segundo a arquiteta Maria Regina Pontin de Mattos do INEPAC/RJ, a solução anterior, um equipamento para subir degraus na entrada da rua posterior do teatro, foi 
considerada muito excludente. Assim, na nova intervenção uma bilheteria foi suprimida para que no local fosse instalado um elevador que permitisse o acesso pela entrada principal.

Quem usa cadeira de rodas ou tem algum outro comprometimento motor que impeça subir escadas fica restrito à plateia, segundo Carla Camurati, presidente da Fundação Theatro Municipal, por conta da própria estrutura do teatro que impossibilitou dar acesso a outras áreas ${ }^{43}$.

A solução adotada anteriormente talvez fosse suficiente para a tecnologia disponível e para os conceitos de inclusão e acessibilidade em vigor. E nada mais correto do que aproveitar um momento de ampla intervenção para reavaliar as posturas e sua validade, em busca de garantir um acesso mais equitativo.

Segundo a Profa. Dra. Regina Cohen ${ }^{44}$, arquiteta associada ao programa de pós-graduação em Arquitetura e Urbanismo da Universidade Federal do Rio de Janeiro (UFRJ), apesar da importante mudança ainda há problemas. Ao descer do carro não há rampa para subir a calçada e o piso do passeio em mosaico português também prejudica o acesso; do foyer à plateia existem dois degraus que são transpostos normalmente por rampas móveis, mas no dia de sua visita não estavam disponíveis e teve de ser carregada; e o sanitário, como observou, também tem inadequações. Ou seja, a necessária revisão do acesso foi feita, mas outros pontos permanecem carentes de novo exame, e fica a incógnita de quando haverá momento tão oportuno para tal.

\footnotetext{
43 Segundo notícia publicada, em 27 maio 2010, no Portal R7: "Teatro municipal do Rio é reinaugurado nesta quinta". Disponível em: <http://noticias.r7.com/cidades/noticias/theatro-municipaldo-rio-e-reinaugurado-nesta-quinta-20100527.html>. Acesso em: 29 set. 2011.

44 COHEN, R. Sobre o Teatro Municipal. [mensagem pessoal]. Mensagem recebida por <contato@elisaprado.com.br> em 23 fev. 2012.
} 


\section{Igreja do Nosso Senhor do Bonfim em Salvador - Bahia}

A igreja do Senhor do Bonfim foi erguida a partir de 1745, em estilo barroco e concluída em 1772, com a chegada das imagens do Senhor Jesus do Bonfim e de Nossa Senhora da Guia, trazidas de Portugal.

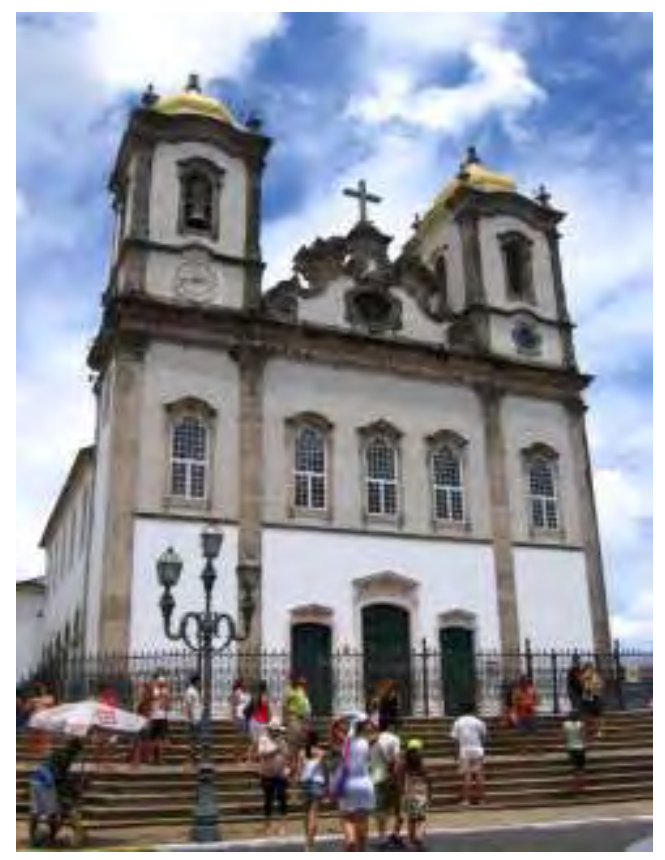

Figura 18 - Escadaria na fachada principal da Igreja do Bonfim. 2009.

Em janeiro de 2010, nessa que é uma das igrejas mais visitadas de

Salvador, finalmente os fiéis com deficiência também tiveram oportunidade de participar de suas missas e prender fitinhas do Bonfim, e fazer seus pedidos, nas grades em frente à famosa escadaria.

Tudo isso, graças a uma pequena adequação utilizando rampas no acesso lateral da Igreja do Bonfim. O acesso lateral se fez necessário devido à escadaria que fica no acesso principal. A rampa colocada na fachada lateral tem duas vantagens nesse caso: o desnível a ser vencido é menor, por conta da própria topografia, e não há alteração na fachada principal. Com esse conjunto de rampas se chega à entrada lateral e à frente da igreja. 

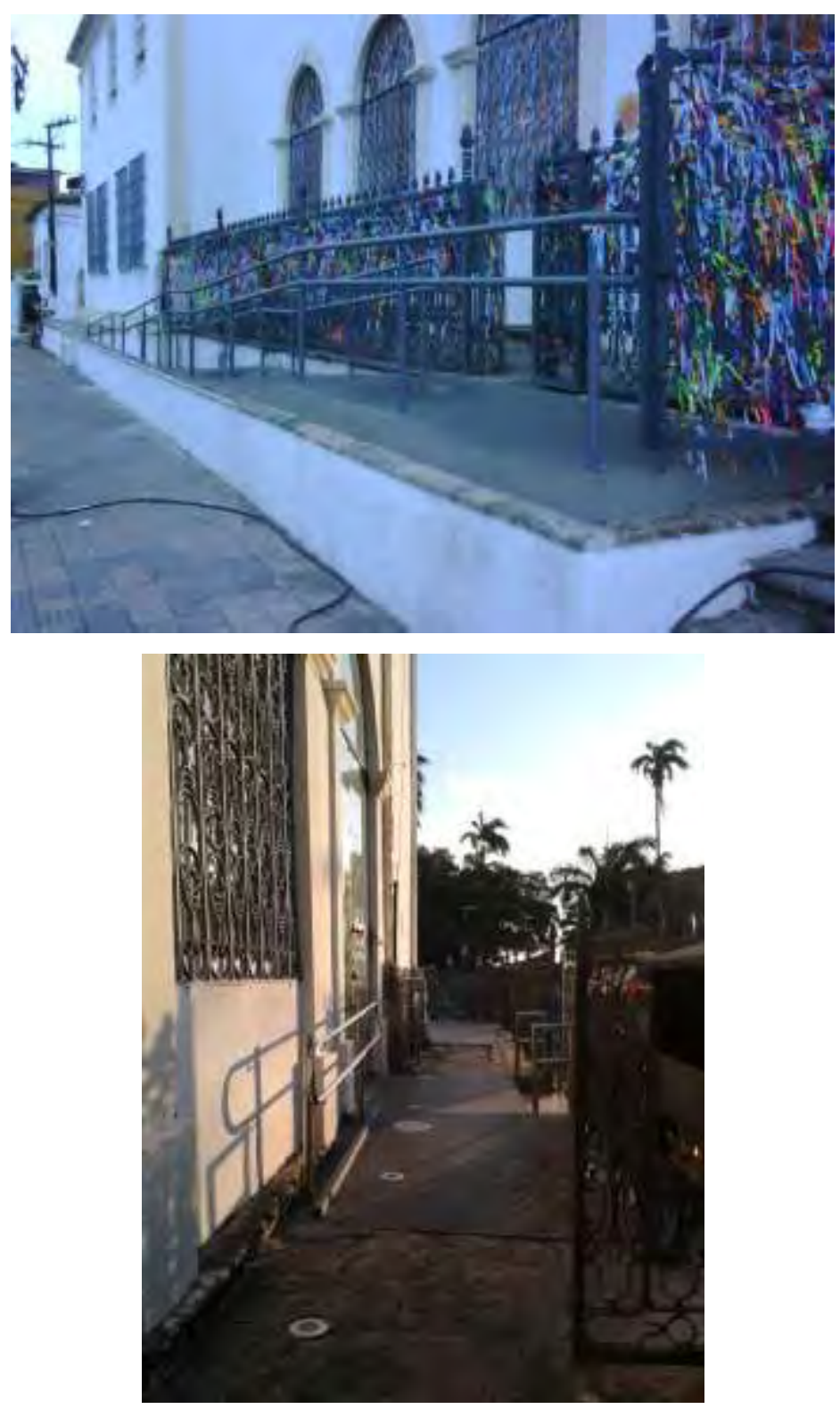

Figura 19 - Rampa de alvenaria na fachada lateral. Foto: Eduardo Romero. Data: 2010.

Figura 20 - Rampa metálica para entrada lateral e acesso à parte frontal. 2011.

A rampa metálica primeiramente sobe, para dar acesso em nível à porta lateral, e depois desce, para o acesso à parte frontal da igreja, permitindo visibilidade do entorno que é também um dos atrativos, já que a igreja está localizada na Colina Sagrada, em cota bastante elevada da cidade.

Palacete das Artes Rodin Bahia em Salvador - Bahia 
O Palacete do Comendador Bernardo Martins Catharino, de 1912, idealizado pelo arquiteto Rossi Baptista e decorado por Oreste Sercelli, expressa o forte poder econômico, advindo do cacau, das famílias baianas, em especial no bairro da Graça. A "Vila Catharino", em estilo eclético, foi escolhida para receber a primeira filial do Museu Rodin fora da França, em 2003, pois guardava "relativa semelhança com o Hotel Biron, local onde está instalado o Museu Rodin Paris" (JORDAN, 2006)

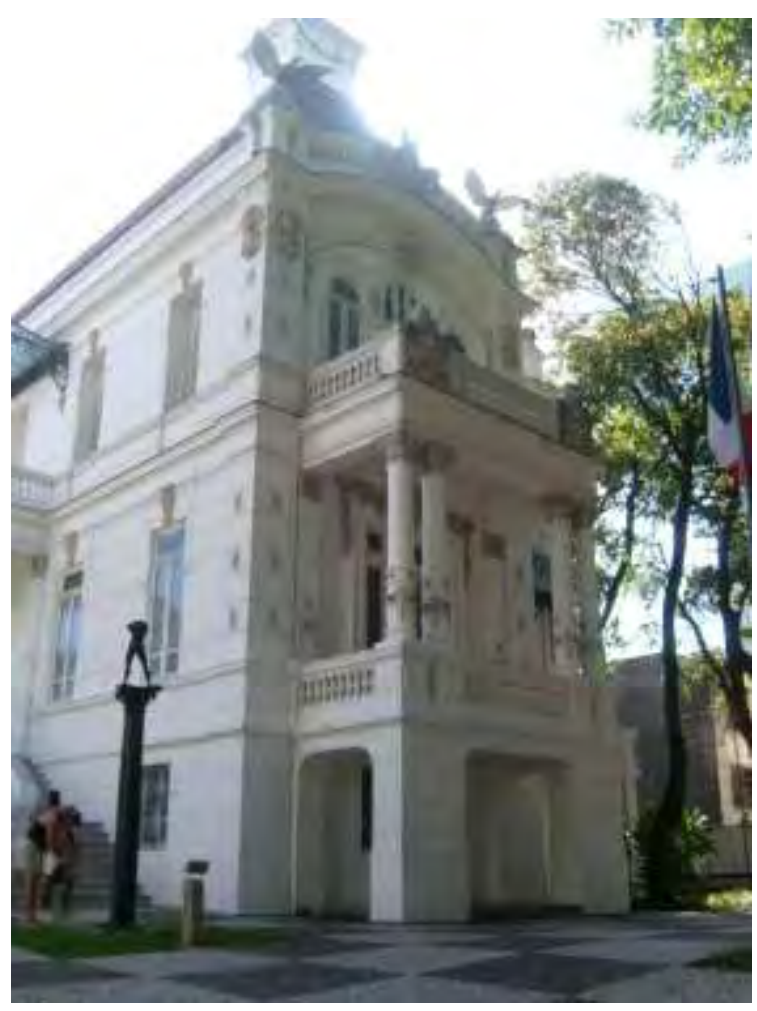

Figura 21 - Vista da fachada principal. 2010.

O escritório Brasil Arquitetura, a cargo dos arquitetos Marcelo Ferraz e Francisco Fanucci, foi o escolhido para transformar a residência em Palacete das Artes Rodin Bahia. A proposta, que incluiu a restauração para recuperação dos elementos estruturais e decorativos da mansão, adicionou um novo volume contemporâneo encaixado em sua parte posterior, além de um anexo posicionado no fundo do lote e interligado por passarela. O volume encaixado, segundo os autores, 
se fez necessário para "criar um novo sistema de circulação vertical ágil e eficiente" (CALDEIRA et al., 2005).

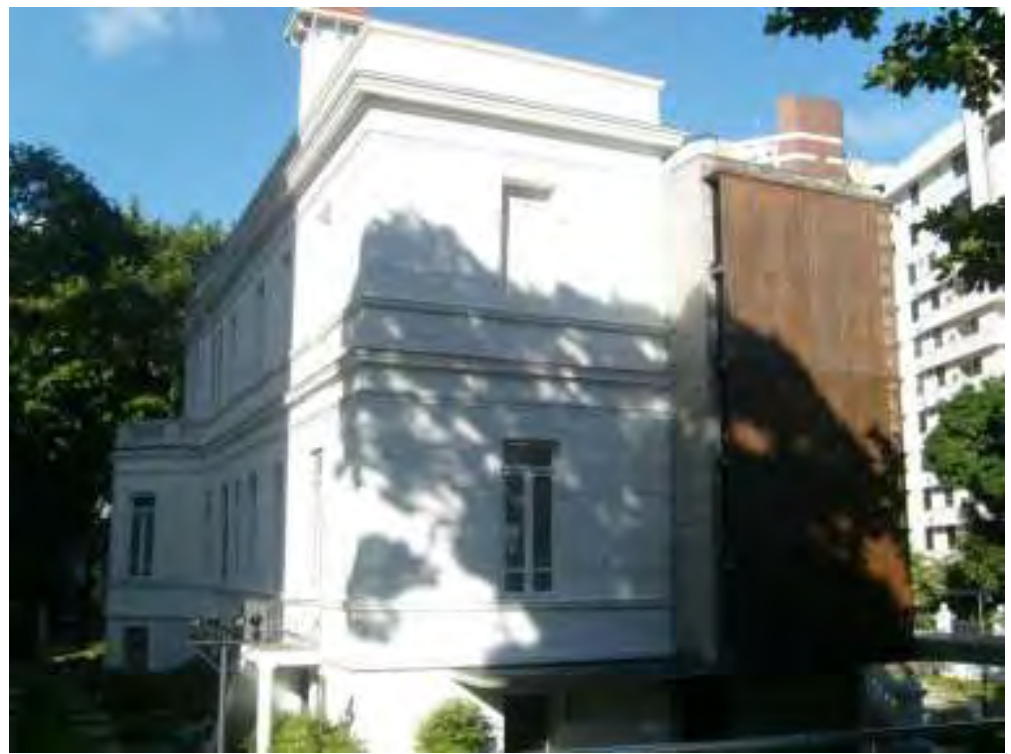

Figura 22 - Vista posterior com novo bloco inserido. 2010.

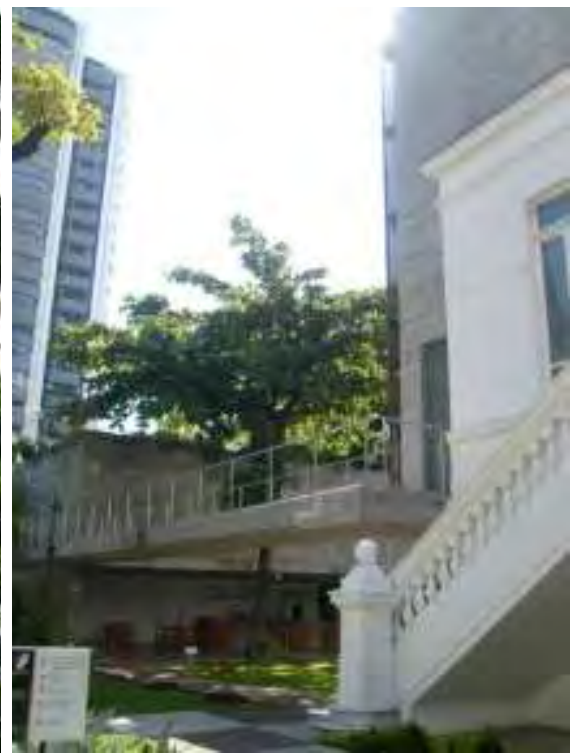

Figura 23 - Passarela e anexo. 2010.

E de fato, essa inserção garante a circulação das pessoas com algum comprometimento motor, entre os três pavimentos abertos ao público. A inserção tem um caráter mais invasivo do que os outros exemplos apresentados, mas ocorre dentro do contexto da intervenção como um todo. A exigência de dispor de mais espaço às novas funções foi resolvida no fundo do lote com o anexo em concreto aparente, de apenas dois pavimentos, para não competir com a construção principal. Portanto, não teria andares suficientes para incorporar a circulação vertical do palacete; e exigiria que as pessoas se deslocassem para fora da área destinada à exposição do Museu Rodin, já que este anexo recebe exposições temporárias de outra natureza. Ao mesmo passo que o anexo se coloca em distância respeitadora ao edifício histórico para não prejudicar suas visuais, a passarela aproxima ambos, como uma ponte entre passado e futuro, arrematado pelo bloco de concreto encaixado. 
Cidade de Veneza - Itália

O centro histórico de Veneza pode ser considerado como uma grande barreira arquitetônica por conta de sua morfologia, constituida de 121 ilhas ligadas por 435 pontes. De um problema aparentemente insolúvel surge uma condição de acessibilidade bastante satisfatória. Em torno de $70 \%$ da cidade histórica é acessível às pessoas com deficiência, graças ao serviço de transporte público.

Para dar visibilidade a essa qualidade um sítio na Internet $t^{45}$ traz as informações necessárias para o turista definir sua visita dentro de sua necessidade. As imagens aqui apresentadas são do sítio em questão.

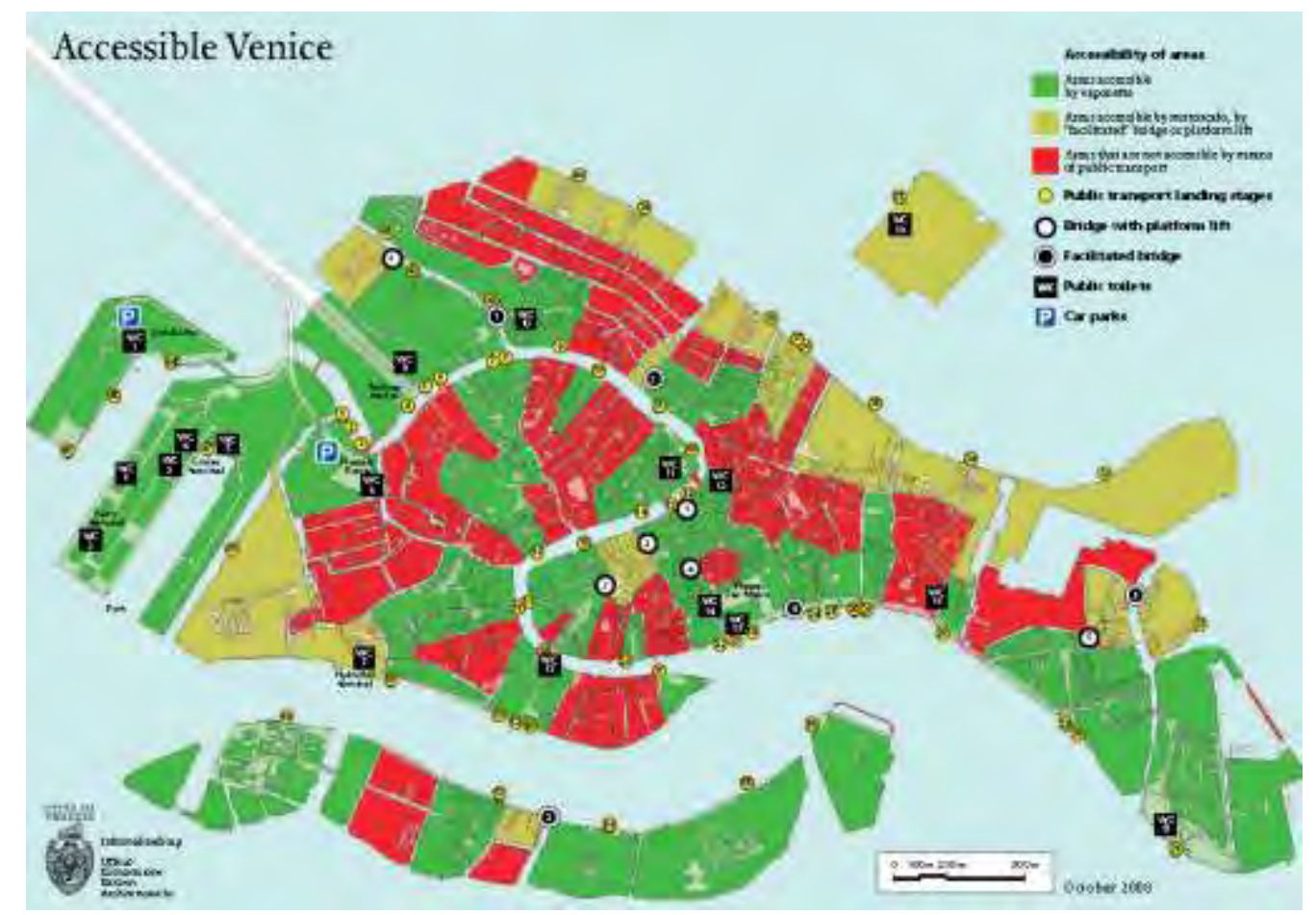

Figura 24 - Mapa indicativo das áreas e serviços acessíveis em Veneza.

Um mapa resume as informações práticas para ajudar as pessoas com

${ }^{45}$ Disponível em:

<http://www.comune.venezia.it/flex/cm/pages/ServeBLOB.php/L/EN/IDPagina/23431 >. Acesso em: 19 set. 2011. 
deficiência e mobilidade reduzida a visitar a cidade. A utilização de cores indica os níveis de acessibilidade pela ausência ou presença de transporte público. As áreas verdes no mapa podem ser alcançadas por vaporetto que transporta até quatro cadeiras de rodas por vez; as áreas amarelas podem ser alcançadas por motoscafi, espécie de barco-táxi, que só pode transportar uma cadeira de rodas por vez; e as áreas vermelhas representam aquelas onde não é possível chegar por transporte público. Também, é indicada a localização de pontes com plataformas ou rampas, além de sanitários públicos e estacionamentos. Além do mapa geral, há mapas para diversas rotas livres de barreiras para pessoas em cadeiras de rodas.

Para chegar às ilhas sem pontes acessíveis será necessário usar o transporte público, que tem preço reduzido para usuário de cadeira de rodas e seu acompanhante.

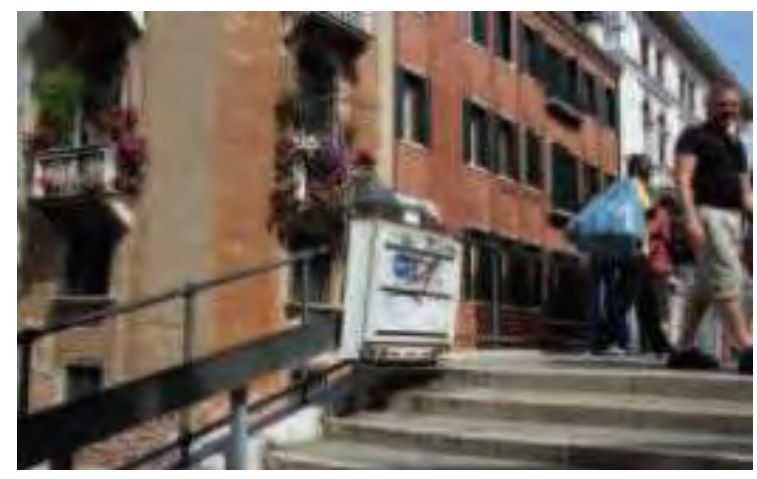

Figura 25 - Plataforma de escada.

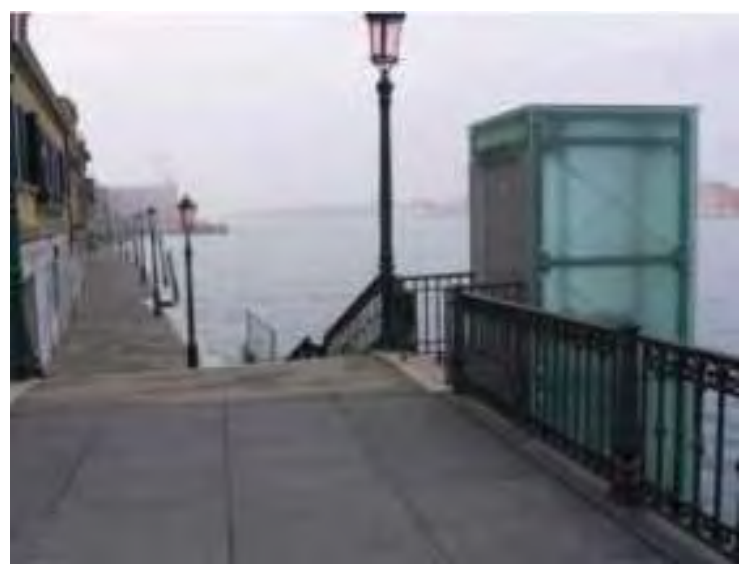

Figura 26 - Elevador/plataforma vertical.

Atualmente o sítio informa que as plataformas de escada nos percursos Rialto e S. Stefano foram retiradas, em fevereiro de 2010 , por não concederem a condição de acessibilidade esperada, sem explicar profundamente. Mas provavelmente isso está ligado à problemas recorrentes nesse tipo de equipamento: dificuldade de autonomia no uso e manutenção constante, em especial por ficar sujeito à intempéries. Como alternativa, deve ser usado o transporte público, 
enquanto não for disponibilizada outra solução mais adequada.

As escadas com extensos degraus permitiram uma solução que utiliza rampas móveis feitas de material plástico antiderrapante. Outra situação disponível são as rampas comuns, instaladas, em poucos locais em Veneza; a situação típica que se encontra são grandes desníveis associado à reduzidos espaços, a qual inviabiliza rampas com inclinações adequadas.

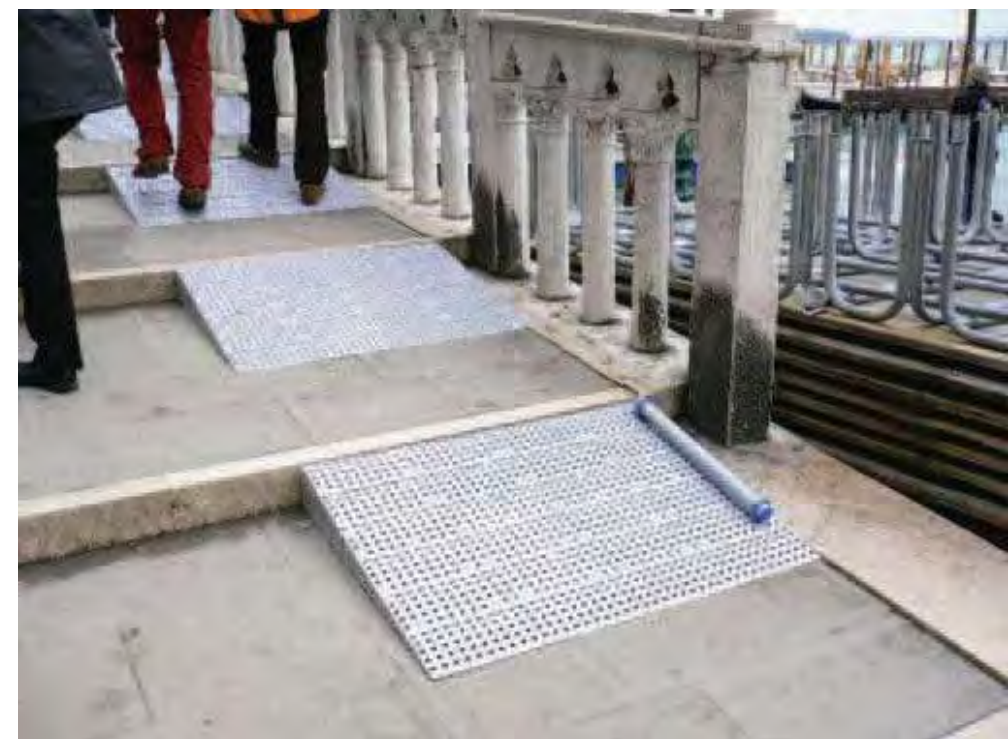

Figura 27 - Rampa móvel na Ponte della Paglia.

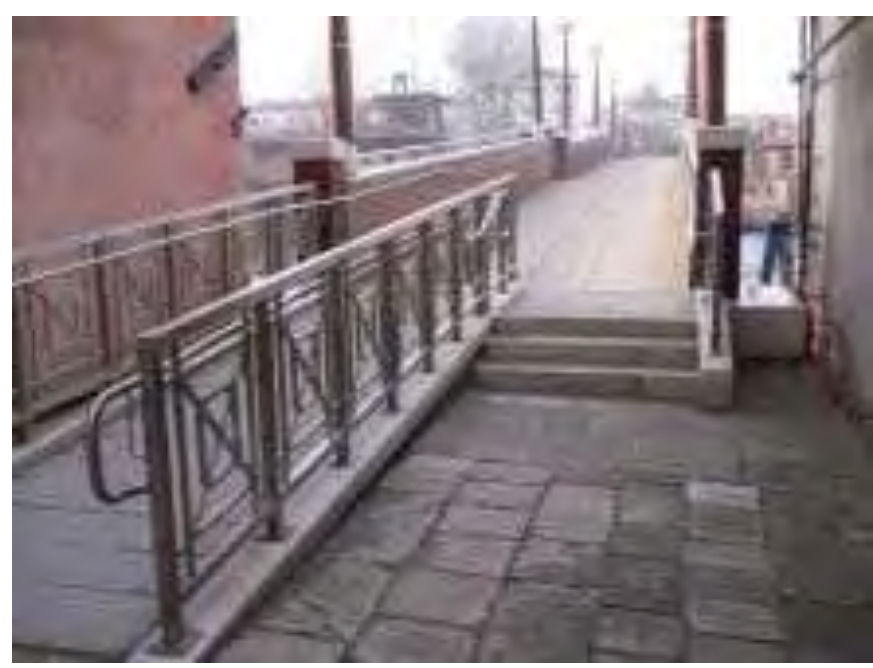

Figura 28 - Rampa na Ponte dei Lavraneri.

Para os visitantes com deficiência visual, foram instalados em alguns 
pontos pisos táteis de alerta ou portões de proteção ao longo das margens do canal para alertar/proteger do risco de queda na água. As quedas nos canais, na verdade, são um problema antigo em Veneza e os portões já eram utilizados pelos venezianos. Em alguns trechos, onde pontes estão localizadas fora do percurso natural, foram colocados pisos táteis direcionais favorecendo a orientação.

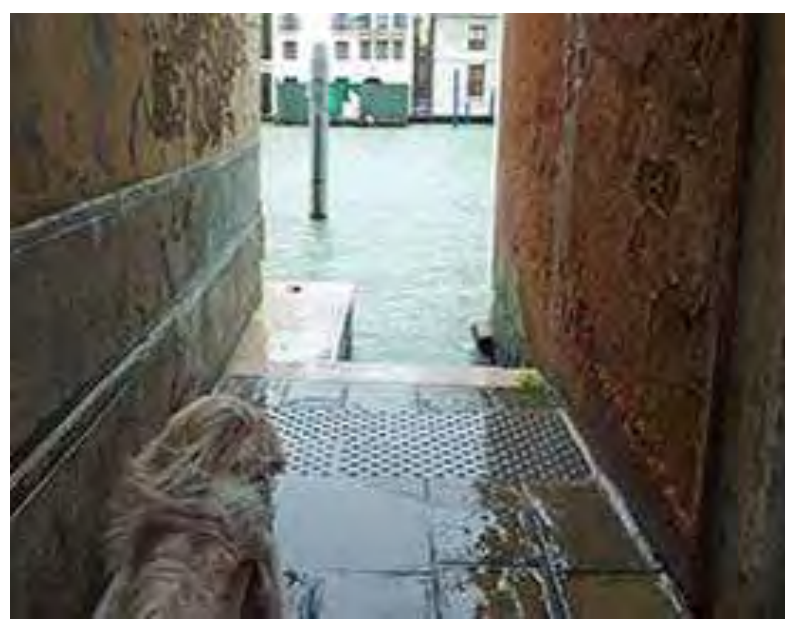

Figura 29 - Piso tátil de alerta na Calle Bernardo.

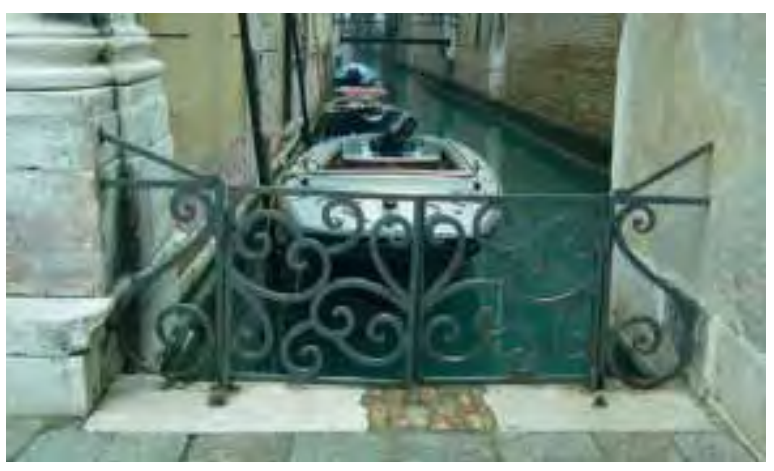

Figura 30 - Portão móvel para prevenção de queda em Campo S. Stefano.

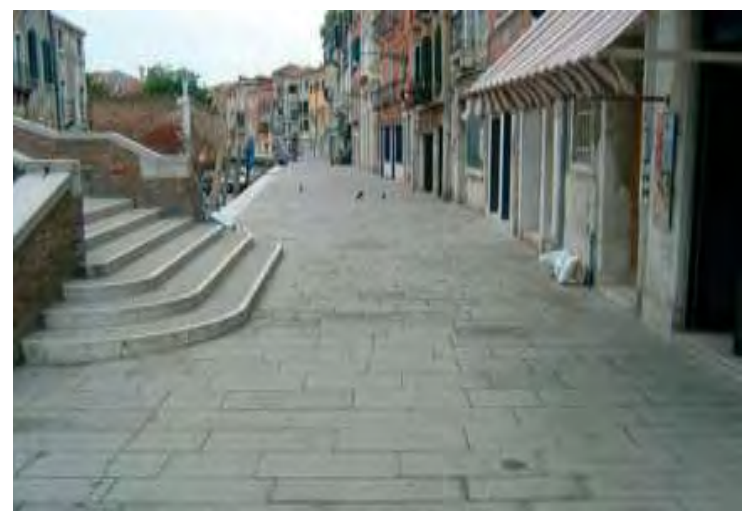




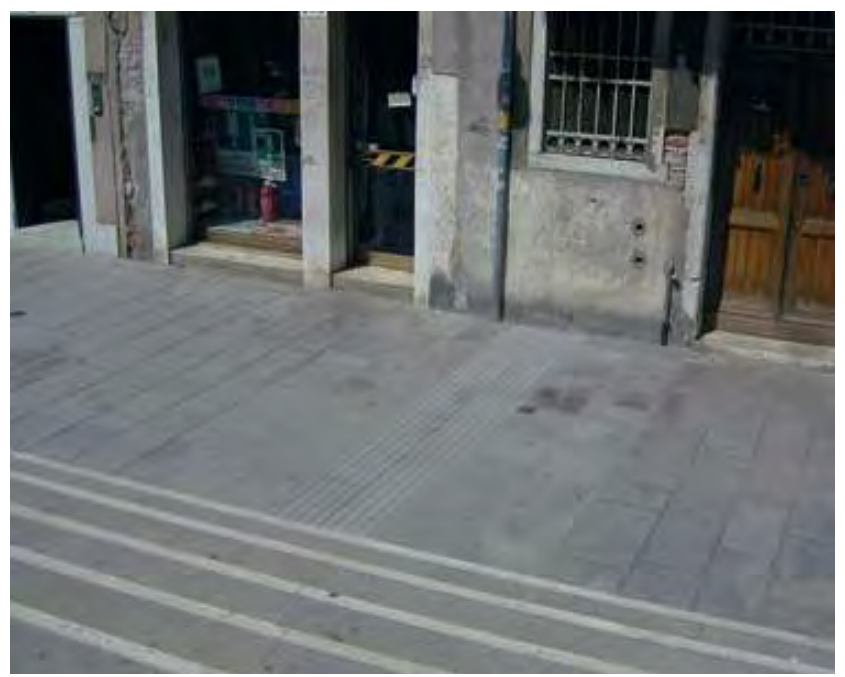

Figura 31 - Via com acesso perpendicular à ponte.
Figura 32 - Piso tátil direcional orientando percurso à ponte.

\section{Villa d'Este em Tivoli - Itália}

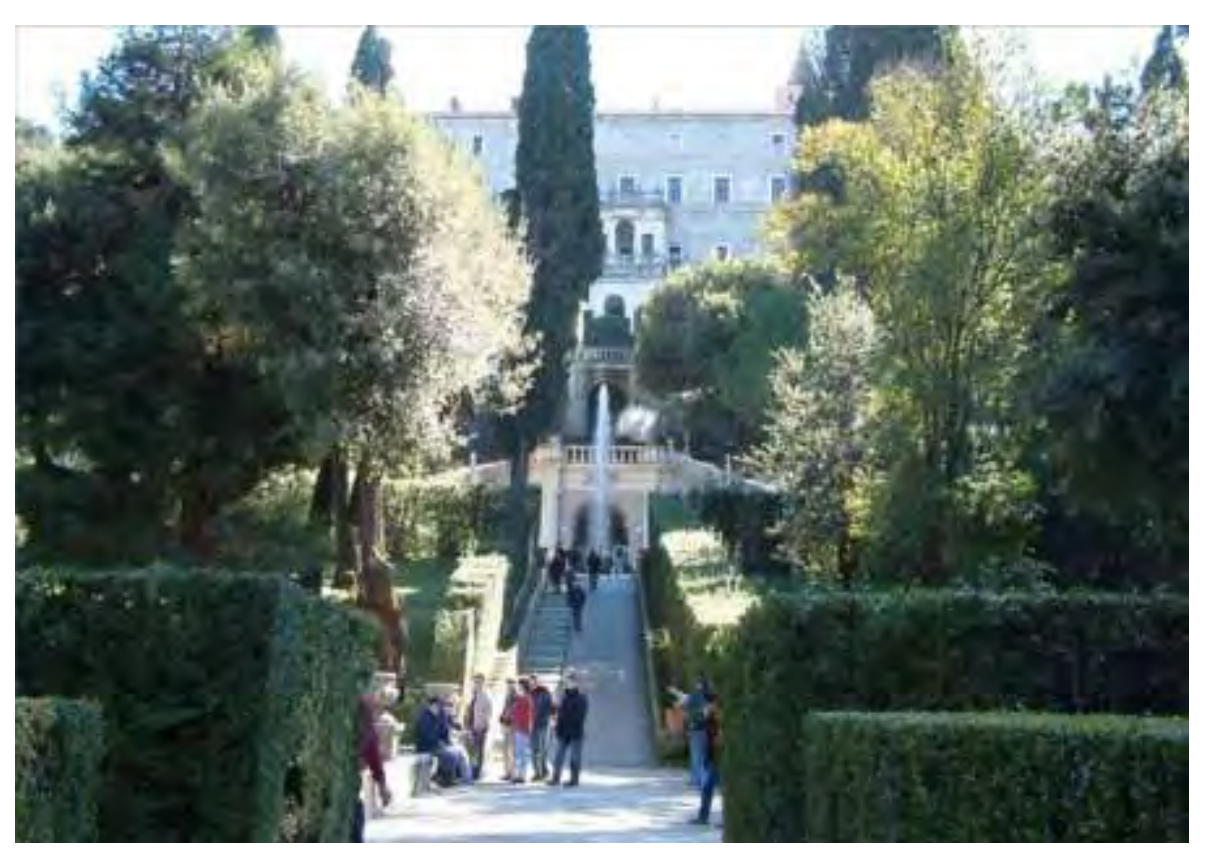

Figura 33 - Visão geral da Villa d'Este. Foto: Fabrizio Vescovo.

A Villa d'Este em Tivoli, na Itália, considerada como patrimônio da 
humanidade pela UNESCO, trazia um desafio enorme para a promoção da acessibilidade. O conjunto do século XVI tem um jardim que ocupa uma extensão de 4.5 ha, dividido em diversos níveis. A solução encontrada pelo arquiteto Fabrizio Vescovo foi utilizar um sistema de transporte com carros elétricos, que pode tanto transportar pessoas em suas cadeiras de rodas, como pessoas com mobilidade reduzida, utilizando os assentos disponíveis. É possível percorrer boa parte do jardim, o qual recebeu mínimas correções de circulações e acessos para permitir a passagem deste equipamento, o que configura uma solução mais simples, eficiente e adequada do que a adaptação de toda a área para as limitações de um usuário de cadeira de rodas.

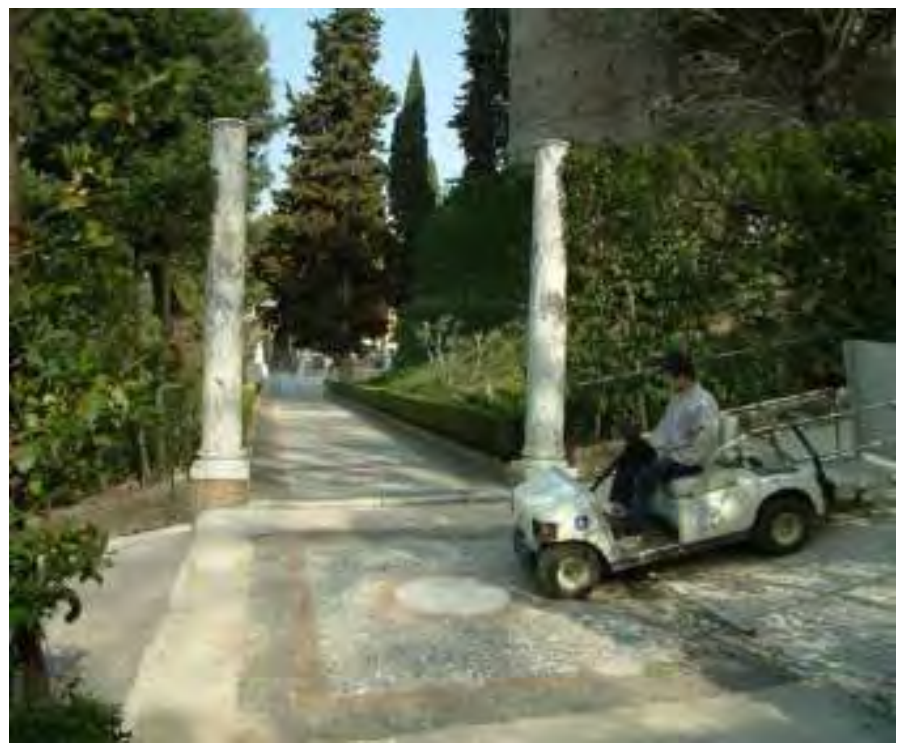

Figura 34 - Carro elétrico percorre o jardim. Foto: Fabrizio Vescovo.

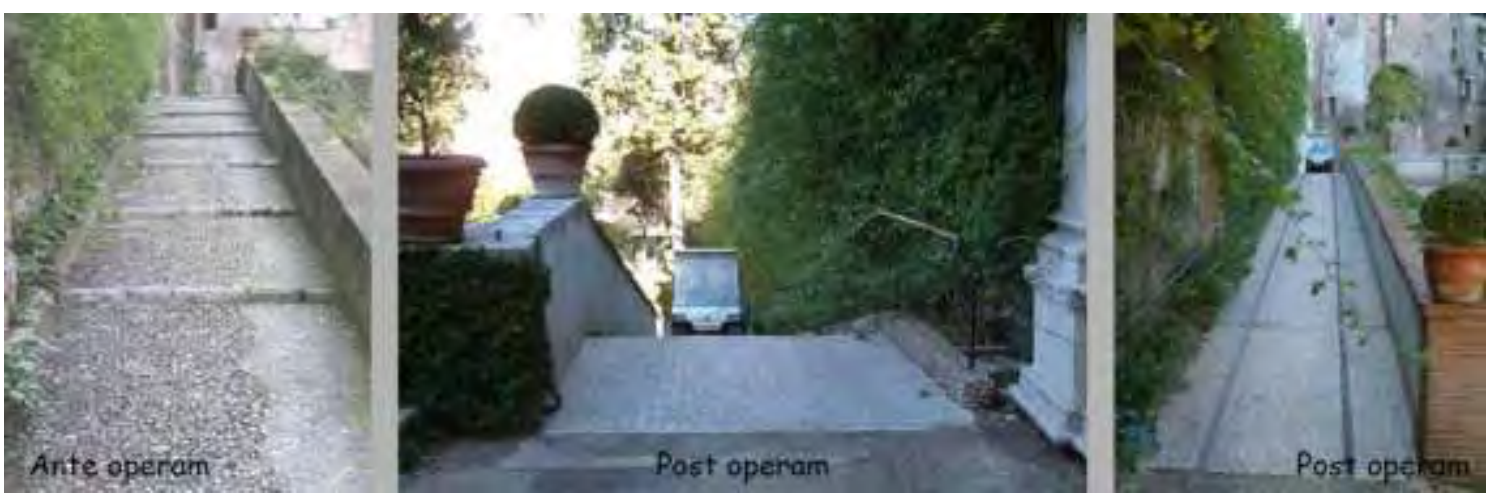


Figura 35 - Antes e depois da alteração de um percurso para a passagem do carro elétrico. Foto: Fabrizio Vescovo.
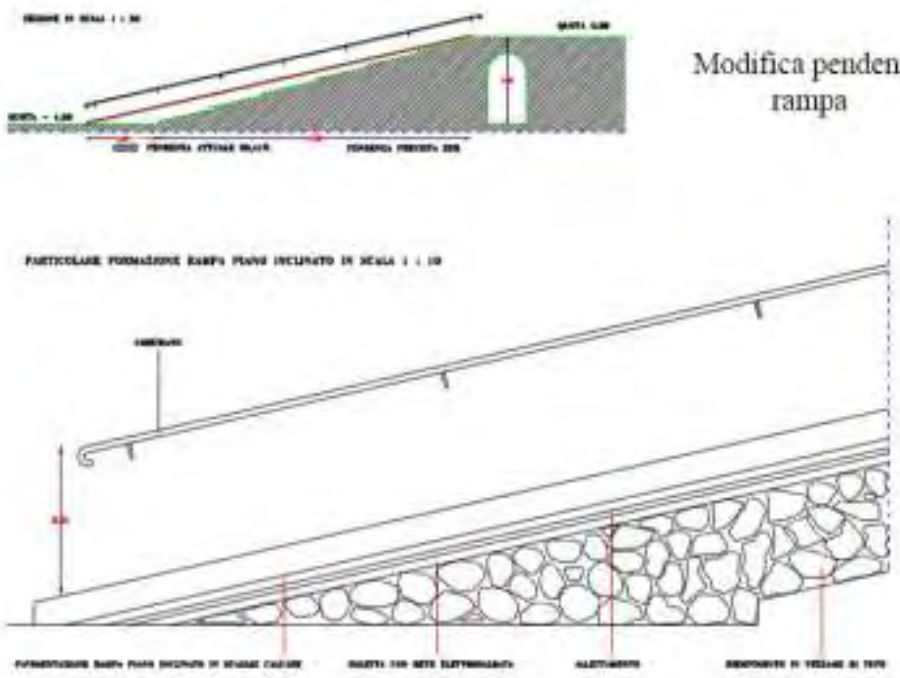

Figura 36 - Projeto alterou a escada com degraus inclinados sobrepondo uma rampa para a passagem do carro elétrico. Desenho: Fabrizio Vescovo.

Quanto ao Palácio, que abriga um museu, a intervenção contemplou a solução para pequenos desníveis, principalmente nas soleiras de entrada, e a construção de um elevador em um pátio secundário, atendendo aos quatro andares, além de instalações sanitárias adequadas. 

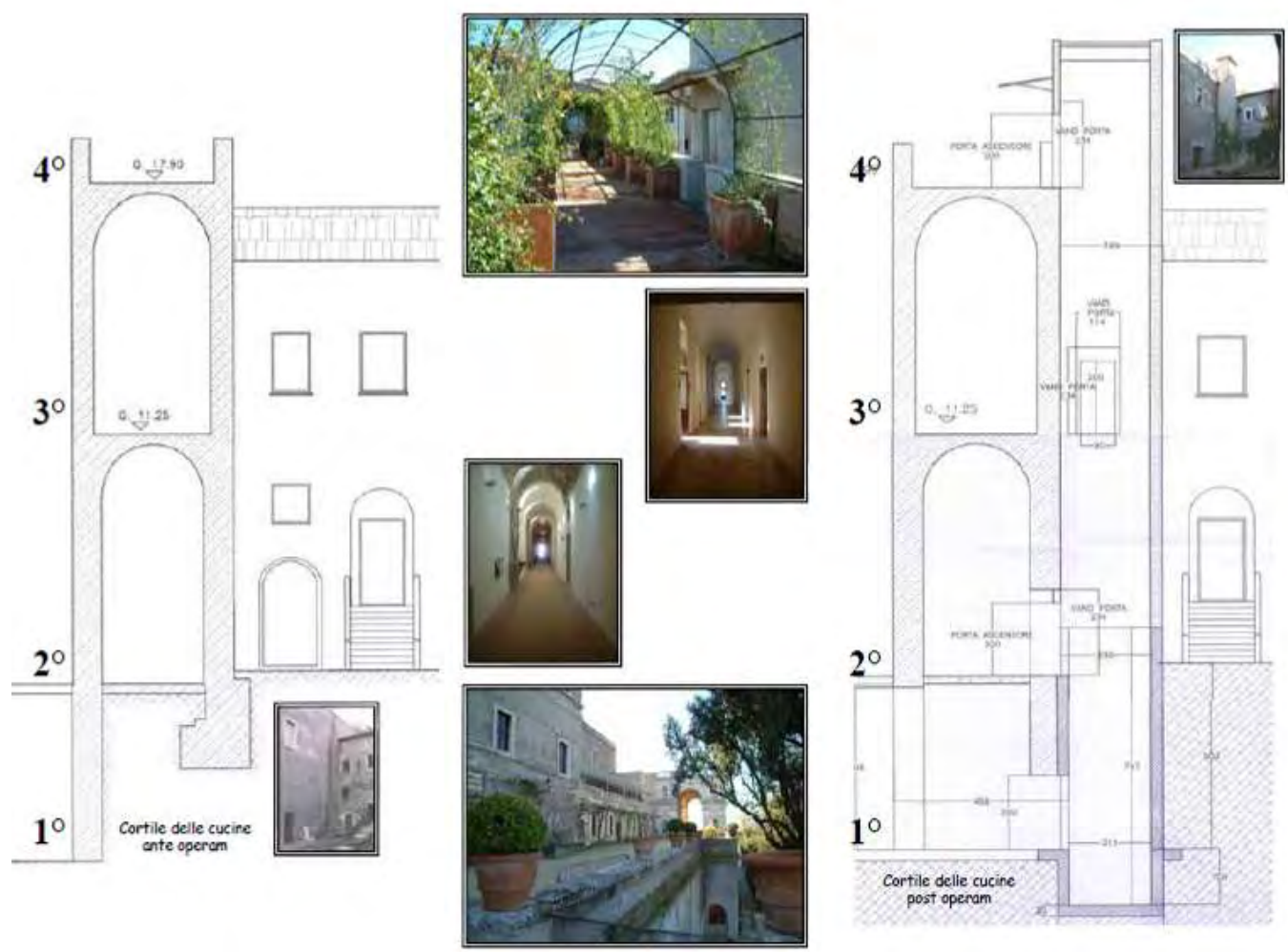

Figura 37 - Projeto para inserção de um elevador. Foto e desenhos: Fabrizio Vescovo.

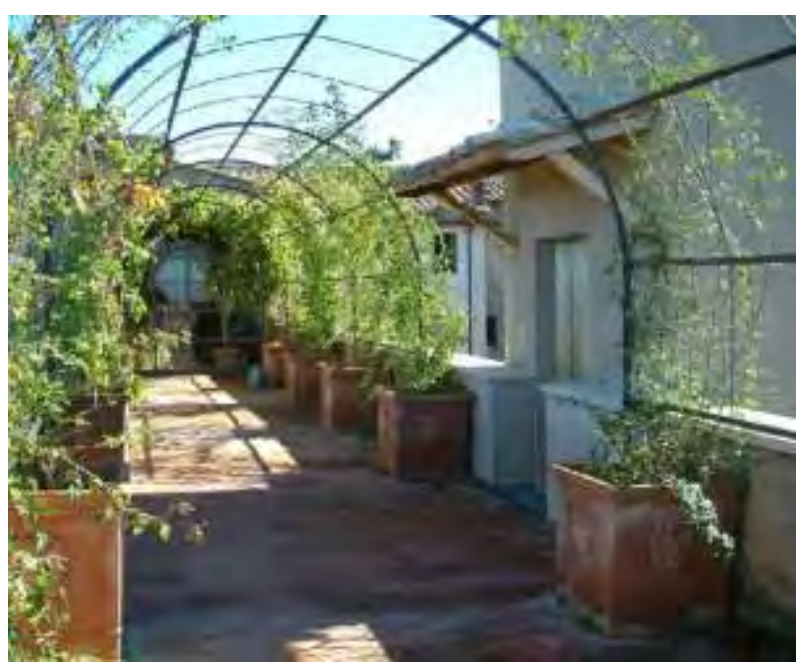

Figura 38 - Porta do elevador à direita. Foto: Fabrizio Vescovo.

Fórum de Trajano em Roma - Itália 


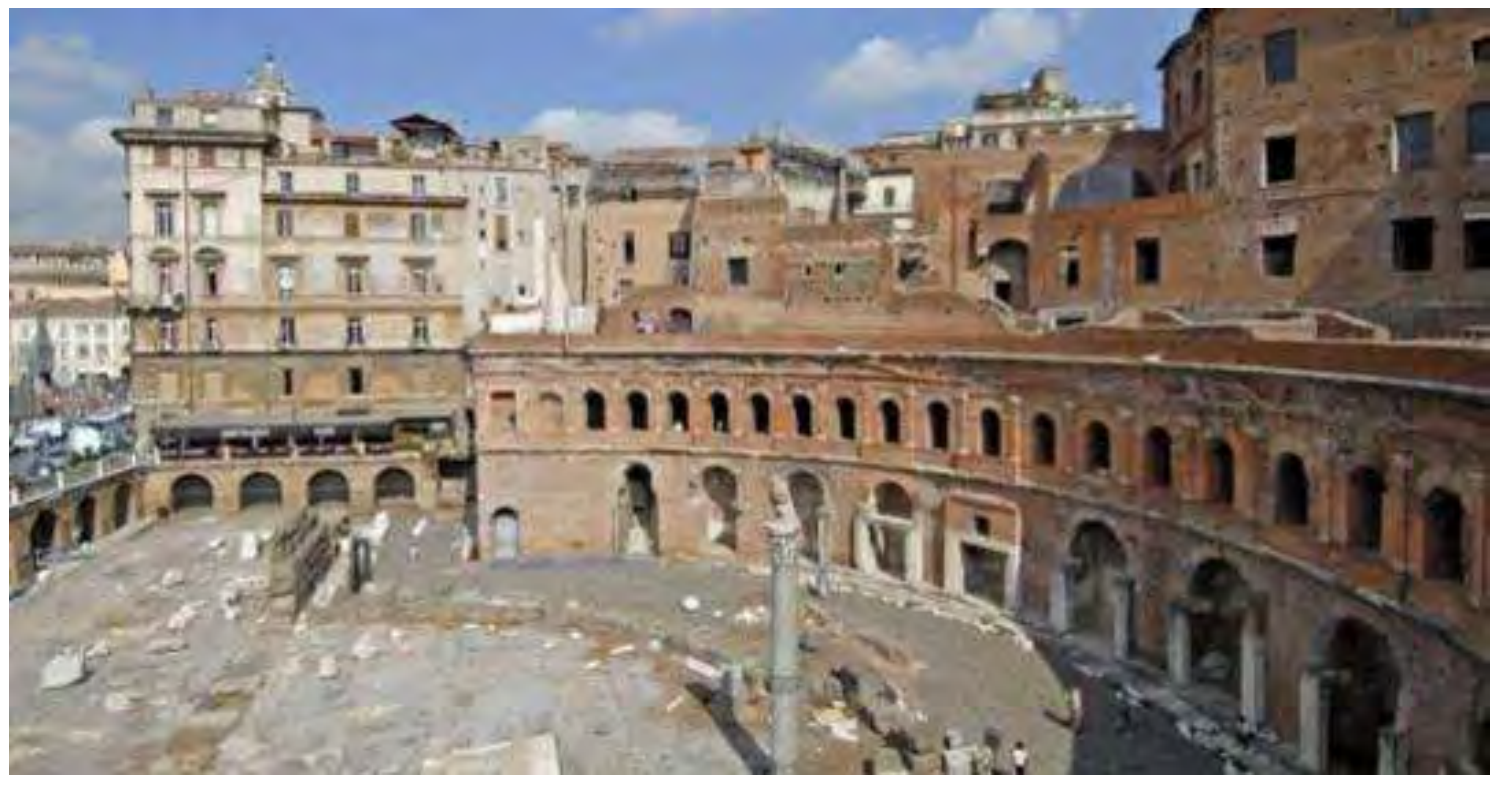

Figura 39 - Vista geral do Fórum de Trajano. Foto: http://en.mercatiditraiano.it

O Fórum Trajano é cronologicamente o último dos fóruns imperiais da Roma Antiga. Foram necessárias extensas escavações, removendo parcialmente os montes do Quirinal e Capitólio, que fechavam o vale ocupado pelos fóruns imperiais, para a construção deste complexo em 112 d.C.

Todo o complexo monumental foi adaptado para receber as pessoas com deficiência, estabelecendo acessos e percursos possíveis. Para resolver o grande desnível na ligação entre a Piazza della Madonna di Loreto e o sítio arqueológico foi instalada uma plataforma elevatória de percurso vertical. Esse elemento não é tão visível e resolve adequadamente as barreiras arquitetônicas existentes. 

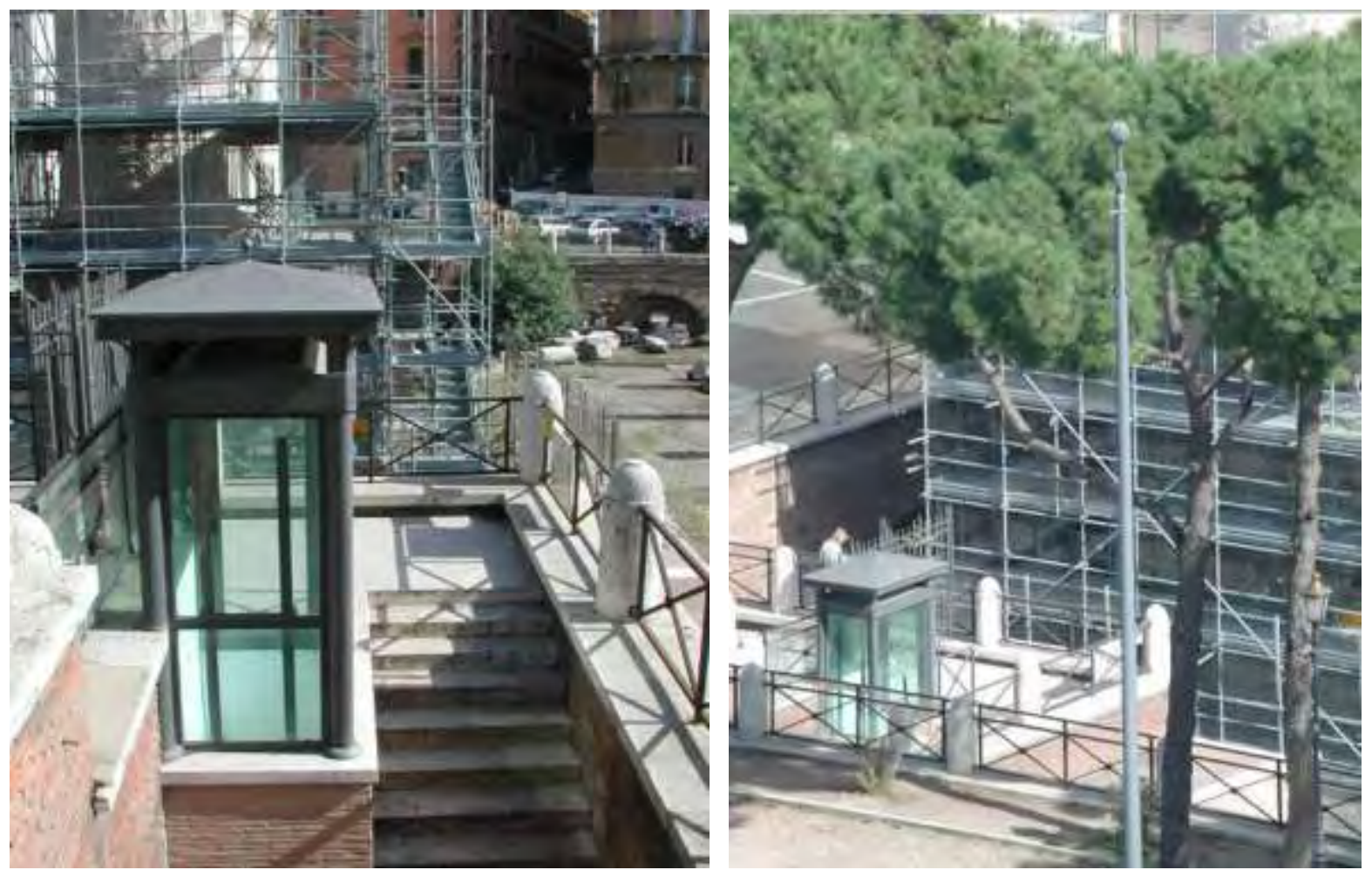

Figuras 40 e 41 - Plataforma e escada de acesso ao nível inferior. Foto: Fabrizio Vescovo.

No nível inferior passarelas de transição suave permitem uma circulação parcial. Caminhos externos, fora do monumento, também dão acesso a atrativos pontos do Fórum.

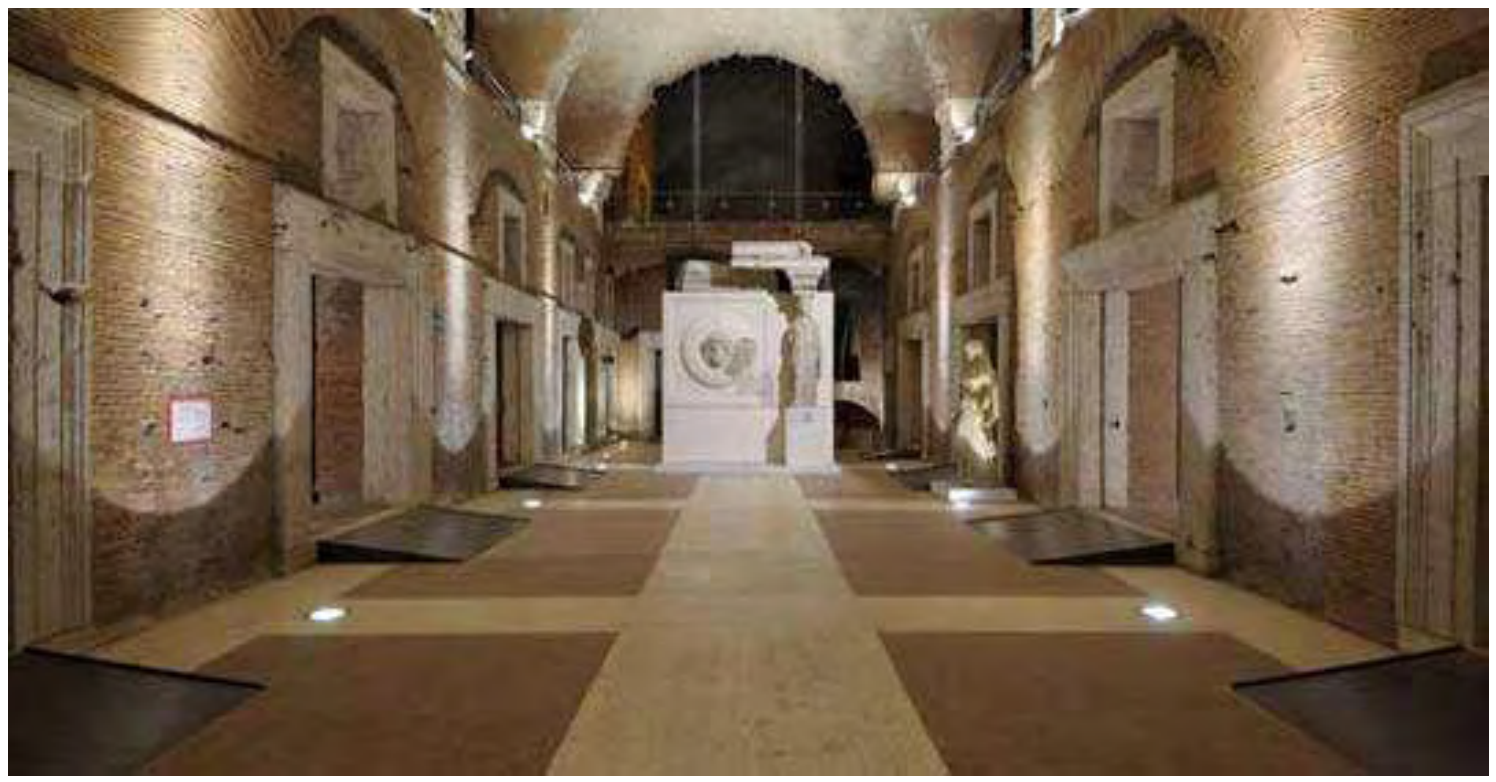

Figura 42 - Vista interior do Grande Salão do Mercado de Trajano. Foto: http://en.mercatiditraiano.it 


\section{Museu Nacional Centro de Arte Reina Sofia em Madrid - Espanha}

O edifício histórico, ocupado hoje pelo Museu Reina Sofia, é resultado do trabalho dos arquitetos José de Hermosilla e Francisco Sabatini para o Hospital San Carlos, que iniciou suas atividades em 1788 com apenas um terço da construção finalizada. Diversas modificações e adições foram feitas ao longo de sua ocupação até o hospital ser fechado em 1965. Em 1977, em meio ao risco de demolição o edifício foi declarado monumento nacional, devido ao seu valor histórico e artístico, passando por restauração em 1980. No final de 1988, os arquitetos José Luis Iñiguez de Onzoño e Antonio Vázquez de Castro fizeram as modificações finais para receber o museu definitivamente.

Essa última intervenção concedeu ao edifício três torres do elevador de aço e vidro - concebido em colaboração com o arquiteto britânico lan Ritchie, renomado por seu trabalho com esses materiais.
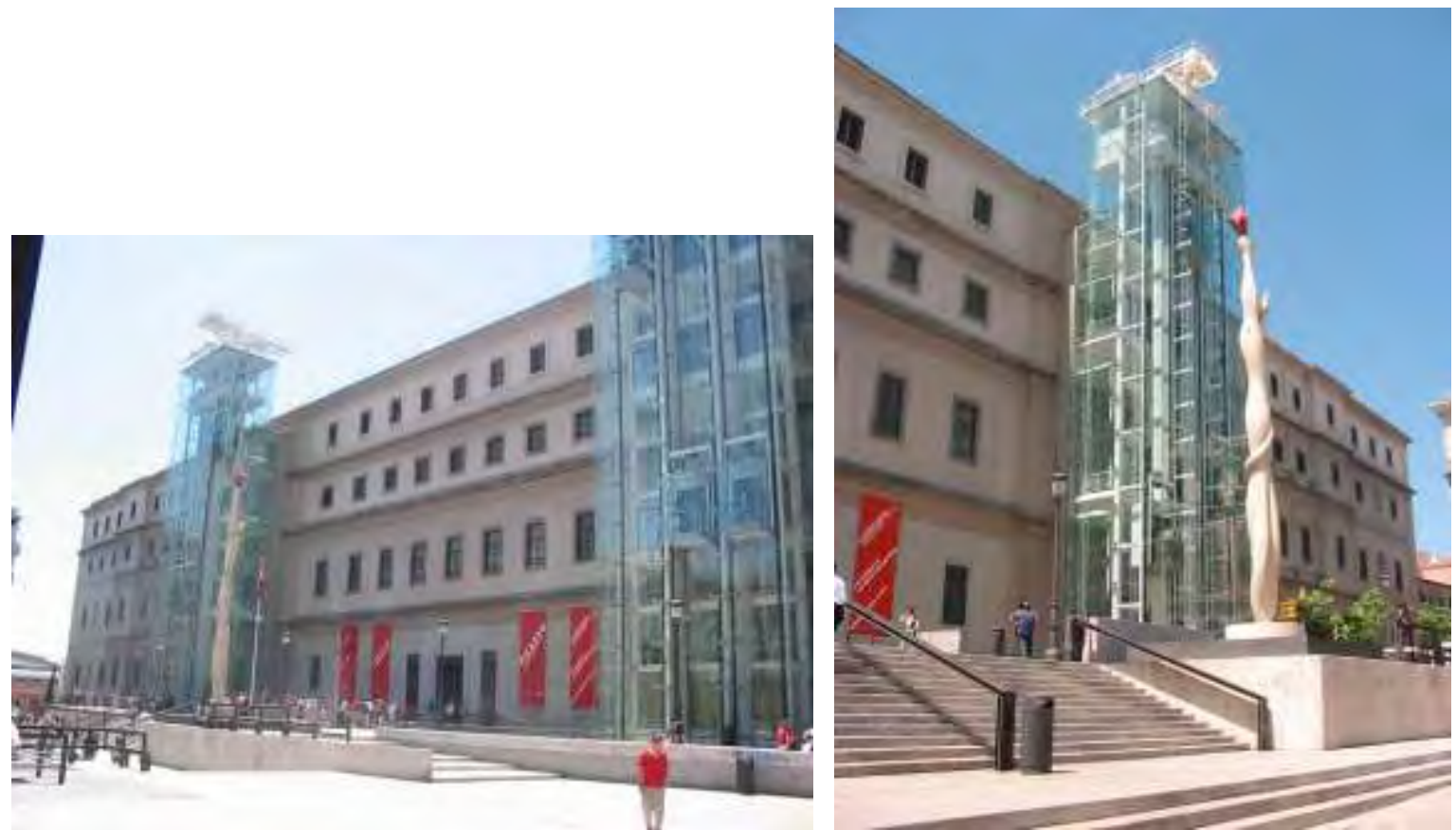

Figura 43 - Torres de circulação vertical. 2006.

As duas torres de circulação vertical são correspondentes às duas 
entradas principais. A definição pelo vidro veio em decorrência da característica de transparência do material, para causar o mínimo de impacto visual no monumento. Apesar das notáveis escadas existentes na praça em frente ao acesso do museu, há rota acessível por rampa até o acesso do elevador.

O Museu Reina Sofia, informa em seu sítio na Internet $^{46}$, que busca promover o acesso universal baseado em evolução contínua dos serviços aos visitantes, incluindo programas educacionais para atender aos diferentes públicos. O objetivo é proporcionar igualdade de acesso e participação integrada em qualquer atividade proposta aos visitantes do museu.

Todas as escadas das galerias de exposição estão equipadas com rampas, exceto os degraus da galeria $\mathrm{E} 1$, onde o museu informa que deve ser solicitada ajuda aos funcionários da segurança. Outro problema são os elevadores, que apesar de terem braile e relevo nas botoeiras, não anunciam o andar por aviso sonoro e nem são sinalizados com piso tátil de alerta.

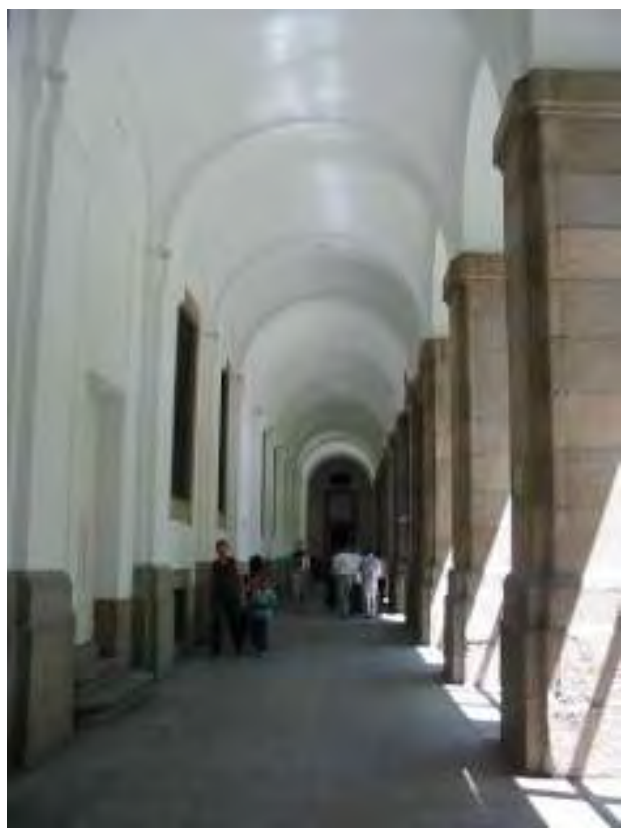

Figura 44 - Circulação interna. 2006.

\footnotetext{
${ }^{46}$ Disponível em: <http://www.museoreinasofia.es/visita/accesibilidad.html>. Acesso em 12 fev. 2012.
} 
Há banheiros acessíveis, mapas orientativos, folhetos em braile e em fonte ampliada e audioguias para pessoas com deficiência visual; além disso, há signoguias para pessoas com deficiência auditiva e amplificadores de sinal nas bilheterias e individuais para facilitar a comunicação de pessoas que utilizam prótese auditiva ou implante coclear. 


\section{CASA DAS ROSAS}

A Casa das Rosas foi escolhida como um dos três casos de estudo por sua importância arquitetônica e histórica para o nosso patrimônio. Entre as três edificações, esta é a de menor escala e única projetada para fins particulares, como uso residencial. Porém, não é pequena: totaliza 41 ambientes no seu conjunto, entre casa e edícula.

Está entre as poucas casas que ainda permanecem na Av. Paulista, como testemunha de uma época em que a emblemática avenida era constituída por casarões dos barões e dos fazendeiros, conforme Lemos (1987).

Projetada pelo escritório de Ramos de Azevedo, para ser a moradia de sua filha e genro, importante comerciante de materiais de construção de São Paulo, a residência segue o programa residencial do período, e teve grande parte de seus materiais e acabamentos importados do exterior.

A casa foi construída nos padrões do classicismo, como aponta Lemos (1987, p. 155), com "jardim geometrizado ao gosto francês [...] mansarda coberta de ardósia assentada pelo sistema de escamas onde vemos as aberturas típicas [...] rodeada por uma varanda coberta por um terraço, parecendo ambos predispostos à fruição do jardim".

Neste capítulo, assim como nos demais estudos de caso, serão apresentadas informações coletadas sobre a edificação, e a análise de suas características de acessibilidade e preservação, com base em normas, leis, recomendações e na percepção dos usuários, conforme metodologia apresentada anteriormente. 


\subsection{Dados}

- Endereço: Av. Paulista no 37 e Al. Santos no 74

- Endereço à época da construção: Av. Paulista no 186

- Cadastro de logradouro: 15656-6

- Dados cadastrais: Lote 131 - Quadra 010 - Setor 036

- CEP: 01311-200

- Bairro: Bela Vista

- Subprefeitura: Vila Mariana

- Área do lote: $5.500 \mathrm{~m}^{2}$

- Área construída: $1.300 \mathrm{~m}^{2}$ (aproximadamente)

- Projeto: Escritório F. P. Ramos de Azevedo

- Ano do projeto: 1922

- Execução: Escritório F.P. Ramos de Azevedo, Severo \& Villares

- $\quad$ Ano de conclusão: 1935

- Uso original: Particular - residência de Ernesto Dias de Castro e Lúcia Azevedo Dias de Castro

- Uso atual: Local de reunião - espaço cultural dedicado à poesia

- Proprietários: Governo do Estado de São Paulo / Secretaria de Estado da Cultura

- Proteção legal:

Resolução nº 57/85 Condephaat - Tombamento da Casa das Rosas

Resolução no 05/91 Conpresp - Tombamento ex-officio

Resolução nº 18/92 Conpresp - Regulamentação da área envoltória

\subsection{Localização e estrutura urbana}

Localizada na via mais conhecida da cidade, a Casa das Rosas repousa em plena Av. Paulista e seu outro acesso, na Al. Santos, não é menos nobre. Fica próximo à Pça. Oswaldo Cruz, no bairro da Bela Vista, um dos extremos da avenida. A Av. Paulista é um dos principais eixos da cidade, interligando grandes avenidas como a Dr. Arnaldo, Rebouças, 9 de Julho, Brigadeiro Luís Antônio, 23 de 
Maio e Rua da Consolação. Portanto, o acesso por automóvel está garantido por diversas rotas. E a orientação garantida pela sinalização turística viária, instalada no entorno da Casa das Rosas, desde 2008. Essa sinalização segue padrão internacional, na cor marrom, com o nome do ponto turístico, seta mostrando a direção a seguir e ícone indicativo sobre o tipo de atração. Os pontos de táxi mais próximos estão nas vias transversais da Av. Paulista e na Alameda Santos.

Por transporte público é possível chegar ao local utilizando metrô ou ônibus, municipal e intermunicipal. Segundo informações dos sítios na Internet da São Paulo Transportes (SPTRANS) e da Empresa Metropolitana de Transportes Urbanos (EMTU) são 22 linhas de ônibus municipais e três intermunicipais, sendo que dessas, 20 linhas municipais possuem ônibus acessível em sua frota. A EMTU não informa se as linhas em questão possuem carros acessíveis. No percurso, a partir das paradas de ônibus nos dois sentidos da avenida, há travessias com rebaixamento de guia, sinalizada com piso tátil de alerta, interligadas ao piso tátil direcional ao longo da calçada. A estação de metrô mais próxima está a cerca de 250m de distância da entrada principal da Casa das Rosas. A Estação Brigadeiro faz parte da linha verde do Metrô, que vai da Vila Prudente à Vila Madalena e está integrada às linhas azul (Norte-Sul) e amarela (Centro-Oeste). O acesso da estação mais próxima à Casa das Rosas é justamente o mais acessível, pois possui elevador. 


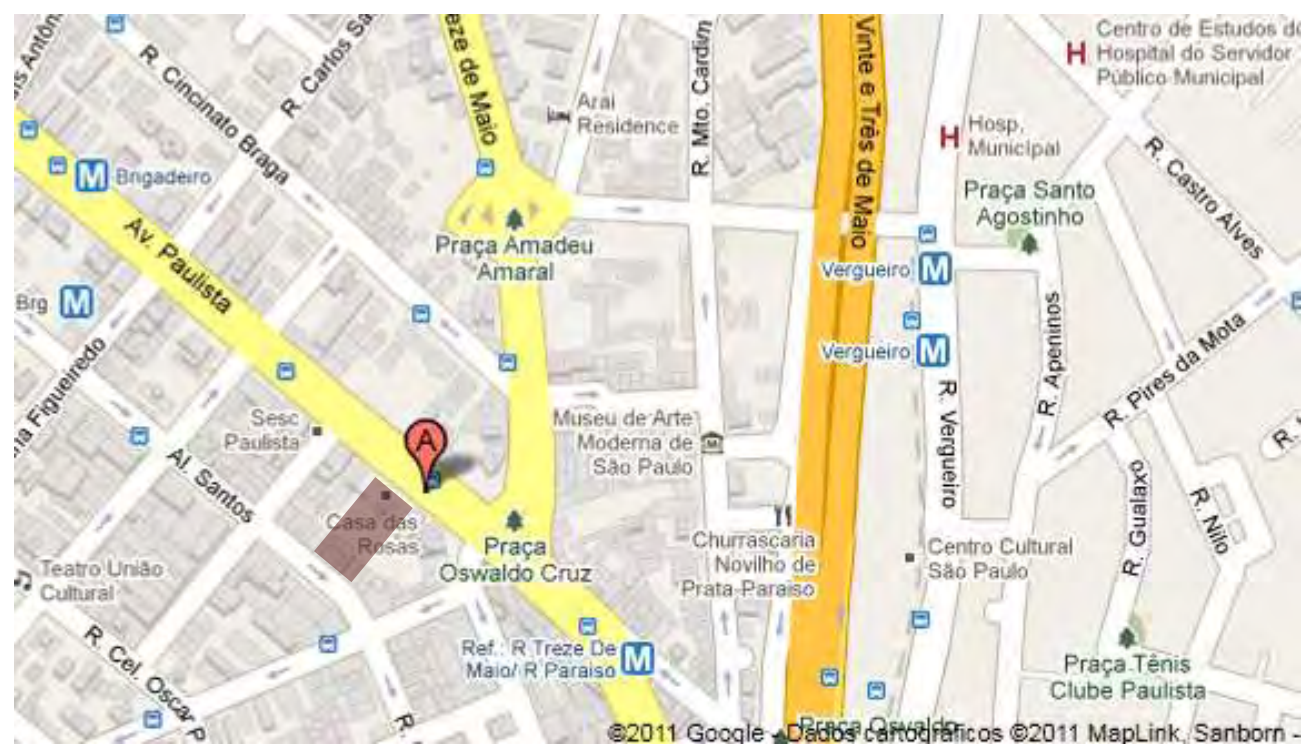

Figura 45 - Mapa de localização. Fonte: Google, 2011.

\subsection{Plantas}

As plantas a seguir foram fornecidas em cópia impressa pela Organização Social Poiesis - Associação dos Amigos da Casa das Rosas, da Língua e da Literatura, que administra o local, em convênio com a Secretaria de Cultura Estadual. As plantas originais do projeto, com diversas revisões, foram encontradas na casa durante o restauro e doadas à Biblioteca da Faculdade de Arquitetura e Urbanismo da Universidade de São Paulo.

As cópias fornecidas foram confrontadas com as plantas originais, e com as plantas anexadas ao Processo de tombamento no $22104 / 1982$, do acervo do Condephaat/ Unidade de Preservação do Patrimônio Histórico da Secretaria da Cultura do Estado de São Paulo. As plantas aqui apresentadas foram digitalizadas a partir das cópias fornecidas, com exceção da planta do porão, digitalizada a partir de cópia da Biblioteca da FAU-USP e reproduzidos os nomes dos ambientes para facilitar a legibilidade.

Algumas partes diferem do que realmente foi construído, provavelmente 
por mudanças de projeto ou ocorridas durante a obra. No caso da Implantação, por exemplo, a família relatou no processo de tombamento que a quadra de tênis representada nunca foi construída ${ }^{47}$. E as fachadas, datadas de 1928, apresentamse com ornamentação diferente do que encontramos hoje, além de não representar o terraço do andar superior. Na Biblioteca é possível ter acesso a diversas pranchas com detalhes construtivos e diversas revisões das plantas.

${ }^{47}$ Processo de Tombamento no 22104/1982, fl. 127. Acervo do Condephaat/ Unidade de Preservação do Patrimônio Histórico da Secretaria da Cultura do Estado de São Paulo. 


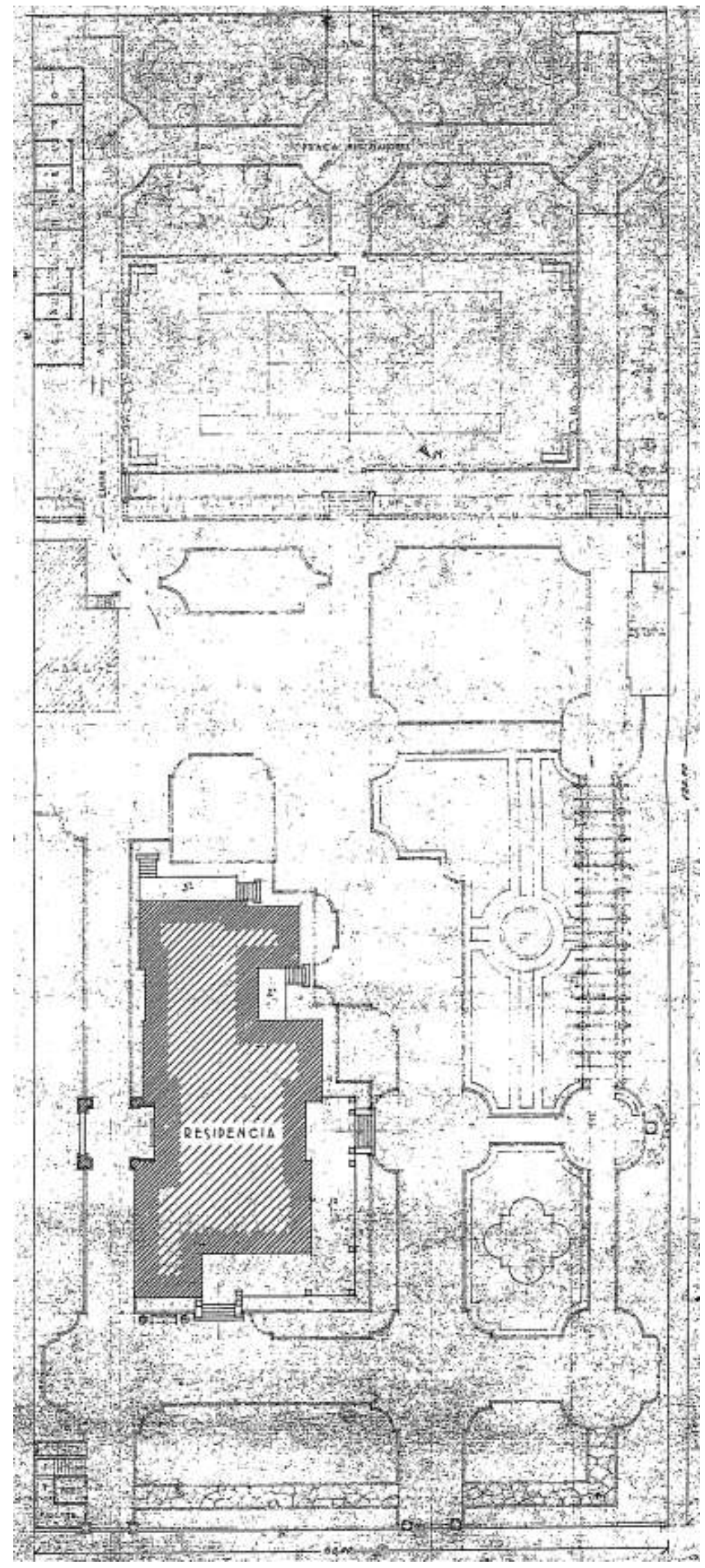

Figura 46 - Implantação. Data: 1935. 


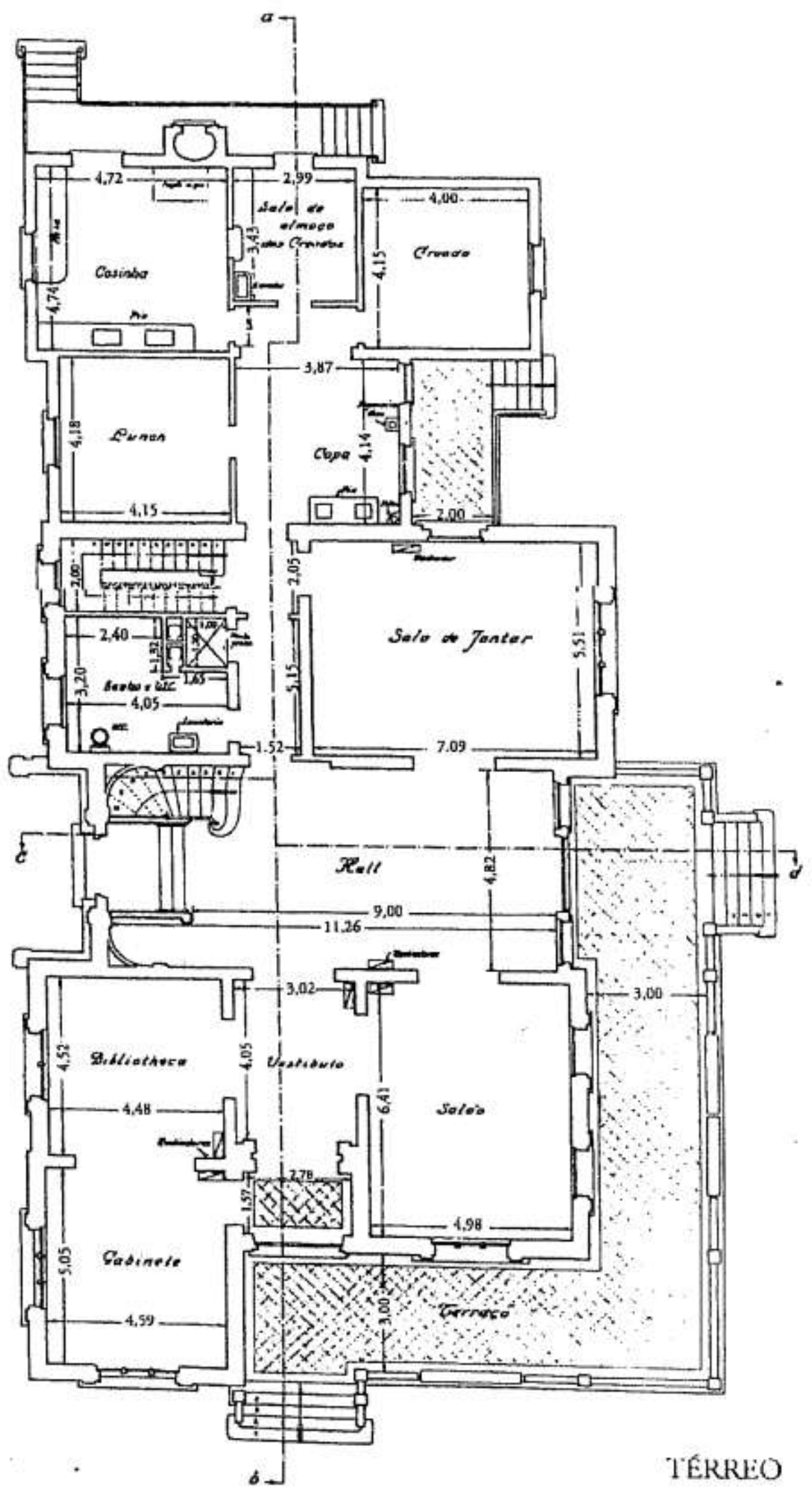

Figura 47 - Planta do pavimento térreo. Data: 1929. 


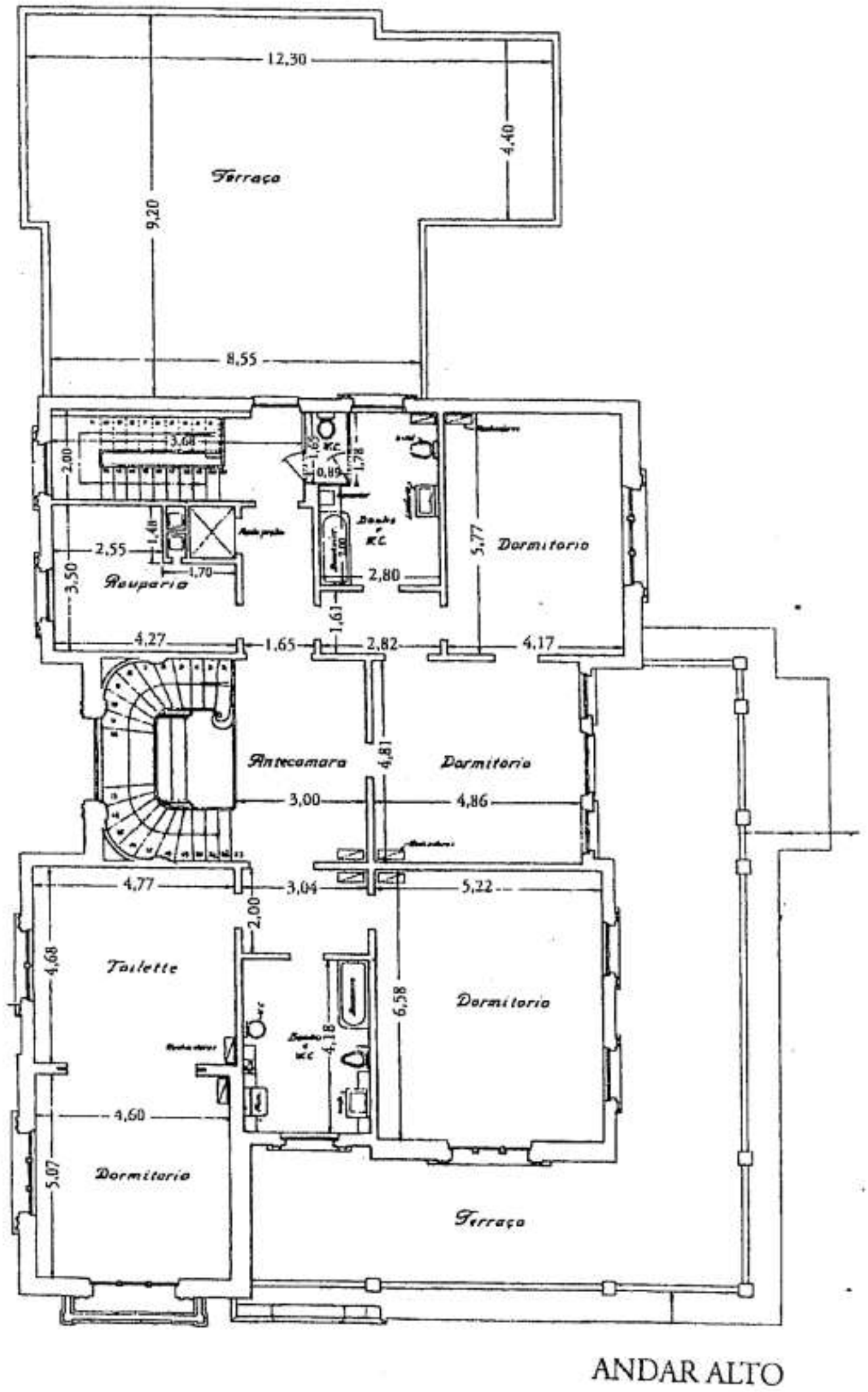

Figura 48 - Planta do pavimento superior (Andar Alto). Data: 1929. 


\section{Mancardat Enotro}

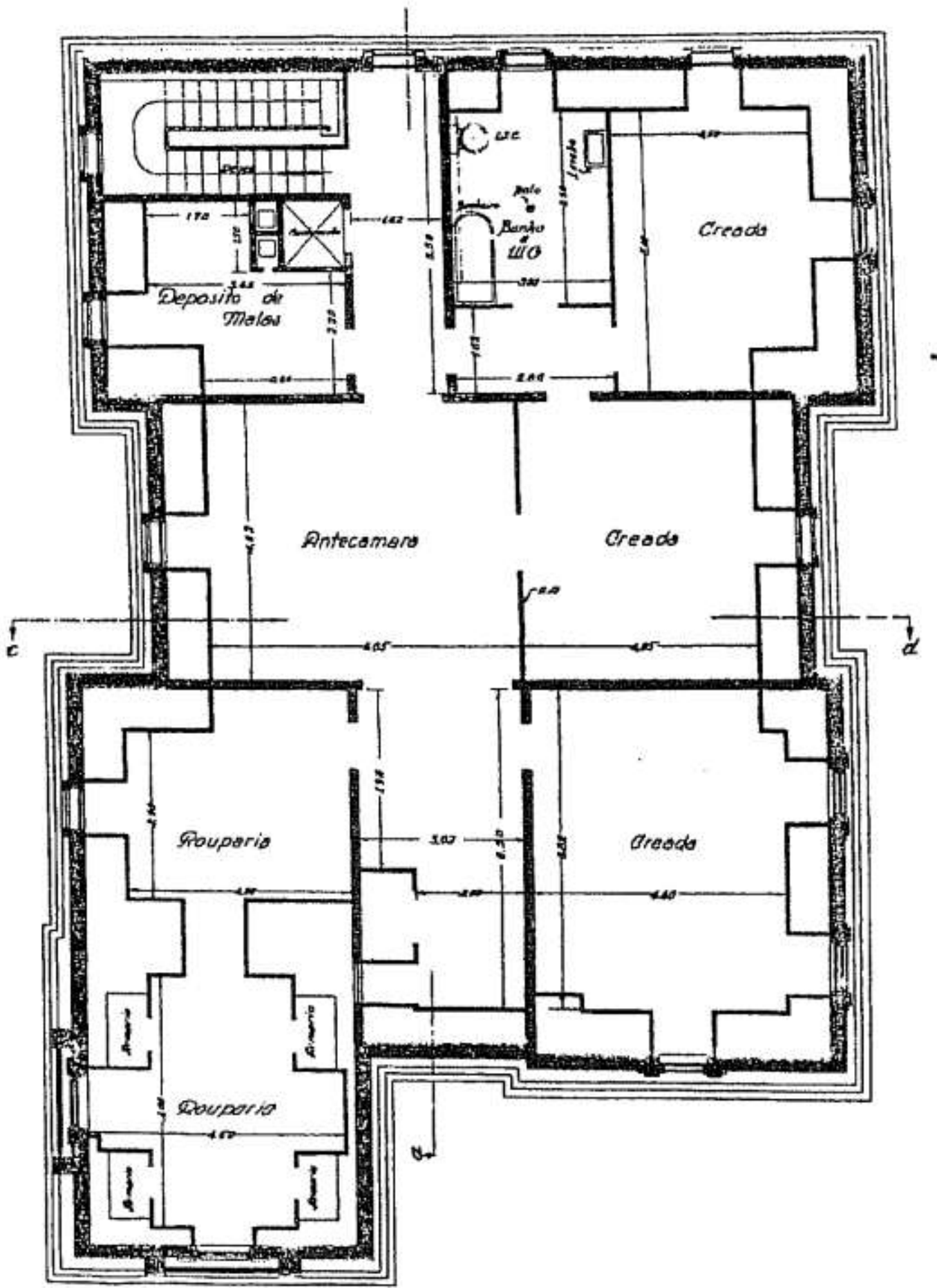

Figura 49 - Planta da mansarda. Data: 1929. 


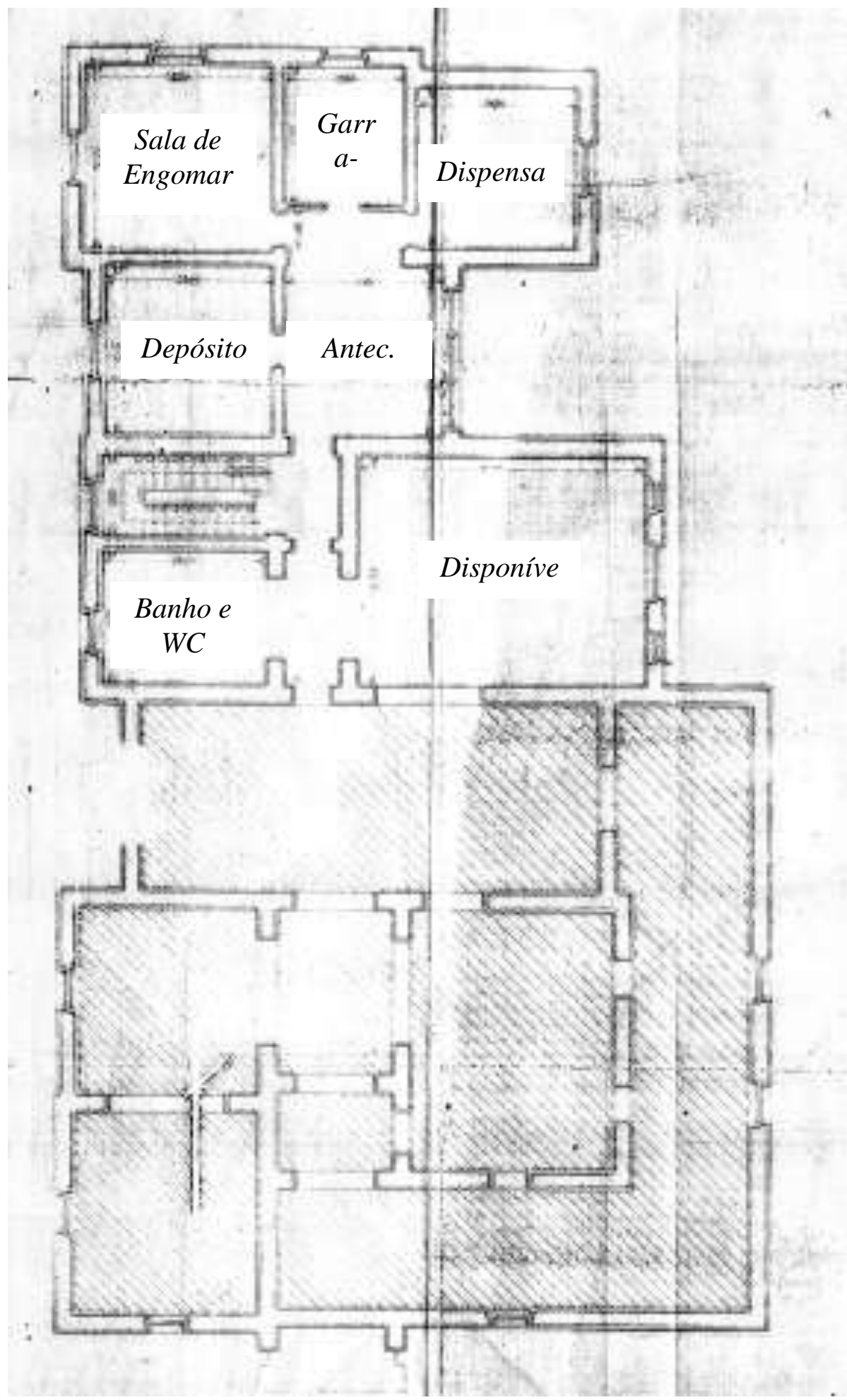

Figura 50 - Planta do porão. Data: [1928 ou 1929] (data não legível). 


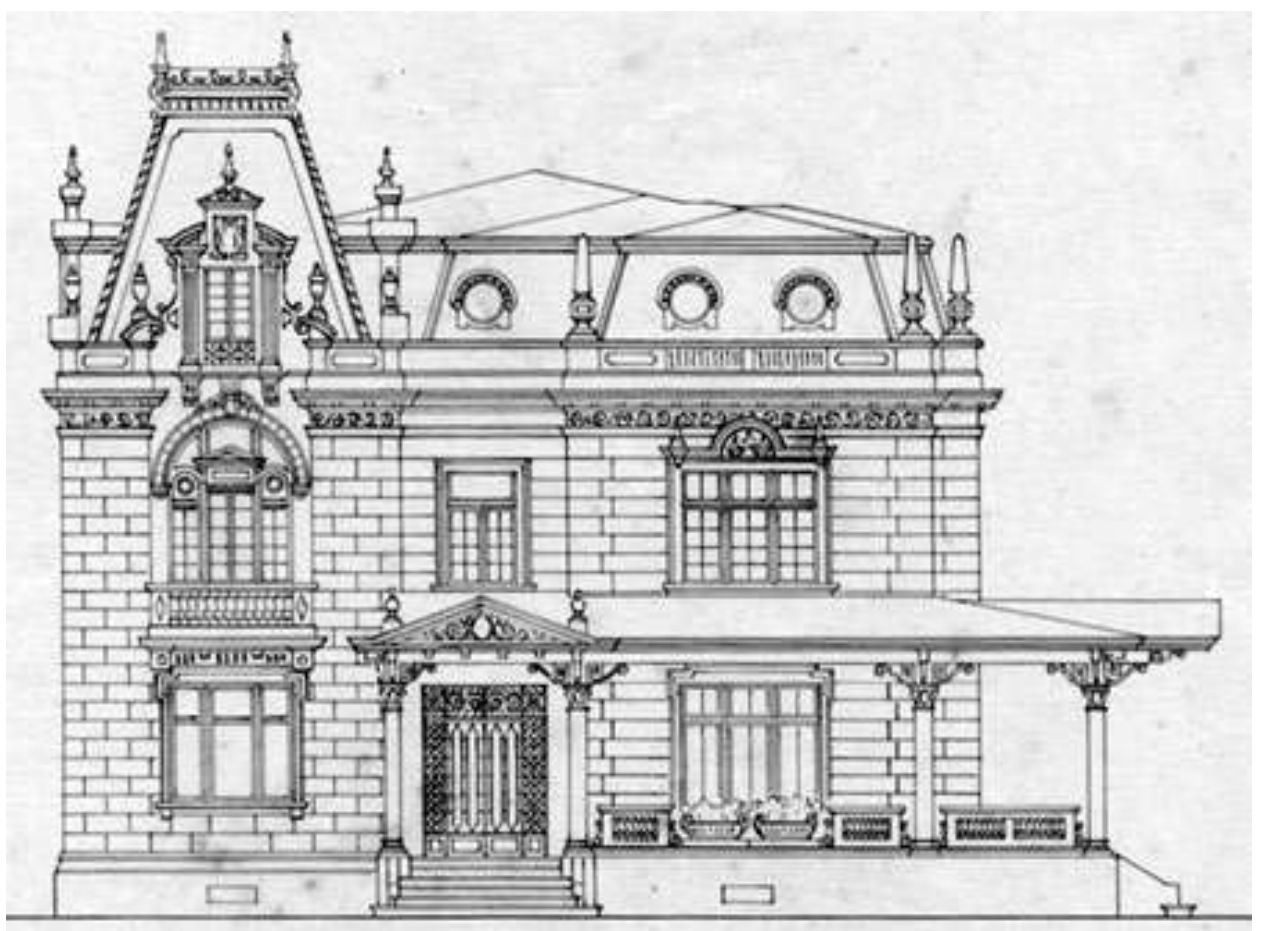

Figura 51 - Projeto para a fachada voltada à Av. Paulista. Data: 1929.

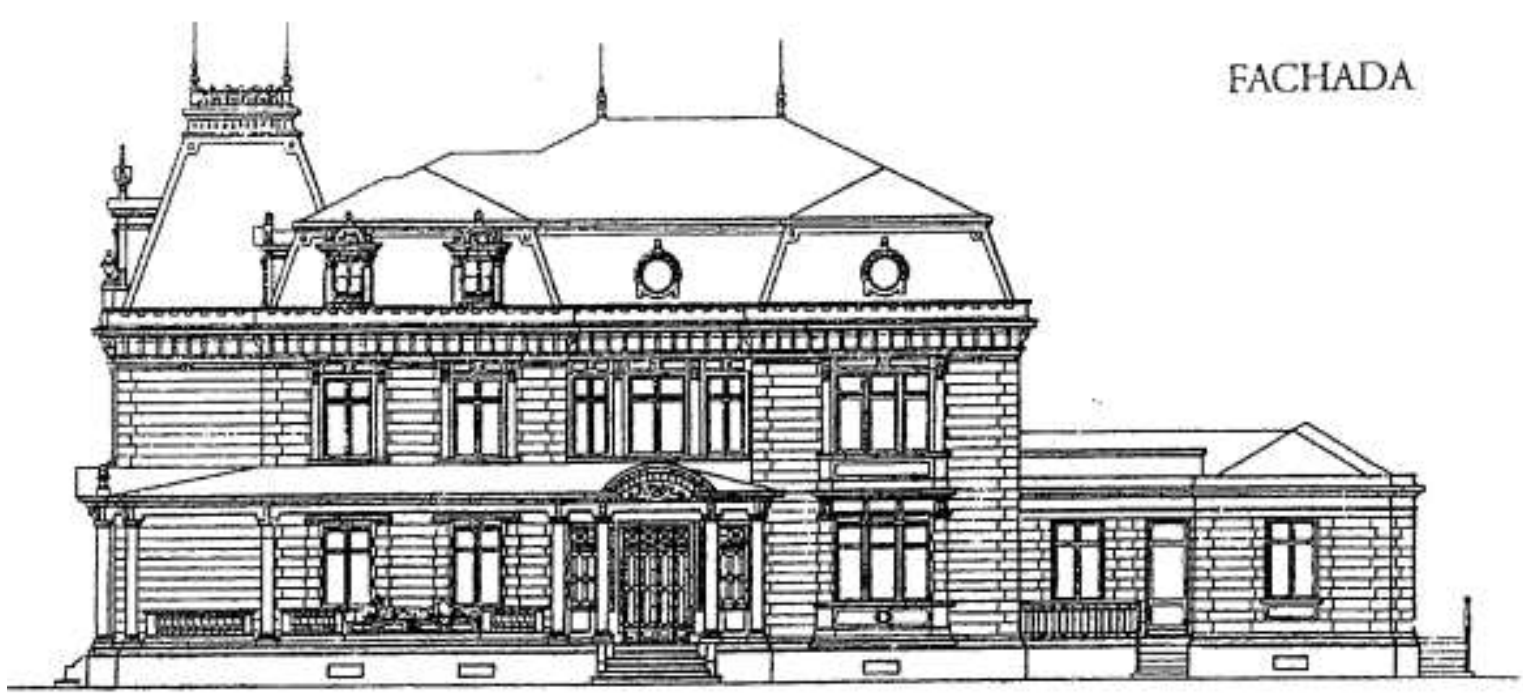

Figura 52 - Projeto para a fachada voltada ao jardim. Data: 1928. 
As plantas atuais, a seguir apresentadas, foram feitas com uso do programa Auto CAD, com base nas cópias fornecidas e nas observações in loco.
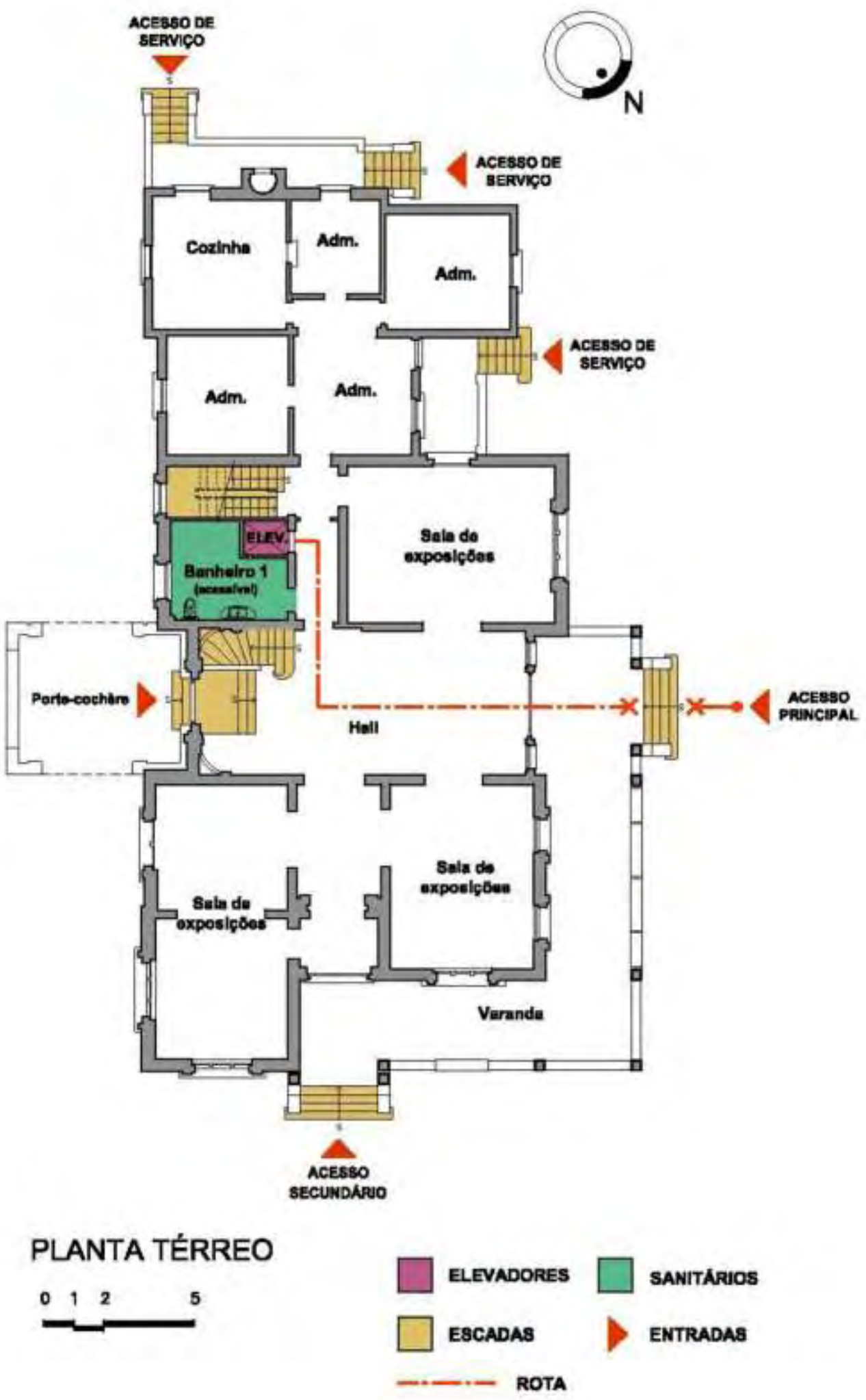

Figura 53 - Planta do pavimento térreo. 

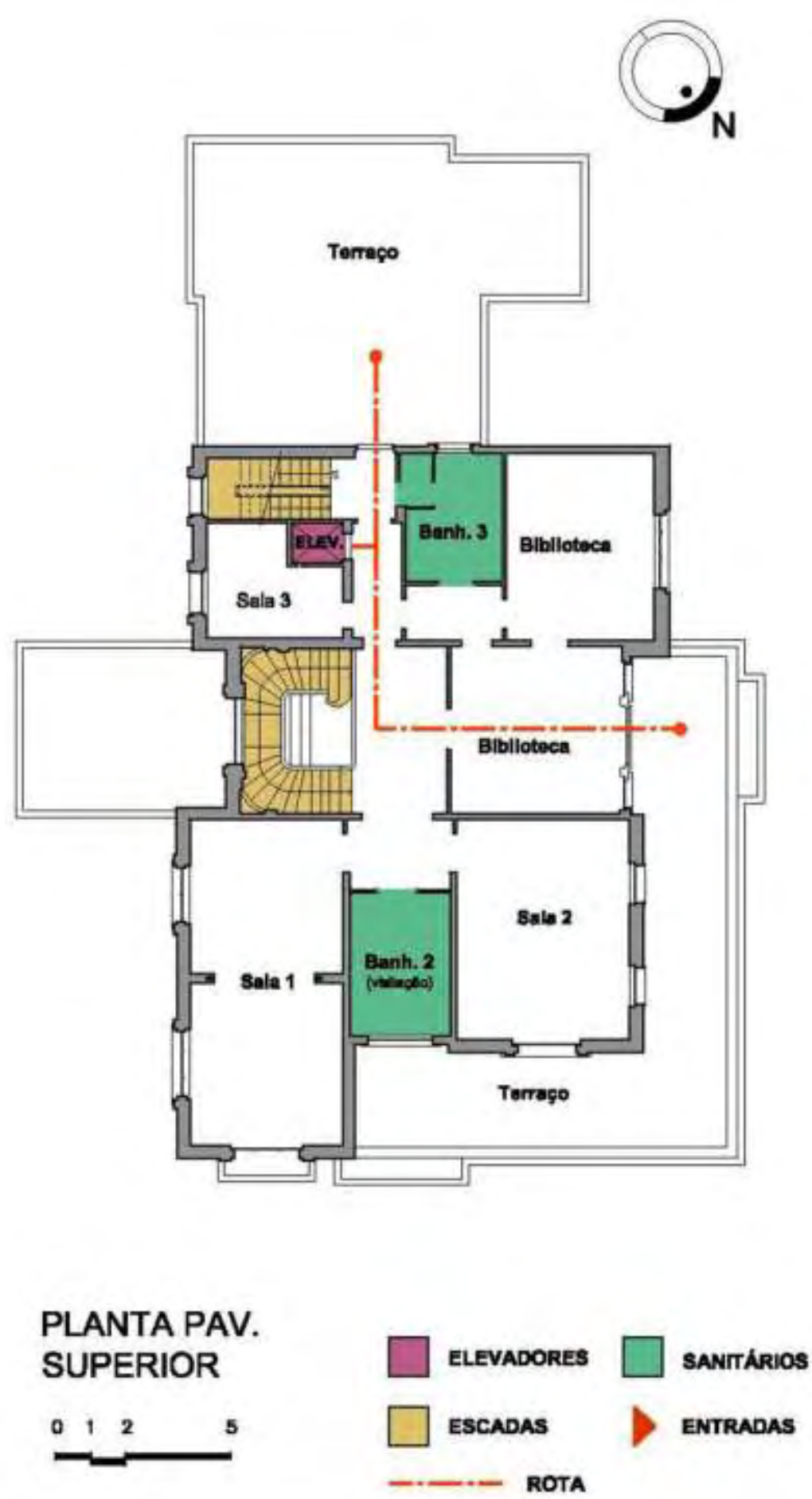

Figura 54 - Planta do pavimento superior. 

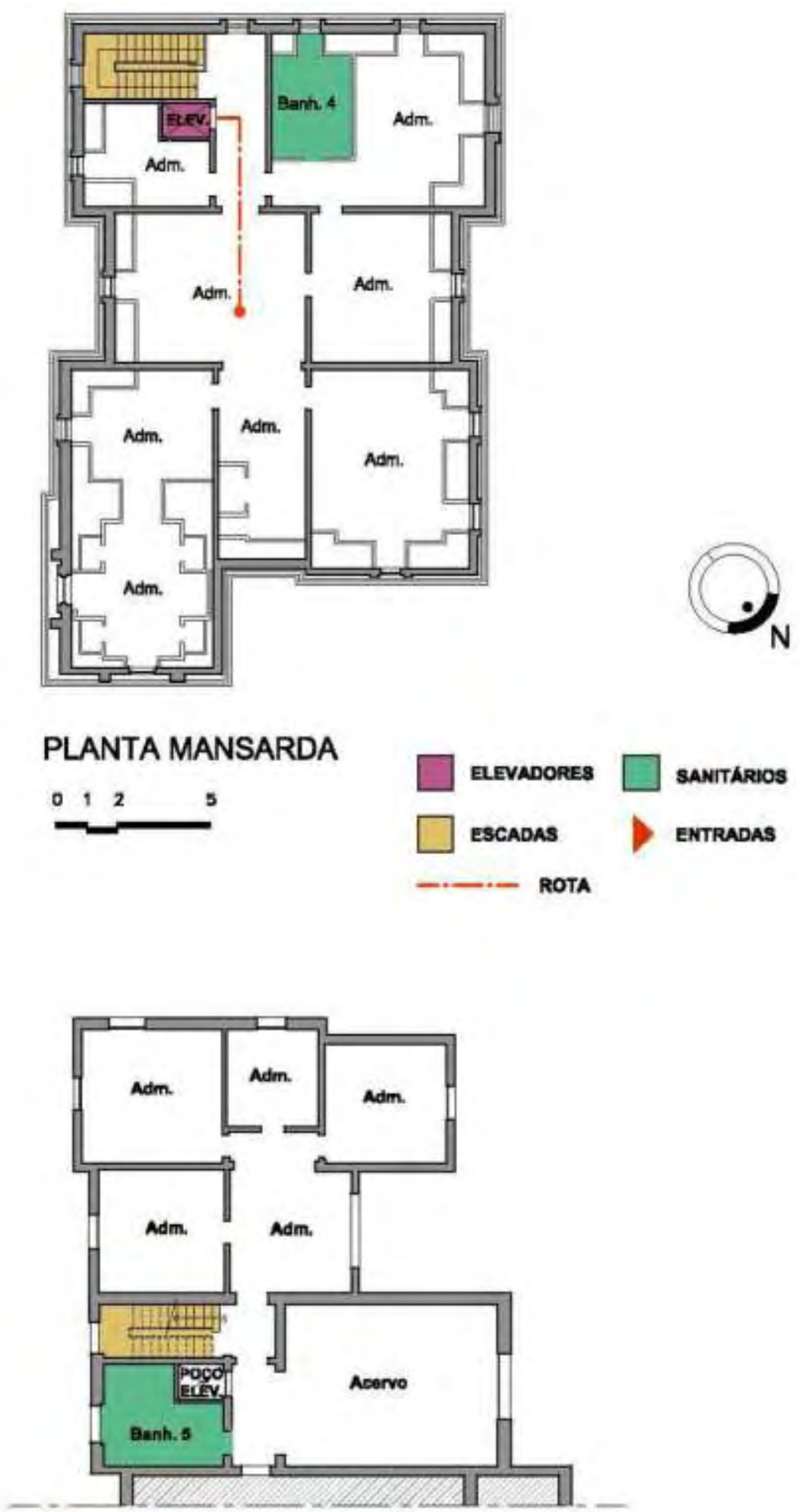

\section{PLANTA PORĀO}

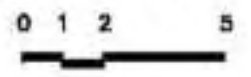

Figura 55 - Plantas dos pavimentos da mansarda e do porão. 

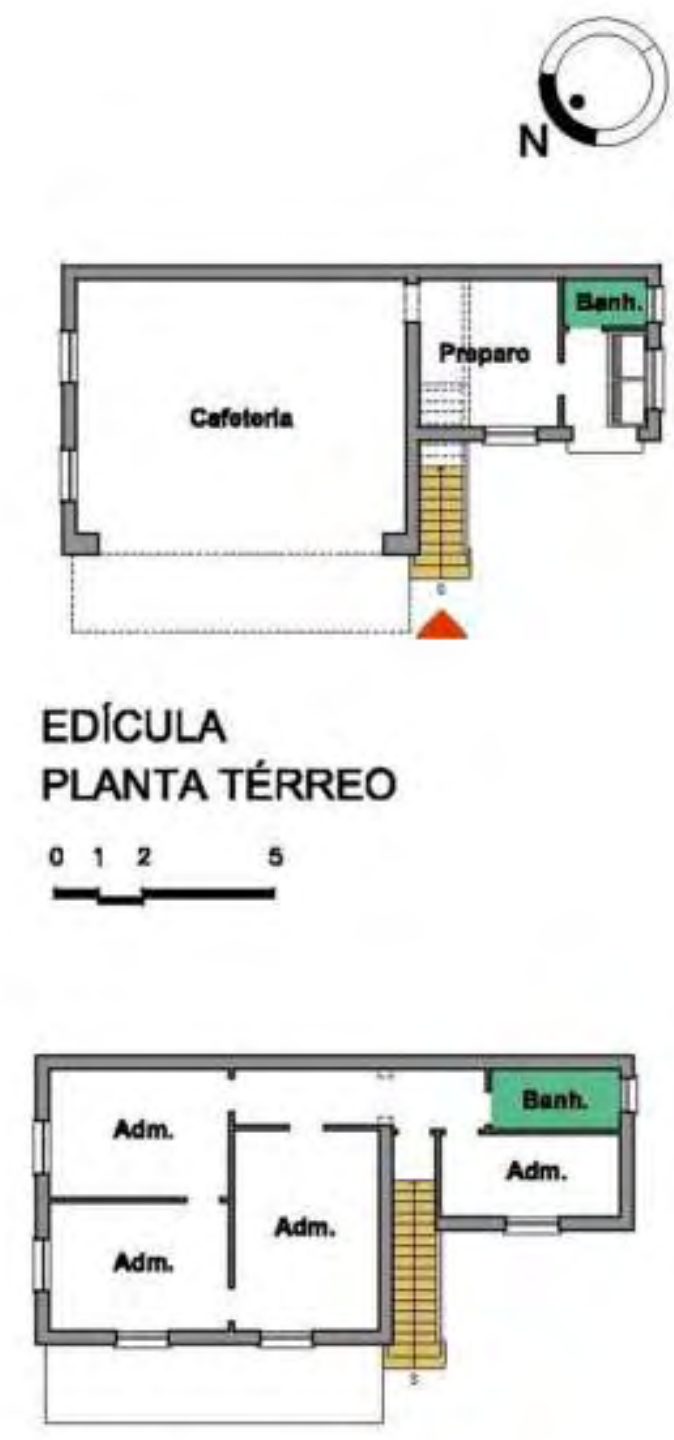

\section{EDICULA}

\section{PLANTA PAV. SUPERIOR}
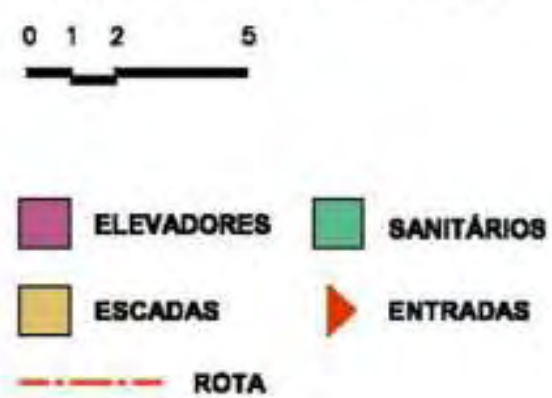

Figura 56 - Plantas dos pavimentos térreo e superior da edícula. 


\subsection{Histórico}

A Casa das Rosas, assim conhecida por seu jardim, tem projetos de autoria do escritório Ramos de Azevedo, datados desde 1922. Uma das últimas construções residenciais realizadas na avenida, a casa foi um presente para Lúcia Ramos de Azevedo, filha do arquiteto, recém-casada com o engenheiro Ernesto Dias de Castro, proprietário de uma firma de importação de materiais construtivos.

Finalizada apenas em 1935, a residência foi habitada por seus descentes por 51 anos. Após Lúcia e Ernesto, pertenceu ao filho do casal, Ernesto Dias de Castro Filho, também engenheiro da Politécnica. E sua segunda esposa foi a última descendente a habitar este casarão, permanecendo até 1986. Ramos de Azevedo não chegou a ver o projeto concluído, pois faleceu em 1928. Sua construção foi assinada por Felisberto Ranzini, integrante do escritório F.P. Ramos de Azevedo, Severo \& Villares.

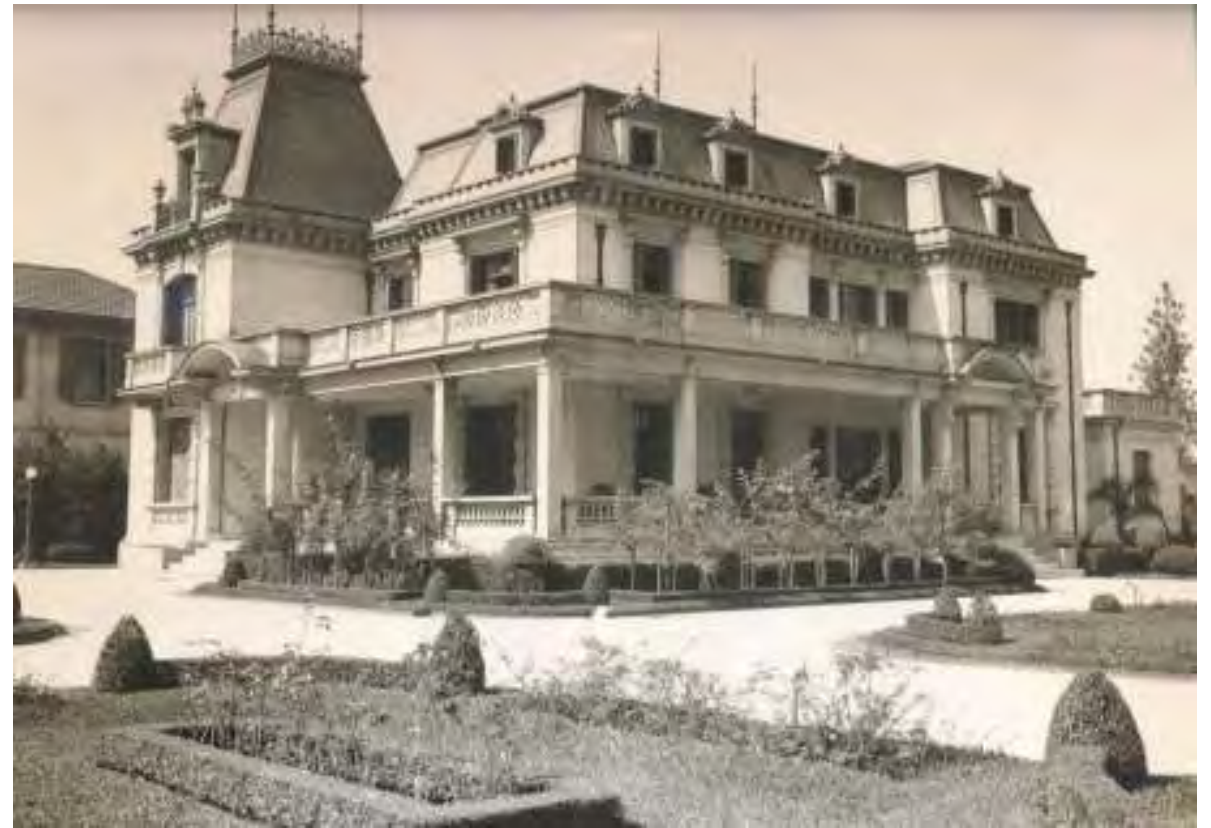

Figura 57 - Foto da residência de Ernesto de Castro na década de 1970 (TOLEDO, 1987).

A firma de Ernesto Dias de Castro, que havia passado para a geração de 
Ernesto Filho, fechou, ficando cada vez mais difícil para a família arcar com os altos impostos de um imóvel em plena av. Paulista, uma das regiões mais valorizadas do País. Por isso, a família acabou obrigada a vendê-la.

Em 1982 o Conselho de Defesa do Patrimônio Histórico, Arqueológico, Artístico e Turístico do Estado de São Paulo (Condephaat) abriu processo para estudar o tombamento da casa, ato efetivado em 22 de outubro de 1985. A Construtora Júlio Neves e o empreendedor Mário Pimenta Camargo adquiriram o lote no ano seguinte com a intenção de construir dois grandes prédios comerciais. $\mathrm{O}$ lote estava desmembrado, e o quintal da casa pertencia a três entidades assistenciais, que concordaram com a venda à Construtora, permitindo a restituição do perímetro original.

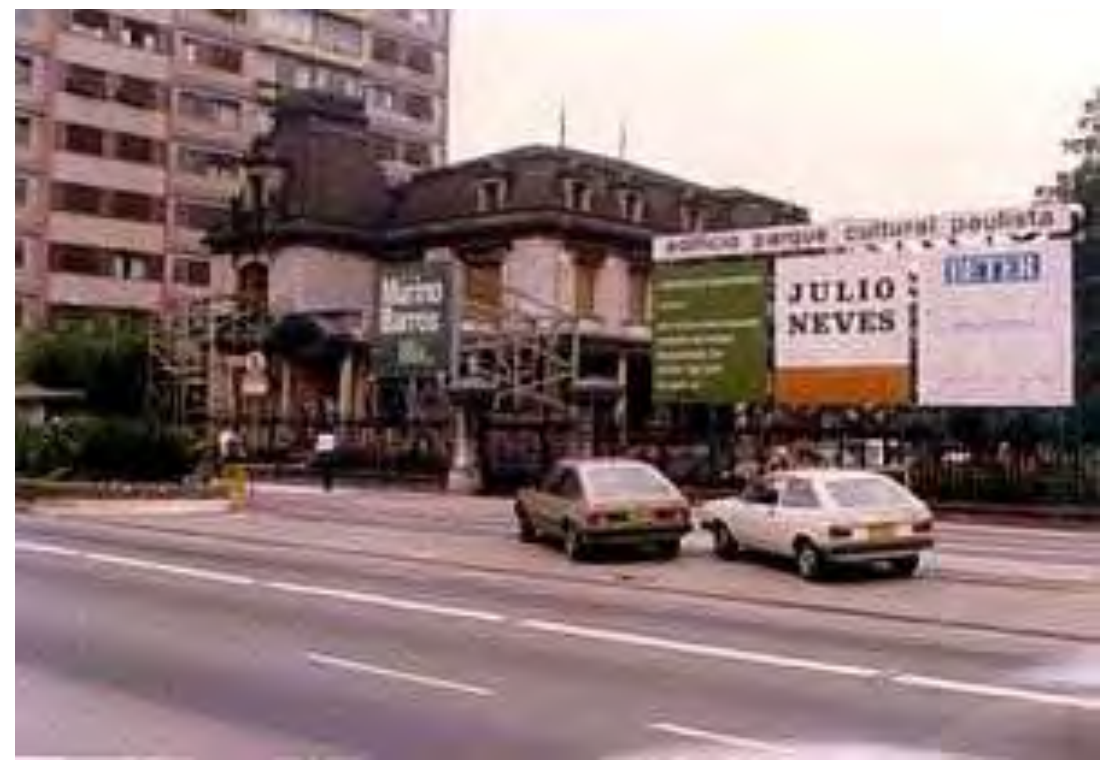

Figura 58 - Restauro e construção do edifício Parque Cultural Paulista. Fonte: Laudo técnico do restauro - Construtora Marino Barros.

Diante do tombamento e do interesse da Construtora em aproveitar o potencial construtivo do terreno tão valorizado, iniciou-se complexo processo de viabilização do empreendimento na parte dos fundos do terreno. Conforme Rodrigues (2000, p. 117) "Os empreendedores do moderno edifício comprometeram- 
se a restaurar a residência, [...] e a considerar no projeto a manutenção da visibilidade do bem de valor histórico". O Condephaat exigiu que o bloco de escritórios repousasse sobre pilotis, elevando-se 10 metros, para desobstruir as visuais da casa, inclusive da Alameda Santos.

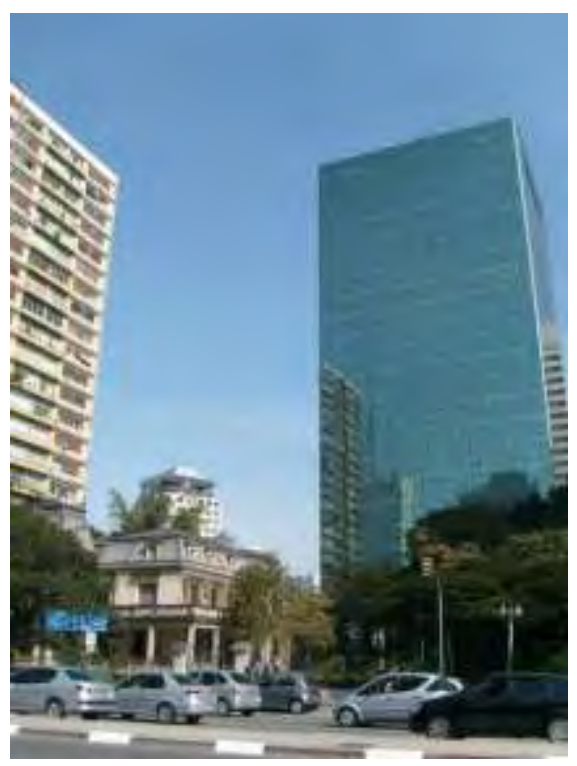

Figura 59 - Casa das Rosas e Edifício Parque Cultural. 2011.

De 1987 a 1991 acontecia a restauração da residência, sua edícula, jardins, caramanchão e estufa, paralelamente à construção do edifício de escritórios. A restauração, primeira da residência, ficou a cargo do Eng. Alberto Barth, da Construtora Marino Barros, com a consultoria do Arq. Prof. Dr. Carlos Alberto Cerqueira Lemos, professor da Faculdade de Arquitetura e Urbanismo da Universidade de São Paulo.

Ao término do restauro, o governo estadual desapropriou a residência para instalar um espaço cultural conhecido por Casa das Rosas - Galeria Estadual de Arte, que exibia mostras temporárias de obras do acervo artístico do Estado.

Em 2003 a galeria foi fechada e o espaço passou por reforma para, em 09 de dezembro de 2004, ser reinaugurada como o primeiro espaço público do País destinado à poesia, nomeado Espaço Haroldo de Campos de Poesia e Literatura, 
administrado, hoje, pela Organização Social denominada Poiesis.

De julho a novembro de 2007 a Casa das Rosas, como espaço de literatura e poesia, ficou fechada ao público para receber a mostra CAD Brasil Casa Arte \& Design, evento de arquitetura de interiores semelhante à CASA COR. A organização do evento diz ter preservado completamente as estruturas do prédio e realizado algumas benfeitorias, tais como, reforma total da elétrica, revisão da hidráulica, construção de um elevador, colocação de rampas de acesso e banheiro para pessoas com deficiência, além do espaço de cafeteria na edícula.

A motivação para as adaptações às pessoas com deficiência adviria de um despacho ${ }^{48}$ da Secretaria de Planejamento da Prefeitura de São Paulo que exigia o atendimento de diversas exigências, entre elas a acessibilidade. Em contato com a Comissão Permanente de Acessibilidade, órgão ligado à Secretaria da Pessoa com Deficiência e Mobilidade Reduzida da Prefeitura de São Paulo, foram discutidas as soluções que iriam garantir o acesso e circulação desse público à Casa das Rosas pela primeira vez.

Após a mostra, a rampa de estrutura metálica e de madeira não demorou a se deteriorar, justamente por não ter sido feita com materiais e técnicas visando sua incorporação definitiva, ainda que garantindo reversibilidade. Por deliberação do Conpresp a rampa para a mostra deveria ser removida após o término de evento ${ }^{49}$. Os visitantes, usuários de cadeiras de rodas, ficaram, então, sem opção adequada de acesso, apesar do elevador no interior da edificação.

\footnotetext{
${ }^{48}$ Despacho SEMPLA.CTLU/246/2007, publicado no Diário Oficial da Cidade de São Paulo em 11 jul. 2007.

${ }^{49}$ Despacho Secretaria de Cultura - Conpresp, publicado no Diário Oficial da Cidade de São Paulo em 13 jul. 2007. Sobre a solicitação de execução da rampa de acesso ao imóvel, o colegiado aprovou "desde que seja rampa provisória, removível após o termino do evento, sem causar dano de qualquer espécie a integridade física do imóvel". Isso demonstra a completa ignorância quanto ao assunto, e a falta de senso de oportunidade para conquistar o acesso pleno à Casa, sem dispor de recursos públicos.
} 


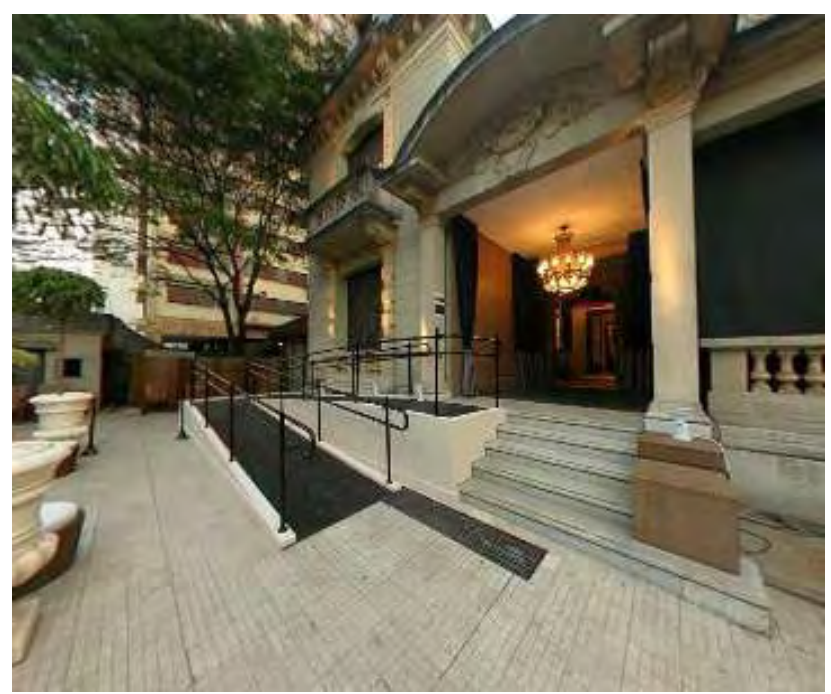

Figura 60 - Rampa colocada para a mostra. Fonte: http: http://www.casaartedesign.com.br

Desde 2008 a Poiesis e o CONDEPHAAT estão estudando a implantação de uma rampa que será incorporada à residência definitivamente. Em fevereiro de 2011, o Colegiado deliberou pelo indeferimento do pedido de aprovação de proposta de rampa, por considerar que a intervenção afetaria negativamente a fachada, e que os interessados deveriam apresentar uma solução mais adequada ${ }^{50}$. Em novembro do mesmo ano, o Colegiado deliberou pela manutenção do indeferimento do projeto da rampa, determinando que a acessibilidade do local deva ser realizada a partir de plataforma elevatória, solução considerada mais adequada e conciliatória com a preservação do bem tombado ${ }^{51}$.

Desde dezembro de 2010 a proposta de rampa de acesso à Casa das Rosas, em discussão no Condephaat, está aprovada pelo Conpresp ${ }^{52}$.

${ }^{50}$ Comunicado Secretaria de Cultura - Condephaat, publicado no Diário Oficial [do] Estado de São Paulo, em 24 fev. 2011.

${ }^{51}$ Comunicado Secretaria de Cultura - Condephaat, publicado no Diário Oficial [do] Estado de São Paulo, em 12 nov. 2011.

${ }^{52}$ Ata da 494a reunião extraordinária do Conpresp, publicado no Diário Oficial da Cidade de São Paulo, em 09 dez. 2011. 


\subsection{Características físicas}

A residência é dividida em térreo, pavimento superior, mansarda e porão. $\mathrm{Na}$ sua função original o pavimento térreo tinha ambientes sociais, como sala de jantar e de estar; ambientes íntimos, como gabinete, biblioteca e sala de almoço (Lunch); e ambientes de serviço, como cozinha e sala de almoço dos empregados. Os ambientes do pavimento superior são predominantemente de caráter íntimo, como os dormitórios, salas de banho e terraço; o único ambiente com características de serviço é a rouparia. Na mansarda temos ambientes de serviço para uso apenas dos empregados da casa, como dormitórios, banhos, rouparia e depósito de malas.

Próximo à Al. Santos, no fundo do lote, está a edícula, com garagem e quartos para os empregados homens, e o quintal, que tinha um galinheiro e área para horta. Na lateral do lote fica a estufa.

Em questão de características formais, o palacete segue o padrão descrito por Lemos (1989, p. 78-79) do que seria usual nas residências mais ricas, a partir da Primeira Guerra. As construções passavam a estar isoladas no lote, e ter internamente um hall distribuindo "[...] as três zonas: de serviço, de estar e de repouso. [...] No hall ficava a escada de ligação aos quartos, nos casos dos palacetes assobradados". Outros aspectos observados por Lemos (1989, p. 74), estão presentes na Casa das Rosas, como a edícula assobradada com espaço para os automóveis, tanques e instalação sanitária no térreo, e quarto do chofer no andar superior. Além do galinheiro, estufa e caramanchão. Esses dois últimos "[...] sobre o alinhamento do lote em jardim lateral". Ou seja, se insere no padrão de programa residencial do período.

A Casa das Rosas tem implantação típica de uma casa burguesa urbana 
do início do século XX, diferente das casas urbanas do século XIX que ocupavam os limites do lote. Ela atende as características descritas por Reis Filho em que "os esquemas arquitetônicos [...] prendiam-se a soluções de rígido paralelismo em relação aos limites, ainda que os lotes apresentassem, em média, maiores dimensões" (2010, p. 71).

Especificamente sobre a residência, Lemos afirma, que a casa foi construída nos padrões do classicismo, com "jardim geometrizado ao gosto francês [...] mansarda coberta de ardósia assentada pelo sistema de escamas onde vemos as aberturas típicas [...] rodeada por uma varanda coberta por um terraço, parecendo ambos predispostos à fruição do jardim" (1987, p. 155).

Talvez a diferença na implantação da Casa das Rosas está em ter sua frente voltada para o jardim, e não para a av. Paulista; para este lado ficava a entrada próxima ao gabinete usado por Ernesto de Castro, que se caracteriza como uma entrada não social mas para atender demandas de trabalho. Não que a avenida seja ignorada: há um pequeno balcão no quarto do casal, o principal da casa, voltado para ela. A casa se orienta da seguinte forma: frente voltada para o jardim (a lateral do terreno), uma lateral para a Av. Paulista e outra para a Al. Santos, e fundos para o lote vizinho, onde ficava a entrada e desembarque de veículos (portecochère)

Apesar da conclusão de sua construção datar de 1935, seu projeto foi iniciado pelo Escritório de Ramos de Azevedo em 1922, o que ajudaria explicar a eleição do ecletismo. Características do ecletismo classicizante afrancesado podem ser vistos no seu telhado, frontões com pilares marcando as entradas e jardins geométricos, além dos elementos decorativos, externos e internos.

Os materiais empregados são de alta qualidade e em sua grande maioria 
importados da Europa: "[...] de requintados detalhes de acabamento, executado com os melhores materiais para construção, grande parte deles de qualidade superior aos encontrados atualmente em nosso mercado." (BARTH, 1987, p. 01).

O sobrado, avarandado no pavimento térreo e com terraços descobertos, guarnecidos de guarda-corpos com elementos vazados, no superior, possui telhado em ardósia, com águas acentuadamente inclinadas. Esta é uma construção de alvenaria de tijolos estrutural revestida com argamassa do tipo raspada e do tipo batida. Destacam-se o uso de ladrilho de cimento no jardim, terraços e áreas de serviço, os pisos de régua de madeira bicolor e mármore, e forros de estuque e gesso trabalhado. Tudo à moda da época.

\subsection{Estado de conservação e preservação do patrimônio}

Nas visitas realizadas à Casa das Rosas, principalmente no ano de 2010, foi constatado que seu estado de conservação era razoável, destacando-se o excesso de fuligem e poluição acomodada em suas fachadas e pontos de infiltração, provavelmente por entupimento de calhas e condutores de águas pluviais, problemas de impermeabilização e algum rompimento de tubulação. Aparentemente, a argamassa de revestimento da fachada nunca foi pintada, o que poderia ocasionar outros danos ao seu estado de conservação. 


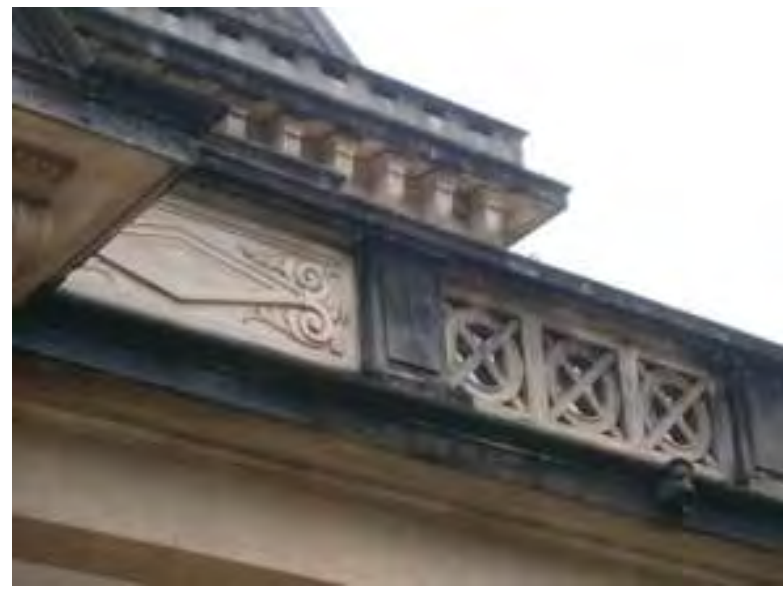

Figura 61 - Exemplo de argamassa da fachada com acumulo de poluição atmosférica.
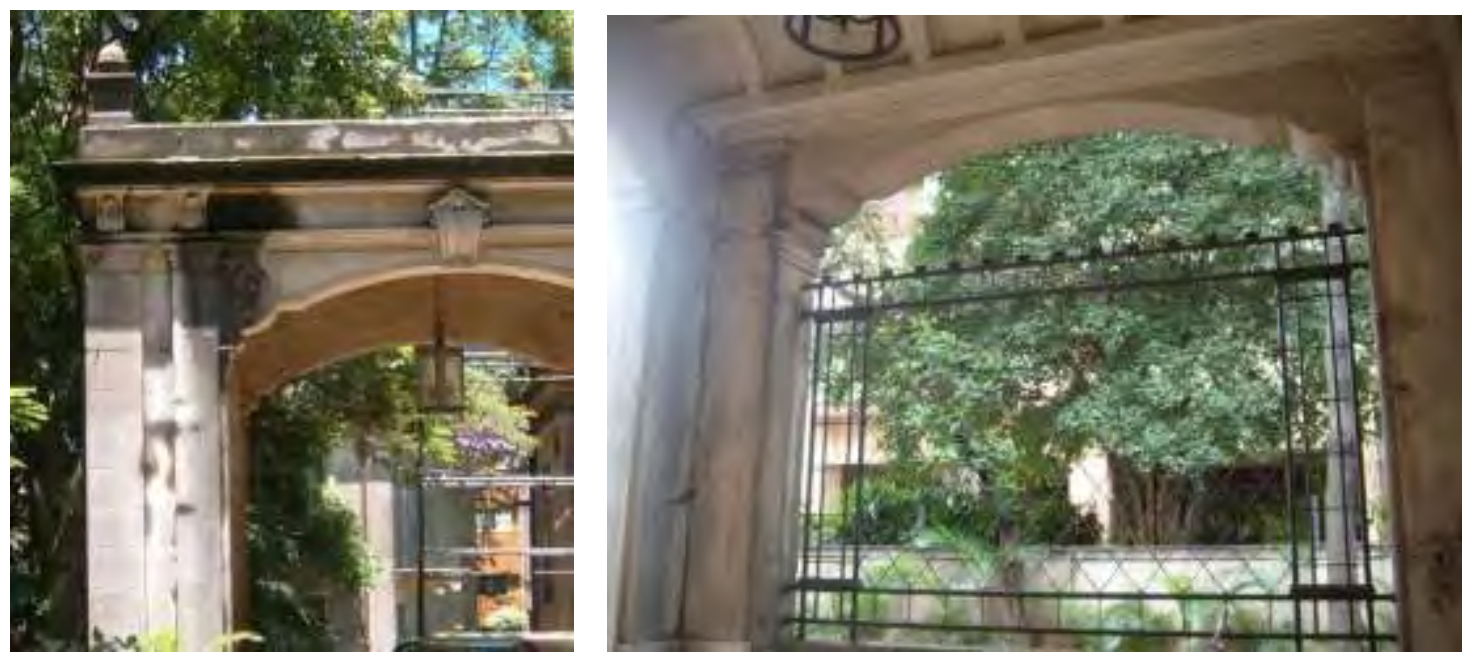

Figura 62 e 63 - Manchas revelam a infiltração na cobertura e/ou condutores

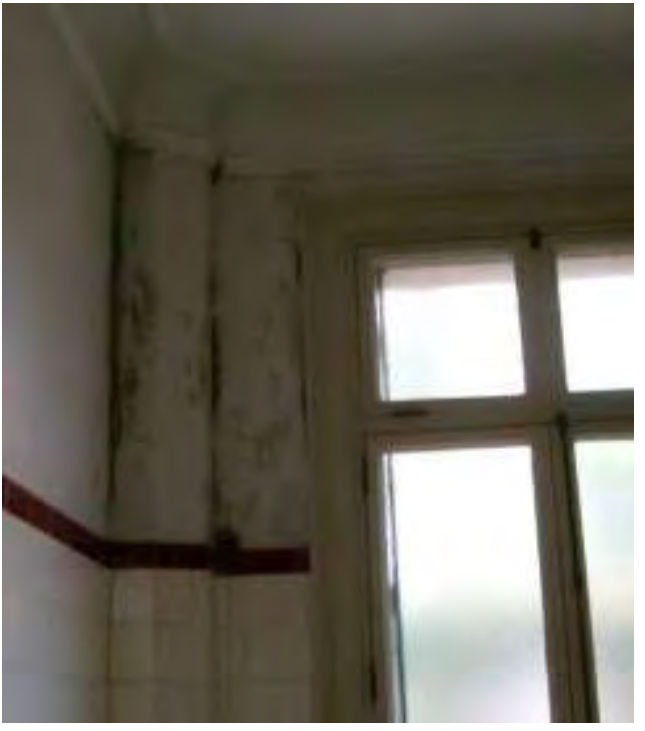

Figura 64 - Infiltração no sanitário do térreo. 2010.

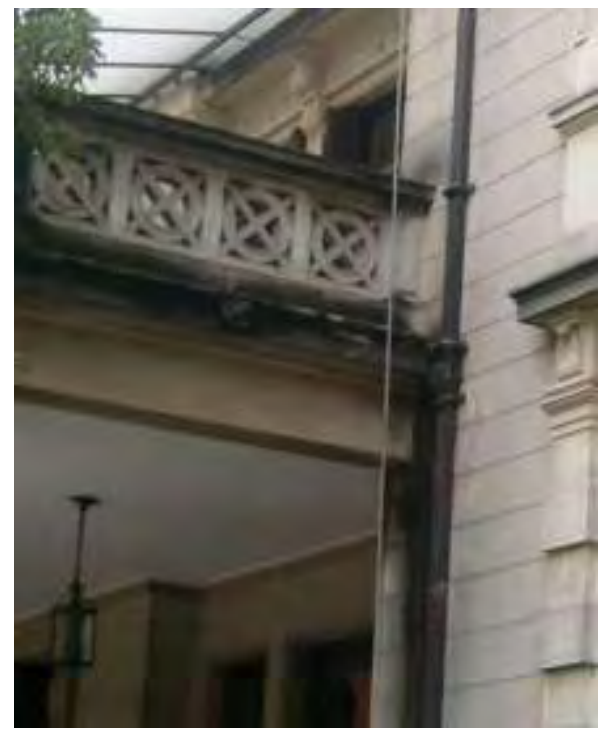

Figura 65 - Carranca que esconde o buzinote e a mancha na fachada, ao lado do condutor de água pluvial. 2010. 


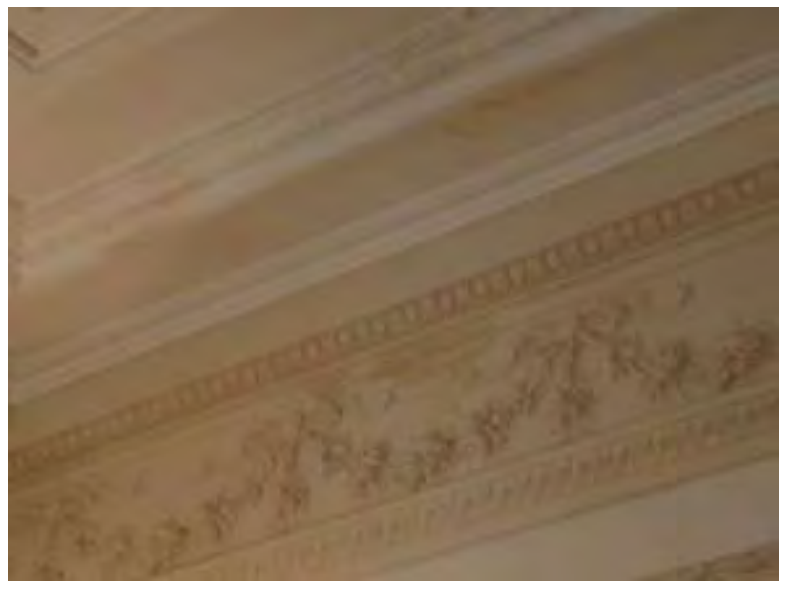

Figura 66 - Manchas amareladas no forro do Salão do térreo. 2010.

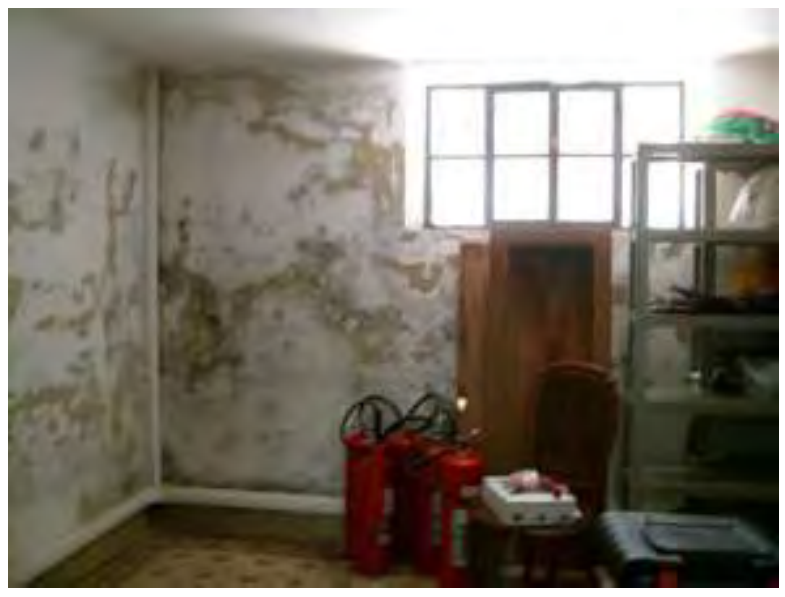

Figura 68 - Depósito do porão tomado por infiltrações por capilaridade. 2010.

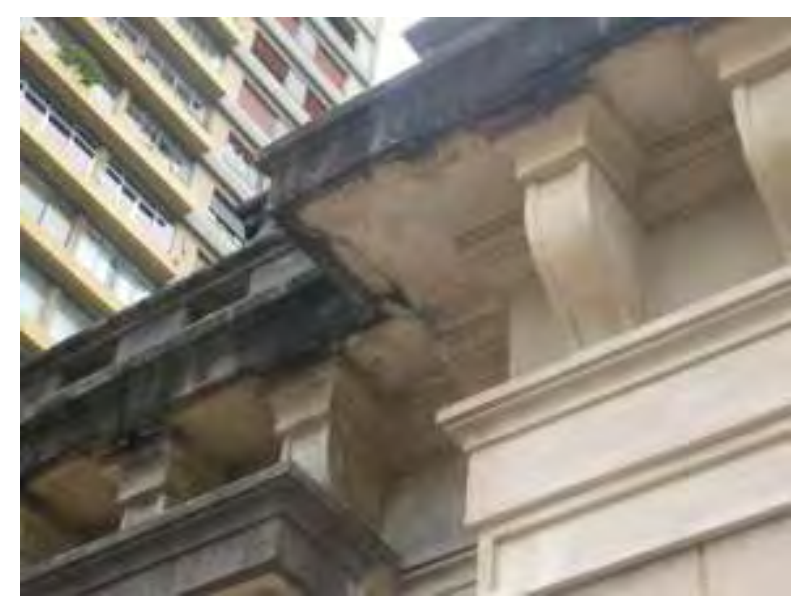

Figura 67 - Beiral danificado, na fachada para Av. Paulista. 2010.

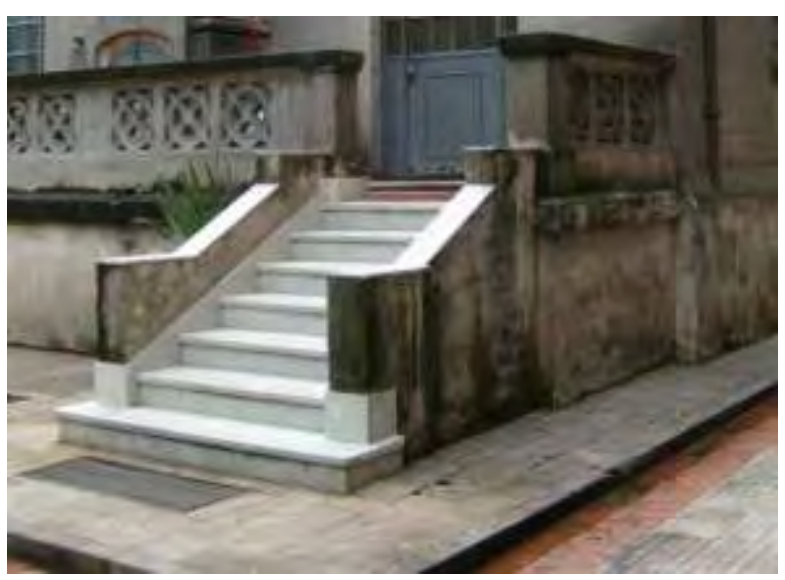

Figura 69 - Muretas com formação de musgo. 2010.

Será necessário realizar revisão de calhas e condutores de águas pluviais e da tubulação de hidráulica, de forma geral, o quanto antes, pois estes problemas podem causar grandes estragos ao patrimônio se não forem sanados. Além disso, deve ser dada atenção à impermeabilização do porão e da cobertura da área de desembarque de veículos. 


\subsection{Programas de atendimento às pessoas com deficiência}

Hoje a edificação é ocupada pelo Espaço Haroldo de Campos de Poesia e Literatura, o qual integra os equipamentos culturais da Secretaria Estadual de Cultura. O Espaço, que recebe cerca de 80.000 pessoas por ano, é administrado pela Organização Social Poiesis, que regularmente realiza exposições, cursos e palestras com temas voltados à poesia e literatura.

As atividades propostas para a ação educativa, conforme informações fornecidas pela educadora Kryslei Cipriano Goes, em dezembro de 2011, possuem atualmente poucos recursos para atender as pessoas com deficiência. As ações existentes, basicamente, se apoiam nos recursos humanos disponíveis, utilizando-se apenas do esforço e interesse dos educadores em busca de atender esse público, sem propostas mais profundas de adequação e integração.

Não há materiais em braile correspondentes aos impressos em tinta. Todavia, a biblioteca, maior atrativo do espaço, dispõe de 23 audiolivros e equipamento adequado para reprodução. Também há a possibilidade de emprestar esse material, que está disponível para o público em geral.

O Educativo atende grupos de pessoas com deficiência, que venham visitar a Casa das Rosas de forma espontânea ou não. No entanto, consideram as visitas agendadas mais adequadas para esse público, por ser possível propor um conteúdo mais atraente ao grupo. Normalmente, recebem pessoas em cadeiras de rodas que vêm acompanhados por seus familiares ou inseridos nos grupos escolares, além de grupos com outras deficiências, como os da APAE, quando procuram manter o roteiro, usando conteúdo mais lúdico. 
O espaço cultural não possui recursos de acessibilidade, como material em relevo, braile ou audiodescrição, nem intérprete de Libras. Nos percursos das visitas usam os materiais disponíveis, como imagens, poemas impressos, livros e o espaço em si, como objeto que pode ser tocado para ampliação da percepção em relação ao ambiente, segundo informa a educadora.

A educadora ainda fala sobre a falta de acesso adequado na entrada e acredita que a rampa existente hoje, por ser móvel, não atrai os visitantes, principalmente pessoas usuárias de cadeira de rodas e que, com a adequação para uma rampa fixa permitirá a entrada autônoma.

Não possuem também, como dito, intérprete de Libras, ou pessoal treinado para se comunicar em Libras. Portando, orientam que grupos de pessoas com deficiência auditiva venham acompanhados de intérprete.

Em resumo, atendem com algum recurso pessoas com deficiência física (utilizando a rampa móvel e o elevador), com deficiência visual (propõem o toque durante a visita para conhecer o edifício, além de possuir audiolivros) e com deficiência intelectual (recursos lúdicos para as atividades). No entanto, não há qualquer recurso, nem mesmo básico, para as pessoas que se comunicam por língua de sinais. 


\subsection{Análise técnica da acessibilidade}

As condições de acessibilidade da Casa das Rosas foram verificadas em visitas técnicas nas seguintes datas: 27 de fevereiro de 2009, 22 de janeiro de 2010, 03 de fevereiro de 2010 e 20 de janeiro de 2012. Foi permitida a análise ampla e irrestrita das áreas que compõem a Casa: do porão à mansarda, da edícula à estufa. Optou-se por apresentar separadamente a análise da Casa das Rosas, propriamente dita (corpo principal), e das áreas administrativas da edícula. Em 2.8.8 estão descritas as condições da edícula de forma resumida, sem subdivisões.

\subsubsection{Passeios}

A Avenida Paulista, principal porta de entrada para a Casa das Rosas, passou por ampla reforma para troca do piso entre 2007 e 2008. Hoje o piso de placas de concreto armado moldadas in loco garante todas as características necessárias para um deslocamento seguro: piso nivelado, regular, estável e antiderrapante ${ }^{53}$. Apenas uma pequena faixa, junto aos muros mantém o piso de

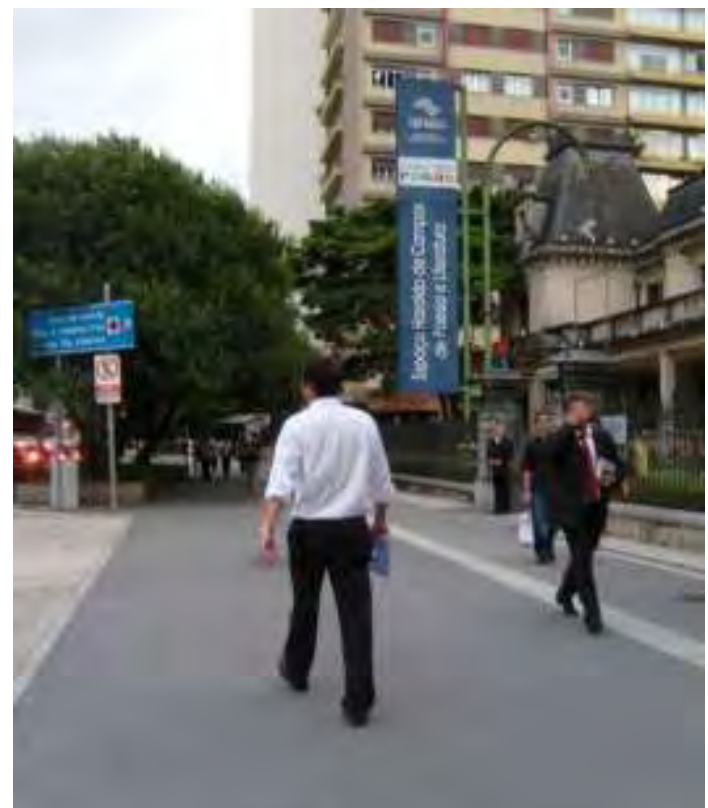

Figura 70 - Passeio da Av. Paulista em frente à Casa das Rosas. 2009.

\footnotetext{
${ }^{53}$ Atende ao disposto no art. 29 do Decreto municipal no 45.904/2005 e na ABNT NBR 9050/2004 item 6.1.1.
} 
mosaico português ${ }^{54}$, do projeto original da década de 1970 da arquiteta e paisagista Rosa Grena Kliass. Os equipamentos e mobiliários urbanos estão organizados de forma a garantir ampla circulação. Essa reforma na Av. Paulista ainda garantiu um melhor deslocamento para as pessoas com deficiência visual, pois podem dispor de piso tátil direcional, contrastante, ao longo de toda a avenida.

A mesma qualidade não pode ser verificada no outro acesso da Casa das Rosas, localizado na Alameda Santos. O piso da calçada é de mosaico português, portanto irregular e trepidante ${ }^{55}$, dificultando

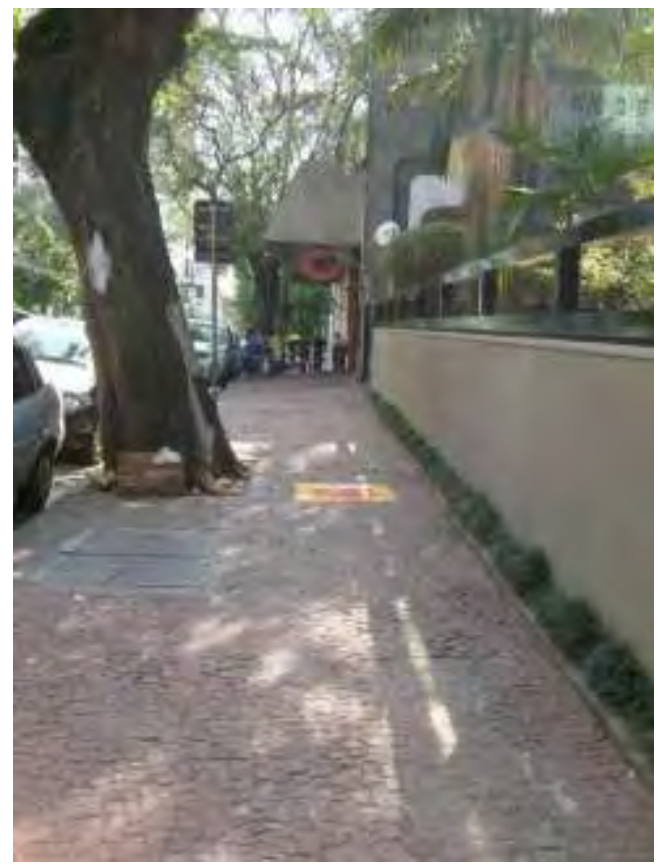

Figura 71 - Calçada revestida em mosaico português da Al. Santos. 2011. o deslocamento.

\subsubsection{Circulação externa}

No acesso de pedestres pela Av. Paulista, a interligação entre passeio público e lote não apresenta desníveis. A largura de passagem pelo portão é bastante ampla, mesmo com um dos portões fechados, não apresentando qualquer restrição no acesso.

No outro acesso, pela Al. Santos, existe um degrau, seguido de escada, impedindo a interligação entre passeio e lote, portanto não faz parte de rota

\footnotetext{
${ }^{54}$ Atende ao disposto no art. 30 do Decreto municipal o 45.904/2005.

${ }^{55}$ Não atende ao disposto no art. 29 do Decreto municipal no 45.904/2005 e na ABNT NBR 9050/2004 - item 6.1.1.
} 
acessível. O item 6.2.2 da NBR 9050/2004 diz que "Na adaptação de edificações e equipamentos urbanos existentes deve ser previsto no mínimo um acesso [...]. Nestes casos a distância entre cada entrada acessível e as demais não pode ser superior a $50 \mathrm{~m}$ ". Existe aqui uma inadequação, pois o percurso real entre as entradas é maior que o exigido ${ }^{56}$. Como hoje, a entrada da Al. Santos não é acessível, deveria existir uma sinalização com 0 Símbolo Internacional de Acesso (SIA), direcionando à entrada acessível, até sua adaptação ${ }^{57}$. Além disso, nessa escada o corrimão é apenas central e não tem prolongamento ${ }^{58}$.

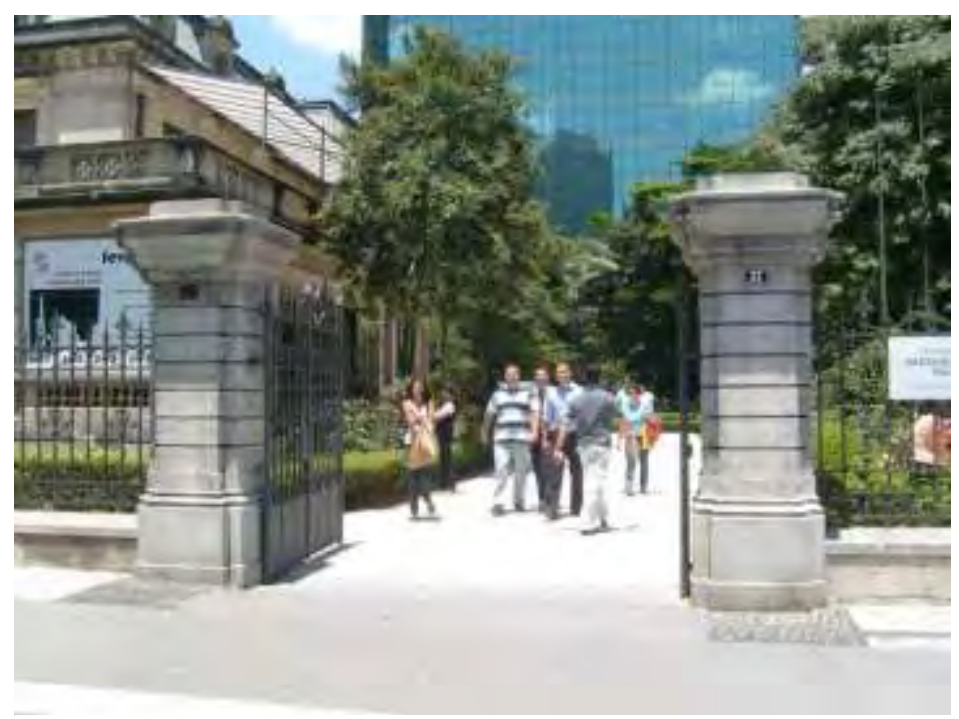

Figura 72 - Portão de entrada pela Av. Paulista. 2010.
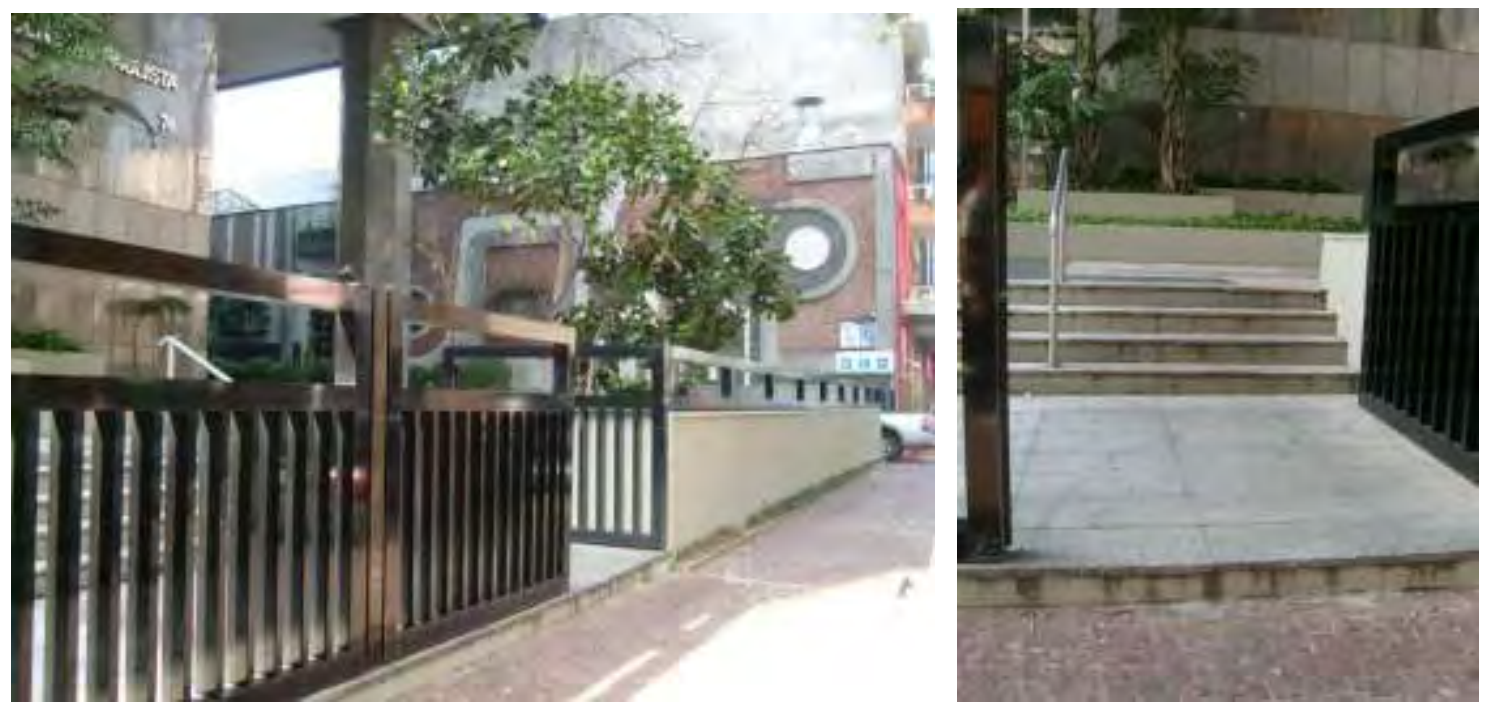

Figuras 73 e 74 - Entrada de pedestres da Al. Santos. 2011.

\footnotetext{
${ }^{56}$ Não atende ao disposto na ABNT NBR 9050/2004 - item 6.2.2.

${ }^{57}$ Não atende ao disposto na ABNT NBR 9050/2004 - item 5.4.1.3.

${ }^{58}$ Não atende ao disposto na ABNT NBR 9050/2004 - itens 6.7.1.1 e 6.7.1.4.
} 
O piso da área externa da Casa das Rosas é em ladrilho hidráulico que apesar da textura pode ser considerado regular, por causar nenhuma ou pouca trepidação na circulação de cadeiras de $\operatorname{rodas}^{59}$. Na área do Parque Cultural Paulista, o piso é de mosaico português, que causa maior trepidação ${ }^{60}$.

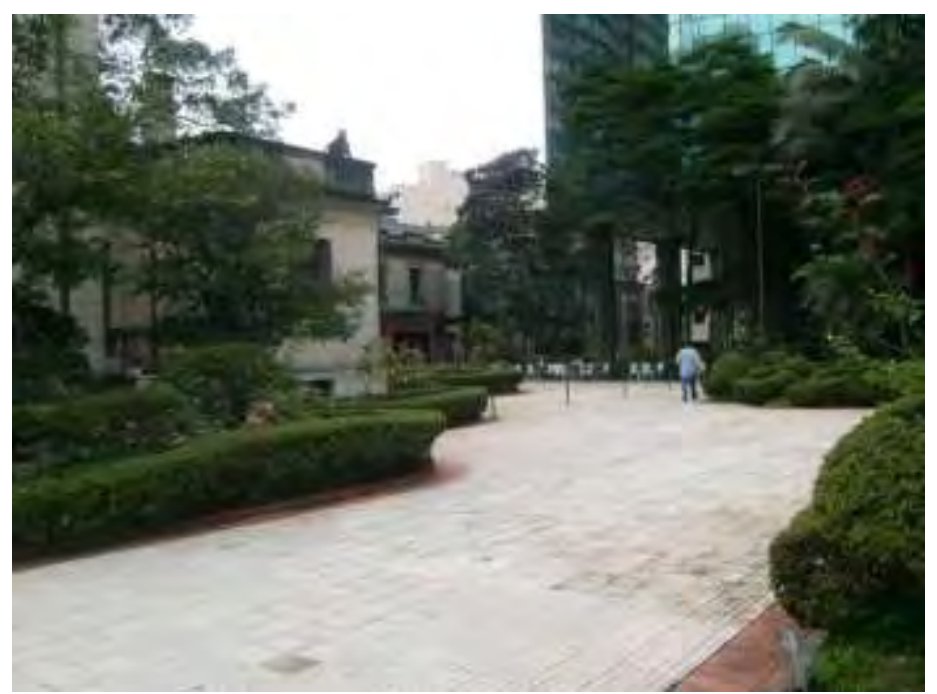

Figura 75 - Área externa em piso de ladrilho hidráulico. 2011.

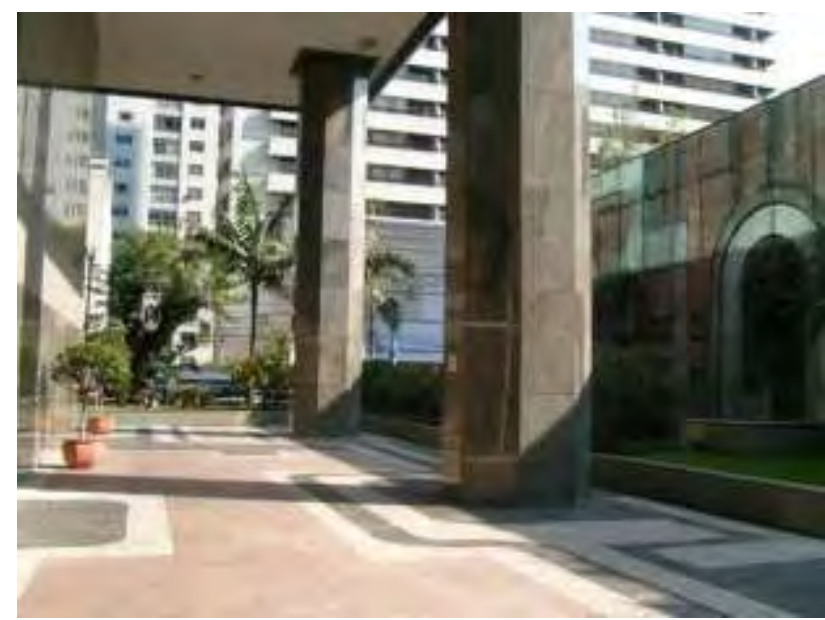

Figura 76 - Área externa do Parque Cultural Paulista em mosaico português. 2011.

O desnível existente na interligação entre a Casa das Rosas e o Parque Cultural Paulista pode ser transposto por degraus ou rampa. São dois tipos de degraus, um revestido de tijolos e outro em granito. Os degraus de tijolos têm

\footnotetext{
${ }^{59}$ Atende ao disposto na ABNT NBR 9050/2004 - item 6.1.1.

${ }^{60}$ Não atende ao disposto na ABNT NBR 9050/2004 - item 6.1.1.
} 
características adequadas $^{61}$, porém não possuem corrimão ${ }^{62}$. Os degraus em granito, também tem dimensionamento adequado $^{63}$, com corrimão de apoio sem prolongamento e no centro da largura ${ }^{64}$. A rampa, também revestida em mosaico português, não atende adequadamente por não possuir corrimão ${ }^{65}$ e ter inclinação acima de $8,33 \%{ }^{66}$.

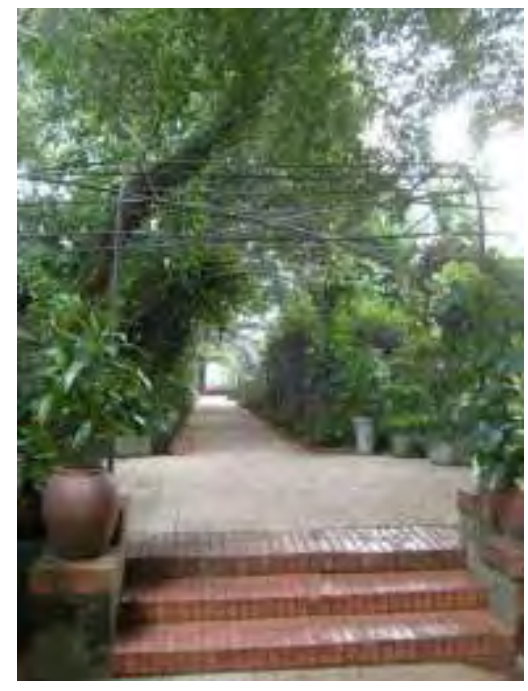

Figura 77 - Degraus em tijolo sem corrimão de apoio. 2009.

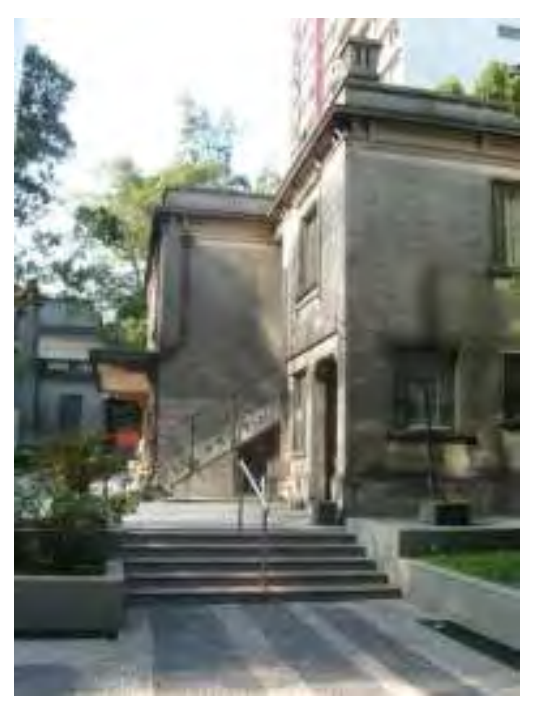

Figura 78 - Degraus em granito. 2011.

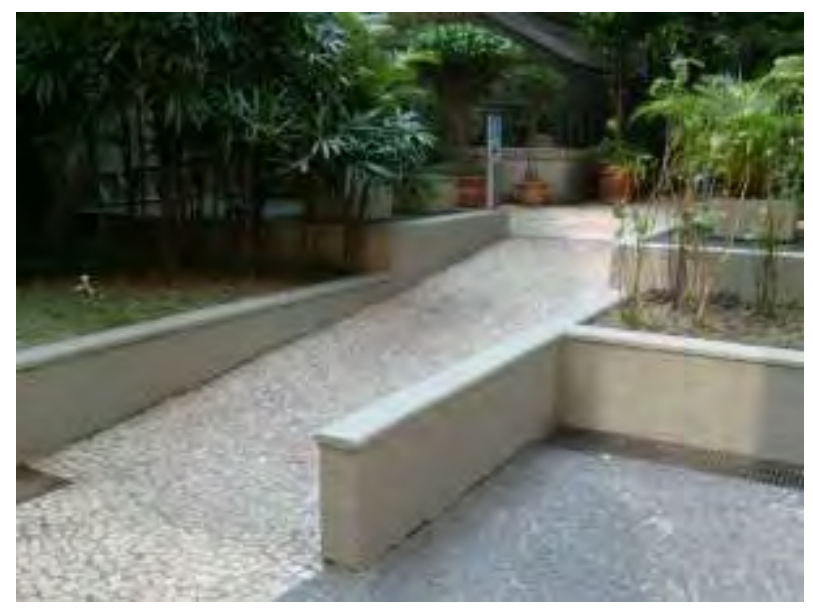

Figura 79 - Rampa em mosaico português. 2011.

\footnotetext{
${ }^{61}$ Atende ao disposto na ABNT NBR 9050/2004 - item 6.6.3.

62 Não atende ao disposto na ABNT NBR 9050/2004 - item 6.7.1.1.

${ }^{63}$ Atende ao disposto na ABNT NBR 9050/2004 - item 6.6.3.

${ }^{64}$ Não atende ao disposto na ABNT NBR 9050/2004 - itens 6.7.1.1 e 6.7.1.4.

${ }^{65}$ Não atende ao disposto na ABNT NBR 9050/2004 - item 6.7.1.1.

${ }^{66}$ Não atende ao disposto na ABNT NBR 9050/2004 - item 6.5.1.2.
} 
As grelhas nas áreas

externas, embora localizadas no fluxo de circulação, estão corretas, pois são niveladas com o piso, e a dimensão do vão e a orientação das arestas não prejudicam a circulação de usuários de cadeiras de rodas e de bengalas ${ }^{67}$.

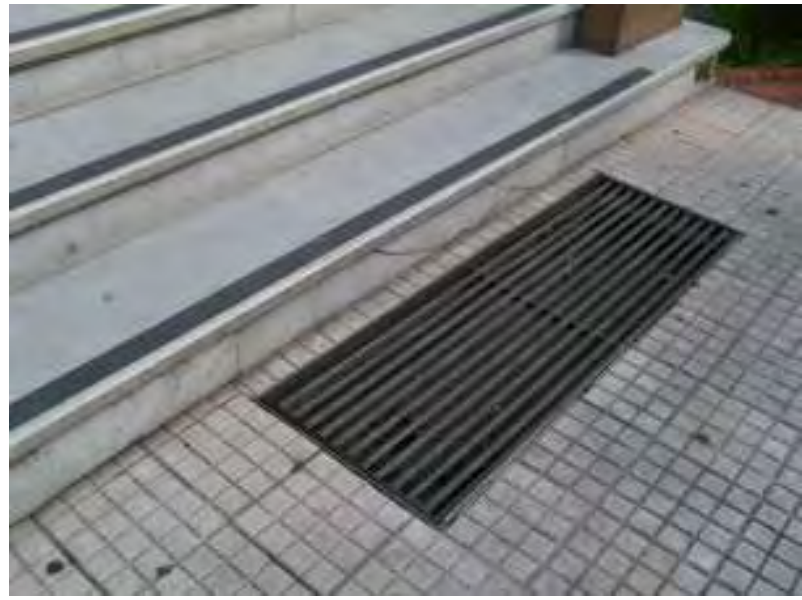

Figura 80 - Exemplo de grelha na circulação externa. 2009.

\subsubsection{Estacionamento}

A Casa das Rosas não possui estacionamento próprio. O Edifício Parque Cultural Paulista têm estacionamento no seu subsolo, com serviço de manobrista. $\mathrm{O}$ acesso acontece a partir da Al. Santos, e o usuário pode utilizar o elevador do Edifício Parque Cultural Paulista, para acessar a área externa do edifício.

\subsubsection{Entradas e saídas}

Existem diversos acessos à Casa, geralmente, envolvendo varandas e terraços intermediários até a soleira de ingresso. O pavimento térreo fica acima do piso do jardim, o que faz com que todos os acessos tenham degraus. Há dois acessos utilizados pelo público, um acesso pelo porte-cochère (geralmente de uso restrito), e três acessos restritos às áreas administrativas. Todas as escadas têm as

\footnotetext{
${ }^{67}$ Atende ao disposto na ABNT NBR 9050/2004 - item 6.1.5.
} 
mesmas características: dimensões

adequadas de espelho e piso ${ }^{68}$, porém, sem corrimão ${ }^{69}$.

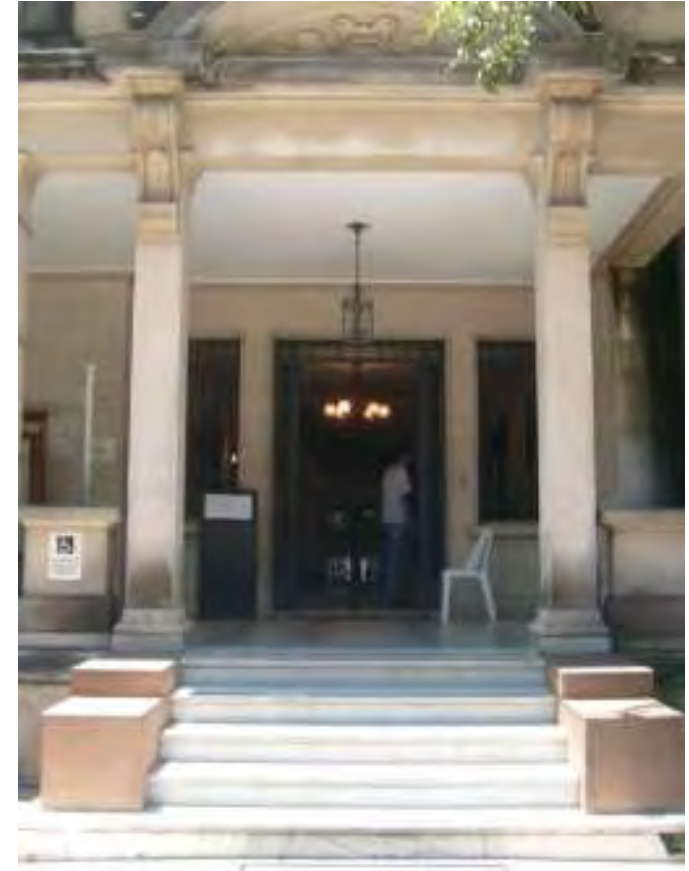

Figura 81 - Entrada principal, voltada para o jardim. 2010.

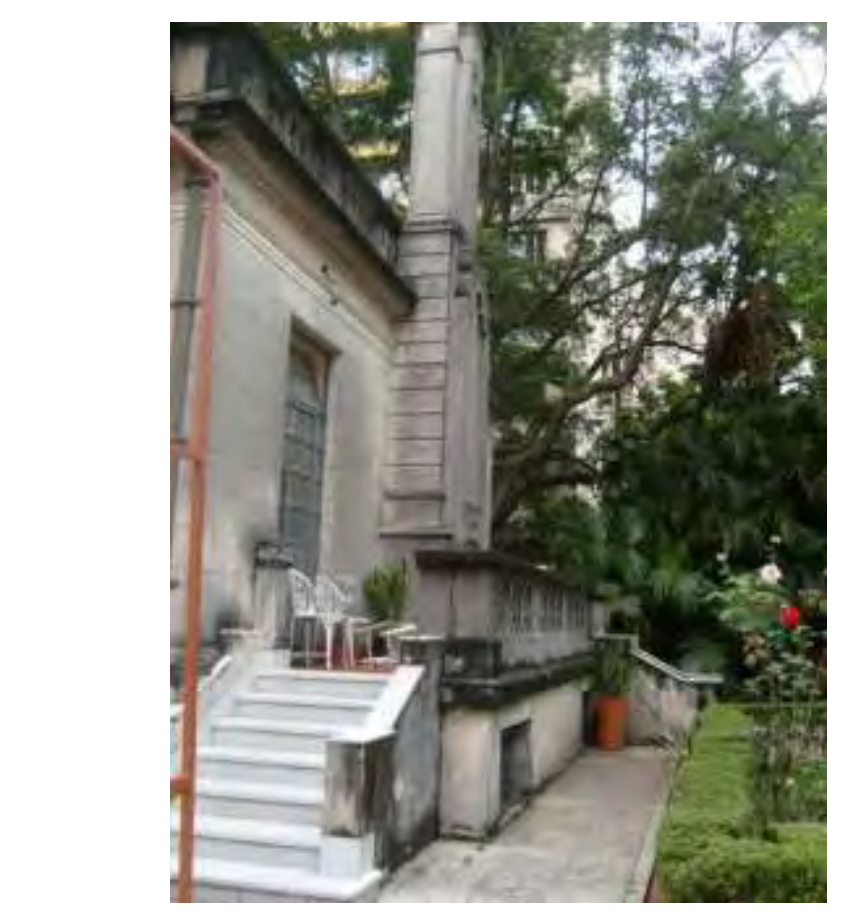

Figura 83 - Entrada lateral, voltada para Av.

Paulista. 2010.
Figura 82 - Escada de acesso à área de
Figura 82 - Escada de acesso
administrativa. 2010.

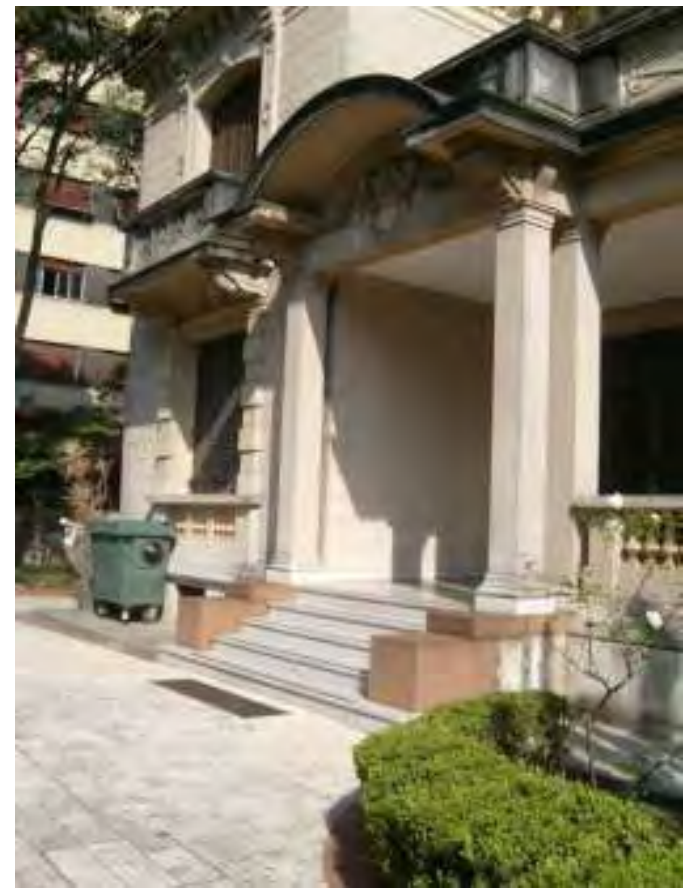

\footnotetext{
${ }^{68}$ Atende ao disposto na ABNT NBR 9050/2004 - item 6.6.3.

${ }^{69}$ Não atende ao disposto na ABNT NBR 9050/2004 - item 6.7.1.1.
} 


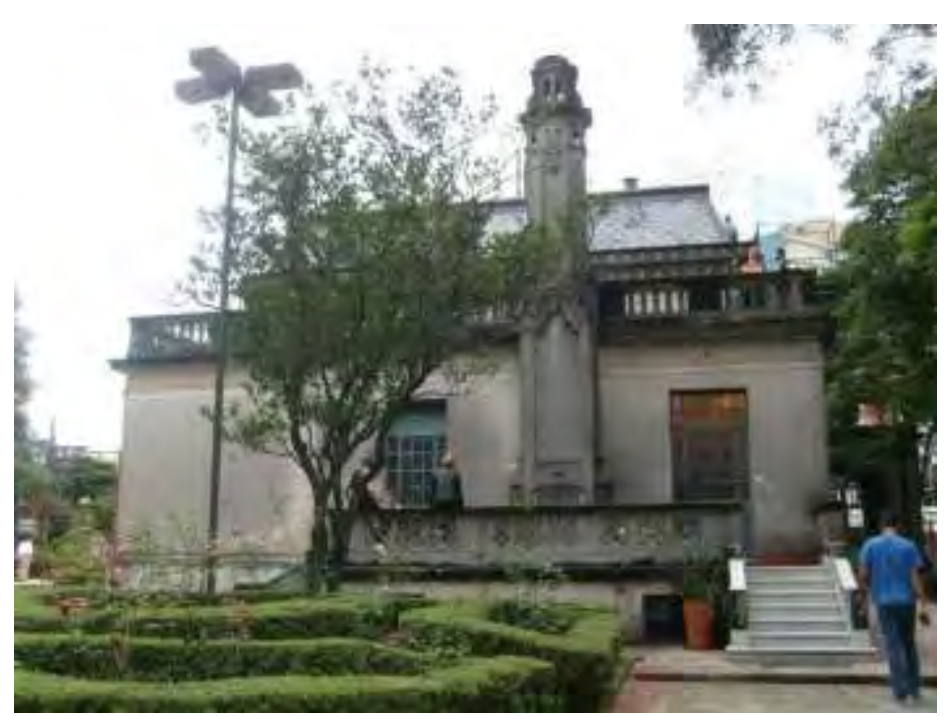

Figura 84 - Escada de acesso à área administrativa. 2010

O acesso próximo ao pórtico de entrada (porte-cochère) apresenta dois degraus junto à porta e três degraus internos, com as mesmas características apresentadas.

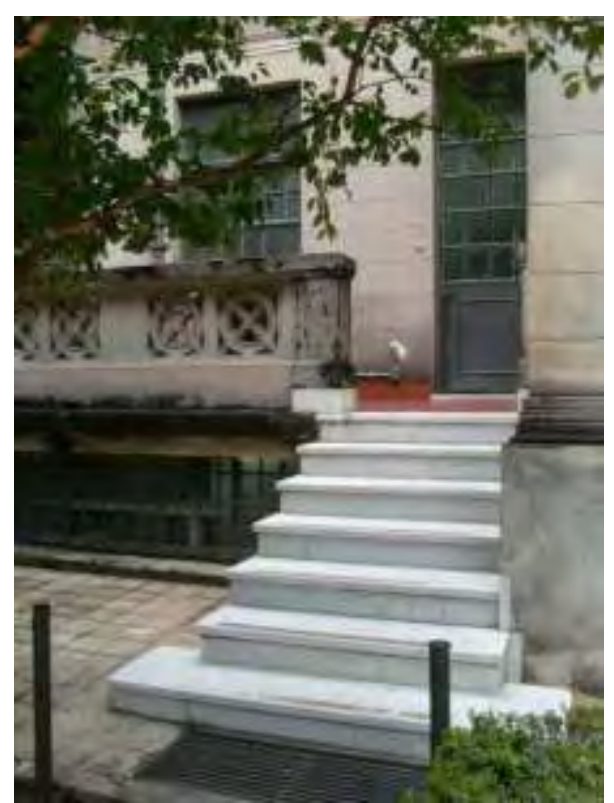

Figura 85 - Escada de acesso à área administrativa

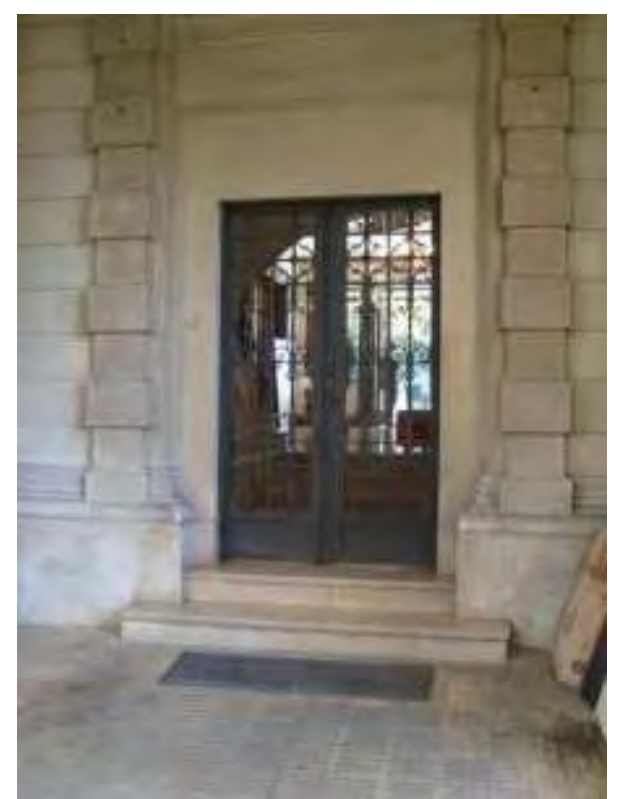

Figura 86 - Entrada dos fundos: portecochère. 2011.

Dadas às características de acesso relatadas, a Casa das Rosas não 
possui nenhuma entrada acessível com autonomia ${ }^{70}$. Hoje, as pessoas com deficiência que quiserem acessar a edificação devem solicitar ajuda aos funcionários, conforme indicado em placa na entrada principal:

PESSOAS COM DEFICIÊNCIA FÍSICA: sejam muito bem vindos à Casa das Rosas! Por favor, solicitem nossa ajuda para entrar. $O$ interior da Casa conta com elevador e plenas condições de acesso. Em breve instalaremos também uma rampa nesta entrada, para melhor atendê-los!
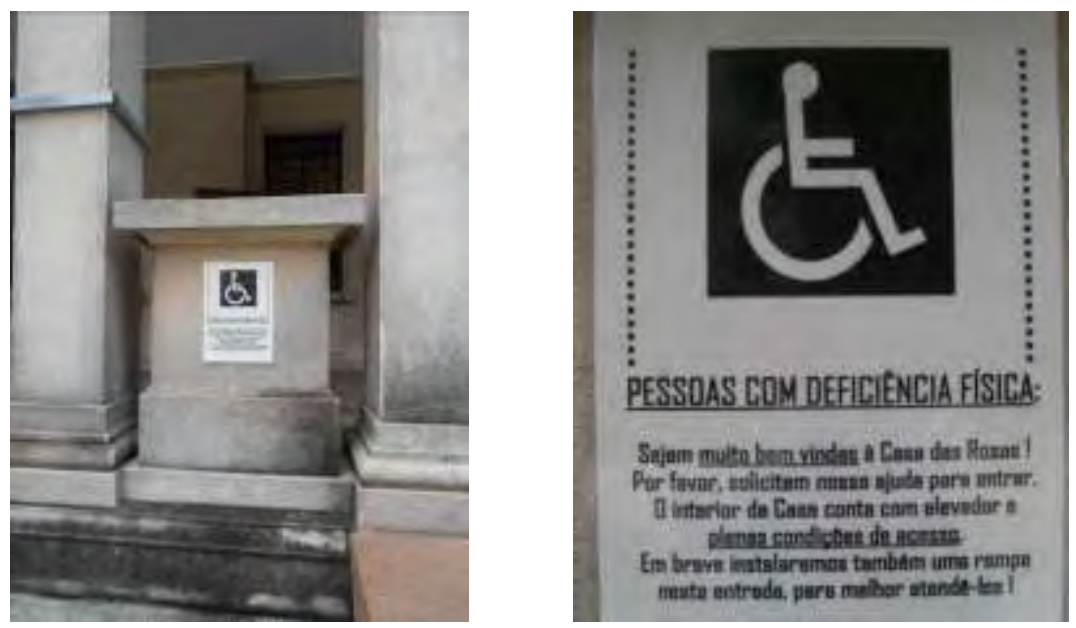

Figuras 87 e 88 - Sinalização com orientações para o acesso de pessoas com deficiência física. 2010.

O acesso se dá por duas rampas metálicas paralelas que, ficam apoiadas no degrau superior e no piso do jardim. Com a ajuda de um funcionário, da equipe de segurança, o usuário de cadeira de rodas será empurrado. A descida é feita de costa, também com o auxílio de um funcionário.

Essa situação é perigosa de diversas maneiras: sem qualquer fixação a rampa pode mover-se durante o uso; inclinação muito superior à máxima permita ${ }^{71}$; ausência de corrimãos de apoio $^{72}$; total comprometimento da autonomia e da

\footnotetext{
${ }^{70}$ Não atende ao disposto no art. 19 e 20 do Decreto federal ํㅜ 5.296/04 e na ABNT NBR 9050/2004 - item 6.2.2.

${ }^{71}$ Não atende ao disposto na ABNT NBR 9050/2004 - item 6.5.1.2.

${ }^{72}$ Não atende ao disposto na ABNT NBR 9050/2004 - item 6.7.1.1.
} 
segurança pessoal ${ }^{73}$. Portanto, não há efetivamente nenhuma entrada que possa ser considerada acessível ${ }^{74}$.

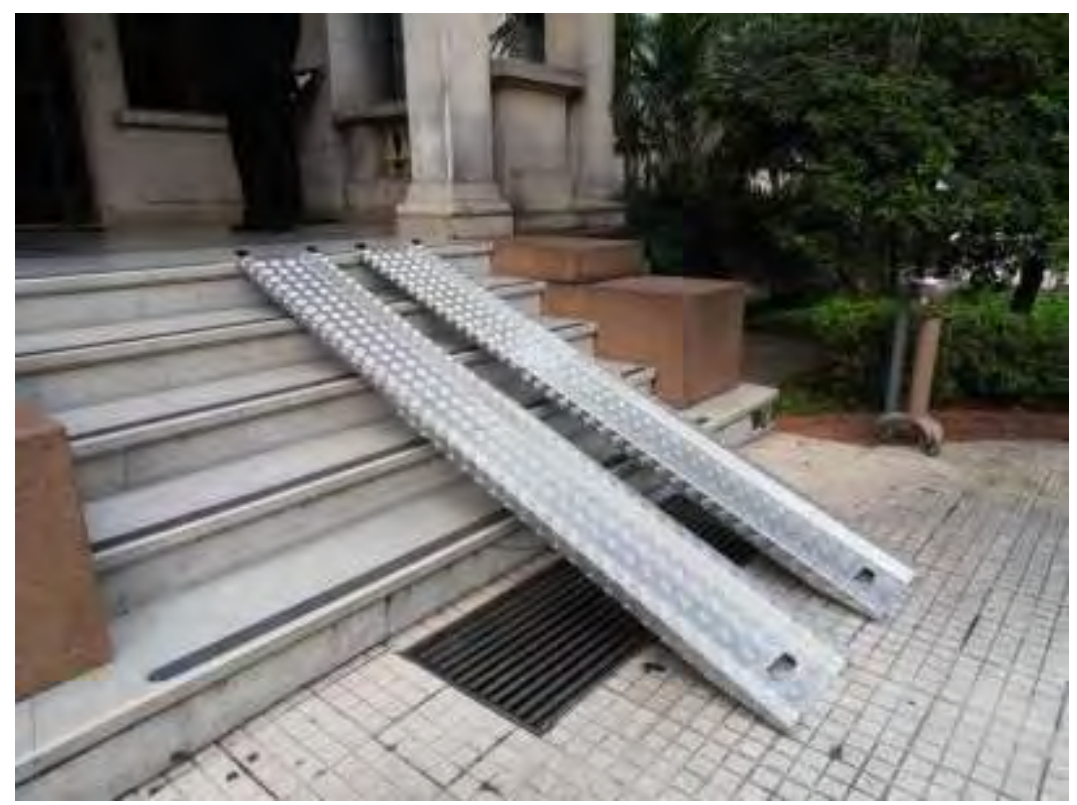

Figura 89 - Rampa metálica para acesso à Casa das Rosas. 2012.

Até 2008 existia uma rampa de estrutura metálica e de madeira, com corrimão, no acesso voltado para a Av. Paulista, que se deteriorou e não foi substituída por opção equivalente.

As portas de entrada, de visitantes e funcionários, apresentam vão livre de passagem de 0,80m, independente de quando há uma ou duas folhas de abertura $^{75}$. A soleira das portas principais tem um centímetro de desnível em relação à varanda que embora não seja chanfrada, conforme previsto na ABNT NBR $9050 / 2004^{76}$, é boleada, o que facilita a passagem. As maçanetas originais são do tipo alavanca em altura adequada.

\footnotetext{
${ }^{73}$ Não atende ao disposto na ABNT NBR 9050/2004 - item 1.3.

${ }^{74}$ Não atende ao disposto na ABNT NBR 9050/2004 - item 3.1.

${ }^{75}$ Atende ao disposto na ABNT NBR 9050/2004 - item 6.9.2.1.

${ }^{76}$ Item 6.1.4: "[...] Desníveis superiores a $5 \mathrm{~mm}$ até $15 \mathrm{~mm}$ devem ser tratados em forma de rampa, com inclinação máxima de 1:2 (50\%) [...].
} 

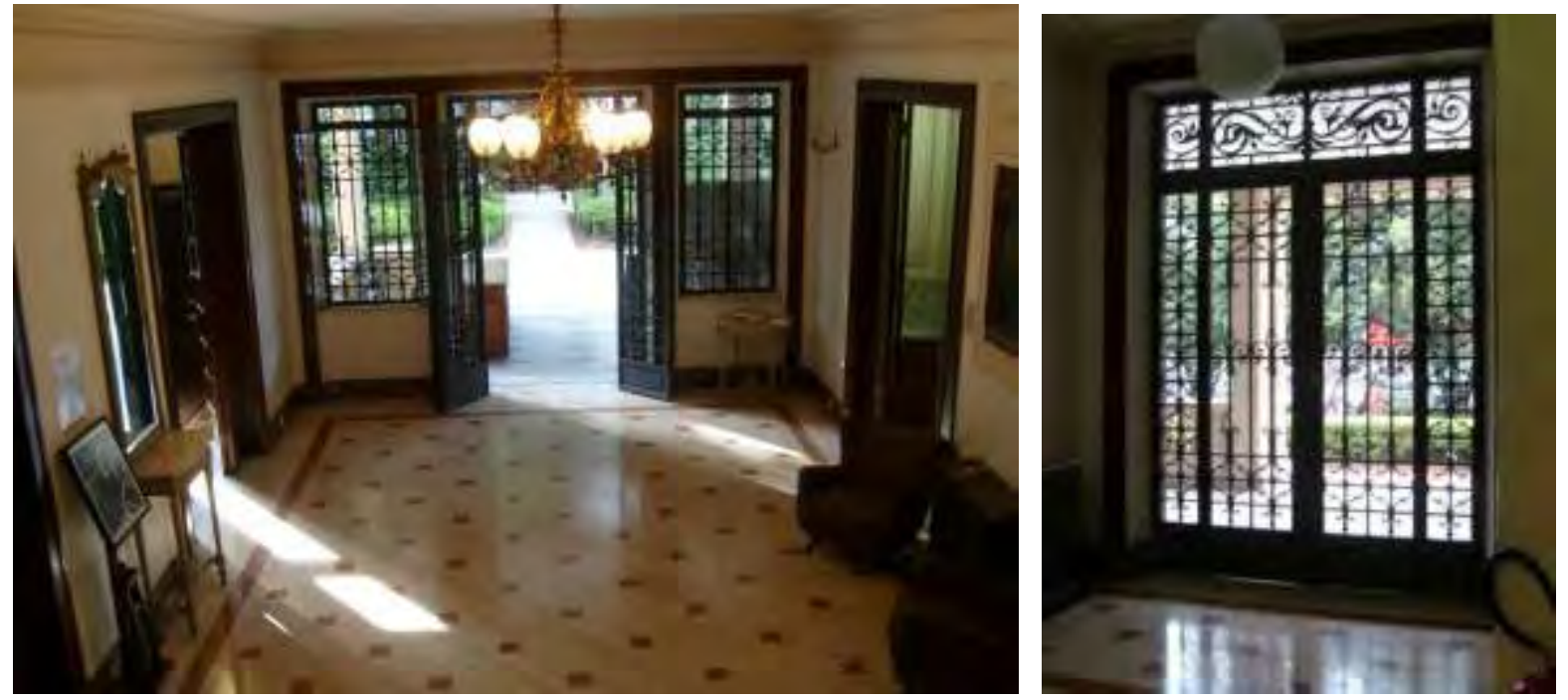

Figuras 90 e 91 - Porta da entrada principal (esquerda) e lateral (direita). 2009.

Nas portas das áreas administrativas, a soleira tem desnível de cerca de 5 $\mathrm{cm}$, em relação ao pequeno terraço que a precede.

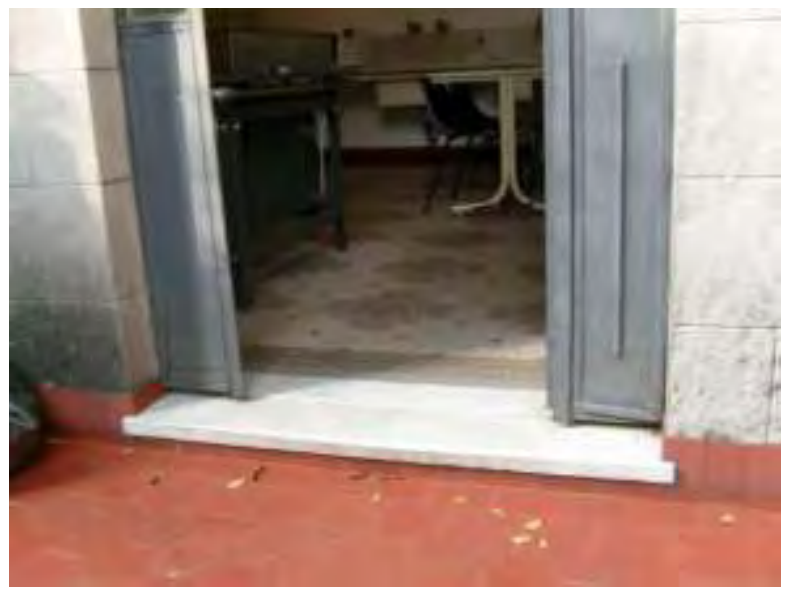

Figura 92 - Soleira de ingresso à cozinha. 2009.

\subsubsection{Circulação interna}

As larguras de circulação do pavimento térreo e superior são suficientemente amplas, quando não prejudicadas por elementos móveis, como os extintores na circulação próxima ao elevador ${ }^{77}$. Os pisos das áreas internas são

\footnotetext{
${ }^{77}$ Não atende ao disposto no item 9.5.5 do Anexo I da Lei municipal no 11.228/1992.
} 
regulares, estáveis e antiderrapantes ${ }^{78}$.

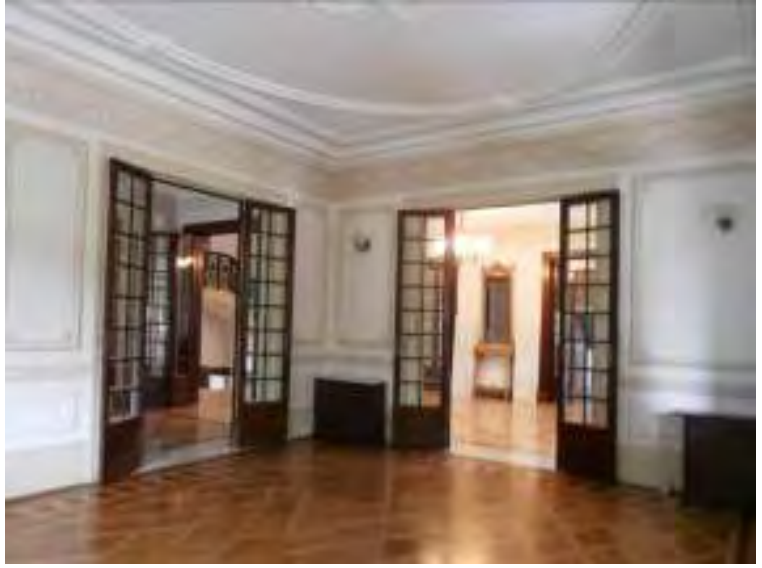

Figura 93 - Circulação no térreo. 2012.

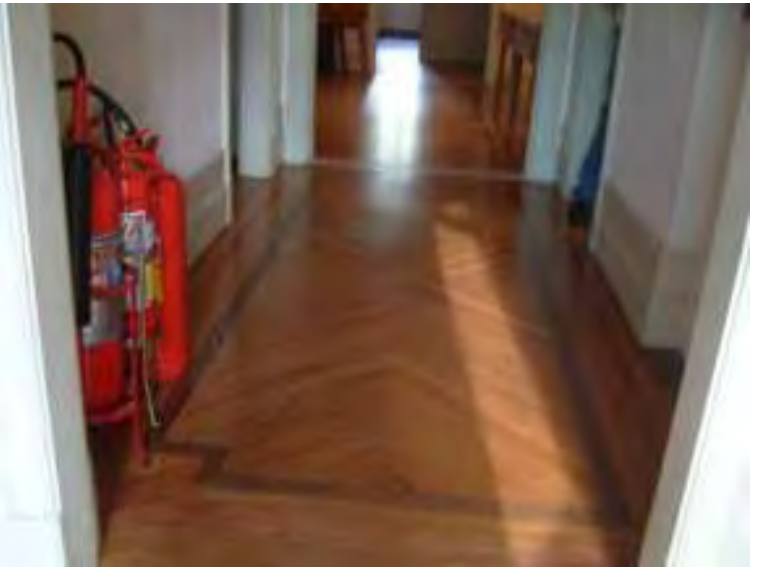

Figura 94 - Extintores em frente ao elevador. 2009.

No porão e na mansarda encontramos as mesmas características, entretanto, com maior quantidade de móveis, o que por vezes prejudica a circulação, principalmente no porão.

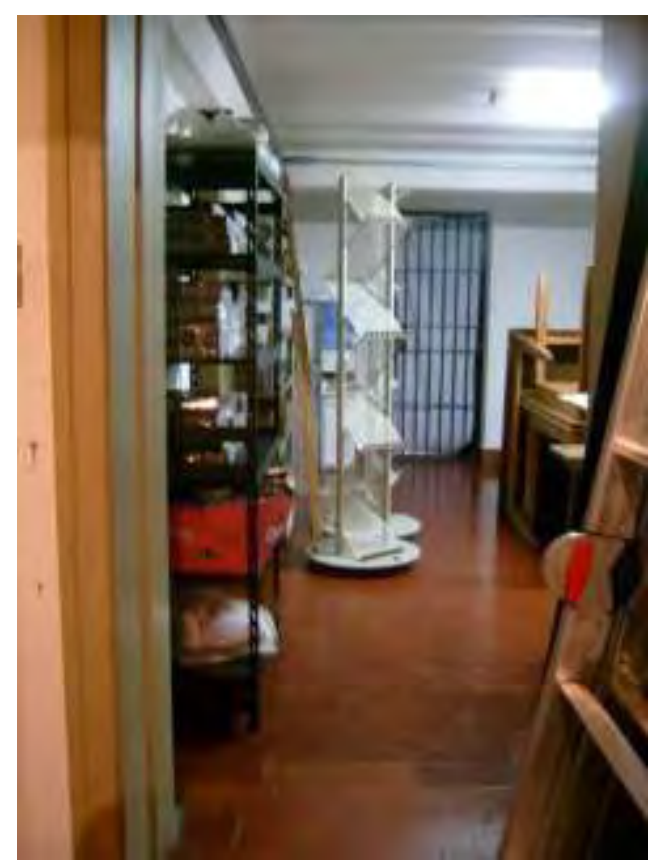

Figura 95 - Circulação no porão. 2010.

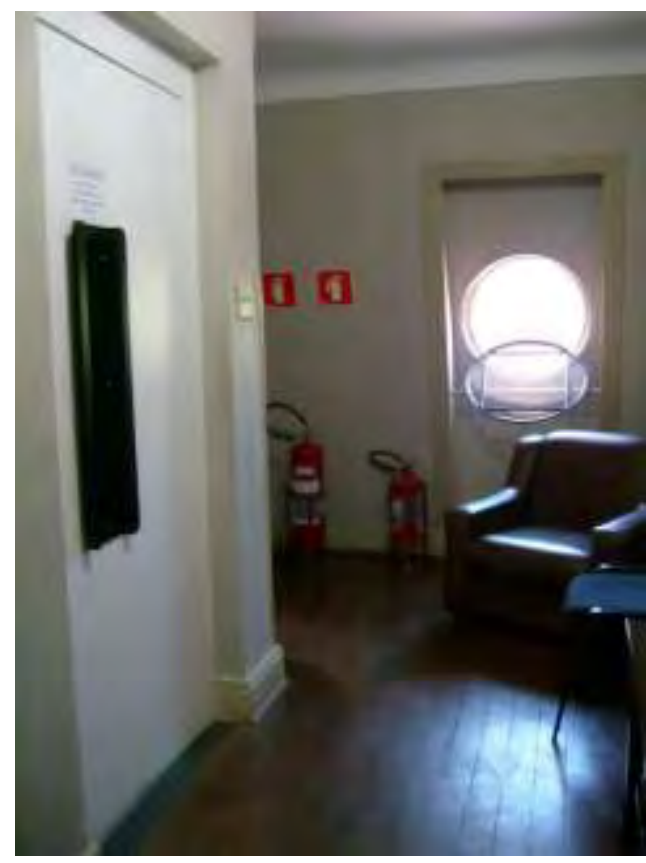

Figura 96 - Circulação na mansarda. 2010

No pavimento superior existem dois terraços, um voltado para a parte

\footnotetext{
${ }^{78}$ Atende ao disposto na ABNT NBR 9050/2004 - itens 6.9.1.1 e 6.1.1.
} 
frontal da casa e outro voltado para o edifício Parque Cultural Paulista. Ambos possuem desnível de cerca de um centímetro, entre a cota de nível interna e externa, na soleira de ingresso que, é boleada.

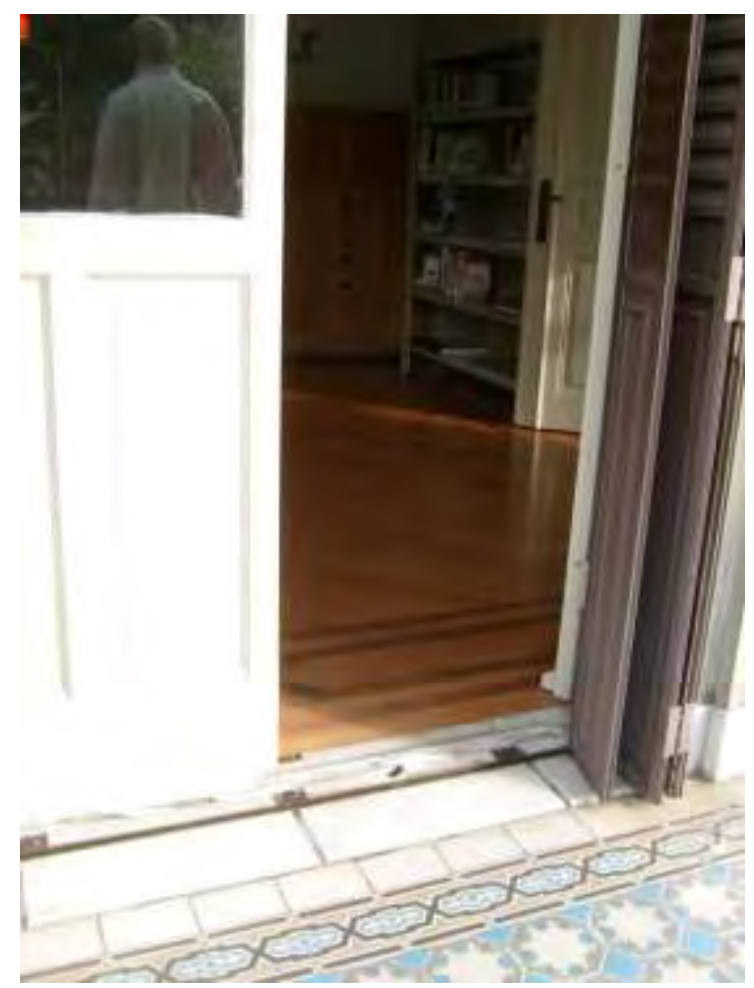

Figura 97 - Terraço do piso superior. 2009.

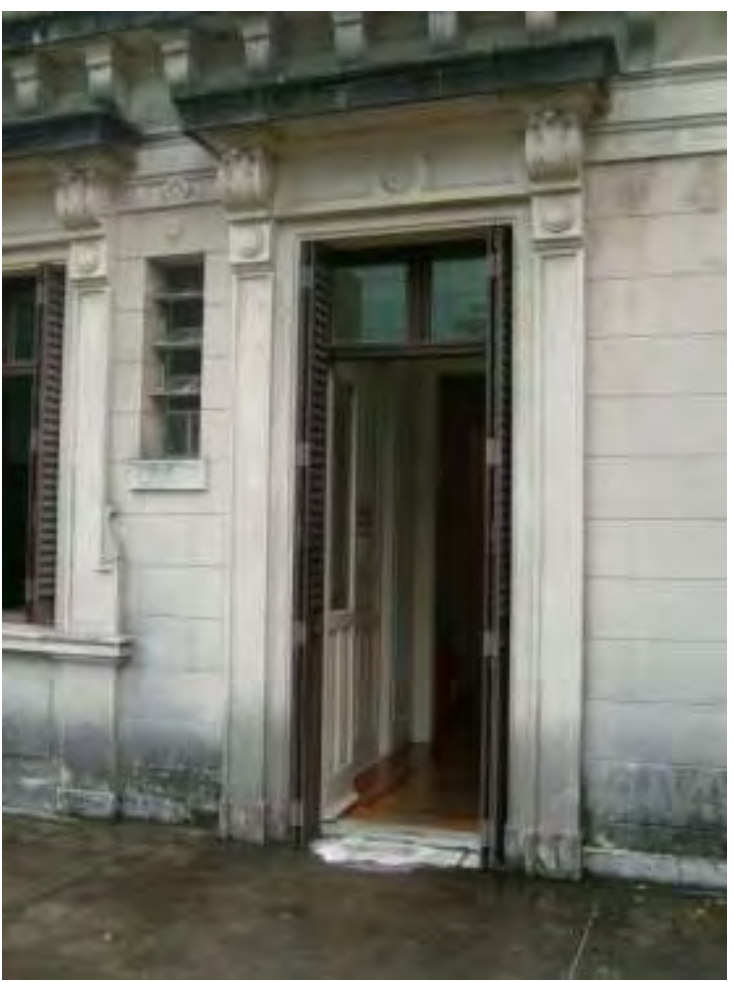

Figura 98 - Terraço lateral. 2010.

As portas são originais e têm vão adequado de passagem, com exceção de algumas delas, como a do Banheiro 1, que têm 0,78m, e da área que separa a bacia no Banheiro 3, com apenas $0,70 \mathrm{~m}$ de largura $^{79}$. Este último, menos severo, por não ser o sanitário acessível, diferente do primeiro.

Há duas escadas e um elevador como circulação vertical da Casa das Rosas. A escada no hall de entrada interliga apenas o térreo ao pavimento superior. A outra escada, de madeira, interliga todos os pavimentos e é destinada hoje principalmente à circulação de funcionários. E o elevador interliga o térreo à mansarda, sendo a rota acessível interna.

\footnotetext{
${ }^{79}$ Não atende ao disposto na ABNT NBR 9050/2004 - item 6.9.2.1.
} 


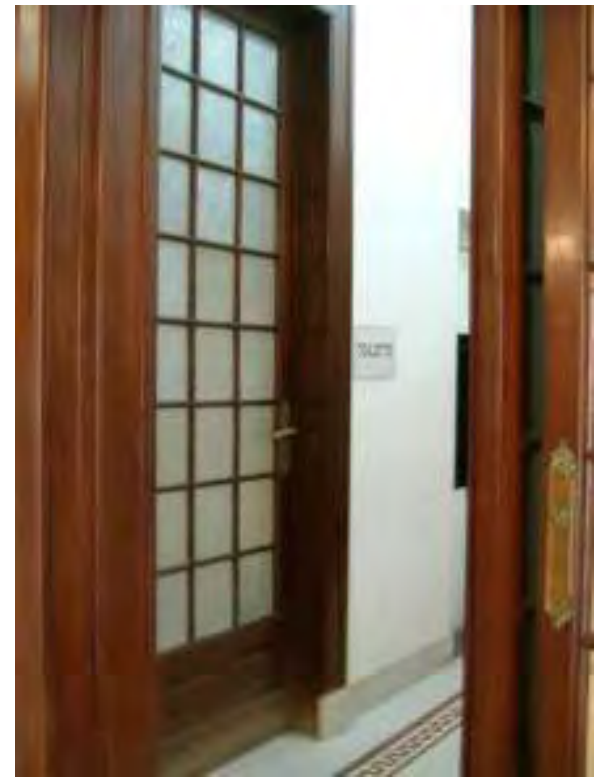

Figura 99 - Porta do Banheiro 1, no térreo. 2009.

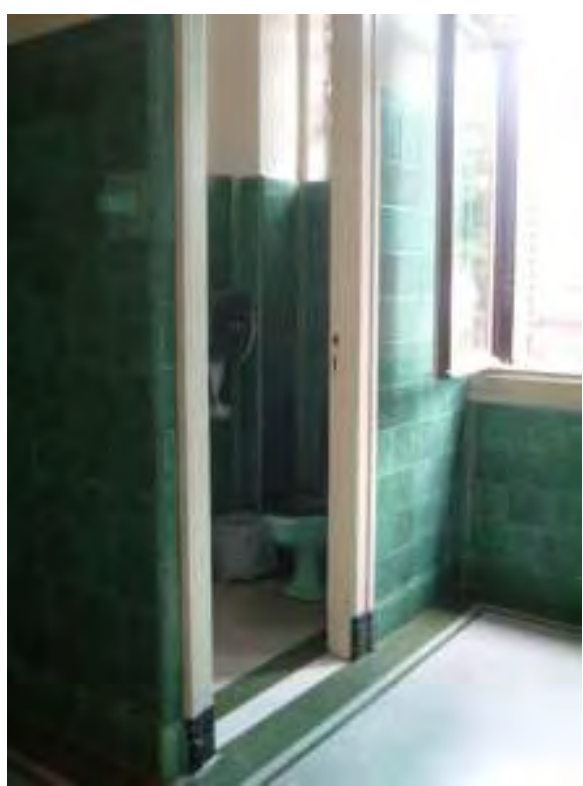

Figura 100 - Porta que separa a bacia do Banheiro 3. 2010.

A escada principal preserva as condições originais e tem corrimão somente de um dos lados e em característica distinta da prevista na ABNT NBR 9050/2004, como altura, formato e prolongamento ${ }^{80}$. A outra escada apresenta as mesmas inadequações, e adicionalmente sua largura é menor que $0,80 m^{81}$. acesso ao porão e à mansarda é restrito aos funcionários.

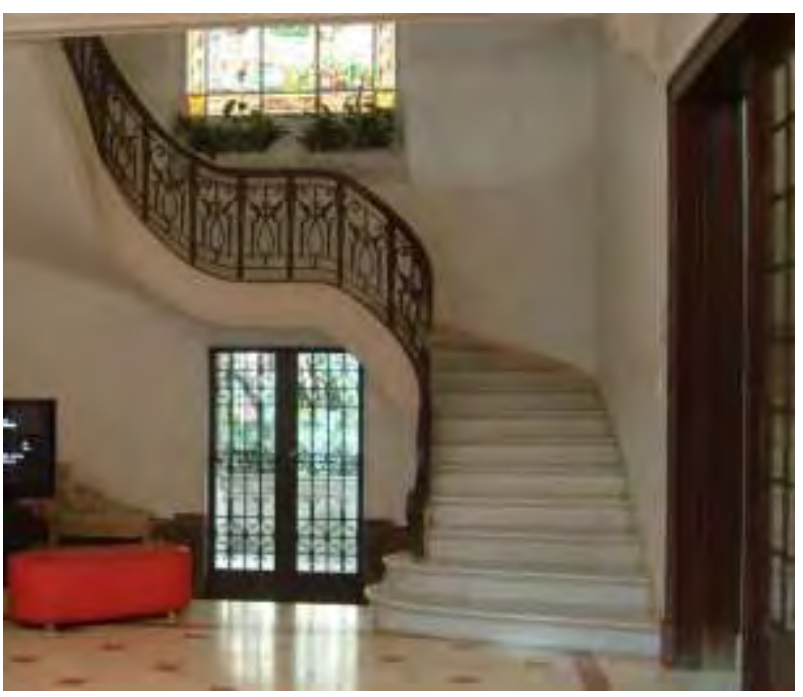

Figura 101 - Escada principal. 2011.

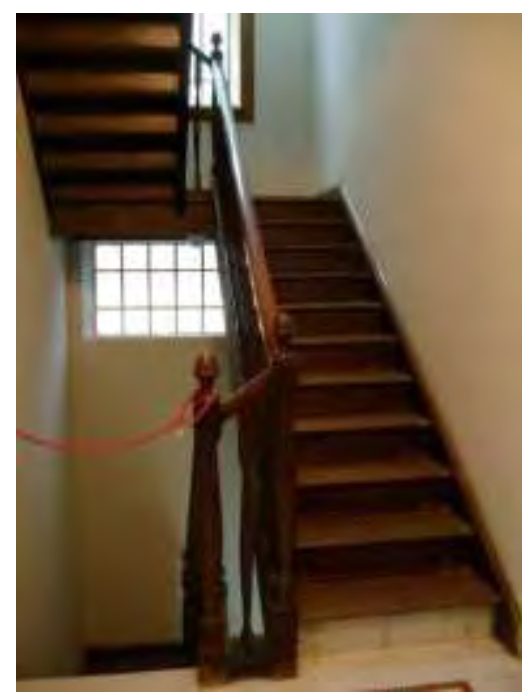

Figura 102 - Escada secundária. 2009.

\footnotetext{
${ }^{80}$ Não atende ao disposto na ABNT NBR 9050/2004 - itens 6.7.1.6, 4.6.5 e 6.7.1.4.

${ }^{81}$ Não atende ao disposto na ABNT NBR 9050/2004 - item 6.6.4.3.
} 
O elevador, que atende três dos quatro pavimentos da casa ${ }^{82}$ (não há acesso ao porão), é caracterizado como de uso específico, ou seja, destinado exclusivamente às pessoas com deficiência. Dentro dessas características ele está enquadrado nas obrigações em vigor para a cidade de São Paulo previstas na Resolução CPA/SEHAB-G/010/2003, e, assim sendo tem exigências distintas de plataforma vertical ou de elevador de uso geral.

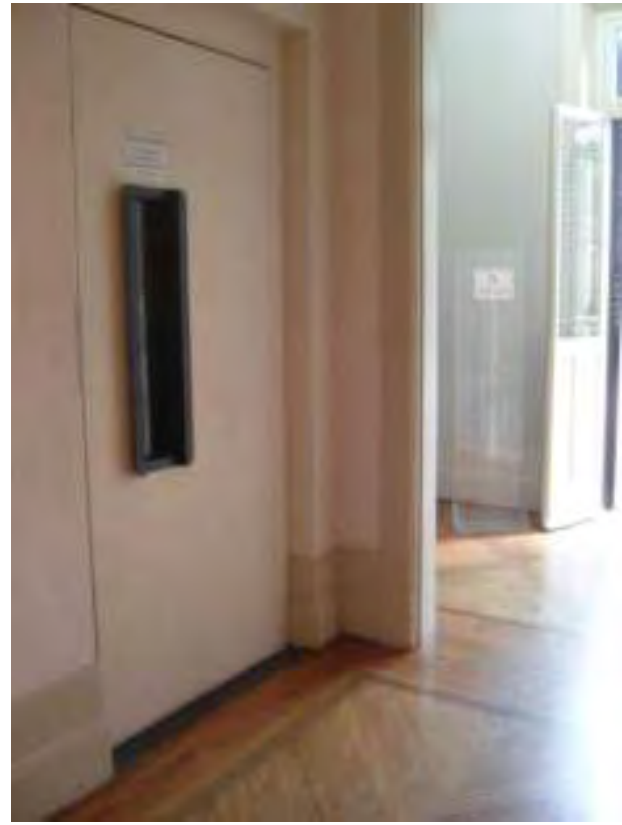

Figura 103 - Porta do elevador. 2010.

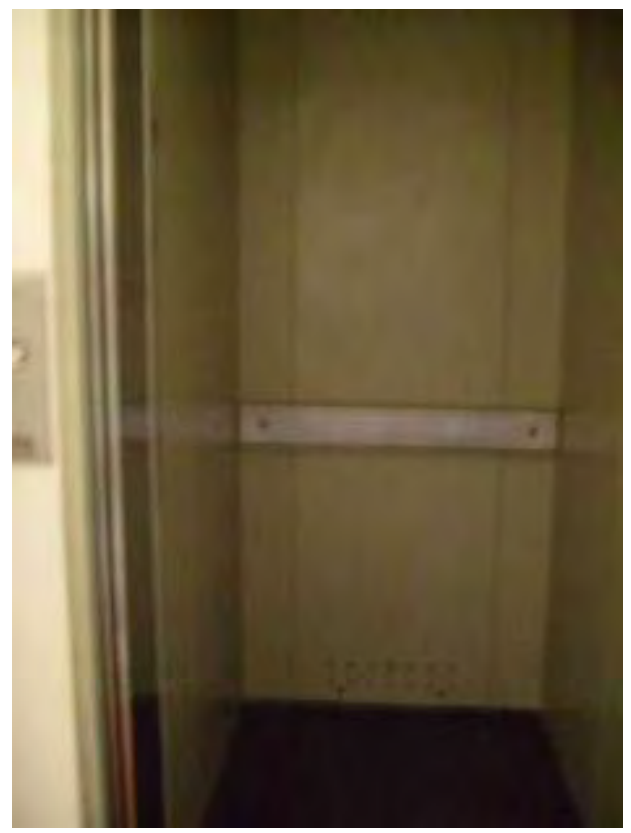

Figura 104 - Interior do elevador. 2009.

Suas medidas internas são $0,90 \mathrm{~m}$ de largura por $1,20 \mathrm{~m}$ de profundidade $^{83}$, sendo que a medida mínima exigida é $0,90 \mathrm{~m}$ de largura por $1,30 \mathrm{~m}$ de profundidade. No entanto, seu uso sem acompanhante é possível, pois a dimensão do módulo de referência para uma cadeira de rodas é $0,80 \mathrm{~m}$ por 1,20m. Sua porta tem vão de passagem de $0,80 \mathrm{~m}^{84}$, é do tipo eixo vertical ${ }^{85}$, com visor ${ }^{86}$ e

\footnotetext{
${ }^{82}$ Não atende ao disposto no art. 19 do Decreto federal no 5.296/04 e na ABNT NBR 9050/2004 item 6.2.2.

${ }^{83}$ Não atende ao disposto na Resolução CPA/SEHAB-G/010/2003 - item 4.12.1.

${ }^{84}$ Atende ao disposto na Resolução CPA/SEHAB-G/010/2003 - item 4.11.1.1.

${ }^{85}$ Atende ao disposto na Resolução CPA/SEHAB-G/010/2003 - item 4.11.1.4.
} 
puxador adequado para canhotos ou destros. Por ser bastante robusta, torna difícil seu manuseio, exigindo demasiado esforço. A botoeira de chamada do piso está a uma altura de $1,17 \mathrm{~m}^{87}$, sendo $1,10 \mathrm{~m}$ a altura máxima adequada. A botoeira interna está compreendida entre 1,12m e 1,22m e, logo está correta, pois sua variação deve ser entre $0,80 \mathrm{~m}$ e $1,20 \mathrm{~m}^{88}$. Falta espelho no interior da cabine ${ }^{89}$ para facilitar a manobra de saída do usuário, que não terá espaço para fazer a rotação da cadeira de rodas internamente. No painel do fundo há barra de apoio de boa empunhadura, com largura de $3,5 \mathrm{~cm}$, posicionada em altura correta ${ }^{90}$.

O prejuízo, em relação ao elevador está principalmente na falta de acesso a um dos pavimentos.

\subsubsection{Infraestrutura expositiva e educativa}

O Espaço Haroldo de Campos de Poesia e Literatura possui uma biblioteca e salas de aula no pavimento superior. As exposições, voltadas ao universo da literatura, ocorrem nas salas do pavimento térreo ou em expositores na circulação do pavimento superior. Parte do acervo de livros da biblioteca fica exposta, e parte fica guardada em área de acesso restrito ao bibliotecário, no porão. Não constam do acervo obras em braile, mas há 23 audiolivros disponíveis para consulta e empréstimo.

As áreas citadas não apresentam restrições quanto ao acesso e

\footnotetext{
${ }^{86}$ Atende ao disposto na Resolução CPA/SEHAB-G/010/2003 - item 4.11.2.

${ }^{87}$ Não atende ao disposto na Resolução CPA/SEHAB-G/010/2003 - item 4.13.1.

${ }^{88}$ Atende ao disposto na Resolução CPA/SEHAB-G/010/2003 - item 4.13.2.

${ }^{89}$ Não atende ao disposto na Resolução CPA/SEHAB-G/010/2003 - item 4.12.3.

${ }^{90}$ Atende ao disposto na Resolução CPA/SEHAB-G/010/2003 - item 4.12.2.
} 
circulação ${ }^{91}$. O mobiliário destas áreas será avaliado em outra parte do capítulo.

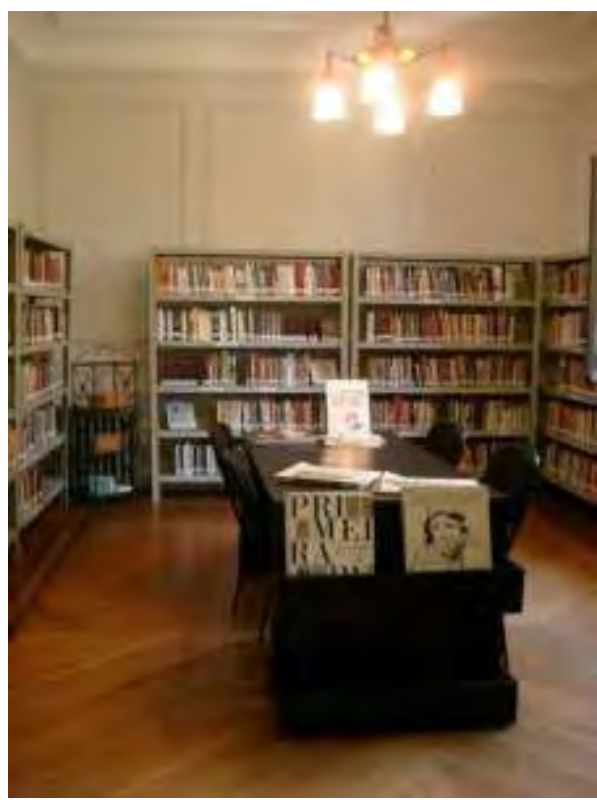

Figura 105 - Biblioteca. 2010.

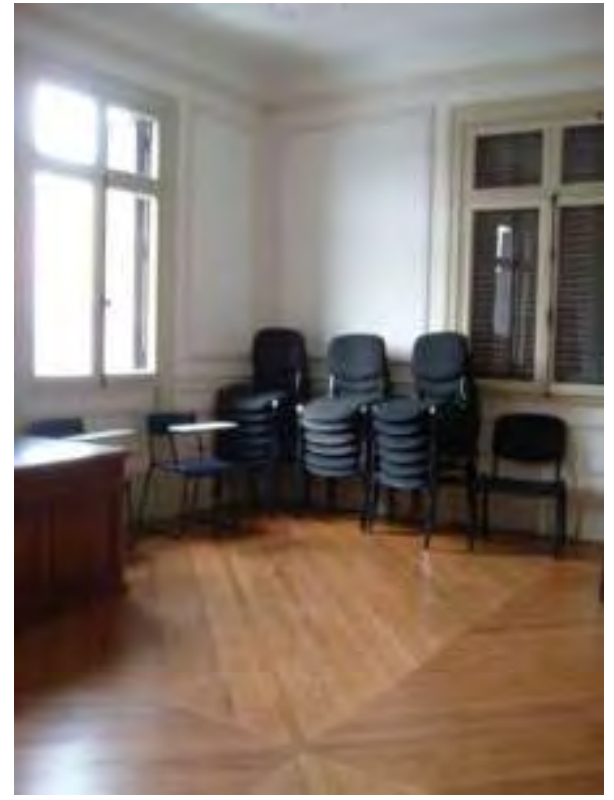

Figura 106 - Sala de aula. 2009.

\subsubsection{Locais de refeição}

A Casa das Rosas possui uma cafeteria, de administração terceirizada, que fica no pavimento térreo da edícula, onde originalmente era a garagem da casa. $\mathrm{Na}$ antiga sala de engomar fica a área de preparo dos alimentos. No pavimento superior da edícula, originalmente ocupado por quartos para os empregados, está hoje parte da

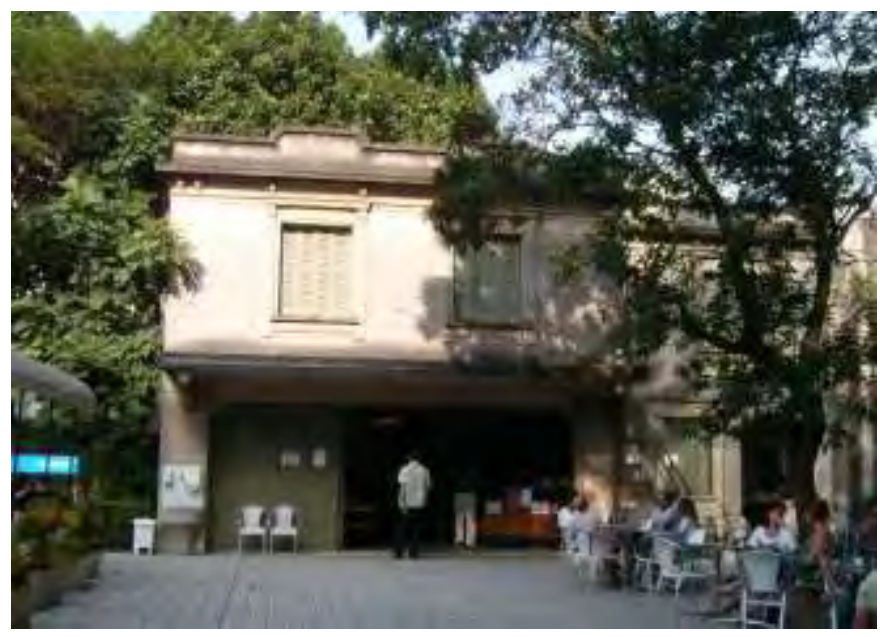

Figura 107 - A cafeteria ocupa a garagem na edícula. 2011.

\footnotetext{
${ }^{91}$ Atende ao disposto na ABNT NBR 9050/2004 - itens 6.9.1.1 e 6.1.1.
} 
administração da Casa das Rosas, que será analisada em 2.8.8.

Não existe desnível na entrada do café e há largura suficiente para passagem junto ao balcão, porém não há o espaço necessário, por conta da distribuição de mesas, para fazer a rotação da cadeira de rodas ${ }^{92}$. O café não dispõe de cardápio em braile ${ }^{93}$. Sobre o mobiliário ver 2.8.10.

\subsubsection{Outras áreas}

No térreo da edícula está a cafeteria, a qual foi analisada em 2.8.7, e um pequeno sanitário individual, utilizado pelos funcionários. No pavimento superior estão parte das salas administrativas do espaço cultural. O acesso por escada tem corrimão unilateral $^{94} \mathrm{e}$ inadequado quanto à sua espessura ${ }^{95}$ e prolongamento ${ }^{96}$.

Como a escada é a única forma de acesso ao pavimento superior, não há, consequentemente, rota acessível ${ }^{97}$.

As portas todas tem vão livre de $0,80 \mathrm{~m}$, adequado à passagem ${ }^{98}$. Apenas a porta de entrada tem maçaneta tipo

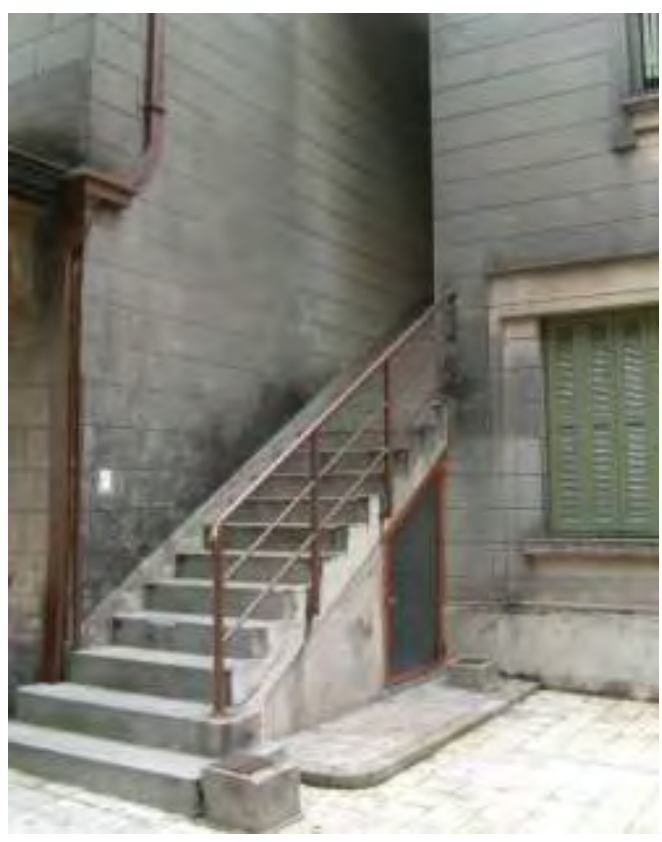

Figura 108 - Acesso ao pavimento superior da edícula. 2010.

\footnotetext{
92 Não atende ao disposto na ABNT NBR 9050/2004 - item 9.3.3.3.

93 Não atende ao disposto no art. 1ำ da Lei municipal nำ12.363/1997.

${ }^{94}$ Não atende ao disposto na ABNT NBR 9050/2004 - item 6.7.1.1.

${ }^{95}$ Não atende ao disposto na ABNT NBR 9050/2004 - itens 4.6.5 e 6.7.1.1.

${ }^{96}$ Não atende ao disposto na ABNT NBR 9050/2004 - item 6.7.1.4.

${ }^{97}$ Não atende ao disposto na ABNT NBR 9050/2004 - item 6.2.1.

${ }^{98}$ Atende ao disposto na ABNT NBR 9050/2004 - item 6.9.2.1.
} 
alavanca $^{99}$. As demais são de difícil manuseio.

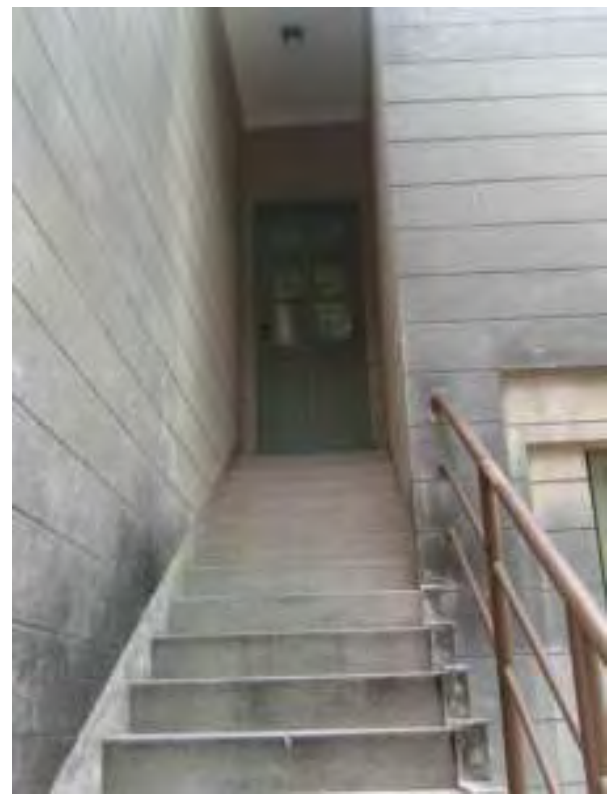

Figura 109 - Escada e porta de acesso ao pavimento superior da edícula. 2010.

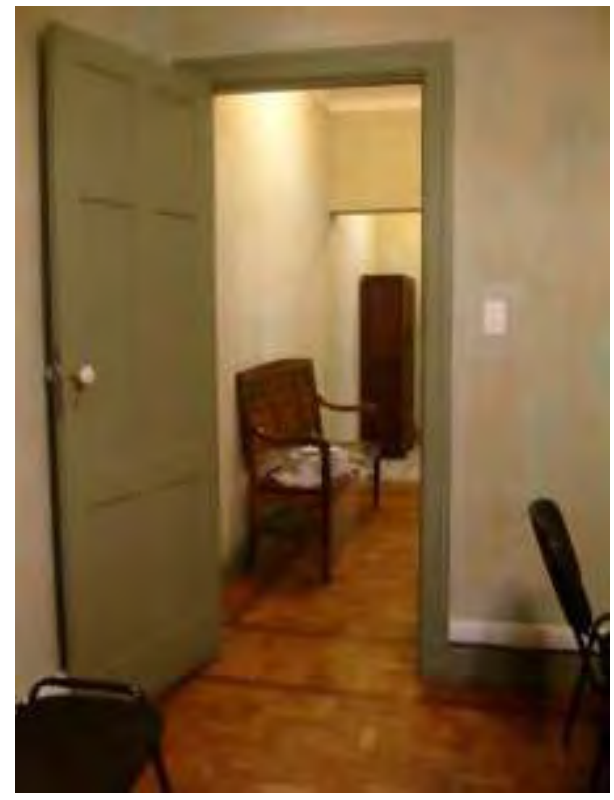

Figura 110 - Exemplo de porta interna da edícula. 2010.

O piso é regular, estável e antiderrapante ${ }^{100}$ e a circulação interna é ampla, mas geralmente prejudicada por móveis, assim como nas outras áreas.

Além da edícula, há a estufa, que fica em rota acessível. Esta área não está aberta para visitação, mas por ser totalmente transparente e estar dentro do

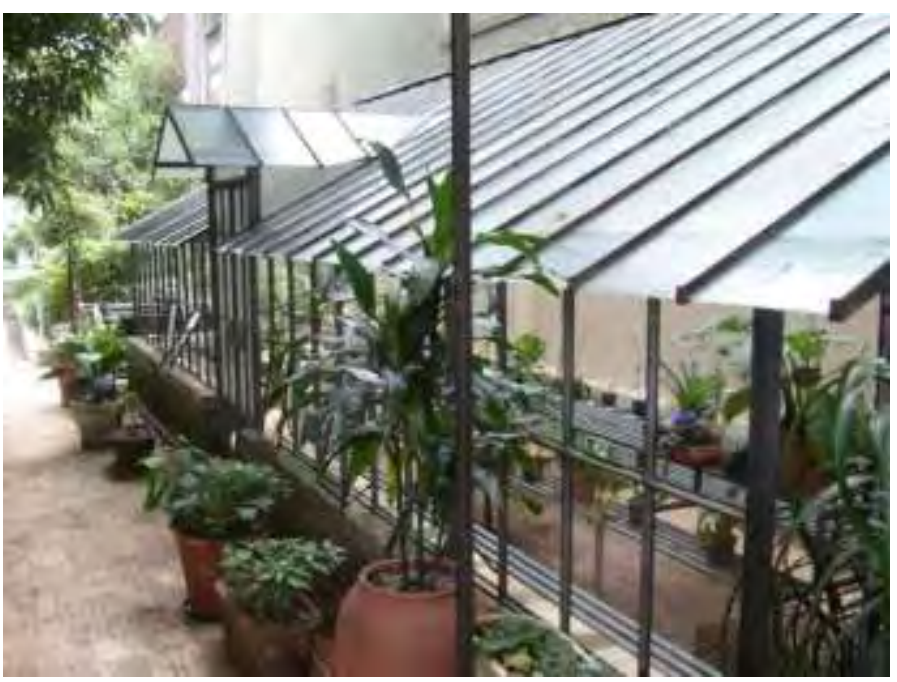
alcance visual é possível visualizar seu interior a partir de fora. O degrau na sua entrada inviabiliza o acesso, por exemplo, de pessoas usuárias de cadeira de rodas.

Figura 111 - Estufa. 2010.

\footnotetext{
${ }^{99}$ Atende ao disposto na ABNT NBR 9050/2004 - item 6.9.2.3.

${ }^{100}$ Atende ao disposto na ABNT NBR 9050/2004 - itens 6.9.1.1 e 6.1.1.
} 


\subsubsection{Instalações sanitárias}

Todas as instalações sanitárias, na Casa das Rosas e sua edícula, são utilizadas por ambos os sexos. Apesar de haver chuveiros e banheiras nenhum deles é utilizados nem mesmo pelos funcionários. Permanecem, como há de ser, como referência do uso original da edificação. Pelo exposto, serão avaliados apenas as bacias e lavatórios.

A edificação principal possui cinco sanitários: dois abertos ao público (térreo e pavimento superior), um aberto a visitação (pavimento superior) e dois de uso dos funcionários (porão e mansarda). Na edícula há um sanitário em cada pavimento. As peças estão distribuídas conforme Tabela 3, a seguir:

EDIFICAÇÃO PRINCIPAL

\begin{tabular}{lcc}
\multicolumn{1}{c}{} & \multicolumn{2}{c}{ UNISSEX } \\
& lavatório & bacia \\
\hline PORÃO & 1 & 1 \\
\hline TÉRREO & 1 & 1 \\
\hline PAV. SUPERIOR & 2 & 2 \\
\hline MANSARDA & 1 & 1 \\
\hline \multicolumn{1}{r|}{ total } & $\mathbf{5}$ & $\mathbf{5}$
\end{tabular}

EDÍCULA

\begin{tabular}{|c|c|c|}
\hline & \multicolumn{2}{|c|}{ UNISSEX } \\
\hline & lavatório & bacia \\
\hline TÉRREO & 1 & 1 \\
\hline PAV. SUPERIOR & 1 & 1 \\
\hline total & 2 & 2 \\
\hline
\end{tabular}

Tabela 3 - Distribuição de peças sanitárias.

Apesar dos sanitários no porão e na mansarda serem de uso exclusivo dos funcionários por conta da restrição de acesso, nos demais pavimento não há exclusividade de uso, para visitantes ou funcionários. O sanitário no térreo, também, não é de uso exclusivo de pessoas com deficiência.

O sanitário do térreo foi o único a receber adaptações para atender às pessoas com deficiência. Dentro do total de peças sanitárias adaptadas, a 
quantidade está adequada à exigência normativa de $5 \%{ }^{101}$. Como é uma edificação de uso público existente, se enquadra na exigência prevista no art. 22 do Decreto federal $n^{\circ} 5.296 / 2004$ de ter "[...] no mínimo, uma cabine para cada sexo em cada pavimento da edificação, com entrada independente dos sanitários coletivos [...]". Sua entrada de fato é independente, contudo, como já apresentado, é o único sanitário acessível na Casa das Rosas ${ }^{102}$.

Quanto às características do sanitário acessível no térreo, veremos que não estão de acordo com os parâmetros técnicos.

A porta do sanitário tem vão de passagem menor do que o exigido, conforme já informado, abre incorretamente para dentro ${ }^{103}$ e não possui puxador horizontal ${ }^{104}$. O sanitário é bastante amplo e, portanto, tem espaço suficiente para manobra da cadeira de rodas e para transferência ao vaso ${ }^{105}$.

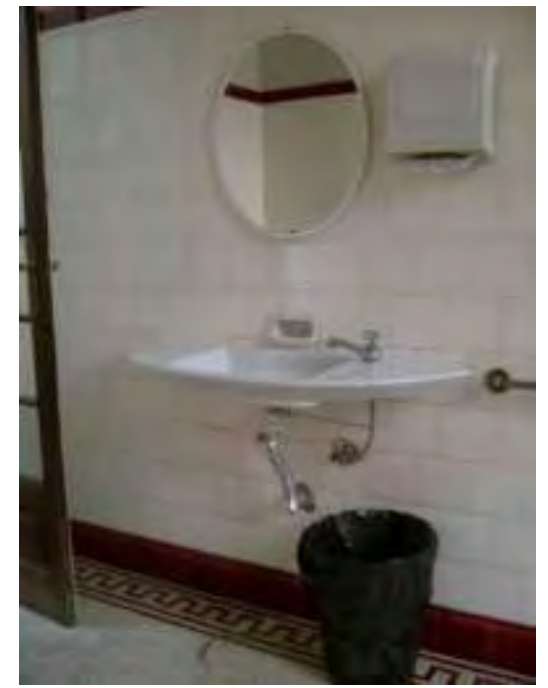

Figura 112 - Lavatório do sanitário do pavimento térreo. 2009.

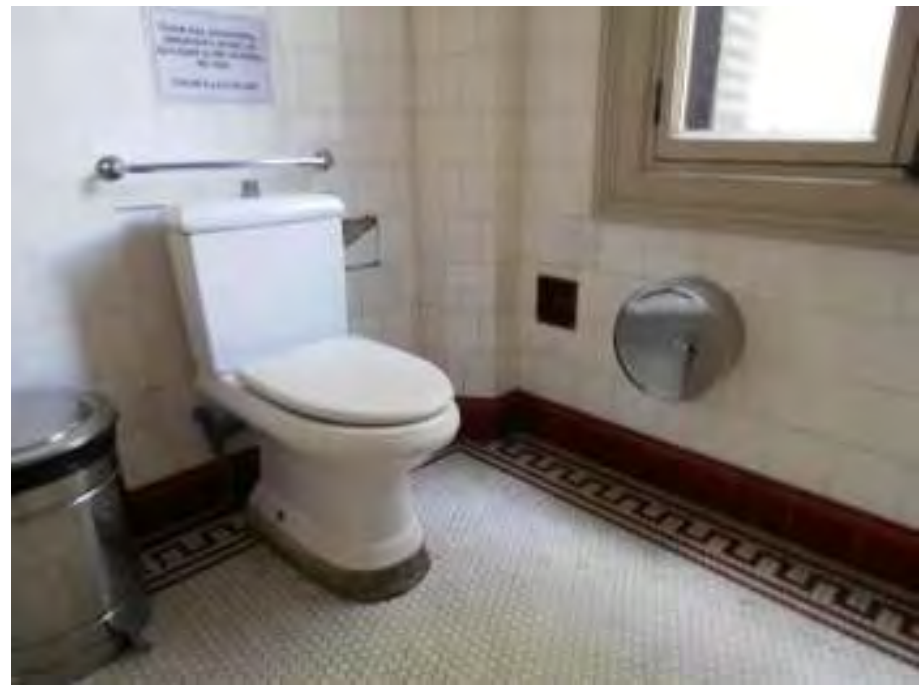

Figura 113 - Bacia, barra e papeleira. 2012.

\footnotetext{
${ }^{101}$ Atende ao disposto na ABNT NBR 9050/2004 - item 7.2.2.

102 Não atende ao disposto no parágrafo $2^{\circ}$ do art. 22, do Decreto Federal 5.296/2004.

103 Não atende ao disposto na ABNT NBR 9050/2004 - item 7.3.3.4.

${ }^{104}$ Não atende ao disposto na ABNT NBR 9050/2004 - itens 6.9.2.4 e 7.3.8.5.

${ }^{105}$ Atende ao disposto na ABNT NBR 9050/2004 - item 7.3.3.1.
} 
A utilização de bacia com caixa acoplada prejudicou a altura de instalação da barra posterior de apoio, que está 0,20m acima da altura adequada, que seria 0,75m do piso acabado. Não possui barra lateral e a barra posterior tem comprimento menor que $0,80 m^{106}$. Com a utilização de sóculo, a altura de instalação da bacia está correta ${ }^{107}$. A papeleira fica muito distante da bacia, ademais de estar posicionada muito baixa ${ }^{108}$. E não há dispositivo de sinalização junto à bacia, para chamar alguém em caso de emergência ${ }^{109}$.

A altura de instalação e o tipo de acionamento do lavatório estão incorretos $^{110}$. Não há barra de apoio ${ }^{111}$, os acessórios estão posicionados em altura acima do alcance manual ${ }^{112}$, e o espelho fora do alcance visual ${ }^{113}$.

\subsubsection{Mobiliário}

Diversos mobiliários serão analisados: balcões de atendimento da biblioteca e da cafeteria, mesa de leitura e de consulta da biblioteca, mesa de refeição da cafeteria, prateleiras da biblioteca e livraria e móveis expositores.

Na biblioteca, localizada no pavimento superior, o balcão de atendimento tem altura adequada ${ }^{114}$, porém não tem reentrância para permitir aproximação de

\footnotetext{
${ }^{106}$ Não atende ao disposto na ABNT NBR 9050/2004 - item 7.3.1.2.

${ }^{107}$ Atende ao disposto na ABNT NBR 9050/2004 - itens 7.3.1.3 e 7.3.1.4.

${ }^{108}$ Não atende ao disposto na ABNT NBR 9050/2004 - item 7.3.8.2.

${ }^{109}$ Não atende ao disposto na ABNT NBR 9050/2004 - item 7.2.1.

${ }^{110}$ Não atende ao disposto na ABNT NBR 9050/2004 - itens 7.3.6.2 e 7.3.6.3.

${ }^{111}$ Não atende ao disposto na ABNT NBR 9050/2004 - item 7.3.6.4.

${ }^{112}$ Não atende ao disposto na ABNT NBR 9050/2004 - item 7.3.8.

${ }^{113}$ Não atende ao disposto na ABNT NBR 9050/2004 - item 7.3.8.1.

${ }^{114}$ Atende ao disposto na ABNT NBR 9050/2004 - item 9.5.2.1.
} 
usuário de cadeira de rodas ${ }^{115}$. A única mesa de leitura tem $0,67 \mathrm{~m}$ de altura livre inferior, menos do que o exigido para permitir a aproximação, que é $0,73 \mathrm{~m}^{116}$. As mesas dos terminais de consulta têm altura, inferior e superior, adequada $^{117}$. Ambas estão em locais com suficiente espaço para circulação ${ }^{118}$.

A maior parte das prateleiras de livros está fora do alcance manual de uma pessoa usuária de cadeira de rodas, ou de baixa estatura,

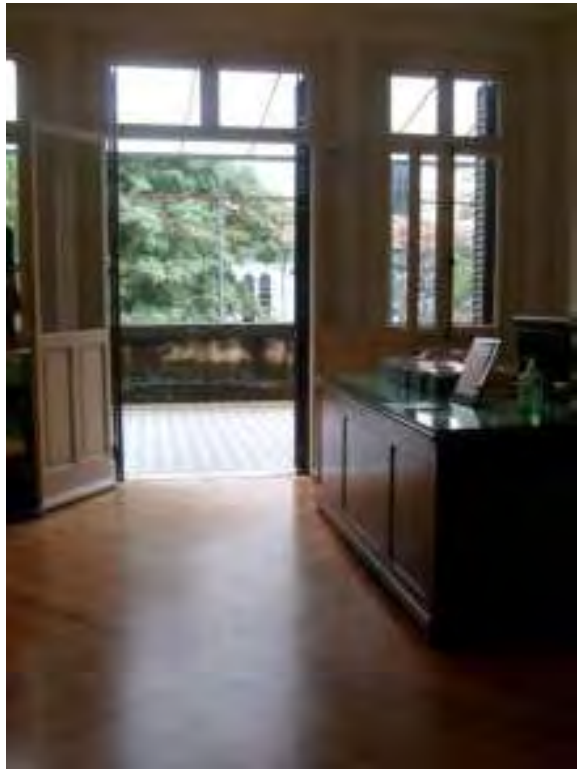

Figura 114 - Balcão de atendimento da biblioteca. 2009.

contudo essa condição não é obrigatória.
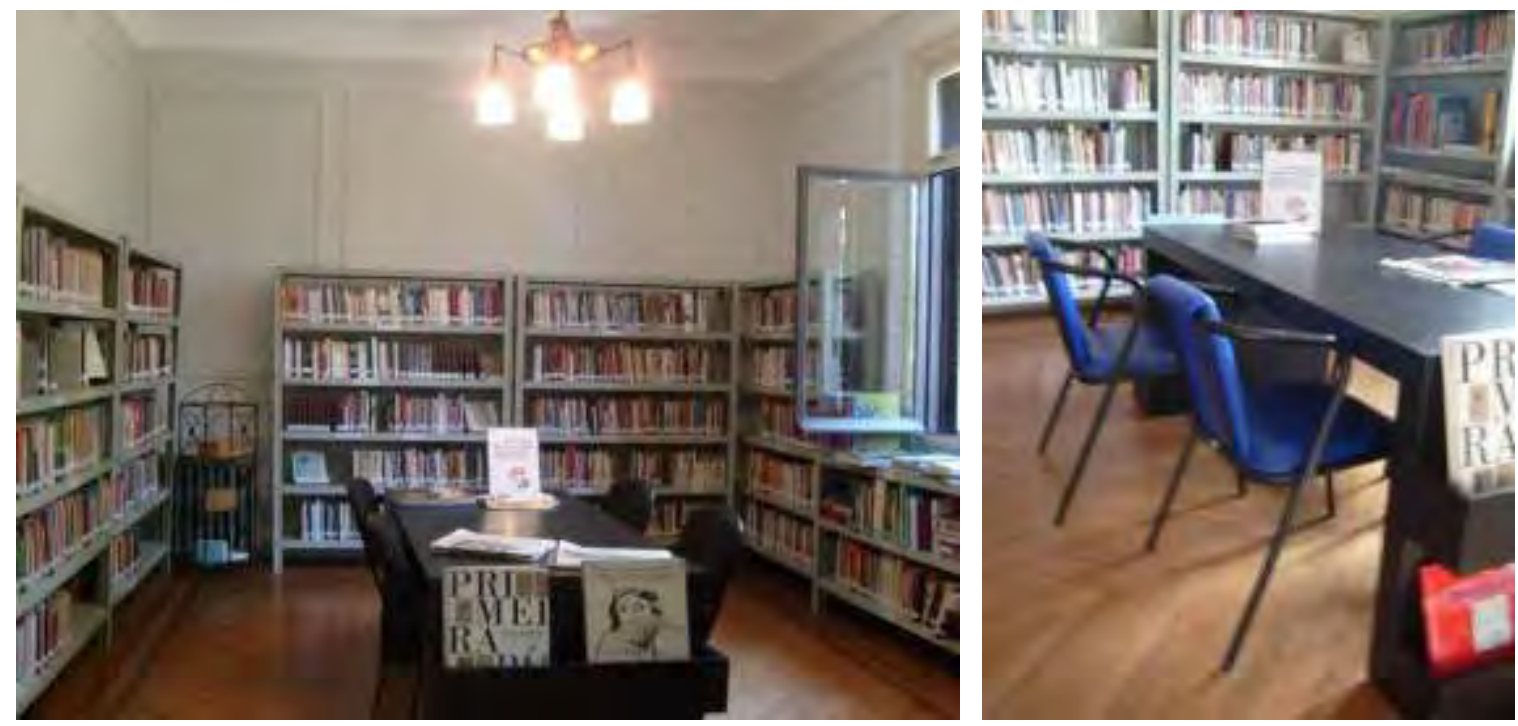

Figura 115 e 116 - Prateleiras e mesa da biblioteca. 2010 e 2009.

Foram verificadas distintas características nos móveis expositores ao longo período que se realizaram as visitas. Serão analisados três modelos de

\footnotetext{
${ }^{115}$ Não atende ao disposto na ABNT NBR 9050/2004 - item 9.5.2.2.

${ }^{116}$ Não atende ao disposto na ABNT NBR 9050/2004 - itens 8.7.2 e 9.3.3.1.

${ }^{117}$ Atende ao disposto na ABNT NBR 9050/2004 - itens 8.7.6 e 9.3.3.1.

${ }^{118}$ Atende ao disposto na ABNT NBR 9050/2004 - item 9.3.3.3.
} 
expositores: um utilizado no térreo e dois utilizados no primeiro pavimento.

O móvel expositor do térreo não permite aproximação ${ }^{119}$ e parte do que estava exposto nele ficava fora do alcance visual ${ }^{120}$. Um dos expositores do primeiro pavimento têm altura superior adequada, e altura inferior que permite pequena aproximação de usuários de cadeiras de $\operatorname{rodas}^{121}$, pois não há $0,73 m$ de

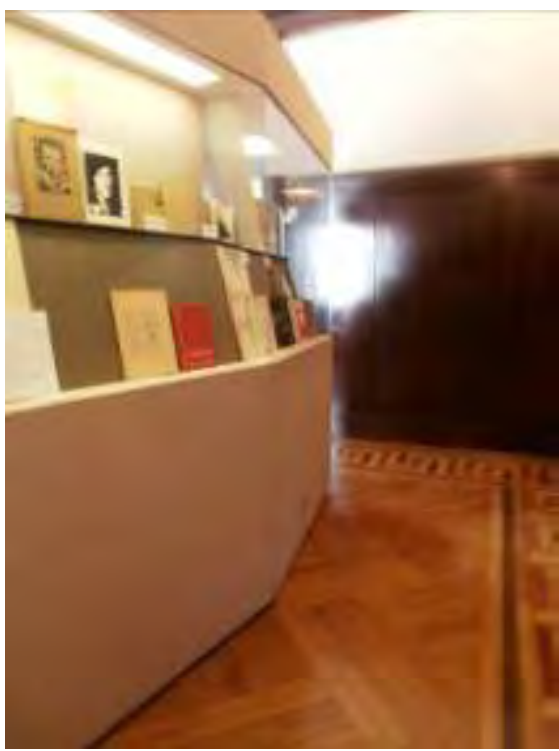

Figura 117 - Expositor do térreo. 2012. altura livre inferior. Permite boa visualização do que é exposto $^{122}$. O segundo expositor, repete características do expositor do térreo, com a diferença que há mais elementos expostos dentro do alcance visual, mas não todos $^{123}$
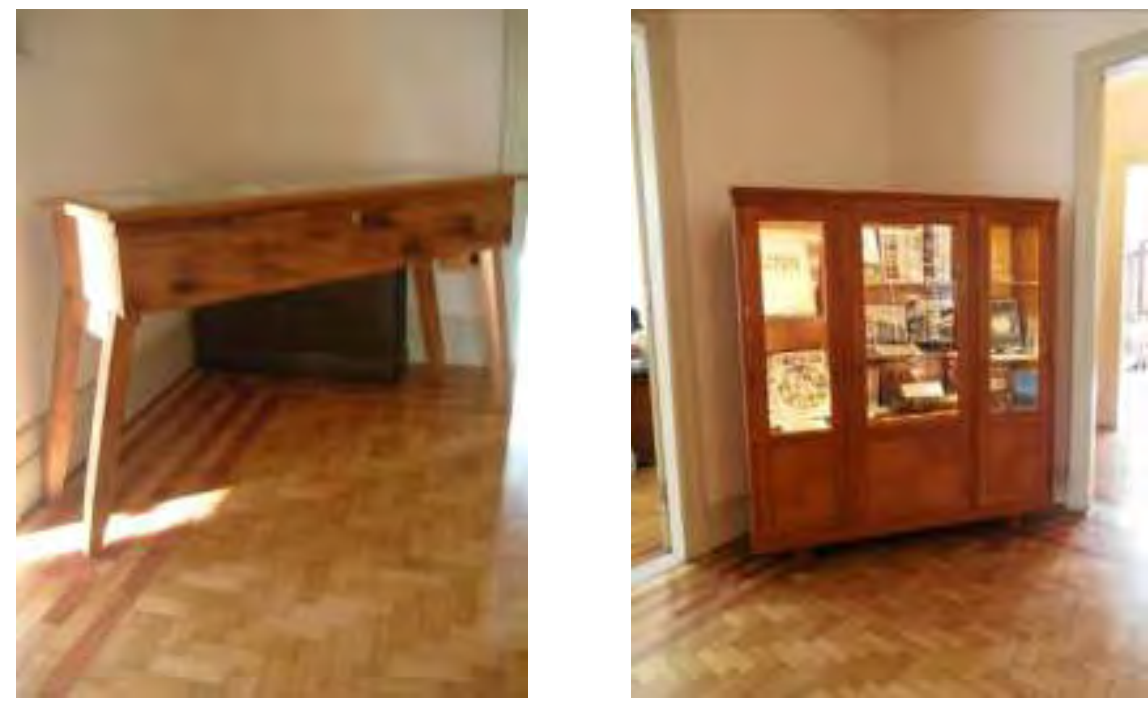

Figura 118 e 119 - Expositores do primeiro andar. 2009 e 2012.

\footnotetext{
${ }^{119}$ Não atende ao disposto na ABNT NBR 9050/2004 - item 4.5.

${ }^{120}$ Não atende ao disposto na ABNT NBR 9050/2004 - item 4.7.2.

${ }^{121}$ Atende ao disposto na ABNT NBR 9050/2004 - item 4.5.

${ }^{122}$ Atende ao disposto na ABNT NBR 9050/2004 - item 4.7.2.

${ }^{123}$ Não atende ao disposto na ABNT NBR 9050/2004 - item 4.7.2.
} 
No café, localizado no térreo da edícula, o balcão de atendimento tem altura superior a 0,90m, sem reentrância para aproximação de pessoa em cadeira de rodas $^{124}$. As mesas na parte de dentro do café permitem a aproximação ${ }^{125}$; o mesmo não acontece com as mesas da área externa, pelo tipo de base ${ }^{126}$. Há pelo menos $5 \%$ das mesas acessíveis ${ }^{127}$. Não há assento para obesos ${ }^{128}$.

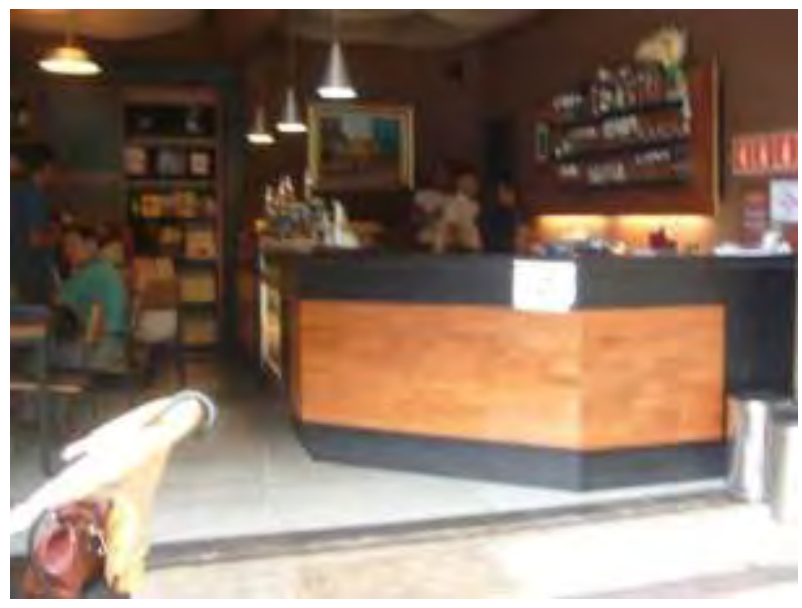

Figura 120 - Balcão de atendimento do café. 2010.

O bebedouro no térreo é do tipo garrafão e sua altura de alcance é adequada, assim como dos copos, que ficam em um suporte lateral $^{129}$

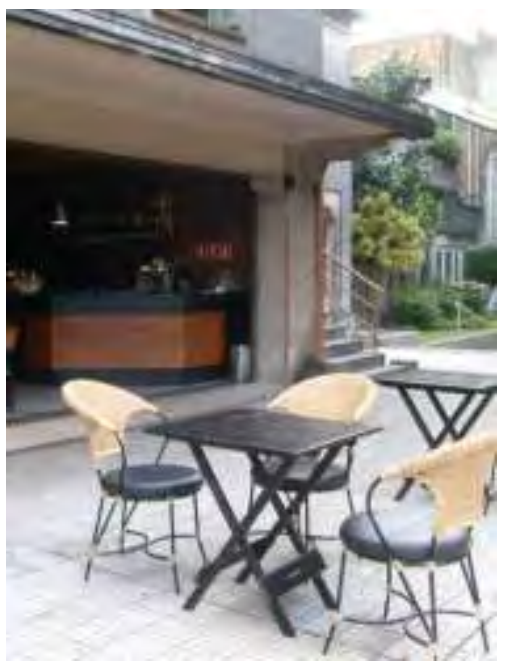

Figura 121 - Mesa de refeição do café. 2009.

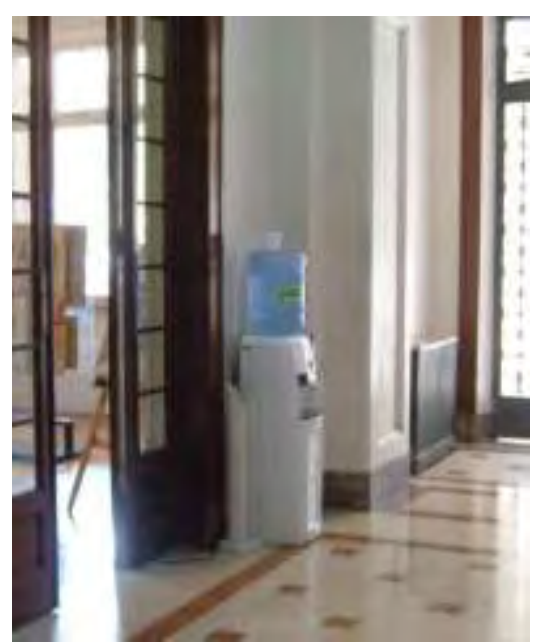

Figura 122 - Bebedouro. 2011.

\footnotetext{
${ }^{124}$ Não atende ao disposto na ABNT NBR 9050/2004 - itens 9.5.2.1 e 9.5.2.2.

${ }^{125}$ Atende ao disposto na ABNT NBR 9050/2004 - item 9.3.3.

${ }^{126}$ Não atende ao disposto na ABNT NBR 9050/2004 - item 9.3.3.

${ }^{127}$ Atende ao disposto na ABNT NBR 9050/2004 - item 9.3.1.

${ }^{128}$ Não atende ao disposto no art. 1ํ da Lei municipal no $12.658 / 1998$.

${ }^{129}$ Atende ao disposto na ABNT NBR 9050/2004 - item 9.1.3.2.
} 


\subsubsection{Sinalização e comunicação}

O Símbolo Internacional de Acesso (SIA) foi utilizado na entrada da Casa das Rosas e no elevador, ambos atendem corretamente às características de representação ${ }^{130}$. Na entrada é utilizado para chamar atenção do público em questão para as instruções de acessibilidade assistida. Contudo, o SIA deve ser utilizado apenas em "[...] locais que possibilitem acesso, circulação e utilização por pessoas portadoras de deficiência [...]", conforme Lei federal $n^{0} 7.405 / 1985^{131}$. Não há sinalização indicando o sanitário acessível ${ }^{132}$.

De forma geral a Casa das Rosas não possui sinalização adequada, seguindo o princípio de redundância da informação. Quando há, é apenas visual. Não existe sinalização em braile e/ou em relevo para identificar a entrada da Casa das Rosas ou qualquer uma das salas abertas ao público, assim como para as salas administrativas. A única sinalização tátil em toda a Casa está no elevador: braile na botoeira interna e externa e piso tátil de alerta em frente à porta. $\mathrm{O}$ piso não tem largura mínima de $0,25 \mathrm{~m}^{133}$. E falta sinalização sonora e visual para identificação do andar e de chagada do elevador e tátil, em braile e relevo,

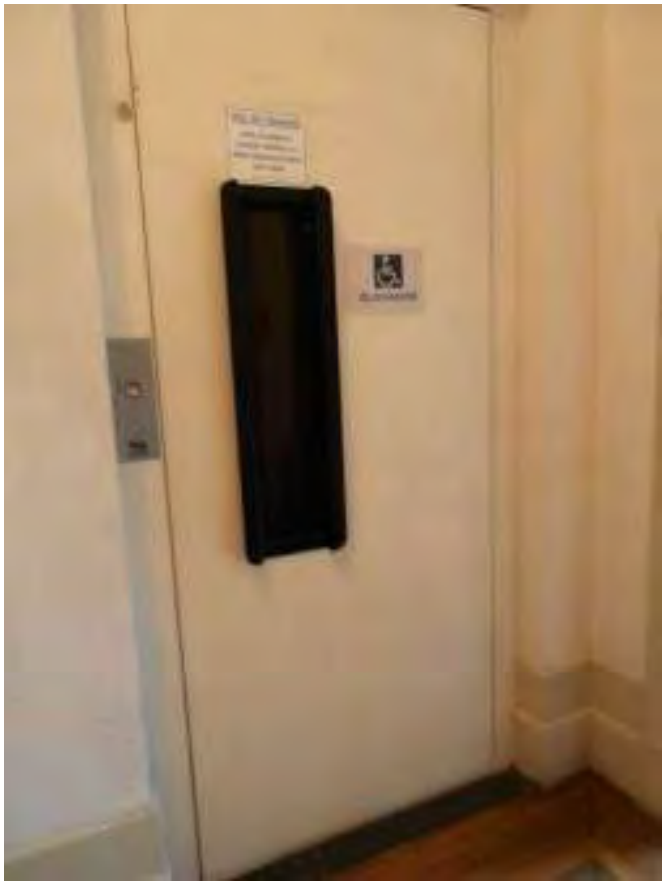

Figura 123 - SIA para identificar o elevador. 2012.

\footnotetext{
${ }^{130}$ Atende ao disposto na ABNT NBR 9050/2004 - item 5.4.1.1.

${ }^{131}$ Não atende ao disposto no art. $1^{\circ}$ da Lei federal $\mathrm{n}$ ำ 7.405/1985.

132 Não atende ao disposto na ABNT NBR 9050/2004 - itens 5.4.1.3, 5.4.4.2 e 7.2.1.

${ }^{133}$ Não atende ao disposto na ABNT NBR 9050/2004 - item 5.14.1.2.
} 
identificando o andar no batente do elevador ${ }^{134}$. Também não há braile nos corrimãos identificando os andares $^{135}$ e piso tátil de alerta em degraus, escadas e rampas ${ }^{136} \mathrm{da}$ Casa, edícula ou área externa. A faixa contrastante de degraus foi aplicada apenas na entrada do

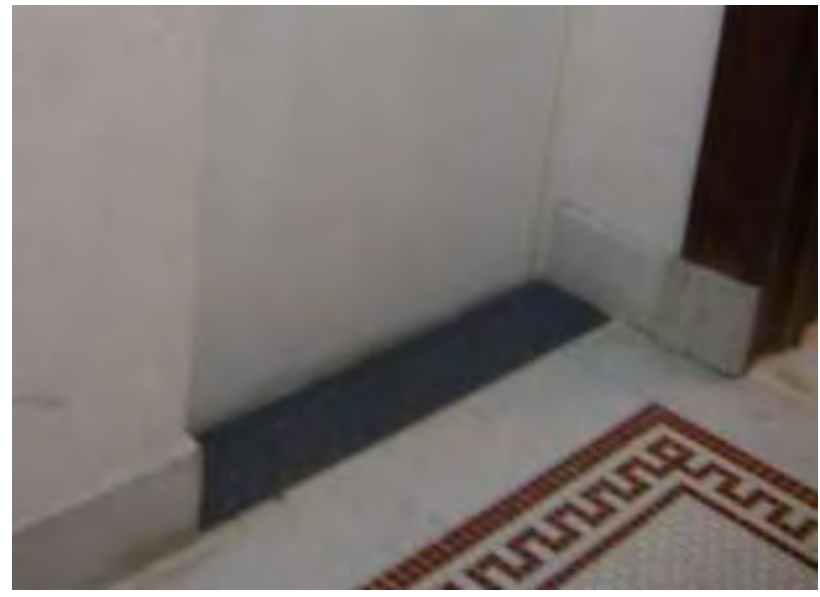

Figura 124 - Piso tátil de alerta em frente à porta do elevador no pav. térreo. 2009. público $^{137}$.
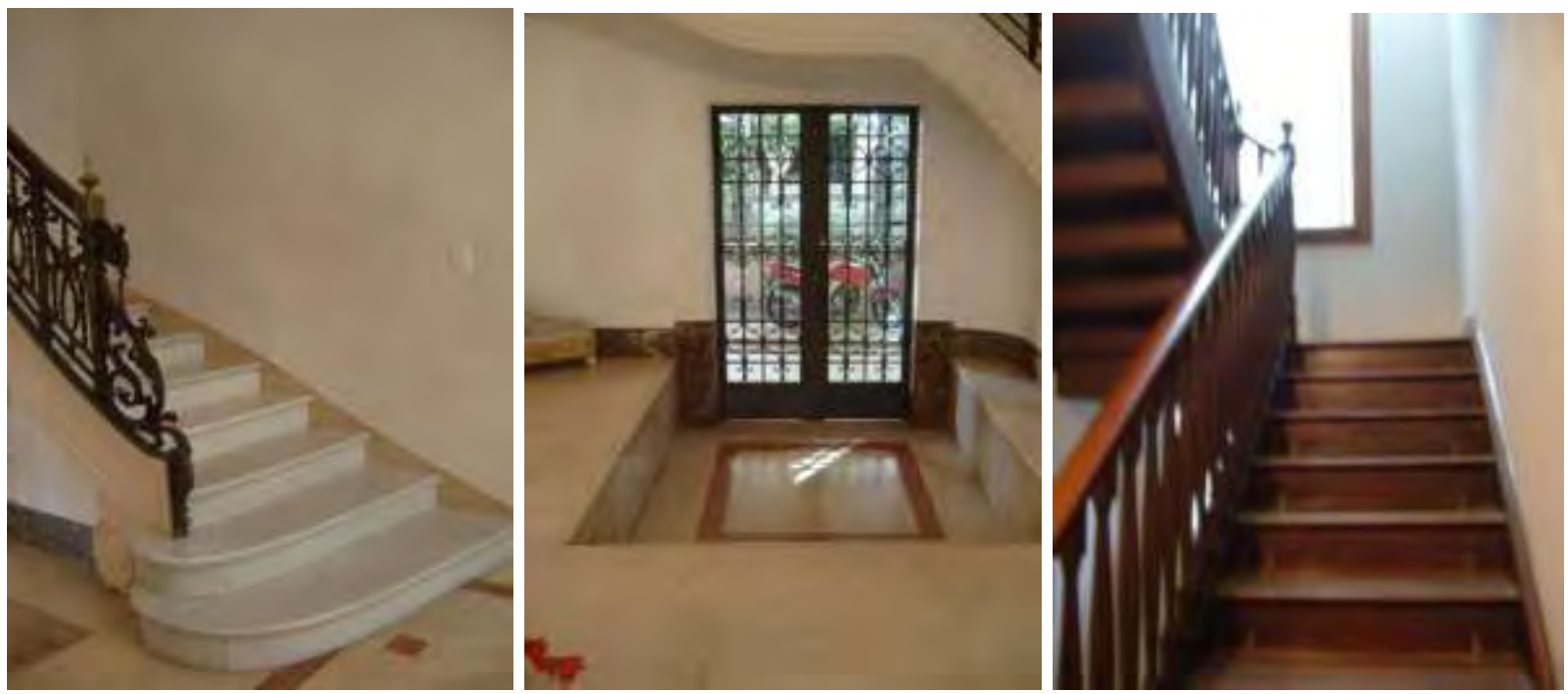

Figura 125, 126 e 127 - Exemplos de escadas e degraus sem piso tátil de alerta e faixa contrastante. 2009.

O piso tátil direcional, que deve ser usado em locais muito amplos, não foi instalado; este ajudaria a orientar pessoas com deficiência visual do portão de entrada até o acesso principal da Casa das Rosas ${ }^{138}$.

\footnotetext{
${ }^{134}$ Não atende ao disposto na Resolução CPA/SEHAB-G/004/2000 - item 10.

${ }^{135}$ Não atende ao disposto na ABNT NBR 9050/2004 - item 5.15.1.2.

${ }^{136}$ Não atende ao disposto na ABNT NBR 9050/2004 - item 5.14.1.2.

${ }^{137}$ Não atende ao disposto na ABNT NBR 9050/2004 - item 5.13.

${ }^{138}$ Não atende ao disposto na ABNT NBR 15599/2008 - item 5.1.1.5.
} 
A sinalização visual peca por quase passar despercebida, que apesar do bom contraste (preto/branco) ${ }^{139}$, utiliza tamanho de letra de difícil leitura para a grande maioria das pessoas $^{140}$.

Não são reproduzidas em braile e em fonte ampliada, para atender pessoas com baixa visão ${ }^{141}$, as informações de atividades, apresentações e cursos, expostas na fachada da edificação, em folhetos e painéis.
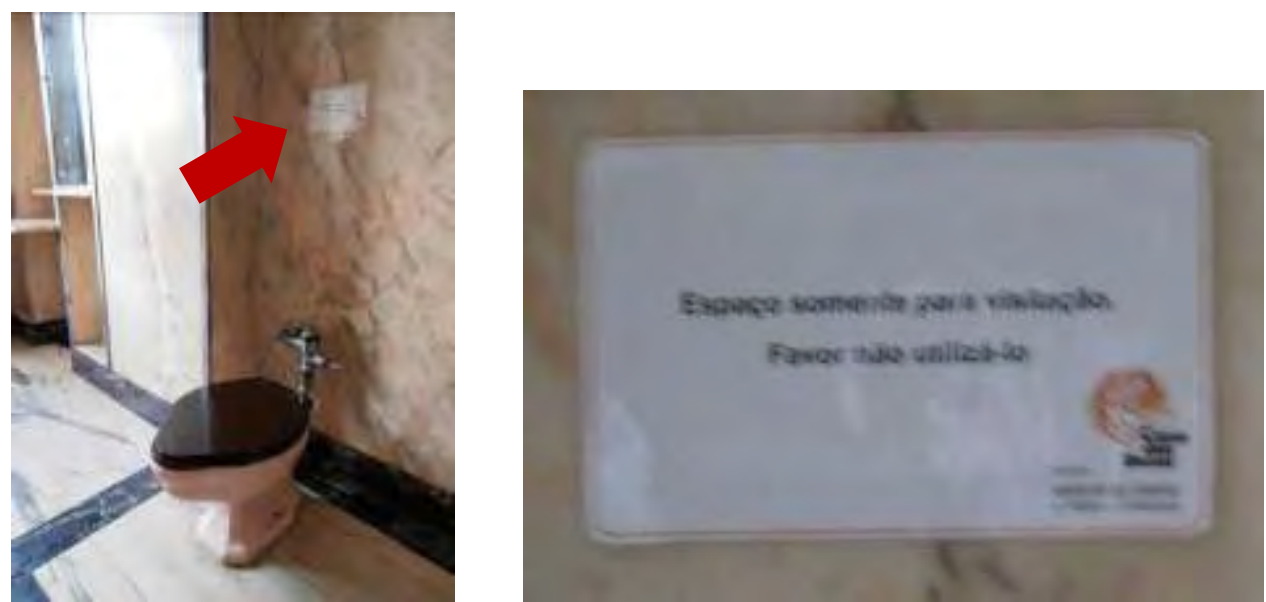

Figura 128 e 129 - Sinalização no sanitário aberto apenas à visitação e detalhe. 2009.

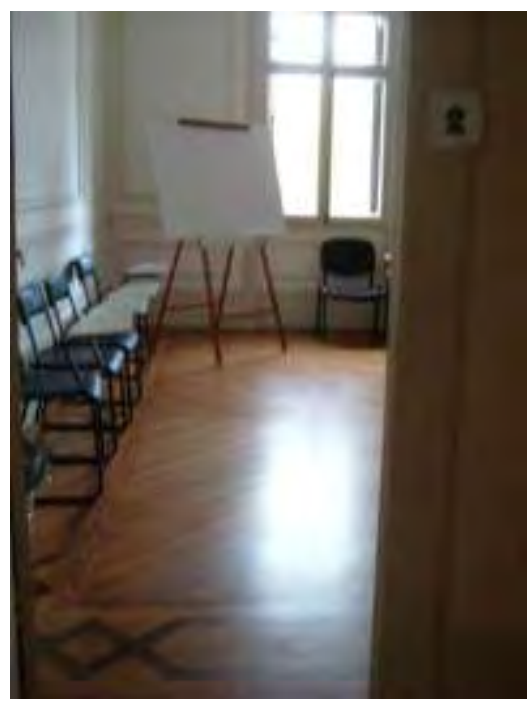

Figura 130 - Sinalização visual indicativa da sala. 2009.

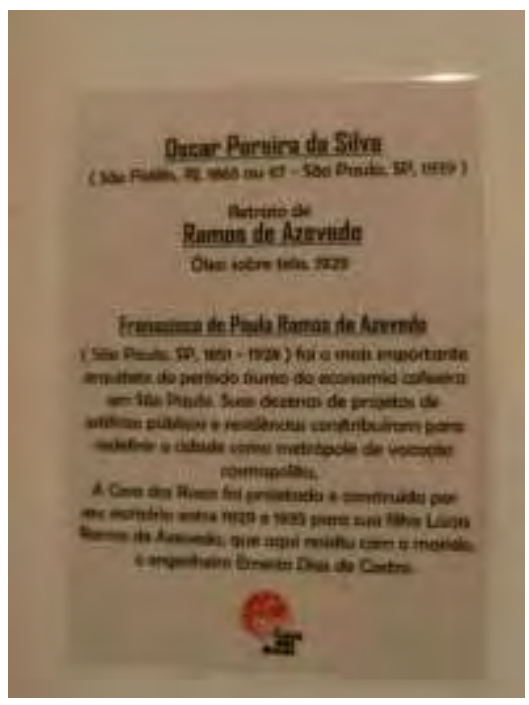

Figura 131 - Informações sobre quadros expostos. 2010.

\footnotetext{
${ }^{139}$ Atende ao disposto na ABNT NBR 9050/2004 - item 5.5.2.1.

${ }^{140}$ Não atende ao disposto na ABNT NBR 9050/2004 - item 5.5.4.

${ }^{141}$ Não atende ao disposto na ABNT NBR 15599/2008 - item 5.4.1.
} 


\subsection{Análise com base no Desenho Universal}

Os quadros a seguir demonstram a necessidade de melhora nos sete princípios do Desenho Universal.

\begin{tabular}{|c|c|c|}
\hline $\begin{array}{l}\text { PRINCÍPIO 1: } \\
\text { Uso equitativo }\end{array}$ & É útil e utilizável por pessoas com habilidades diversa & \\
\hline 1a & $\begin{array}{l}\text { Fornece os mesmos meios de utilização para todos os } \\
\text { usuários: idêntico - quando possível -, ou equivalente. }\end{array}$ & $\mathbf{X}$ \\
\hline & $\begin{array}{l}\text { Não há acesso à Casa das Rosas com autonomia e segu } \\
\text { pessoas em cadeiras de rodas, usuárias de equipamentos } \\
\text { idosas / Não há acesso adaptado pela Al. Santos. }\end{array}$ & \\
\hline 1b & Não segrega ou estigmatiza qualquer usuário. & $\mathbf{X}$ \\
\hline & $\begin{array}{l}\text { Segrega a entrada de alguns usuários que não queiram } / \mathrm{p} \\
\text { as rampas disponíveis, como idosos. }\end{array}$ & utilizar \\
\hline 1c & $\begin{array}{l}\text { Elementos relacionados à privacidade, proteção e } \\
\text { segurança estão igualmente disponíveis para todos os } \\
\text { usuários. }\end{array}$ & $\mathbf{X}$ \\
\hline & $\begin{array}{l}\text { Acesso para usuários de cadeira de rodas traz riscos / } \\
\text { de apoio e pisos táteis de alerta. }\end{array}$ & rimão \\
\hline 1d & Tem design atraente para todos os usuários. & $\sqrt{ }$ \\
\hline & $\begin{array}{l}\text { As portas têm cor contrastante com as paredes, facilita } \\
\text { identificação. Há bom contraste entre parede e piso. }\end{array}$ & \\
\hline
\end{tabular}

\begin{tabular}{|c|c|c|}
\hline $\begin{array}{l}\text { PRINCÍPIO 2: } \\
\text { Uso flexível }\end{array}$ & $\begin{array}{l}\text { Acomoda uma ampla variedade de preferências individ } \\
\text { habilidades }\end{array}$ & \\
\hline $2 \mathbf{a}$ & Proporciona escolha dos métodos de utilização. & $\mathrm{X}$ \\
\hline & $\begin{array}{l}\text { Não oferece opções de acesso / Não tem corrimão de apo } \\
\text { menos uma das entrada. }\end{array}$ & belo \\
\hline $2 b$ & Permite uso e acesso por pessoas canhotas ou destras. & $\sqrt{ }$ \\
\hline & $\begin{array}{l}\text { Carteiras para canhotos e destros nas salas de aulas / Pur } \\
\text { elevador simétrico. }\end{array}$ & \\
\hline 2c & Facilita a exatidão e precisão do usuário. & $\mathbf{x}$ \\
\hline & Falta de autonomia no acesso prejudica esse ponto. & \\
\hline $2 d$ & É adaptável ao ritmo do usuário. & $\mathrm{x}$ \\
\hline & $\begin{array}{l}\text { Falta corrimão de apoio para permitir a subida/descida do } \\
\text { tempo dele. }\end{array}$ & \\
\hline
\end{tabular}




\begin{tabular}{|c|c|c|}
\hline \multirow{2}{*}{$\begin{array}{l}\text { PRINCÍPIO 3: } \\
\text { Uso simples e } \\
\text { intuitivo } \\
3 a\end{array}$} & \multicolumn{2}{|c|}{$\begin{array}{l}\text { O uso é fácil de compreender, independente da experiência do } \\
\text { usuário, seus conhecimentos, habilidades de linguagem ou nível } \\
\text { de concentração }\end{array}$} \\
\hline & Elimina a complexidade desnecessária. & $\mathbf{X}$ \\
\hline & \multicolumn{2}{|c|}{$\begin{array}{l}\text { Espaço se torna de difícil leitura pela ausência de sinalização } \\
\text { adequada / não utiliza pictogramas na sinalização e não há mapas de } \\
\text { orientação. }\end{array}$} \\
\hline \multirow[t]{2}{*}{$3 b$} & É coerente com as expectativas do usuário e intuição. & $\mathbf{X}$ \\
\hline & \multicolumn{2}{|l|}{ Espaço não é intuitivo. } \\
\hline \multirow[t]{2}{*}{$3 c$} & $\begin{array}{l}\text { Atende a uma gama variada de níveis de alfabetização e } \\
\text { de aprendizado de idiomas. }\end{array}$ & $\mathbf{X}$ \\
\hline & \multicolumn{2}{|l|}{ Sinalização apenas escrita / Não utiliza pictogramas. } \\
\hline \multirow[t]{2}{*}{ 3d } & Hierarquiza a informação de acordo com a importância. & $\mathbf{X}$ \\
\hline & \multicolumn{2}{|l|}{ Não há indicação das principais rotas e serviços. } \\
\hline $3 e$ & $\begin{array}{l}\text { Fornece alerta ou retorno eficaz durante e após a } \\
\text { conclusão da tarefa. }\end{array}$ & $\mathbf{X}$ \\
\hline & ador não el & \\
\hline
\end{tabular}

\begin{tabular}{|c|c|c|}
\hline $\begin{array}{l}\text { PRINCÍPIO 4: } \\
\text { Informação } \\
\text { fácil e } \\
\text { berceptível }\end{array}$ & $\begin{array}{l}\text { Comunica eficazmente a informação necessária ao usu } \\
\text { independentemente das condições do ambiente ou des } \\
\text { habilidades sensoriais }\end{array}$ & \\
\hline $4 a$ & $\begin{array}{l}\text { Usa diferentes modos de comunicação (visual, sonora, } \\
\text { tátil) para apresentar a informação essencial. }\end{array}$ & $\mathbf{X}$ \\
\hline & Ambientes não têm sinalização tátil e sonora, e a visual é c & \\
\hline 4b & $\begin{array}{l}\text { Proporciona contraste adequado entre as informações } \\
\text { essenciais e seu entorno. }\end{array}$ & $\sqrt{ }$ \\
\hline & Quando há, a sinalização ambiental tem bom contraste. & \\
\hline 4c & Maximiza a legibilidade da informação essencial. & $\mathbf{X}$ \\
\hline & Uso de fontes pequenas para a sinalização de uma forma & \\
\hline 4d & $\begin{array}{l}\text { Oferece compatibilidade com uma variedade de técnicas } \\
\text { ou dispositivos utilizados por pessoas com limitações } \\
\text { sensoriais. }\end{array}$ & $\mathbf{X}$ \\
\hline & A biblioteca possui recursos limitados ao acervo. & \\
\hline
\end{tabular}




\begin{tabular}{|c|c|c|}
\hline $\begin{array}{l}\text { PRINCÍPIO 5: } \\
\text { Tolerância ao } \\
\text { erro }\end{array}$ & \multicolumn{2}{|l|}{$\begin{array}{l}\text { Minimiza perigos e consequências adversas de ações } \\
\text { involuntárias ou imprevistas }\end{array}$} \\
\hline \multirow[t]{2}{*}{$5 a$} & $\begin{array}{l}\text { Organiza os elementos para minimizar riscos e erros: os } \\
\text { elementos mais utilizados ficam mais acessíveis; os } \\
\text { elementos perigosos são eliminados, isolados ou } \\
\text { protegidos. }\end{array}$ & $\mathbf{X}$ \\
\hline & \multicolumn{2}{|c|}{$\begin{array}{l}\text { Não há piso tátil para sinalizar situações de risco, corrimão de apoio } \\
\text { para evitar queda e barras adequadas para transferência à bacia no } \\
\text { sanitário. }\end{array}$} \\
\hline \multirow[t]{2}{*}{$5 b$} & Fornece alertas de perigos e erros. & $\mathrm{X}$ \\
\hline & \multicolumn{2}{|c|}{$\begin{array}{l}\text { Situações de risco não são sinalizadas com piso tátil de alerta / Não há } \\
\text { dispositivo de chamada no sanitário em caso de emergência. }\end{array}$} \\
\hline \multirow[t]{2}{*}{$5 c$} & Fornece recursos à prova de falhas. & $\mathrm{x}$ \\
\hline & \multicolumn{2}{|c|}{$\begin{array}{l}\text { Rampa móvel inadequada pode acarretar em acidente / Ausência de } \\
\text { piso tátil de alerta. }\end{array}$} \\
\hline \multirow[t]{2}{*}{$5 d$} & $\begin{array}{l}\text { Desencoraja ações inconscientes em tarefas que } \\
\text { requerem vigilância. }\end{array}$ & $\mathbf{X}$ \\
\hline & \multicolumn{2}{|l|}{ Ausência de corrimão. } \\
\hline
\end{tabular}

\begin{tabular}{|c|c|c|}
\hline $\begin{array}{l}\text { PRINCÍPIO 6: } \\
\text { Baixo esforço } \\
\text { físico }\end{array}$ & $\begin{array}{l}\text { Pode ser usado eficientemente, confortavelmente e cor } \\
\text { mínimo de fadiga. }\end{array}$ & \\
\hline $6 \mathbf{a}$ & Permite ao usuário manter uma posição corporal neutra. & $\mathbf{X}$ \\
\hline & Porta do elevador exige esforço e, portanto mudança da p & \\
\hline $6 b$ & Exige razoável força de operação. & $\mathbf{X}$ \\
\hline & Porta do elevador exige esforço para abertura. & \\
\hline $6 c$ & Minimiza ações repetitivas. & $\sqrt{ }$ \\
\hline & $\begin{array}{l}\text { O elevador minimiza o esforço dos degraus para a mudans } \\
\text { pavimento. }\end{array}$ & \\
\hline $6 d$ & Minimiza o esforço físico contínuo & $\mathbf{X}$ \\
\hline & Não há bancos de descanso. & \\
\hline $6 e$ & $\begin{array}{l}\text { Permite o uso com apenas uma das mãos e sem } \\
\text { necessitar de habilidade. }\end{array}$ & $\mathbf{X}$ \\
\hline & Maçanetas do tipo 'bola' exigem mobilidade da mão. & \\
\hline
\end{tabular}




\begin{tabular}{|c|c|c|}
\hline \multirow{2}{*}{$\begin{array}{l}\text { PRINCÍPIO 7: } \\
\text { Dimensão e } \\
\text { espaço para } \\
\text { aproximação e } \\
\text { uso } \\
7 a\end{array}$} & \multicolumn{2}{|c|}{$\begin{array}{l}\text { Tamanho e espaço apropriado para aproximação, alcance, } \\
\text { manipulação e uso, independentemente do tamanho, postura ou } \\
\text { mobilidade do usuário. }\end{array}$} \\
\hline & $\begin{array}{l}\text { Fornece uma linha clara de visão dos elementos } \\
\text { importantes para qualquer usuário, sentado ou em pé. }\end{array}$ & $\sqrt{ }$ \\
\hline & \multicolumn{2}{|l|}{ Circulação ampla permite perceber os componentes do espaço. } \\
\hline \multirow[t]{2}{*}{$7 b$} & $\begin{array}{l}\text { Alcance confortável a todos os componentes para } \\
\text { pessoas sentadas ou em pé. }\end{array}$ & $\mathbf{X}$ \\
\hline & \multicolumn{2}{|l|}{ Prateleiras da biblioteca fora do alcance manual. } \\
\hline 7d & $\begin{array}{l}\text { Proporciona espaço adequado para o uso de espaços e } \\
\text { dispositivos de apoio ou de ajuda pessoal. }\end{array}$ & $\mathbf{X}$ \\
\hline & Portas estreitas / balcão da cafeteria alto. & \\
\hline
\end{tabular}

O resultado massivamente negativo demonstra como a ausência de certos elementos, prejudica o sistema como um todo, causando barreiras. Por exemplo, uma pessoa cega encontra um ambiente totalmente ausente de referências e que causa dependência. Para uma pessoa em cadeira de rodas, a acessibilidade se torna nula, por não conseguir entrar, mesmo tendo condições de circulação interna. Uma pessoa idosa pode preferir não entrar, mesmo conseguindo, pois os degraus no acesso, sem corrimão de apoio, representam um risco, que ela pode não estar disposta a correr. Já uma pessoa surda, teria dificuldade em aproveitar os cursos oferecidos e informar-se sobre a programação e o local, pela ausência de intérprete de Libras.

\subsection{0. Ótica do usuário}

A seguir são apresentadas as principais considerações de algumas pessoas com deficiência, sobre o local visitado, registradas utilizando-se a técnica 
de grupo focal, conforme metodologia anteriormente apresentada.

\subsubsection{Pessoa usuária de cadeira de rodas (PCR)}

Ao chegar à frente da Casa das Rosas viu a enorme escada, como descreveu, e questionou como faria para entrar. Foi orientado a aguardar trazerem a rampa. Pegaram duas rampas, uma para cada roda passar, esticaram apoiando nos degraus, e empurraram a cadeira para cima. Ele e sua esposa consideraram o recurso oferecido muito perigoso. Disse ter aceito o uso, pois queria ver qual era o procedimento e que por ser jovem, fica mais fácil encarar situações como essas; para um idoso seria impossível.

Entrou e achou a casa maravilhosa, gostou muito do ambiente, conforme suas palavras. Quis saber a história da casa e contaram que utilizaram um fosso original para instalar o elevador. Diz ter compreendido o fato de o elevador ser pequeno, como o é, por ser um patrimônio tombado que não permite muita alteração. Percebeu que, além do elevador, o prédio não tinha qualquer adaptação, e questionou um funcionário. Foi informado que havia três anos que uma licitação tinha sido feita e aguardavam a rampa.

Sobre o banheiro disse que é o mesmo para todo mundo; que embora seja muito grande, não foi feita qualquer adaptação.

Não recomendaria aos seus amigos a visita à Casa das Rosas, pois sabe que alguns não teriam condição de utilizar a rampa disponível. Finalizou com a seguinte declaração: "Eu fiquei decepcionado com a Casa das Rosas porque a gente sempre acha que tem uma luz no fim do túnel, mas lá não tinha". 


\subsubsection{Pessoa idosa (PI)}

A pessoa idosa deu a volta em toda a Casa e verificou que havia degrau em todos os acessos. Criticou, por ser um espaço cultural sem acesso. Os degraus da escada a desencorajaram, e a pessoa que ofereceu ajuda, a deixou constrangida, ao pegar em seu braço para subir, sem pedir permissão.

A falta de acesso adequado fez com que ela não entrasse no local e, portanto não conhecesse o interior da Casa das Rosas. Já havia caído em situação semelhante e preferia não correr o risco.

Questionou sobre a ausência de rampa na saída para a Al. Santos, pois não viu motivo, já que ali, um jardim moderno como caracterizou, não parecia ser tombado como a área da Casa das Rosas.

Disse que, os funcionários devem ser capacitados para saber atender as pessoas, dentro de suas dificuldades. E que quando houver rampa, voltará para conhecer a Casa das Rosas.

\subsubsection{Pessoa com deficiência visual (PDV)}

Vindo da estação Brigadeiro do Metrô, teve ajuda de um funcionárioaprendiz, que não conhecia a Casa das Rosas, mas sabia que uma das saídas tinha a indicação. Só podia acompanhá-lo até a travessia. A orientação dada é que seria uma casa amarela no próximo quarteirão. Teve grande facilidade para percorrer a Avenida Paulista sem qualquer acompanhamento, pois tem piso tátil direcional.

Ao atravessar avistou uma construção amarela, e achando que o percurso tinha sido menor do que esperava, parou em uma banca de jornal em frente para confirmar. Foi informado que ainda teria que fazer mais uma travessia e 
na próxima banca, em frente, encontraria a Casa das Rosas. Seguindo as instruções não avistou nenhuma construção amarela, como tinha sido informado no início, contudo o jornaleiro da segunda banca confirmou estar no lugar correto. Neste momento do relato, a PDV explicou que a orientação feita de forma correta e detalhada é essencial para o sucesso do deslocamento. Complementou dizendo que, seria bem-vinda uma ramificação do piso tátil direcional para a entrada da Casa das Rosas.

Sua impressão foi que a Casa das Rosas não possui qualquer recurso de acessibilidade, com exceção do elevador. Ao apresentar seu desejo de visitar o local foi dito que ficasse à vontade. Neste momento questionou os recursos de acessibilidade para sua visita, então a recepcionista chamou alguém para conduzilo. Como já havia passado das 19 horas não havia mais educadores que pudessem acompanhá-lo. A própria recepcionista iniciou a visitação, até a chegada da outra pessoa, mostrando os detalhes da parede e descrevendo o teto de gesso. Um segurança do local deu continuidade à visita. Pela roupa, o visitante notou que se tratava de um segurança. E julgou que foi muito bem na condução, considerando que esse funcionário não recebeu qualquer treinamento para tal atividade. O segurança disse ter observado o pessoal que faz esse atendimento especializado e assim, aprendido pelo o convívio. Recebeu a informação de que as visitas acessíveis, geralmente para grupos pré-agendados, acontecem duas vezes ao dia.

\subsubsection{Pessoa com deficiência auditiva (PS)}

Nunca tinha ido à Casa das Rosas, mas tinha conhecimento que se tratava de um patrimônio histórico e que suas atividades eram relacionadas à 
literatura. Encontrar o local e entrar não foram dificuldades para esta pessoa.

Dos locais visitados, foi o pior em sua avaliação, pois sentiu que os funcionários não fizeram esforço nenhum em tentar se comunicar com ela. Tudo que fizeram foi entregar-Ihe um papelzinho, largando-a sem qualquer atendimento mais adequado.

Foi ao banheiro rosa e gostou do espaço, mas não havia ninguém para passar qualquer informação.

De forma geral, considerou o espaço sem qualquer atrativo para ela.

\subsection{Análise da relação entre preservação e acessibilidade}

Os elementos a garantir a acessibilidade parcial da Casa das Rosas foram incorporados em 2007, para a mostra CAD Brasil.

Não cabe aqui listar todas as adições, supressões e sobreposições feitas ao longo da vida do edifício, em relação à estrutura existente hoje, mas sim aquelas que deram base para a condição de acessibilidade atual, sem levar em consideração os problemas relatados na análise técnica de acessibilidade, e sim avaliando a relação com a preservação.

\subsection{1. $\quad$ Adições}

Não foi necessário adicionar elementos de grande impacto, como torres de circulação vertical, ou construção de sanitário em área originalmente não molhada. Os elementos adicionados para atender a acessibilidade estão tão integrados à estrutura original, que quase passam despercebidos: bacia sanitária, 
lavatório, barra de apoio, e o equipamento do elevador. Esses estão relacionados diretamente às supressões das peças sanitárias originais, do antigo monta-carga e dos alçapões de passagem de roupa suja e lixo, descritos em 2.11.2. As adições foram essenciais para garantir a acessibilidade parcial, existente hoje.

O impacto no sanitário é mínimo se considerar que há dois vistosos banheiros com todas as peças sanitárias preservadas, no andar superior. E que de forma geral, os revestimentos no sanitário térreo foram mantidos, garantindo a preservação da ambiência. Quanto ao elevador, já havia um espaço praticamente disponível para ele, não precisando criar qualquer elemento externo para o percurso vertical. Ambos, elementos fundamentais, que garantem o respeito aos direito humanos e à preservação.

\subsubsection{Supressões}

O monta-carga original, utilizado para transportar roupas de cama e malas, foi retirado, para no lugar ser instalado o elevador. Também com esse propósito foram eliminados dois alçapões que serviam para passagem de roupa suja e lixo, pois o elevador ocupa um espaço maior que o monta-carga ocupava. As alvenarias que dividiam os três dutos, consequentemente, foram eliminadas. No porão ainda é possível ver a aparência externa deste monta-carga, que está preservado, já que naquele nível fica parte do maquinário do elevador, e

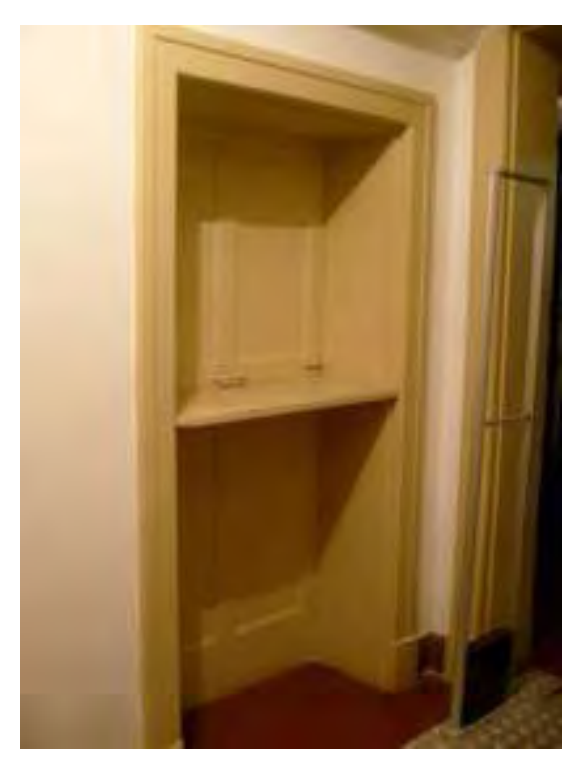

Figura 132 - Abertura original para monta-carga, no subsolo. 2010. 
portando não há transporte de pessoas até este pavimento. E em alguns pavimentos ainda é possível ver a abertura dos alçapões.

Outra supressão ocorrida é a das peças sanitárias originais substituídas por peças que pudessem atender à acessibilidade, no sanitário do térreo. Ainda está exposto, em um dos cantos deste sanitário, o lavatório que se

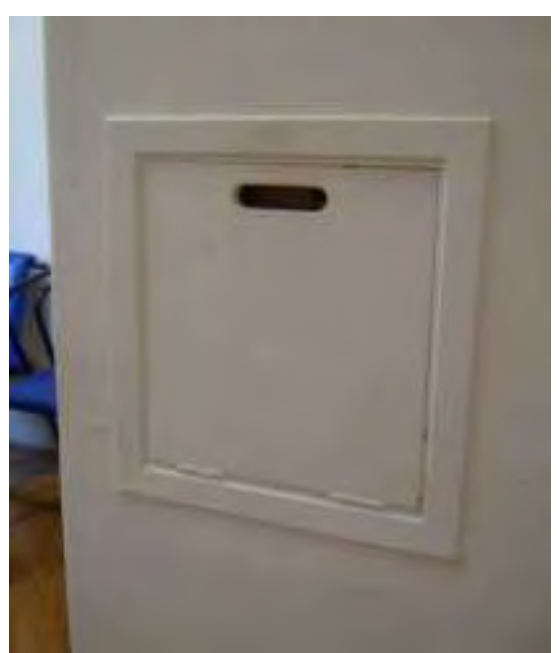

Figura 133 - Abertura para alçapão no primeiro pavimento. 2010. acredita ser o original.

Como já relatado em 2.11.1, foram supressões necessárias e de pequeno impacto. A manutenção da porta do monta-carga no porão é relevante. No entanto, com o avanço tecnológico talvez seja possível instalar um equipamento de deslocamento vertical que possa também atender esse andar. $E$ nesse caso, a manutenção da aparência externa, me parece, é menos importante do que o acesso pleno, de visitantes e funcionários, aos diversos pavimentos.

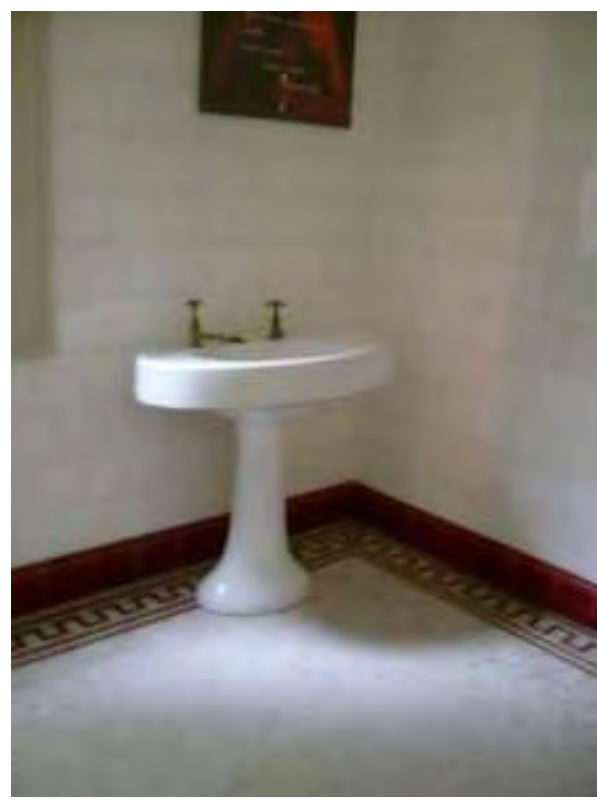

Figura 134 - Lavatório original do banheiro do térreo. 2010.

\subsubsection{Sobreposições}

Hoje, não existem elementos de sobreposições na Casa das Rosas para atender à acessibilidade. A rampa no acesso, criada temporariamente para a mostra, 
se enquadraria neste item, contudo, não será analisada por não mais existir.

\subsection{Conclusões e recomendações de adequação}

Após as avaliações técnicas e dos usuários chega-se à conclusão que os problemas de acessibilidade existentes revelaram um espaço que não atrai, não se comunica e não convida as pessoas com deficiência a entrar.

A ausência de entrada adequada há mais de três anos é incongruente com um espaço aberto ao público. Torna os recursos internos, que acredito serem mais complexos de serem inseridos, praticamente inoperantes.

Porém, analisando primeiro o que há, em vez do que falta, pode-se dizer que pouco foi alterado da estrutura original da Casa das Rosas para atender a acessibilidade. Mesmo com a alteração do monta-carga e dos alçapões, ainda há resquícios de seu caráter original. E visto que esses elementos não são necessários na função que o espaço tem hoje, pouco prejudica por esse aspecto. O retorno que essa alteração gera é mais importante; mais importante até que a eliminação por completa dos resquícios mencionados. E essa solução interfere de forma mínima no aspecto da Casa, sem qualquer alteração de sua volumetria.

Para complementar a rota vertical falta o acesso ao porão. Sendo hoje o acesso restrito aos funcionários, conclui-se que esses não podem ter deficiência, o que pode gerar uma situação de discriminação, ao contratar novos funcionários ou no caso de um funcionário adquirir alguma restrição de mobilidade. A falta de acesso inviabiliza a implantação de atividades voltadas ao público, como por exemplo, uma visita monitorada para conhecer os vários espaços de uma casa típica burguesa da época. O elevador poderia ser substituído por modelo que ocupe espaço mínimo de 
poço, e ter esse espaço escavado abaixo do porão para instalação, e assim garantir acesso ao único pavimento faltante. Essa possibilidade deve ser avaliada por engenheiros e técnicos aptos.

O impacto no sanitário foi pequeno também, uma vez que o local já tinha esse destino, e a troca de peças pouco interferiu, face a permanência nos outros andares de sanitário que mantém seus aspectos originais. Esse sanitário precisa de adequações para garantir seu uso pleno. Não considero necessária a alteração da porta por conta do vão de $0,78 \mathrm{~m}$, pois afinal, levando em consideração a preservação, este vão permite sim a passagem de cadeira de rodas, e o acesso não é prejudicado. O sentido de abertura da porta é uma demanda por conta do risco de queda, no momento da transferência. Como a área de transferência desse sanitário está distante da porta, o risco de ocorrer queda justamente em frente é mínima. Mas não é possível abrir mão de barras e acessórios em altura adequada.

Sobre a distribuição de sanitários em todos os andares, conforme Decreto federal 5.296/2004, acredito ser possível propor adequações no sanitário da mansarda, que é utilizado pelos funcionários e assim ter melhor distribuição de sanitários acessíveis. Mas não vejo, diante da importância da manutenção dos aspectos originais dos sanitários do pavimento superior, ser válida a adequação desses sanitários.

Mas a maior prioridade da Casa das Rosas é definir nova forma de acesso e viabilizá-la, uma vez que a rampa móvel, como já visto, não é opção a ser considerada. É necessário garantir o acesso com autonomia de pessoas que não possam transpor os degraus de entrada. Para isso podem ser utilizados elementos de sobreposição, sem precisar alterar características originais.

Poderá ser uma rampa fixa que se sobreponha aos degraus, ou ao jardim, 
neste caso retirando uma floreira da varanda e suprimindo parte do jardim, mas interligando diretamente ao terraço, sem ocupar a escada. A comparação entre essas duas opções já faz imaginar que, a primeira tem mais qualidades, uma vez que a escolha, de forma resumida, fica entre a diminuição do fluxo de passagem, devido à restrição da largura dos degraus, e a retirada de elementos originais, mesmo que de forma reversível. Como há dois acessos por degraus para a entrada principal, é possível escolher a fachada onde a interferência seja menor na percepção do bem tombado.

Antes de avaliar esse ponto, acho necessário avaliar outra opção de acesso. A utilização de equipamento eletromecânico, no caso plataforma vertical, pode se colocar da mesma maneira: em frente aos degraus fazendo passagem por passarela, ou sobre o jardim, retirando uma floreira. As observações são as mesmas, mas cabe avaliar que uma plataforma vertical, é um recurso mais delicado e, principalmente, ao estar sujeito às variações climáticas, exigirá manutenção mais constante que a rampa. O equipamento também se destacará mais na fachada do que a rampa. Plataformas são mais adequadas para grandes desníveis ou para locais em que falte espaço para a rampa, que não acredito ser o caso aqui. A rampa promove um acesso mais direto e autônomo, sem necessidade de paradas ou entendimento, uma vez que algumas pessoas podem não saber operar o equipamento.

Não acredito ser adequada, entre as opções, rampa ou plataforma, a proposta de retirada da floreira e supressão de parte do jardim, uma vez que este é parte simbólica da Casa das Rosas, estando representada essa importância até mesmo em seu nome. Essa opção exige supressão, o que também faz acreditar que posicionar uma rampa sobre os degraus seja a melhor opção, entre as 
apresentadas. Adicionalmente, há a possibilidade de instalar corrimão fixado à rampa servindo de apoio a quem usa a escada. Lembrando que a rampa proposta deve ser reversível, podendo ser substituída por opções, que se demonstrarem melhores, caso haja um avanço de tecnologia, conforme diretriz da Carta de Veneza. Também devem ser escolhidos materiais que promovam distinguibilidade em relação ao aspecto original da Casa, princípio da mesma Carta.

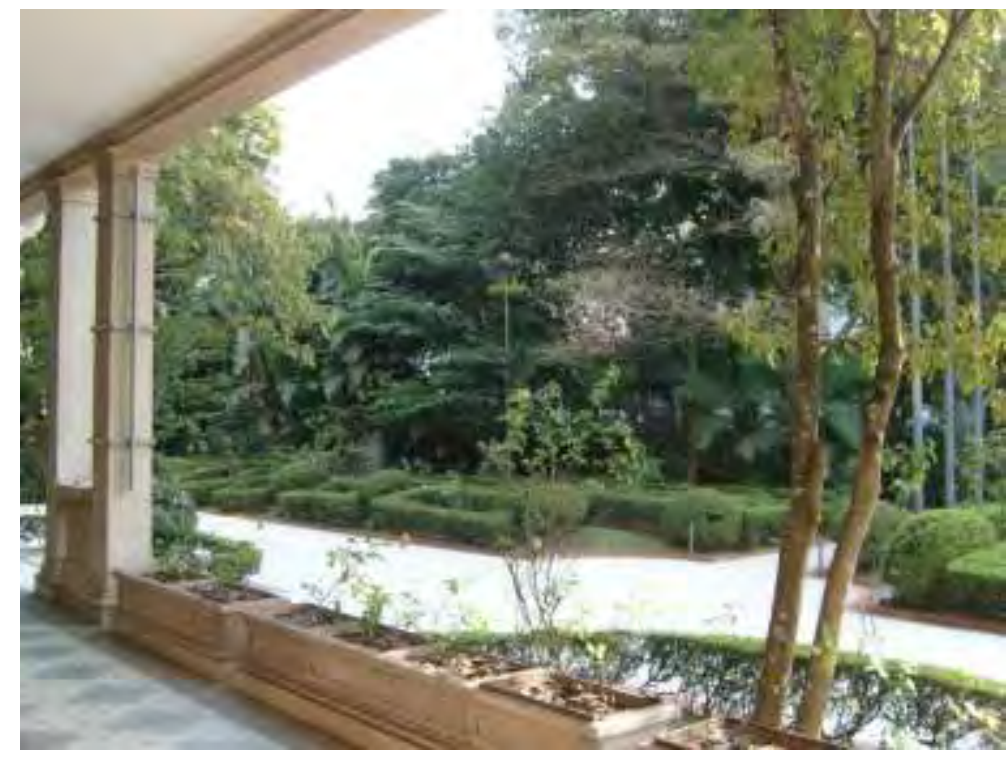

Figura 135 - Floreiras na varanda. 2011.

Com o pressuposto apresentado, a definição pelo qual conjunto de degraus a ser alterado vai depender essencialmente de qual melhor preserva a fruição da ambiência, ou que menos prejudica. Pelo ponto de vista da acessibilidade, qualquer uma das opções se mostra adequada, pela pequena distância entre elas e por se interligarem à porta principal da mesma maneira.

São duas opções: acesso voltado à Av. Paulista, ou àquele voltado ao jardim. O voltado à famosa avenida, de fato, é o primeiro a ser percebido. Mas é também da calçada, pelo portão aberto, que se percebe melhor a casa e o seu acesso, que foi a principal entrada social da casa, e é hoje a do espaço cultural. A fachada do jardim é, também, aquela que permite melhor afastamento para a 
percepção do todo. Mas colocar o acesso aí garante proximidade da entrada usadas pelos demais visitantes. Entre os pontos apresentados, acredito que o acesso a ser preservado é o da fachada voltada para o jardim. A rampa seria sobreposta aos degraus, sem que isso cause prejuízos aos elementos originais ou ao acesso adequado às pessoas com deficiência, pois será até mais próximo do passeio.

Esses são os pontos mais controversos e urgentes, mas há outros elementos ausentes que podem ser solucionados de forma sobreposta.

Pelo menos uma das escadas de entrada deve dispor de corrimão de apoio, para atender pessoas com restrições de mobilidade, como idosos e usuários de muletas. Essas pessoas podem preferir usar os degraus à rampa, devido ao seu percurso mais longo e a declividade, que dificulta manter o equilíbrio. É importante dar opção de escolha aos usuários, devido às diferentes habilidades individuais.

Não há sinalização tátil na Casa das Rosas e em sua área externa. Para sinalizar situações de risco, como escadas e rampas, utiliza-se piso tátil de alerta por fixação de elementos, que são colados sobre o piso original e são reversíveis, sem necessidade de suprimir pisos existentes.

Quanto à sinalização ambiental, pode ser fixada nas paredes, sem prejuízo. Deve-se estudar o local mais adequado, que permita boa visibilidade e não esconda elementos de maior interesse, como por exemplo, os decorativos. Suas características devem atendes aos parâmetros da ABNT NBR 9050/2004.

Ou seja, muitos problemas podem ser resolvidos com relativa facilidade e mínima ou nenhuma interferência aos elementos originais da Casa, promovendo maior autonomia e segurança aos usuários. Isso fica mais claro nas planilhas a seguir: 
ATENDIMENTO ÀS LEIS E NORMAS DE ACESSIBILIDADE

\begin{tabular}{|c|c|c|}
\hline & \\
\hline & SITUAÇÃO & OBSERVAÇÃO \\
\hline Passeio & & $\begin{array}{l}\text { ótima qualidade de revestimento e } \\
\text { com pisto tátil direcional }\end{array}$ \\
\hline Circulação externa & & $\begin{array}{l}\text { pela Av. Paulista bom, mas pela Al. } \\
\text { Santos péssimo. }\end{array}$ \\
\hline Estacionamento & - & não há \\
\hline Entradas e saídas & & não há acesso adequado \\
\hline Circulação interna & & falta corrimão e acesso ao porão \\
\hline Infraestrutura expositiva & & boa circulação \\
\hline Locais de reunião & - & não há \\
\hline Locais de refeição & & circulação inadequada \\
\hline Outras áreas & & $\begin{array}{l}\text { sem acesso ao pavimento superior } \\
\text { da edícula e ao interior da estufa. }\end{array}$ \\
\hline Instalações sanitárias & & $\begin{array}{l}\text { bacia com caixa acoplada, sem } \\
\text { barras adequadas, sem sanitários em } \\
\text { todos os andares }\end{array}$ \\
\hline Mobiliário & & $\begin{array}{l}\text { inadequações nos balcões, mesas de } \\
\text { leitura e expositores }\end{array}$ \\
\hline Sinalização e comunicação & & $\begin{array}{l}\text { sem sinalização ambiental, sem piso } \\
\text { tátil de alerta e sem indicação em } \\
\text { braile nos ambientes }\end{array}$ \\
\hline
\end{tabular}

\section{LEGENDA}

GRAVE

MÉDIO

BOM 


\begin{tabular}{|c|c|c|}
\hline \multicolumn{3}{|c|}{ PRIORIDADE DE ADEQUAÇÃO } \\
\hline & SITUAÇÃO & OBSERVAÇÃO \\
\hline Passeio & & melhorar deslocamento na Al. Santos \\
\hline Circulação externa & & $\begin{array}{l}\text { corrimãos nos degraus e rampas da } \\
\text { área externa }\end{array}$ \\
\hline Estacionamento & - & não há \\
\hline Entradas e saídas & & $\begin{array}{l}\text { ausência de acesso adequado deve } \\
\text { ser resolvido com máxima prioridade }\end{array}$ \\
\hline Circulação interna & & $\begin{array}{l}\text { corrimão nas escada e acesso ao } \\
\text { porão pode ser feito com melhora da } \\
\text { tecnologia }\end{array}$ \\
\hline Infraestrutura expositiva & - & não há necessidade de adequação \\
\hline Locais de reunião & - & não há \\
\hline Locais de refeição & & falta cardápio braile \\
\hline Outras áreas & & $\begin{array}{l}\text { acesso ao pav. superior da edícula } \\
\text { deve ser fruto de debate mais } \\
\text { extenso }\end{array}$ \\
\hline Instalações sanitárias & & $\begin{array}{l}\text { ausência de barras prejudica a } \\
\text { transferência }\end{array}$ \\
\hline Mobiliário & & $\begin{array}{l}\text { assentos para obesos, expositores e } \\
\text { balcões. }\end{array}$ \\
\hline Sinalização e comunicação & & $\begin{array}{l}\text { a sinalização irá garantir um } \\
\text { deslocamento mais seguro }\end{array}$ \\
\hline LEGENDA & & \\
\hline $\begin{array}{l}1^{\circ} \\
2^{\circ} \\
3^{\circ}\end{array}$ & & \\
\hline
\end{tabular}




\section{DIFICULDADE ADEQUAÇÃO}

\begin{tabular}{|c|c|c|}
\hline & \multirow{2}{*}{ SITUAÇÃO } & \multirow{2}{*}{ OBSERVAÇÃO } \\
\hline & & \\
\hline Passeio & & $\begin{array}{l}\text { troca do piso da Al. Santos, } \\
\text { interromperá temporariamente aquele } \\
\text { acesso, mas há outro }\end{array}$ \\
\hline Circulação externa & & $\begin{array}{l}\text { rampa no acesso da Al. Santos e } \\
\text { colocação de corrimãos adequados }\end{array}$ \\
\hline Estacionamento & - & não há \\
\hline Entradas e saídas & & $\begin{array}{l}\text { situação complexa; faz mais de três } \\
\text { anos que é debatida, portanto basta a } \\
\text { aprovação }\end{array}$ \\
\hline Circulação interna & & troca do elevador \\
\hline Infraestrutura expositiva & - & não há necessidade de adequação \\
\hline Locais de reunião & - & não há \\
\hline Locais de refeição & & $\begin{array}{l}\text { confecção de cardápio e } \\
\text { redistribuição das mesas }\end{array}$ \\
\hline Outras áreas & & $\begin{array}{l}\text { acesso ao pav. superior da edícula } \\
\text { exige equipamento eletromecânico }\end{array}$ \\
\hline Instalações sanitárias & & $\begin{array}{l}\text { retirada da bacia de caixa acoplada e } \\
\text { colocação de barras }\end{array}$ \\
\hline Mobiliário & & $\begin{array}{l}\text { entre os mobiliários inadequados não } \\
\text { há nenhum original }\end{array}$ \\
\hline Sinalização e comunicação & & estudo de sinalização adequada \\
\hline
\end{tabular}

\section{LEGENDA}

COMPLEXO
MÉDIO
SIMPLES




\begin{tabular}{|c|c|c|}
\hline \multicolumn{3}{|c|}{ IMPACTO PARA A PRESERVAÇÃO } \\
\hline & SITUAÇÃO & OBSERVAÇÃO \\
\hline Passeio & & $\begin{array}{l}\text { passeio inadequado não está } \\
\text { relacionado mais com a ambiência }\end{array}$ \\
\hline Circulação externa & & $\begin{array}{l}\text { acesso da Al. Santos e falta de } \\
\text { corrimãos na circulação externa são } \\
\text { em locais onde o piso não é mais } \\
\text { original }\end{array}$ \\
\hline Estacionamento & - & não há \\
\hline Entradas e saídas & & $\begin{array}{l}\text { rampa ou equipamento } \\
\text { eletromecânico na entrada altera a } \\
\text { percepção da fachada }\end{array}$ \\
\hline Circulação interna & & $\begin{array}{l}\text { alteração do elevador pouco } \\
\text { interfere, uma vez que já existe um } \\
\text { elevador / corrimãos podem alterar } \\
\text { percepção }\end{array}$ \\
\hline Infraestrutura expositiva & - & não há necessidade de adequação \\
\hline Locais de reunião & - & não há \\
\hline Locais de refeição & & cardápio em braile \\
\hline Outras áreas & & $\begin{array}{l}\text { equipamento eletromecânico altera } \\
\text { muito a percepção }\end{array}$ \\
\hline Instalações sanitárias & & $\begin{array}{l}\text { não há grande interferência uma vez } \\
\text { que já foram feitas alterações. }\end{array}$ \\
\hline Mobiliário & & não são mobiliários originais \\
\hline Sinalização e comunicação & & $\begin{array}{l}\text { piso tátil e sinalização ambiental não } \\
\text { trazem impactos permanentes }\end{array}$ \\
\hline LEGENDA & & \\
\hline $\begin{array}{r}\text { SEVERA } \\
\text { SATISFATÓRIA } \\
\text { ISENTA }\end{array}$ & & \\
\hline
\end{tabular}




\section{CENTRO CULTURAL BANCO DO BRASIL}

O imponente edifício de estilo eclético, que marca uma das esquinas da Rua Álvares Penteado com a Rua da Quitanda é um dos remanescentes representativos da ocupação bancária do centro de São Paulo, nas primeiras décadas do século XX. Como à moda da época, mistura na ornamentação interna $e$ externa referências de arquitetura neoclássica, art nouveau e art déco.

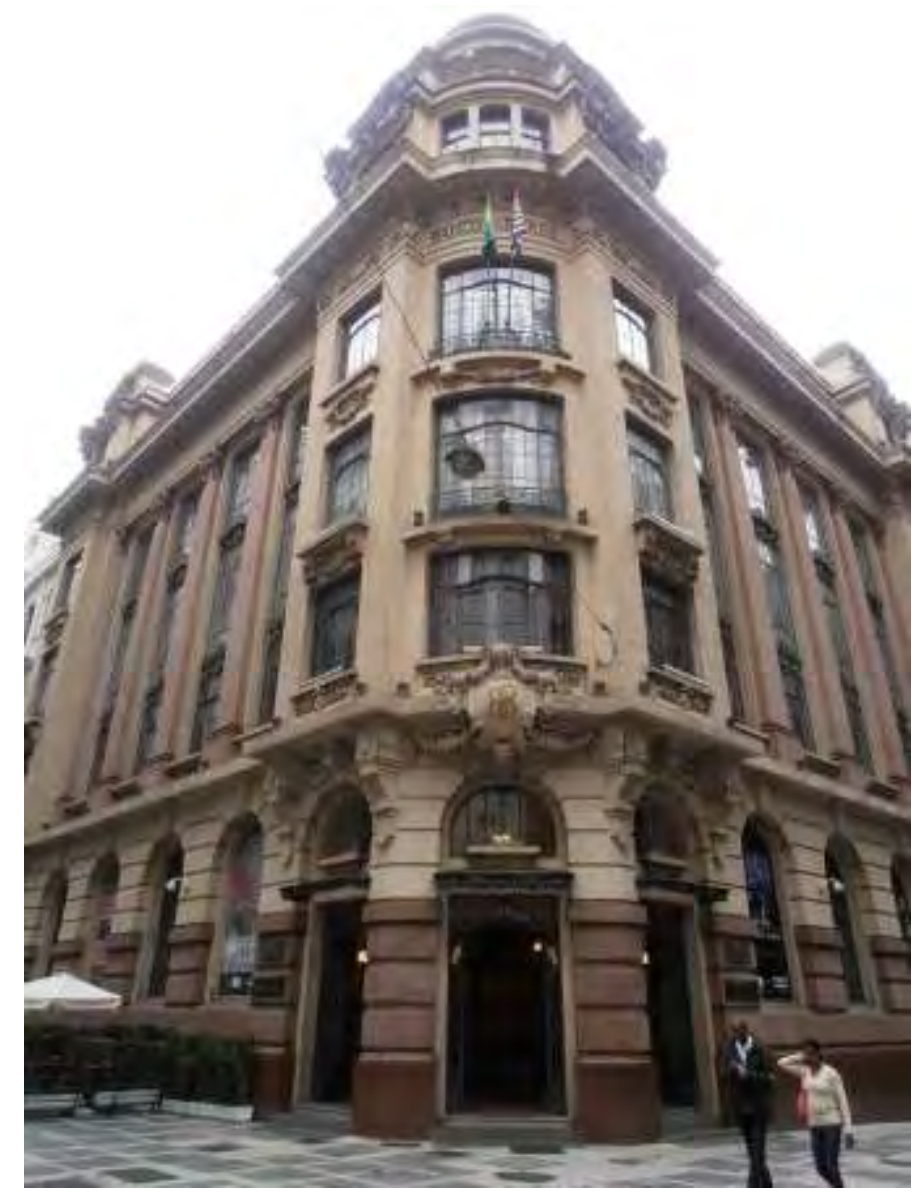

Figura 136 - Vista do Centro Cultural Banco do Brasil. 2011.

Originalmente o edifício é de 1901, no entanto foi em 1927 que ele adquiriu as características formais atuais, com a readequação de sua estrutura para se tornar sede do Banco do Brasil em São Paulo. O engenheiro-arquiteto Hippolyto 
Gustavo Pujol Jr., mesmo autor do edifício Guinle na Rua Direita, foi o escolhido pela instituição financeira para projetar a agência, passo inicial para ser o edifício que é hoje. O passo seguinte, para a transformação da obra de Pujol Jr. no Centro Cultural Banco do Brasil (CCBB), foi dado pelo arquiteto Luiz Telles, na década de 1990.

Desde a abertura do centro cultural em 2001, a mais diversa gama de atividades está disponível à população, regularmente de terça a domingo: exposições, projeção de filmes, peças de teatro e atividades culturais ligadas à arte e cultura. Diariamente, cerca de 300 pessoas, entre estudantes, famílias, turistas e demais interessados, circulam pelo CCBB buscando as atividades programadas, que em sua maioria são gratuitas ou de valor bastante reduzido.

\subsection{Dados}

Os dados a seguir foram coletados de diversas fontes, como o Cadastro de Imóveis Tombados da Prefeitura de São Paulo, o processo de tombamento do Condephaat ${ }^{142}$ e publicações sobre o centro cultural:

- Endereço: Rua Álvares Penteado no 112

- Endereço à época da construção: Rua Álvares Penteado esquina com a Rua da Quitanda

- Cadastro de logradouro: 00866-4

- Dados cadastrais: Setor 001 - Quadra 082 - Lote 0014

- CEP: 01012-000

- Bairro: Centro

- Subprefeitura: Sé

- Área do lote: $621,89 \mathrm{~m}^{2}$

- Área construída: $3.600 \mathrm{~m}^{2}$ (original) / $4.100 \mathrm{~m}^{2}$ (após a reforma)

\footnotetext{
142 Processo de Tombamento № 24084/1985, o qual faz parte do acervo do Condephaat/ Unidade de Preservação do Patrimônio Histórico da Secretaria da Cultura do Estado de São Paulo.
} 
- Projeto: desconhecido

- Ano do projeto original: desconhecido

- Execução: desconhecido

- Ano de conclusão: 1901

- Projeto para conversão em agenda bancária: 1923-1925

- Projeto: Escritório Técnico Hippolyto Gustavo Pujol Jr.

- Proprietários: Banco do Brasil

- Proteção legal:

Resolução ํo 40/2004 CONDEPHAAT - Tombamento do edifício

Resolução no 44/1992 Conpresp - Abertura de Processo de Tombamento de imóveis enquadrados na Z8-200

Resolução no 17/2007 Conpresp - Tombamento do Centro Velho

\subsection{Localização e estrutura urbana}

O Centro Cultural Banco do Brasil fica localizado no calçadão dentro do perímetro do Centro Velho, portanto o trânsito de automóveis é restrito. Segundo informações do próprio centro cultural as ruas João Brícola e Quinze de Novembro, próximas ao CCBB, estão liberadas para trânsito de táxis e carros particulares, apenas para embarque e desembarque, reduzindo bastante o percurso a pé, caso seja necessário.

Por ser o centro da cidade, está conectado a importantes avenidas de ligação com as diversas regiões da cidade, como Vinte e Três de Maio, do Estado, Radial Leste e Prestes Maia. Mas sua principal forma de acesso é por transporte público. Está próximo às estações do metrô São Bento (350 metros) e Sé (400 metros), portanto em duas linhas distintas: Norte-Sul e Leste-Oeste. Ambas as estações dispõem de elevadores de circulação exclusiva de pessoas com deficiência e mobilidade reduzida. E nas vias de trânsito de veículos no entorno do CCBB 
circulam mais de 50 linhas de ônibus, muitas com parada final nas proximidades do Largo São Francisco.

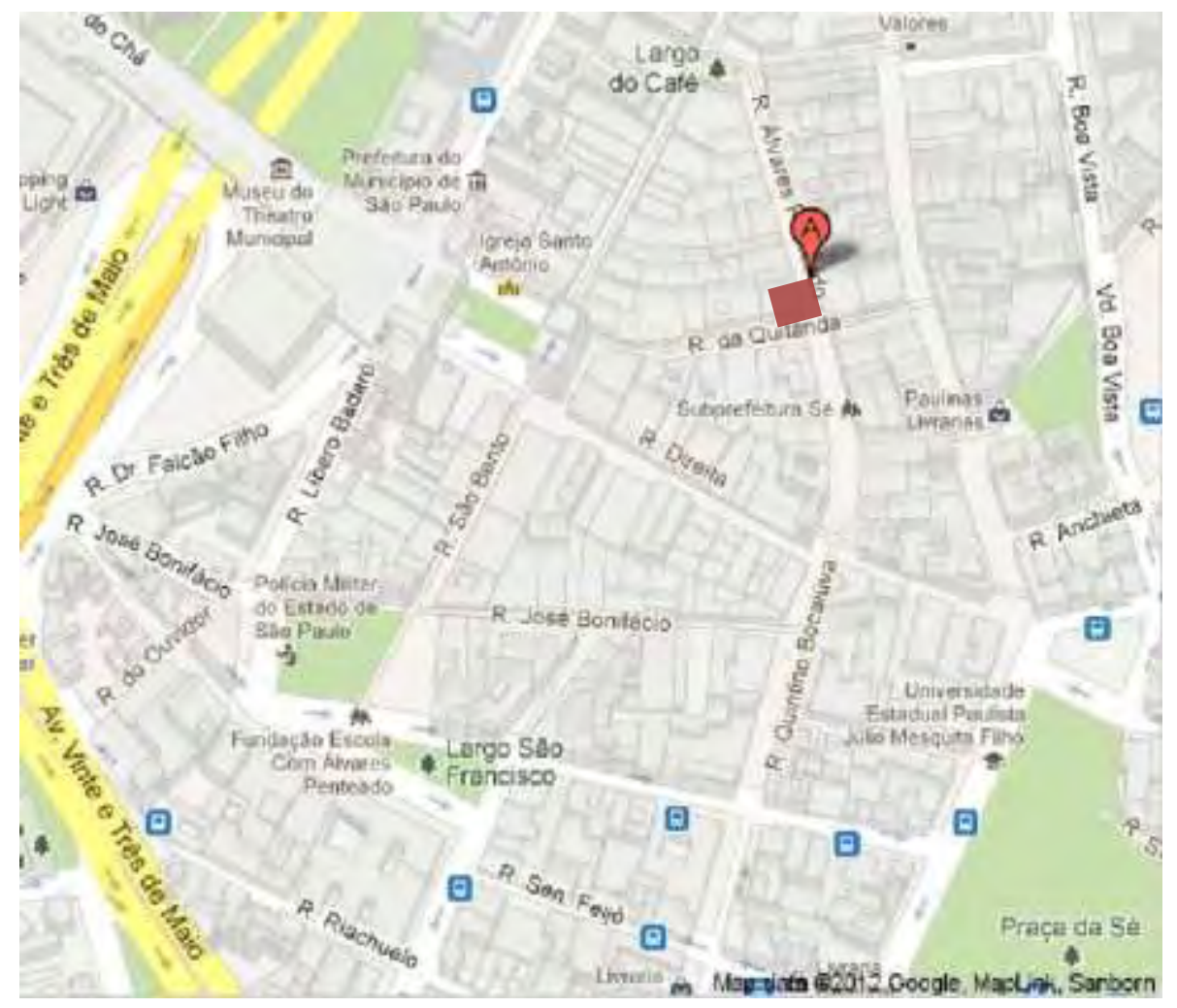

Figura 137 - Mapa de localização. Fonte: Google, 2012.

\subsection{Plantas}

Em consulta ao acervo do Condephaat / Unidade de Preservação do Patrimônio Histórico (UPPH) da Secretaria da Cultura do Estado de São Paulo foi possível localizar no Processo de tombamento n 24084/1985, referente ao edifício hoje denominado Centro Cultural Banco do Brasil, algumas plantas de autoria do Escritório Técnico Hippolyto Gustavo Pujol Jr., à época da conversão do prédio de 1901 para agência bancária. Estão destacadas as paredes a serem construídas em azul, as retiradas em roxo e aquelas mantidas em preto. 


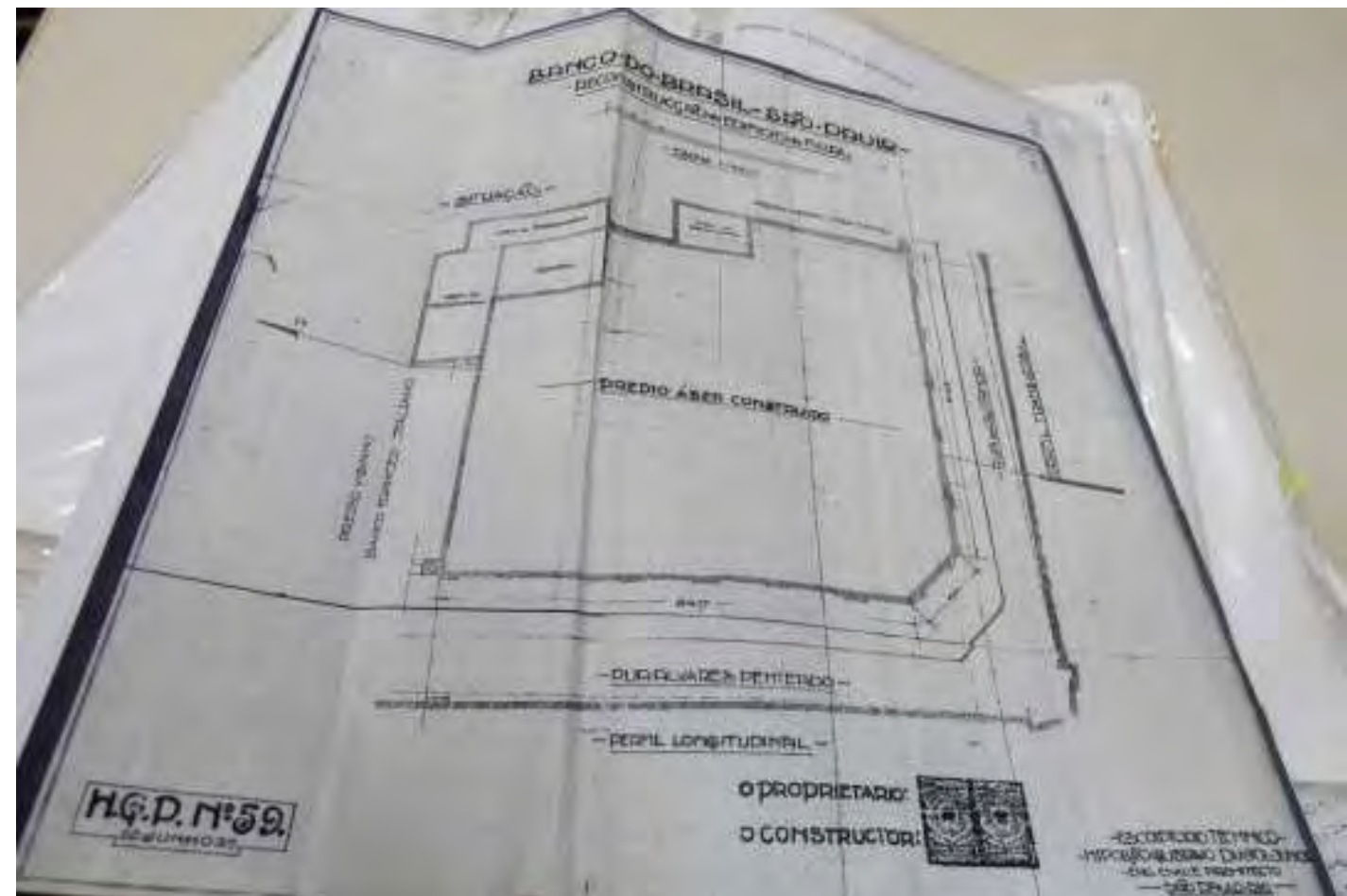

Figura 138 - Planta de situação. Data: 22 jun. 1925. Fonte: Acervo do Condephaat / UPPH.

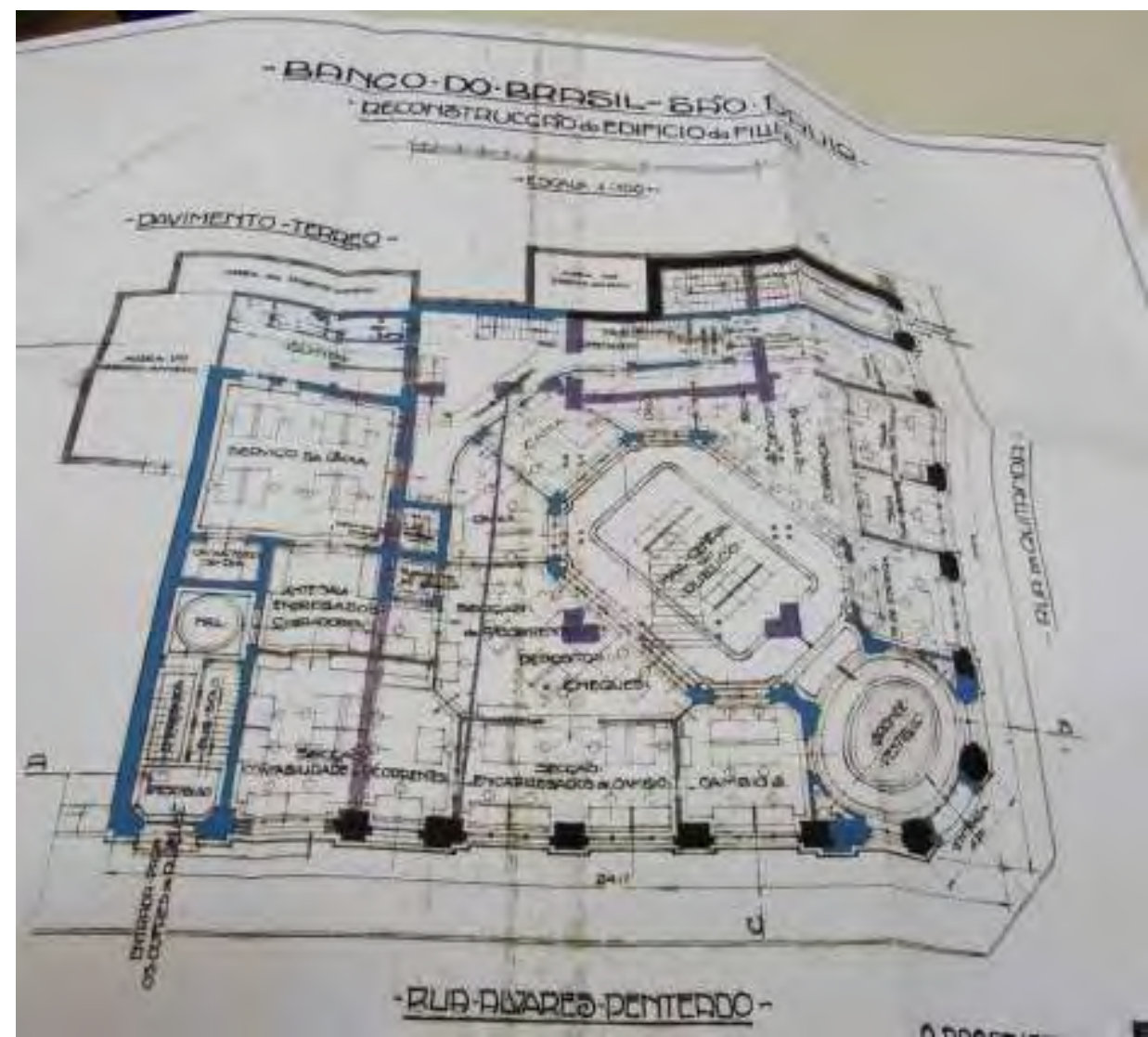

Figura 139 - Planta do pav. térreo de autoria de Pujol Jr. para a agência do Banco do Brasil. Data: 10 dez. 1924. Fonte: Acervo do Condephaat / UPPH. 


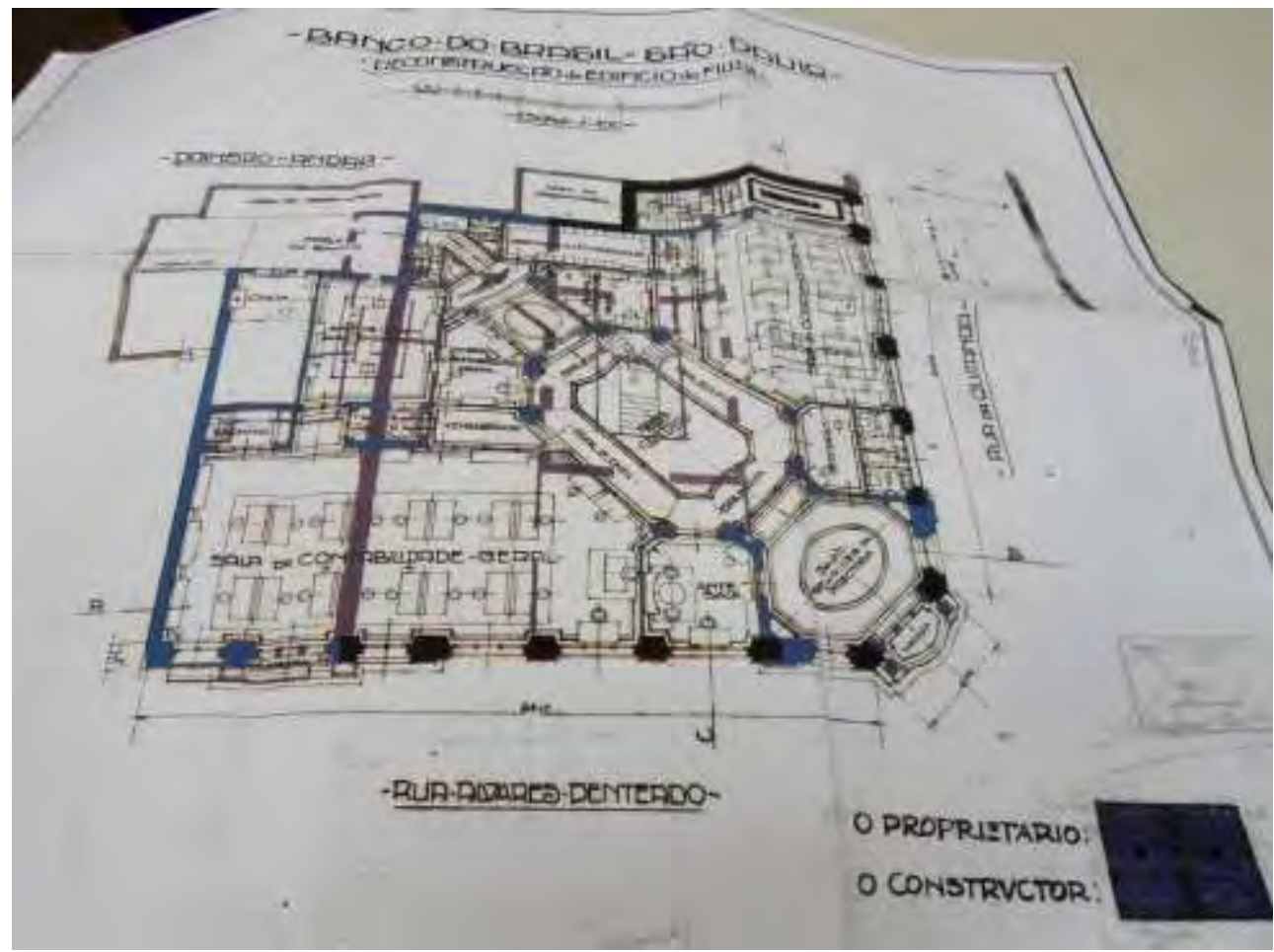

Figura 140 - Planta do $1^{\circ}$ pav. Data: 10 dez. 1924. Fonte: Acervo do Condephaat / UPPH.

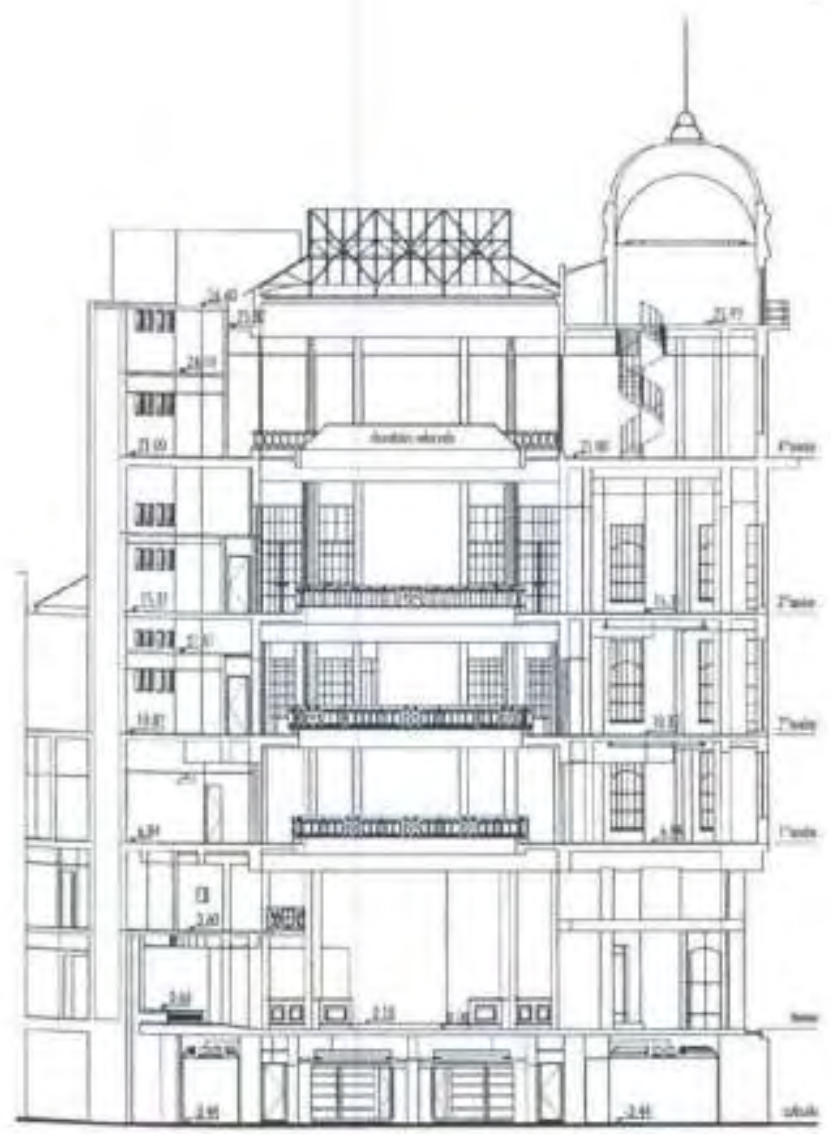

Figura 141 - Corte. Fonte: Revista Finestra/Brasil. 
As plantas após a reforma/restauro estão reproduzidas em artigos sobre a inauguração do Centro Cultural Banco do Brasil, na Revista $A^{143}$ e na Revista Finestra $^{144}$. Notam-se diferenças entre as plantas constantes nas publicações e a situação atual, como a continuação da escada helicoidal até o mezanino, que aparece na planta e em foto no sítio da Internet ArqBrasil ${ }^{145}$, na qual a LT Arquitetura divulga parte de seus trabalhos. No entanto, estas plantas representam de forma muito próxima o centro cultural hoje.

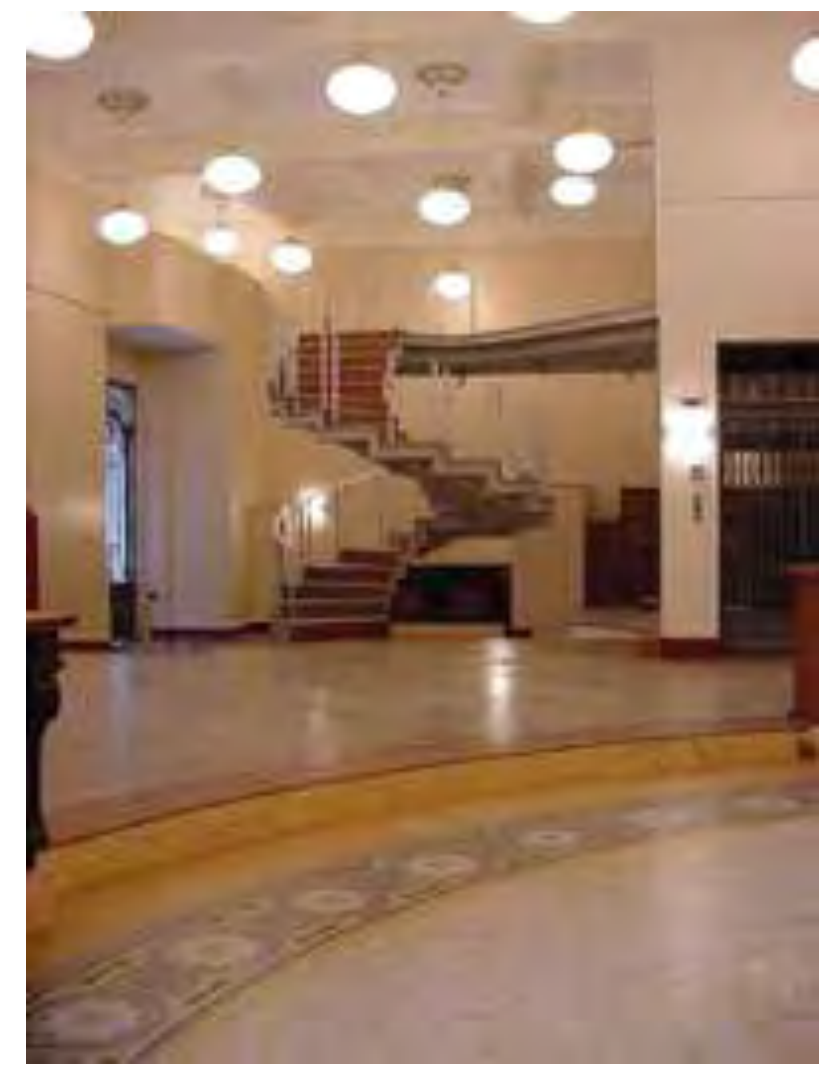

Figura 142 - Escada Helicoidal subindo para o mezanino. Data: 2001. Fonte: http://www.arqbrasil.com.br/_arq/lt_arquitetura/lt_arq_ccbb.htm.

\footnotetext{
${ }^{143}$ PORTELA, C. Agência de cultura, Revista AU, São Paulo, n. 96, p. 46-53, jun./jul. 2001. ${ }^{144}$ Resgate Histórico, Revista Finestra Brasil, São Paulo, v.7, n.25, p.16-18, abr./jun, 2001.

${ }^{145}$ Disponível em: <http://www.arqbrasil.com.br/_arq/lt_arquitetura/lt_arq_ccbb.htm>. Acesso em: 09 jan. 2012.
} 

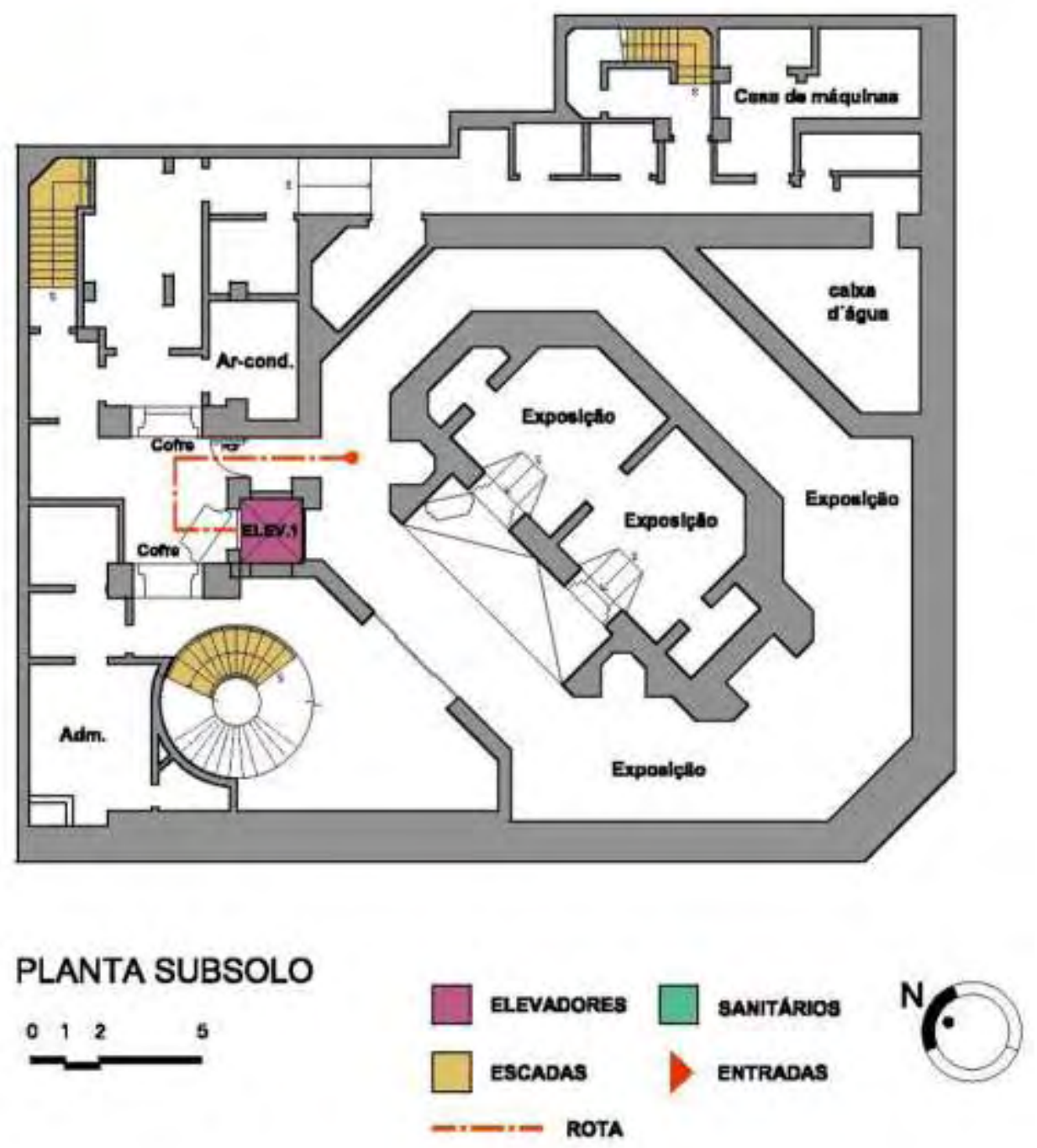

Figura 143 - Planta do subsolo. 


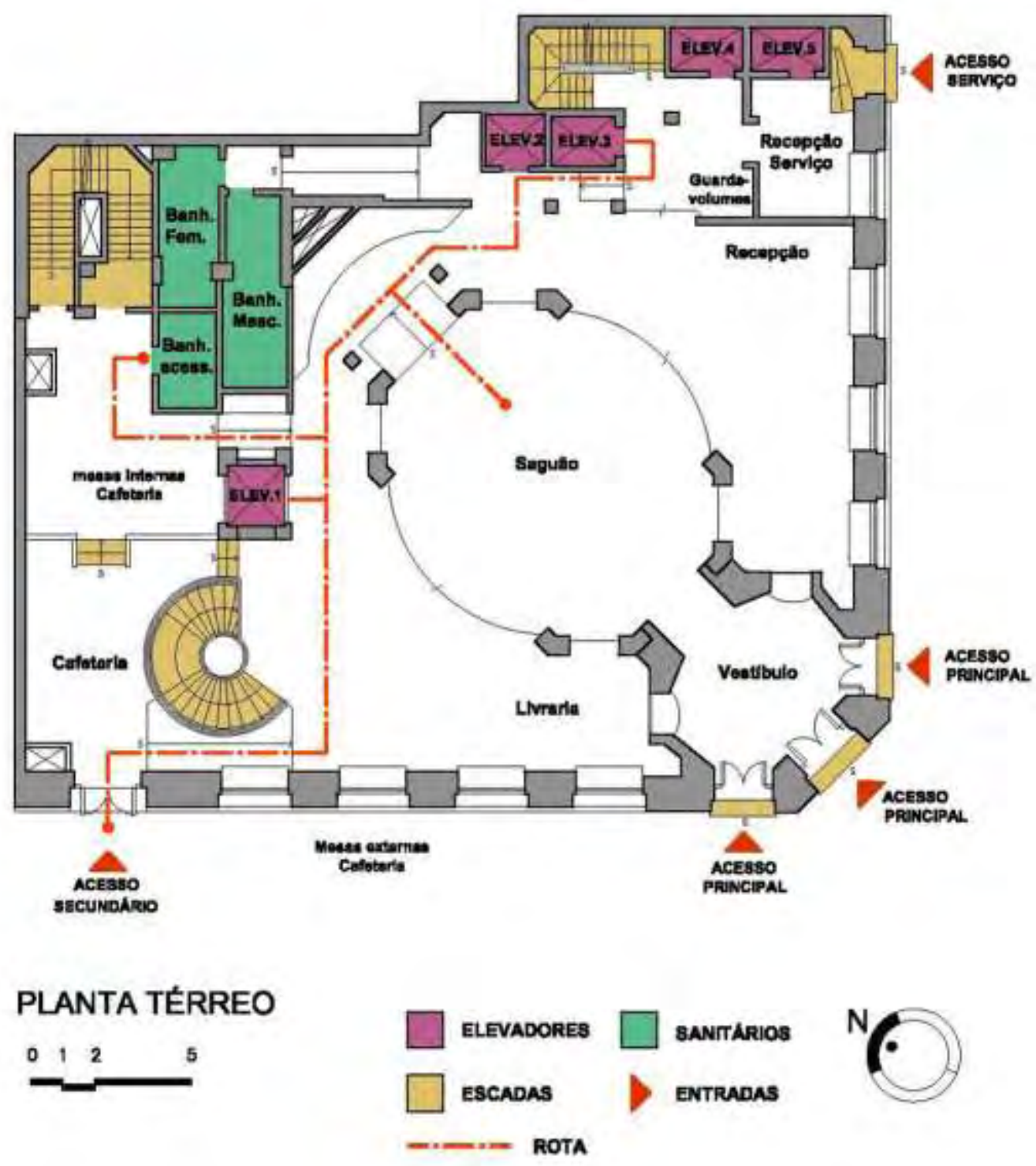

Figura 144 - Planta do pavimento térreo. 

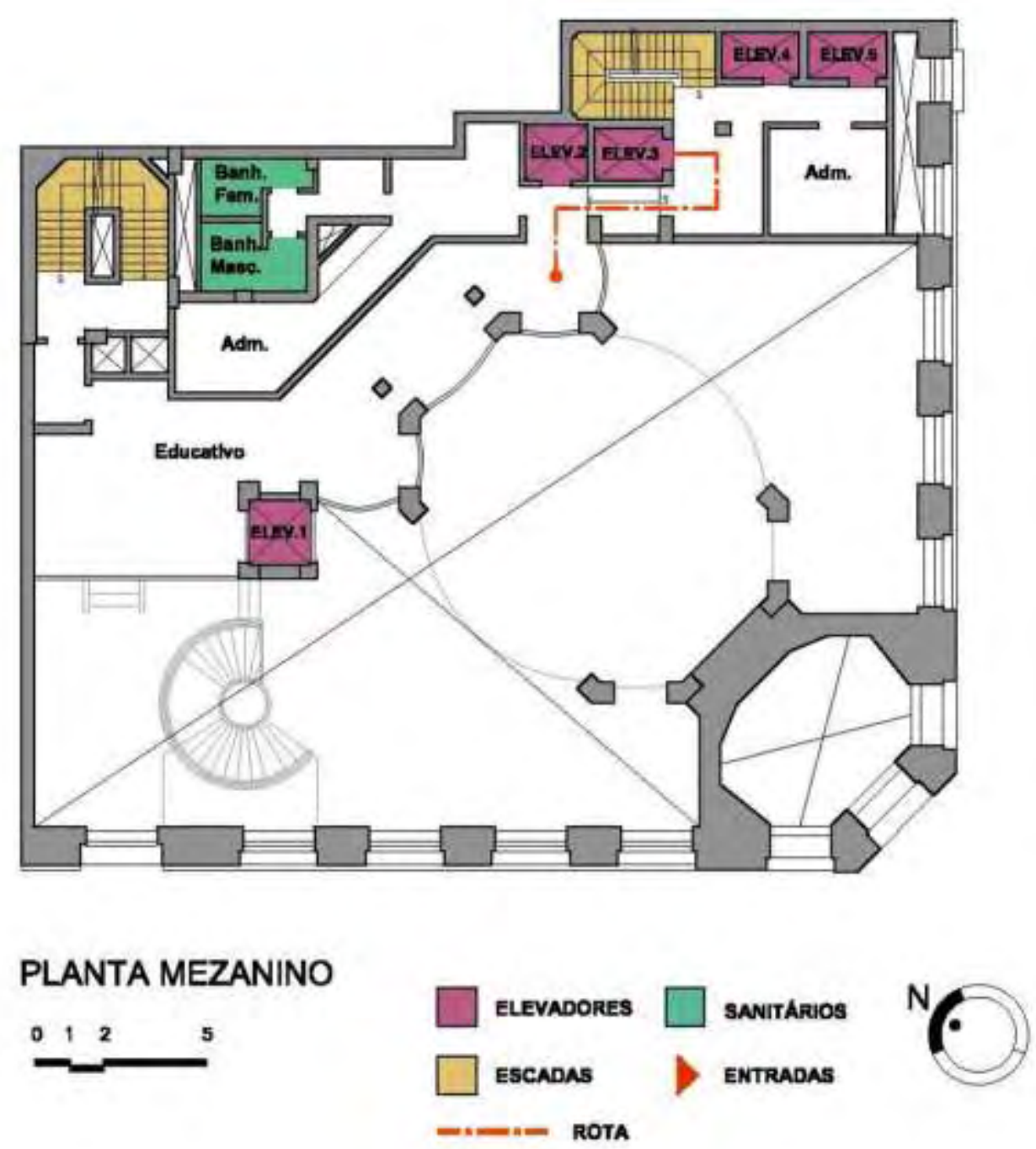

Figura 145 - Planta do mezanino. 


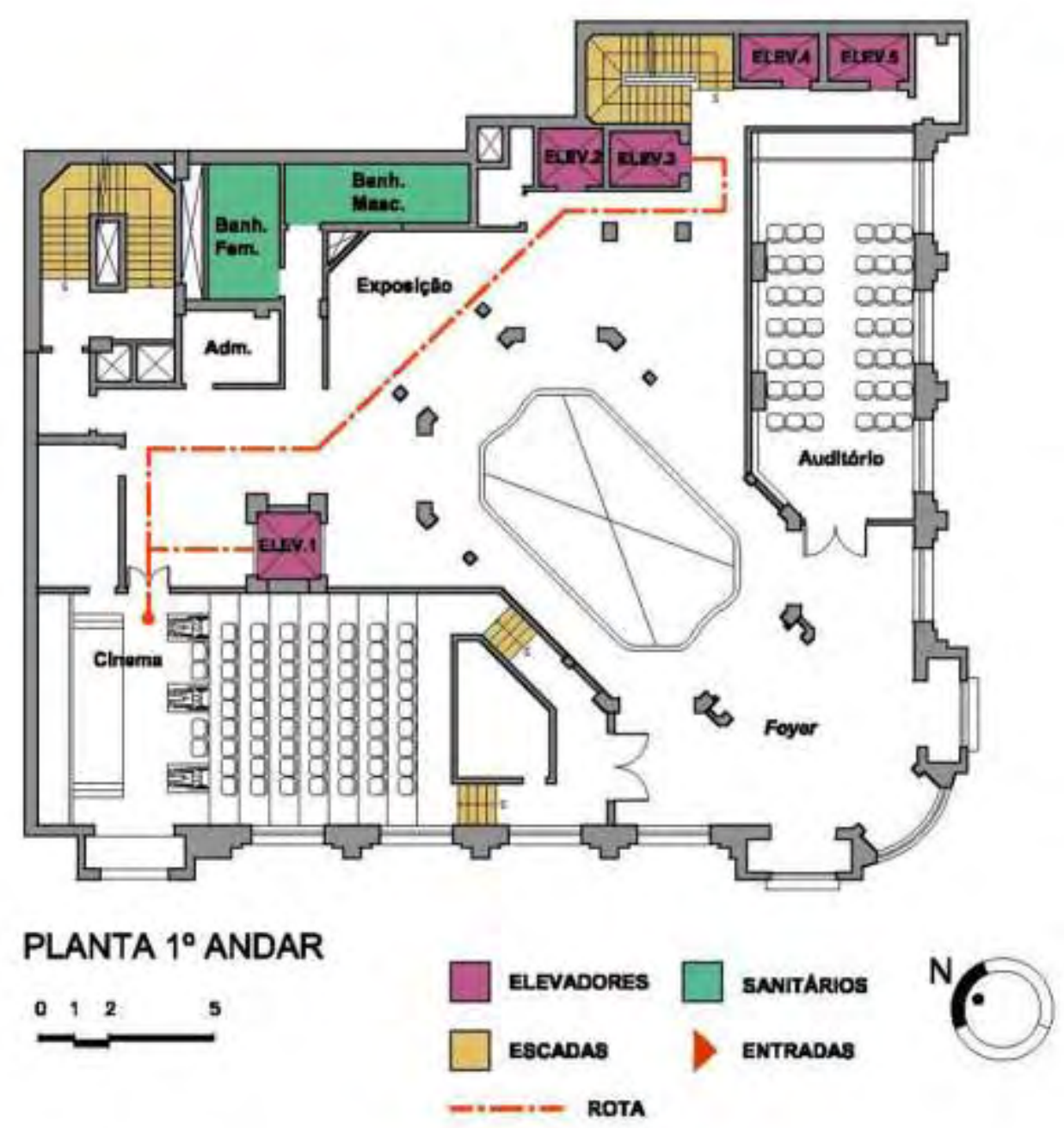

Figura 146 - Planta do 1 - pavimento. 


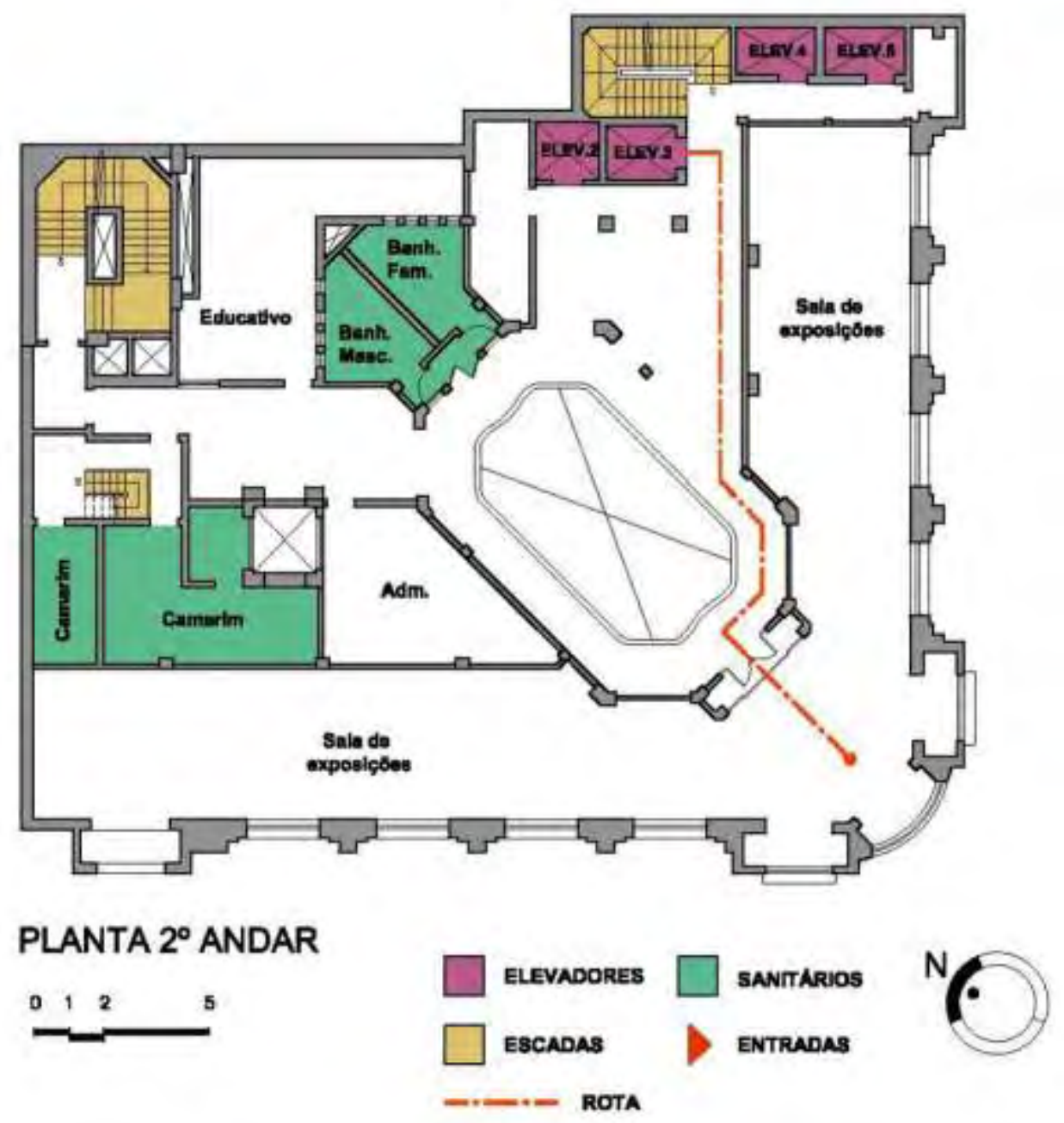

Figura 147 - Planta do 2 pavimento. 


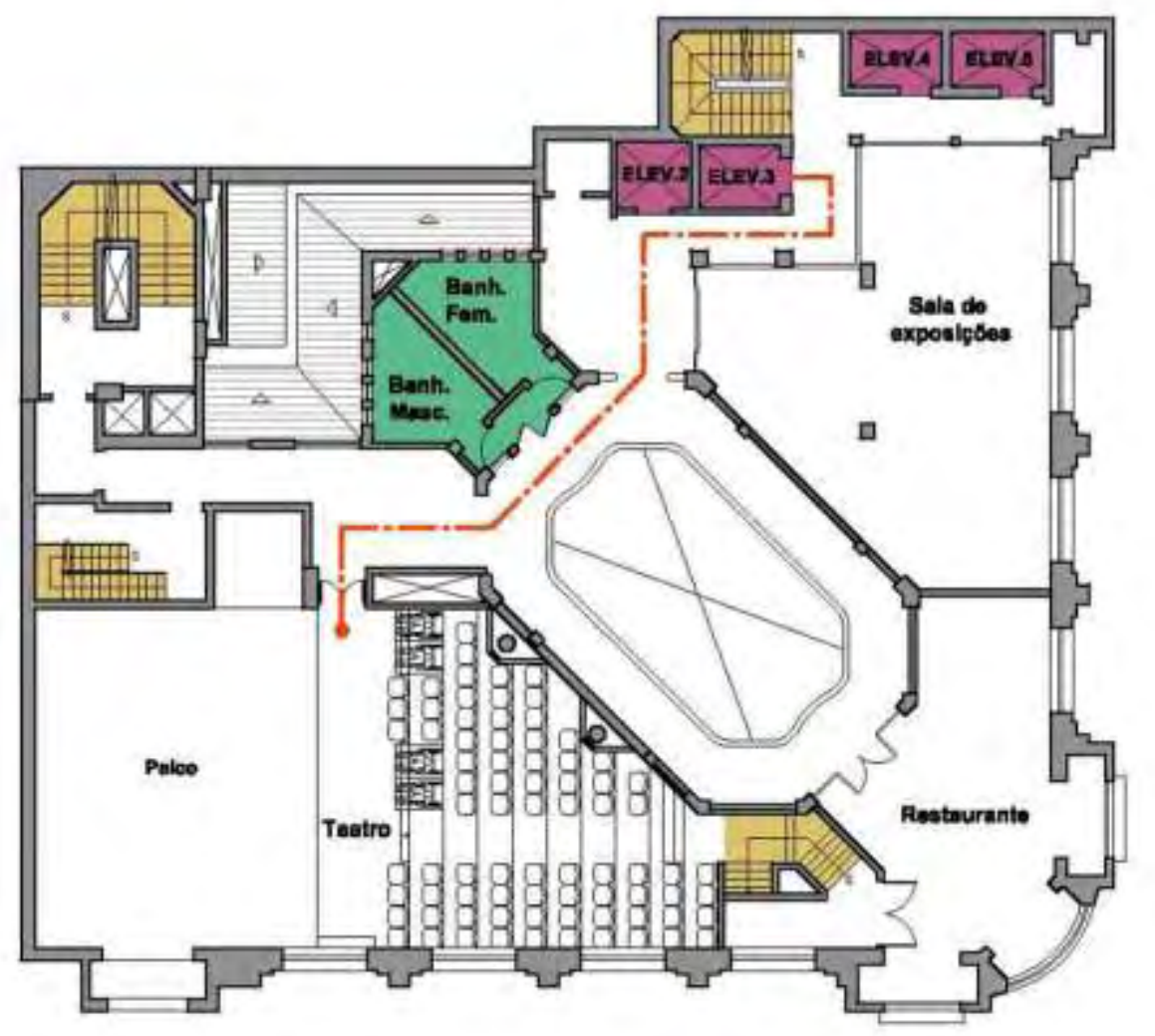

PLANTA $3^{\circ}$ ANDAR
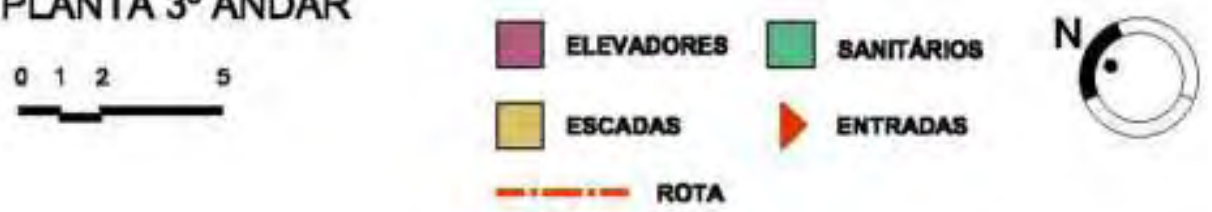

Figura 148 - Planta do 3 o pavimento. 


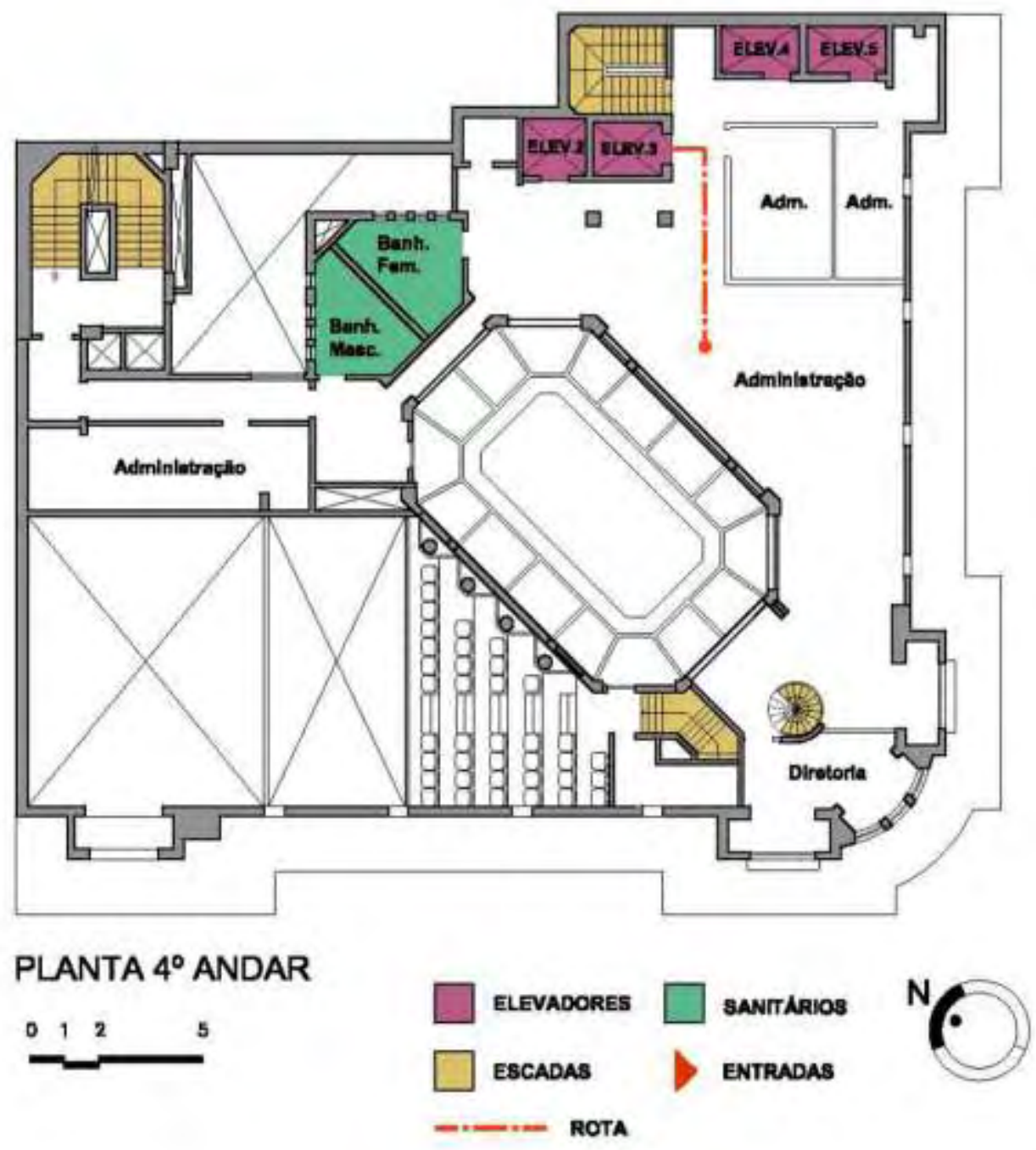

Figura 149 - Planta do 4ํ pavimento. 


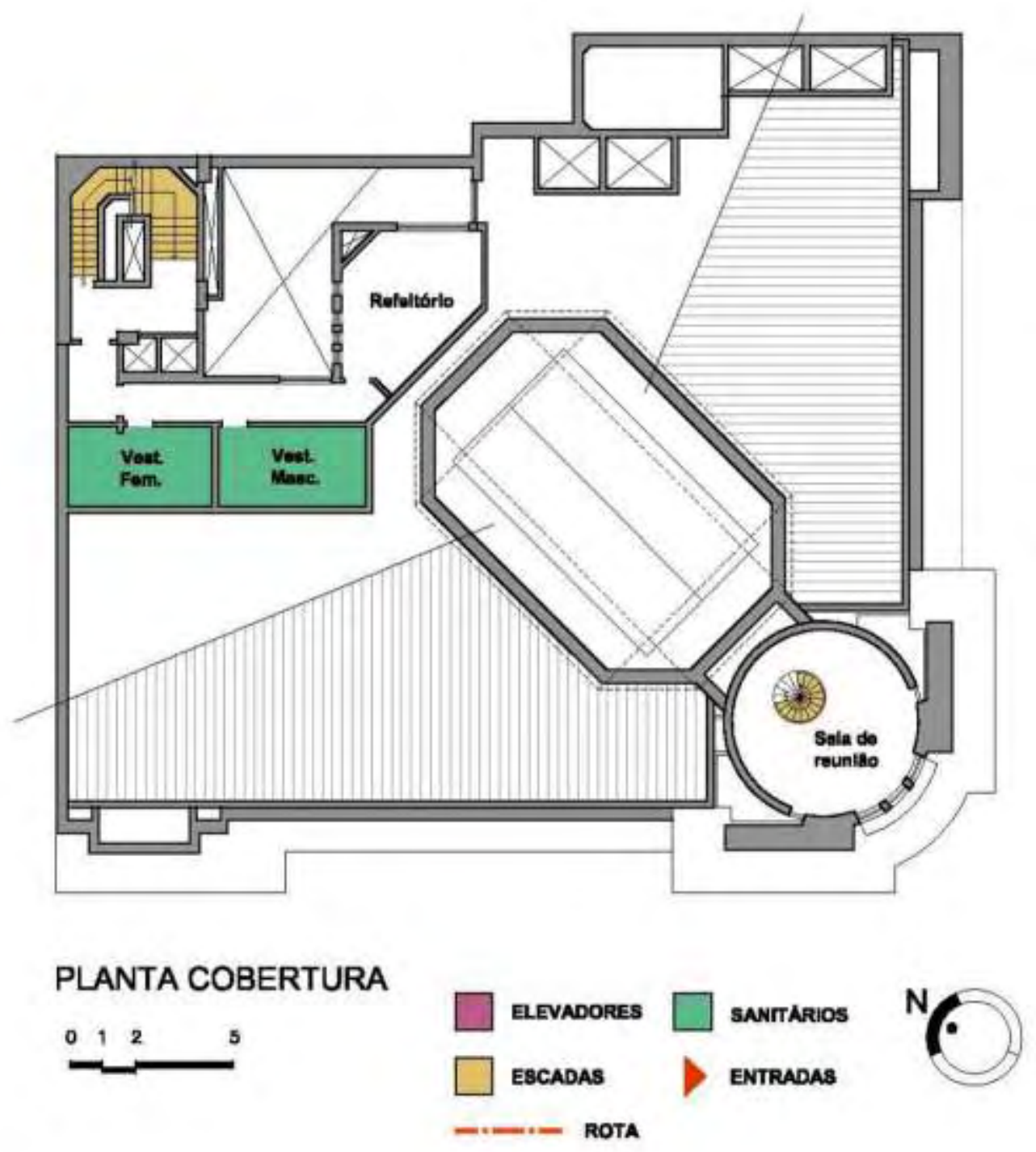

Figura 150 - Planta da cobertura. 


\subsection{Histórico}

Quase nada se sabe sobre o edifício na esquina da Rua Álvares Penteado com a Rua da Quitanda, antes que ele fosse transformado em agência do Banco do Brasil. O edifício de 1901 foi comprado pelo Banco do Brasil em 1923 para ser sua sede na capital paulista. Coube ao engenheiro-arquiteto Hippolyto Gustavo Pujol Júnior projetar a conversão do edifício em agência bancária, inaugurada em 1927.

Segundo os dados apurados pela historiadora Daisy de Camargo ${ }^{146}$, em especial no Arquivo Municipal Washington Luís, registrados no Processo de Tombamento do edifício, os projetos assinados pelo "Escriptorio Technico - Hippolyto Gustavo Pujol Júnior" são datados do ano de 1925. O memorial descritivo datado de 30 de julho de 1925, assinado pelo Diretor Técnico Frederico Reimann explica que dos edifícios existentes ${ }^{147}$ seriam aproveitados os muros externos e as fundações, sendo refeita a estrutura interna com a mesma quantidade de andares, para a nova agência projetada por Pujol Jr.

Inaugurada oficialmente em 10 de outubro de $1927^{148}$, a agência ocupava o subsolo, o térreo, o mezanino e o primeiro pavimento da seguinte forma: caixasfortes para uso do banco e para aluguel, localizados no subsolo; atendimento ao público no pavimento térreo; e áreas de uso mais restrito, como sala de reuniões,

\footnotetext{
${ }^{146}$ Processo de Tombamento Condephaat no 24084/1985, p. 67.

147 Os edifícios existentes são compostos pelo edifício em si e alguns anexos na parte posterior do lote, que podem ser observados na Figura 139: "O edifício projectado, a ser executado com aproveitamento parcial dos prédios existentes à esquina da Rua da Quitanda com a Rua Álvares Penteado e sob o no. 24 desta ultima Rua, destina-se à instalação da filial do BANCO DO BRASIL nesta capital".

${ }^{148}$ Apesar de algumas fontes, inclusive o Processo de Tombamento, indicarem esta como primeira agência do Banco do Brasil no estado, não foi possível verificar essa informação. O memorial descritivo do projeto de Pujol indica que ali seria a filial do Banco do Brasil. Pode se tratar talvez da primeira sede própria do Banco do Brasil na capital, mas não necessariamente a primeira agência.
} 
arquivos e diretoria, no primeiro andar; não relata o uso do mezanino. Os dois pavimentos superiores, foram usados como escritórios para locação, com entrada independente pela Rua da Quitanda.

A agência como foi projetada por Pujol Jr. funcionou até 1957, quando passou a ser utilizada pelo departamento de Administração do Patrimônio Imobiliário do banco, mantendo um posto bancário no térreo.

Em 1985, o Banco do Brasil contratou a empresa Interplanus para realizar projeto de reforma sem acréscimo de área no edifício. Ao ser analisado pela Secretaria Municipal de Planejamento, exigiu em "comunique-se"149 que o mesmo fosse submetido à análise do CONDEPHAAT, pois o edifício estava enquadrado na zona de uso Z8-200, com nível de proteção 1 (P1). Como resultado o CONDEPHAAT decidiu-se pela abertura de processo de tombamento.

A proposta de centro cultural só teria início em 1992 com o projeto concebido pelo escritório LT Arquitetura, comandado pelo arquiteto Luiz Benedito Castro Telles. O objetivo era reproduzir o sucesso ocorrido no centro cultural da mesma instituição no Rio de Janeiro, que contribuiu para a revitalização do centro histórico. Em 1996, os serviços restantes no edifício foram transferidos para a Rua Líbero Badaró, dando início ao desejado processo. No entanto, somente em junho 1999 o assunto do centro cultural tomaria fôlego definitivo com a reformulação do projeto pelo mesmo escritório de arquitetura.

Finalmente, em 21 de abril de 2001, no centenário da construção do edifício, era inaugurado o espaço, adequado à sua nova função, após minucioso trabalho de restauro e reforma, com grande respeito às características originais

\footnotetext{
${ }^{149}$ Aqui, refere-se a um tipo de comunicado oficial da Prefeitura, emitido após a análise do projeto, no qual solicita correções e medidas visando o atendimento às posturas municipais.
} 
primordiais e melhorias no quesito tecnológico. O projeto beneficiou-se das leis da Operação Urbana Centro ${ }^{150}$, que permitiu o aproveitamento do recuo dos fundos do lote para a ampliação da área construída de $3.600 \mathrm{~m}^{2}$ para $4.100 \mathrm{~m}^{2}$, diferença usada para acomodar a escada de incêndio e parte dos equipamentos de ar condicionado.

Em 2004, o Conselho de Defesa do Patrimônio Histórico, Arqueológico, Artístico e Turístico do Estado - CONDEPHAAT - tombou o edifício como bem cultural de interesse artístico, urbanístico, arquitetônico, histórico e turístico ${ }^{151}$, por seu valor documental da ocupação bancária na cidade de São Paulo, em especial no centro da cidade, concentração que ainda persiste.

\subsection{Características físicas}

O edifício de cinco andares, mais subsolo, mezanino e cobertura, em estrutura de concreto armado e alvenaria de tijolos, tem partido e implantação de inspiração francesa com esquina marcada por um torreão, de forma a destacar a entrada principal. Sua ornamentação é eclética, característica regularmente adotada nas construções paulistanas da época. Segundo o arq. Luiz Telles, a beleza de sua fachada deve ser atribuída à Pujol Jr., que não teria preservado nada do edifício de 1901, aproveitando apenas a estrutura como base para a sua obra. Telles, com base em estudos do conjunto da obra de Pujol Jr., percebeu vários elementos do prédio do Banco do Brasil presentes em outras de suas obras. E ainda afirma que, "O brasão do Banco do Brasil está em perfeita sintonia e coerência com os demais

${ }^{150}$ Lei municipal oㅜ 12.349, de 6 de junho de 1997.

${ }^{151}$ Ato oficializado pela Secretaria de Cultural, por meio da Resolução SC - 40 em 02 set. 2004, e publicada no Diário Oficial [do] Estado de São Paulo - Poder Executivo, São Paulo, SP, 14 set. 2004. Seção I, p. 75. 
elementos e não deve ter sido anexado décadas depois". Tudo isso faz acreditar que, o que deve ser preservado é o edifício criado pelo escritório de Pujol Jr. e não a construção de 1901, que serviu apenas de base para o edifício que hoje compõe a imagem da cidade na memória coletiva.

Segundo Segawa (1984, p. 53), a agência do Banco do Brasil na esquina das ruas Álvares Penteado e da Quitanda "adota uma solução de balcões periféricos com circulação pública central, ostentando um pé-direito avantajado e deslumbrantemente decorado".

No processo de estudo de tombamento foi relatado que o edifício se encontrava em bom estado de conservação, tanto interna como externamente, preservando suas características originais. Essa informação foi confirmada pelo engenheiro Joaquim Andrade Filho, gerente da Divisão de Obras do Banco do Brasil à época, afirmando que o maior problema durante o restauro foram as estruturas do prédio, que eram de pedra e tiveram de ser todas reforçadas (VESPUCCl; CICCACIO, 2001, p. 51).

O projeto de adequação ao novo uso foi bem ousado ao alterar o nível de parte do piso do pavimento térreo e ao criar uma escada helicoidal para acesso ao subsolo, eliminando a existente. De forma geral, foram preservadas fachadas, caixilhos, elementos decorativos, arandelas, serralherias e principalmente o saguão central. Com o objetivo de integrar os espaços dos usuários do centro cultural, conforme informações constantes no Processo de tombamento, a claraboia que se encontrava colocada entre $01^{\circ}$ e $02^{\circ}$ andares, foi cuidadosamente removida, restaurada e reposicionada pela Conrado Vitrais \& Cristais entre o $3^{\circ}$ e $04^{\circ}$ andares. Foi utilizada uma estrutura de perfis metálicos revestida com gesso para apoiar a claraboia, por ser menor do que o vazio central do $4^{\circ}$ andar. A Conrado Vitrais \& 
Cristais instalou os vitrais originais em 1927 e realizou o restauro em 1984.

O elevador que interliga o subsolo ao $1^{\circ}$ andar (Elevador 1$)$ foi restaurado, e suas portas pantográficas originais preservadas, como referência histórica. Esse elevador é a única forma de acesso ao subsolo pelos usuários de cadeira de rodas.

Há, hoje, outros quatro elevadores, três deles com fossos existentes antes da reforma de 2001 (Elevadores 2, 4 e 5). Esses elevadores foram substituídos por novos equipamentos ou modernizados, conforme a necessidade. Um deles foi destinado ao uso exclusivo de funcionários (Elevador 5). E para garantir a rota acessível entre o térreo e o $4^{\circ}$ pavimento foi inserido um novo elevador (Elevador 3), com as características dimensionais necessárias, para uso de pessoas com deficiência.

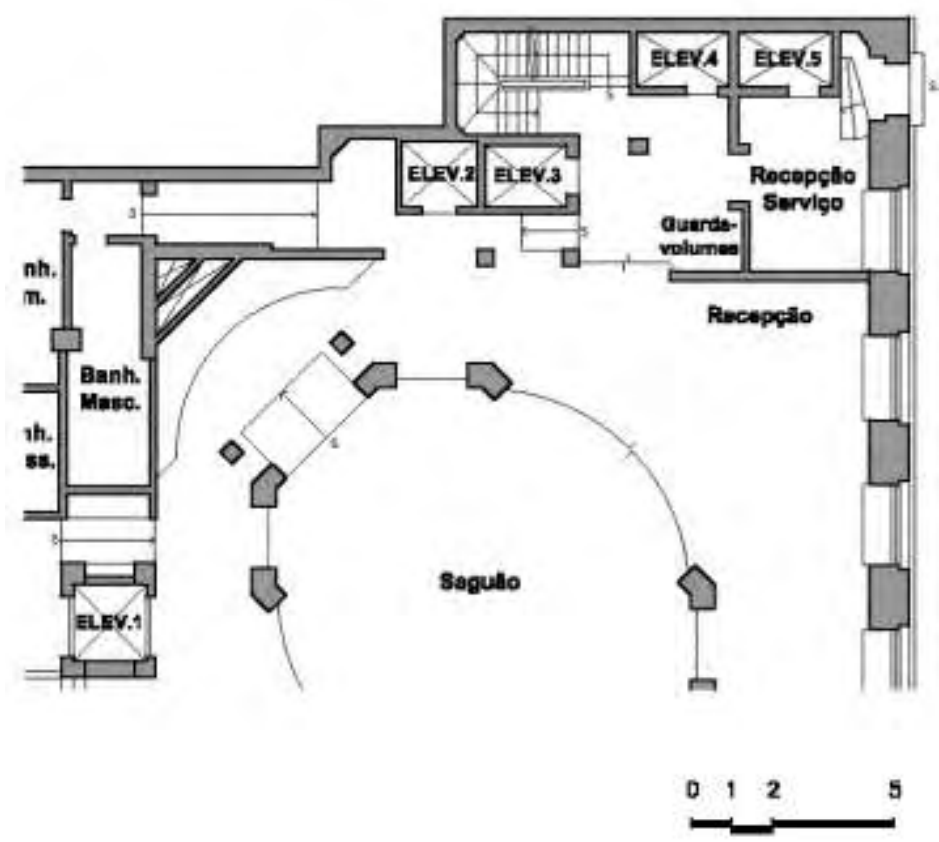

Figura 151 - Planta parcial do pav. térreo: elevadores. 


\subsection{Estado de conservação e preservação do patrimônio}

Por seu uso e administração o edifício se mantém bastante conservado, sem apresentar patologias aparentes. Sua manutenção é constante. Como às segundas o centro cultural não abre ao público, semanalmente a equipe de manutenção entra em cena para realizar qualquer serviço necessário. O processo contínuo de cuidados com o edifício, aliado ao fato de estar distante de rota de tráfego intenso de veículos ${ }^{152}$, faz com que o edifício se mantenha conservado sem necessidade de intervenções de grande escala.

E pouco foi alterado das áreas abertas ao público desde a obra de restauro.

\subsection{Programas de atendimento às pessoas com deficiência}

O centro cultural mantém intensa programação de atividades voltadas ao público que frequenta a região central ou que vêm de outras áreas da cidade, especialmente para apreciar exposições de importantes artistas plásticos, peças de teatro, filmes, espetáculos de dança, workshops e oficinas.

Em 2010 foi criado dentro do programa do Educativo do CCBB o Grupo de Pesquisa em Acessibilidade, que busca pesquisar e desenvolver propostas para o público com deficiência, procurando envolver os outros grupos de pesquisa (grupos de Música, Cênicas, Artes Visuais e Patrimônio) para que as propostas de visitas e atividades explorem diversas possibilidades sensoriais, segundo informou a arte-educadora Maryana Rela.

\footnotetext{
${ }^{152}$ No calçadão de pedestres há restrição de tráfego de veículos, contudo alguns veículos circulam todos os dias, como carros para recolhimento de lixo, carros-fortes e carros oficiais.
} 
Importante iniciativa que merece destaque é a Semana de Acessibilidade, realizada anualmente, com programação inteiramente acessível (no que concerne às atividades do Educativo), com Laboratórios de Ações Criativas inclusivos e voltados para público com deficiência e agendamento de horários exclusivos para instituições que atendem pessoas com deficiência. Neste momento também ocorrem palestras sobre o tema com profissionais de diversas áreas, voltados ao público em geral.

Entre as atividades que ocorrem regularmente há contação de histórias em Libras ("Em cantos e contos em Libras"). Essa atividade procura atender não só as crianças surdas, mas também ouvintes. A educadora surda conta histórias em Libras relacionadas às exposições e um intérprete de Libras traduz as histórias para o português. A visita sensorial voltada para cegos também tem caráter inclusivo: o público é convidado a tocar o prédio e explorar sua história e detalhes arquitetônicos, ao mesmo tempo em que o educador fornece detalhes e informações. Há material tátil específico para a visita, e o público vidente poderá tanto utilizar vendas quanto exercer a função de guia. Há outros materiais para serem distribuídos ao público, escritos em braile e também em fonte ampliada, que descrevem detalhes arquitetônicos. Para as visitas mediadas às exposições e ao edifício, o centro cultural dispõe de uma educadora surda e um intérprete fluente em Libras (disponíveis em horários específicos) bem como materiais táteis e sensoriais.

A arte-educadora conta que a intenção é propor que todas as pessoas possam explorar todos os sentidos, não se restringindo os recursos e atividades somente às pessoas com deficiência. Além disso, valorizam a convivência de pessoas com diferentes deficiências e sem deficiência, com o intuito de encurtar distâncias e promover o convívio com a diversidade. E ela ainda salienta que boa 
parte desse público não está acostumada a ter programações culturais preparadas para recebê-los. Quando recebem crianças surdas, muitas se surpreendem em ver que há uma educadora também surda, o que promove identificação.

\subsection{Análise técnica da acessibilidade}

Em visitas técnicas ocorridas em 31 de julho de 2009, 21 de novembro de 2011, 06 e 15 de dezembro de 2011, foi verificado o atendimento às leis e normas de acessibilidade do edifício ocupado pelo CCBB. Quando necessário serão realizados comparativos com legislação à época da reforma, para melhor embasar as condições encontradas.

A administração do Centro Cultural do Banco do Brasil permitiu a visita ao local para realizar medições e fotos, porém restrita às áreas destinadas ao público, mesmo após ser explicada a importância de avaliar a acessibilidade de forma integral. Portanto, não fazem parte desta avaliação áreas restritas aos funcionários como salas de trabalho, reunião, refeitório, sanitários, vestiários, escadas de emergência e camarins.

\subsubsection{Passeios}

Por estar localizado no calçadão da área central, só existe acesso para pedestres $^{153}$. O calçadão tem seu piso composto por placas de granito e pedras

\footnotetext{
${ }^{153}$ Apenas os carros de carga e descarga, coleta de lixo, transporte de valores e carros autorizados têm permissão da Companhia de Engenharia de Tráfego para trafegar no calçadão de pedestres.
} 
portuguesas brancas formando desenhos geométricos ${ }^{154}$. Os materiais apresentamse irregulares, trepidantes e escorregadios ${ }^{155}$ para a circulação de pedestres.
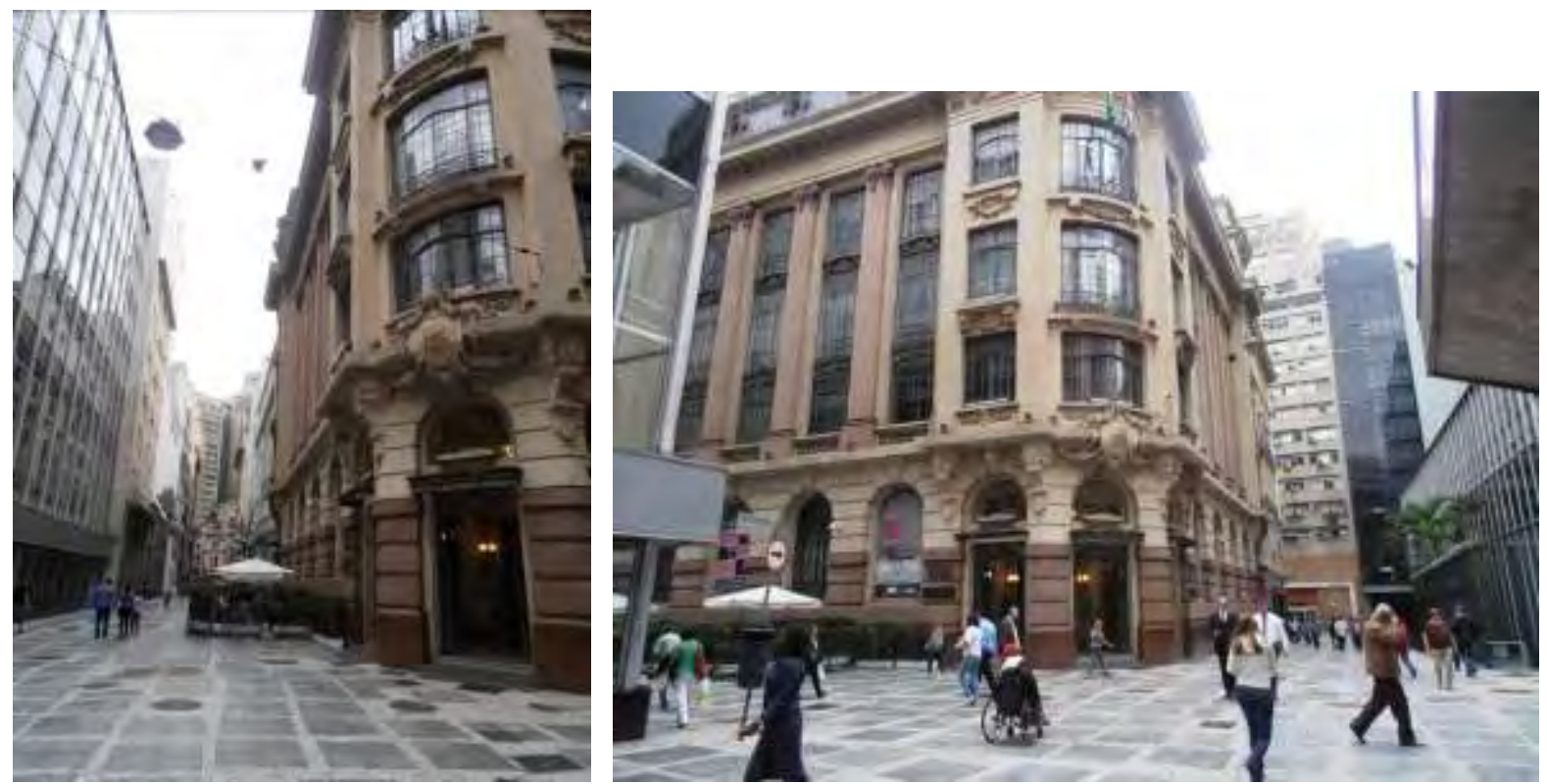

Figuras 152 e 153 - Calçadão das ruas Álvares Penteado e da Quitanda. 2011.

\subsubsection{Estacionamento}

Por estar localizado no calçadão central onde não há trânsito de carros, o

CCBB não possui estacionamento próprio.

\subsubsection{Entradas e saídas}

O centro cultural tem duas entradas para visitantes, uma delas acessível, e uma terceira destinada aos funcionários.

A entrada principal, que fica exatamente na esquina das ruas Álvares

\footnotetext{
154 Segunda matéria publicada na p. 12 da edição de 17 dez. 1976 do jornal Folha de S. Paulo, o projeto do calçadão foi executado de fev. a dez. de 1976, no governo do prefeito Olavo Setúbal, totalizando 3.350 metros de extensão, nos centros Velho e Novo. O contexto histórico em que essa reurbanização está inserida faz crer que não houve qualquer preocupação com a acessibilidade, na escolha dos materiais.

${ }^{155}$ Não atende ao disposto na ABNT NBR 9050/2004 - item 6.1.1 e no art. 29 do Decreto municipal no $45.904 / 2005$.
} 
Penteado e da Quitanda, não é acessível. Esta entrada possui três aberturas, igualmente compostas por dois degraus cada. Esses degraus não possuem faixas contrastantes $^{156}$ pisos táteis de alerta ${ }^{157}$ e $\operatorname{corrimãos}^{158}$, prejudicando a segurança, principalmente do público idoso.

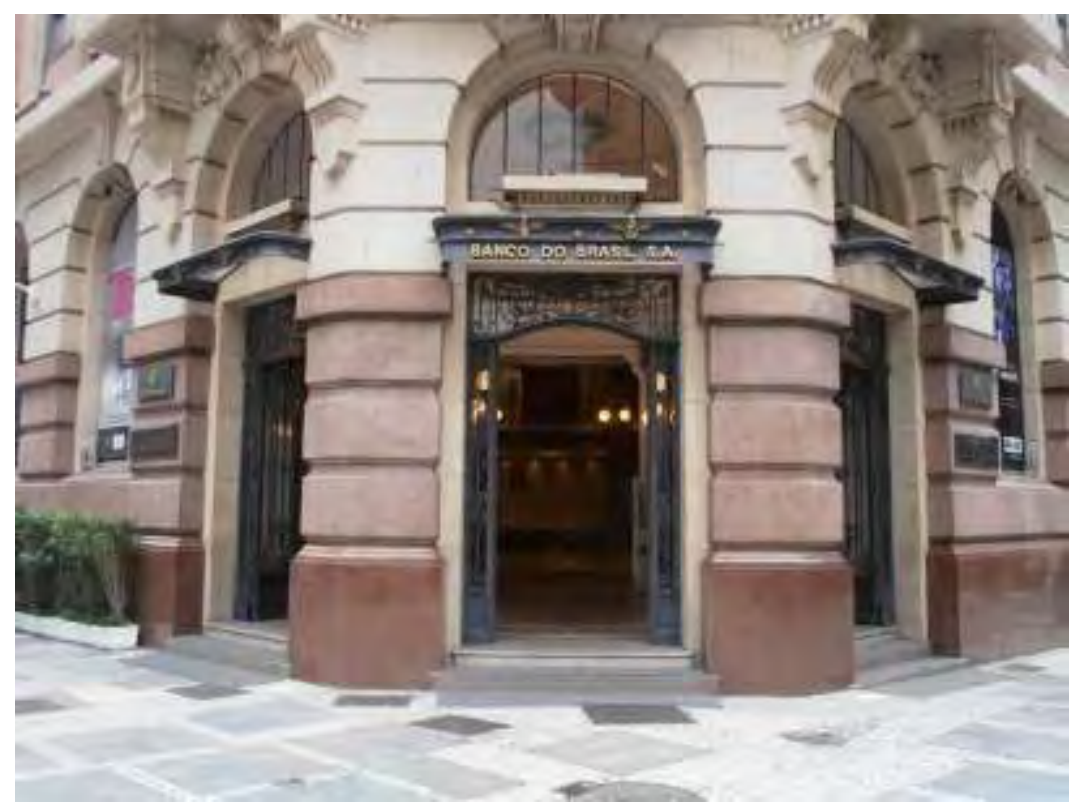

Figura 154 - Entrada principal. 2011.

Uma entrada lateral, na Rua Álvares Penteado, também destinada ao público, não possui desnível, pois foi levemente alterado o nível do calçadão para criar o acesso destinado às pessoas com deficiência

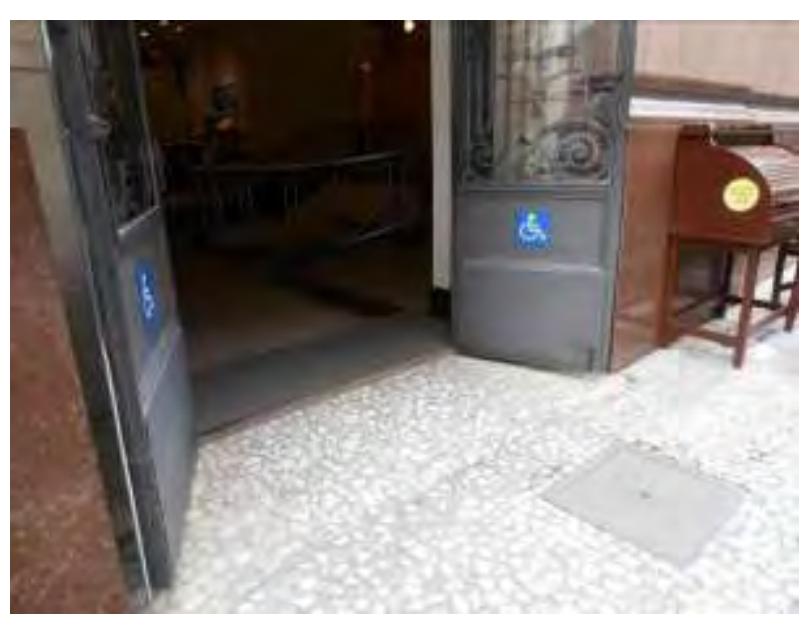

Figura 155 - Entrada acessível. 2011.

\footnotetext{
${ }^{156}$ Não atende ao disposto na ABNT NBR 9050/2004 - item 5.13.

${ }^{157}$ Não atende ao disposto na ABNT NBR 9050/2004 - item 5.14.1.2.

${ }^{158}$ Não atende ao disposto na ABNT NBR 9050/2004 - item 6.7.1.1.
} 
A terceira entrada, localizada na Rua da Quitanda, é utilizada pelos funcionários. Às segundas-feiras, quando o centro cultural não funciona, esta é a única entrada disponível. Esta entrada não possui condição de acesso, pois a porta é seguida por um percurso com seis degraus, e o seu interfone fica fora do alcance manual.

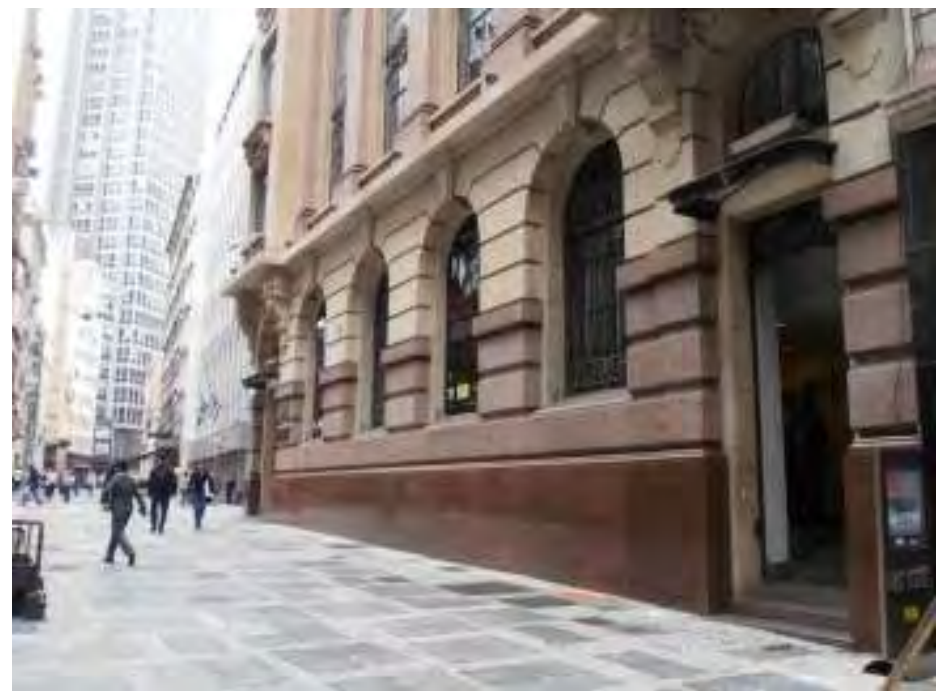

Figura 156 - Entrada de serviço na Rua da Quitanda. 2011.

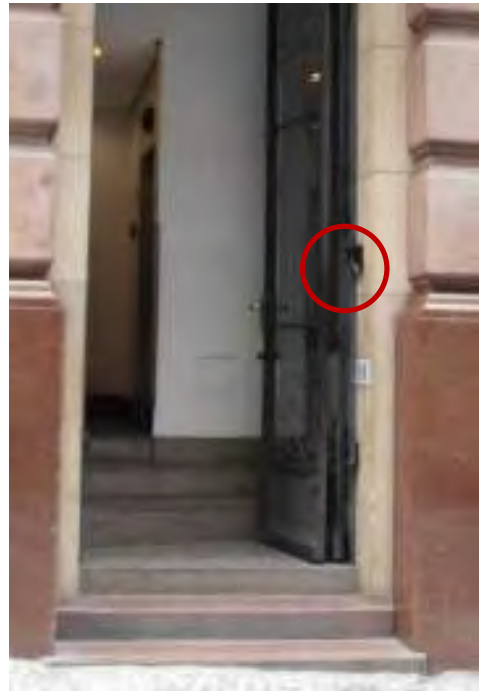

Figura 157 - Entrada de serviço: detalhe para o interfone. 2011.

As portas de acesso para visitantes são bastante amplas, compostas por duas folhas de $0,75 \mathrm{~m}$ cada, porém esta medida é menor que o exigido ${ }^{159}$. Ao menos uma das folhas da porta deve ter vão livre mínimo de $0,80 \mathrm{~m}$, pois como referencial a cadeira de rodas é representada pelo módulo de referência (MR) de $0,80 \mathrm{~m}$ de largura por $1,20 \mathrm{~m}$ de comprimento ${ }^{160}$. Durante o funcionamento do Centro Cultural as portas permanecem abertas. No entanto, já foram verificadas vezes em que a entrada da Rua Álvares Penteado estava com uma das folhas fechadas.

\footnotetext{
${ }^{159}$ Não atende ao disposto na ABNT NBR 9050/2004 - item 6.9.2.1.

${ }^{160}$ O item 4.2.2 da ABNT NBR 9050/2004 demonstra a projeção do espaço utilizado por uma cadeira de rodas.
} 


\subsubsection{Circulação interna}

As circulações de todos os pavimentos abertos ao público, de forma geral, são amplas. Apenas alguns corredores são um pouco mais estreitos, porém sempre garantindo o acesso e circulação de pessoas com os mais diversos equipamentos auxiliares.

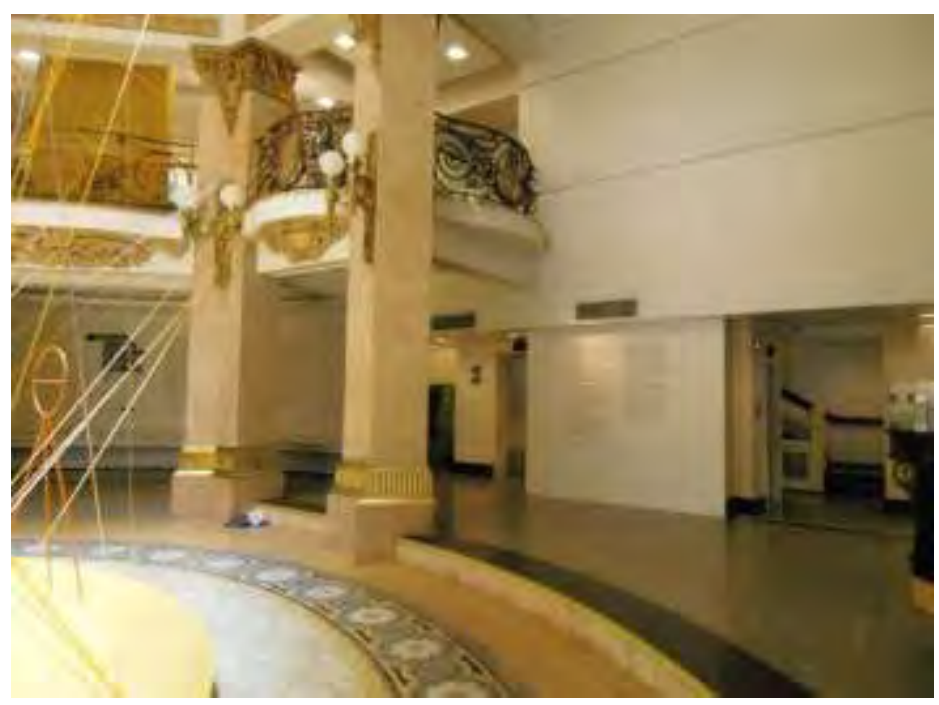

Figura 158 - Exemplo de circulação no pav. térreo. 2011.

A partir da entrada acessível, uma sequência de duas rampas permite que a pessoa em cadeira de rodas chegue ao saguão central, no pavimento térreo. Outra rampa interliga o nível superior do saguão e o hall no qual está localizado parte da circulação vertical. Mais uma rampa interliga o átrio com a circulação do sanitário acessível. Essas quatro rampas são utilizadas para vencer diversos desníveis e permitir a circulação em todas as partes do pavimento. A rampa de interligação

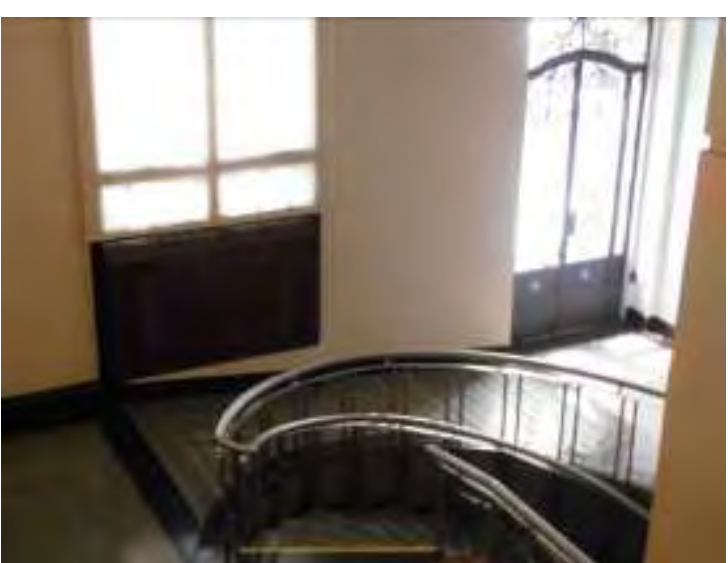

Figura 159 - Rampa próxima à entrada acessível. 2011. 
entre sanitário acessível e o saguão é na realidade um plano inclinado, bastante suave $^{161}$ e, portanto não necessita de piso tátil de alerta e corrimão, pois são exigências para rampas com inclinação longitudinal superior a $5 \%$. As demais rampas estão

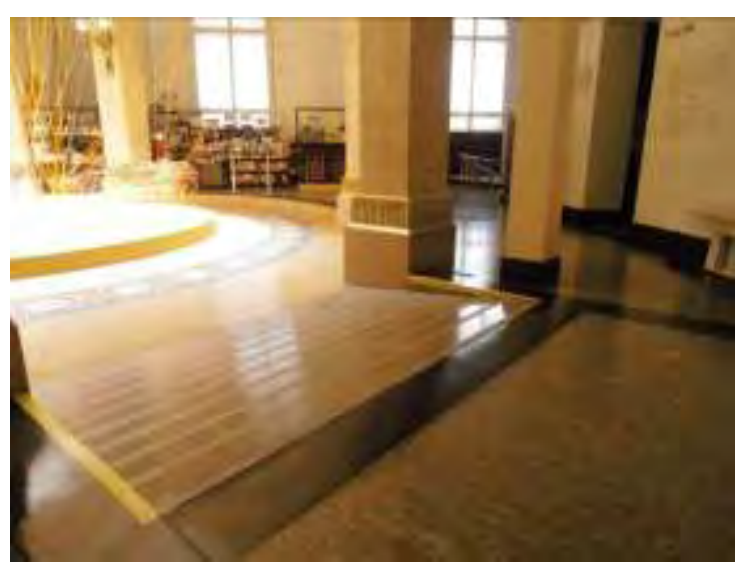

Figura 160 - Rampa de acesso ao saguão central. 2011.

incorretas por não possuírem

corrimãos $^{162}$ nem pisos táteis de alerta $^{163}$. Além disso, a rampa próxima à entrada para vencer desnível de $0,18 \mathrm{~m}$ tem inclinação aproximada de $12 \%$, que é acima do permitido até mesmo para uma reforma ${ }^{164}$.

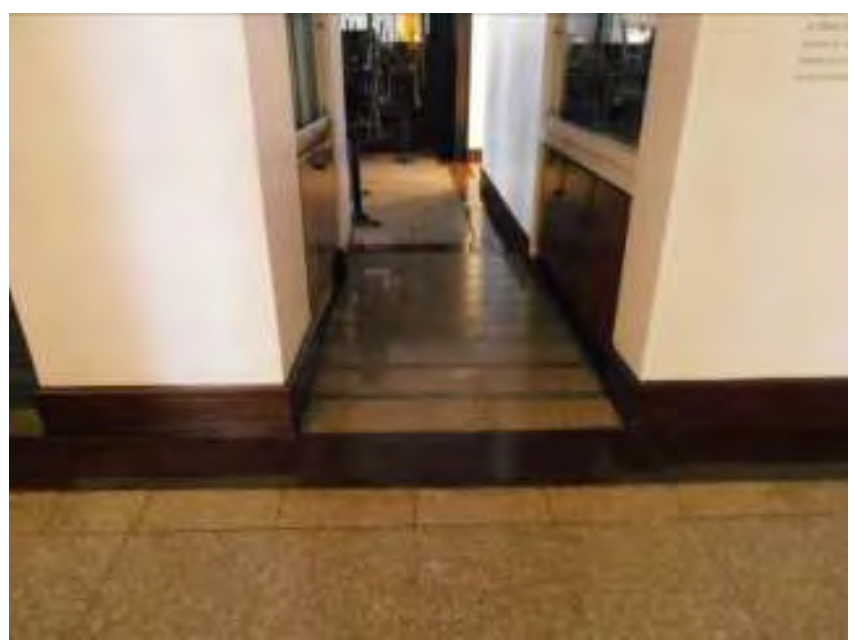

Figura 161 - Plano inclinado no acesso ao banheiro acessível. 2011.

\footnotetext{
${ }^{161}$ Atende ao disposto na ABNT NBR 9050/2004 - item 6.1.1, pois "Admite-se [...] inclinação longitudinal máxima de $5 \%$. Inclinações superiores a $5 \%$ são consideradas rampas e, portanto, devem atender a 6.4". Ou seja, apenas inclinações acima de $5 \%$ necessitam serem sinalizadas com piso tátil de alerta e ter corrimão de apoio.

${ }^{162}$ Não atende ao disposto na ABNT NBR 9050/2004 - item 6.7.1.1.

${ }^{163}$ Não atende ao disposto na ABNT NBR 9050/2004 - item 5.14.1.2.

${ }^{164}$ Não atende ao disposto na ABNT NBR 9050/2004 - item 6.5.1.3.
} 


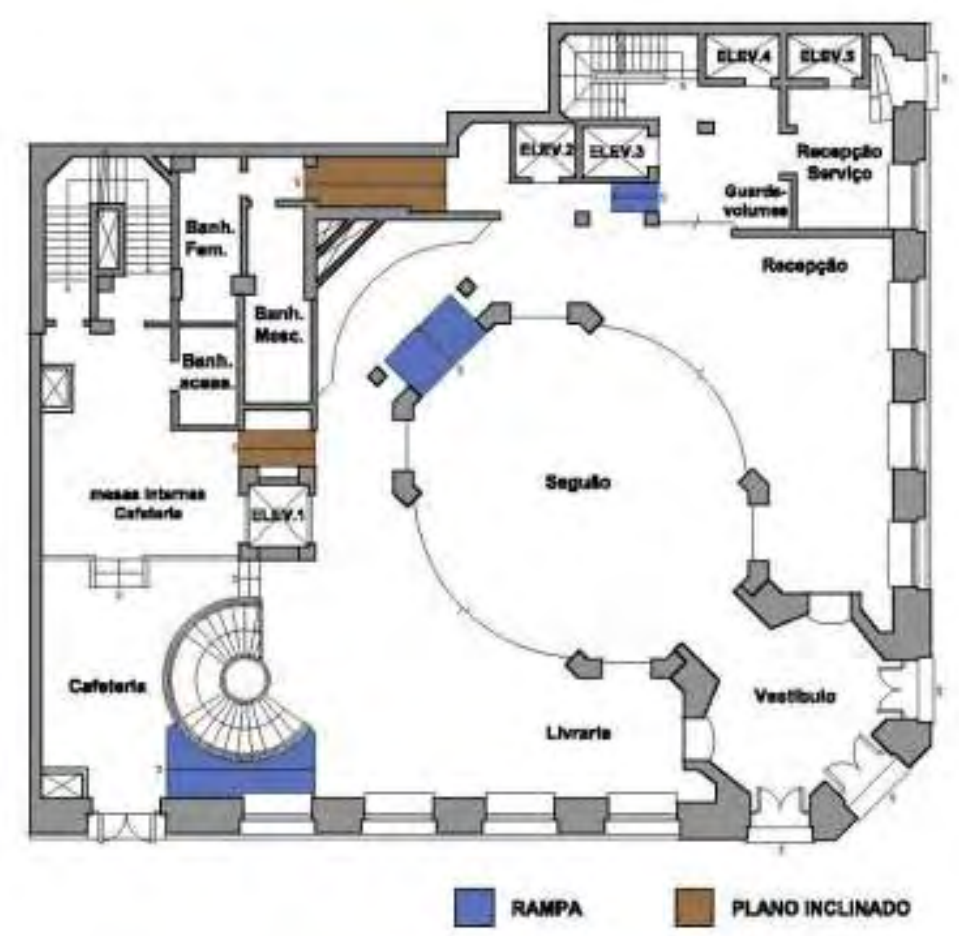

Figura 162 - Identificação das rampas e planos inclinados no pav. térreo. 2011.

Assim, no pavimento térreo, a circulação da pessoa usuária de cadeira de rodas está garantida através dessas rampas, que interligam as áreas de atendimento, exposição, sanitário, telefone e elevadores: sempre há uma rampa que permita circular pelas áreas com desnível de piso. Entretanto, algumas pessoas podem necessitar ser assistidas para vencer a rampa mais inclinada e, portanto a autonomia fica comprometida ${ }^{165}$.

Os corrimãos existentes nas escadas e degraus no térreo estão em altura correta $^{166}$ e prolongamento menor até mesmo que $0,10 \mathrm{~m}^{167}$ em alguns casos. Quanto à espessura, o corrimão da escada helicoidal e dos degraus próximos às

\footnotetext{
${ }^{165}$ Como já visto, a ABNT NBR 9050/2004 define acessibilidade, como "Possibilidade e condição de alcance, percepção e entendimento para a utilização com segurança e autonomia de edificações, espaço, mobiliário, equipamento urbano e elementos" [grifo nosso].

${ }^{166}$ Atende ao disposto na ABNT NBR 9050/2004 - item 6.7.1.6.

${ }^{167}$ Não atende ao disposto na ABNT NBR 9050/2004 - item 6.7.1.4. O prolongamento de 0,10m é permitido apenas para edificações existentes onde for impraticável o prolongamento de $0,30 \mathrm{~m}$. As escadas no pavimento térreo são novas inserções em uma edificação existente.
} 
mesas internas da cafeteria tem espessura maior que $4,5 \mathrm{~cm}$, máximo permitido ${ }^{168}$. E a escada de circulação do público, do térreo ao $4^{0}$ pavimento, possui corrimão apenas de um dos lados ${ }^{169}$, com espessura adequada. Do outro lado há apenas o guarda-corpo original, que é inadequado como corrimão de apoio.

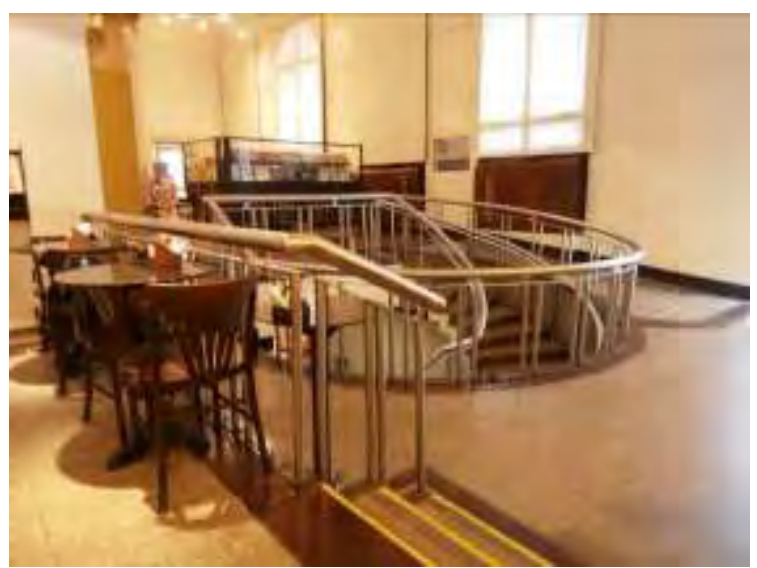

Figura 163 - Exemplos de corrimãos inadequados. 2011.

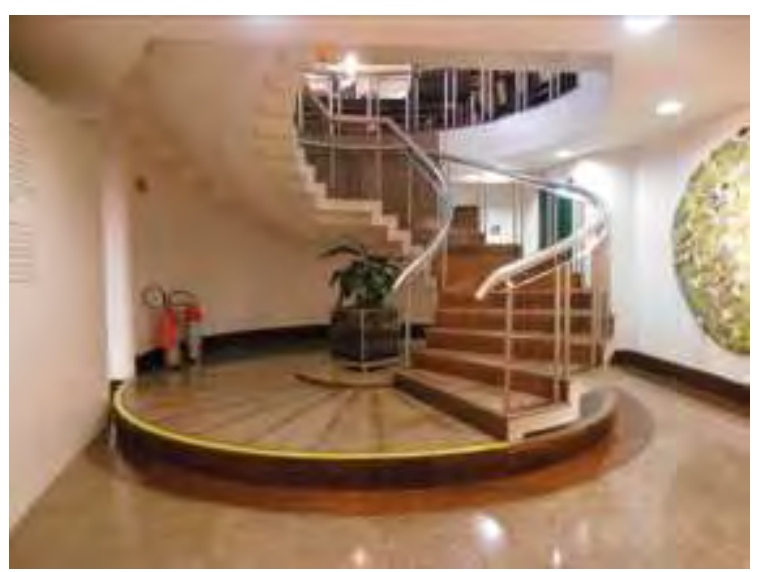

Figura 164 - Escada com prolongamento menor. 2011.

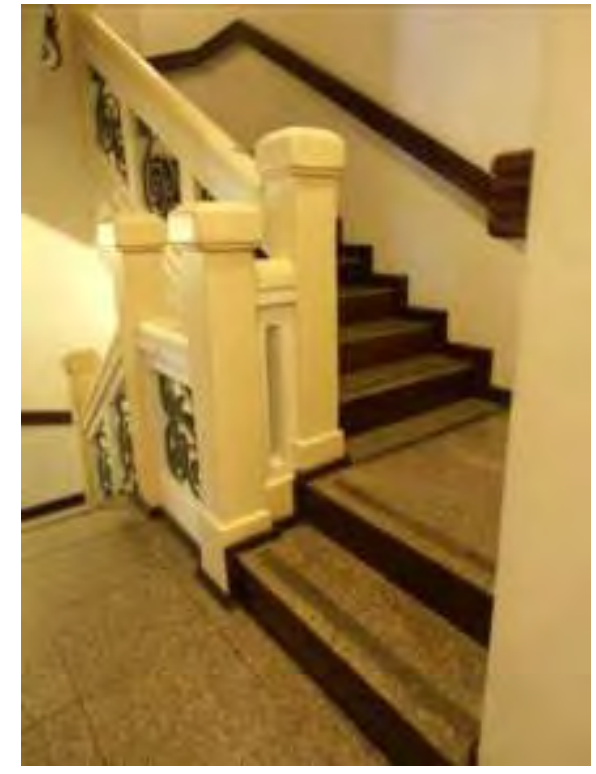

Figura 165 - Escada de circulação do público. 2011.

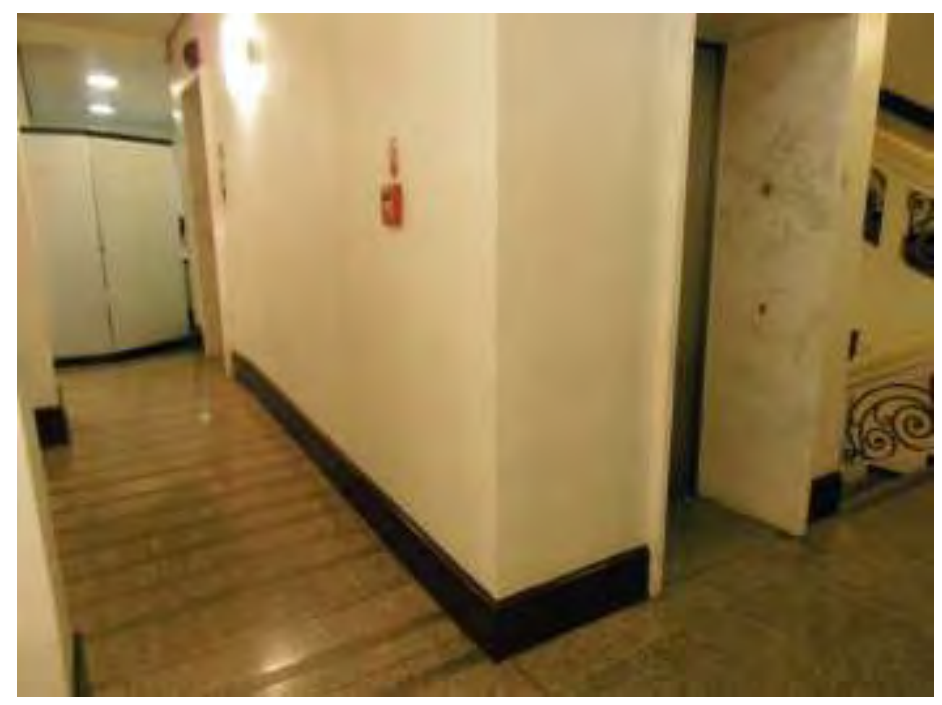

Figura 166 - Plano inclinado no mezanino. 2011.

\footnotetext{
${ }^{168}$ Não atende ao disposto na ABNT NBR 9050/2004 - item 6.7.1.2.

${ }^{169}$ Não atende ao disposto na ABNT NBR 9050/2004 - item 6.7.1.1.
} 
Além do pavimento térreo, apenas no mezanino há uma rampa suave na circulação entre elevadores e área para as atividades do educativo. Nos demais pavimentos não há desníveis no piso que precisem ser vencidos por rampas.

No subsolo o acesso das pessoas com deficiência ou mobilidade reduzida ocorre de forma diferente dos demais visitantes, que utilizam apenas a escada helicoidal. Como já dito, o acesso é feito pelo elevador original (Elevador 1) e a saída para o andar encontra-se na lateral da área de exposições, próxima à saída de emergência e, portanto é necessário passar por uma porta corta-fogo ${ }^{170}$. Esse elevador tem porta pantográfica e seu funcionamento sempre acontece com o auxílio de ascensorista ${ }^{171}$, para garantir a segurança dos usuários.

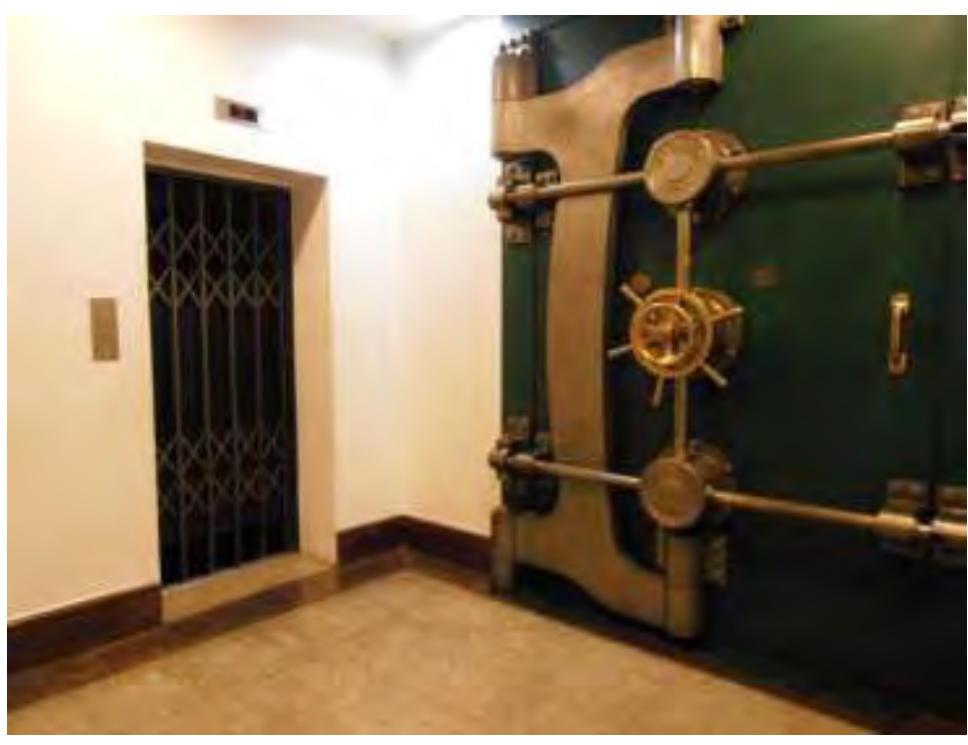

Figura 167 - Elevador de porta pantográfica para acesso ao subsolo. 2011.

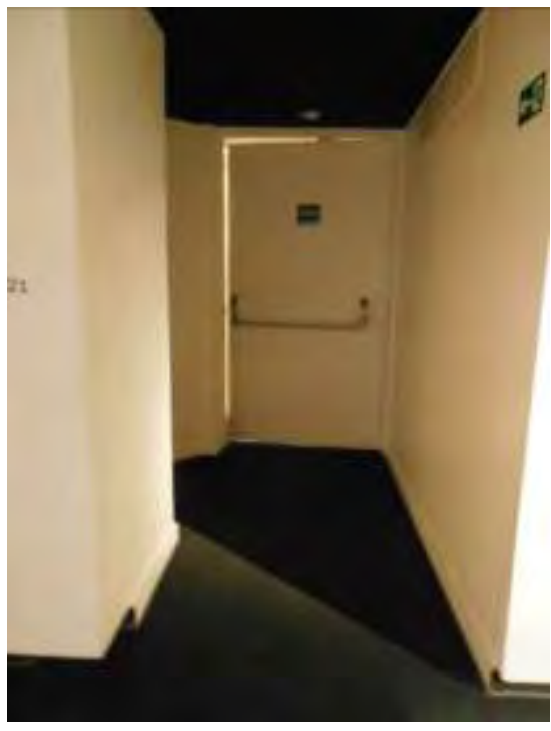

Figura 168 - Porta corta-fogo entre elevador e área de exposições. 2011.

A parte central do subsolo é o antigo cofre do banco. Existe um desnível em decorrência das soleiras das portas do cofre, existente por conta da vedação

${ }^{170}$ Como qualquer porta corta-fogo ela é pesada e pode dificultar o manuseio com autonomia, por exigir maior esforço físico.

${ }^{171}$ Apesar de a ABNT NM 313/2007, norma atualmente em vigor para elevadores nada dizer sobre o uso de portas pantográficas, fica subentendido no item 5.2.3 que este tipo não seria adequado, pois não garante autonomia e não tem funcionamento automático. A ABNT NBR 13994 nas versões 1997 e 2000, no item 5.2.4.1, diz que portas pantográficas são proibidas para elevadores acessíveis. A ABNT NM 313/2007 por ser posterior, não foi a norma utilizada como referência para a adequação deste edifício. 
necessária ao uso original do espaço. Externamente o piso é todo rampeado em frente às duas portas. E, internamente, rampas são usadas para vencer o desnível e permitir o acesso, a este ambiente que também recebe exposições. A rampa interna tem inclinação acentuada, e não possui corrimão ou piso tátil de alerta. A ausência de patamar com $1,20 \mathrm{~m}$ de comprimento entre as duas rampas, faz com que ao chegar ao fim da rampa subindo, já há outra rampa descendo, o que pode prejudicar o controle da cadeira de rodas. Portanto, o acesso a esse ambiente está condicionado à ajuda de alguém que conduza a cadeira de rodas.

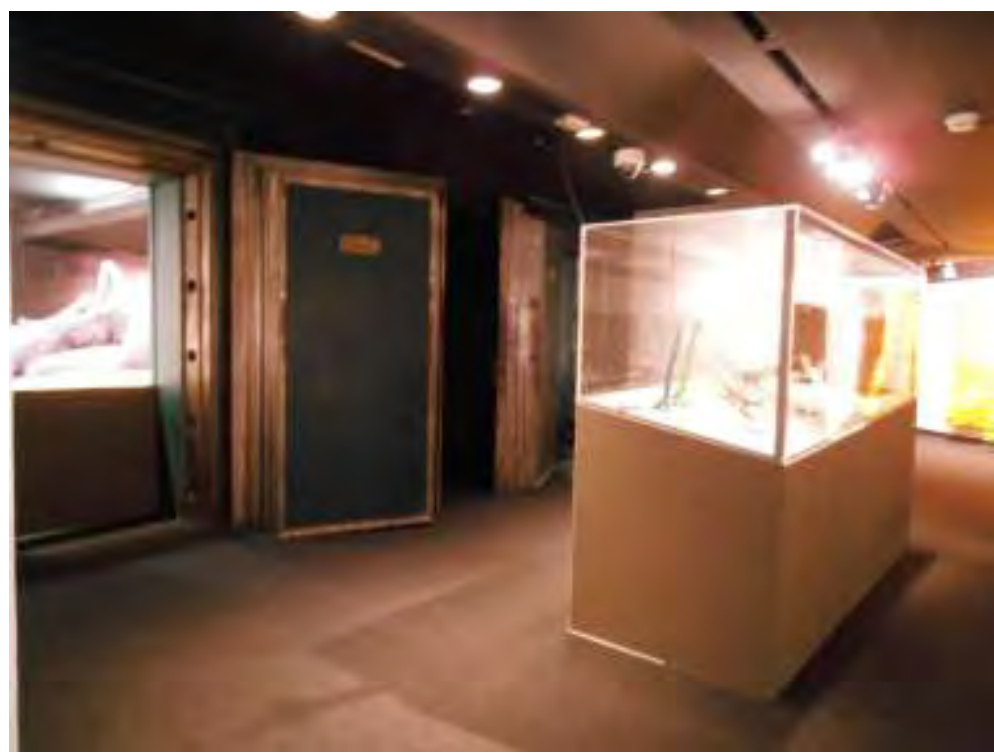

Figura 169 - Piso rampeado em frente às portas do cofre central. 2011.

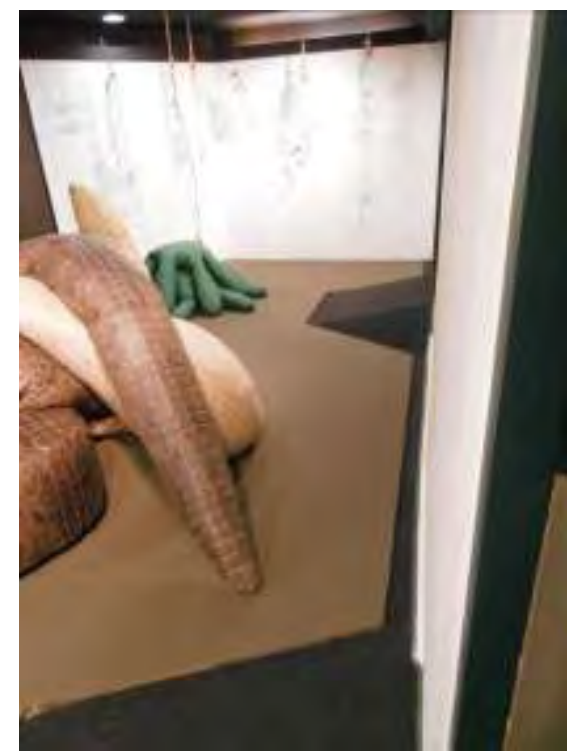

Figura 170 - Rampas internas em frente às portas do cofre. 2011.

Em cada um dos andares abertos ao público, do subsolo ao 3ํandar, a circulação e os vãos de portas garantem largura suficiente de passagem para cada um dos ambientes e espaços, exceto pelas portas de acesso ao corredor dos sanitários do $2^{\circ}$ e do $3^{\circ}$ andares e da entrada acessível ao teatro que tem duas folhas menores que $0,80 \mathrm{~m}$ cada $^{172}$. As portas nas áreas expositivas, localizadas nos $2^{\circ}$ e $3^{\circ}$ andares, são automáticas, e possuem sensor capaz de captar pessoas de

\footnotetext{
${ }^{172}$ Não atende ao disposto na ABNT NBR 9050/2004 - item 6.9.2.1.
} 
baixa estatura, crianças e pessoas usuárias de cadeiras de rodas ${ }^{173}$.

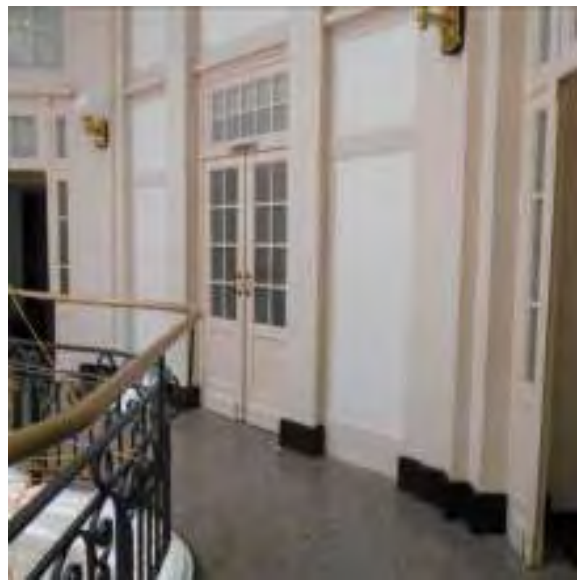

Figura 171 - Entrada para circulação dos sanitários. 2011.

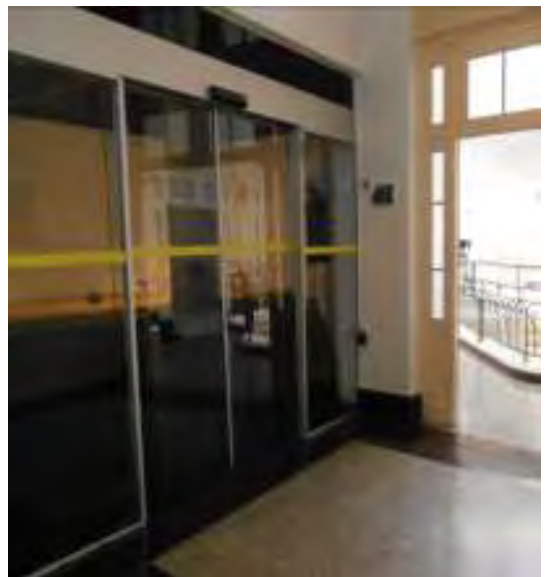

Figura 172 - Porta de abertura automática para área expositiva. 2011.

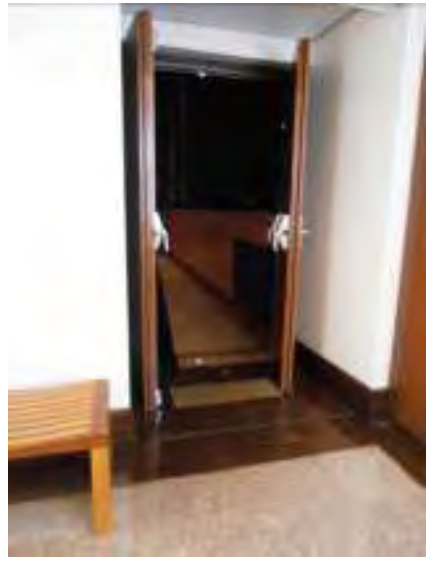

Figura 173 - Porta do teatro. 2011.

A circulação vertical dispõe de quatro elevadores novos e um elevador original (Elevador 1), além de duas escadas, uma delas de emergência ${ }^{174}$ e outra para circulação do público. Esta segunda escada, original do edifício, dispõe de um corrimão do lado interno, também original, e outro novo, no lado oposto, instalado durante o restauro. $O$ novo corrimão atende a altura ${ }^{175}$ e a espessura exigidas ${ }^{176}$, diferente do corrimão original, porém não há prolongamento nos andares ${ }^{177}$.

\footnotetext{
${ }^{173}$ Atende ao disposto na ABNT NBR 9050/2004 - item 6.9.2.7.

${ }^{174}$ As rotas de emergência por serem consideradas áreas onde o público não circula normalmente, não fizeram parte da avaliação, por determinação do CCBB. Ver explicação no item 3.8.

${ }^{175}$ Atende ao disposto na ABNT NBR 9050/2004 - item 6.7.1.6.

${ }^{176}$ Atende ao disposto na ABNT NBR 9050/2004 - item 6.7.1.2.

${ }^{177}$ Não atende ao disposto na ABNT NBR 9050/2004 - item 6.7.1.4.
} 

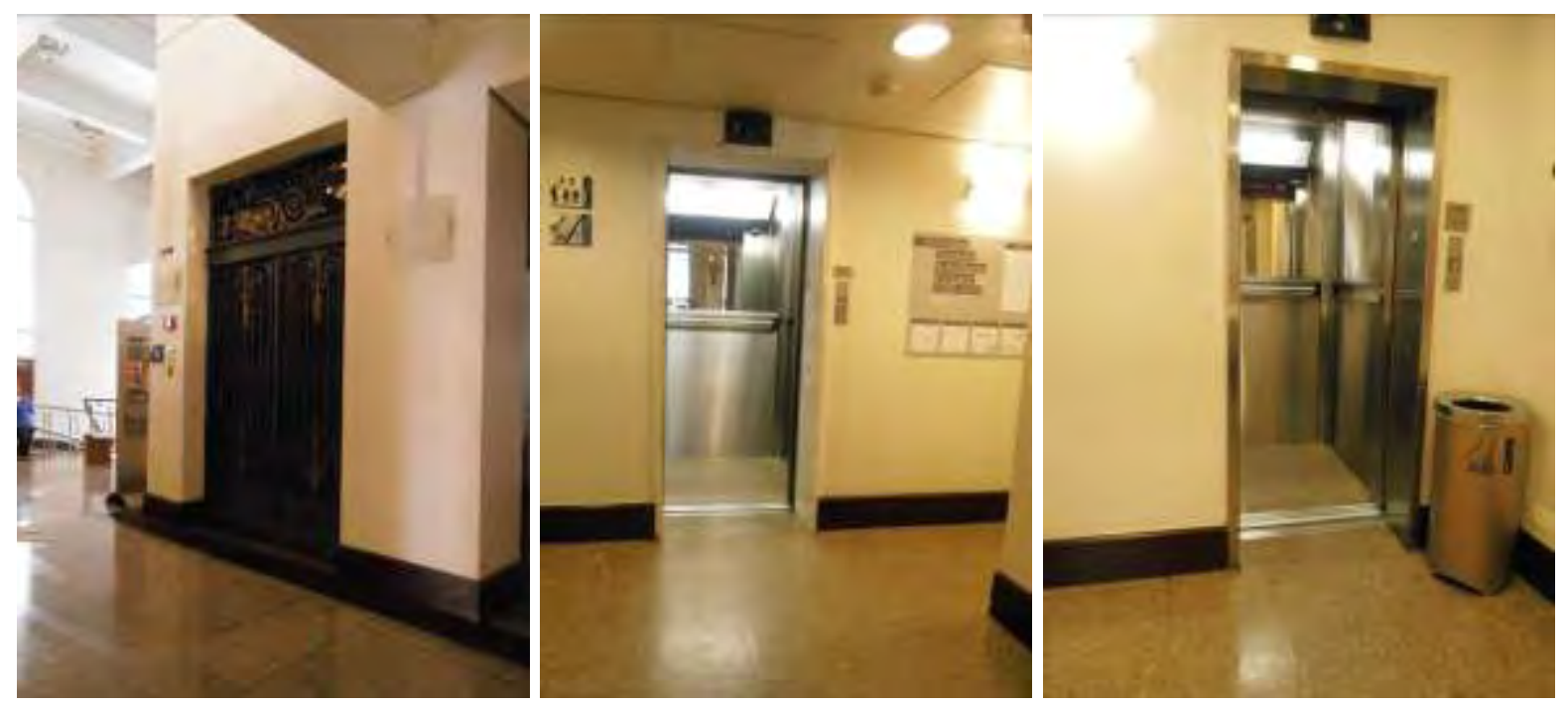

Figuras 174, 175 e 176 - Elevadores 1, 2 e 4, respectivamente. 2011.

Com exceção do Elevador 1, os demais conectam o térreo até o quarto andar. Um dos quatro elevadores novos (Elevador 5) é de uso exclusivo dos funcionários. E outro, entre os quatro elevadores, apresenta o Símbolo Internacional de Acesso (SIA) indicando ser este o acessível (Elevador 3). O acesso ao quinto andar é feito apenas pela escada de emergência, sendo que este pavimento tem áreas de funcionários, como vestiários, refeitório e sala de reunião. Portanto o edifício tem um pavimento sem rota acessível ${ }^{178}$.

O elevador identificado com o SIA tem tamanho adequado, de $1,10 \mathrm{~m}$ de largura por $1,40 \mathrm{~m}$ de profundidade $^{179}$. Internamente tem

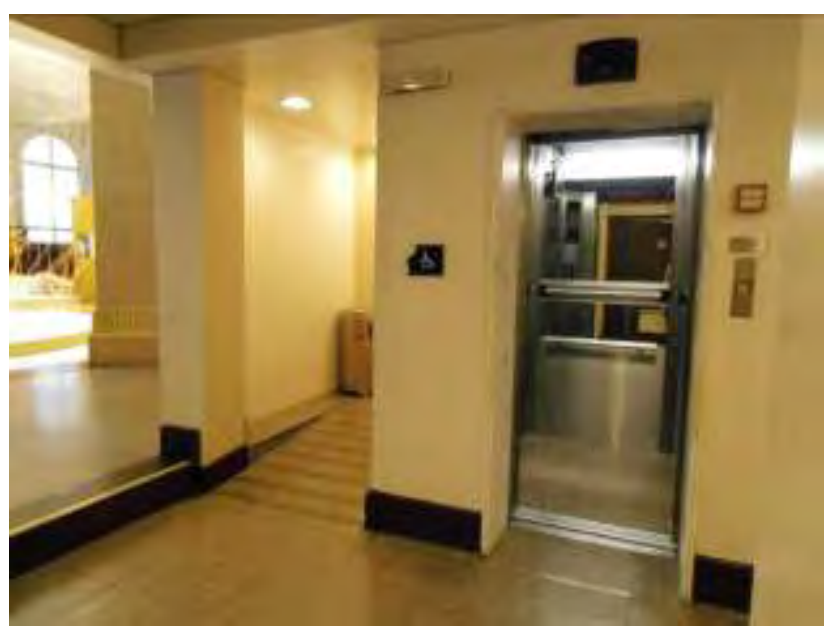

Figura 177 - Elevador 3: acessível. 2011

\footnotetext{
178 Não atende ao disposto no art. 19 do Decreto Federal 5.296/2004: "Art. 19. A construção, ampliação ou reforma de edificações de uso público deve garantir, pelo menos, um dos acessos ao seu interior, com comunicação com todas as suas dependências e serviços, livre de barreiras e de obstáculos que impeçam ou dificultem a sua acessibilidade".
}

${ }^{179}$ Atende ao disposto na ABNT NBR NM 313/2007 - item 5.3.1 e Tabela 1. 
espelho que, permite ao usuário de cadeira de rodas observar obstáculos quando se movem para trás ao sair do elevador ${ }^{180}$. Há barra de apoio no painel do fundo ${ }^{181} \mathrm{e}$ suas características de altura e espessura são adequadas, no entanto, o elevador não atende integralmente a essa necessidade, pois não há barra de apoio nos painéis laterais. A botoeira externa de chamada fica a 1,30m de altura, excedendo, portanto a altura adequada que deve estar entre 0,90 e $1,10 \mathrm{~m}$ do piso ${ }^{182}$.

\subsubsection{Infraestrutura expositiva e educativa}

As áreas expositivas estão distribuídas no subsolo, térreo, $1^{\circ}, 2^{\circ}$ e $3^{\circ}$ pavimentos. Todos esses ambientes apresentam largura de circulação adequada. As salas expositivas têm portas com sensor óptico e abrem automaticamente ${ }^{183}$.

No mezanino, hoje, funciona uma área utilizada pela equipe do programa educativo, onde ficam mesas e materiais para as atividades. A porta de acesso tem dimensão adequada conforme exigência normativa ${ }^{184}$. Quanto ao mobiliário, este será abordado em outra parte do capítulo.

\footnotetext{
${ }^{180}$ Atende ao disposto na ABNT NBR NM 313/2007 - item 5.3.2.3.

${ }^{181}$ Não atende integralmente ao disposto na ABNT NBR NM 313/2007 - item 5.3.2.1.

${ }^{182}$ Não atende ao disposto na ABNT NBR NM 313/2007 - item 5.4.1.1 e Tabela 2.

${ }^{183}$ Atende ao disposto na ABNT NBR 9050/2004 - item 6.9.2.7.

${ }^{184}$ Atende ao disposto na ABNT NBR 9050/2004 - item 6.9.2.1.
} 
Durante a visita do dia 21 de novembro de 2011 foram verificados expositores suspensos que prejudicam 0 alcance visual $^{185}$ de pessoas de baixa estatura, crianças e usuários de cadeiras de rodas. Os objetos expostos de pequena dimensão ou a parte inferior dos maiores não poderão ser percebidos em sua totalidade.

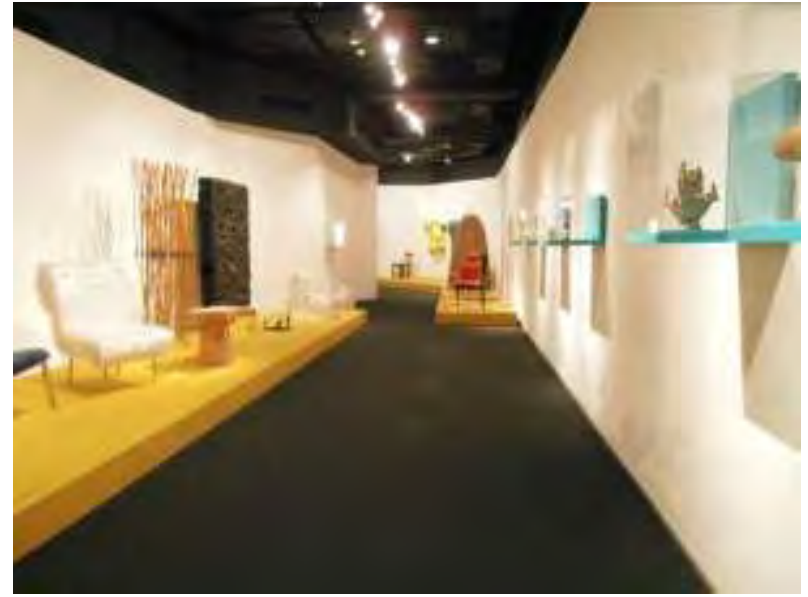

Figura 178 - Circulação e expositores suspensos. 2011.

\subsubsection{Locais de reunião}

No centro cultural há um teatro, um cinema e um auditório, cujas atividades integram a programação regular. O cinema e o auditório ficam no 1ำ andar, e têm lotação de 70 e 45 lugares respectivamente. O teatro tem acesso pelo $3^{\circ}$ andar e lotação de 130 lugares - 92 na plateia e 38 no mezanino. Tanto o cinema como o teatro têm suas plateias escalonadas. 0 acesso regular do público em ambos acontece pela parte posterior da plateia, através de escadas, com exceção das pessoas com deficiência que utilizam a porta de saída da

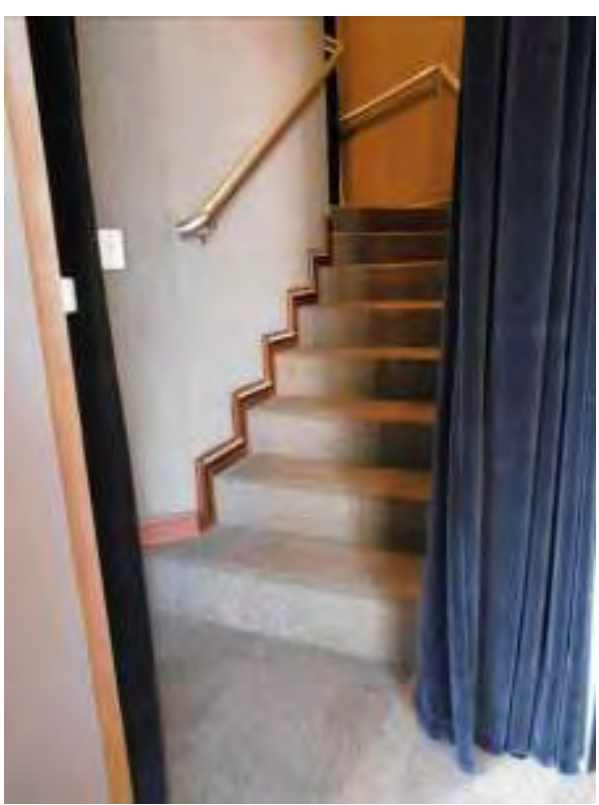

Figura 179 - Escada de acesso ao teatro. 2011.

\footnotetext{
${ }^{185}$ Não atende ao disposto na ABNT NBR 9050/2004 - item 4.7.2.
} 
plateia, que fica na lateral da primeira fileira da plateia, onde estão localizadas as áreas para cadeiras de rodas.

O menor dos três ambientes

é o auditório. Nele, cadeiras soltas são dispostas conforme a atividade programada. O acesso e a circulação interna da sala estão nivelados e a porta é composta por duas folhas de largura adequada, maiores que 0,80m cada uma $^{186}$. O ambiente com mobiliário flexível permite adequar o espaço para posicionamento de usuários de cadeiras de rodas e acompanhante $^{187}$. Porém não foi encontrada cadeira para obeso ${ }^{188}$.

$$
\text { O cinema tem } 70 \text { assentos }
$$

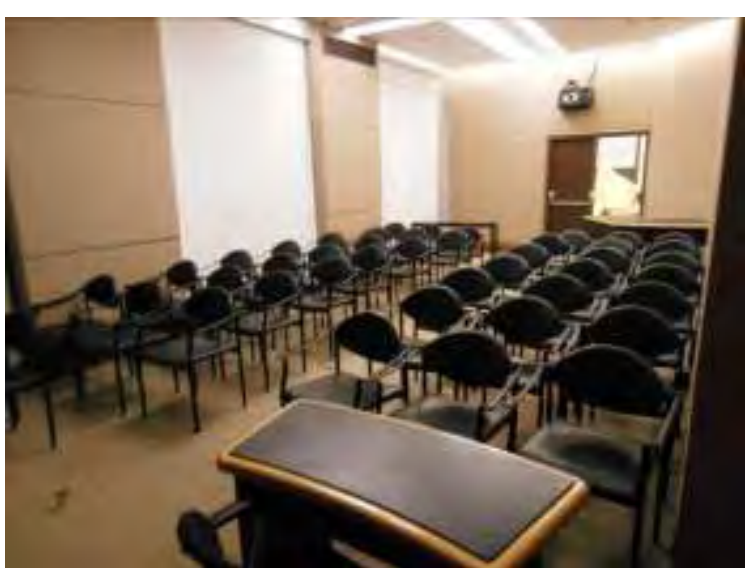

Figura 181 - Auditório. 2011.

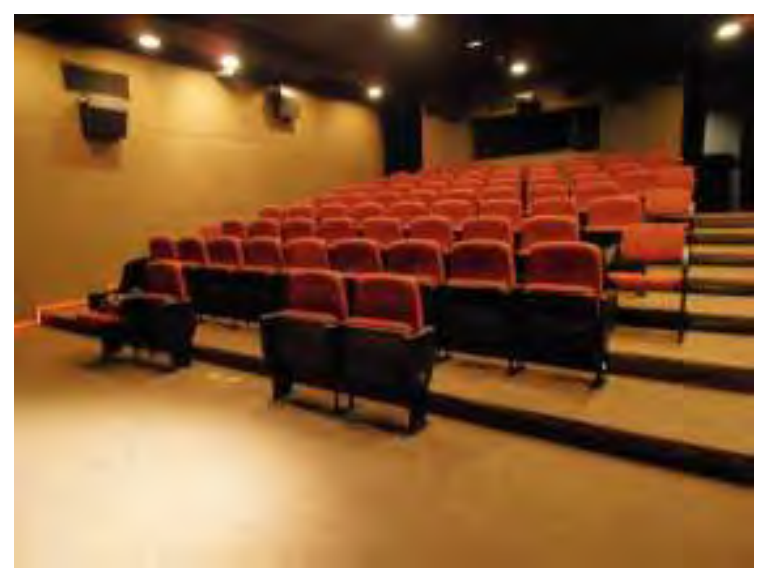

Figura 180 - Cinema. 2011. fixos e espaço livre para três cadeiras de rodas, todos com possibilidade de assento fixo ao lado para acompanhante ${ }^{189}$, porém sem o deslocamento necessário de 0,30m para que este esteja na mesma direção do usuário de cadeira de rodas ${ }^{190}$. Além dos assentos fixos, no dia da visita foi verificado que havia sete cadeiras não fixas para possibilitar ampliação da

\footnotetext{
${ }^{186}$ Atende ao disposto na ABNT NBR 9050/2004 - item 6.9.2.1.

${ }^{187}$ Atende ao disposto na ABNT NBR 9050/2004 - item 8.2.1.

${ }^{188}$ Não atende ao disposto na ABNT NBR 9050/2004 - item 8.2.1.3.3.

${ }^{189}$ Atende ao disposto na ABNT NBR 9050/2004 - item 8.2.1.

${ }^{190}$ Não atende ao disposto na ABNT NBR 9050/2004 - item 8.2.1.3.1.
} 
capacidade da sala, o que permite flexibilidade à demanda, desde que não prejudique a circulação. O cinema atende à quantidade de espaços reservados para cadeira de rodas e para pessoa com mobilidade reduzida ${ }^{191}$, porém não há assentos para obesos $^{192}$

A sala tem um palco retrátil, que pode ficar embutido na parede onde está a tela de projeção, permitindo eliminar o desnível do palco, ou do contrário, seria necessário prever 0 acesso ao palco. O corrimão das escadas de acesso ao cinema tem espessura maior que o permitido ${ }^{193}$, mas está

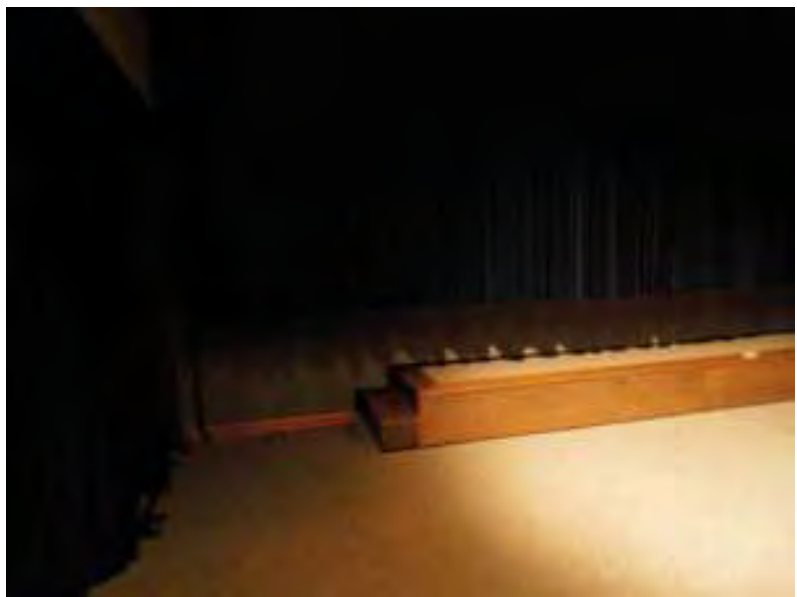

Figura 182 - Palco retrátil do cinema. 2011. posicionado na altura correta.

O teatro está dividido entre plateia e mezanino. Os quatro espaços para usuários de cadeira de rodas estão localizados na primeira fileira da plateia, em dois grupos de duas cadeiras cada. Portanto, dois espaços não possuem assento fixo para acompanhante ${ }^{194}$; nenhum dos espaços reservados possui deslocamento em relação ao assento fixo ${ }^{195}$. Há um pequeno rampeado de madeira colocado no pequeno desnível existente entre a primeira e a segunda fileira, para o posicionamento da cadeira de rodas.

\footnotetext{
${ }^{191}$ Atende ao disposto na ABNT NBR 9050/2004 - item 8.2.1.1.

192 Não atende ao disposto no art. 1ㅇ da Lei municipal no 12.658/1998, no art. 1ㅇ da Lei estadual 12.225/2006, no art. 23 do Decreto Federal 5.296/2004 e na ABNT NBR 9050/2004 - item 8.2.1.1.

${ }^{193}$ Não atende ao disposto na ABNT NBR 9050/2004 - item 6.7.1.2.

${ }^{194}$ Não atende ao disposto na ABNT NBR 9050/2004 - item 8.2.1.

${ }^{195}$ Não atende ao disposto na ABNT NBR 9050/2004 - item 8.2.1.3.1.
} 
Foi localizado um assento junto

à circulação central, maior que os demais, que poderia ser o assento para obeso, porém, sua largura não é o dobro das demais, como exigido pela ABNT NBR 9050/2004. Os assentos comuns têm largura de $0,48 \mathrm{~m}$, e esse tem largura de $0,53 m^{196}$. Todos os assentos são rebatíveis e tem apoio fixo para os braços $^{197}$. Assim como ocorre no cinema, tanto a quantidade de assentos para pessoa com mobilidade reduzida e como os espaços reservados para usuários de cadeiras de rodas estão adequadas.

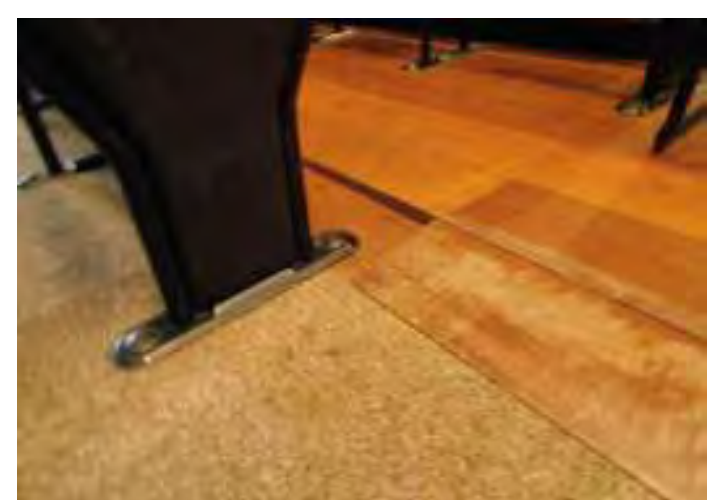

Figura 184 - Rampeado corrige desnível entre $1^{\mathrm{a}}$ e $2^{\mathrm{a}}$ fileiras. 2011.

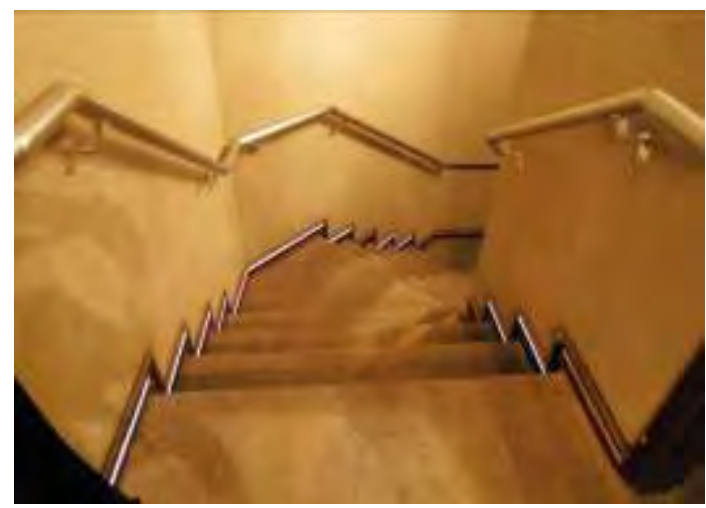

Figura 183 - Escada de acesso às plateias do teatro. 2011.
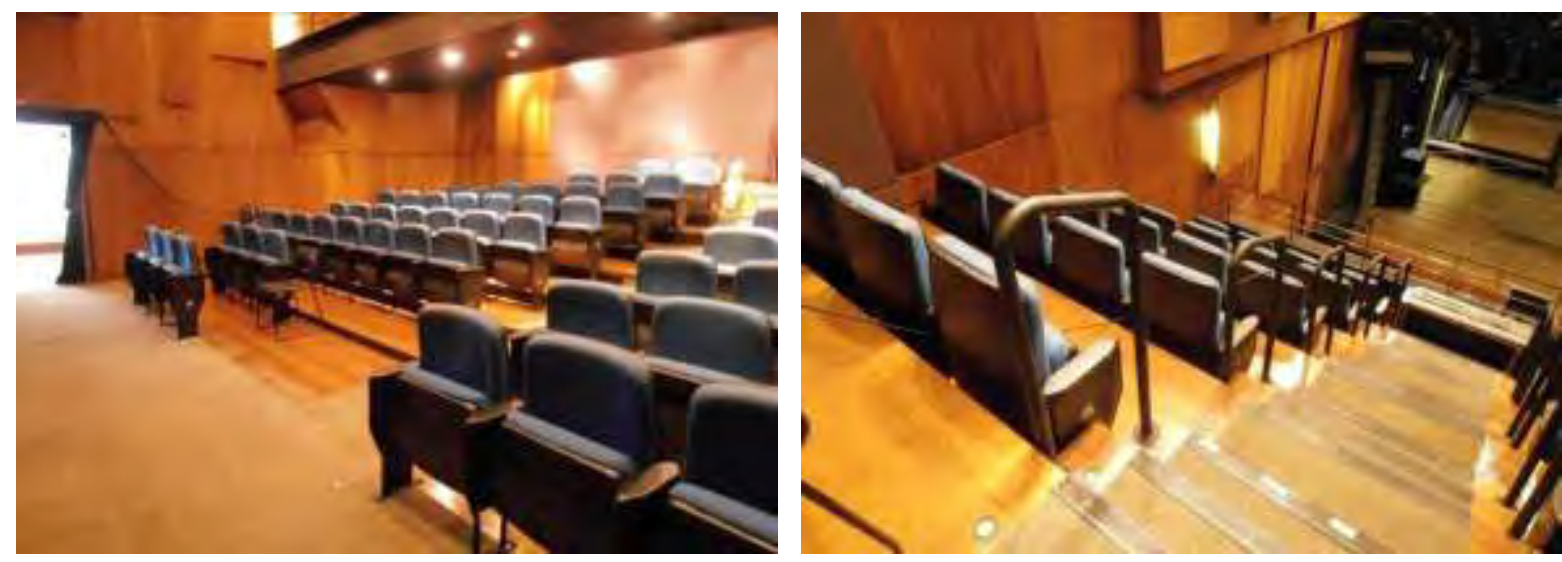

Figuras 185 e 186 - Plateias, inferior e superior, do teatro. 2011.

O corrimão na escada de acesso tem pontos de interrupção, mas é

\footnotetext{
${ }^{196}$ Não atende ao disposto na ABNT NBR 9050/2004 - item 8.2.1.3.3.

${ }^{197}$ Não atende ao disposto na ABNT NBR 9050/2004 - item 8.2.1.2.5.
} 
predominantemente contínuo $^{198}$ e sua espessura erroneamente é de $5 \mathrm{~cm}$ de diâmetro $^{199}$, ultrapassando os $4,5 \mathrm{~cm}$ permitido; sua altura a $0,92 \mathrm{~m}$ do piso está adequada $^{200}$. Os degraus da plateia inferior são centrais e não têm corrimão ${ }^{201}$. Pontos de iluminação de piso, acompanhando os degraus, servem de recurso visual. No mezanino permanecem as mesmas características, com exceção do corrimão de apoio, que foi posicionado junto às fileiras.

O palco tem 1,06m de altura e, portanto está corretamente abaixo da linha do horizonte de uma pessoa sentada em cadeira de rodas, que é de 1,15m, respeitando o ângulo visual ${ }^{202}$. Porém não é respeitada a necessidade de piso tátil de alerta na borda do palco ${ }^{203}$. O acesso ao palco é feito por meio de plataforma eletromecânica posicionada na lateral do palco ${ }^{204}$, que fica embutida na parede quando não está sendo utilizada.

\footnotetext{
${ }^{198}$ Não atende ao disposto na ABNT NBR 9050/2004 - item 6.7.1.7.

${ }^{199}$ Não atende ao disposto na ABNT NBR 9050/2004 - item 6.7.1.2.

${ }^{200}$ Atende ao disposto na ABNT NBR 9050/2004 - item 6.7.1.6.

${ }^{201} \mathrm{~A}$ exemplo do mezanino do teatro poderiam ser dispostos apoios junto às fileiras, mesmo que isso não seja citado como obrigatório.

202202 Atende ao disposto na ABNT NBR 9050/2004 - item 8.2.1.2.3.

${ }^{203}$ Não atende ao disposto na ABNT NBR 9050/2004 - item 8.2.1.4.3.

${ }^{204}$ Atende ao disposto na ABNT NBR 9050/2004 - item 8.2.1.4.2, porém não garante acesso imediato ou fora do campo visual da plateia.
} 


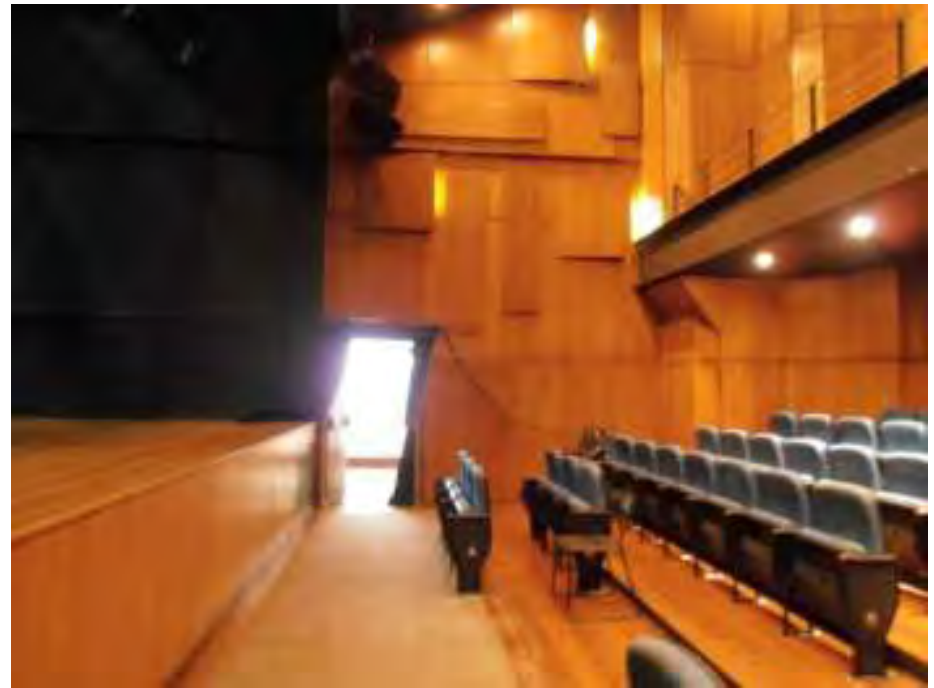

Figura 187 - Palco do teatro. 2011.

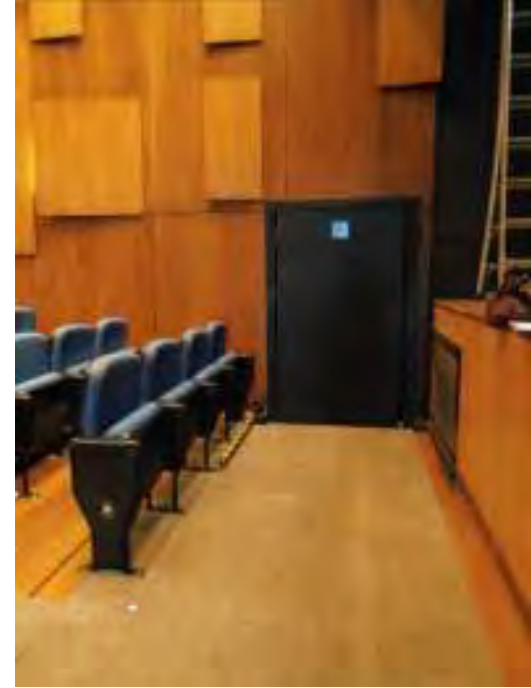

Figura 188 - Plataforma para acesso ao palco. 2011.

\subsubsection{Locais de refeição}

São dois os locais de refeição do centro cultural: cafeteria no térreo e restaurante, no $3^{\circ}$ andar. Em ambos foi reaproveitado parte do balcão original que era utilizado como caixa do banco.

A cafeteria fica próxima da entrada acessível do edifício que é acessível, isto é a entrada secundária. Parte das mesas fica no salão interno, e o restante é colocado no calçadão, com sua área delimitada por jardineiras. Apesar das mesas internas estarem em nível três degraus acima, existe rota acessível por rampa - a

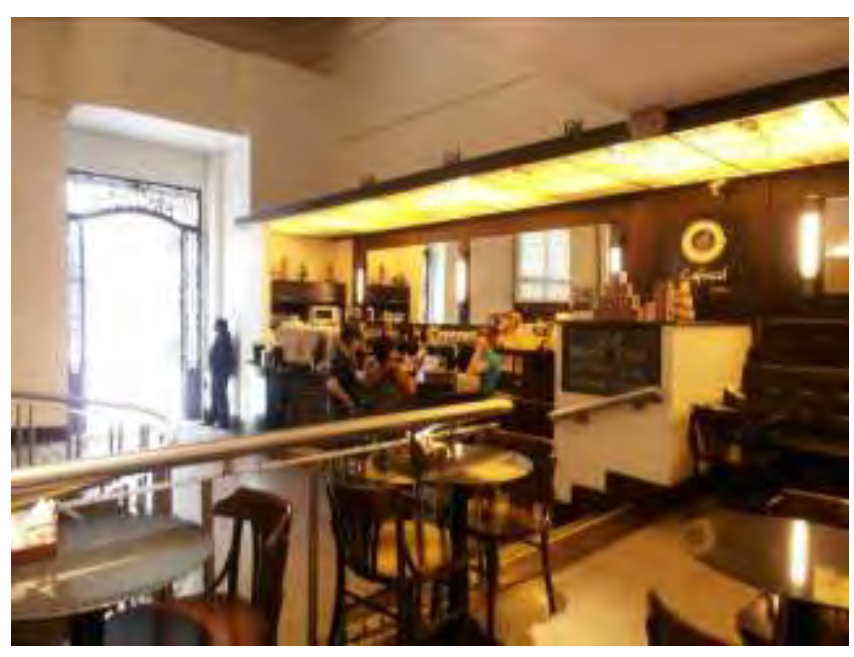

Figura 189 - Cafeteria. 2011. mesma que dá acesso ao sanitário. 
O restaurante, que fica ao

lado da entrada do teatro, funciona no período de almoço. A entrada é feita por uma porta com duas folhas de $0,65 m$ cada $^{205}$, que permanecem abertas durante o funcionamento do teatro e do restaurante.

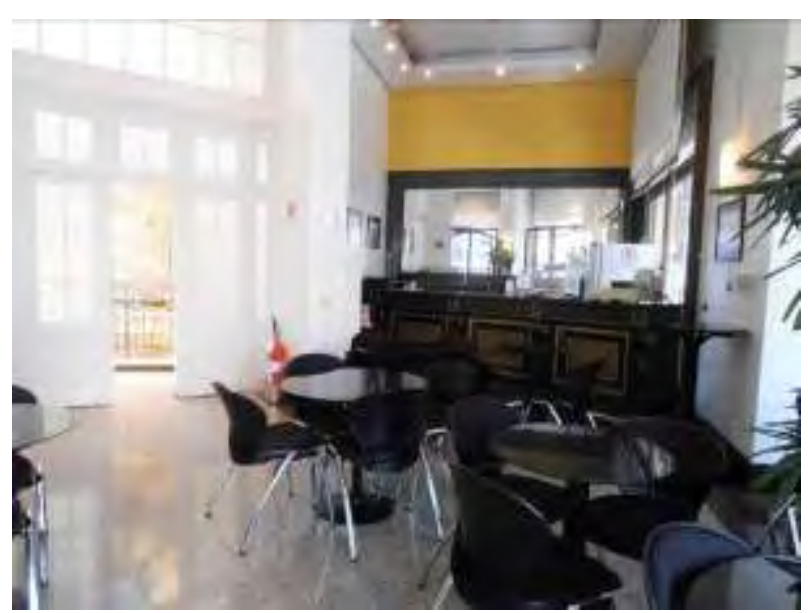

Figura 190 - Restaurante. 2011.

Nos dois ambientes há pelo menos uma circulação ampla onde o espaço é suficiente para circular com cadeiras de rodas, andadores ou muletas ${ }^{206}$. O mobiliário será analisado em outra parte deste capítulo.

\subsubsection{Outras áreas}

No térreo há uma livraria, onde são vendidos livros, catálogos e lembranças de visita. A largura entre estantes é adequada e o espaço para rotação é estreito em algumas partes, mas suficiente para circular ${ }^{207}$.

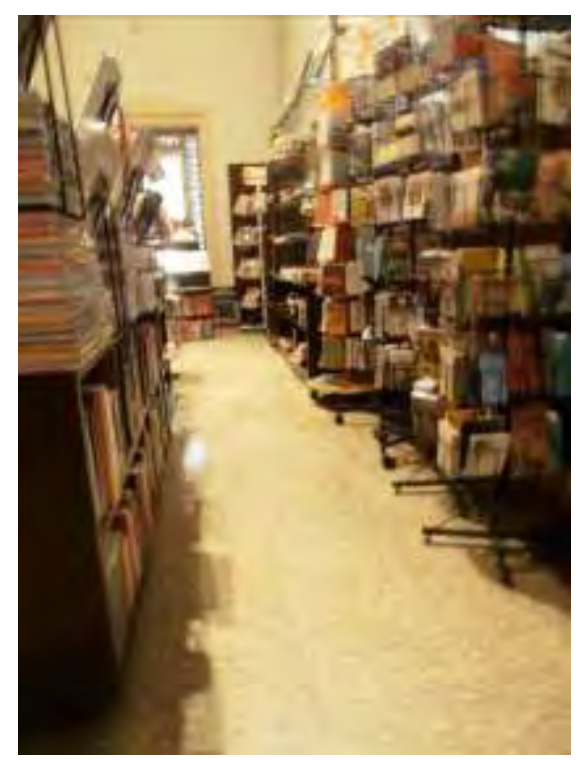

Figura 191 - Livraria. 2011.

\footnotetext{
${ }^{205}$ Não atende ao disposto na ABNT NBR 9050/2004 - item 6.9.2.1.

${ }^{206}$ Atende ao disposto na ABNT NBR 9050/2004 - item 9.3.3.3.

${ }^{207}$ Atende ao disposto na ABNT NBR 9050/2004 - item 4.3.4.
} 


\subsubsection{Instalações sanitárias}

Apenas no pavimento térreo há um sanitário acessível, de uso unissex, localizado em circulação separada dos demais sanitários do andar. O sanitário acessível é do tipo isolado, permitindo a entrada de acompanhante de sexo distinto que preste auxílio, quando há essa necessidade, sem o constrangimento, que ocorreria nos casos em que há um boxe acessível no sanitário coletivo.

O total de peças por andar, conforme uso e sexo, representado na Tabela 4, foi verificado com base nas plantas publicadas ${ }^{208}$. Os dados que se referem às áreas de funcionários podem não estar mais nessa condição, já que essas áreas não foram verificadas e as plantas são de 2001.

\section{VISITANTES}

\begin{tabular}{|c|c|c|c|c|c|c|c|}
\hline & \multicolumn{2}{|c|}{ FEMININO } & \multicolumn{3}{|c|}{ MASCULINO } & \multicolumn{2}{|c|}{$\begin{array}{l}\text { ACESSÍVEL } \\
\text { UNISSEX }\end{array}$} \\
\hline & lavatório & bacia & lavatório & bacia & mictório & lavatório & bacia \\
\hline SUBSOLO & 0 & 0 & 0 & 0 & 0 & 0 & 0 \\
\hline TÉRREO & 2 & 2 & 2 & 2 & 2 & 1 & 1 \\
\hline MEZANINO & 0 & 0 & 0 & 0 & 0 & 0 & 0 \\
\hline 10 ANDAR & 2 & 2 & 2 & 2 & 2 & 0 & 0 \\
\hline 20 ANDAR & 2 & 2 & 2 & 2 & 1 & 0 & 0 \\
\hline 3 ANDAR & 2 & 2 & 2 & 2 & 1 & 0 & 0 \\
\hline 4 ANDAR & 0 & 0 & 0 & 0 & 0 & 0 & 0 \\
\hline COBERTURA & 0 & 0 & 0 & 0 & 0 & 0 & 0 \\
\hline total & 8 & 8 & 8 & 8 & 6 & 1 & 1 \\
\hline
\end{tabular}

* total segundo plantas publicadas na Revista AU, n. 96, jun./jul. 2001.

Tabela 4 - Distribuição de peças sanitárias para visitantes.

\footnotetext{
${ }^{208}$ Como não foi possível circular pelas áreas restritas aos funcionários o cálculo foi feito com base nas plantas do local, disponíveis na revista AU, São Paulo, n. 96, pg. 46-53, jun./jul. 2001.
} 
FUNCIONÁRIOS

\begin{tabular}{|c|c|c|c|c|c|c|c|}
\hline & \multicolumn{3}{|c|}{ FEMININO } & \multicolumn{4}{|c|}{ MASCULINO } \\
\hline & lavatório & bacia & chuveiro & lavatório & bacia & mictório & chuveiro \\
\hline SUBSOLO & 0 & 0 & 0 & 0 & 0 & 0 & 0 \\
\hline TÉRREO & 0 & 0 & 0 & 0 & 0 & 0 & 0 \\
\hline MEZANINO & 1 & 1 & 1 & 1 & 1 & 1 & 1 \\
\hline 10 ANDAR & 0 & 0 & 0 & 0 & 0 & 0 & 0 \\
\hline 20 ANDAR ** & 1 & 1 & 1 & 2 & 1 & 1 & 1 \\
\hline 3ㅇ ANDAR ** & 2 & 2 & 2 & 0 & 0 & 0 & 0 \\
\hline 4\% ANDAR & 2 & 2 & 0 & 2 & 2 & 1 & 0 \\
\hline COBERTURA & 2 & 1 & 1 & 2 & 1 & 1 & 1 \\
\hline total & 8 & 7 & 5 & 7 & 5 & 4 & 3 \\
\hline
\end{tabular}

* total segundo plantas publicadas na Revista AU, n. 96, jun./jul. 2001.

** Nos 2 e e 3ำ andares há camarins, que foram consideradas como instalações para funcionários

Tabela 5 - Distribuição de peças sanitárias para funcionários.

O local não tem quantidade adequada de $5 \%$ das peças sanitárias acessíveis, se considerarmos para o cálculo a divisão por sexo e uso ${ }^{209}$. Com base nas plantas, não há também vestiários adequados ao uso de pessoas com deficiência. Os vestiários localizados na cobertura estão em andar inacessível; os que estão no mezanino, antes utilizados pelos funcionários do restaurante que ficava nesse andar, não se sabem se foram adaptados, apesar de estarem em andar acessível. Também não atende a distribuição de um sanitário acessível por andar 210 prevista no Decreto Federal 5.296/2004, exigida em adaptação de edifícios de administração pública, como é este centro cultural.

Quanto às características deste único sanitário acessível, há apenas algumas incorreções que podem facilmente serem corrigidas, visto que o tamanho,

\footnotetext{
${ }^{209}$ Não atende ao disposto na ABNT NBR 9050/2004 - item 7.2.2. "Os sanitários e vestiários de uso comum ou uso público devem ter no mínimo $5 \%$ do total de cada peça instalada acessível, respeitada no mínimo uma de cada. Quando houver divisão por sexo, as peças devem ser consideradas separadamente para efeito de cálculo" (grifo nosso).

${ }^{210}$ Não atende ao disposto no parágrafo $2^{\circ}$ do art. 22, do Decreto Federal 5.296/2004.
} 
espaços para rotação e aproximação ${ }^{211}$ são adequados.
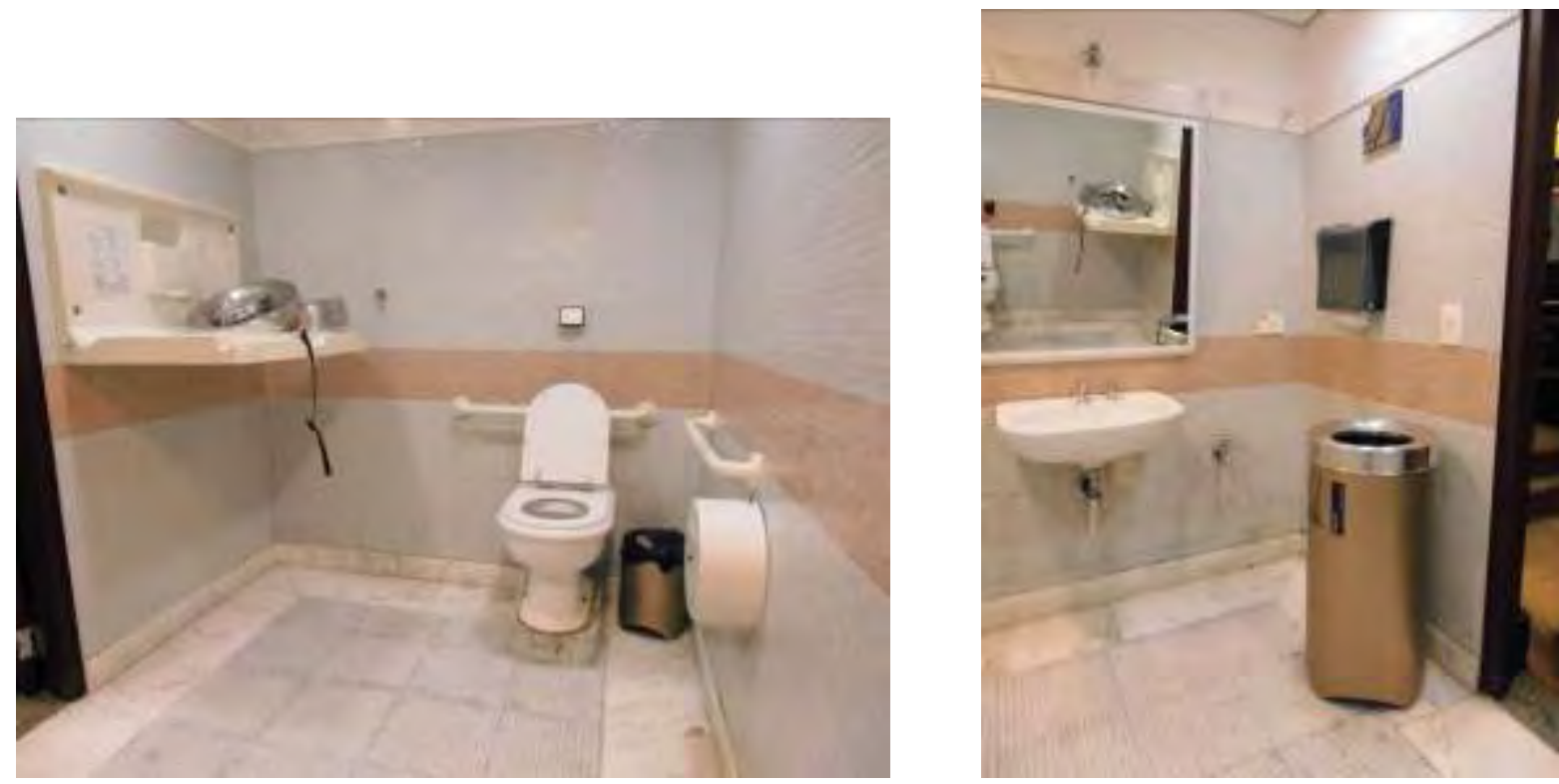

Figuras 192 e 193 - Sanitário acessível no térreo: bacia e lavatório. 2011.

A altura da bacia com assento é de $0,51 \mathrm{~m}$, superior à medida máxima de $0,46 \mathrm{~m}^{212}$, devido ao sóculo que é mais alto que o necessário. As barras de apoio com diâmetro de $3,5 \mathrm{~cm}^{213}$ estão posicionadas corretamente ${ }^{214}$. A papeleira está instalada em altura incorreta e está muito distante da bacia. Papeleiras externas à parede devem estar posicionadas acima da barra e alinhadas com a borda da bacia $^{215}$. O acionamento da descarga também está em altura incorreta, pois está a $1,10 \mathrm{~m}$ do piso $^{216}$.

\footnotetext{
${ }^{211}$ Atende ao disposto na ABNT NBR 9050/2004 - item 7.3.1.1 e item 7.3.3.1.

${ }^{212}$ Não atende ao disposto na ABNT NBR 9050/2004 - item 7.3.1.3.

${ }^{213}$ Atende ao disposto na ABNT NBR 9050/2004 - item 7.2.4.

${ }^{214}$ Atende ao disposto na ABNT NBR 9050/2004 - item 7.3.1.2.

${ }^{215}$ Não atende ao disposto na ABNT NBR 9050/2004 - item 7.3.8.2.

${ }^{216}$ Não atende ao disposto na ABNT NBR 9050/2004 - item 7.3.1.5.
} 
O lavatório, posicionado corretamente, e com apenas meia coluna ${ }^{217}$ permite aproximação frontal $^{218}$. A torneira é do tipo pressão e atende ao exigido $^{219}$. Porém não há barra de apoio ${ }^{220}$. espelho fixado com inclinação de $10^{\circ}$ em relação ao plano vertical está colocado à altura inicial de $0,94 \mathrm{~m}$ do piso, que está dentro da variação de altura permitida $^{221}$. Os acessórios estão posicionados dentro da faixa de alcance confortável ${ }^{222}$.

A porta do sanitário abre corretamente para fora ${ }^{223}$ e está sinalizada com o SIA. Apenas apresenta uma incorreção quanto ao puxador horizontal que está a $0,15 \mathrm{~m}$ de distância da extremidade, onde está a dobradiça, e a $0,80 \mathrm{~m}$ de altura do piso 224 .

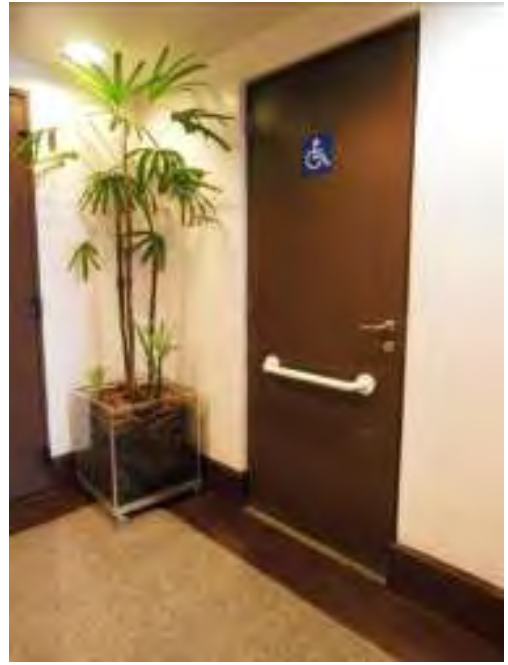

Figura 194 - Porta do sanitário acessível. 2011.

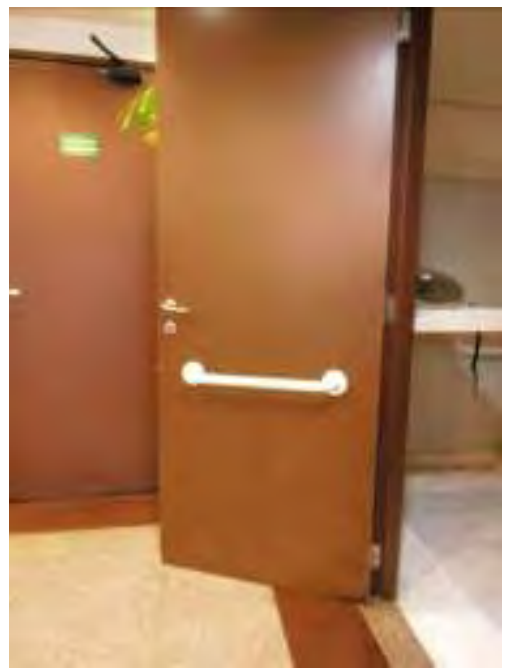

Figura 195 - Porta do sanitário acessível. 2011.

\footnotetext{
${ }^{217}$ Atende ao disposto na ABNT NBR 9050/2004 - item 7.3.6.2.

${ }^{218}$ Atende ao disposto na ABNT NBR 9050/2004 - item 7.3.6.1.

${ }^{219}$ Atende ao disposto na ABNT NBR 9050/2004 - item 7.3.6.3. A torneira de pressão pode ser caracterizada como "dispositivos equivalentes", conforme texto da norma, pois não facilmente manipulada por quem não tem mobilidade dos dedos para utilizar a torneira tipo cruzeta ou similar. Porém, se a torneira de pressão exigir demasiado esforço, pode não ser adequada também.

${ }^{220}$ Não atende ao disposto na ABNT NBR 9050/2004 - item 7.3.6.4.

${ }^{221}$ Atende ao disposto na ABNT NBR 9050/2004 - item 7.3.8.1.

${ }^{222}$ Atende ao disposto na ABNT NBR 9050/2004 - item 7.3.8.

${ }^{223}$ Atende ao disposto na ABNT NBR 9050/2004 - item 7.3.3.4.

${ }^{224}$ Não atende ao disposto na ABNT NBR 9050/2004 - item 6.9.2.4.
} 


\subsubsection{Mobiliário}

Neste item serão analisados mesas, balcões, bebedouros, telefones e suporte de folhetos e programação.

As mesas são de refeição, no restaurante e na cafeteria, e de trabalho, no educativo. As mesas de refeições nos dois ambientes não permitem o uso adequado por uma pessoa em cadeira de rodas. As mesas de tampo redondo são inadequadas porque não tem altura livre inferior suficiente $^{225}$ e a mesa dobrável, utilizada no calçadão, porque o tipo de base de sustentação não permite profundidade para fazer aproximação frontal $^{226}$. Portanto, os locais de refeição não possuem pelo menos $5 \%$ das mesas acessíveis ${ }^{227}$. Quanto aos assentos, na cafeteria existe um sofá que pode ser utilizado por obesos, resultando em três assentos ${ }^{228}$ para esse fim, do total de $58^{229}$ disponíveis. No restaurante, não há cadeiras para obesos entre as 24 presentes no ambiente ${ }^{230}$.

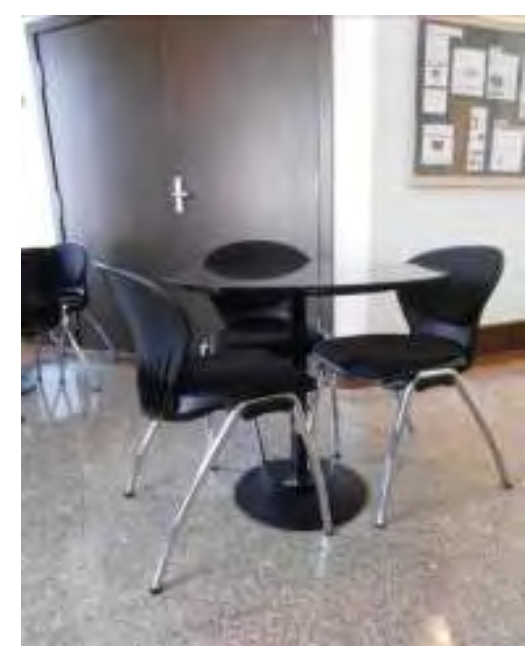

Figura 196 - Mobiliário do restaurante. 2011.

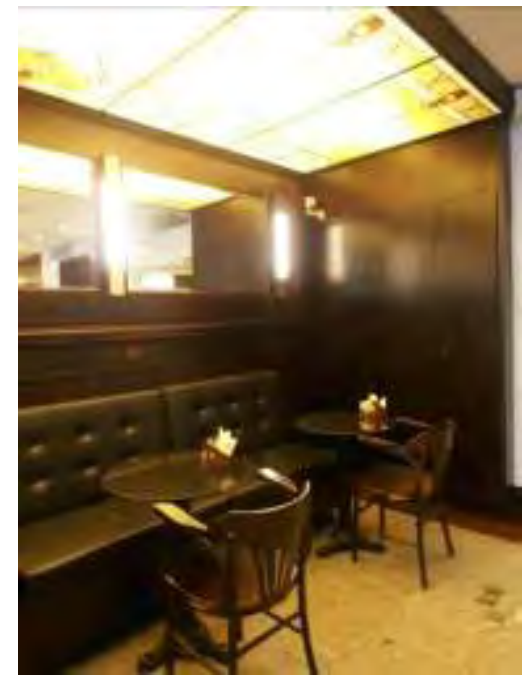

Figura 197 - Mobiliário da cafeteria. 2011.

\footnotetext{
${ }^{225}$ Não atende ao disposto na ABNT NBR 9050/2004 - item 9.3.3.1.

${ }^{226}$ Não atende ao disposto na ABNT NBR 9050/2004 - item 9.3.3.2.

${ }^{227}$ Não atende ao disposto na ABNT NBR 9050/2004 - item 9.3.1.

${ }^{228}$ Atende ao disposto no art. $1^{\circ}$ da Lei municipal ํㅜ 12.658/1998.

${ }^{229}$ Apesar de a cafeteria ter mais assentos de obeso do que o exigido, não há nenhum assento para as mesas externas. Portando, não há igual oferta de serviço para os obesos.

${ }^{230}$ Não atende ao disposto no art. 1ํ da Lei municipal oㅜ 12.658/1998.
} 


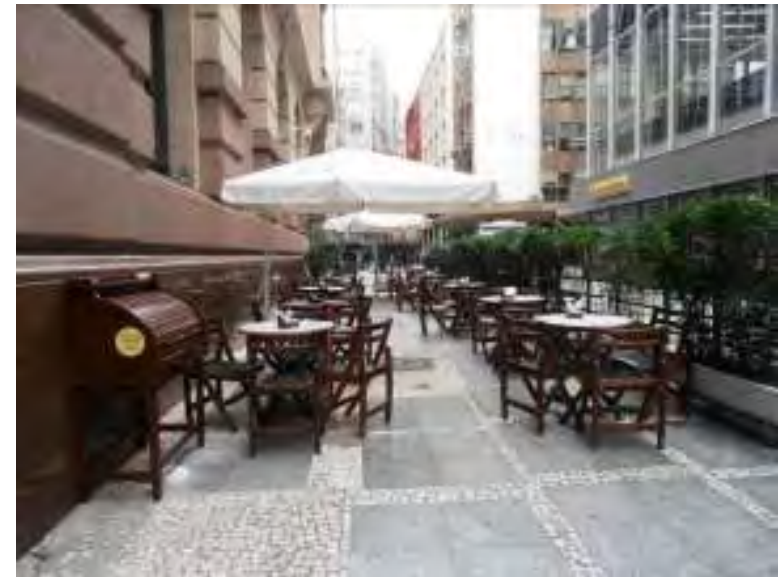

Figura 198 - Mobiliário da cafeteria - externo. 2011.

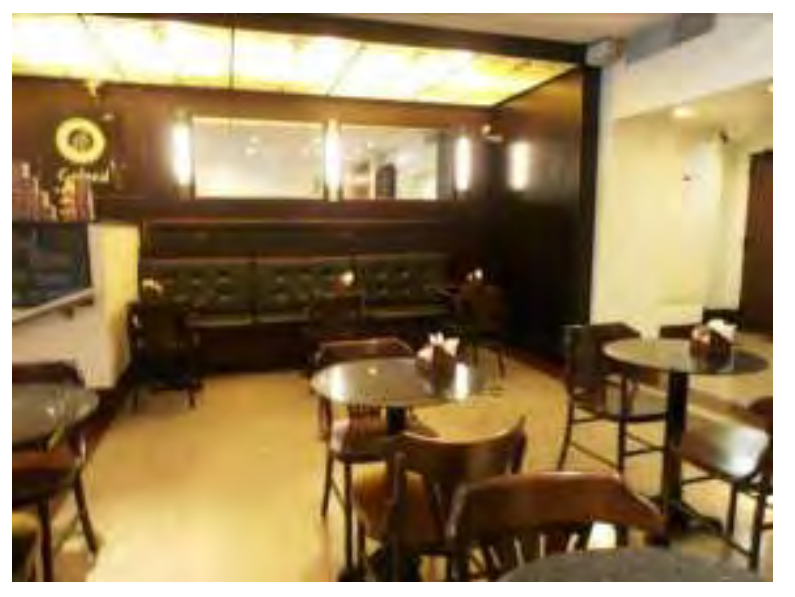

Figura 199 - Mobiliário da cafeteria interno. 2011.

No mezanino, a única mesa existente é utilizada pela equipe educativa durante as atividades da programação; a altura livre na parte inferior e a profundidade são adequadas para usuários de cadeira de rodas ${ }^{231}$.

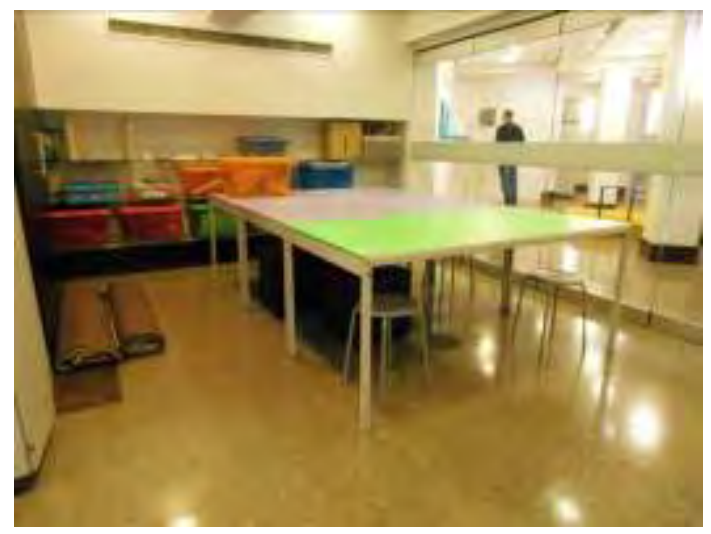

Figura 200 - Mesa para as atividades educativas. 2011

Parte da lateral do balcão de informações, no térreo, é corretamente rebaixado $^{232}$ porém, sem profundidade livre de $0,30 \mathrm{~m}$ para aproximação ${ }^{233}$. Essa mesma parte serve para atendimento de informações, bilheteria e guarda-volumes. Os balcões da cafeteria, do restaurante e da livraria são altos ${ }^{234}$, não sendo

\footnotetext{
${ }^{231}$ Atende ao disposto na ABNT NBR 9050/2004 - itens 9.3.3.1 e 9.3.3.2.

${ }^{232}$ Atende ao disposto na ABNT NBR 9050/2004 - item 9.5.2.1.

${ }^{233}$ Não atende ao disposto na ABNT NBR 9050/2004 - item 9.5.2.2.

${ }^{234}$ Não atende ao disposto na ABNT NBR 9050/2004 - item 9.5.2.1.
} 
adequados para o uso de pessoas de baixa estatura e usuárias de cadeiras de rodas. Esses balcões apresentam três situações diferentes. Os balcões do restaurante e da cafeteria aproveitam o mobiliário original do banco. Na cafeteria há uma parte nova complementar a esse balcão, que também não tem altura adequada. O restaurante conta apenas com o mobiliário original. E, na livraria o mobiliário é totalmente novo, assim, teria sido possível adequá-lo.

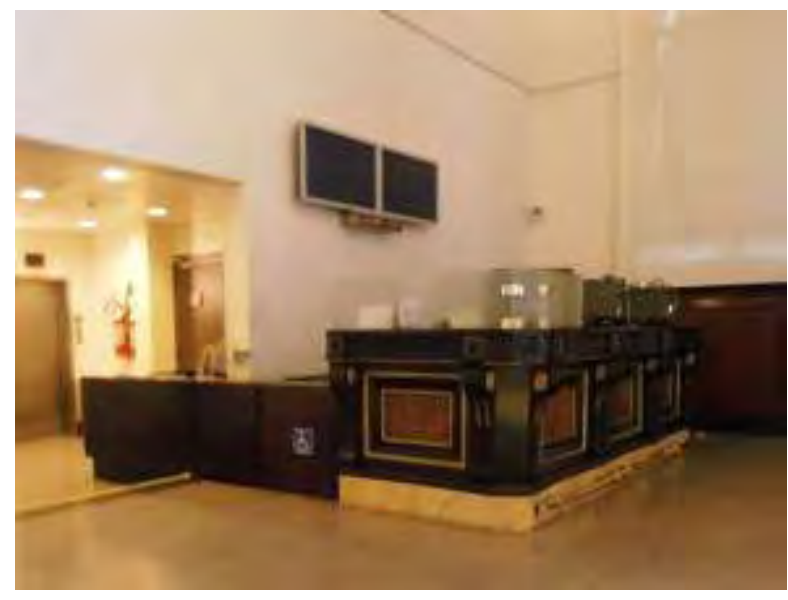

Figura 201 - Balcão de informações. 2011.

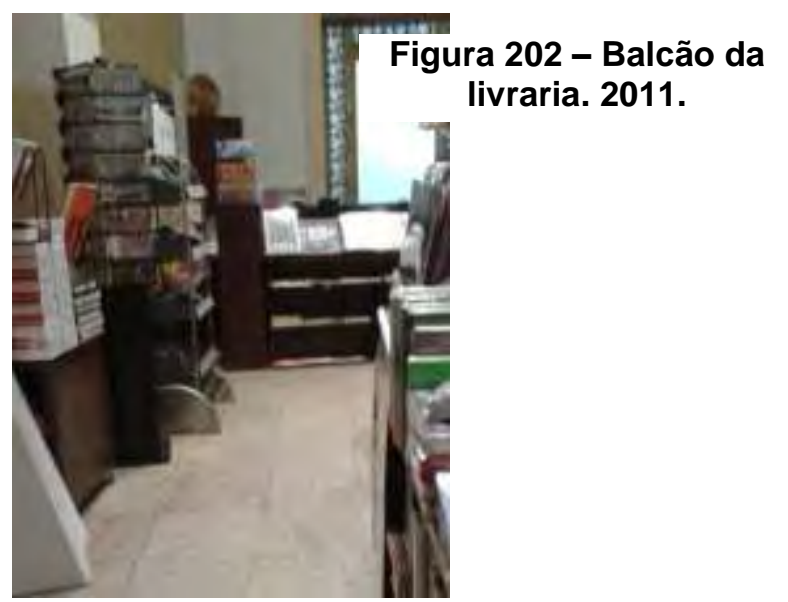




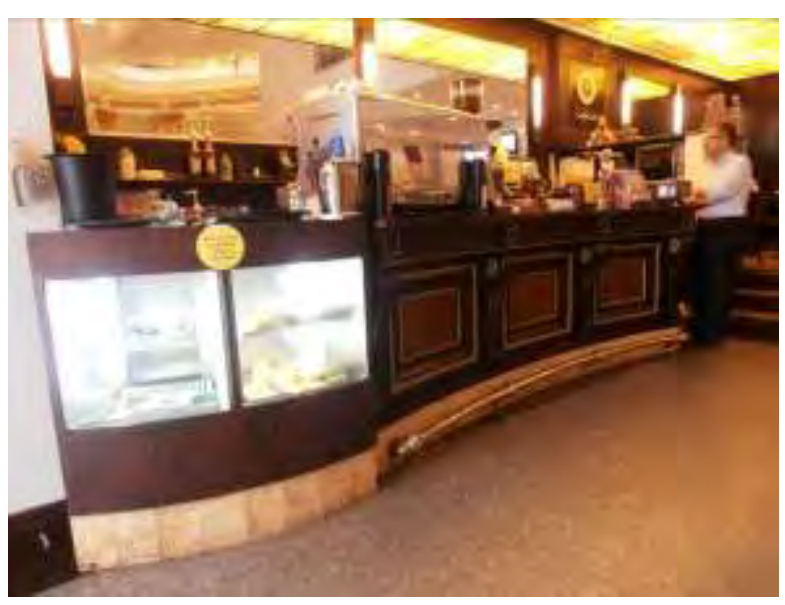

Figura 203 - Balcão da cafeteria. 2011.

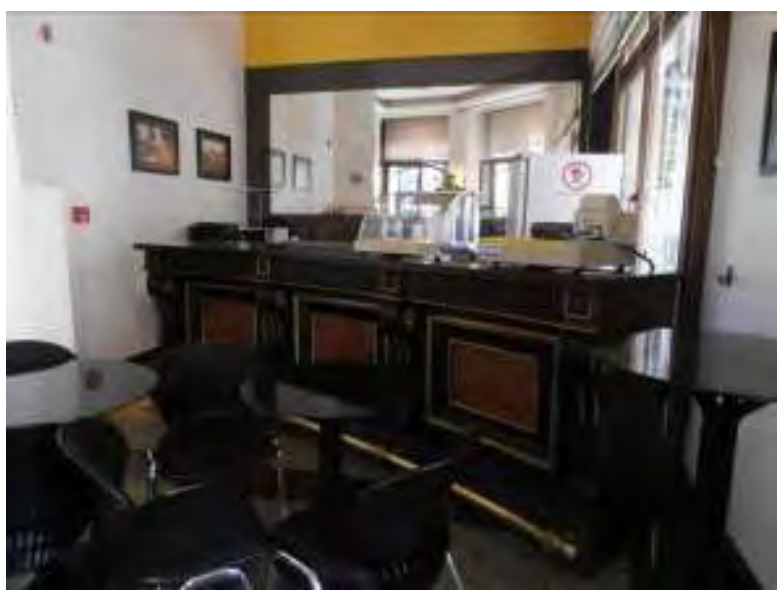

Figura 204 - Balcão do restaurante. 2011.

Os bebedouros estão distribuídos em todos os andares, exceto no mezanino e no subsolo, sempre próximos às circulações dos banheiros. No térreo e no $2^{\circ}$ andar há apenas um bebedouro comum com um infantil fixado em sua lateral $^{235}$, portanto não é atendida a exigência de que $50 \%$ dos bebedouros devem ser acessíveis por andar ${ }^{236}$. No $1^{\circ}$ e no $3^{\circ}$ andares há bebedouros adequados para serem utilizados por pessoas em cadeiras em rodas ${ }^{237}$.

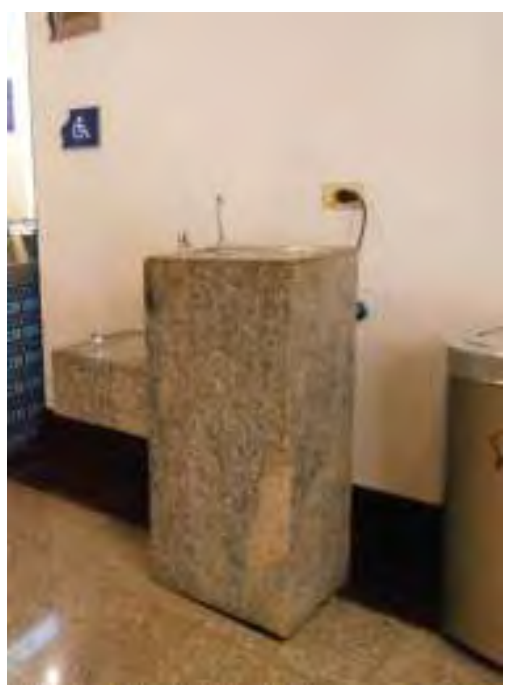

Figura 205 - Bebedouros

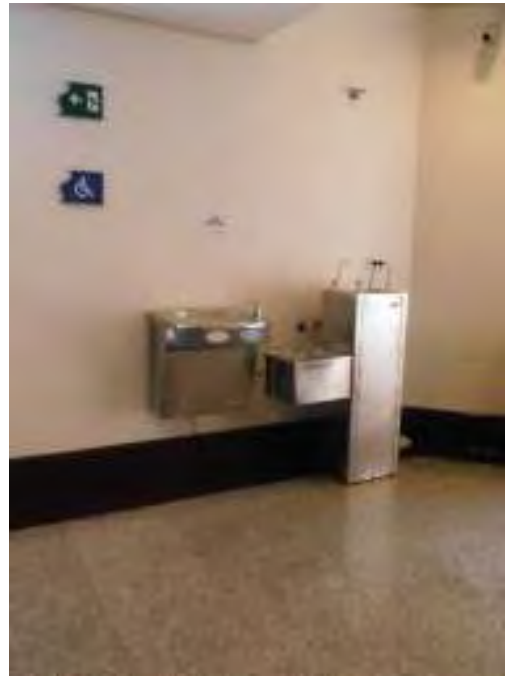

Figura 206 - Bebedouros acessível, infantil e comum.

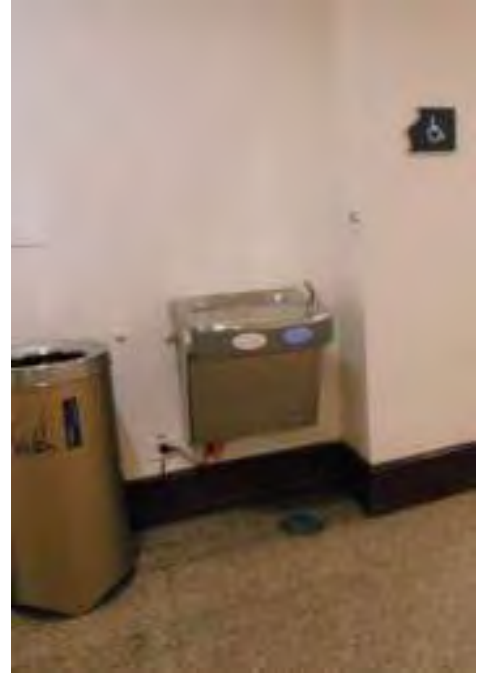

Figura 207 - Bebedouro

${ }^{235} \mathrm{O}$ bebedouro fixo ao comum geralmente tem altura para atender crianças, pois sua altura livre inferior é 0,44m em média, e não 0,73m, para permitir a aproximação de cadeira de rodas.

${ }^{236}$ Não atende ao disposto na ABNT NBR 9050/2004 - item 9.1.1.

${ }^{237}$ Atende ao disposto na ABNT NBR 9050/2004 - itens 9.1.2.1, 9.1.2.2 e 9.1.3.1. 
comum e infantil. 2011.

2011.

acessível. 2011.

Apenas no pavimento térreo há telefones públicos. No total são três telefones comuns, um acessível e um para surdos (TDD) ${ }^{238}$. O pequeno aparador fixo na parede abaixo dos telefones reduziu a altura livre inferior para apenas $0,60 \mathrm{~m}$, prejudicando a aproximação frontal do telefone acessível ${ }^{239}$.
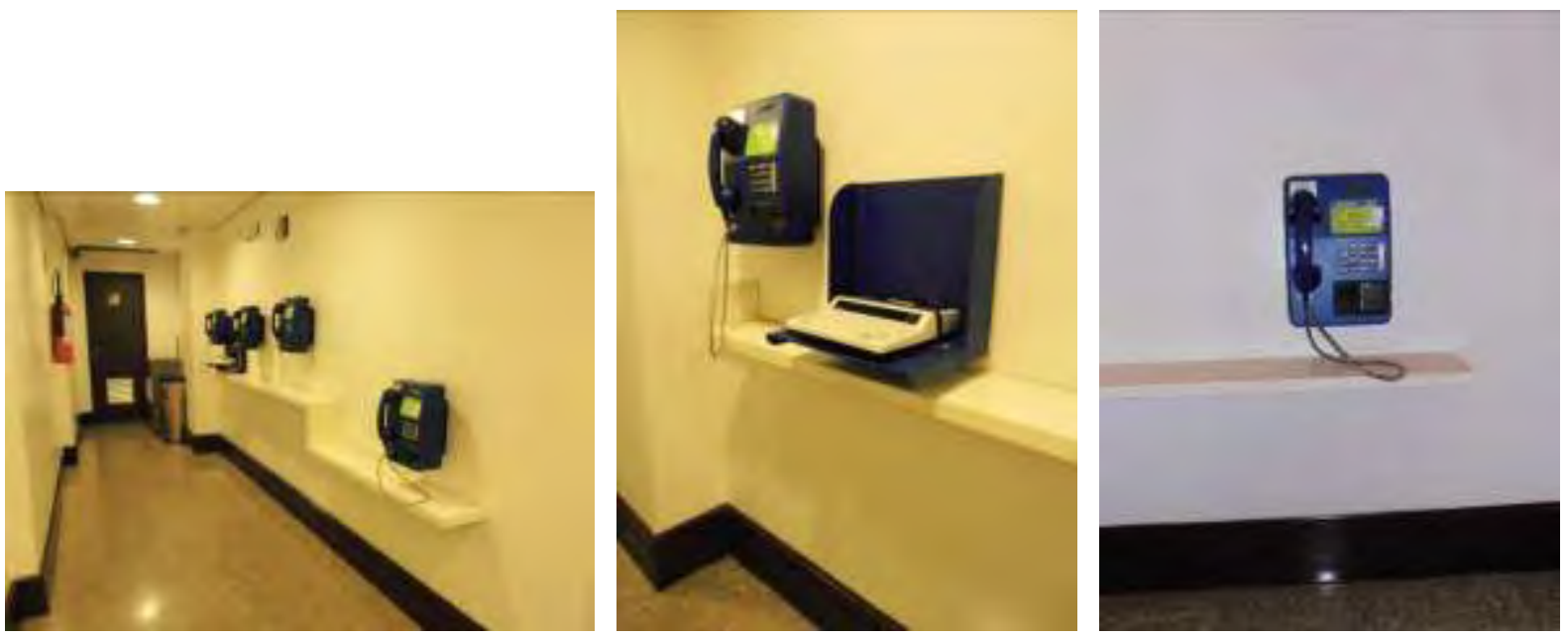

Figuras 208, 209 e 210 - Conjunto de telefones no térreo, telefone para surdos e acessível. 2011.

Os suportes de folhetos, colocados no pavimento térreo estão dentro da faixa de alcance confortável para uma pessoa em cadeira de rodas ${ }^{240}$.

\footnotetext{
${ }^{238}$ Atende ao disposto na ABNT NBR 9050/2004 - itens 9.2.1.1, 9.2.1.2 e 9.2.3.1.

${ }^{239}$ Não atende ao disposto na ABNT NBR 9050/2004 - item 9.2.5.2.

${ }^{240}$ Atende ao disposto na ABNT NBR 9050/2004 - item 4.6.2.
} 


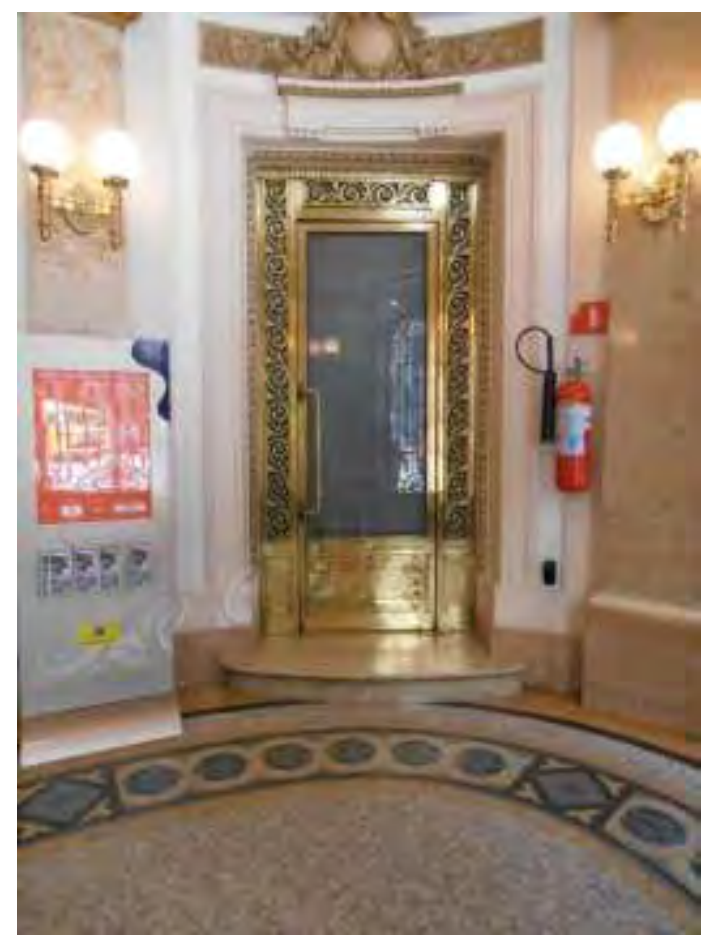

Figura 211 - Suporte de folhetos da programação (esquerda). 2011.

\subsubsection{Sinalização e comunicação}

Da entrada já é possível perceber uma falha na sinalização ${ }^{241}$ pela ausência de direcionamento à entrada acessível a partir da entrada principal que não é acessível ${ }^{242}$; apesar da entrada acessível estar corretamente sinalizada com o $\operatorname{SIA}^{243}$ (Figura 154 e 155).

O SIA foi aplicado corretamente nos locais previstos na ABNT NBR 9050/2004 ${ }^{244}$ : balcão de informações, elevadores, bebedouros e sanitário acessível. Contudo, o telefone acessível e o TDD (Telecommunication device for the deaf) não

\footnotetext{
${ }^{241}$ Não atende ao disposto na ABNT NBR 9050/2004 - item 5.2.2.

${ }^{242}$ Não atende ao disposto na ABNT NBR 9050/2004 - item 5.4.1.3.

${ }^{243}$ Atende ao disposto na ABNT NBR 9050/2004 - itens 6.2.6, 5.4.1.1 e 5.4.1.3.

${ }^{244}$ Atende ao disposto na ABNT NBR 9050/2004 - item 5.4.1.3.
} 
estão sinalizados ${ }^{245}$. Porém, é utilizado indevidamente nos bebedouros infantis, que não são adequados ao uso de pessoas usuárias de cadeira de rodas (Figura 205).

Nenhum dos degraus, escadas da circulação, escadas de acesso ao cinema e ao teatro e a suas plateias, rampas e elevadores possui piso tátil de alerta $^{246}$. Nos degraus isolados no térreo há faixa contrastante delimitando o bocel $^{247}$; nas demais escadas não. Na escada helicoidal só há faixa contrastante nos degraus de início do térreo e do subsolo ${ }^{248}$. Ademais, os telefones, por serem barreiras suspensas, que representam riscos para pessoas cegas, deveriam ser sinalizados com piso tátil de alerta ${ }^{249}$. Ver figuras do item 3.8.4.

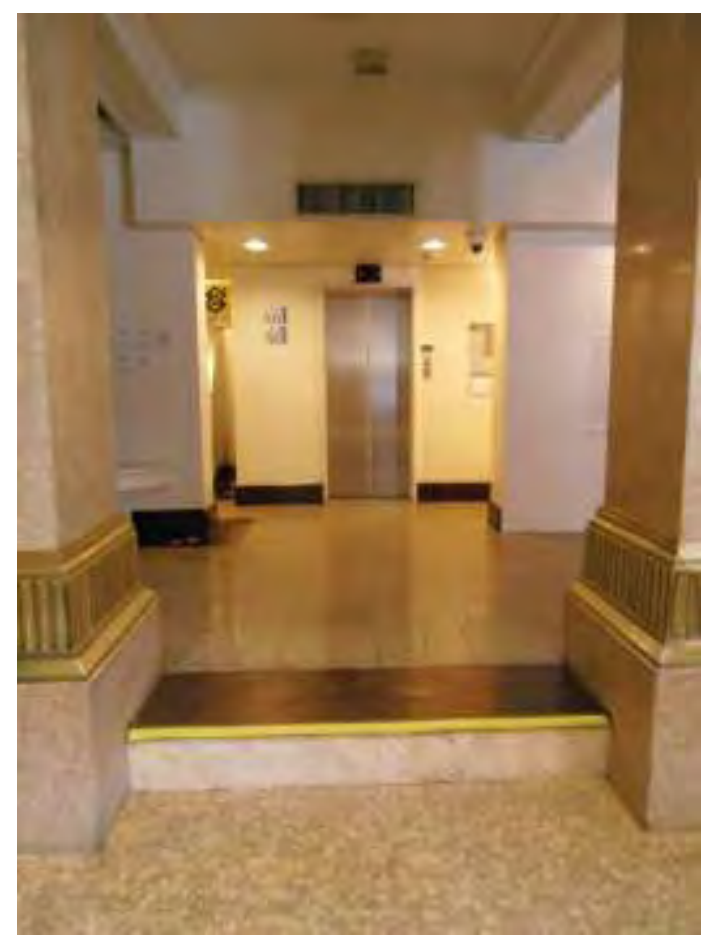

Figura 212 - Exemplo de degrau sem piso tátil de alerta, mas sinalizado com faixa contrastante. 2011.

A sinalização visual, indicativa dos principais ambientes e salas, garante

\footnotetext{
${ }^{245}$ Não atende ao disposto na ABNT NBR 9050/2004 - itens 5.4.1.3, 5.4.3.2 e 9.2.3.2.

${ }^{246}$ Não atende ao disposto na ABNT NBR 9050/2004 - item 5.14.1.2.

${ }^{247}$ Atende ao disposto na ABNT NBR 9050/2004 - item 5.13.

${ }^{248}$ Não atende ao disposto na ABNT NBR 9050/2004 - item 5.13.

${ }^{249}$ Não atende ao disposto na ABNT NBR 9050/2004 - item 5.14.1.2.
} 
boa legibilidade ${ }^{250}$, principalmente pela escolha de cores. Para indicar a localização dos sanitários foi utilizado o termo "toaletes" o que pode prejudicar a compreensão da informação. Os símbolos internacionais de sanitários são utilizados para orientar sua localização ${ }^{251}$, mas não nas portas dos mesmos ${ }^{252}$, e sim outros desenhos representando masculino e feminino que não pictogramas, dificilmente reconhecíveis à distância. Não há sinalização direcional indicando a localização do sanitário acessível.

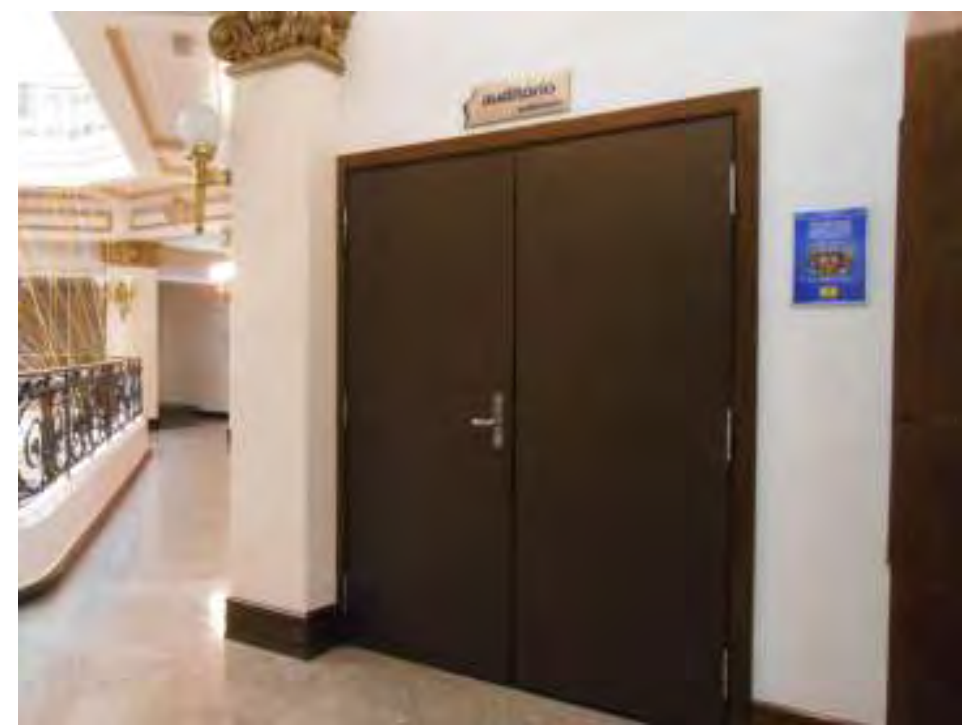

Figura 213 - Exemplo de sinalização visual identificando o ambiente, no alto da porta. 2011.

\footnotetext{
${ }^{250}$ Atende ao disposto na ABNT NBR 9050/2004 - item 5.5.2.

${ }^{251}$ Atende ao disposto na ABNT NBR 9050/2004 - item 5.4.4.1.

${ }^{252}$ Não atende ao disposto na ABNT NBR 9050/2004 - item 5.4.4.1.
} 


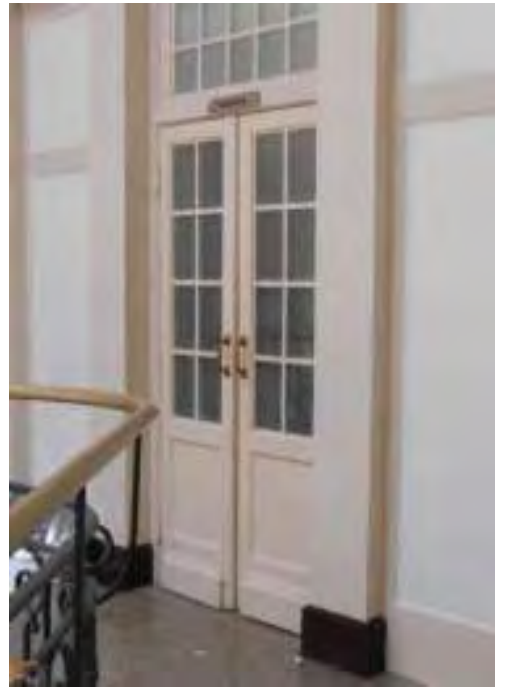

Figura 214 - Acesso aos sanitários indicado por "toalete". 2011.

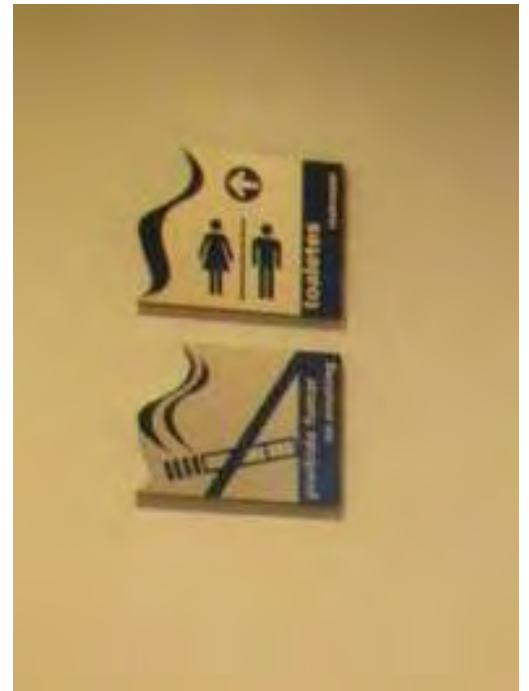

Figura 215 - Indicação direcional com pictograma, mas usa termo "toaletes". 2011.

A comunicação visual criada para a exposição que ocorria durante as visitas realizadas em novembro e dezembro de 2011 deixa a desejar. Os painéis nas paredes trazem mapas das áreas de exposição, utilizando-se de plantas de contornos excessivamente suaves ${ }^{253}$ e sem referencial que permita identificar sua própria localização, o que torna a leitura duplamente difícil, nos quesitos percepção visual e compreensão, e dificulta a eleição de uma rota a percorrer no espaço. Parte do texto tem bom contraste, com uso de cinza-claro e cinza-escuro ${ }^{254}$, e outra parte não, por usar cinza-claro e branco ${ }^{255}$. A fonte utilizada nas legendas das obras é bastante reduzida ${ }^{256}$, prejudicando a leitura, e elas estão agrupadas, dificultando a associação com a respectiva obra.

\footnotetext{
${ }^{253}$ Não atende ao disposto na ABNT NBR 9050/2004 - item 5.5.5.1.

${ }^{254}$ Atende ao disposto na ABNT NBR 9050/2004 - itens 5.5.2.2 e 5.5.2.3.

${ }^{255}$ Não atende ao disposto na ABNT NBR 9050/2004 - item 5.5.2.3.

${ }^{256}$ Não atende ao disposto na ABNT NBR 9050/2004 - item 5.5.4.
} 


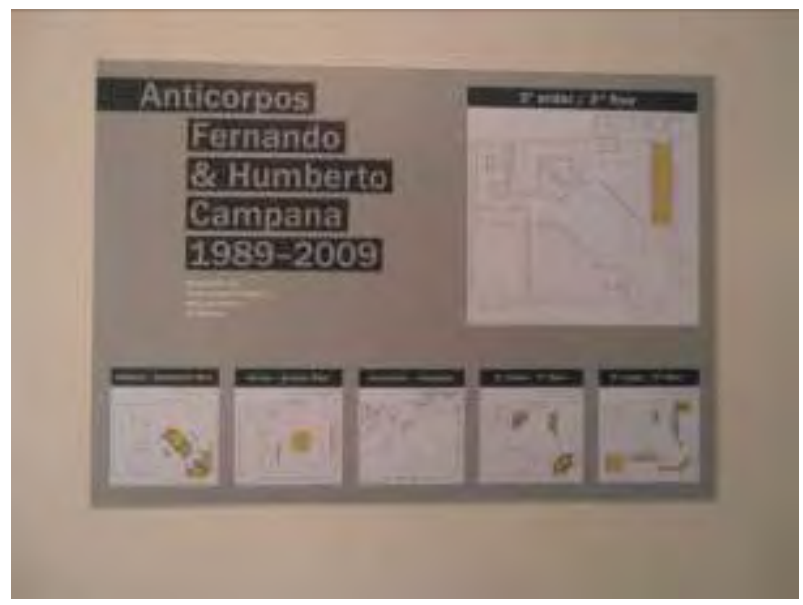

Figura 216 - Identificação das exposições nos andares. 2011.
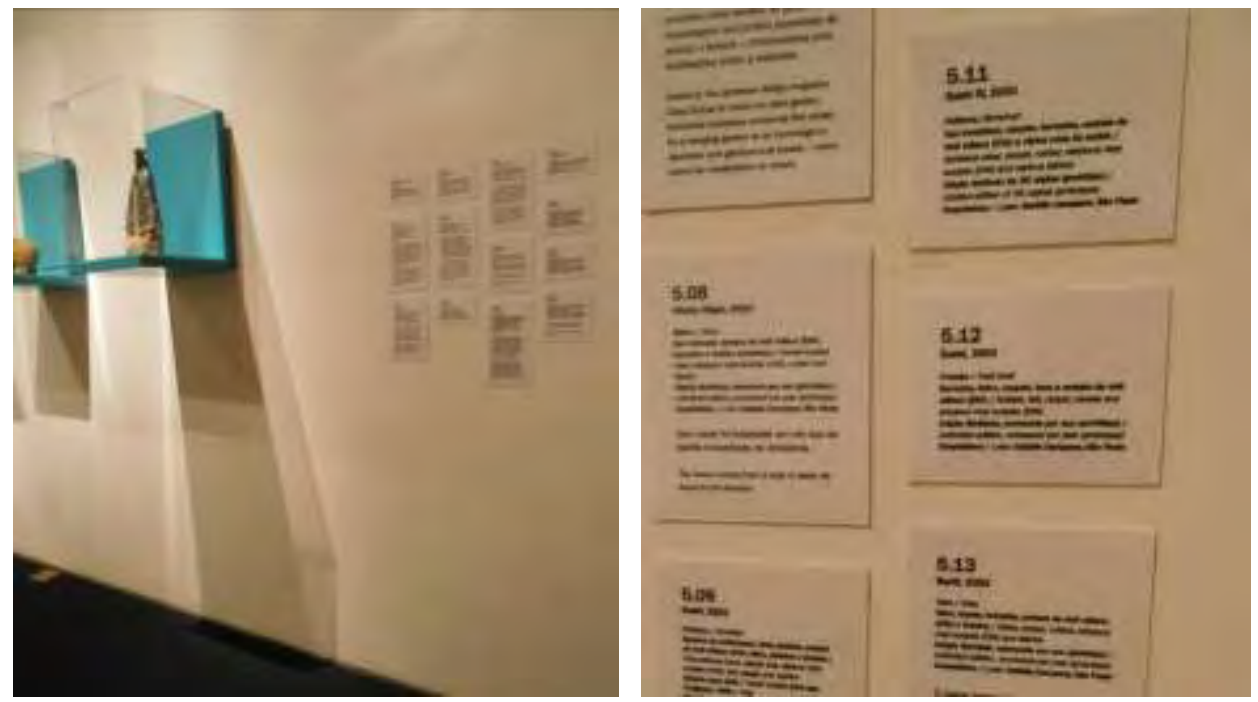

Figuras 217 e 218 - Legendas das obras e detalhe. 2011.

O teatro e o cinema não possuem sinalização indicando os espaços e lugares reservados ${ }^{257}$. Ver figuras do item 3.8.6.

No que se refere ao elevador acessível, este possui todas as características de comunicação sonora e visual, indicando sentido do elevador e andares de parada ${ }^{258}$. A botoeira interna tem sinalização em braile ao lado esquerdo

\footnotetext{
${ }^{257}$ Não atende ao disposto na ABNT NBR 9050/2004 - item 8.2.1. Apesar de esta norma indicar a necessidade de sinalização, não consta como deve ser a identificação dos assentos para pessoa obesa e pessoa com mobilidade reduzida.

${ }^{258}$ Atende ao disposto na ABNT NBR NM 313/2007 - item 5.4.3 e 5.4.4.
} 
do botão correspondente $e^{259}$. Há sinalização tátil nos batentes ${ }^{260}$ junto aos elevadores. Esta sinalização também foi utilizada nos corrimãos da escada utilizada pelo público, para identificar os andares ${ }^{261}$.

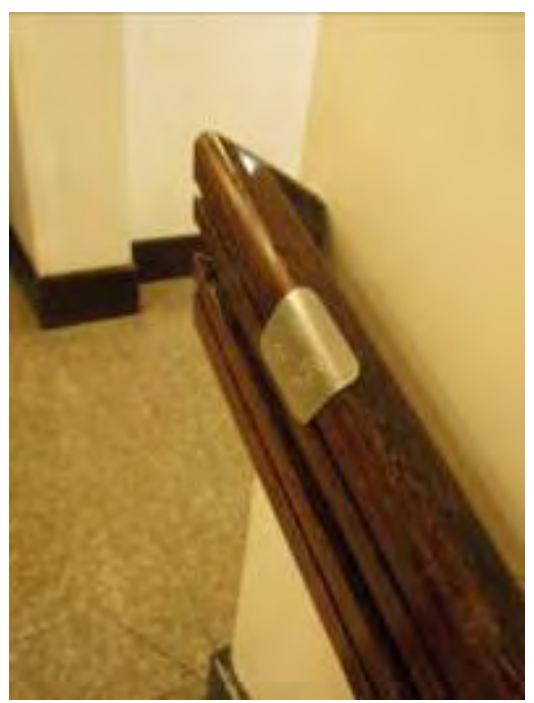

Figura 219 - Sinalização braile no corrimão da escada. 2011.

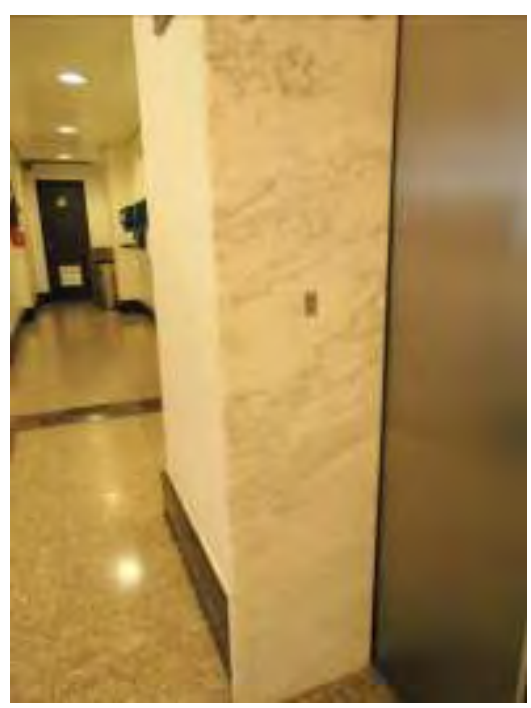

Figura 220 - Sinalização em braile no batente. 2011.

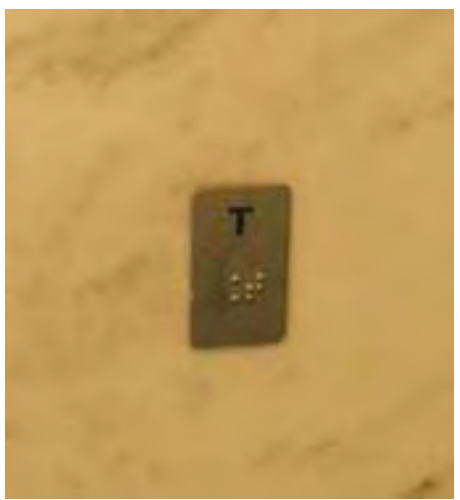

Figura 221 - Detalhe do braile do batente. 2011.
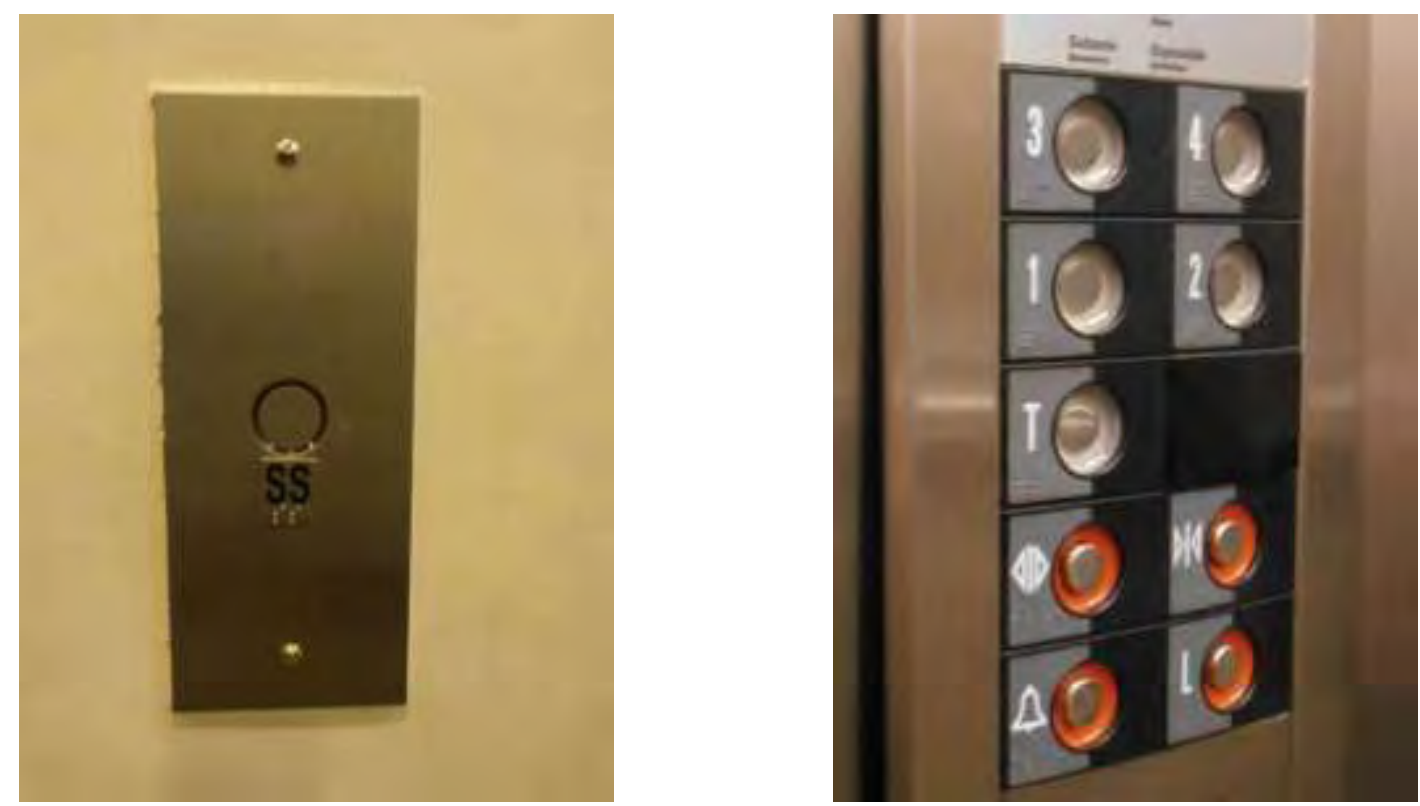

${ }^{259}$ Atende ao disposto na ABNT NBR NM 313/2007 - item 5.4 e Tabela 2.

${ }^{260}$ Atende ao disposto na Resolução CPA/SEHAB-G/004/2000 - item 10.

${ }^{261}$ Atende ao disposto na ABNT NBR 9050/2004 - item 5.12. A sinalização em braile é apenas recomendada para as escadas em geral pela ABNT NBR 9050/2004 - item 5.12. Para escadas de emergência é uma opção de aplicação para a sinalização obrigatória de indicação de pavimentos, conforme ABNT NBR 9050/2004 - item 5.15.1.2. 
Figura 222 - Botoeira de chamada do pavimento. 2011.
Figura 223 - Botoeira interna do elevador acessível. 2011.

Não há correspondente em braile e relevo na indicação nas salas de exposições, nas saídas de emergência e nos mapas de localização ${ }^{262}$. Sendo essas informações essenciais, é necessário propor diversas formas de leitura, para a sinalização ambiental.

\subsection{Análise com base no Desenho Universal}

Como exposto anteriormente, segue-se uma análise do edifício baseada nos sete princípios do Desenho Universal, que utiliza como ferramenta uma lista de verificação da publicação Universal Design Handbook elaborado pelo governo da cidade de Calgary, no Canadá, adaptada pela autora.

\begin{tabular}{|r|l|c|}
\hline $\begin{array}{l}\text { PRINCÍPIO 1: } \\
\text { Uso equitativo }\end{array}$ & \multicolumn{2}{|l|}{ É útil e utilizável por pessoas com habilidades diversas } \\
\hline $\mathbf{1 a}$ & $\begin{array}{l}\text { Fornece os mesmos meios de utilização para todos os } \\
\text { usuários: idêntico - quando possível -, ou equivalente. }\end{array}$ & $\sqrt{ }$ \\
\hline & Entrada lateral acessível. & $\mathrm{X}$ \\
\hline $\mathbf{1 b}$ & Não segrega ou estigmatiza qualquer usuário. & $\mathrm{X}$ \\
\hline & $\begin{array}{l}\text { No teatro, pela ausência de acompanhante para todos os espaços } \\
\text { reservados pode haver segregação; }\end{array}$ \\
\hline $\mathbf{1 c}$ & $\begin{array}{l}\text { Elementos relacionados à privacidade, proteção e } \\
\text { segurança estão igualmente disponíveis para todos os } \\
\text { usuários. }\end{array}$ &
\end{tabular}

\footnotetext{
${ }^{262}$ Não atende ao disposto na ABNT NBR 9050/2004 - itens 5.3, 5.10 e Tabela 1.
} 


\begin{tabular}{|c|c|c|}
\cline { 2 - 3 } & \multicolumn{2}{|l|}{$\begin{array}{l}\text { Não há equipamentos para a retirada de usuários com deficiência em } \\
\text { casos de emergência. }\end{array}$} \\
\hline 1d & Tem design atraente para todos os usuários. & $\checkmark$ \\
\hline & $\begin{array}{l}\text { Espaços amplos e iluminados facilitam o deslocamento. O vão central } \\
\text { permite melhor entendimento dos pavimentos abertos à circulação. }\end{array}$ \\
\hline
\end{tabular}

\begin{tabular}{|c|c|c|}
\hline \multirow{2}{*}{\begin{tabular}{|l}
$\begin{array}{l}\text { PRINCÍPIO 2: } \\
\text { Uso flexível }\end{array}$ \\
$2 a$ \\
\end{tabular}} & \multicolumn{2}{|c|}{$\begin{array}{l}\text { Acomoda uma ampla variedade de preferências individuais e } \\
\text { habilidades }\end{array}$} \\
\hline & Proporciona escolha dos métodos de utilização. & $\sqrt{ }$ \\
\hline & \multicolumn{2}{|l|}{ Há opção de circulação por elevadores, rampas e escadas. } \\
\hline \multirow[t]{2}{*}{$2 b$} & Permite uso e acesso por pessoas canhotas ou destras. & $\sqrt{ }$ \\
\hline & \multicolumn{2}{|l|}{ Não há elementos que prejudiquem. } \\
\hline \multirow[t]{2}{*}{$2 c$} & Facilita a exatidão e precisão do usuário. & $\mathbf{X}$ \\
\hline & \multicolumn{2}{|c|}{$\begin{array}{l}\text { Rampas muito inclinadas e escadas sem corrimão adequado dificultam } \\
\text { a precisão. }\end{array}$} \\
\hline \multirow[t]{2}{*}{ 2d } & É adaptável ao ritmo do usuário. & $\sqrt{ }$ \\
\hline & \multicolumn{2}{|c|}{$\begin{array}{l}\text { O espaço pode ser percorrido no tempo necessário e há bancos de } \\
\text { descanso. }\end{array}$} \\
\hline
\end{tabular}

\begin{tabular}{|r|l|c|}
\hline $\begin{array}{l}\text { PRINCÍPIO 3: } \\
\text { Uso simples e } \\
\text { intuitivo }\end{array}$ & $\begin{array}{l}\text { O uso é fácil de compreender, independente da experiência do } \\
\text { usuário, seus conhecimentos, habilidades de linguagem ou nível } \\
\text { de concentração }\end{array}$ \\
\hline 3a & $\begin{array}{l}\text { Elimina a complexidade desnecessária. } \\
\text { O espaço é de difícil leitura e compreensão, em especial pela ausência } \\
\text { de sinalização direcional. Mapas de orientação são complexos. }\end{array}$ \\
\hline 3b & $\begin{array}{l}\text { É coerente com as expectativas do usuário e intuição. } \\
\text { Não é intuitivo, pela complexa divisão interna de ambientes. }\end{array}$ & $\mathbf{X}$ \\
\hline 3c & $\begin{array}{l}\text { Atende a uma gama variada de níveis de alfabetização e de } \\
\text { aprendizado de idiomas. }\end{array}$ & $\mathbf{X}$ \\
\hline & $\begin{array}{l}\text { Apesar de dispor de comunicação bilingue - português/inglês - não } \\
\text { apresenta a segunda língua oficial do Brasil: Libras. }\end{array}$ \\
\hline 3d & Hierarquiza a informação de acordo com a importância. & $\mathbf{X}$ \\
\hline
\end{tabular}




\begin{tabular}{|l|l|c|}
\cline { 2 - 3 } \multicolumn{1}{|l|}{ Não há sinalização direcional ao sanitário acessível. } \\
\hline $3 e$ & $\begin{array}{l}\text { Fornece alerta ou retorno eficaz durante e após a } \\
\text { conclusão da tarefa. }\end{array}$ & $\sqrt{ }$ \\
\hline O elevador emite os alertas necessários. \\
\hline
\end{tabular}

\begin{tabular}{|l|l|c|}
\hline $\begin{array}{l}\text { PRINCÍPIO 4: } \\
\text { Informação } \\
\text { fácil e } \\
\text { perceptível }\end{array}$ & $\begin{array}{l}\text { Comunica eficazmente a informação necessária ao usuário, } \\
\text { independentemente das condições do ambiente ou de suas } \\
\text { habilidades sensoriais } \\
\end{array} \quad \begin{array}{l}\text { Usa diferentes modos de comunicação (visual, sonora, } \\
\text { tátil) para apresentar a informação essencial. }\end{array}$ & $\mathbf{X}$ \\
\hline & Ambientes não têm sinalização tátil. & $\mathbf{X}$ \\
\hline $\mathbf{4 b}$ & $\begin{array}{l}\text { Proporciona contraste adequado entre as informações } \\
\text { essenciais e seu entorno. }\end{array}$ & $\mathbf{X}$ \\
\hline & \begin{tabular}{l} 
Contraste ruim em algumas peças de comunicação. \\
\hline 4c
\end{tabular} & $\begin{array}{l}\text { Maximiza a legibilidade da informação essencial. } \\
\text { Letras pequenas. Simbologia diferente da padronização internacional. }\end{array}$ \\
\hline & $\begin{array}{l}\text { Oferece compatibilidade com uma variedade de técnicas } \\
\text { ou dispositivos utilizados por pessoas com limitações } \\
\text { sensoriais. }\end{array}$ & $\sqrt{ }$ \\
\hline & $\begin{array}{l}\text { Em momentos específicos são oferecidos recursos como intérprete de } \\
\text { Libras, e audiodescrição e legendas nos filmes. }\end{array}$ \\
\hline
\end{tabular}

\begin{tabular}{|c|c|c|}
\hline $\begin{array}{l}\text { PRINCÍPIO 5: } \\
\text { Tolerância ao } \\
\text { erro }\end{array}$ & \multicolumn{2}{|c|}{$\begin{array}{l}\text { Minimiza perigos e consequências adversas de ações involuntárias } \\
\text { ou imprevistas }\end{array}$} \\
\hline $5 a$ & $\begin{array}{l}\text { Organiza os elementos para minimizar riscos e erros: os } \\
\text { elementos mais utilizados ficam mais acessíveis; os } \\
\text { elementos perigosos são eliminados, isolados ou } \\
\text { protegidos. }\end{array}$ & $\mathbf{X}$ \\
\hline & Não possui sinalização com piso tátil de alerta. & \\
\hline \multirow[t]{2}{*}{$5 b$} & Fornece alertas de perigos e erros. & $X$ \\
\hline & Não possui sinalização com piso tátil de alerta. & \\
\hline $5 c$ & Fornece recursos à prova de falhas. & $\sqrt{ }$ \\
\hline
\end{tabular}

Acessibilidade nos bens culturais imóveis 


\begin{tabular}{|l|l|l|}
\cline { 2 - 3 } \multicolumn{2}{|c|}{} & \multicolumn{2}{|l|}{$\begin{array}{l}\text { Elevadores possuem alerta de porta e sensor, assim como portas } \\
\text { automáticas nas salas expositivas. }\end{array}$} \\
\hline $\mathbf{5 d}$ & $\begin{array}{l}\text { Desencoraja ações inconscientes em tarefas que requerem } \\
\text { vigilância. }\end{array}$ & $\sqrt{ }$ \\
\hline & $\begin{array}{l}\text { Ausência de sinalização indicando existência de entrada lateral } \\
\text { acessível pode fazer com que uma pessoa idosa se arrisque em uma } \\
\text { entrada sem corrimão de apoio. }\end{array}$ \\
\hline
\end{tabular}

\begin{tabular}{|c|c|c|}
\hline $\begin{array}{l}\text { PRINCÍPIO 6: } \\
\text { Baixo esforço } \\
\text { físico }\end{array}$ & $\begin{array}{l}\text { Pode ser usado eficientemente, confortavelmente e com } \\
\text { mínimo de fadiga. }\end{array}$ & \\
\hline $6 a$ & Permite ao usuário manter uma posição corporal neutra. & $\mathbf{x}$ \\
\hline & Rampas muito inclinadas. & \\
\hline $6 b$ & Exige razoável força de operação. & $\mathrm{X}$ \\
\hline & $\begin{array}{l}\text { Rampas muito inclinadas, piso irregular na entrada e porta } \\
\text { subsolo na ligação entre elevador e área expositiva. }\end{array}$ & \\
\hline $6 c$ & Minimiza ações repetitivas. & $\sqrt{ }$ \\
\hline & Não exige ações repetitivas. & \\
\hline $6 \mathrm{~d}$ & Minimiza o esforço físico contínuo & $\sqrt{ }$ \\
\hline & Existem elevadores como forma alternativa ao percurso da & \\
\hline $6 e$ & $\begin{array}{l}\text { Permite o uso com apenas uma das mãos e sem } \\
\text { necessitar de habilidade. }\end{array}$ & $\mathbf{X}$ \\
\hline & $\begin{array}{l}\text { Percorrer piso irregular no passeio exige habilidade para ma } \\
\text { cadeira de rodas. }\end{array}$ & \\
\hline
\end{tabular}

\begin{tabular}{|l|l|c|}
\hline $\begin{array}{l}\text { PRINCíPIO 7: } \\
\text { Dimensão e } \\
\text { espaço para } \\
\text { aproximação e } \\
\text { uso }\end{array}$ & $\begin{array}{l}\text { Tamanho e espaço apropriado para aproximação, alcance, } \\
\text { manipulação e uso, independentemente do tamanho, postura ou } \\
\text { mobilidade do usuário. }\end{array}$ & $\mathrm{X}$ \\
\hline $\mathbf{7 a}$ & $\begin{array}{l}\text { Fornece uma linha clara de visão dos elementos } \\
\text { importantes para qualquer usuário, sentado ou em pé. }\end{array}$ & $\mathrm{X}$ \\
\hline & Elementos expostos não têm bom alcance visual. \\
\hline $\mathbf{7 b}$ & $\begin{array}{l}\text { Alcance confortável a todos os componentes para } \\
\text { pessoas sentadas ou em pé. }\end{array}$ \\
\hline & Alguns andares não têm bebedouro acessível. \\
\hline
\end{tabular}




\begin{tabular}{|l|l|l|}
$\mathbf{7 d}$ & $\begin{array}{l}\text { Proporciona espaço adequado para o uso de espaços e } \\
\text { dispositivos de apoio ou de ajuda pessoal. }\end{array}$ & $\checkmark$ \\
\hline & $\begin{array}{l}\text { Há equipamentos adequados, como bebedouros, balcão de } \\
\text { atendimento e sanitário. }\end{array}$ \\
\hline
\end{tabular}

A sinalização, de forma geral, acarreta em diversos problemas que podem ser resolvidos com a correção deste ponto. Outros problemas são as rampas inclinadas e altura de elementos expositivos. Problemas fáceis de serem resolvidos, sem interferência no patrimônio edificado.

\subsection{0. Ótica do usuário}

A percepção do usuário, foco das intervenções para adequar à acessibilidade, deve ser levada em consideração. Conforme anteriormente explicado na metodologia adotada para a presente dissertação, serão apresentadas as principais considerações de algumas pessoas com deficiência, que estiveram no local de estudo.

\subsubsection{Pessoa usuária de cadeira de rodas (PCR)}

O visitante PCR não identificou onde seria a entrada acessível, a partir da sua chegada à entrada principal e, portanto aguardou do lado de fora que algum funcionário o visse e orientasse sua entrada, aguardando para ver qual era o procedimento. Internamente, conseguiu identificar as rampas para fazer sua circulação. Para ir ao sanitário, mais uma vez teve de contar com a ajuda de funcionários que orientassem sua localização. Não foi ao subsolo, pois não 
identificou que havia esse andar com exposições. De forma geral, circulou pelo espaço cultural sem problemas, utilizando-se do elevador.

\subsubsection{Pessoa idosa (PI)}

Apesar de morar próximo ao local, nunca tinha ido ao CCBB. Nunca tinha se interessado em ver o que existia no local. Quando chegou utilizou a entrada por escada, apesar de sua dificuldade em subir degraus, principalmente sem corrimão, pois achou que a entrada lateral era do prédio vizinho. Quando um funcionário informou que havia outra entrada, ela foi conhecer e disse ter gostado do acesso. Achou o local, como um todo, muito bonito.

\subsubsection{Pessoa com deficiência visual (PDV)}

Com algumas orientações dadas por um amigo de como chegar ao local a partir da estação do Metrô Sé, o visitante PDV chegou à Rua da Quitanda, vindo da Rua Quinze de Novembro, porém, mesmo tendo certo resíduo visual, não conseguiu identificar o CCBB. Sem a informação precisa da quadra e posição, recorreu a uma pessoa que o informou que havia passado pelo local, que ficava na esquina, e precisaria voltar.

Ao entrar no local foi recepcionado por um funcionário que ofereceu a possibilidade de realizar visita acompanhada por um educador. $O$ procedimento do centro cultural, segundo ele disse, é que o visitante seja acompanhado pelo educador por até uma hora. Contudo, no dia de sua visita, circulou por duas horas com um monitor e outras duas com outro monitor. Foi informado que o visitante não 
poderia tocar em muita coisa, porém, tudo que não podia ser tocado, era descrito pelo educador. E esta pessoa, segundo sua percepção, foi devidamente treinada para fazer a descrição o mais próximo do real possível. E que, para ele, era quase como se estivesse tocando. Conheceu desta forma a história e os elementos mais relevantes da edificação, além de visitar a exposição. Considerou que apesar da ausência do piso tátil e do braile, o apoio do monitor supriu a falta.

Ao ser questionado sobre sua opinião em relação à adaptação parcial, por conta da limitação imposta pelo tombamento, como por exemplo, não ter piso tátil no CCBB, o visitante PDV disse que ele até tenta compreender, e se colocar no lugar das pessoas, no entanto diz que se se apegar muito na estética das coisas, vai dificultar a acessibilidade para muitos lugares. Dependendo do lugar, a ausência de piso tátil pode prejudicar sua segurança. Para ele que tem baixa visão, ou para o cego, é difícil ouvir que o piso tátil de alerta não é colocado por causa do piso que é bonito. Pois no final, para ele, o que importa é a acessibilidade.

Segundo seu relato, até sem piso tátil e sem instrutor, conseguiu se locomover tranquilamente no CCBB, após ter feito o percurso acompanhado do primeiro educador.

Entre os locais visitados, o CCBB foi o que mais gostou de visitar, apesar de não ter sido adaptado fisicamente para a pessoa com deficiência visual. Ele considera que o bom atendimento é primordial em qualquer espaço, independente de ser para a pessoa com deficiência. E no CCBB, avaliou que os monitores foram devidamente treinados para atender ao cego, que disse ser um desafio.

\subsubsection{Pessoa com deficiência auditiva (PS)}


Ao entrar, o visitante PS se dirigiu ao balcão de atendimento para buscar orientação sobre a programação, saber que filme estava passando e como faria para assistir. Tentou obter informações se comunicando por Libras e por mímicas, porém sem sucesso. Os atendentes se entreolharam com cara de desespero e cochicharam, segundo seu relato. Telefonaram e pediram para aguardar. Veio ao seu encontro uma pessoa que aparentava ser da equipe de vigilância, pela sua roupa. De início a visitante ficou assustada, por não saber o porquê de um policial ter ido falar com ela. Essa pessoa começou a sinalizar e foi possível estabelecer uma comunicação. A visitante questionou sobre o funcionário surdo e o intérprete que ela sabia trabalharem ali e foi informada que aos sábados e domingos não há esse atendimento, apenas durante semana ou mediante agendamento prévio. O diálogo com este funcionário desenrolou-se de forma limitada, pois não entendia completamente a língua de sinais.

A visitante observou que os textos da comunicação são sempre escritos em português e inglês, inclusive nas peças expositivas, porém não há recursos para quem se comunica em Libras. Ela esclarece que os textos da exposição podem ser de difícil compreensão para a pessoa surda, pois nem sempre tem boa compreensão da língua portuguesa, já que sua primeira língua é a Libras. Que o mais adequado seria ter formas de comunicação em língua de sinais, com uso de vídeos.

A visitante ponderou que esse "é um espaço cultural bem interessante, e o surdo precisa ter acesso a esse espaço cultural e a todo esse conhecimento cultural de qualidade".

Ao final, considerou o espaço pouco atraente para visitação, dizendo que não voltaria ao local, a não ser em uma atividade programada. Sentiu que faltou 
informação visual e um melhor atendimento.

\subsection{Análise da relação entre preservação e acessibilidade}

Aqui serão analisados os impactos que ocorreram na estrutura original do Centro Cultural Banco do Brasil para receber as adaptações necessárias para a promoção da acessibilidade. Vale ressaltar que as características físicas existentes hoje para atender às pessoas com deficiência foram inseridas como parte integrante do projeto de restauração e restruturação do espaço para o novo uso cultural.

\subsubsection{Adições}

Devido aos incentivos existentes na legislação que regula a Operação Urbana Centro e buscando atender às necessidades trazidas com o novo uso, foi promovido o aumento de área, com a ocupação do recuo no fundo do lote, para acomodar a escada de incêndio e equipamentos de ar condicionado. No entanto, essas adições não foram realizadas para atender à acessibilidade no Centro Cultural Banco do Brasil.

A principal adição em função da acessibilidade foi o acréscimo do equipamento do Elevador 3 , interligando o térreo ao $4^{\circ}$ andar. O novo equipamento é adequado para o transporte de pessoas usuárias de cadeiras de rodas. Ao lado dele, o Elevador 2 é totalmente novo, utilizando o espaço de uma escada, que interligava o térreo ao $1^{\circ}$ andar e foi suprimida. O elevador 1 foi restaurado e os elevadores 4 e 5 foram reformados. 
Os sanitários, de forma geral, aproveitam localização próxima aos originais, mas foram redimensionados e redistribuídos. Bacias, lavatórios e mictórios são todos elementos novos. Apenas o sanitário acessível ocupa local onde antes não havia sanitário.

As rampas colocadas na circulação, os degraus na área da cafeteria e a escada helicoidal, todos no pavimento térreo, são elementos novos em consequências das supressões ocorridas.

\subsubsection{Supressões}

Varias supressões fizeram parte do projeto de restauro, finalizado em 2001, para atender a demandas gerais não relativas à acessibilidade, como por exemplo, a abertura de um vão na laje do térreo, para a criação da escada helicoidal e retirada de uma escada estreita que fazia essa interligação, algumas paredes do térreo para a ampliação dos espaços, eliminação de uma escada que interligava o térreo ao $1^{\circ}$ andar para a colocação de mais um elevador, e de vários vedos do $2^{\circ}$ e $3^{\circ}$ pavimentos, onde antes havia salas.

O nível da área onde hoje está o balcão da cafeteria, próximo à entrada na Rua Álvares Penteado, foi rebaixado, reduzindo o desnível equivalente a um degrau. Contudo, isso ocorreu dentro de um contexto de alteração do piso térreo como um todo e não especificamente para a acessibilidade. $O$ piso de mosaico no átrio central, segundo a arquiteta Silvana Nigro $^{263}$, ocupava o térreo todo. Devido ao desgaste natural de uso várias partes estavam danificadas. Para o restauro foi definido que se reduziria a área com mosaico apenas ao átrio central e à entrada

${ }^{263}$, Revista AU, São Paulo, n. 96, jun./jul. 2001, p. 52. 
principal, sendo o restante do piso do térreo revestido com granito e madeira.

Com a mudança de nível houve melhora para o acesso, pois o desnível a ser vencido na entrada, de dois degraus na condição original, foi reduzido a um. 0 rampeamento dessa entrada para pessoas em cadeira de rodas inicia-se na calçada, evitando a colocação de rampa muito extensa diretamente na entrada. $\mathrm{E}$ em conjunto com as demais rampas do piso térreo se resolveu o desnível para o átrio e para o hall. Todas as rampas são revestidas com granito e madeira.

Outra supressão que ocorreu foi a eliminação de degrau entre o hall do elevador e o restante da área do mezanino. Esse desnível surgiu em decorrência da interligação do mezanino com a nova circulação vertical, que antes não tinham comunicação. A escada de circulação utilizada hoje pelo público e esses elevadores não tinham saída para o mezanino, por ser esta área privativa do banco e, portanto, era isolada da circulação vertical dos escritórios existentes a partir do $2^{\circ}$ andar. Para garantir o acesso se fez necessária a criação de passagem em rampa. Na verdade essa supressão não trouxe prejuízos para o conjunto arquitetônico, pois o degrau não era percebido, até ser feita a interligação.

A construção do sanitário acessível implicou o aumento da área molhada. Houve mudança de compartimentação para readequação das instalações sanitárias como um todo, com a supressão de alguns vedos.

A eliminação da escada de circulação entre o térreo e $1^{\circ}$ andar, já mencionada, não teve reflexo para a acessibilidade, uma vez que o Elevador 2 que utilizou seu espaço e vão, não é acessível.

\subsubsection{Sobreposições}


A única sobreposição existente são as rampas no subsolo que foram colocadas sobre o piso para transpor o desnível da porta do cofre. Um carpete cobre todo o piso externo e interno ao cofre, incluindo as rampas, o que garante continuidade visual.

\subsection{Conclusão e recomendações de adequação}

De forma geral, foi grande a alteração na estrutura original interna da edificação para atender ao novo uso. Buscou-se preservar elementos significativos, fachadas, caixilhos e principalmente a área central, que hoje conecta visualmente todos os andares. Se analisarmos comparativamente, a alteração devida à da acessibilidade foi bastante delicada e realizada dentro do contexto da intervenção proposta, sem causar cicatrizes. O fato de a estrutura original dispor de circulação vertical realizada por elevador, que permitia as adequações necessárias, tornou o processo como um todo menos dificultoso para a acessibilidade.

O que se pode destacar é que a condição de acessibilidade hoje disponível aproveitou o momento único do edifício, que foi sua conversão em centro cultural, onde a eliminação de barreiras ocorreu de forma compatível com a sua preservação. Porém, há prejuízos no atendimento das necessidades de pessoas com deficiência, ou por falta de compreendá-las ou por que hoje os parâmetros técnicos diferem das exigências de 2001.

Percebe-se, ao aliar a análise técnica com a análise de percepção do usuário, que muito pode ser feito para melhorar a condição de acesso, sem causar interferências no patrimônio. A sinalização e o mobiliário são dois pontos nos quais isso fica bastante claro. 
A sinalização ambiental e informações disponíveis são bastante deficitárias. O princípio de garantir informação fácil e perceptível, de forma ampla e em redundância não é atendido, o que ocasionou prejuízos para todos os usuários, pois dependeram dos funcionários para se deslocar e encontrar determinados locais dentro do centro cultural. Propor uma revisão desta comunicação garantiria maior autonomia, sem trazer qualquer prejuízo para a estrutura que se quer preservar.

No que tange ao mobiliário, praticamente todas as adequações podem ser feitas, como altura de bebedouro, assento para obeso, mesas dos locais de refeição, garantia de acompanhante para os espaços reservados aos usuários de cadeiras de rodas, no teatro, com a reestruturação da primeira fileira.

Em alguns pontos, é possível melhorar o espaço de forma a atender aos padrões da norma, sem prejuízos para a preservação, como por exemplo, trocar o corrimão da escada helicoidal, que nem mesmo é original e, portanto, não tem qualquer justificativa para manter-se fora do parâmetro normativo. Diferentemente, do guarda-corpo da escada utilizada para interligar todos os andares, que este sim é original, e ao qual veio somar-se um corrimão adequado, do lado oposto da escada. A ausência de um dos lados do corrimão é relevante, pois a pessoa pode não ter força para apoiar-se do lado que tem o corrimão, porém, no CCBB esse fato não é tão grave, pois há a garantia de rota vertical por meio do elevador.

A rampa da entrada não possui corrimãos, porém problema mais grave é sua inclinação. Durante a reforma para se tornar centro cultural, quando foi feita ampla modificação nos níveis do pavimento térreo esse aspecto deveria ter sido corretamente delineado, assim, hoje não teríamos este problema. Agora, a rampa precisa se estender por mais dois metros. Esta intervenção não é tão simples, mas pode ser feita com a diminuição da área da livraria. 


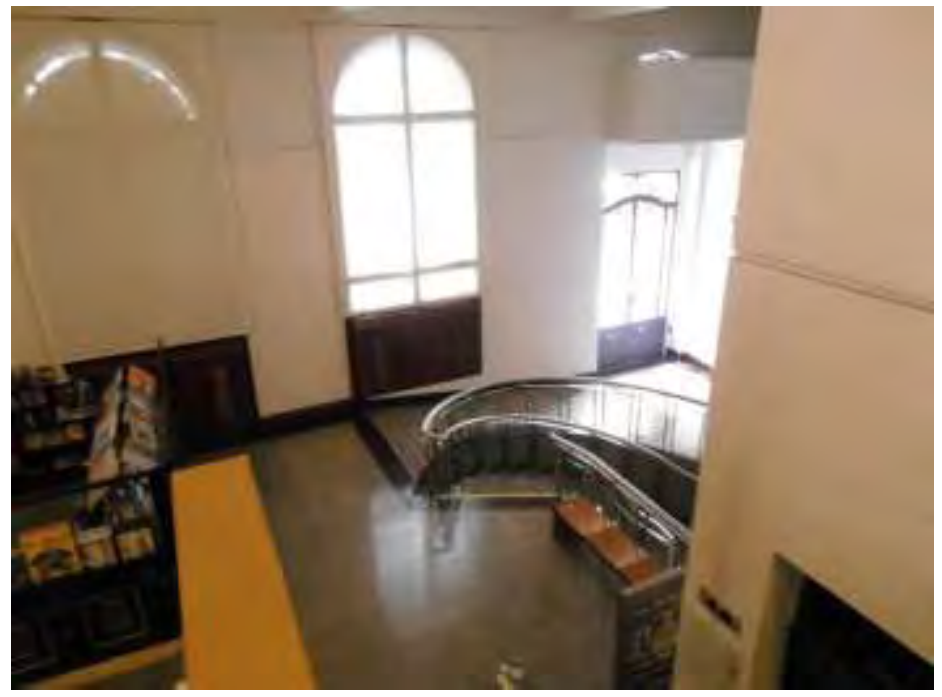

Figura 224 - Espaço entre rampa de entrada e a livraria. 2011.

Duas questões trazem maior complexidade para a discussão, precisando ser analisadas em busca de uma solução ou justificativa para a permanência da situação: acesso ao último andar e a colocação de piso tátil de alerta nas situações de risco. $\mathrm{O}$ andar denominado cobertura é restrito aos funcionários e não há acesso por elevador, mas dois importantes ambientes estão locados lá: vestiários e refeitório. E quanto à aplicação de piso tátil de alerta, em muitos pontos não há qualquer justificativa para não fazê-lo, como as escadas e elevadores, nos quais os pisos imediatamente frontais não são originais e não possuem qualquer desenho, ao contrário do saguão; este, por sua vez, precisa ser estudado, apontando-se os prós e contras da aplicação do piso tátil de alerta. Hoje já existe no mercado produto composto apenas do relevo do piso tátil de alerta que, é colado, interferindo minimamente no desenho, garantindo a sinalização necessária e a possibilidade de ser retirado sem danos à matéria original. 

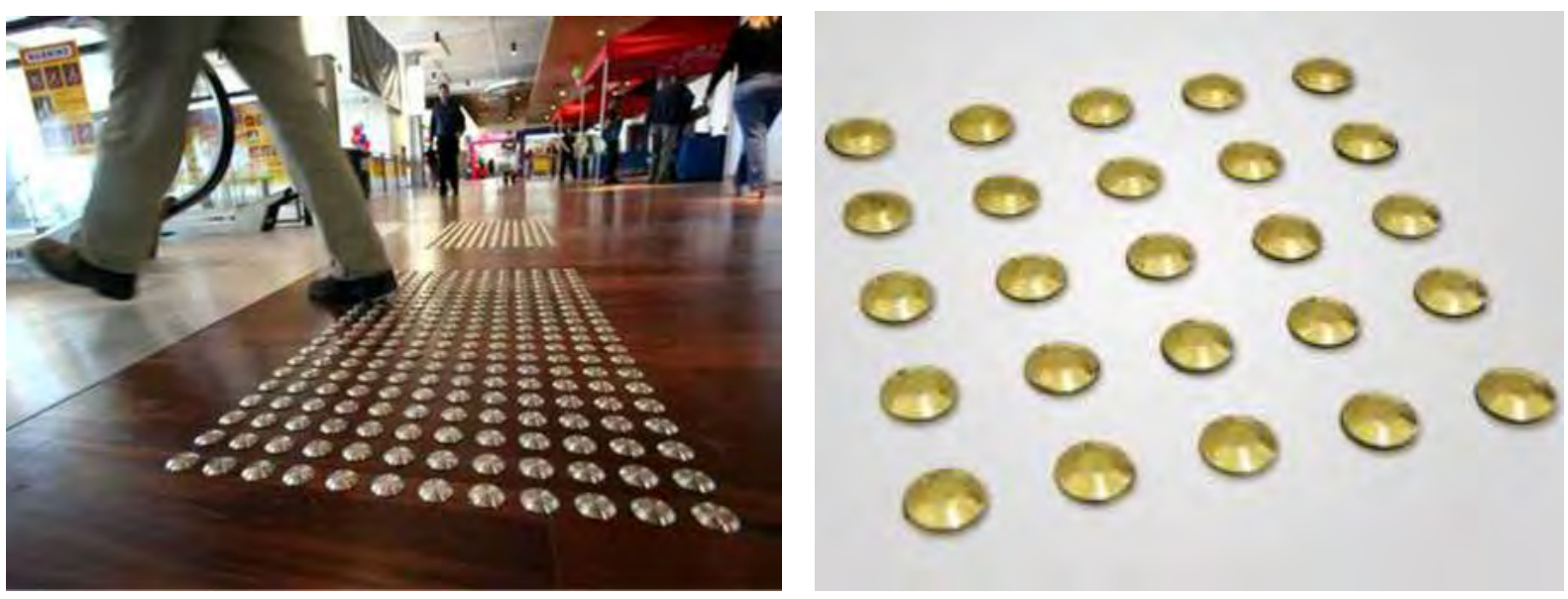

Figura 225 e 226 - Exemplos de piso tátil de alerta colados no piso.

Verificamos que algumas adequações podem ser atendidas imediatamente e outras demandam discussão por uma equipe multidisciplinar, composta por especialistas e representantes das partes interessadas. O usuário merece tal empenho para daí advirem as respostas necessárias.

Outras inadequações podem ser relevadas, em função da preservação das características originais, mas demandam hábitos rígidos. As portas originais que possuem duas folhas menores que 0,80m, como da entrada acessível e do restaurante, merecem ser preservadas, mas devem sempre ficar abertas durante o funcionamento para que o vão individual não prejudique o acesso.

A entrada inacessível de funcionários, na Rua da Quitanda, também está inserida nesse contexto. Eventuais funcionários e convidados para reuniões precisarão utilizar a entrada na Rua Álvares Penteado, única acessível, e o elevador acessível, que atende os mesmos andares que o elevador de uso exclusivo de funcionários. Às segundas-feiras, quando o centro cultural está fechado ao público, essas pessoas terão dificuldade até mesmo de solicitar, a partir da calçada, a abertura da outra entrada ao funcionário que está na recepção de serviço, pois o interfone está totalmente fora de alcance manual. A adequação desse acesso 
demanda grandes transformações, pois é estreito e tem seis degraus de desnível. Como há rota acessível interna, a adequação sugerida é da altura do interfone para melhorar a condição de acesso. É necessário que as pessoas sejam informadas previamente dessa condição de acesso, já que pela preservação necessária não é possível propor adequação mais correta.

O treinamento de funcionários e a disponibilidade de atividades que atendam à diversidade são fundamentais e se mostrou um ponto que ainda precisa ser melhorado para algumas características especificas, como para as pessoas surdas. Porém esse não é o objetivo deste trabalho e não será desenvolvido aqui, mas tal inadequação merece destaque, pois interfere no acolhimento e no aproveitamento por parte do usuário, e não exige qualquer intervenção física no bem cultural.

Com relação às características físicas a seguir são apresentadas planilhas que demonstram de forma resumida os dados e conclusões apurados aqui:

ATENDIMENTO ÀS LEIS E NORMAS DE ACESSIBILIDADE

\begin{tabular}{l|l|l|}
\cline { 2 - 3 } & SITUAÇÃO & OBSERVAÇÃO \\
\hline Passeios & & Calçadão bastante irregular \\
\hline
\end{tabular}




\begin{tabular}{|c|c|}
\hline Estacionamento & não há \\
\hline Entradas e saídas & não há acesso de funcionários acessível \\
\hline Circulação interna & $\begin{array}{l}\text { andares sem acesso / problemas ou ausência } \\
\text { nos corrimãos / inclinações inadequadas de } \\
\text { rampas }\end{array}$ \\
\hline Infraestrutura expositiva & $\begin{array}{l}\text { boa circulação, porém com expositores muito } \\
\text { altos }\end{array}$ \\
\hline Locais de reunião & $\begin{array}{l}\text { ausência de lugar para acompanhante e de } \\
\text { assento para pessoa obesa }\end{array}$ \\
\hline Locais de refeição & circulação adequada \\
\hline Outras áreas & circulação adequada na livraria \\
\hline Instalações sanitárias & $\begin{array}{l}\text { bom espaço para manobra e uso / } \\
\text { pavimentos sem sanitário acessível }\end{array}$ \\
\hline Mobiliário & $\begin{array}{l}\text { inadequações nas mesas de refeição, } \\
\text { bebedouros, telefones e balcões }\end{array}$ \\
\hline Sinalização e comunicação & sinalização deficiente \\
\hline
\end{tabular}

\section{LEGENDA}

GRAVE
MÉDIO
BOM

\section{PRIORIDADE DE ADEQUAÇÃO}

\begin{tabular}{l|l|l|}
\cline { 2 - 3 } & SITUAÇÃO & OBSERVAÇÃO \\
\hline \multirow{2}{*}{ Passeios } & & apesar da inadequação a circulação ocorre \\
\hline
\end{tabular}




\begin{tabular}{|c|c|}
\hline Estacionamento & não há \\
\hline Entradas e saídas & acesso do público ocorre, mas pode melhorar \\
\hline Circulação interna & $\begin{array}{l}\text { correções de corrimãos e inclinação de rampa } \\
\text { / falta de acesso a um andar }\end{array}$ \\
\hline Infraestrutura expositiva & $\begin{array}{l}\text { acessibilidade dos expositores deve ser } \\
\text { prioridade em um local de exposições }\end{array}$ \\
\hline Locais de reunião & reorganização das áreas reservadas \\
\hline Locais de refeição & não há necessidade de adequação \\
\hline Outras áreas & pode melhorar a circulação da livraria \\
\hline Instalações sanitárias & pequenas correções / propor novos sanitários \\
\hline Mobiliário & $\begin{array}{l}\text { não há mesas para refeição e assentos para } \\
\text { pessoas obesas }\end{array}$ \\
\hline Sinalização e comunicação & $\begin{array}{l}\text { grande dificuldade de orientabilidade e } \\
\text { ausência de sinalização tátil }\end{array}$ \\
\hline
\end{tabular}

\section{LEGENDA}

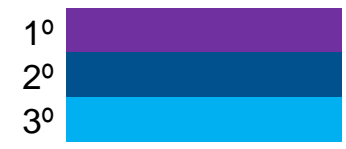




\begin{tabular}{|c|c|c|}
\hline \multicolumn{3}{|c|}{ FACILIDADE DE ADEQUAÇÃO } \\
\hline & SITUAÇÃO & OBSERVAÇÃO \\
\hline Passeios & & $\begin{array}{l}\text { adequações dependem de intervenção da } \\
\text { Prefeitura }\end{array}$ \\
\hline Estacionamento & - & não há \\
\hline Entradas e saídas & & $\begin{array}{l}\text { complexo por conta da entrada de } \\
\text { funcionários, porém há outra entrada / } \\
\text { entradas de público demandam pequenas } \\
\text { correções }\end{array}$ \\
\hline Circulação interna & & $\begin{array}{l}\text { mudança de inclinação de uma rampa / } \\
\text { pavimento sem acesso }\end{array}$ \\
\hline Infraestrutura expositiva & & novos expositores \\
\hline Locais de reunião & & $\begin{array}{l}\text { reestruturação de espaços reservados e } \\
\text { instalação de assentos de obesos }\end{array}$ \\
\hline Locais de refeição & - & não há necessidade de adequação \\
\hline Outras áreas & & redistribuição de prateleiras na livraria \\
\hline Instalações sanitárias & & $\begin{array}{l}\text { sanitário do térreo necessita de simples } \\
\text { adequações, porém há pavimentos sem } \\
\text { sanitário acessível }\end{array}$ \\
\hline Mobiliário & & $\begin{array}{l}\text { substituição de algumas mesas e bebedouros } \\
\text { / retirada de balcão de apoio do telefone }\end{array}$ \\
\hline Sinalização e comunicação & & $\begin{array}{l}\text { propor nossa sinalização ambiental / instalar } \\
\text { pisos táteis }\end{array}$ \\
\hline
\end{tabular}

\section{LEGENDA}

COMPLEXO

MÉDIO

SIMPLES 


\begin{tabular}{|c|c|c|}
\hline \multicolumn{3}{|c|}{ IMPACTO PARA A PRESERVAÇÃO } \\
\hline & SITUAÇÃO & OBSERVAÇÃO \\
\hline Passeios & & $\begin{array}{l}\text { Piso do calçadão não é contemporâneo do } \\
\text { edifício, portanto não prejudica a ambiência }\end{array}$ \\
\hline Estacionamento & - & não há \\
\hline Entradas e saídas & & $\begin{array}{l}\text { grande impacto exigirá garantir a entrada de } \\
\text { funcionários acessível / médio impacto a } \\
\text { instalação de corrimão nos degraus de } \\
\text { entrada }\end{array}$ \\
\hline Circulação interna & & $\begin{array}{l}\text { acesso ao último pav. pode necessitar de } \\
\text { passagem por laje / mudar inclinação da } \\
\text { rampa no térreo não trará grandes impactos, } \\
\text { pois laje foi alterada na reforma }\end{array}$ \\
\hline Infraestrutura expositiva & & troca de expositores não traz impactos \\
\hline Locais de reunião & & $\begin{array}{l}\text { alteração de assentos e espaços reservados } \\
\text { não interfere em nada na estrura existe ou } \\
\text { alterada na reforma }\end{array}$ \\
\hline Locais de refeição & - & não há necessidade de adequação \\
\hline Outras áreas & & $\begin{array}{l}\text { necessita apenas mexer em mobiliário da } \\
\text { livraria }\end{array}$ \\
\hline Instalações sanitárias & & propor novos sanitários pode alterar vedos \\
\hline Mobiliário & & não há impacto \\
\hline Sinalização e comunicação & & $\begin{array}{l}\text { uso do piso tátil de alerta deve ser avaliado } \\
\text { em algumas áreas }\end{array}$ \\
\hline LEGENDA & & \\
\hline $\begin{array}{r}\text { SEVERA } \\
\text { SATISFATÓRIA } \\
\text { ISENTA }\end{array}$ & & \\
\hline
\end{tabular}




\section{PINACOTECA DO ESTADO DE SÃO PAULO}

A Pinacoteca do Estado de São Paulo ocupa o edifício de padrão neoclássico de alvenaria de tijolos aparentes, concebido por Ramos de Azevedo para o Liceu de Artes e Ofícios de São Paulo, desde 1905.

Inserida em bairro com ótima infraestrutura e grande importância histórica, apesar da degradação que hoje se encontra, sua localização permanece privilegiada.

Após ampla reforma e restauração concebida pelos arquitetos Paulo Mendes da Rocha, Eduardo Colonelli e Weliton Torres, entre 1993 e 1998, a Pinacoteca se apresenta ao público de nova maneira. Entre outras características, novas condições que beneficiam o acesso e a circulação de pessoas com deficiência, com rampas e elevadores.

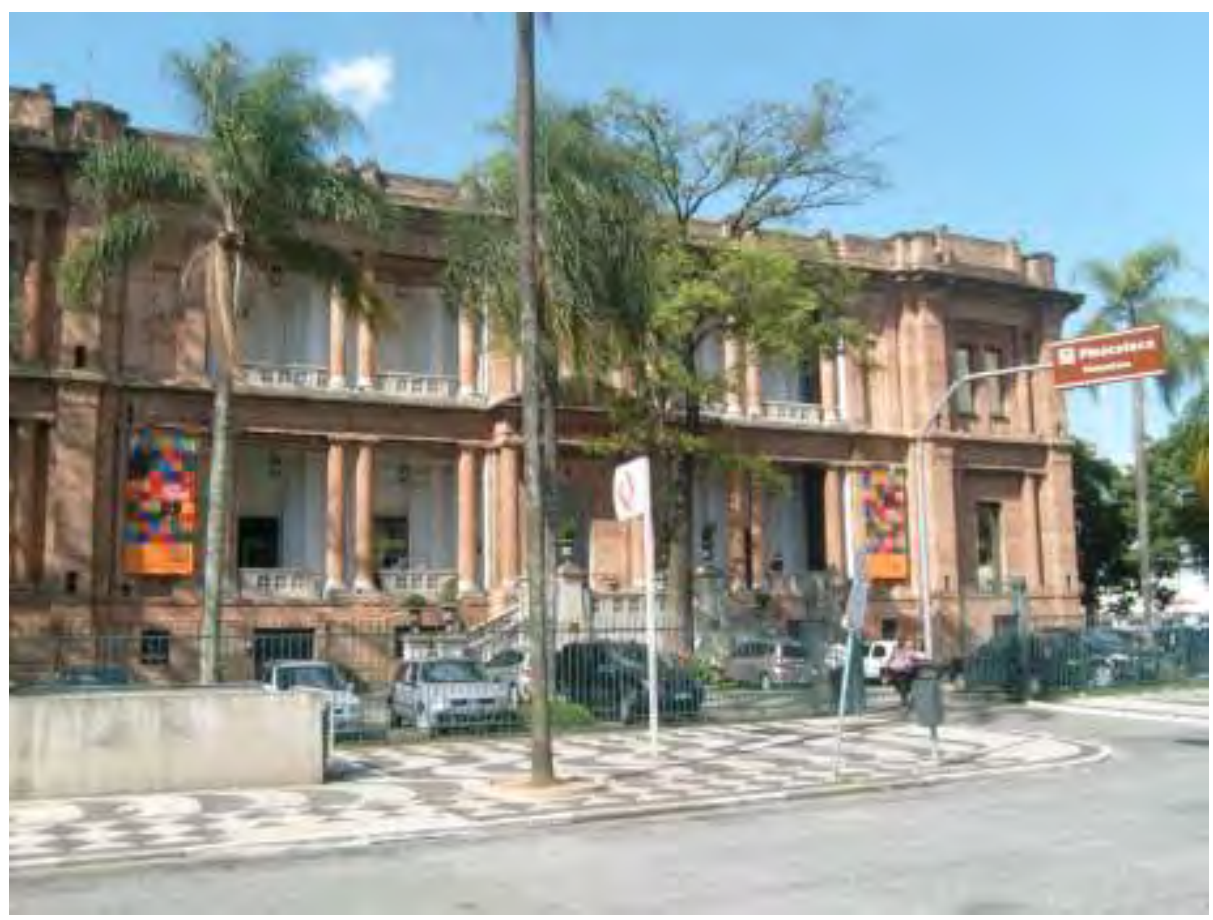

Figura 227 - Vista da Pinacoteca a partir da Estação da Luz. 2011. 
Seu acervo de artes visuais tem ênfase na produção brasileira do século XIX até a contemporaneidade. Segundo dados do seu sítio na Internet a Pinacoteca realiza cerca de 30 exposições e recebe aproximadamente 500 mil visitantes a cada ano. Hoje, o primeiro e o segundo andares são os de maior atrativo ao público, por abrigarem as exposições temporárias e de longa duração do acervo permanente, respectivamente. É também no segundo andar que fica a Galeria Tátil de Esculturas Brasileiras, na qual obras do acervo podem ser tocadas de forma autônoma por pessoas com deficiência visual, com o apoio de etiquetas em braile, mapa e piso tátil e audioguia. No térreo também acontecem exposições de menor porte, além de comportar as áreas técnicas, o auditório e a cafeteria.

Sua escolha como um dos estudos de caso se justifica principalmente pelo importante trabalho educativo dedicado às pessoas com deficiência, realizado desde 2003, o que faz este espaço cultural atraente para esse público.

\subsection{Dados}

- Endereço: Praça da Luz, no 2

- Endereço à época da construção: Avenida Tiradentes, 141

- Cadastro de logradouro: 18993-6

- Dados cadastrais: Setor 001 - Quadra 087 - Lote 0001

- CEP: 01120-010

- Bairro: Luz

- Subprefeitura: Sé

- Área do lote: $6630 \mathrm{~m}^{2}$

- Área construída: $7460 \mathrm{~m}^{2}$

- Projeto: Escritório F. P. Ramos de Azevedo

- Ano do projeto original: [1896?]-1897

- Execução: 1897-1900 
- Ano de conclusão: 1900 (parcial)

- Uso original: Local de ensino - Liceu de Artes e Ofícios

- Uso atual: Local de reunião - museu

- Proprietários: Governo do Estado de São Paulo / Secretaria de Estado da Cultura

- Proteção legal:

Resolução no 24/1982 CONDEPHAAT - Tombamento do edifício 264

Resolução no 05/1991 Conpresp - Tombamento ex-officio

Processo 1463-T-00 IPHAN - Tombamento do Conjunto Arquitetônico e Paisagístico do Bairro da Luz, no qual o edifício da Pinacoteca está incluso ${ }^{265}$

\subsection{Localização e estrutura urbana}

O acesso à Pinacoteca é bastante privilegiado. Localizado no centro da cidade, no bairro da Luz, fica defronte da Av. Tiradentes, via que interliga o eixo Norte-Sul da cidade. Também está próximo à Marginal Tietê, conectado ao eixo Leste-Oeste. No entorno há sinalização turística viária, em padrão internacional, garantindo a orientação do motorista até esse ponto de interesse.

Com relação ao transporte público o local é atendido por linhas de metrô, trem e ônibus. A Estação Luz do Metrô é atendida pelas linhas azul (Norte-Sul) e amarela (Centro-Oeste). Em relação à CPTM três linhas interligam a região da Luz a outras cidades: Mogi das Cruzes, Paranapiacaba e Jundiaí. No entanto a acessibilidade a partir das plataformas de trem está prejudicada por falta de manutenção de equipamento, diferente da estação do Metrô que há elevador na plataforma e para a calçada externa. Diversas linhas de transporte público municipal

\footnotetext{
${ }^{264}$ Processo de Tombamento no 00215/1979, o qual faz parte do acervo do Condephaat/ Unidade de Preservação do Patrimônio Histórico da Secretaria da Cultura do Estado de São Paulo.

${ }^{265}$ Em 03 ago. 2000 o IPHAN já havia notificado a preservação temporária do edifício da Pinacoteca do Estado, integrante do Conjunto Histórico no Bairro da Luz. Em 28 dez. 2011 foi publicado no Diário Oficial da União a efetivação do tombamento do Conjunto Arquitetônico e Paisagístico do Bairro da Luz.
} 
e intermunicipal fazem ponto final na Rua Mauá, e outras tantas passam no entorno da Praça da Luz.

Em frente à Estação de Trem da Luz, do outro lado da calçada da entrada da Pinacoteca, há pontos de táxi, incluindo táxi acessível, sendo um dos poucos pontos de parada fixa desse transporte na cidade.

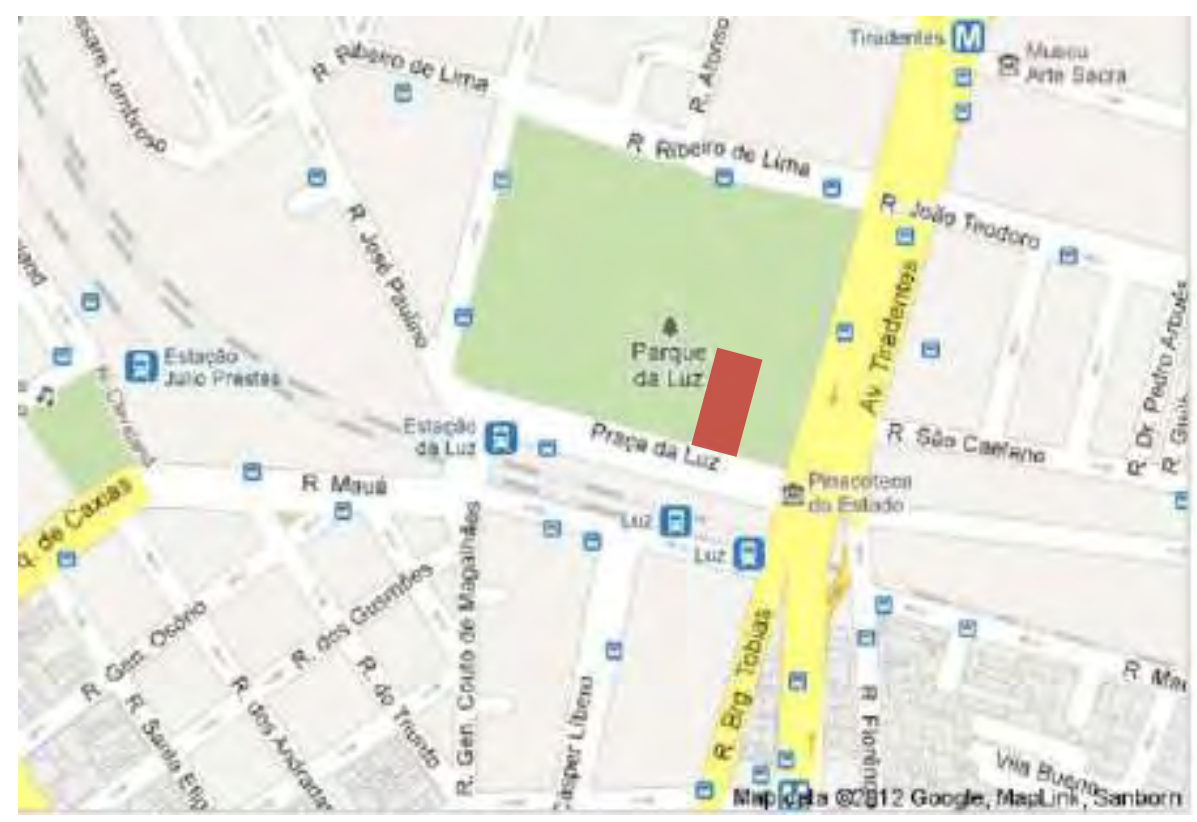

Figura 228 - Mapa de localização. Fonte: Google, 2012

\subsection{Plantas}

Em consulta ao acervo do Condephaat/ Unidade de Preservação do Patrimônio Histórico da Secretaria da Cultura do Estado de São Paulo foi localizado o Processo de tombamento $\mathrm{n}^{\circ}$ 00215/1979, referente ao edifício da Pinacoteca, no qual constam diversas plantas, sendo algumas com a denominação "Liceo de Artes e Ofícios de São Paulo", com áreas como salas de aula e de exposições. Não há identificação do ano de referência das plantas. 


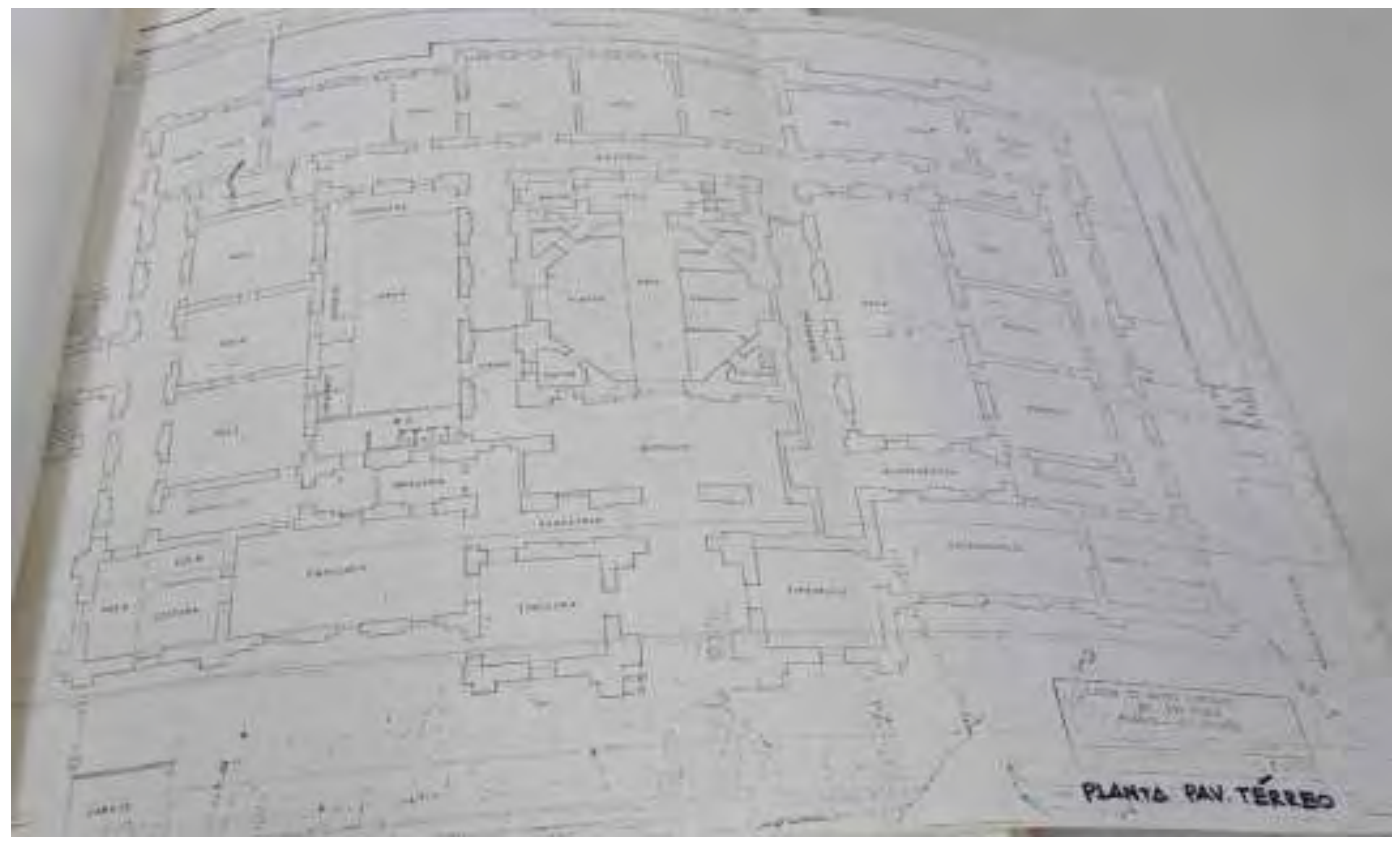

Figura 229 - Planta do pavimento térreo - acervo do Condephaat/ Unidade de Preservação do Patrimônio Histórico da Secretaria da Cultura do Estado de SP.

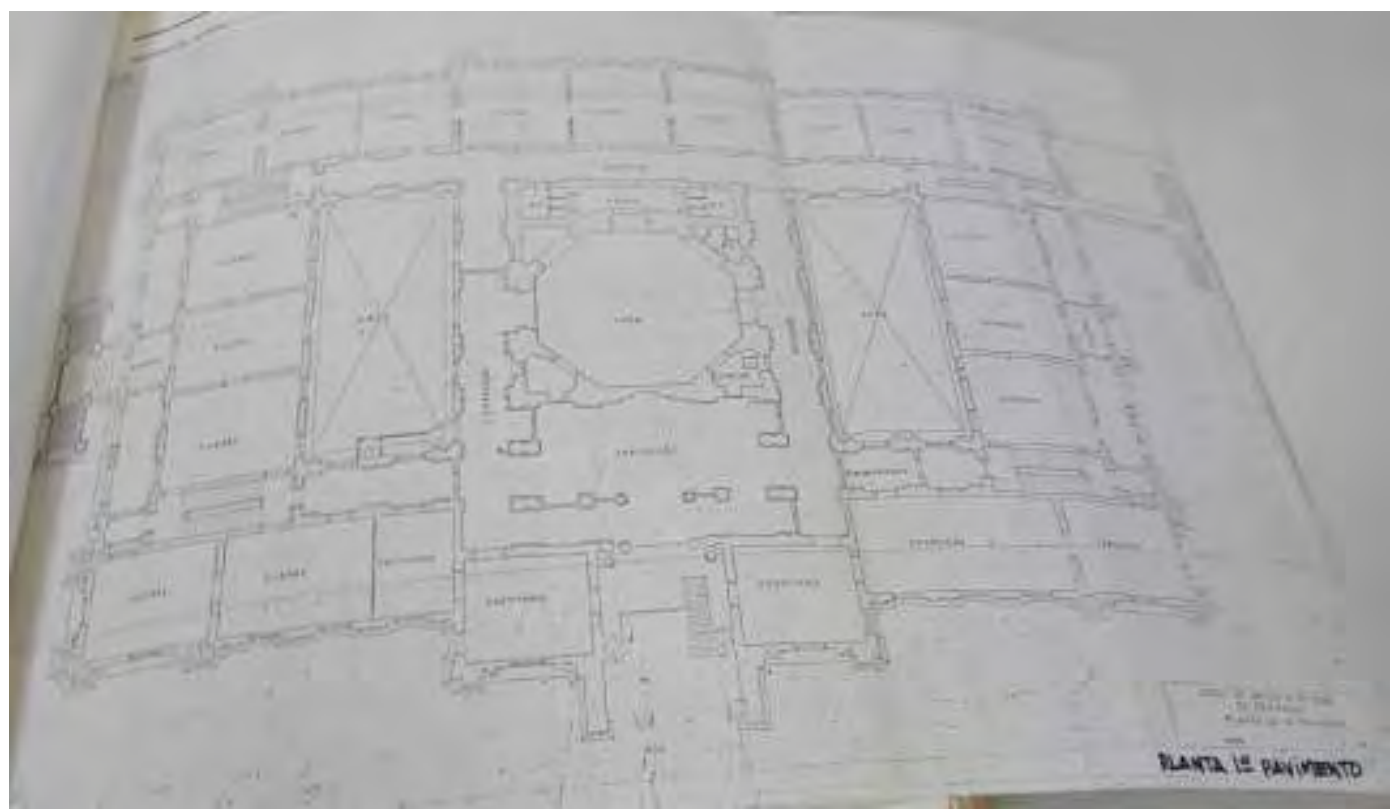

Figura 230 Planta do 1ำ pavimento - acervo do Condephaat/ Unidade de Preservação do Patrimônio Histórico da Secretaria da Cultura do Estado de SP. 


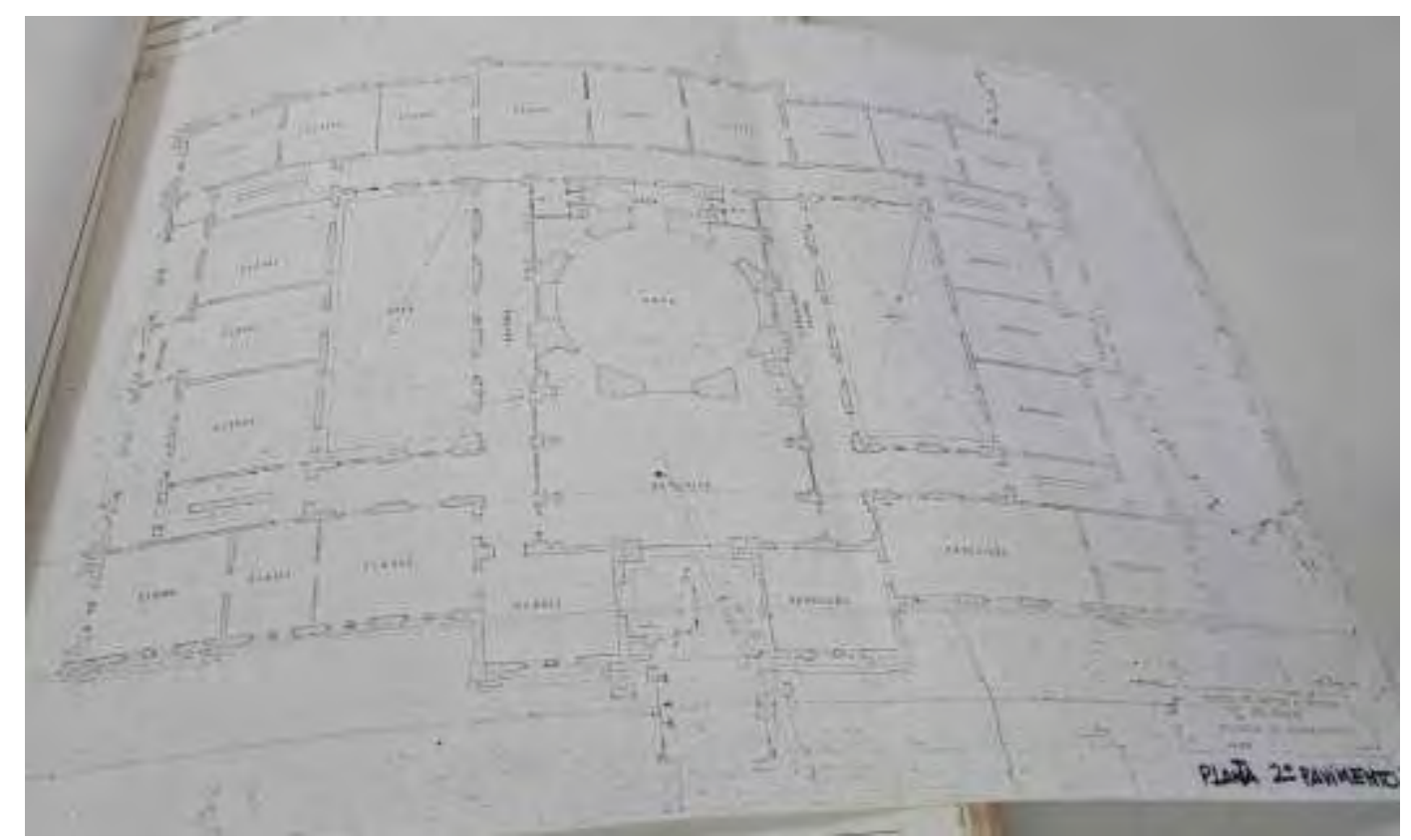

Figura 231 - Planta do $2^{\circ}$ pavimento - acervo do Condephaat/ Unidade de Preservação do Patrimônio Histórico da Secretaria da Cultura do Estado de SP.

As plantas atuais foram fornecidas pela própria Pinacoteca, em formato de arquivo de Auto CAD. O que permitiu adequá-las para as informações que se pretendia representar como, acessos, circulações, sanitários e rotas, conforme a seguir. 


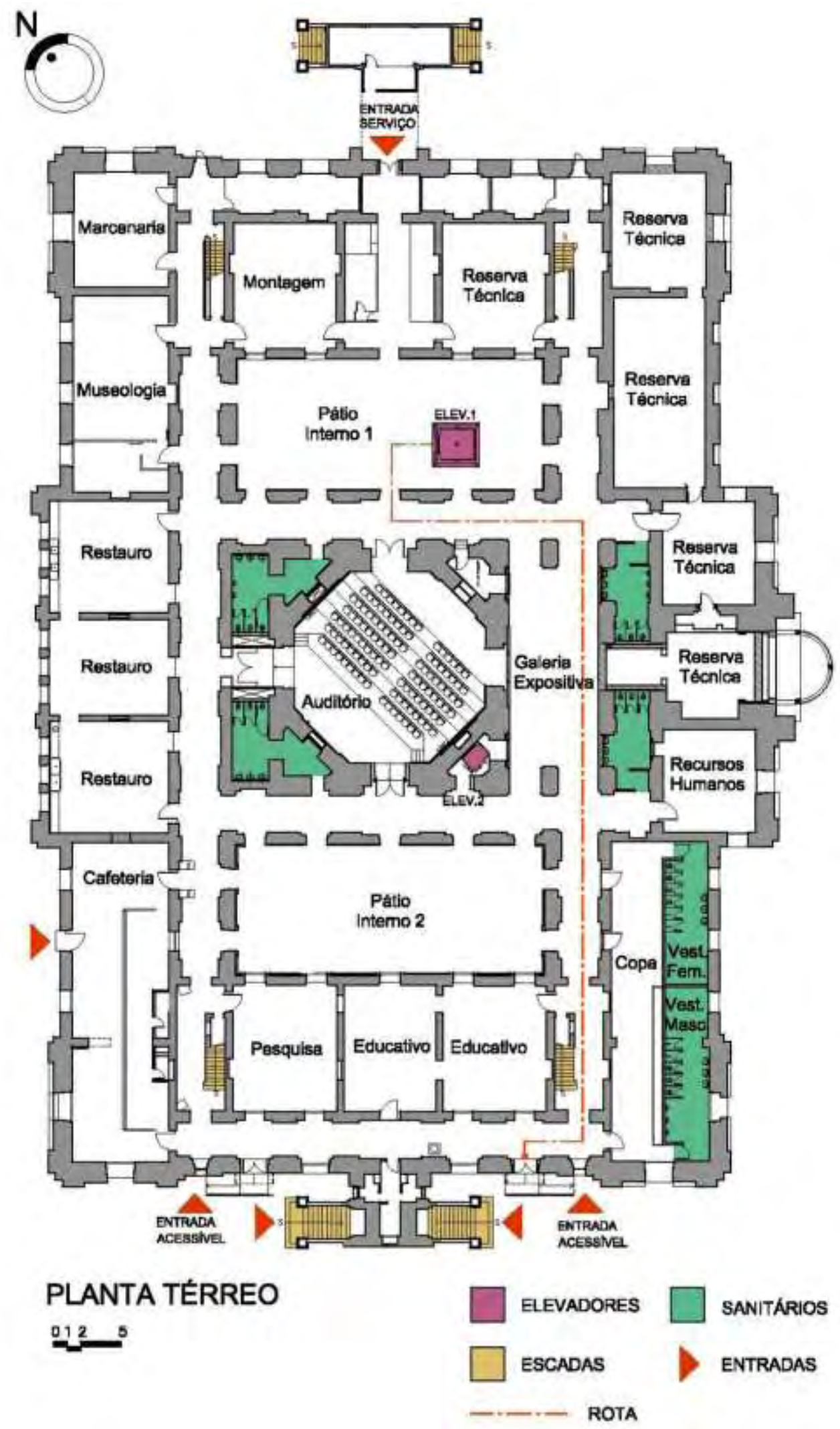

Figura 232 - Planta do pavimento térreo. 


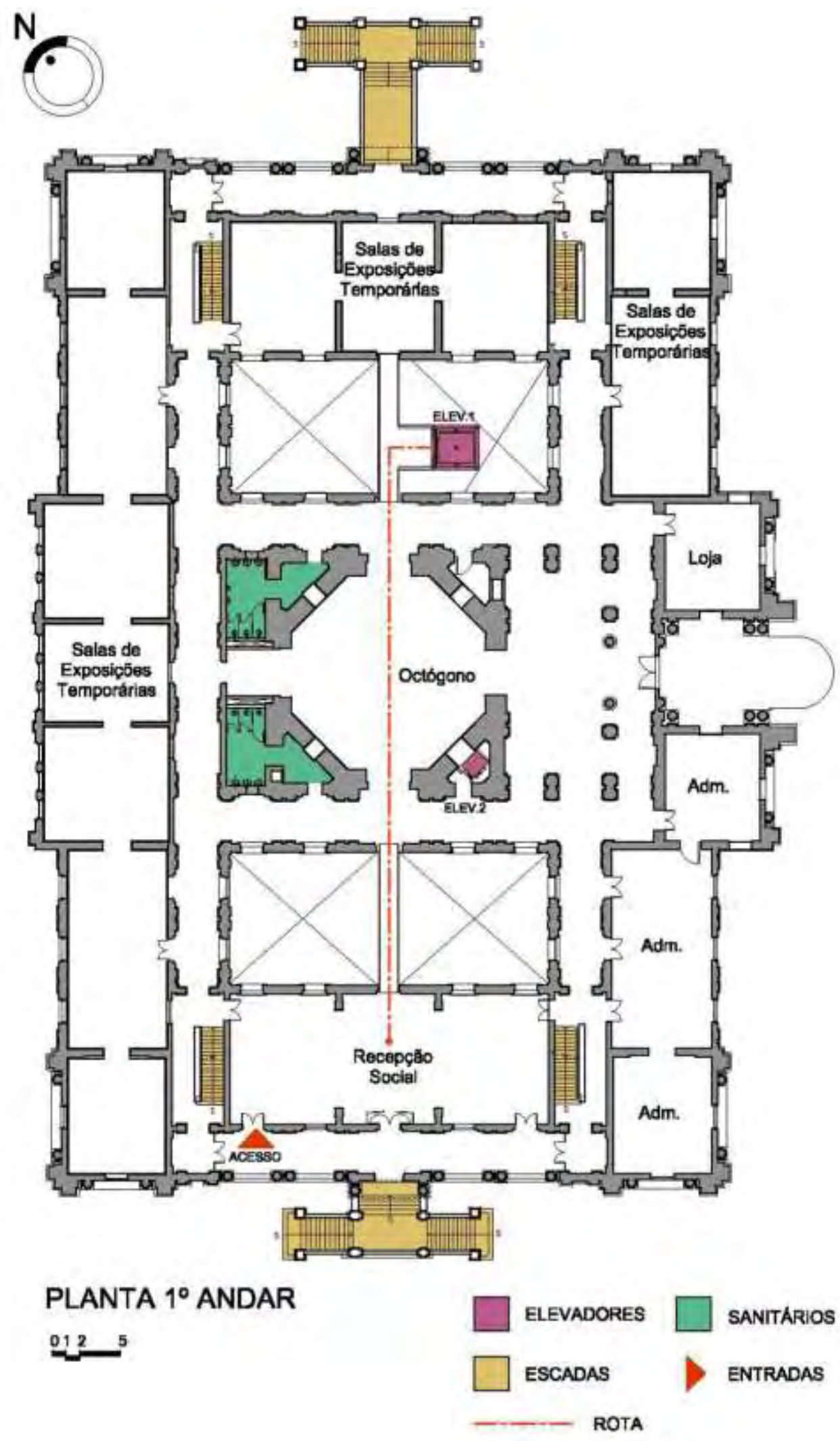

Figura 233 - Planta do 1ำ pavimento. 
$\mathrm{N}$
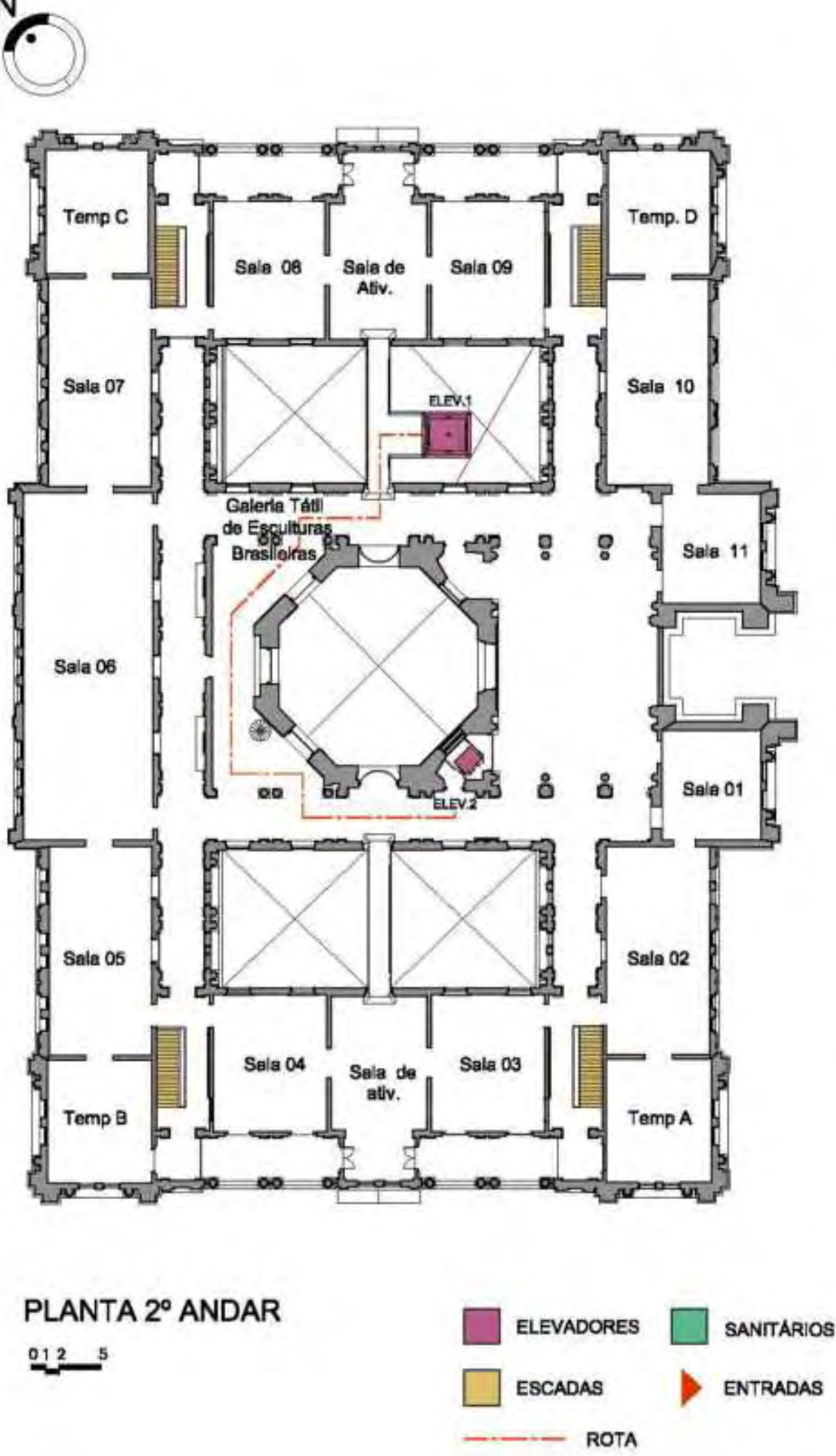

Figura 234 - Planta do 2º pavimento. 


\subsection{Histórico}

A Pinacoteca do Estado nasceu no edifício que foi inicialmente construído para abrigar o Liceu de Artes e Ofícios de São Paulo, escola técnica voltada à formação de profissionais especializados em construção. O edifício foi concebido e construído pelo escritório de Ramos de Azevedo, que foi um dos organizadores e fundadores do Liceu, tendo sido seu Diretor de 1917 até seu falecimento em 1928.

Em 1900 o edifício é parcialmente concluído para abrigar o Liceu e, em 1905, passa abrigar também a Pinacoteca e o Ginásio do Estado. O edifício ocupa uma parte do então Jardim Público de São Paulo, hoje conhecido como Praça da Luz, com a frente voltada para a Av. Tiradentes e a lateral para a Estação ferroviária da Luz, área de intensa movimentação por conta do transporte de pessoas e mercadorias.

Na década de 1930 a Pinacoteca fechou suas portas por dois anos para depois ser transferida para a antiga sede do Diário Oficial, à Rua 11 de Agosto, para em seu lugar permanecer um abrigo militar. Somente no ano de 1947 é que a instituição voltaria ao seu berço original. Juntamente com ela, a Faculdade de Belas Artes de São Paulo (FEBASP) que, também estava no antigo Diário Oficial, passa a ocupar o $2^{\circ}$ andar, enquanto a Pinacoteca ocupava o térreo e o $1^{0}$ pavimentos.

Por total falta de condições a Pinacoteca foi novamente fechada em 1970, quando a Secretaria de Cultura, Esporte e Turismo procedeu a uma reforma completa em seu espaço. Em setembro de 1973 o espaço novamente voltava a ficar disponível ao público

Em maio de 1979 a própria Pinacoteca do Estado solicita o tombamento do edifício ao Condephaat, motivado principalmente pelas transformações advindas 
da ocupação da Faculdade de Belas Artes, que na busca de ampliar sua capacidade criou mezaninos, trocou esquadrias voltadas para a Praça da Luz por janelas basculantes metálicas e retirou portas originais de pinho-de-riga. Enfim, ocorria forte descaracterização e diversos prejuízos ao edifício. E isso chegou a apresentar riscos ao acervo da Pinacoteca que por vezes via água escorrer por suas paredes, nos quais se apoiam os quadros, durante as lavagens de piso ou vazamentos que aconteciam no pavimento utilizado pela FEBASP. Também havia alto risco de incêndio por conta das precárias instalações elétricas.

O tombamento do prédio foi oficializado em 1982 pelo Condephaat, visando à preservação de um dos componentes do conjunto arquitetônico do bairro da Luz. E nessa época a ocupação de uma entidade particular em um prédio do estado, que não respeitava a preservação do edifício, foi fortemente criticada na imprensa. E em 1989, o prédio foi interditado pela Prefeitura por conta dos riscos que apresentava à segurança. E após anos de luta a Secretaria de Estado da Cultura ganha uma ação judicial contra a entidade de ensino, conseguindo a posse total do edifício.

O edifício, que em 1991 foi tombado "ex-officio" pelo Conpresp, passou a ser de uso exclusivo da Pinacoteca do Estado somente no ano de 1992.

Entre 1993 e 1998, o edifício da Pinacoteca sofreu uma ampla reforma para melhorar as condições de circulação, aproveitamento de espaço e iluminação do museu. O projeto de reforma de autoria dos arquitetos Paulo Mendes da Rocha, Eduardo Colonelli e Weliton Torres alterou a entrada do museu, antes localizada na Avenida Tiradentes, para a lateral voltada à Estação da Luz, o que modificou completamente a estrutura espacial e de circulação do edifício. Segundo, o arquiteto 
Haroldo Gallo, uma modernização radical ${ }^{266}$ :

Um dos focos centrais de seu partido foi a inversão do eixo principal do edifício e de sua entrada da avenida Tiradentes, que atravessa transversalmente o bloco edificado. A entrada do público passa a se fazer pela antiga lateral do edifício, pela praça da Luz, e o eixo principal passa a atravessar o bloco edificado longitudinalmente. Com a inversão da entrada original, a escada existente, que era de mármore, foi retirada e substituída por um belvedere com acesso pelo nível interno do átrio, que constitui uma saliência metálica em forma de meio cilindro.

A circulação que antes ocorria em torno de dois pátios, numa composição clássica biaxial, agora é feita por passarelas metálicas que seccionam os espaços. Essas passarelas permitem contemplar por novas perspectivas o edifício e as obras expostas. O pátio central em formato octogonal recebeu um novo piso entre o térreo e $01^{\circ}$ andar, para a criação de um auditório no térreo e continuidade da circulação do pavimento de acesso dos visitantes, no $1^{\circ}$ andar. Como os três pátios foram cobertos houve grande ampliação da área de exposições. Um novo elevador, interligado à passarela de um dos pátios laterais, garante transporte mais cômodo para os visitantes e para obras, que dependiam exclusivamente de quatro escadas nas extremidades do edifício.

Os elementos novos inseridos garantem distinguibilidade de forma marcante à estrutura original. A expressão de Paulo Mendes da Rocha e de sua equipe se une à monumentalidade do edifício histórico neoclássico para criar uma nova leitura do espaço e uma nova forma de uso.

${ }^{266}$ GALLO, H. Júlio Prestes e Pinacoteca: um paradoxo nas intervenções em dois edifícios históricos. In. Revista Projeto Design, São Paulo, n. 252, p.12-14, fev. 2001. 


\subsection{Características físicas}

O edifício de planta retangular ocupado pela Pinacoteca é composto de três pavimentos, denominados térreo, primeiro e segundo andar.

As colunas, pilastras e paredes são de alvenaria de tijolos, e as vigas de ferro são cobertas por tijolos. Nas áreas mais nobres os pisos são de mármore branco e em outras áreas de lajotas de cerâmica, com exceção das salas em que são de madeira. As portas são de madeira trabalhada e as janelas são de madeiras e vidro ou metal e vidro. O edifício de caráter monumental em estilo neoclássico não foi concluído, faltando o reboco e a decoração necessária à época para um edifício deste porte. Outra ausência é a cúpula sobre o vão central, que coroaria o edifício dentro do pradão clássico. O rigor construtivo de Ramos de Azevedo torna o prédio inconcluso em uma aula de técnica para estudantes, engenheiros e arquitetos, até hoje.

\subsection{Estado de conservação e preservação do patrimônio}

Pertencente à Secretaria de Estado da Cultura, a Pinacoteca é considerada um dos mais importantes museus do Brasil. Por isso e pelas obras que guarda seu espaço recebe a devida atenção à manutenção das suas instalações prediais. Seu espaço não presenta patologias aparentes e podemos considerar seu estado de conservação como bom ou ótimo.

O seu maior problema é entorno, em especial a Praça da Luz, que internamente apresenta diversos tipos de piso, de forma geral, em mau estado. Áreas de asfalto, mosaico português e pedriscos apresentam ondulações, que dificultam a circulação. O piso do entorno imediato do edifício da Pinacoteca, em 
mosaico português e paralelepípedo, também apresenta irregularidades. O Jardim da Luz é gerido pela Secretaria do Verde e do Meio Ambiente, da Prefeitura de São Paulo e não pelo Estado, como a Pinacoteca.

A proximidade com uma via de alto tráfego, que interliga o eixo Norte-Sul da cidade, exige maior atenção à conservação da sua fachada, que constantemente sofre com o acumulo de fuligem de veículos.

\subsection{Programas de atendimento às pessoas com deficiência}

A Pinacoteca do Estado de São Paulo, entre os três estudos de caso desta dissertação, é a que há mais tempo desenvolve programas de atendimento às pessoas com deficiência. Por isso, e pela qualidade, este programa se tornou referência para as instituições culturais que buscam propor recursos para esse público. O Programa Educativo Públicos Especiais (PEPE) do Núcleo de Ação Educativa da Pinacoteca, foi implantado no ano de 2003, com o objetivo de possibilitar ao público alvo, a acessibilidade física e sensorial aos espaços expositivos e ampliar o conhecimento e a percepção da arte e da produção artística brasileira, utilizando recursos que exploram a multissensorialidade. As informações foram fornecidas pela Coordenadora do PEPE, Amanda Tojal, que é doutora pela Escola de Comunicações e Artes da Universidade de São Paulo ${ }^{267}$, durante entrevista na Pinacoteca, em 16 dez. 2011.

As atividades são destinadas a grupos compostos por pessoas com deficiências sensoriais, físicas e intelectuais, e também para grupos inclusivos compostos por pessoas com e sem essas deficiências. Hoje a Pinacoteca dispõe de

${ }^{267}$ Cf. TOJAL, 2007. 
recursos de acessibilidade para 30 pinturas e permite o toque em 30 esculturas, por meio de mediação dos educadores, e outras 12 esculturas, de forma autônoma, entre as 9 mil obras do acervo.

Três carrinhos de apoio que ficam nos andares acompanham as visitas educativas e guardam os recursos bi e tridimensionais para as atividades relativas às pinturas. Foram reproduzidas em relevo de resina acrílica, alto contraste em borracha texturizada (preto/amarelo) e maquetes de montar, obras ícones do acervo. A experiência educativa é complementada por extratos sonoros e

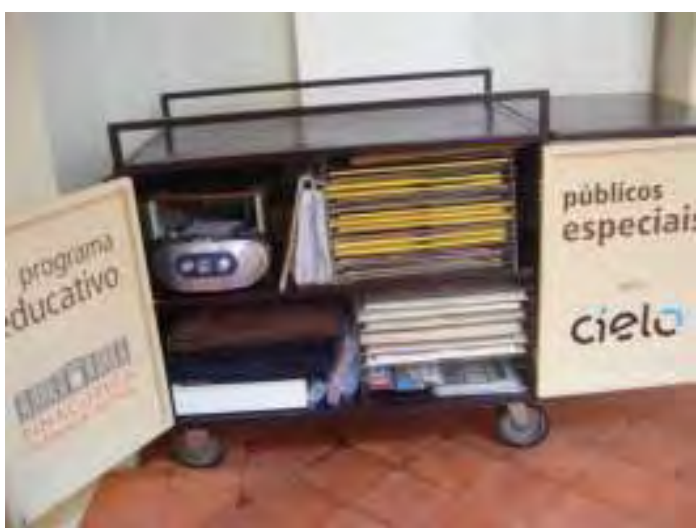

Figura 235 - Carro de apoio com material educativo do Programa Educativo Públicos Especiais da Pinacoteca do Estado. 2011.

olfativos relacionadas à obra, quando há. Todo ano buscam ampliar esse acesso cultural fornecendo recursos a outras pinturas do acervo.

Nas obras tridimensionais as partes são soltas e podem ser manipuladas isoladamente. O próprio visitante pode montar a obra olhando para o quadro original, e assim ter um trabalho de reflexão e composição.

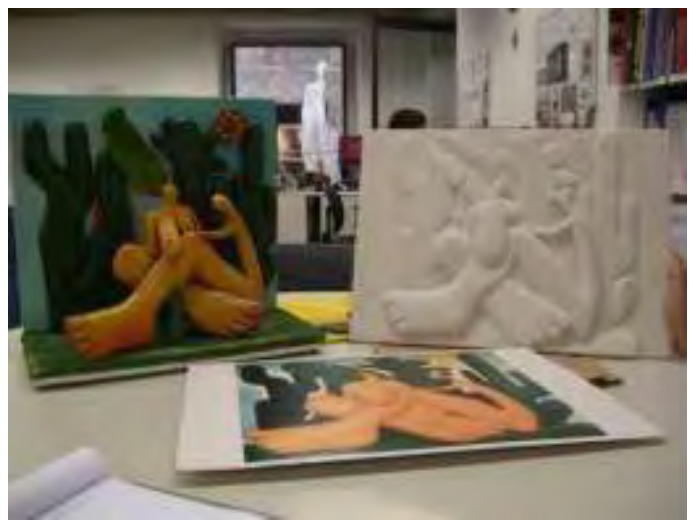

Figura 236 - Maquete de montar e relevo da obra Antropofagia da artista Tarsila do Amaral do Programa Educativo Públicos Especiais da Pinacoteca do Estado. 2011.

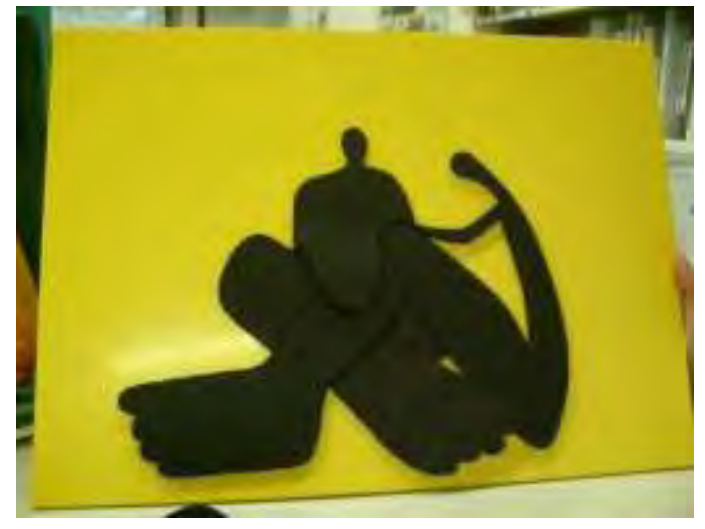

Figura 237 - Reprodução dos elementos principais da obra em alto contraste do Programa Educativo Públicos Especiais da Pinacoteca do Estado. 2011. 
Esses recursos são especialmente necessários para as pessoas com deficiência visual e deficiência intelectual, que dessa forma podem ter uma vivência exploratória da obra de forma mais concreta, gerando mais estímulos e melhorando a apreciação.

O público com deficiência visual conta ainda com a possibilidade de realizar visita autônoma em espaço, do $2^{\circ}$ andar da Pinacoteca, denominado Galeria Tátil de Esculturas Brasileiras. A exposição é composta por 12 obras originais do acervo permanente da Pinacoteca do Estado que permite explorar e reconhecer por meio do toque, as obras expostas com apoio de audioguia, mapa tátil no início do percurso e piso tátil direcional e de alerta orientando deslocamento. As legendas e a sinalização das faixas do audioguia são em dupla leitura, em tinta, com uso de fontes ampliadas, e braile. Caso a pessoa não queira utilizar o audioguia, há um folheto informativo, também em dupla leitura, para acompanhar a visitação.

Dois catálogos do acervo da Pinacoteca, em dupla leitura, são oferecidos gratuitamente aos visitantes com deficiência visual e instituições. Um sobre 0 histórico do museu, artistas e obras selecionadas, e outro sobre as esculturas. Este último, por ser mais novo, já dispõe de cd com a descrição oral do material

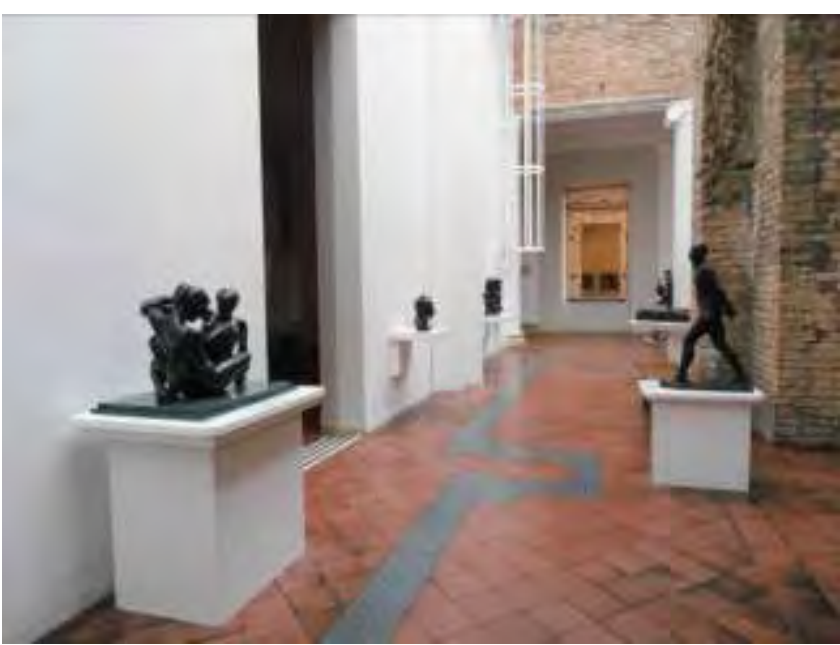

Figura 238 - Galeria Tátil de Esculturas Brasileiras do Programa Educativo Públicos Especiais da Pinacoteca do Estado. 2011. impresso para quem não lê braile. Está em elaboração o cd de áudio para o primeiro. 

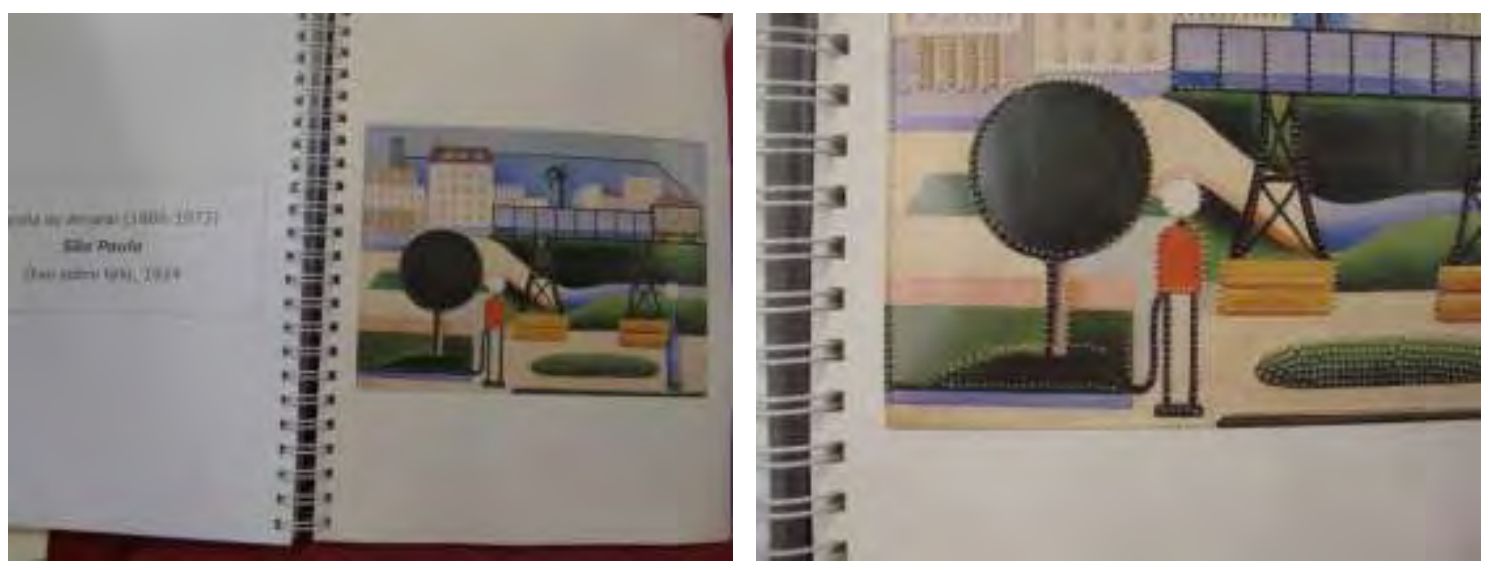

Figura 239 e 240 - Catálogo (e detalhe) do acervo em dupla leitura e relevo, elaborados pelo Programa Educativo Públicos Especiais da Pinacoteca do Estado. 2011.

As visitas educativas se iniciam em um dos pátios onde estão localizadas duas maquetes táteis, do prédio e do entorno. Elas funcionam como recurso para abordar a história do edifício e sua localização em qualquer visita educativa. Para o público cego são retiradas as cúpulas de acrílico para que possam ser tocadas.
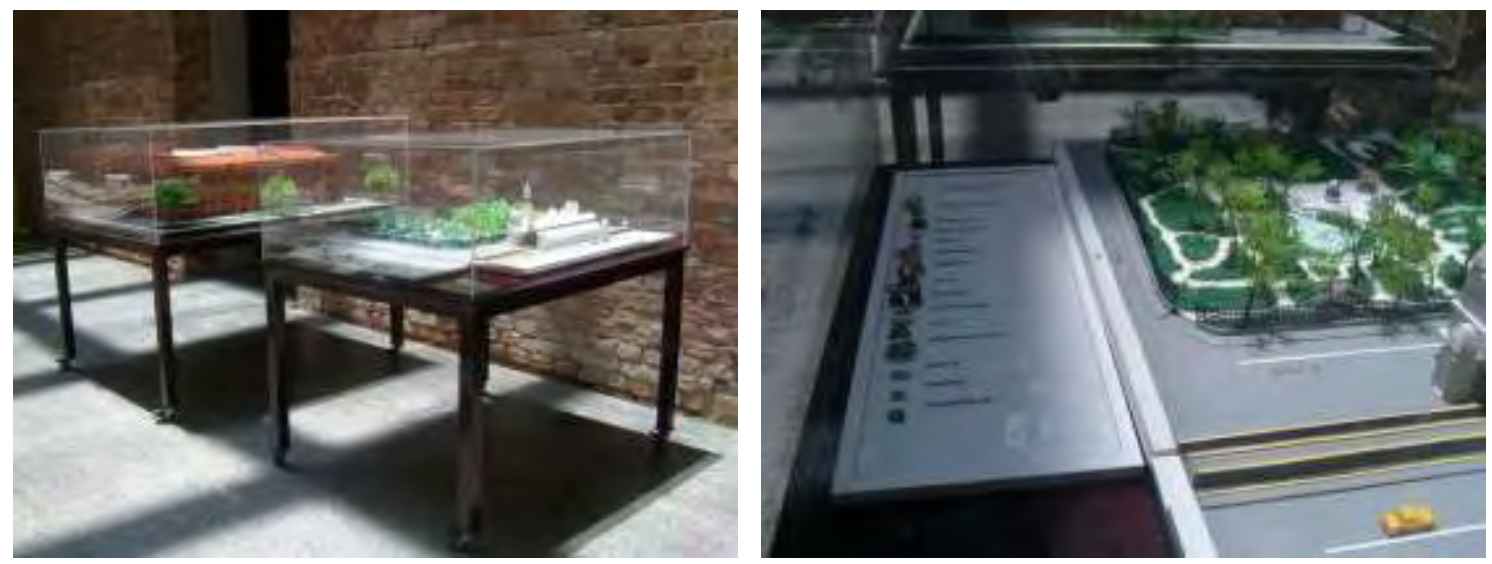

Figura 241 e 242 - Maquetes táteis e detalhe de uma delas, elaboradas pelo Programa Educativo Públicos Especiais da Pinacoteca do Estado. 2011.

Para o público com deficiência auditiva, há uma educadora surda que integra a equipe do PEPE e atende o público surdo em Libras, mediante agendamento, duas vezes por semana. Para realizar visita autônoma, foi elaborado um guia de visitação impresso, com redução de vocabulário, considerada pelo PEPE como mais adequado à compreensão desse público. No ano de 2012 serão disponibilizado signoguias, para a visita autônoma. O signoguia é um dispositivo 
eletrônico de reprodução de imagem, onde a comunicação será feita por Libras, portanto mais adequada à cultura surda.

Figura 243 - Guia de visitação para o público surdo, elaborado pelo Programa Educativo Públicos Especiais da Pinacoteca do Estado. 2011.
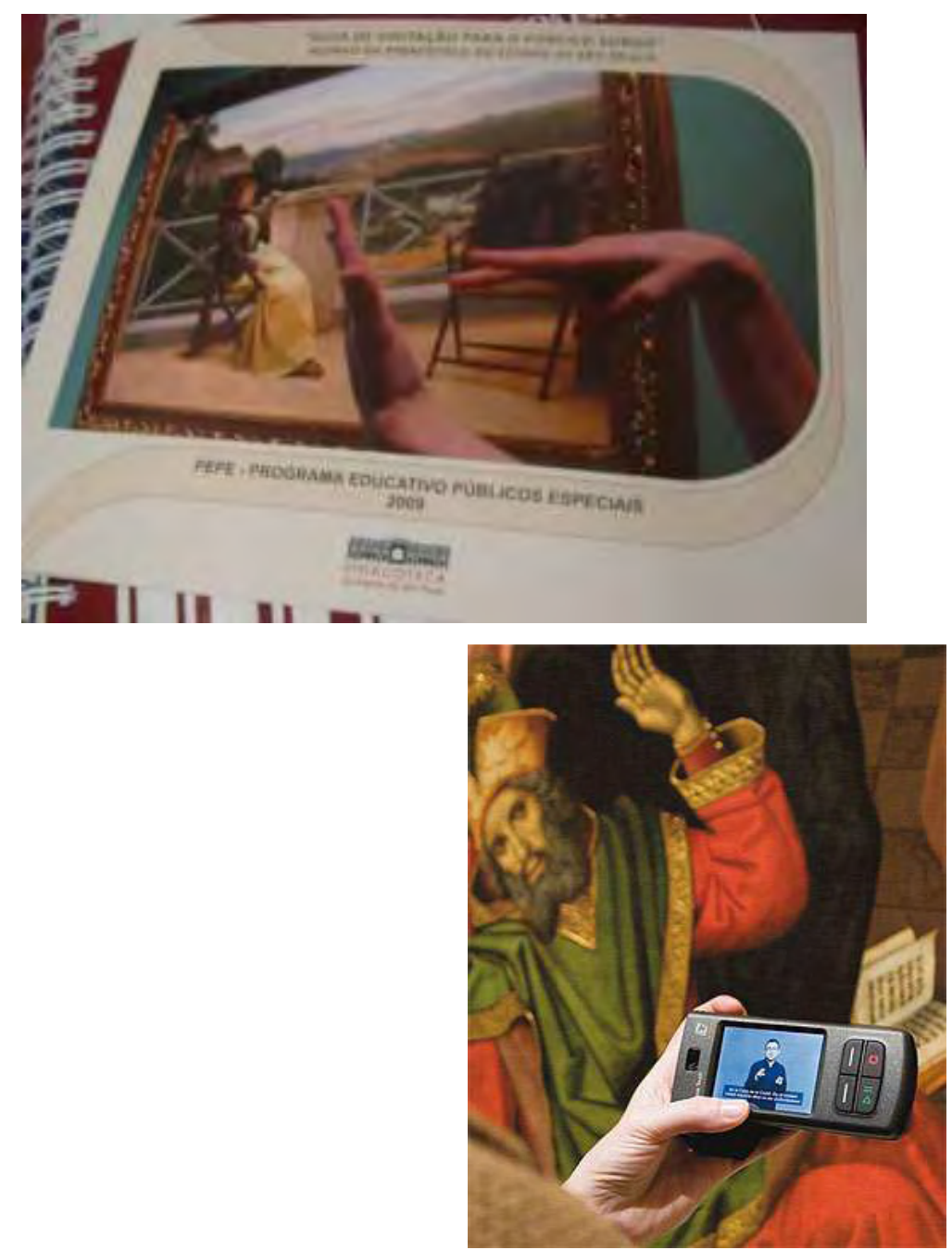

Figura 244 - Exemplo de signoguia, utilizado no Museu Nacional d'Art de Catalunya, Espanha. Fonte: sítio MNAC. 
O PEPE tem como política distinguir o uso dos recursos de acessibilidade, portanto, apenas as pessoas com deficiência têm acesso à eles. A coordenadora explica que o material poderia ser utilizado por todos, mas pela pequena quantidade disponível e por questões de manutenção e conservação, são disponibilizados de forma restrita.

E para o público com deficiência física ela explica que não há a necessidade de adequações por parte das ações do educativo, mas que toda a estrutura expográfica é adequada para a aproximação e alcance visual, além do edifício dispor de adequações como rampas, banheiros etc. Para as pessoas com mobilidade reduzida o museu dispõe de cadeiras de rodas manuais e motorizadas, inclusive para obeso, que podem ser retiradas na recepção para utilização durante a visita.

Os cursos e palestras da Pinacoteca, de forma geral, não dispõem de intérprete de Libras. Segundo a coordenadora, a necessidade desse recurso só é questionada nas fichas de inscrição das atividades do PEPE, sendo disponibilizado quando solicitado.

O PEPE apresenta anualmente no curso "Formação em Acessibilidade e Ação Educativa para Públicos Especiais" sua experiência de vanguarda no cenário nacional para professores e educadores de na área de ensino da arte de educação especial. Além disso, duas vezes ao ano, seguranças, recepcionistas e atendentes de sala são treinados a lidar com as diversas deficiências. 


\subsection{Análise técnica da acessibilidade}

Para verificar as condições de acessibilidade na Pinacoteca, foram realizadas visitas técnicas nas seguintes datas: 31 de julho de 2009, 23 de novembro de 2011 e 16 de dezembro de 2011. Foi permitido que se percorresse todo o edifício, com exceção das salas de Restauro.

\subsubsection{Passeios}

Em relação aos passeios mais próximos à Pinacoteca, voltados para a Estação da Luz e para a Av. Tiradentes, 0 pavimento utilizado foi 0 mosaico português e o bloco intertravado, respectivamente. O piso de mosaico português não é aprovado para os passeios da cidade de São

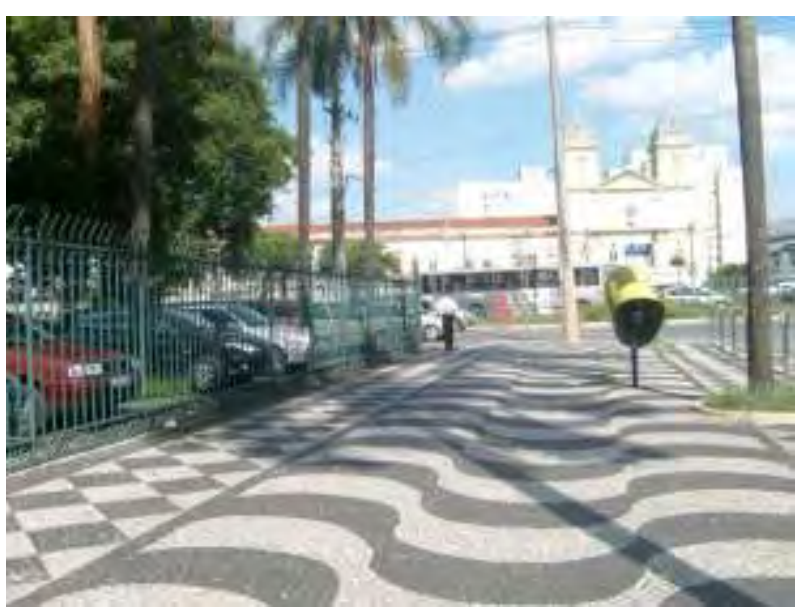

Figura 245 - Passeio em frente à entrada. 2011.

Paulo, por ser trepidante e irregular ${ }^{268}$. Somente em casos excepcionais, fora da faixa livre ${ }^{269}$ e mediante consulta à Prefeitura, esse tipo de piso pode ser usado, conforme art. 30 do Decreto Municipal № 45.904/2005:

\footnotetext{
${ }^{268}$ Não atende ao disposto na ABNT NBR 9050/2004 - item 6.1.1 - e no art. 29 do Decreto municipal no 45.904/2005.

${ }^{269}$ Faixa livre é definida pelo Decreto municipal $n^{\circ} 45.904 / 2005$, como "área do passeio, via ou rota destinada exclusivamente à circulação de pedestres, desobstruída de mobiliário urbano ou outras interferências".
} 
Art. 30. Fora da faixa livre, mediante consulta de acordo com o procedimento previsto nos artigos 38, 39 e 40 deste decreto, no caso das situações especiais, tais como em passeios contíguos às áreas de lazer, de permanência e de pedestres, poderá ser obtida autorização específica da Prefeitura do Município de São Paulo para a utilização dos seguintes materiais no pavimento:

$(\ldots)$

II - mosaico português em áreas de permanência e lazer onde não haja instalação de infra-estrutura no subsolo.

O estado de conservação da calçada pode ser considerado bom, apesar do tipo de piso, pois em poucos pontos há ausência de revestimento. $O$ mosaico português somente é utilizado no passeio em frente à entrada da Pinacoteca. No restante da calçada do entorno, inclusive do outro lado na Estação da Luz, é utilizado concreto ou blocos intertravados, ou a combinação dos dois ${ }^{270}$.

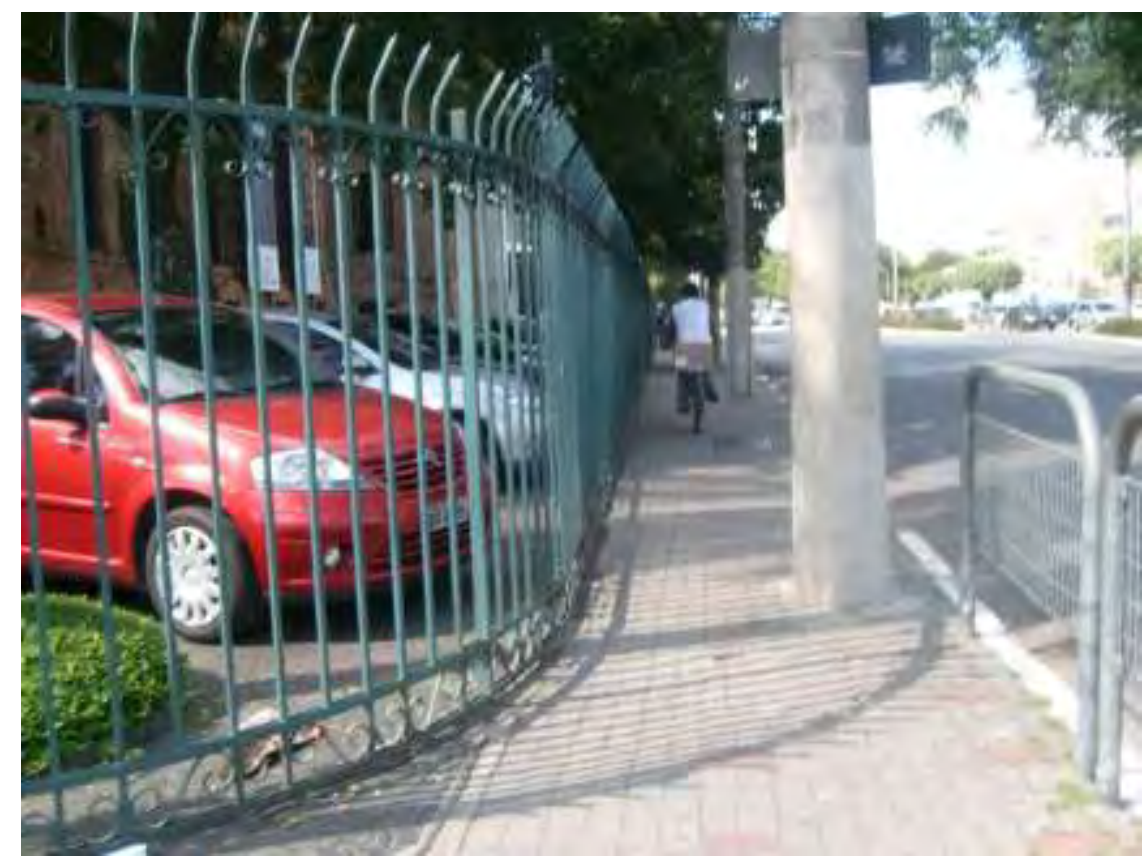

Figura 246 - Passeio voltado para a Av. Tiradentes. 2011.

\footnotetext{
${ }^{270}$ Atende ao disposto na ABNT NBR 9050/2004 - item 6.1.1 - e no art. 29 do Decreto municipal $45.904 / 2005$.
} 
As travessias estão voltadas para a estação da Luz, sendo uma delas próxima à entrada da Pinacoteca e outra próxima à entrada do Jardim da Luz. A travessia mais próxima possui rebaixamento nos dois lados do passeio e no canteiro central. $\mathrm{Na}$ calçada da Estação da Luz, o rebaixamento não possui piso tátil de alerta e há um desnível entre a sarjeta e o fim da rampa ${ }^{271}$.

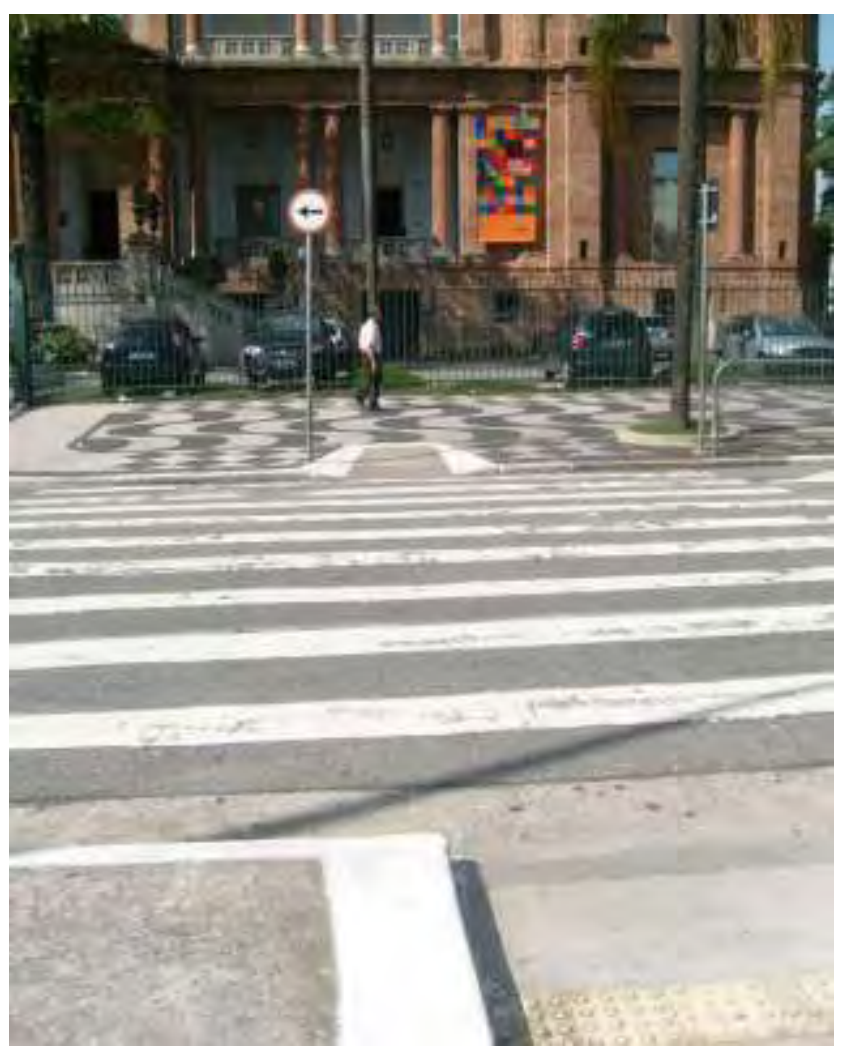

Figura 247 - Rebaixamento na travessia. 2011.

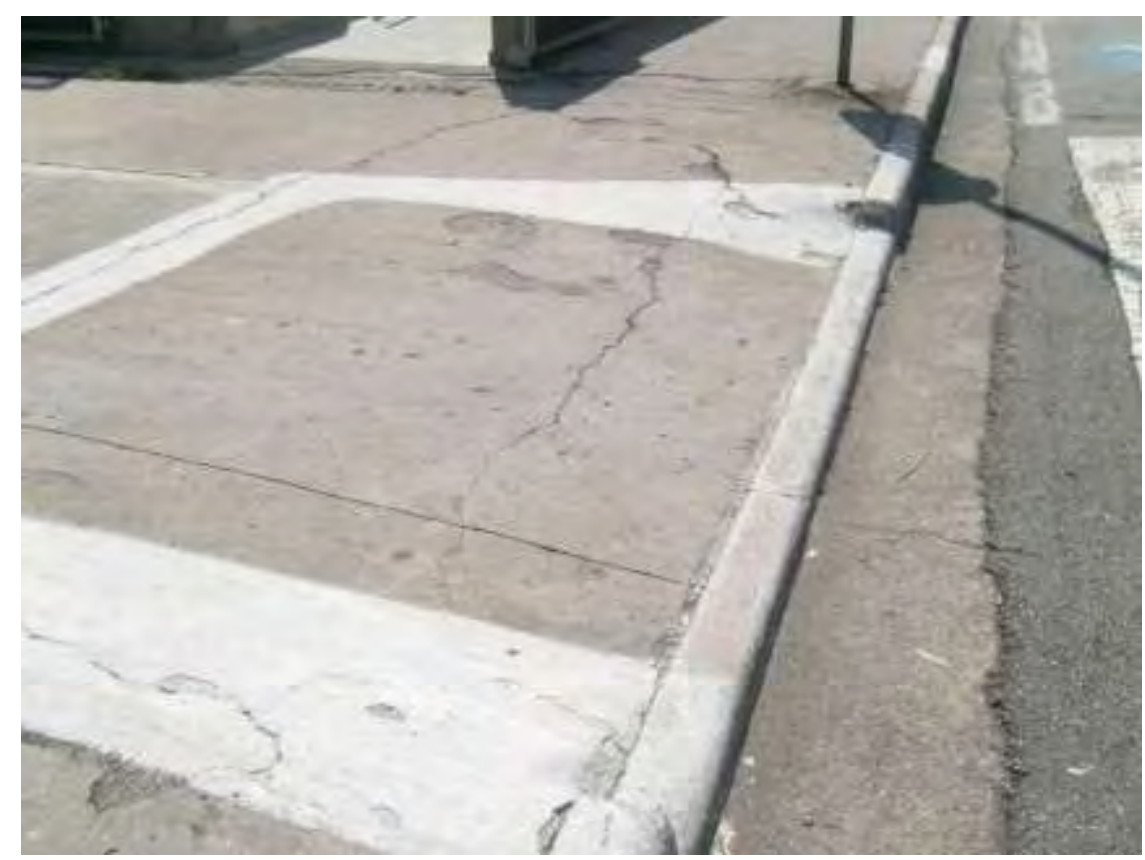

Figura 248 - Rebaixamento sem piso tátil de alerta e com desnível. 2011.

${ }^{271}$ Não atende ao disposto na Resolução CPA/SEHAB-G/011/2003 - item 1.2. 
A outra travessia citada é composta por faixa elevada, dispensando o uso de rebaixamentos, uma vez que o pedestre faz a circulação em nível, alterando o geométrico do leito carroçável. Contudo, não há a necessária sinalização com piso tátil de alerta informando a existência de travessia e situação de risco na interação entre veículos e pedestres ${ }^{272}$.

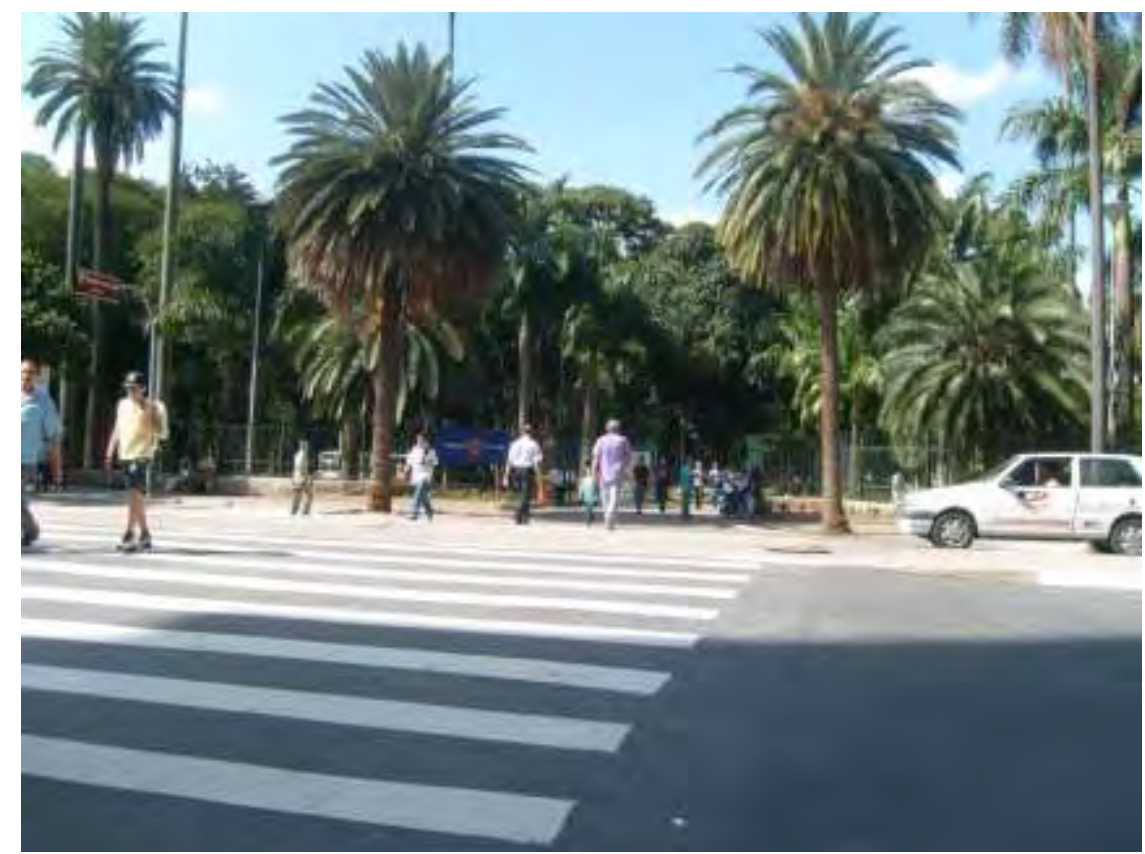

Figura 249 - Travessia elevada em frente à entrada da Praça da Luz. 2011.

Outra inadequação é a interrupção no passeio da continuidade da circulação de pedestres para o acesso de veículos à Pinacoteca. $\mathrm{O}$ desnível resultante da continuidade do leito carroçável no acesso ao estacionamento prejudica o trajeto dos pedestres, em especial àqueles com deficiência. Sendo este portão o único acesso a partir da calçada, vê-se uma valorização da entrada do veículo em detrimento do pedestre ${ }^{273}$.

\footnotetext{
${ }^{272}$ Não atende ao disposto na Resolução CPA/SEHAB-G/011/2003 - item 1.5.

${ }^{273}$ Não atende ao disposto nos art. 16 e 28 do Decreto municipal 45.904/2005 e na ABNT NBR 9050/2004 - item 6.10.5.
} 


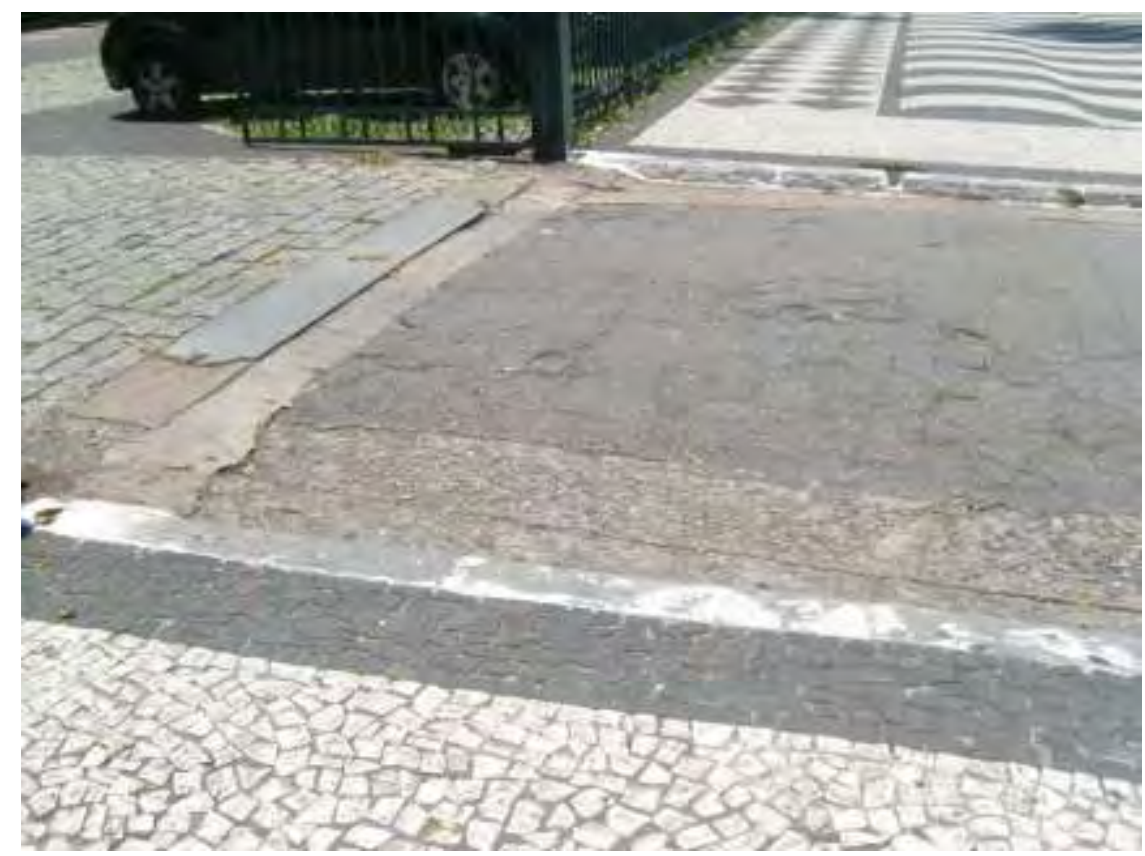

Figura 250 - Desnível existente no único acesso a partir do passeio. 2011.

\subsubsection{Circulação externa}

Como dito, a única entrada a partir do passeio é um portão utilizado para o acesso de veículos, sem percurso distinto para pedestres. Esse acesso, como já dito, fica prejudicado pelo desnível existente na calçada.

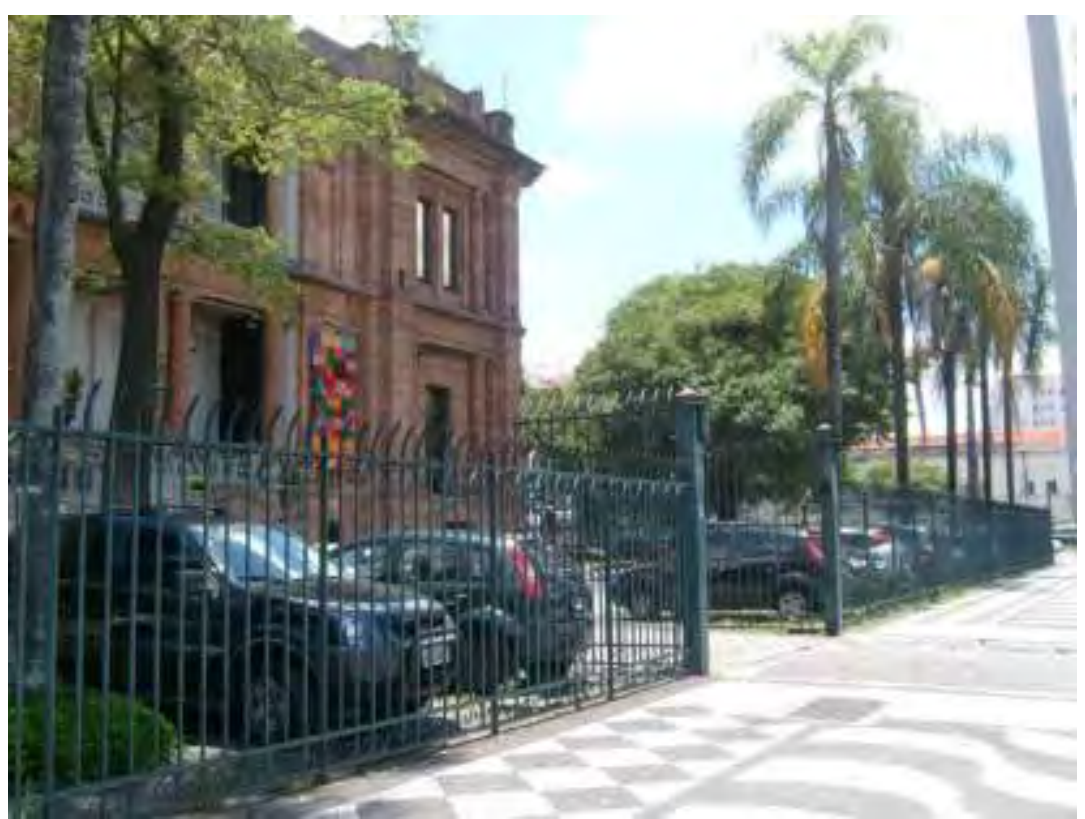

Figura 251 - Acesso único para carros e pedestres. 2011. 
Ao passar o portão de

entrada verifica-se que 0 piso no

entorno do edifício é composto por

mosaico português preto e

paralelepípedos, ambos inadequados

para compor rotas acessíveis, por causar trepidação ${ }^{274}$.

Figura 252 - Pavimento inadequado para circulação de pedestres. 2011.

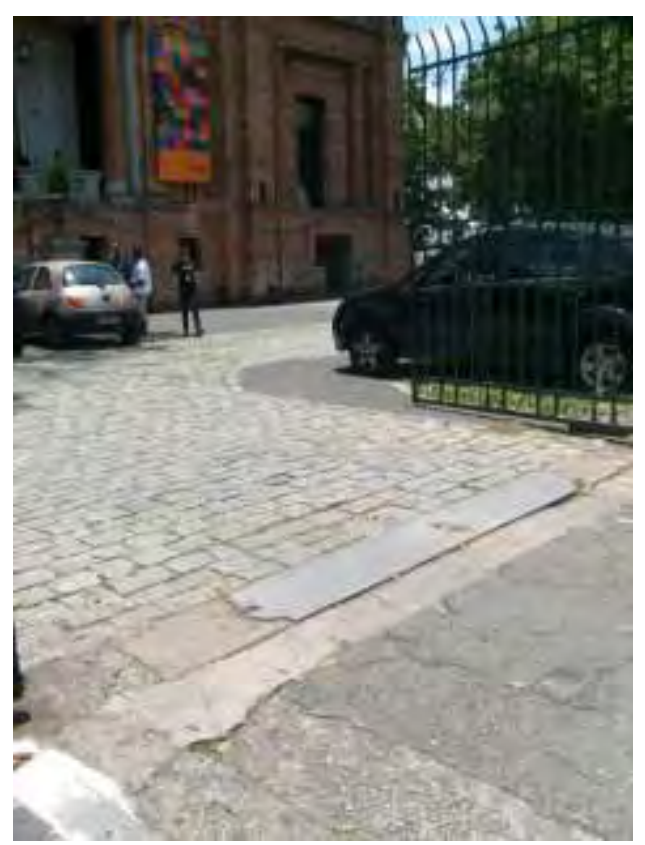

A interligação entre o Parque da Luz e a Pinacoteca apresenta desnível ${ }^{275}$ e uma grelha com hastes corretamente posicionadas no sentido oposto ao do deslocamento, porém desnivelada em relação ao piso. Além disso, o piso neste acesso que interliga as duas áreas, de grande visitação pública, é inadequado como rota acessível $^{276}$.

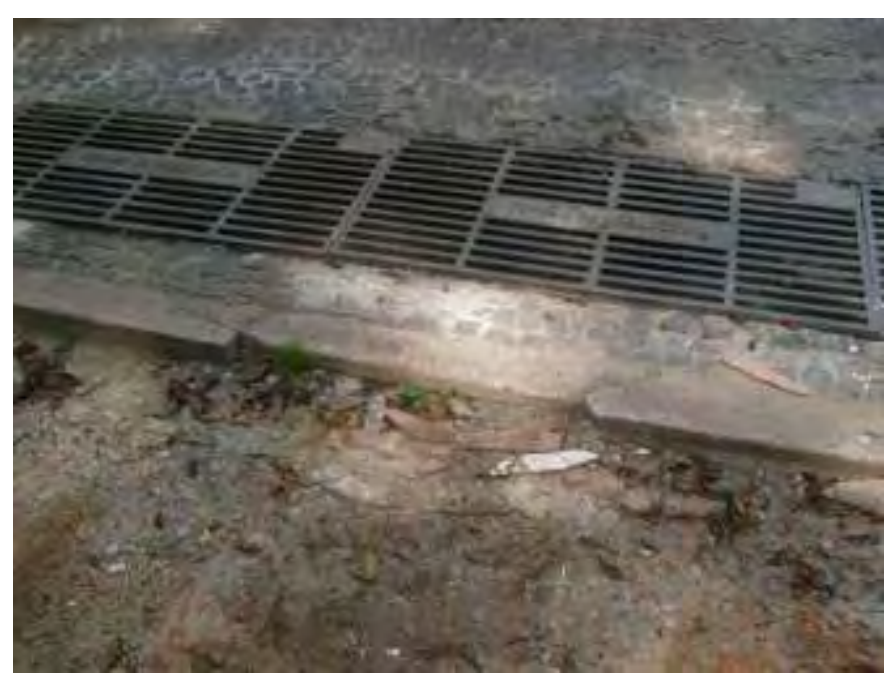

Figura 253 - Desnível na ligação entre o mosaico português na área da pinacoteca e o piso de terra no Parque da Luz. 2011.

\footnotetext{
${ }^{274}$ Não atende ao disposto na ABNT NBR 9050/2004 - item 6.1.1.

${ }^{275}$ Não atende ao disposto na ABNT NBR 9050/2004 - item 6.1.5.

${ }^{276}$ Não atende ao disposto na ABNT NBR 9050/2004 - item 6.1.1.
} 


\subsubsection{Estacionamento}

Na área externa do edifício da Pinacoteca está localizada a área de estacionamento. As vagas não estão demarcadas, mas o estacionamento tem capacidade para aproximadamente 50 veículos. Essa capacidade é ampliada com o uso de serviço de manobrista, principalmente quando há eventos no local (LOPES, 2005, p. 304).

Há uma vaga reservada para pessoas com deficiência no estacionamento, próximo a

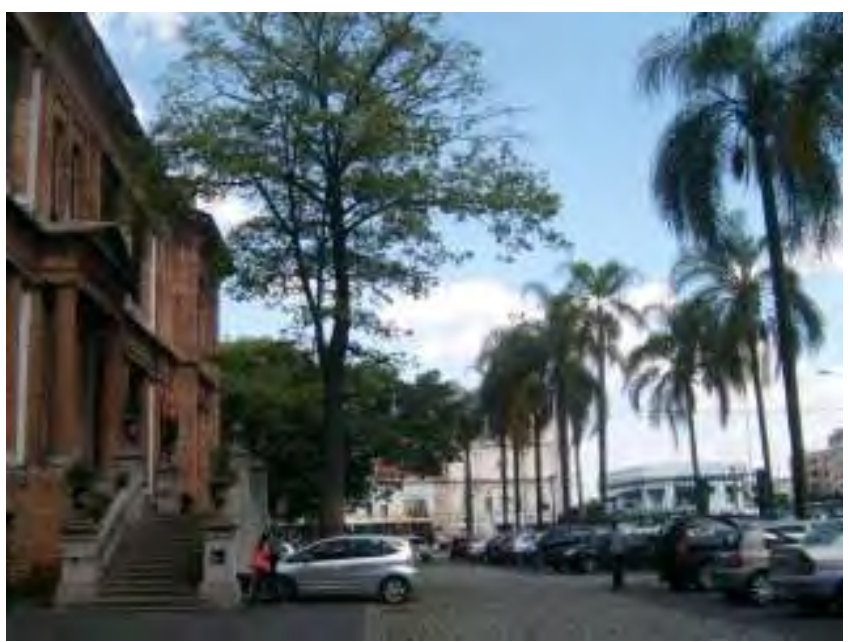

Figura 255 - Estacionamento. 2011.

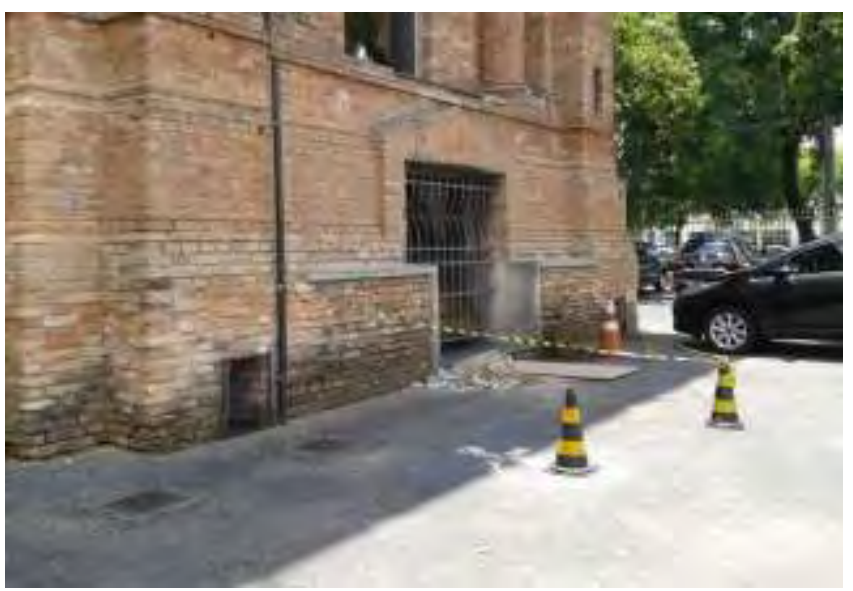

Figura 254 - Vaga com cone. Sinalização apagada. 2011.

que está se apagando. Não há demarcação da vaga e da faixa lateral, o que impediu de verificar se o tamanho estava correto. Falta placa indicativa da vaga. E o estacionamento não tem vagas demarcadas para idosos ${ }^{278}$.

\footnotetext{
${ }^{277}$ Não atende ao disposto na ABNT NBR 9050/2004 - item 6.12.1.

${ }^{278}$ Não atende ao disposto no art. 1ำ da Lei Municipal $n^{\circ}$ 14.481/2007 e no art. 41 da Lei federal $n^{\circ}$ $10.741 / 2003$.
} 


\subsubsection{Entradas e saídas}

São três entradas distintas para a Pinacoteca: duas para o público e uma para os funcionários; há outro acesso na interligação entre o restaurante e o salão externo, porém sem conexão com o Parque da Luz. A escadaria de dois lances laterais é a entrada de uso geral do público, que faz o acesso ao museu diretamente pelo primeiro andar (Entrada 1). Duas entradas no térreo, próximas ao início das escadas simétricas, são rampas utilizadas para a entrada de pessoas com deficiência (Entrada 2). E o acesso de funcionários ocorre na fachada posterior, também pelo nível do térreo (Entrada 3).

A escada de acesso da Entrada 1 tem corrimão de espessura e altura corretas $^{279}$, porém em apenas em um dos lados $^{280}$.

As duas rampas de acessos são idênticas. Possuem guarda-corpo, porém não corrimão de apoio. Sua inclinação é de mais de $11 \%{ }^{281}$, enquanto que o limite normativo é de 8,33\%. O acesso

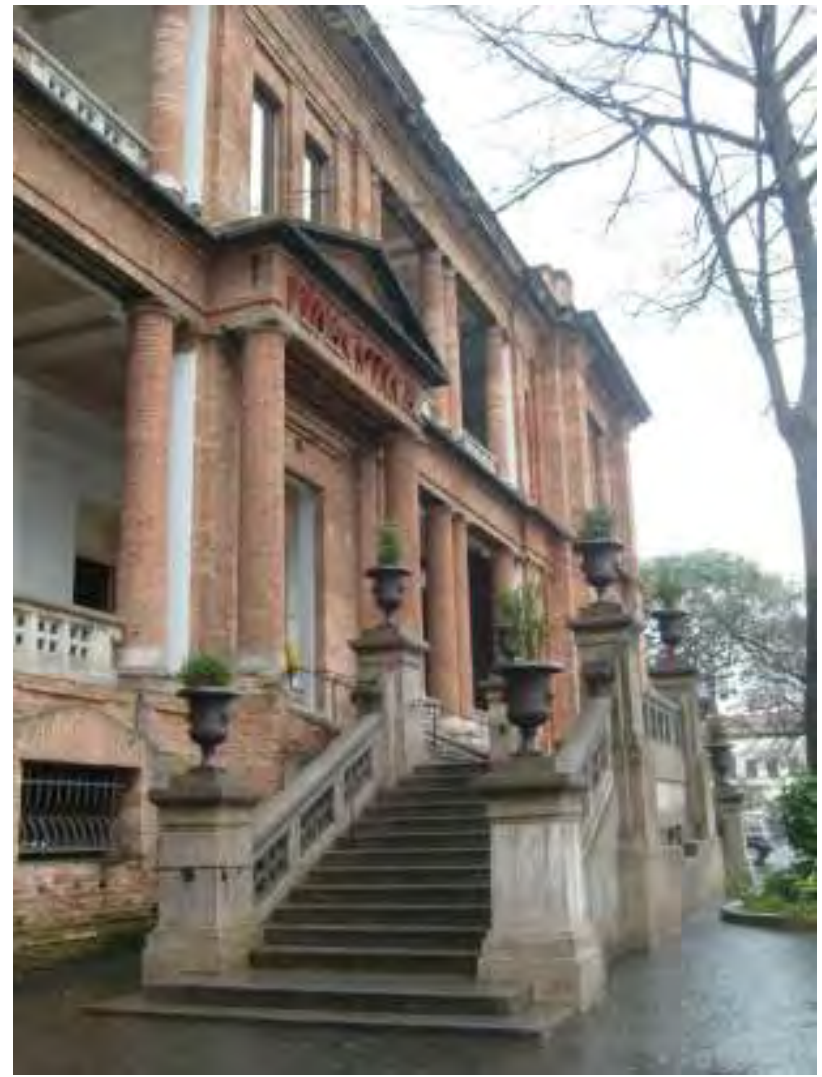

Figura 256 - Escada na entrada principal. 2009.

\footnotetext{
${ }^{279}$ Atende ao disposto na ABNT NBR 9050/2004 - itens 6.7.1.2 e 6.7.1.6.

${ }^{280}$ Não atende ao disposto na ABNT NBR 9050/2004 - item 6.7.1.1.

${ }^{281}$ Não atende ao disposto na ABNT NBR 9050/2004 - item 6.5.1.2 ou 6.5.1.3. Não atende também a ABNT NBR 9050/1994 (item 6.4.1.1 e Tabela 2 - dimensionamento de rampas), versão anterior, em vigor na época da reforma.
} 
pela rampa faz com que esses visitantes entrem pelo pavimento térreo e não pelo $1^{0}$ andar como os demais. E apesar de essa entrada estar a menos de 50 metros da escada na entrada principal, e do elevador garantir a rota vertical, será necessário percorrer 120 metros internamente para chegar ao mesmo ponto inicial das demais pessoas que fizeram uso da entrada principal.

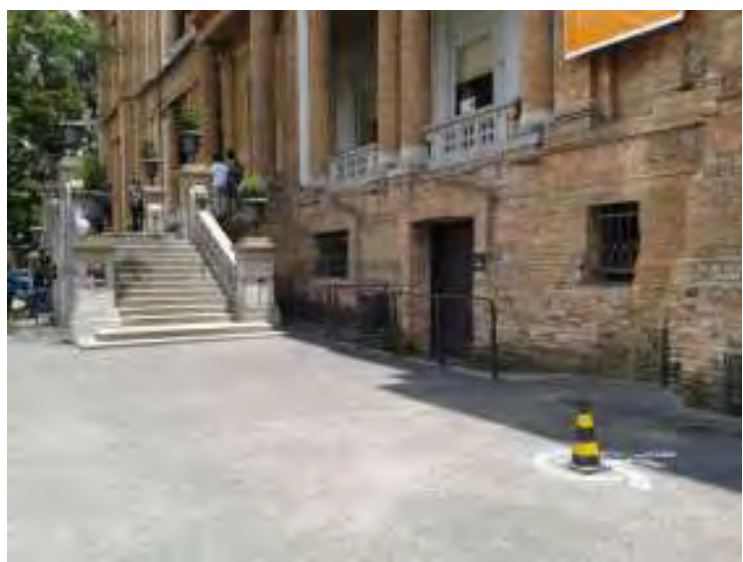

Figura 257 - Posicionamento da entrada acessível em relação à escada. 2011.

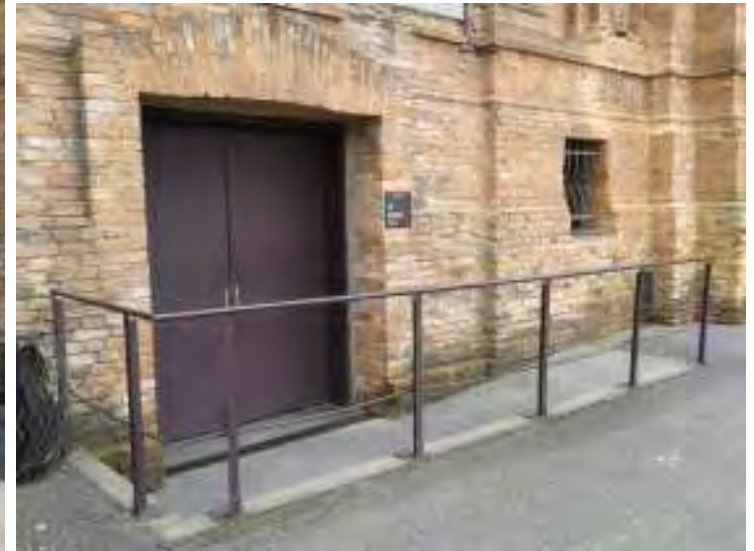

Figura 258 - Entrada acessível. 2011.

A entrada de funcionários está nivelada com o piso externo e não apresenta problemas para o acesso.

As portas originais, de entrada e saída no $1^{\circ}$ andar, são em madeira e uma outra porta de vidro foi colocada recuada no mesmo vão, com sensor para funcionamento automático, o que garante a abertura total.

As portas das entradas acessíveis, no térreo, têm folhas pivotantes, corretamente com vão livre de passagem maior que $0,80 \mathrm{~m}$

Figura 259 - Porta da entrada acessível. 2011.

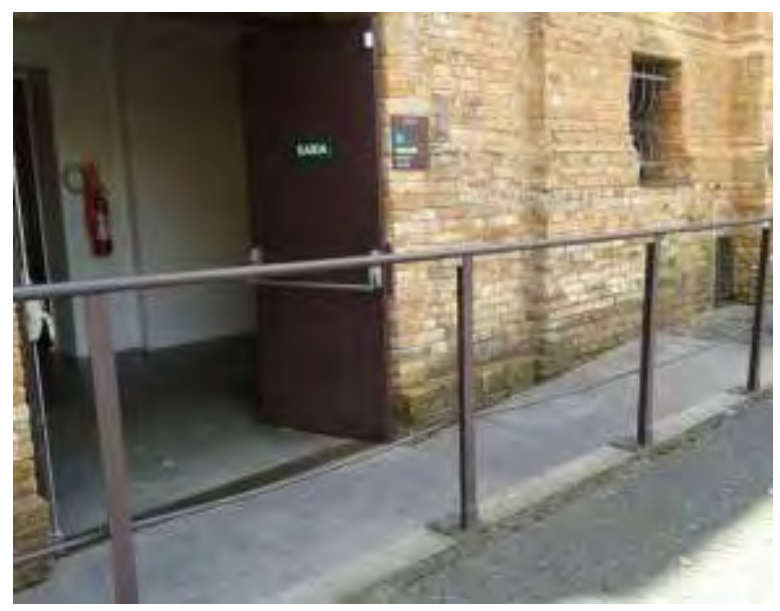


para cada folha ${ }^{282}$. Essa porta não tem maçaneta pelo lado de fora, pois como dá acesso direto ao interior, sem passar pela bilheteria, sua abertura é feita internamente apenas por um funcionário da segurança ${ }^{283}$; é também utilizada como rota de fuga em casos de emergência e, portanto tem barra antipânico.

A porta de entrada de funcionários tem folhas com vãos livres menores que $0,80 \mathrm{~m}$ cada $^{284}$, porém pelo grande fluxo e

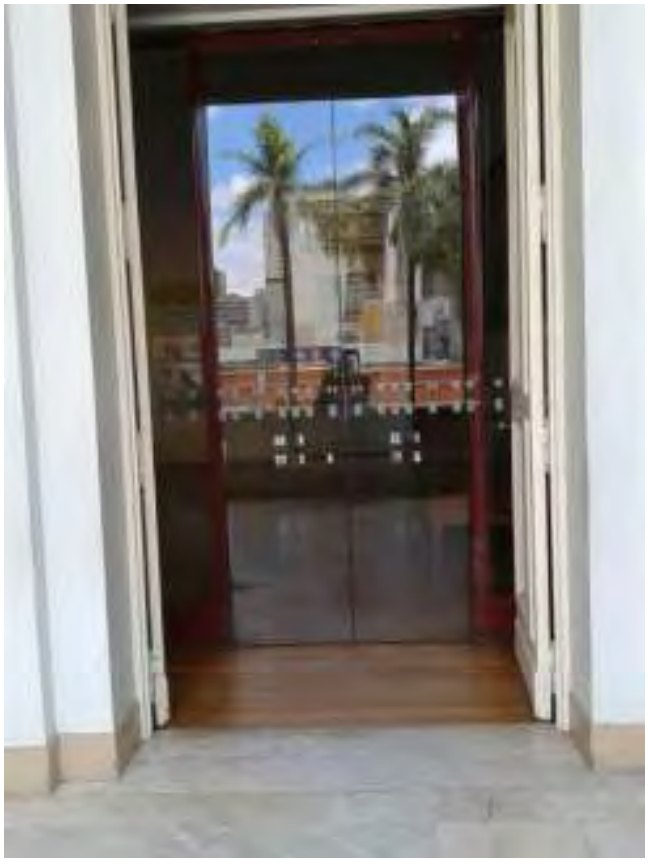

Figura 260 - Porta automática na entrada principal. 2011. por ser entrada de materiais e equipamentos, essa entrada permanece com suas duas folhas abertas durante o horário de funcionamento. Essa porta tem o mesmo sistema de abertura da porta da entrada acessível, porém com maçaneta do tipo alavanca, no lado externo.

\subsubsection{Circulação interna}

Os corredores dos três pavimentos são bastante amplos, não apresentando restrições para a circulação dos mais diversos públicos, de forma a atender adequadamente o fluxo de visitantes e o uso proposto. Os pisos dos três pavimentos são regulares, estáveis e antiderrapantes ${ }^{285}$.

\footnotetext{
${ }^{282}$ Atende ao disposto na ABNT NBR 9050/2004 - item 6.9.2.1.

${ }^{283}$ Não há autonomia no acesso.

${ }^{284}$ Não atende ao disposto na ABNT NBR 9050/2004 - item 6.9.2.1.

${ }^{285}$ Atende ao disposto na ABNT NBR 9050/2004 - itens 6.9.1.1 e 6.1.1.
} 

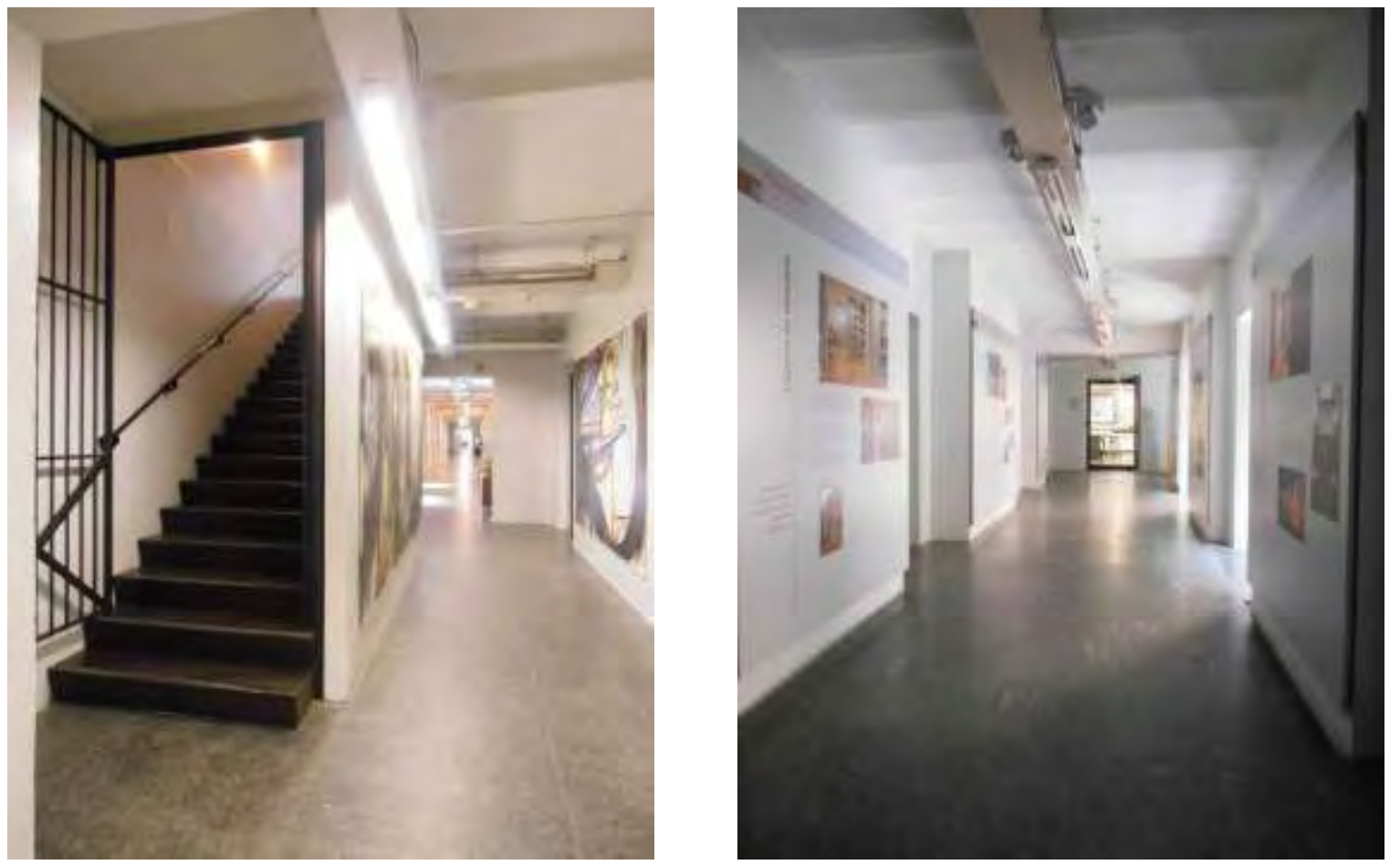

Figuras 261 e 262 - Exemplos de circulação no pavimento térreo. 2011.
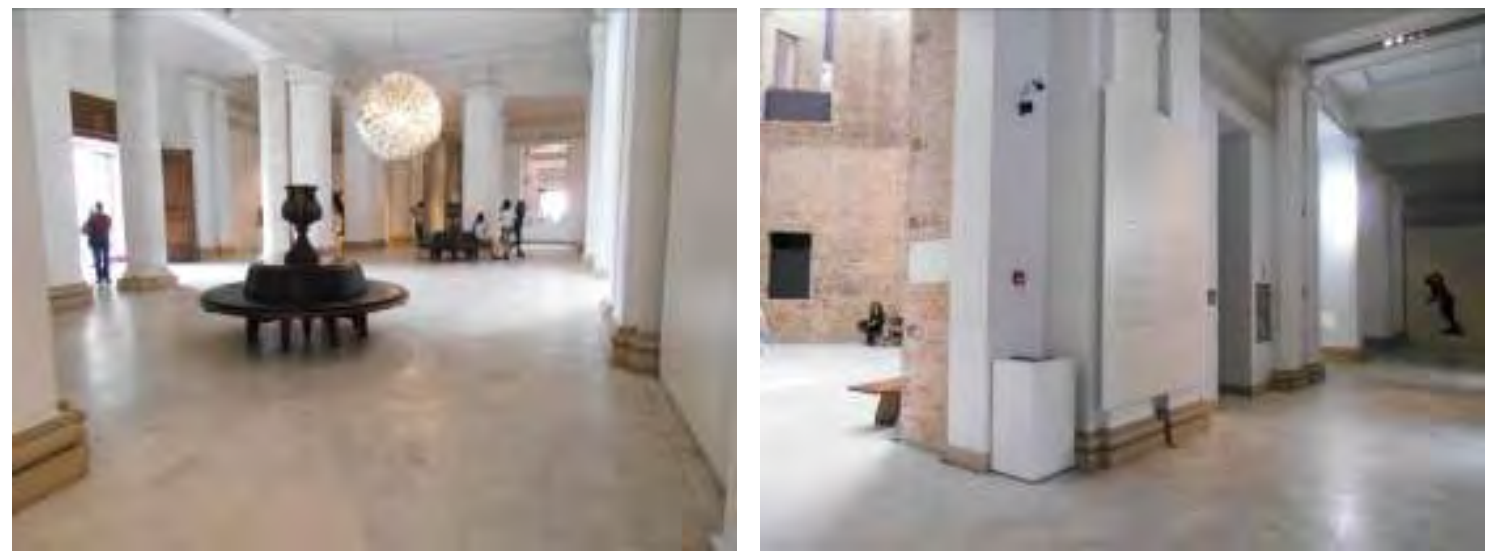

Figuras 263 e 264 - Exemplos de circulação no $1^{\circ}$ pavimento. 2011.
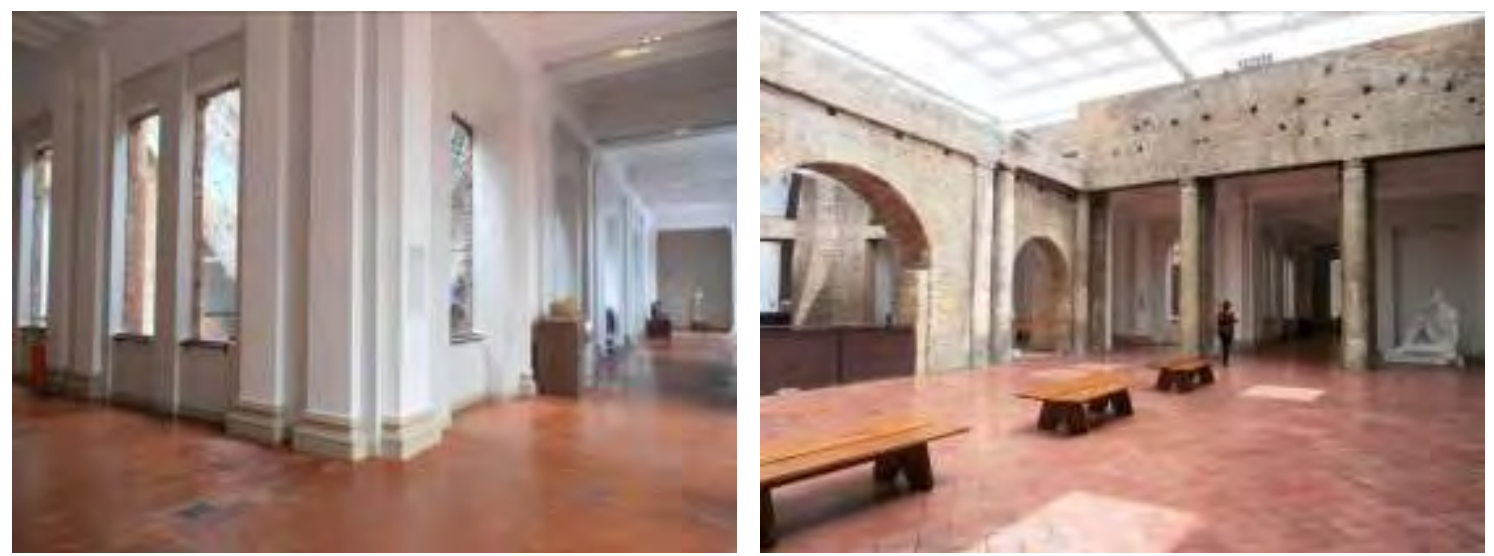

Figuras 265 e 266 - Exemplos de circulação no 2º pavimento. 2011. 
No pavimento térreo as portas existentes atualmente são de ferro e vidro, pivotantes, e com vãos variáveis; no entanto sempre maiores que um metro de vão de passagem ${ }^{286}$. Algumas salas têm portas com as mesmas características dimensionais, porém totalmente de ferro. O auditório, também neste pavimento, tem três acessos: um para a plateia e dois para o palco. As três portas são compostas de folhas duplas, de 1,00m de largura cada.
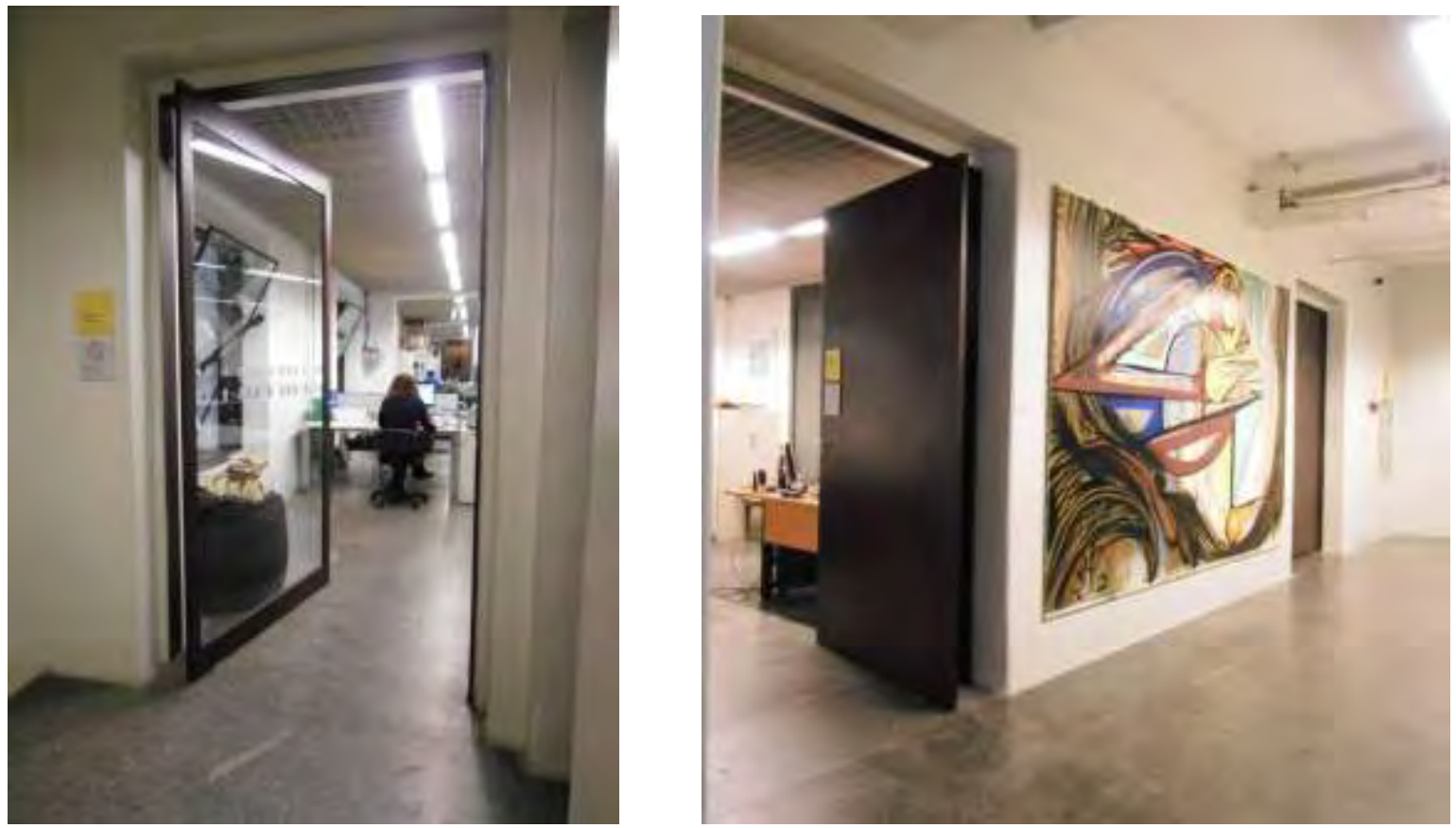

Figuras 267 e 268 - Exemplos de portas de ferro e vidro no pavimento térreo. 2011.

${ }^{286}$ Atende ao disposto na ABNT NBR 9050/2004 - item 6.9.2.1. 
No $1^{\circ}$ andar alguns ambientes, como áreas administrativas $\mathrm{e}$ de exposições, são fechados por portas. Geralmente, nas áreas administrativas as portas são originais de madeira, e nos ambientes de exposição portas de ferro e vidro. Todas, com duas folhas de abrir, sendo cada uma com $0,75 \mathrm{~m}$ de largura, ou menos ${ }^{287}$.

Assim como as portas da entrada principal, a porta de acesso ao Belvedere criado onde antes da reforma de 1998 era a entrada principal da Pinacoteca, há uma nova porta de ferro e vidro de abertura automática por sensor.

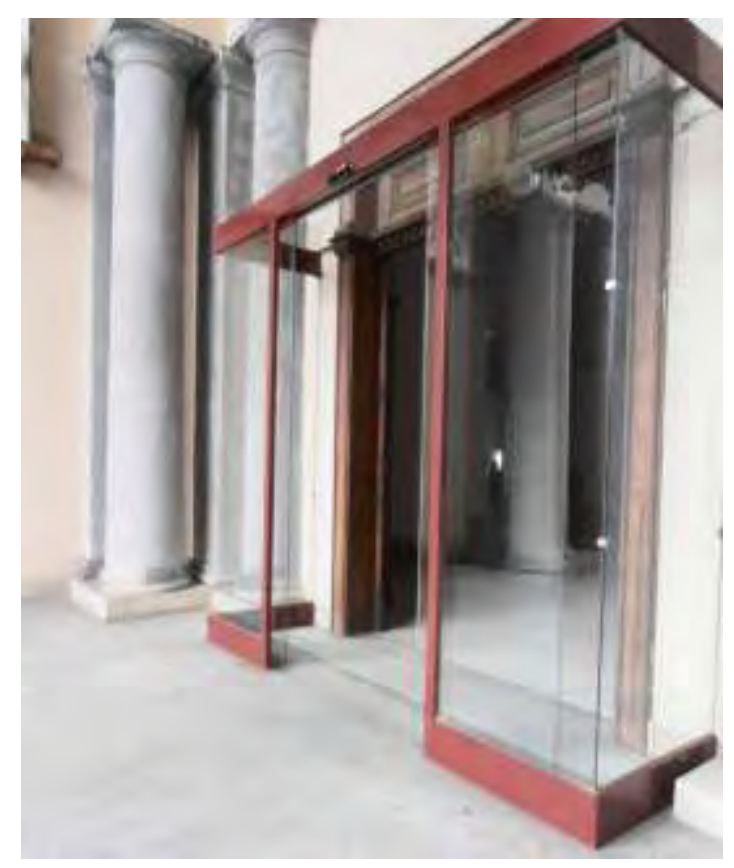

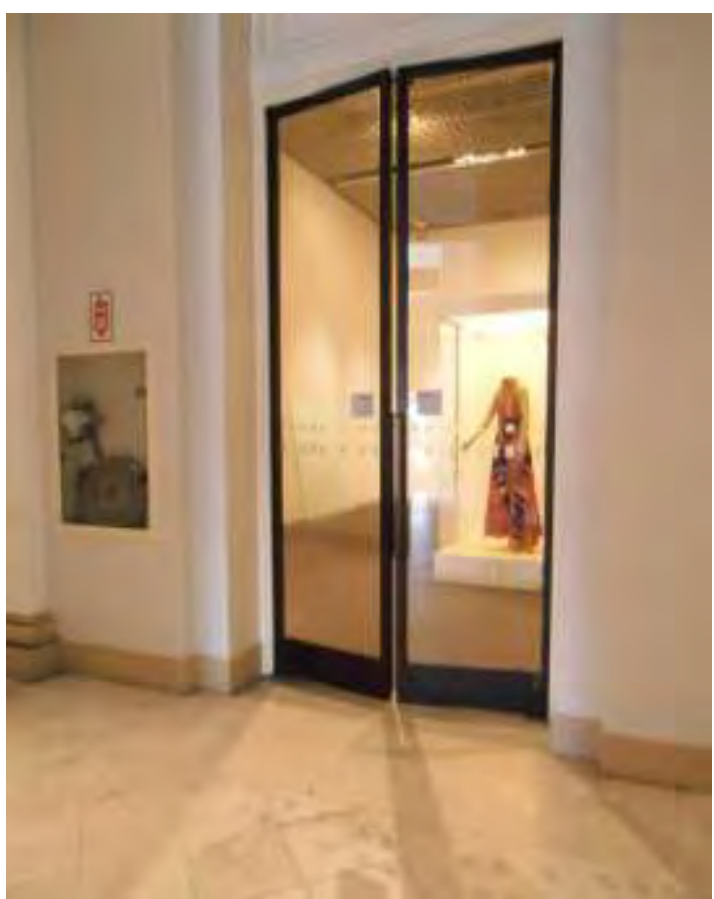

Figura 269 - Exemplo de porta da área de exposições do $1^{\circ}$ andar. 2011.

Figura 270 - Porta automática no acesso ao Belvedere. 2011.

${ }^{287}$ Não atende ao disposto na ABNT NBR 9050/2004 - item 6.9.2.1. 


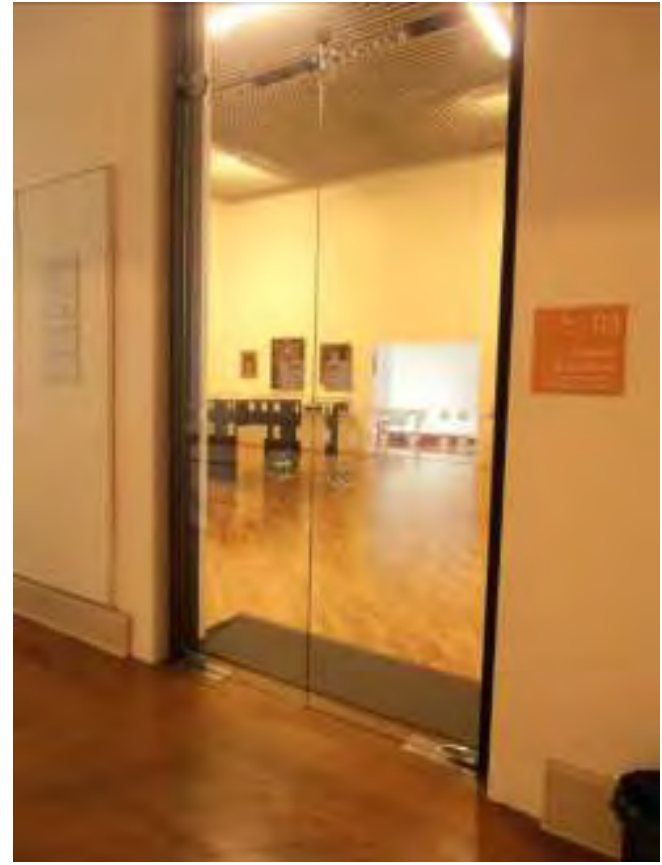

Figura 271 - Porta de sala expositiva do $2^{\circ}$ andar. 2011.

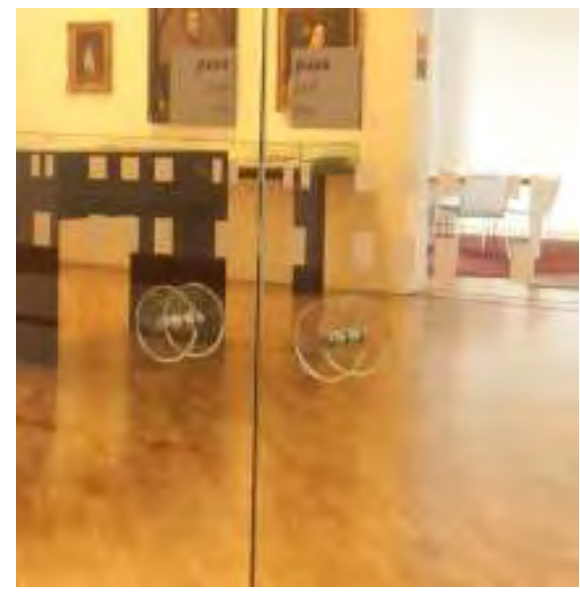

Figura 272 - Detalhe do puxador. 2011.

As portas do $2^{\circ}$ andar também são de vidro, com as mesmas inadequações das salas de exposição do $1^{\circ}$ andar. Adicionalmente, nota-se que essas portas têm puxador inadequado, por conta do difícil manuseio ${ }^{288}$. Por serem totalmente transparentes, com discretas aplicações de adesivo branco, pessoas com baixa visão podem, desavisadamente, chocar-se contra o vidro. Todos os ambientes expositivos desse andar têm um pequeno desnível em relação às circulações, resolvidos com rampa metálica de pequena inclinação em frente às portas. Também são usadas rampas metálicas nos desníveis de soleira existentes nas portas de acesso às varandas.

As portas de duas folhas, além do problema relativo à sua medida, exigem exagerado esforço para sua abertura ${ }^{289}$.

\footnotetext{
${ }^{288}$ Não atende ao disposto na ABNT NBR 9050/2004 - item 6.9.2.3.

${ }^{289}$ Não atende ao disposto na ABNT NBR 9050/2004 - item 6.9.2.2.
} 

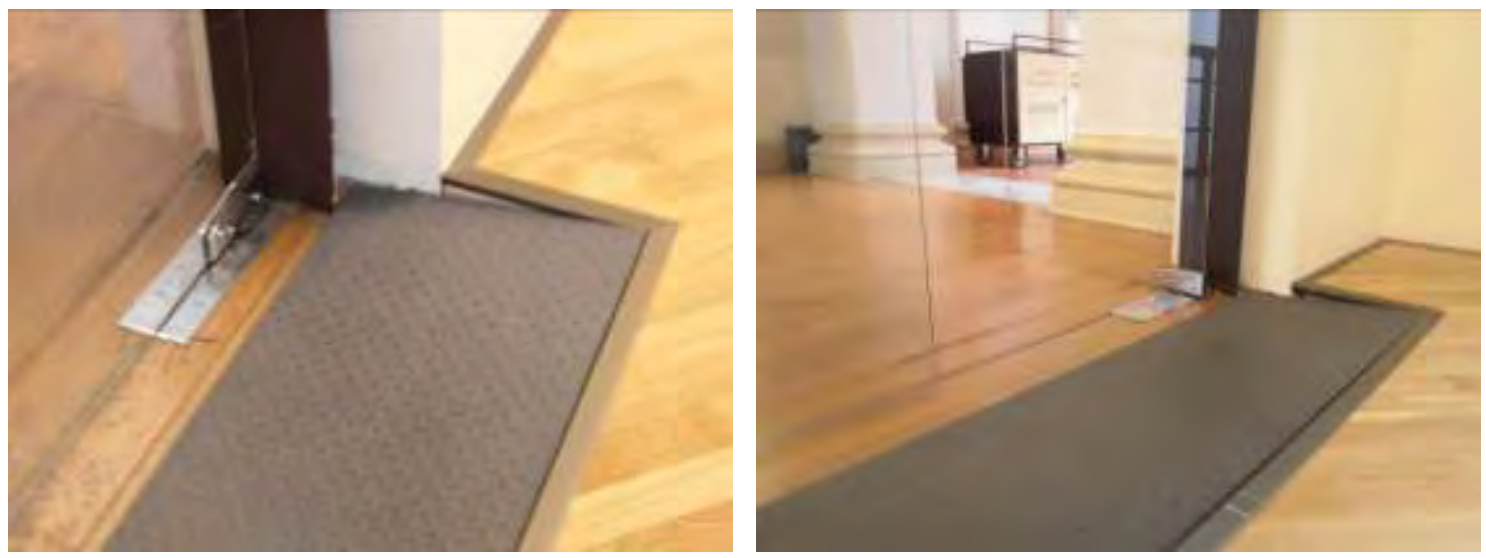

Figura 273 e 274 - Rampas metálicas em frente às portas. 2011.
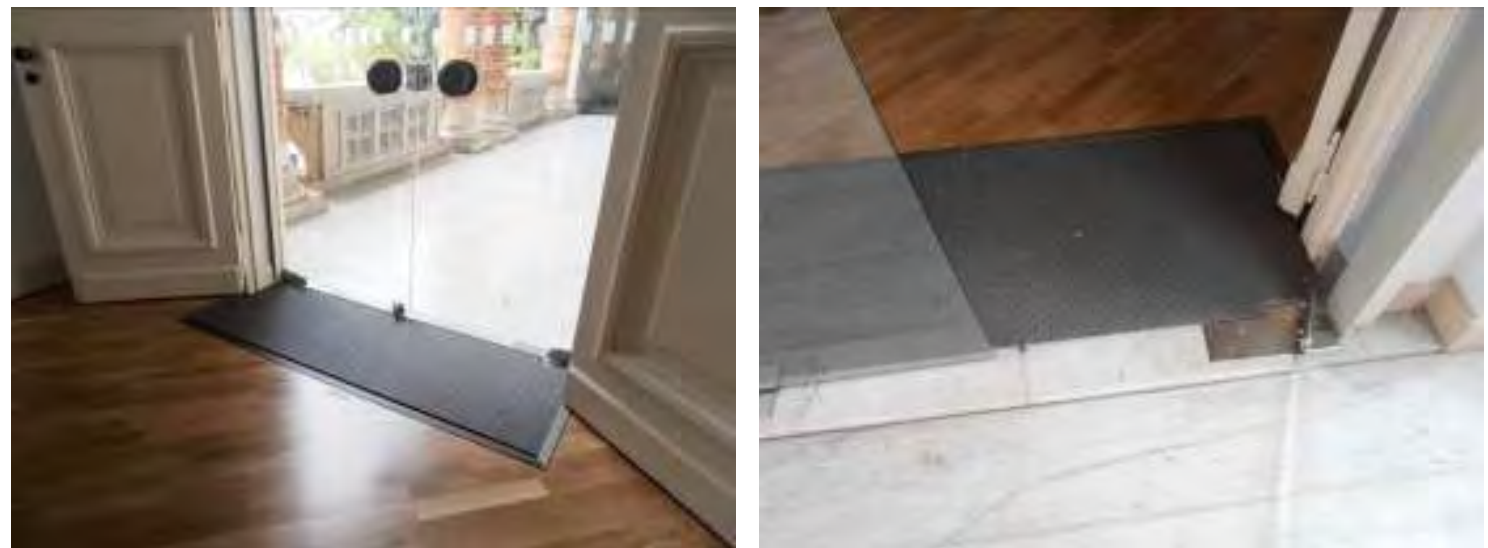

Figura 275 e 276 - Rampas metálicas nas portas de acesso às varandas. 2011.

Os ambientes dos banheiros coletivos, no térreo e no $1^{\circ}$ andar, não têm portas, e o vão é bastante amplo, para a passagem de pessoas que utilizam os mais diversos equipamentos, como cadeiras de rodas, andador, muletas e carrinho de bebê. No $2^{\circ}$ andar não há sanitários.

Figura 277 - Vão de passagem de acesso ao sanitário do $1^{\circ}$ andar. 2011.

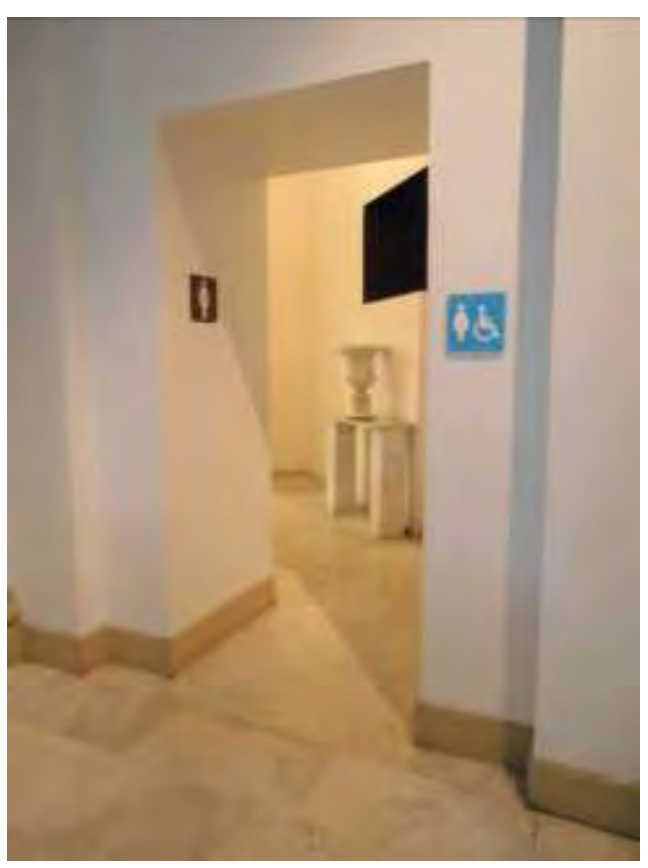


Sobre a circulação vertical, existem quatro escadas e dois elevadores, todos interligando os três andares. As escadas ficam nas extremidades da edificação. Um dos elevadores fica posicionado em um dos pátios retangulares, junto à passarela (Elevador 1). O outro tem entrada pela circulação perimetral ao octógono (Elevador 2).

O Elevador 1 é panorâmico e tem capacidade para 40 pessoas, portanto tem dimensões bastante amplas, podendo transportar várias pessoas em cadeiras de rodas ao mesmo tempo, com espaço suficiente para manobrar a cadeira ${ }^{290}$.

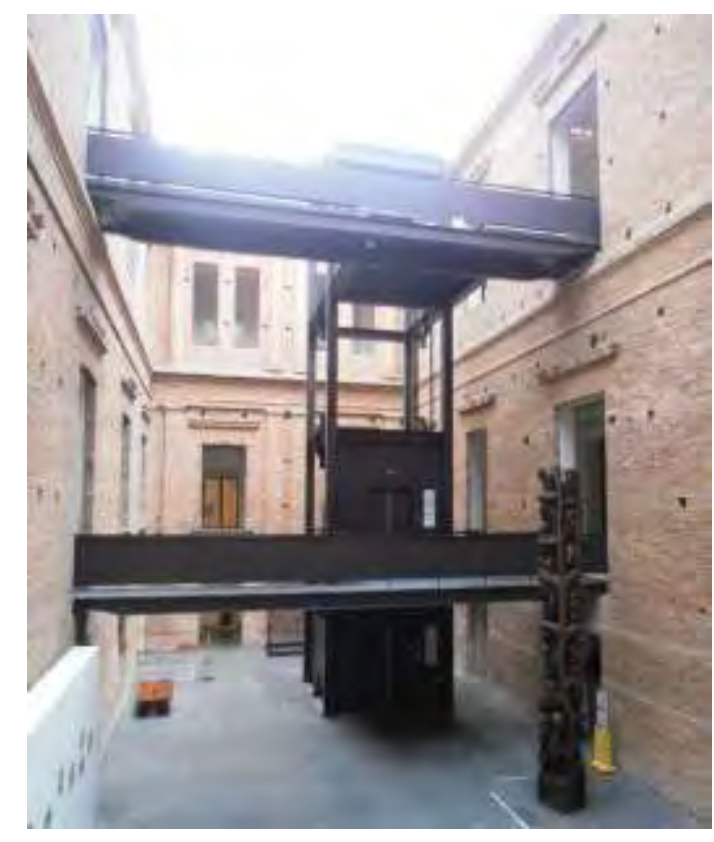

Figura 278 - Vista externa do Elevador 1. 2011.

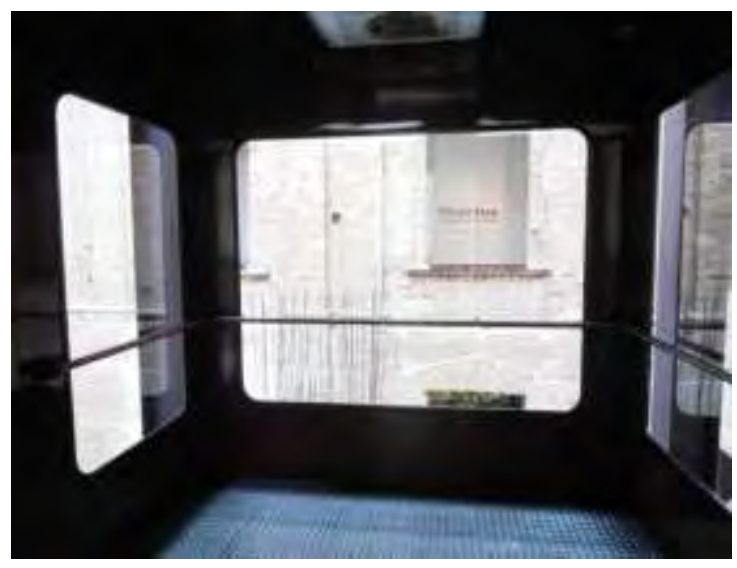

Figura 279 - Vista interna do Elevador 1. 2011.

O Elevador 2 tem menores dimensões mas dentro do mínimo necessário, de $1,10 \mathrm{~m}$ de largura por $1,40 \mathrm{~m}$ de profundidade, suficiente para transportar uma pessoa em cadeira de rodas e uma pessoa em pé ${ }^{291}$.

O principal problema do Elevador 2 é a reduzida circulação em frente à

\footnotetext{
${ }^{290}$ Atende ao disposto na ABNT NBR NM 313/2007 - item 5.3.1 e Tabela 1.

${ }^{291}$ Atende ao disposto na ABNT NBR NM 313/2007 - item 5.3.1 e Tabela 1.
} 
sua porta, dificultando a entrada e saída ${ }^{292}$.
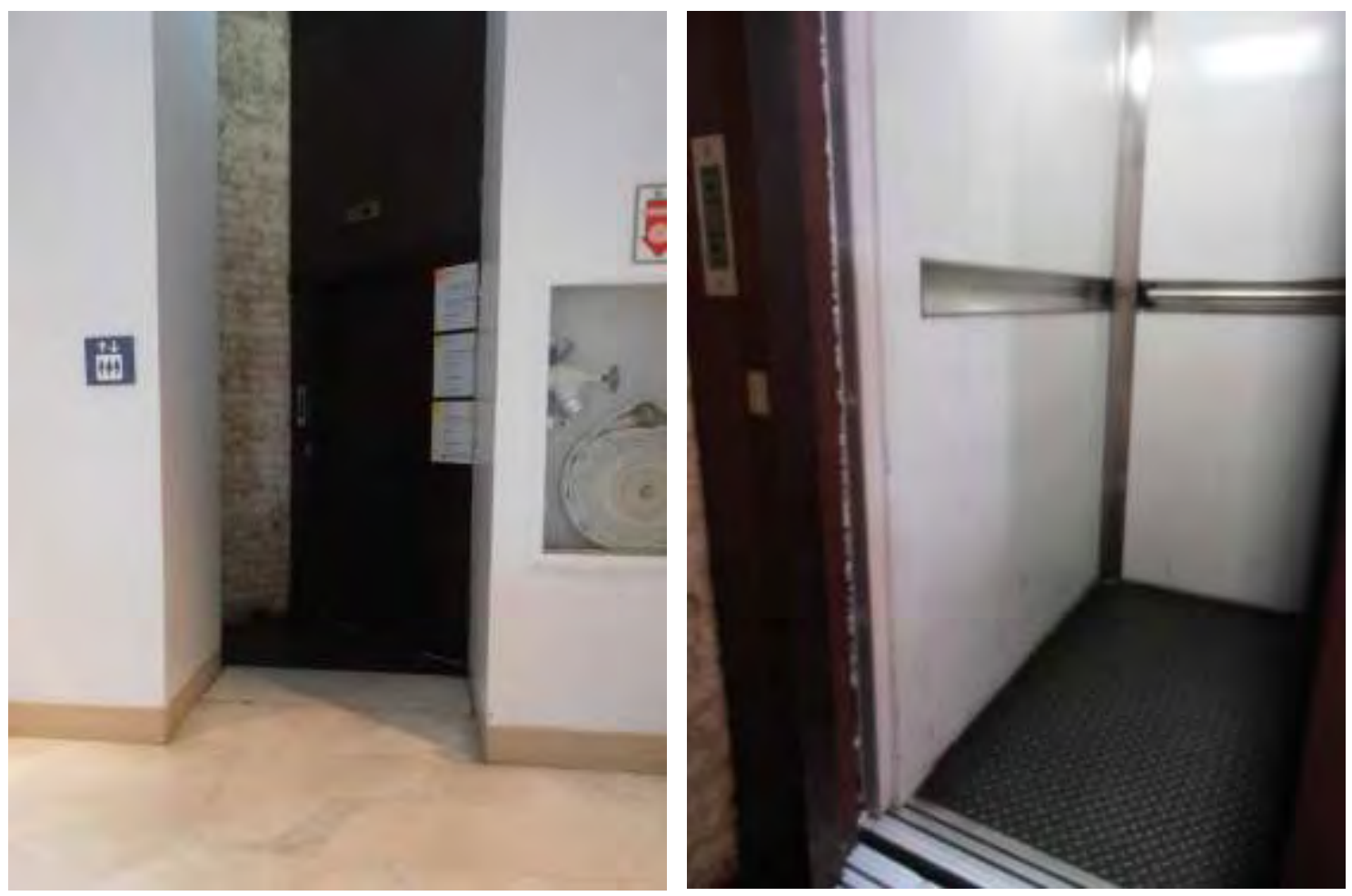

Figura 280 - Vista externa do Elevador 2. 2011.

Figura 281 - Vista interna do Elevador 2. 2011.

As botoeiras, externas e internas dos dois elevadores, estão em alturas inadequadas. As botoeiras do piso estão entre 1,25 e 1,30m e as da cabine compreendidas entre 1,30 e $1,48 \mathrm{~m}$ do eixo ${ }^{293}$. A botoeira do piso deve estar compreendida entre 0,90 e $1,10 \mathrm{~m}$ e a da cabine entre 0,90 e $1,30 \mathrm{~m}$.

Os dois elevadores tem barras internas para apoio. No Elevador 1 há barra nos painéis laterais e do fundo ${ }^{294}$. No Elevador 2 apenas no fundo ${ }^{295}$.

\footnotetext{
${ }^{292}$ Não atende ao disposto no item 9.5.5 do Anexo I da Lei municipal no 11.228/1992.

${ }^{293}$ Não atende ao disposto na ABNT NBR NM 313/2007 - item 5.4.1.1 e Tabela 2.

${ }^{294}$ Atende ao disposto na ABNT NBR NM 313/2007 - item 5.3.2.1.

${ }^{295}$ Não atende integralmente ao disposto na ABNT NBR NM 313/2007 - item 5.3.2.1, pois não há barra de apoio nos painéis laterais.
} 


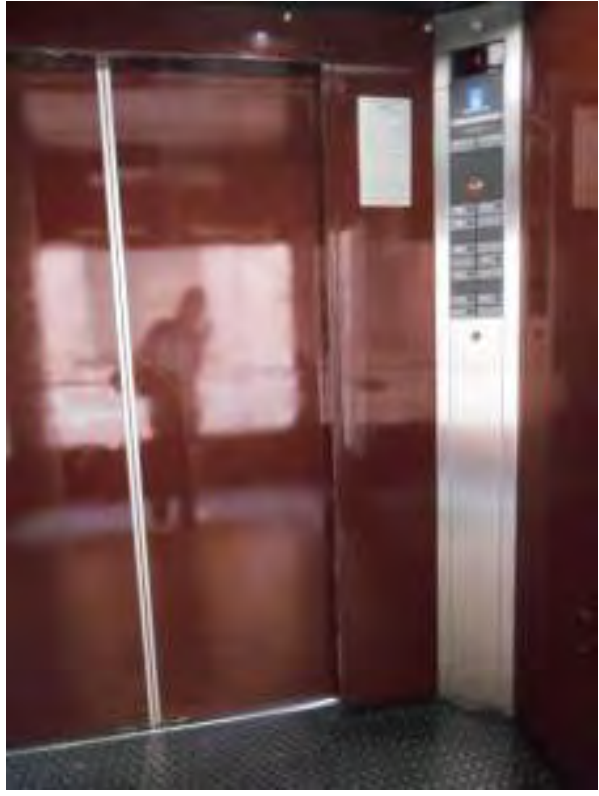

Figura 282 - Vista externa do Elevador 2. 2011.

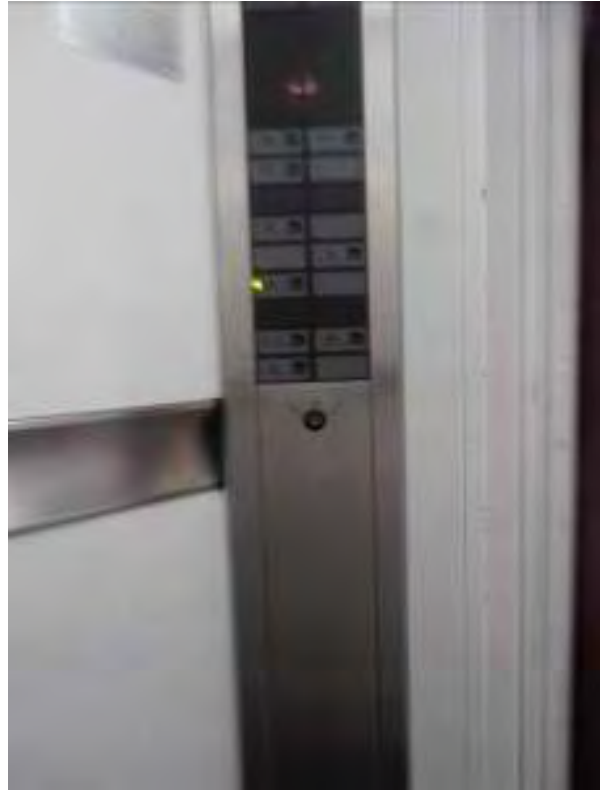

Figura 283 - Vista interna do Elevador 2. 2011.

As escadas apresentam pisos regulares, estáveis e antiderrapantes, e degraus com dimensões adequadas.

Do térreo ao $1^{\circ}$ andar, as escadas têm piso de concreto. Apenas uma das quatro escadas é de piso metálico ${ }^{296}$. E do 1ำ ao 2ำ andar são degraus de madeira, com tapete recobrindo o centro dos degraus. Esses tapetes não apresentam problemas para a circulação segura, pois estão firmemente fixados.

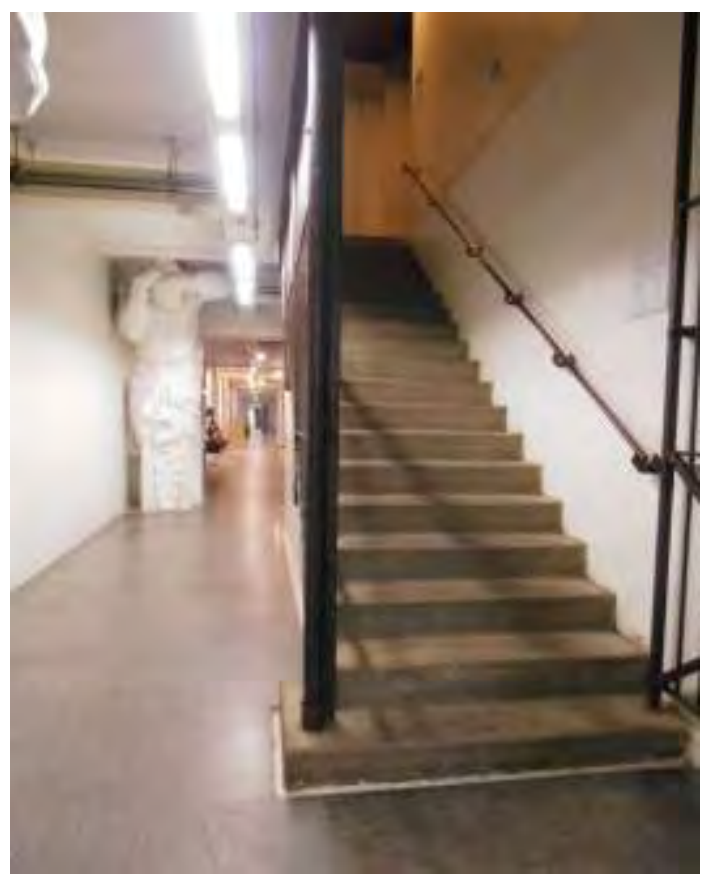

Figura 284 - Escada com degraus em concreto. 2011.

\footnotetext{
${ }^{296}$ Não foram encontradas informações exatas do por que apenas uma escada é em chapa de aço, no entanto, acredito que deve ter sido necessário refazer esta escada, por algum motivo. O aço é o mesmo utilizado em outras partes da revitalização de 1998, como corrimãos, portas e elevadores.
} 


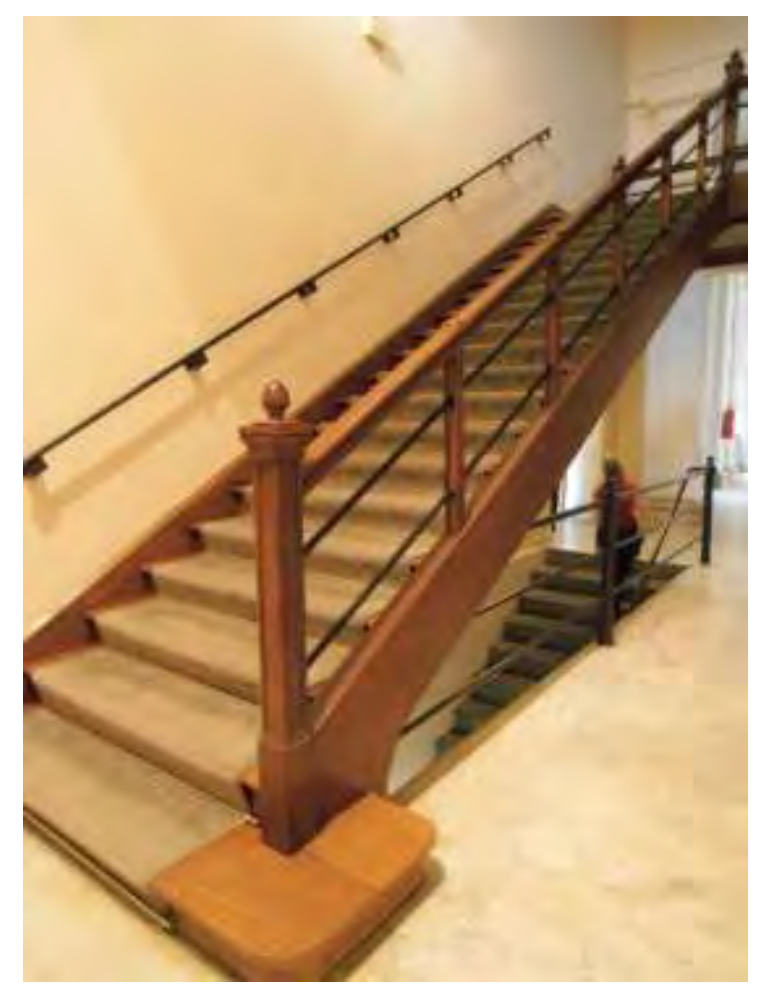

Figura 285 - Escada interligando o $1^{\circ}$ ao $2^{\circ}$ andar. 2011.

As escadas do térreo ao $1^{\circ}$ andar tem corrimão dos dois lados, com espessura correta, de $3,5 \mathrm{~cm}$ e $4 \mathrm{~cm}$ de diâmetro ${ }^{297}$. Porém, um pouco alto, pois está posicionado a $0,97 \mathrm{~m}$ do piso $^{298}$, $5 \mathrm{~cm}$ acima do que seria correto. Esta é a mesma altura do corrimão do lado da parede da escada do $1^{\circ}$ ao $2^{\circ}$ andar. No outro lado, o corrimão original é de madeira e tem formato quadrado, portanto não garante boa empunhadura $^{299}$. Os corrimãos das escadas em todos os pavimentos começam após o primeiro degrau e não tem prolongamento até a parte plana ${ }^{300}$.
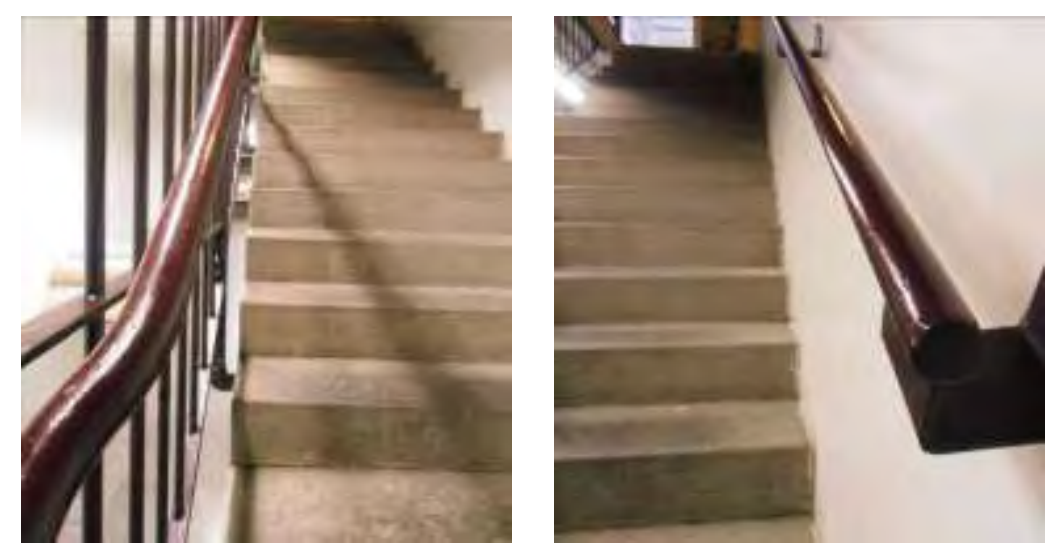

Figura 286 e 287 Detalhes do corrimão da escada do térreo ao $1^{\circ}$ andar. 2011.

\footnotetext{
${ }^{297}$ Atende ao disposto na ABNT NBR 9050/2004 - item 6.7.1.2.

${ }^{298}$ Não atende ao disposto na ABNT NBR 9050/2004 - item 6.7.1.6.

${ }^{299}$ Não atende ao disposto na ABNT NBR 9050/2004 - itens 4.6.5 e 6.7.1.2.

${ }^{300}$ Não atende ao disposto na ABNT NBR 9050/2004 - item 6.7.1.4.
} 


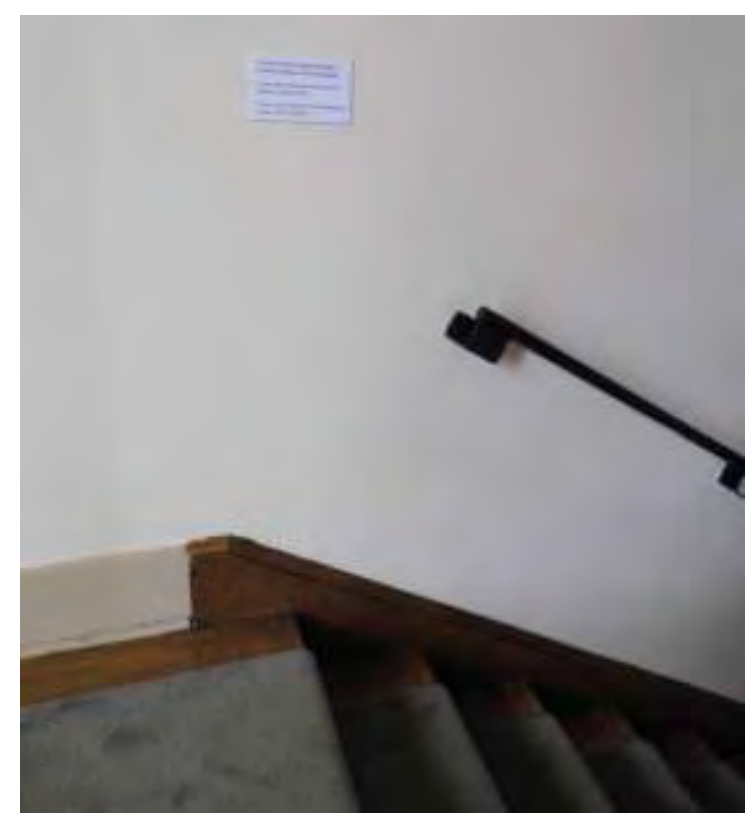

Figura 288 - Corrimão é interrompido antes de chegar ao pavimento. 2011.

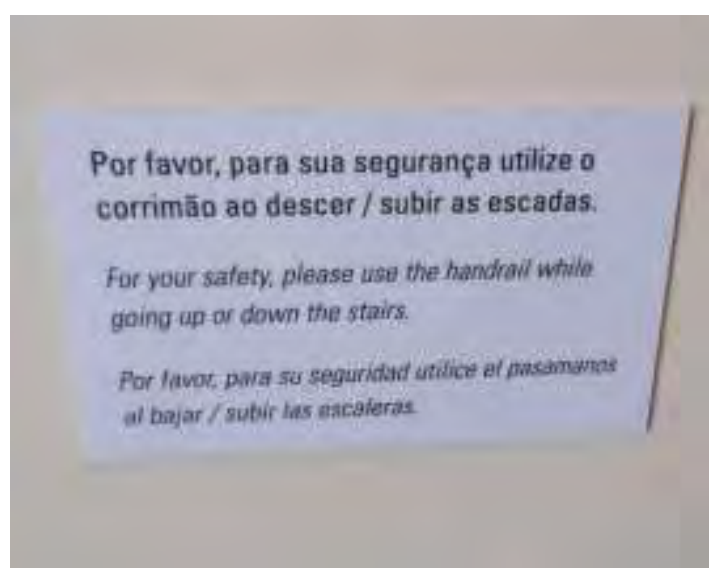

Figura 289 - Aviso pede que se utilize o corrimão para a própria segurança. 2011.

As passarelas que atravessam os pátios no $1^{\circ}$ e $2^{\circ}$ andares tem piso regular, estável e antiderrapante. Apenas no $2^{\circ}$ andar as saídas/entradas das passarelas apresentam desnível em relação ao piso do andar e, portanto têm uma rampa ao final. Estas rampas apresentam inclinação de cerca de $12 \%$, acima do permitido ${ }^{301}$. Esta inclinação é inadequada, segundo a norma, mesmo para o pequeno desnível de $0,20 \mathrm{~m}$ em caso de reforma; mesmo considerando a revisão anterior da norma, a qual estava em vigor no momento da

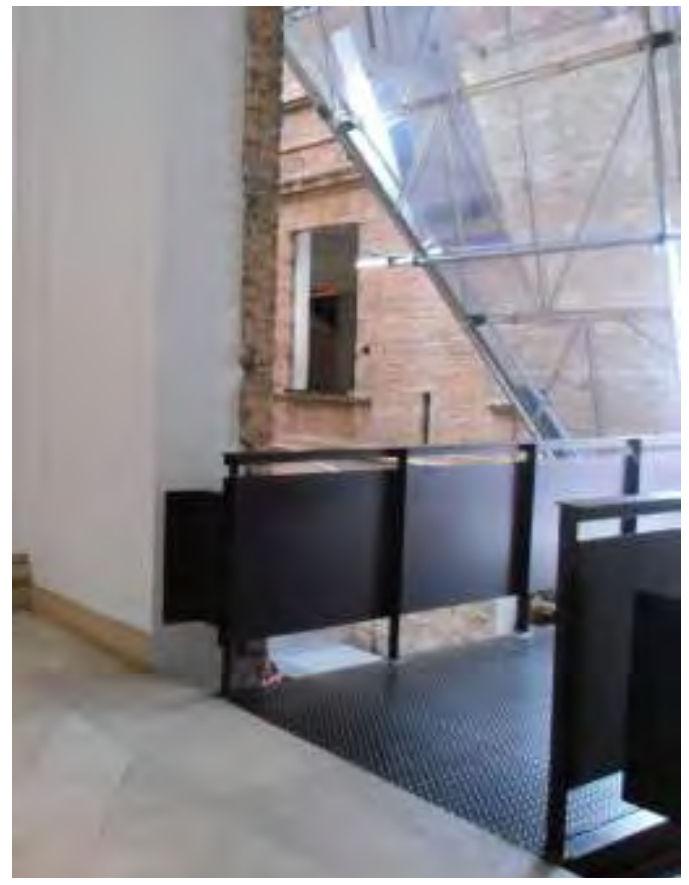

Figura 290 - Saída de uma das passarelas no $1^{\circ}$ andar. 2011.

${ }^{301}$ Não atende ao disposto na ABNT NBR 9050/2004 - item 6.5.1.3. 
reforma $^{302}$. Inclusive essas rampas não tem corrimão prolongando até o seu final ${ }^{303}$.
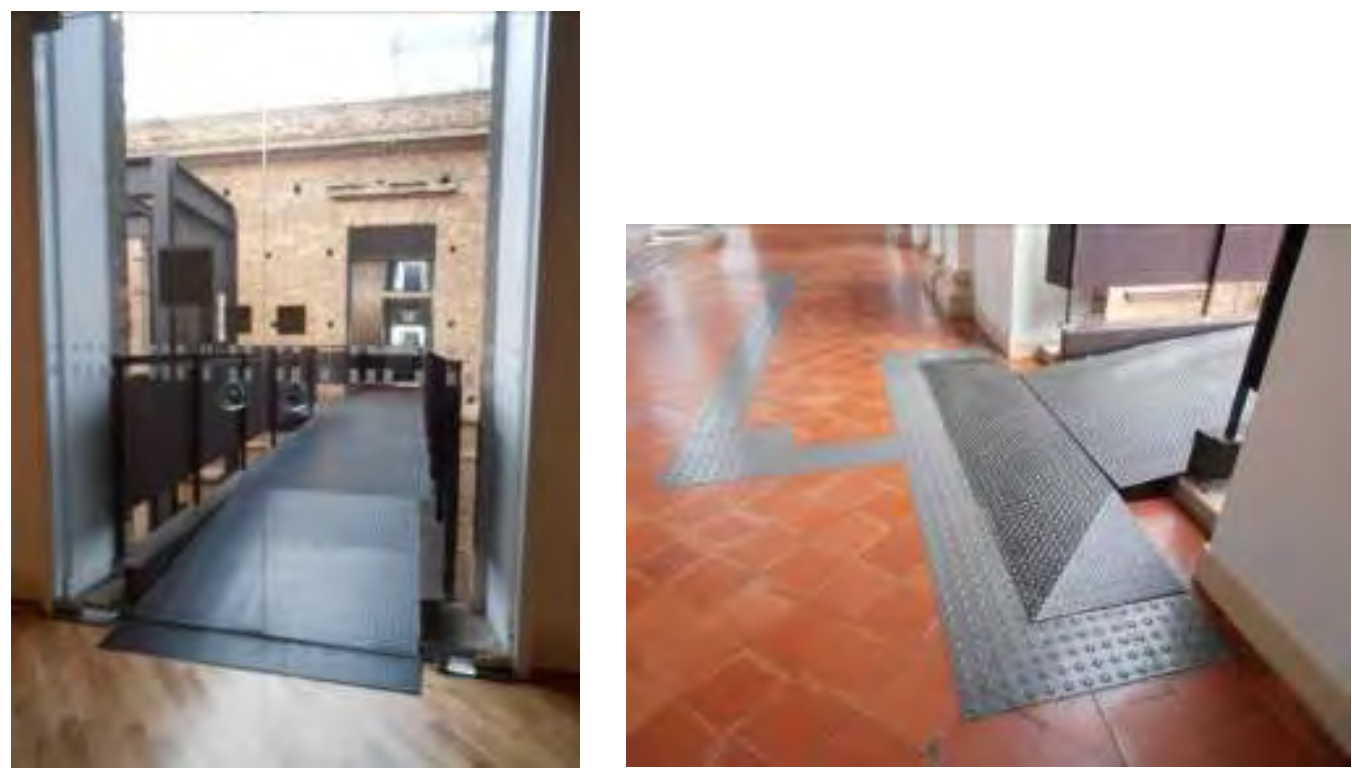

Figura 291 e 292 - Exemplos das saídas de passarela no 2ํandar. 2011.

No 2ํandar há pequenos desníveis que foram rampeados garantindo a circulação acessível. A escada helicoidal de aço é de acesso à área restrita para serviços de manutenção e, portanto não precisa atender às normas de acessibilidade ${ }^{304}$. Mas por ser uma barreira suspensa deveria estar sinalizada com o piso tátil de alerta na sua projeção ${ }^{305}$.

Figura 293 - Circulação rampeada e escada helicoidal no $2^{\circ}$ andar. 2011.

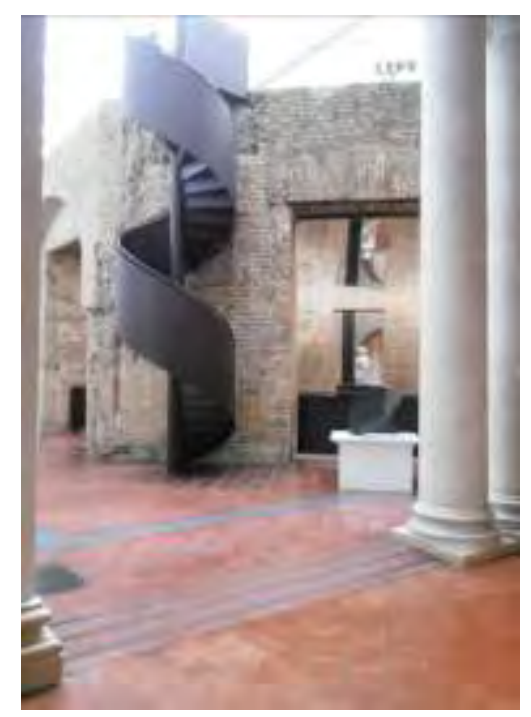

\footnotetext{
${ }^{302}$ A ABNT NBR 9050/1994 foi substituída pela ABNT NBR 9050/2004 em 31 de maio de 2004.

${ }^{303}$ Não atende ao disposto na ABNT NBR 9050/2004 - item 6.7.1.4.

${ }^{304}$ Atende ao disposto na ABNT NBR 9050/2004 - item 1.3.4 , 3.43 e 6.2.7.

${ }^{305}$ Não atende ao disposto na ABNT NBR 9050/2004 - item 5.14.1.2.
} 


\subsubsection{Infraestrutura expositiva e educativa}

Há áreas expositivas nos três pavimentos. Todas apresentam piso adequado e circulação ampla, inclusive em toda a volta de esculturas.
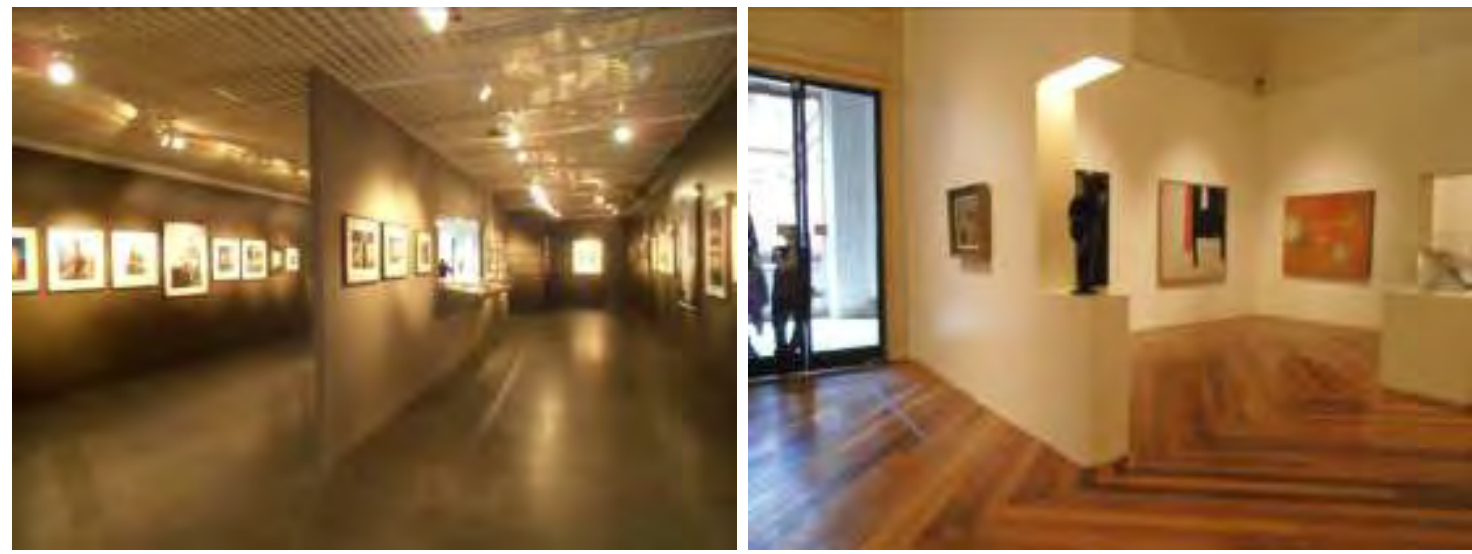

Figura 294 e 295 - Exemplos de circulação dos espaços expositivos. 2011.

O mobiliário expositivo permite a aproximação de usuários de cadeiras de rodas, pois todos têm pelo menos $0,73 \mathrm{~m}$ de altura livre inferior $^{306}$. No caso dos expositores com gavetas, além de permitir a aproximação, atende ao alcance manual ${ }^{307}$. Todos os expositores permitem um

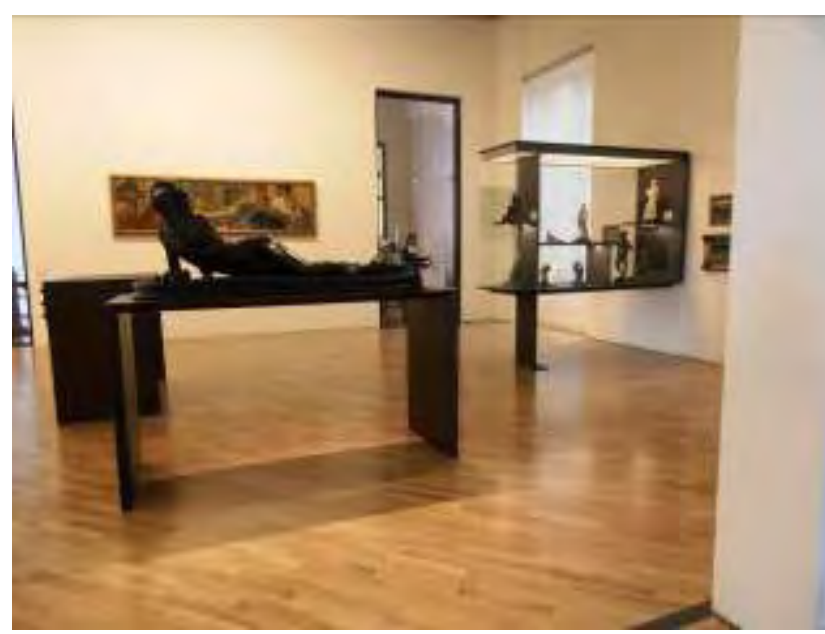

Figura 296 - Exemplos de expositores que permitem aproximação. 2011.

bom alcance visual. Apenas o

vídeo, disponível na Sala 2 "Artistas Viajantes", com o eixo posicionados a 1,45m do piso, fica prejudicado nesse ponto. Como é necessário o uso de fones de ouvido,

\footnotetext{
${ }^{306}$ Atende ao disposto na ABNT NBR 9050/2004 - itens 4.5 e 8.2.2.

${ }^{307}$ Atende ao disposto na ABNT NBR 9050/2004 - item 4.6.1 e 8.2.2.
} 
que estão dentro da faixa de alcance, o fio não permite o distanciamento adequado para visualizar a tela com conforto ${ }^{308}$.

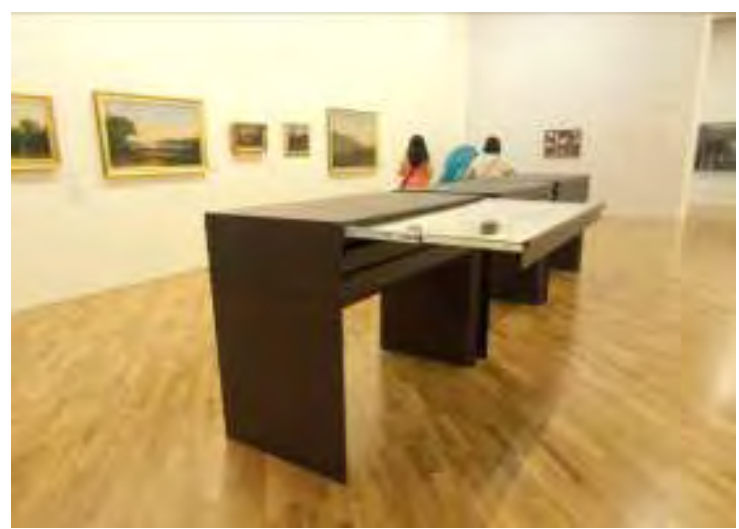

Figura 297 - Expositor com gavetas. 2011.

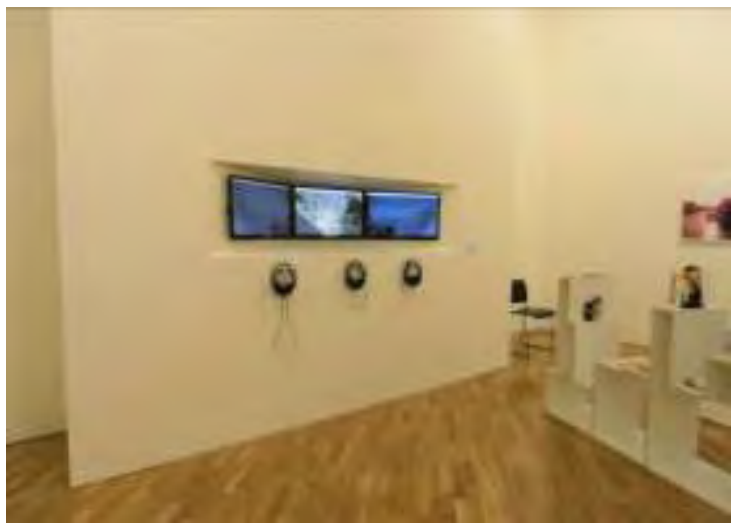

Figura 298 - Vídeo com fones de ouvido. 2011.

De forma geral, as obras expostas apresentam bom alcance visual, e suas legendas ficam geralmente na parte inferior da obra ou à direita, próximas à extremidade inferior. O tamanho da letra das legendas é pequeno, e pessoas idosas podem ter a leitura prejudicada. Não há correspondente em braile ${ }^{309}$. Apenas em algumas esculturas que já fizeram parte da Galeria Tátil.

\footnotetext{
${ }^{308}$ Não atende ao disposto na ABNT NBR 9050/2004 - item 4.7.2.

${ }^{309}$ Não atende ao disposto na ABNT NBR 9050/2004 - item 8.2.2.2.
} 


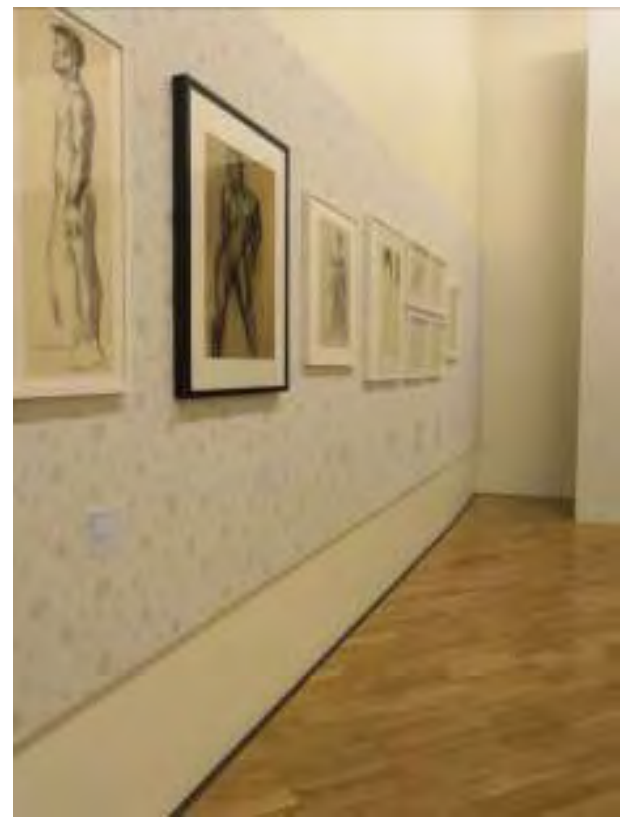

Figura 300 - Legendas na parte inferior das obras. 2011.

Figura 299 - Detalhe do tamanho da letra nas legendas. 2011.

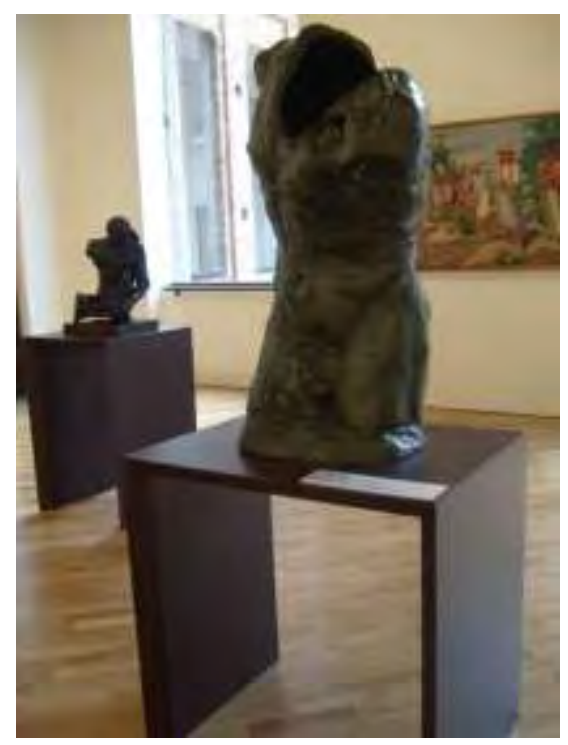

Figura 301 - Exemplo de escultura com legenda em fonte ampliada e braile, fora da Galeria Tátil. 2011.

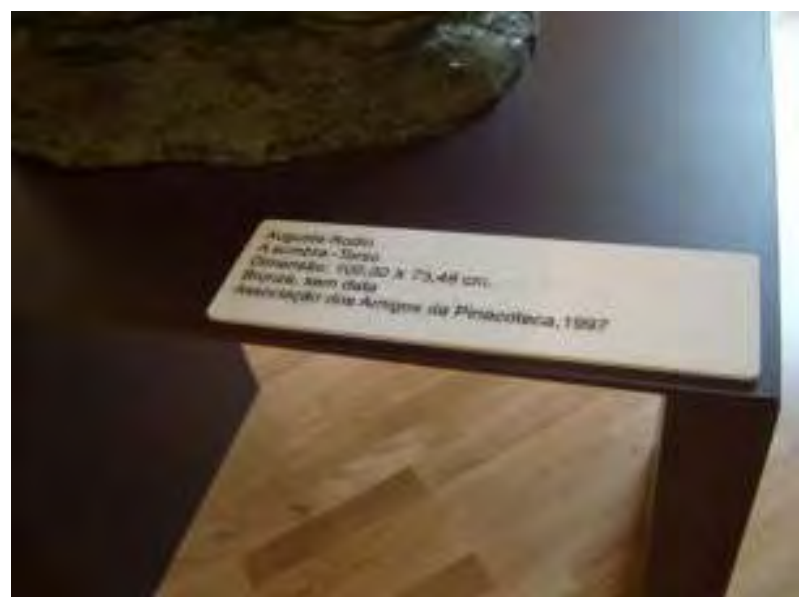

Figura 302 - Detalhe da legenda em braile. 2011.

Diversas áreas expositivas da Pinacoteca contam com bancos no centro da sala que permitem às pessoas sentarem e descansarem durante o longo percurso necessário para ver as diversas exposições. 


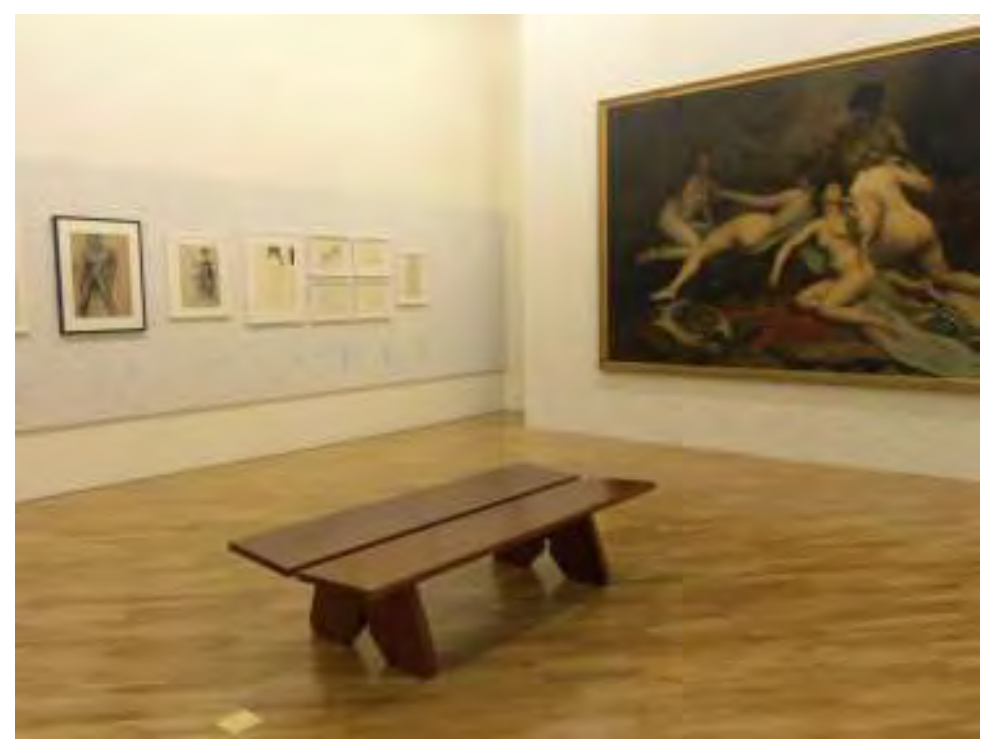

Figura 303 - Banco de madeira para descanso. 2011.

No térreo, há áreas que a equipe do educativo utiliza para reunir grupos e discutir as visitas e as atividades propostas.

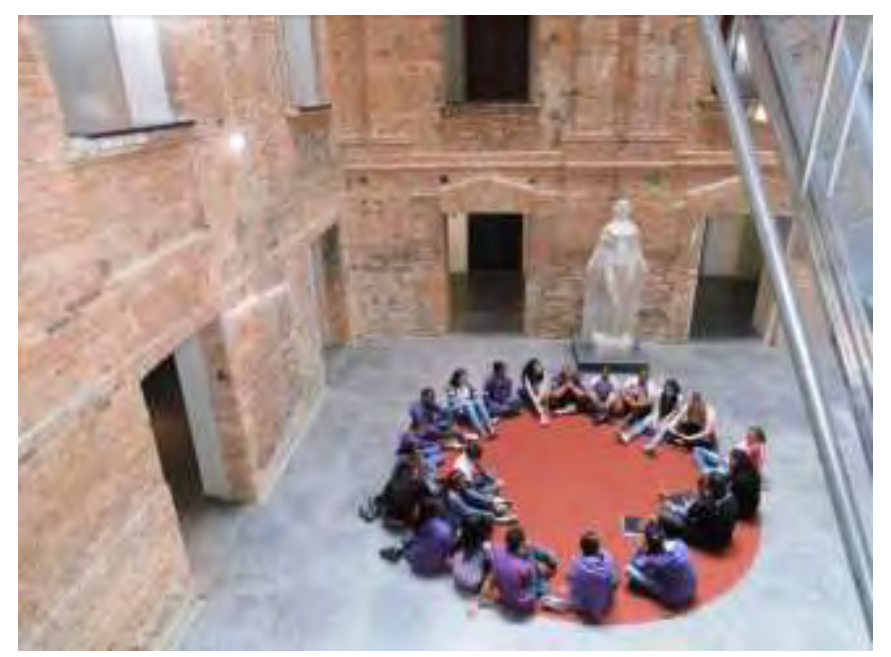

Figura 304 - Áreas livres no térreo para a reunião de grupos. 2011. 


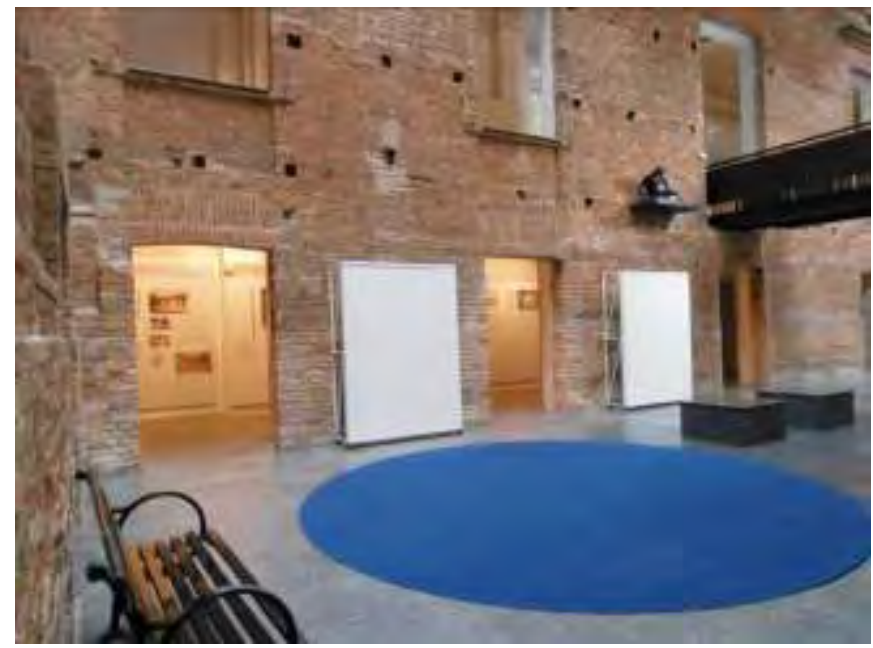

Figura 305 - Áreas livres no térreo para a reunião de grupos. 2011.

A equipe do educativo conta com carrinhos que ficam nos andares para dar apoio às atividades e visitas do PEPE. Esses carrinhos dispõem de recursos que exploram outros pontos da percepção sensorial, atendendo principalmente pessoas com deficiência intelectual e visual nas visitas em grupo. Trazem equivalentes de determinadas obras de artes visuais, como pinturas, gravuras e desenhos, em peças em alto contraste, em relevo ou tridimensionais, além de dispositivos sonoros, que trazem sons relativos à ambiência das obras (Para mais informações ver item 4.7 Programas de atendimento às pessoas com deficiência).

Um dos grandes destaques em questão de acessibilidade e autonomia que a Pinacoteca dispõe para os visitantes cegos é a Galeria Tátil de Esculturas Brasileiras, que fica no $2^{\circ}$ piso. Lá, desde o elevador, há piso tátil direcional, interligando o mapa tátil e o percurso pelas obras expostas. O mapa e todas as obras dispõem de dupla leitura, em tinta e braile ${ }^{310}$. As fontes utilizadas nas legendas são ampliadas na cor preta, sobre fundo branco para permitir boa leitura também por quem tem baixa visão. O mapa tátil indica o percurso a ser feito e um audioguia, que é fornecido na entrada, orienta toda a visitação, com descrições das obras. Todas as

\footnotetext{
${ }^{310}$ Atende ao disposto na ABNT NBR 9050/2004 - itens 5.5.3.2 e 8.2.2.2.
} 
obras estão expostas de forma que a uma pessoa de baixa estatura, em cadeira de rodas, ou uma criança possam ter alcance visual. As obras só podem ser tocadas por pessoas cegas ou com baixa visão.

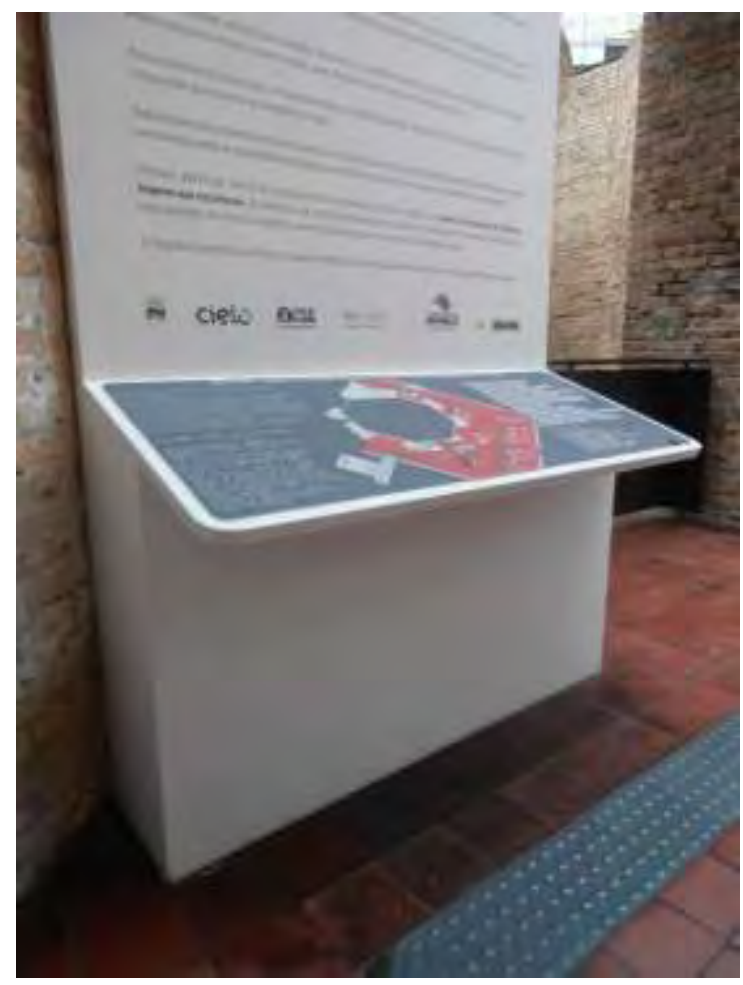

Figura 307 - Mapa tátil da Galeria

Tátil. 2011.

Figura 306 - Detalhe do mapa tátil. 2011.

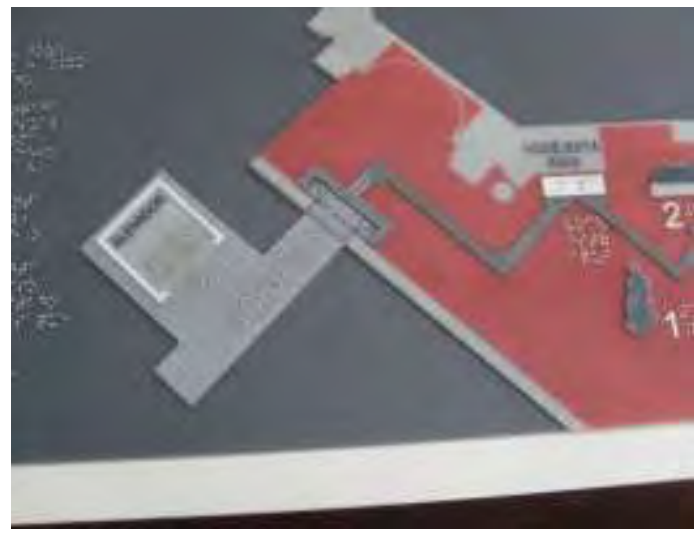

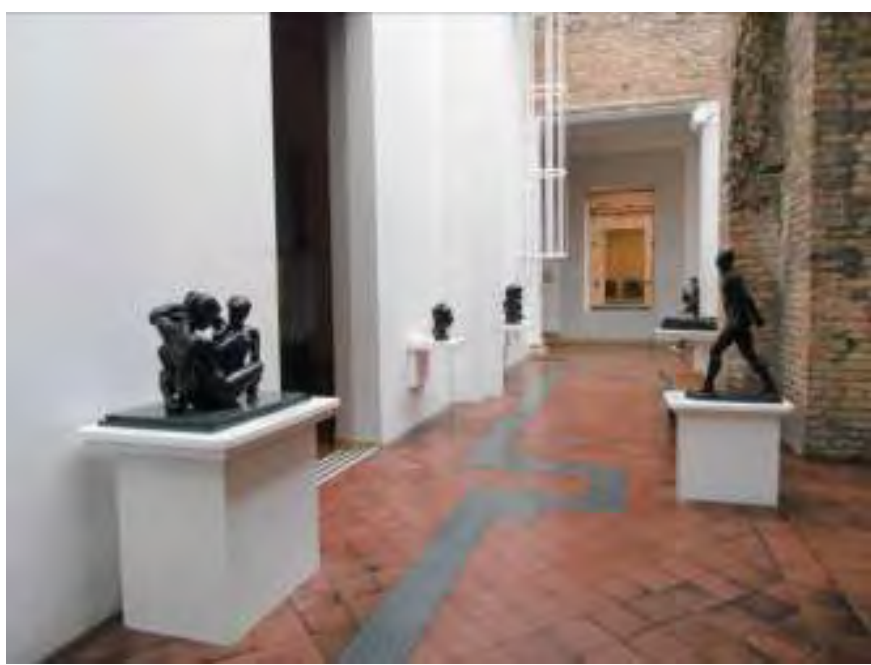

Figura 308 - Rota direcional no percurso da Galeria Tátil. 2011.

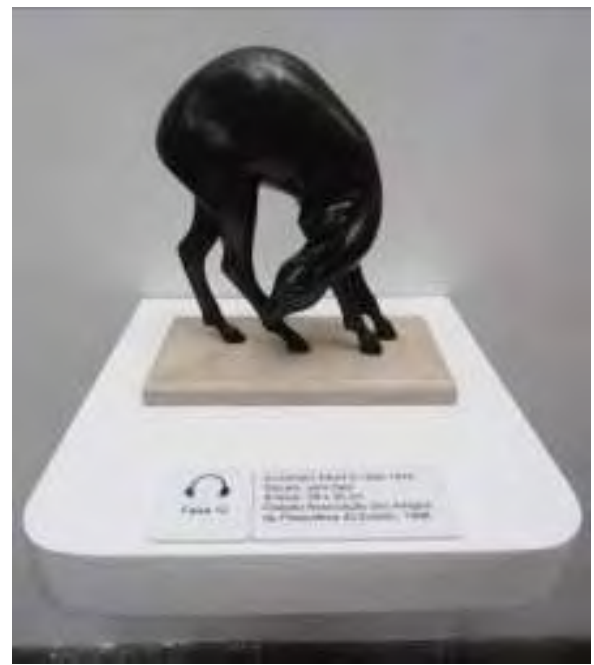

Figura 309 - Detalhe da legenda de escultura exposta na Galeria Tátil. 2011. 
Em suma, existem bastantes recursos para as obras expostas, porém não para todas. No entanto, não há expositor que não seja acessível.

\subsubsection{Locais de reunião}

O único local de reunião

que a Pinacoteca dispõe é o Auditório Alfredo Mesquita no pavimento térreo, localizado exatamente no centro da planta.

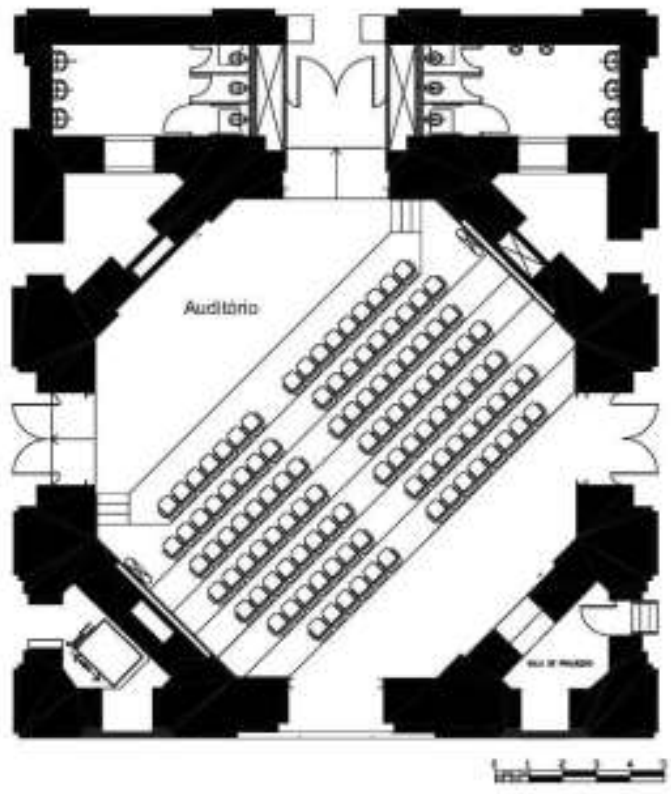

Conforme informado, o auditório tem capacidade para 150 assentos, dispostos em arquibancada. acesso é feito pela parte posterior da plateia, em nível. Para chegar à frente, é necessário descer os degraus nas laterais ou no centro. Essa disposição pode variar, pois os assentos não são fixos.

O acesso ao da. $\mathrm{O}$

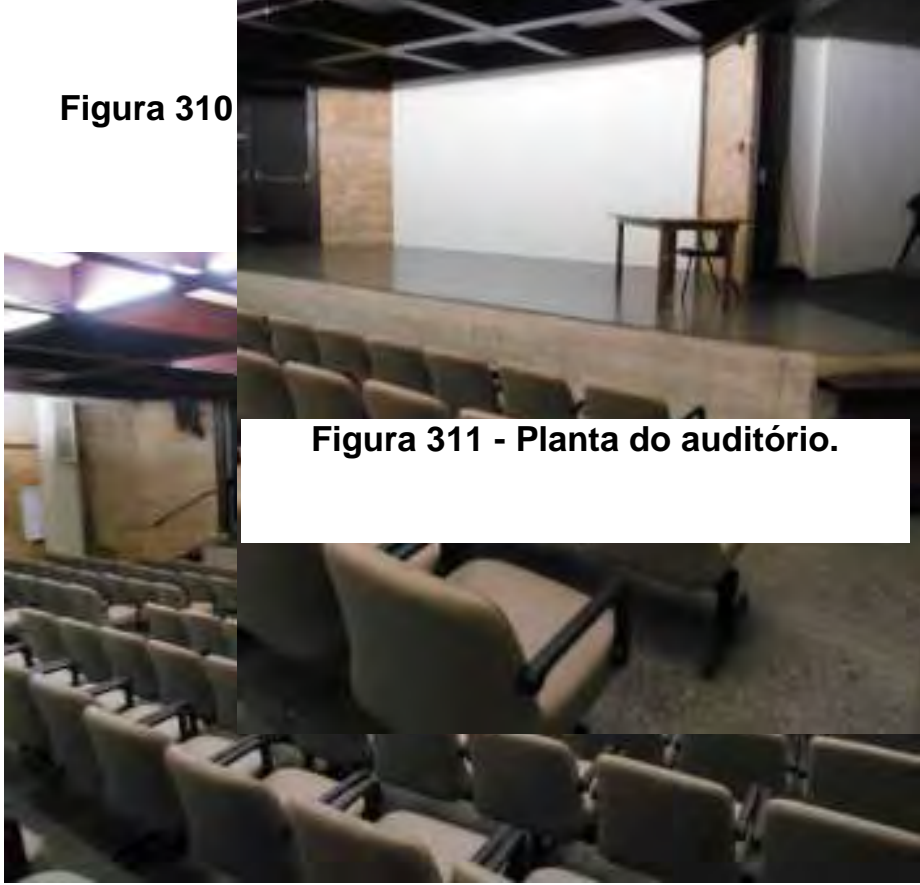
palco, a partir da plateia, é feito por escadas nas extremidades. As portas no fundo 
do palco dão acesso à circulação externa ao auditório. Rampas, no fundo do palco, com inclinação adequada para o desnível de $0,15 \mathrm{~m}$ entre o palco e o nível externo ${ }^{311}$ garantem a rota acessível. No entanto apenas a rampa da direita, de quem olha para o palco, tem patamar antes da porta ${ }^{312}$. Ao menos uma rota está garantida. Nenhuma das rampas possui corrimão, contudo, a ABNT NBR 9050/2004 permite que rampas de acesso ao palco não o tenham. Os degraus de acesso ao palco, a partir da plateia nas duas laterais, têm corrimão apenas de um dos lados, junto à parede. Se for possível transpor para os degraus, de forma comparativa, os parâmetros indicados na ABNT NBR 9050/2004 para rampa de palco, que permite não ter corrimão, verificaríamos que os degraus não estariam inadequados. Assim, a mesma motivação de não prej Figura 313 - Auditório. 2011.

justifica nos degraus, que ao menos o têm em um dos lados. Porém, isso não é explícito na norma em questão.

\footnotetext{
${ }^{311}$ Atende ao disposto na ABNT NBR 9050/2004 - item 8.2.1.4.1.

${ }^{312}$ Atende ao disposto na ABNT NBR 9050/2004 - item 6.5.2.1.
} 
As poltronas comuns do auditório são do tipo longarina, com sequencia de quatro ou seis assentos. Como não são fixas é possível que as pessoas em cadeiras de rodas fiquem na fileira do fundo, que está em nível com o acesso. Falta demarcar os espaços reservados e dispor de assentos para acompanhante $^{313 .}$

fileira da frente, por ter

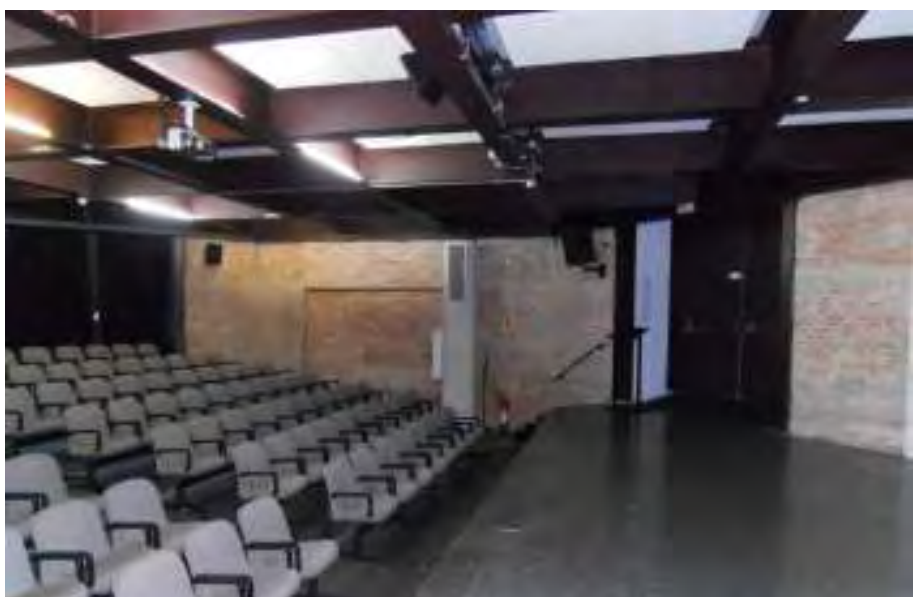

Figura 314 - Espaço no fundo pode acomodar pessoas em cadeiras de rodas. 2011. maior espaço de circulação pode acomodar as pessoas com mobilidade reduzida ${ }^{314}$, porém esta fileira não é a melhor localização, em caso de emergência ${ }^{315}$. Não há assentos para obesos $^{316}$

Não há sinalização tátil de alerta nas rampas, escadas, degraus da plateia e borda do palco ${ }^{317}$.

\subsubsection{Locais de refeição}

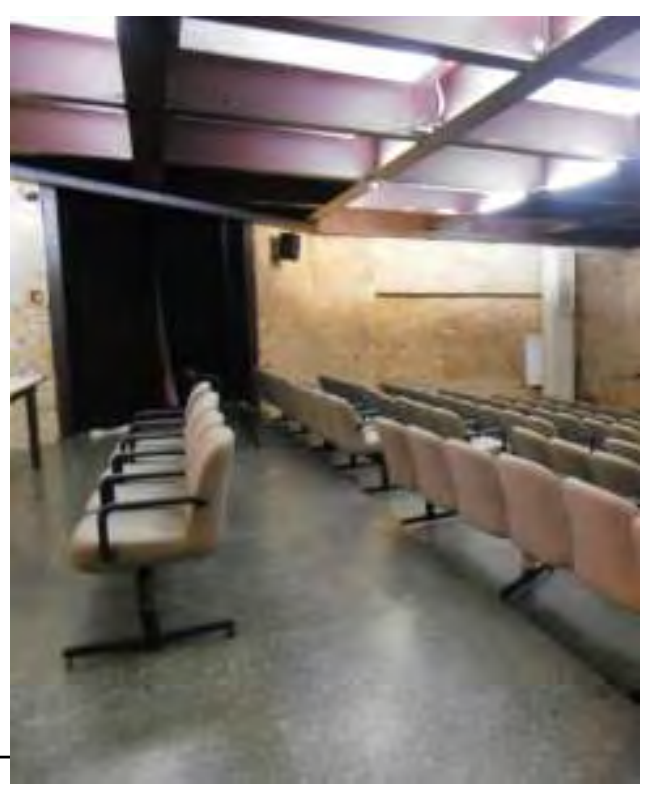

${ }^{313}$ Não atende ao disposto na ABNT NBR 9050/2004

${ }^{314}$ Atende ao disposto na ABNT NBR 9050/2004 - item 8.2.1.3.2.

${ }^{315}$ Não atende ao disposto na ABNT NBR 9050/2004 - item 8.2.1, letra a.

${ }^{316}$ Não atende ao disposto na ABNT NBR 9050/2004 - itens 8.2.1.1 e 8.2.1.3.3.

${ }^{317}$ Não atende ao disposto na ABNT NBR 9050/2004 - item 5.14.1.2. 
Também no andar térreo, fica a cafeteria, na qual são servidos lanches rápidos ou refeições, no sistema de autosserviço. As mesas ficam distribuídas em salão interno e externo. No total são 17 mesas e oito mesas altas. Há ao mínimo um corredor principal com espaço suficiente para circulação nos dois ambientes ${ }^{318}$. As portas de acesso, interno e externo, apresentam largura suficiente para passagem. Não há cardápio em braile ${ }^{319}$. O mobiliário, como mesas e balcões, será analisado em outra parte deste capítulo.

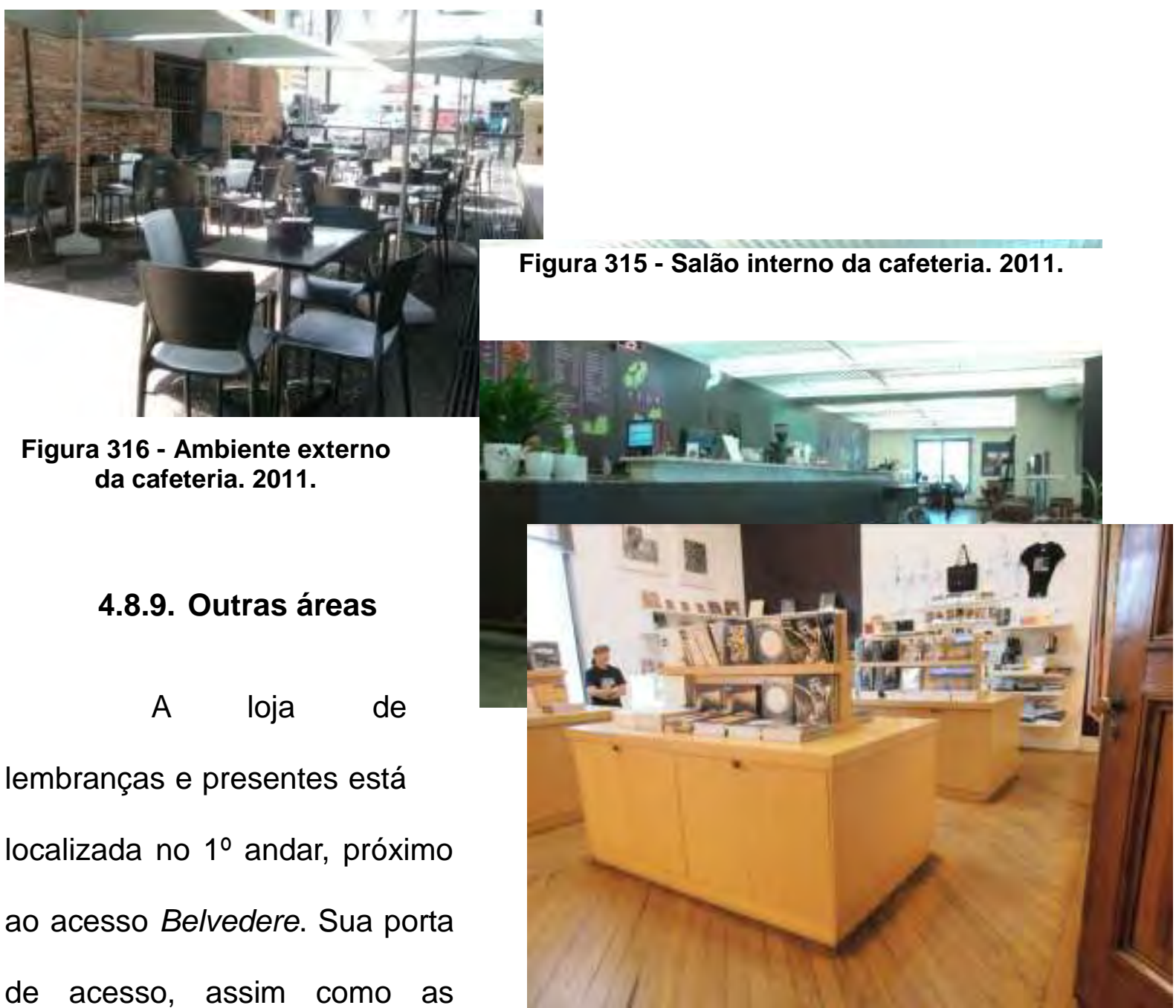

\footnotetext{
${ }^{318}$ Não atende ao disposto na ABNT NBR 9050/2004 - item 9.3.3.3.

${ }^{319}$ Não atende ao disposto no art. 1ำ da Lei municipal ํㅜ 12.363/1997.
} 
demais de madeira do andar, é composta de duas folhas de madeira, com dimensões menores que $0,80 \mathrm{~m}$ cada. A circulação interna entre estantes é ampla e permite passagem de pessoas utilizando equipamentos ${ }^{320}$. Sobre as características do mobiliário ver item específico.

\subsubsection{Instalações sanitárias}

No pavimento térreo há dois conjuntos de sanitários feminino e masculino, além dos vestiários para funcionários, também divididos por sexo. No $1^{\circ}$ andar há um conjunto de cada. E no $2^{\circ}$ andar não há instalações sanitárias.

O total de peças sanitárias destinadas aos visitantes, divididos por sexo e por pavimento, está representado na Tabela 6, a seguir:

\begin{tabular}{|c|c|c|c|c|c|}
\hline & \multicolumn{2}{|c|}{ FEMININO } & \multicolumn{3}{|c|}{ MASCULINO } \\
\hline & lavatório & bacia & lavatório & bacia & mictório \\
\hline TÉRREO & 6 & 6 & 6 & 6 & 5 \\
\hline 10 ANDAR & 3 & 3 & 3 & 3 & 2 \\
\hline 20 ANDAR & 0 & 0 & 0 & 0 & 0 \\
\hline total & 9 & 9 & 9 & 9 & 7 \\
\hline
\end{tabular}

Tabela 6 - Distribuição de peças sanitárias destinadas aos visitantes.

\footnotetext{
${ }^{320}$ Atende ao disposto na ABNT NBR 9050/2004 - item 4.3.4.
} 
Do total apresentado na Tabela 6, quatro, dos seis conjuntos de sanitários, possuem um boxe, com uma bacia sanitária, considerada acessível, sendo então, dois para cada sexo. Quanto ao quantitativo de $5 \%$ do total de peças sanitárias acessíveis, estaria atendido, para bacias e lavatórios, se não fossem as inadequações relativas aos parâmetros exigidos, o que impede de considerar que há instalações sanitárias acessíveis ${ }^{321} 322$.

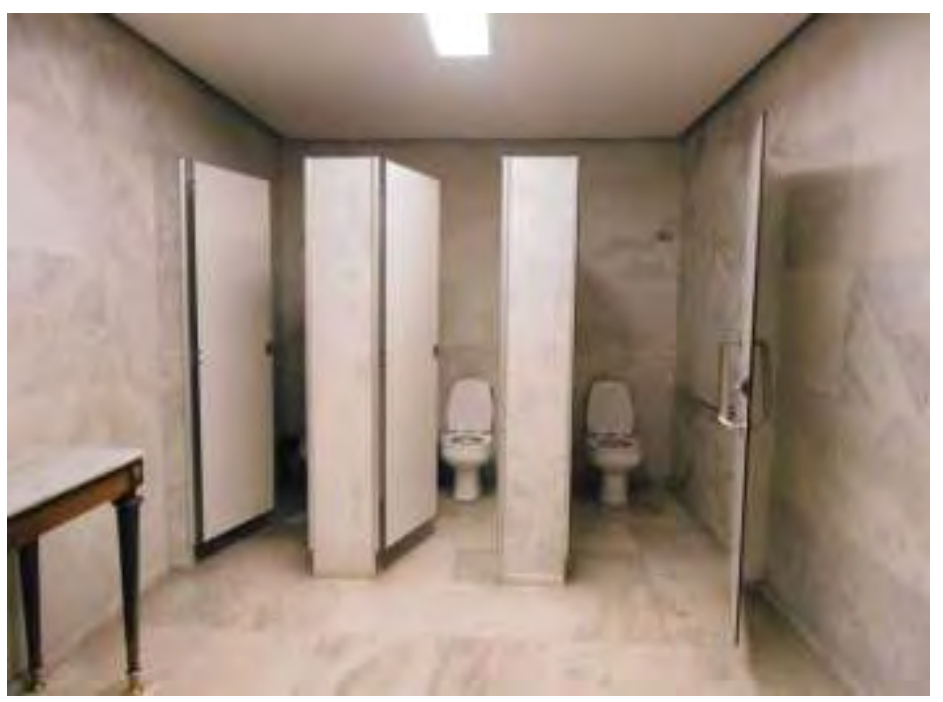

Figura 318 - Boxes com bacias sanitárias. 2011.

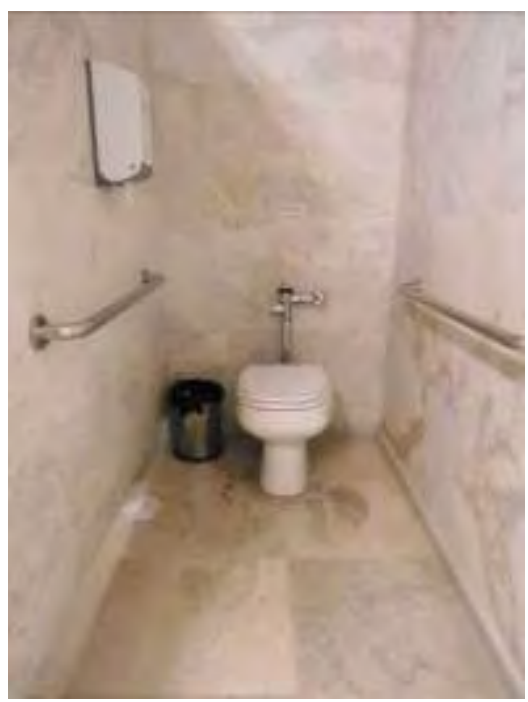

Figura 319 - Detalhe da bacia sanitária. 2011.

Todos os boxes ditos acessíveis apresentam as mesmas características. Boxe interno ao coletivo $^{323}$, largura de porta insuficiente, de $0,72 \mathrm{~m}$ de largura ${ }^{324}$,

\footnotetext{
${ }^{321}$ Não atende ao disposto na ABNT NBR 9050/2004 - item 7.2.2.

322 Como a adaptação foi feita com base na revisão de 1994 da ABNT NBR 9050, era possível em reformas ter sanitários com transferência frontal usando barras laterais, contudo, esta possibilidade não vigora na revisão de 2004, que exige um boxe mínimo de $1,50 \times 1,50 \mathrm{~m}$, em reformas, quando for impossível dispor de boxe de 1,50 x 1,70m.

${ }^{323}$ Não há sanitários com entrada independente, portanto não atende ao disposto no parágrafo $2^{\circ}$ do art. 22, do Decreto Federal 5.296/2004.

${ }^{324}$ Não atende ao disposto na ABNT NBR 9050/2004 - item 6.9.2.1.
} 
abrindo corretamente para fora ${ }^{325}$. Sua fechadura é de difícil manipulação. A barra na porta não é horizontal ${ }^{326}$. A bacia tem altura de $0,42 \mathrm{~m}$ com assento, portanto mais baixa do que o necessário ${ }^{327}$. Dentro do boxe, de $1,00 \mathrm{~m}$ de largura por 1,70m de profundidade $^{328}$ não há espaço para rotação e aproximação ${ }^{329}$. Há duas barras laterais horizontais $^{330}$. A papeleira está em altura adequada de $1,00 \mathrm{~m}$ do piso ${ }^{331}$. $\mathrm{O}$ lavatório fica externo ao boxe ${ }^{332}$, não garantindo assim, a privacidade de uso. Todavia, o lavatório é suspenso e está posicionado em altura correta ${ }^{333}$ e tem acionamento por sensor eletrônico ${ }^{334}$. Não há barra de $a^{2}$ oio $^{335}$. Há prejuízos na altura de posicionamento do toalheiro ${ }^{336}$ e do espelho ${ }^{337}$. No sanitário masculino, não há mictórios acessíveis ${ }^{338}$.

\footnotetext{
${ }^{325}$ Não atende ao disposto na ABNT NBR 9050/2004 - item 7.3.3.4.

${ }^{326}$ Não atende ao disposto na ABNT NBR 9050/2004 - itens 6.9.2.4 e 7.3.8.5.

${ }^{327}$ Não atende ao disposto na ABNT NBR 9050/2004 - item 7.3.1.3.

${ }^{328}$ Não atende ao disposto na ABNT NBR 9050/2004 - item 7.3.3.1.

${ }^{329}$ Não atende ao disposto na ABNT NBR 9050/2004 - itens 7.3.1.1 e 7.3.3.1.

${ }^{330}$ Não atende ao disposto na ABNT NBR 9050/2004 - item 7.3.1.2.

${ }^{331}$ Atende ao disposto na ABNT NBR 9050/2004 - item 7.3.8.2.

${ }^{332}$ Não atende ao disposto na ABNT NBR 9050/2004 - item 7.3.3.3.

${ }^{333}$ Atende ao disposto na ABNT NBR 9050/2004 - item 7.3.6.2

${ }^{334}$ Atende ao disposto na ABNT NBR 9050/2004 - item 7.3.6.3.

${ }^{335}$ Não atende ao disposto na ABNT NBR 9050/2004 - item 7.3.6.4.

${ }^{336}$ Não atende ao disposto na ABNT NBR 9050/2004 - item 7.3.8.

${ }^{337}$ Não atende ao disposto na ABNT NBR 9050/2004 - item 7.3.8.1.

${ }^{338}$ Não atende ao disposto na ABNT NBR 9050/2004 - itens 7.2, 7.2.2, 7.3.7.2 e 7.3.7.4.
} 


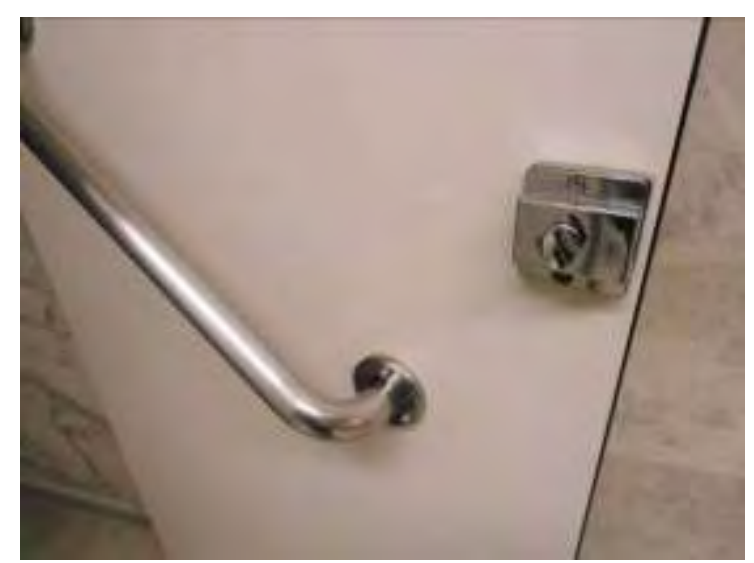

Figura 320 - Detalhe da fechadura. 2011.

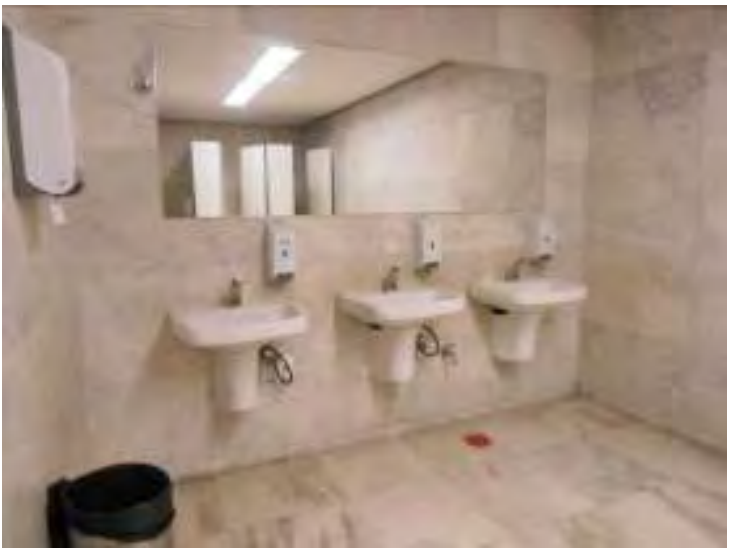

Figura 321 - Lavatórios. 2011.

Nos vestiários, destinado aos funcionários, não há bacias, lavatórios ou chuveiros acessíveis. Apesar de não estar explicito que mesmo atendendo o quantitativo de peças, ainda assim deve haver instalações sanitárias acessíveis especificamente para os funcionários, isso se torna óbvio, de forma a garantir iguais condições para todos os funcionários, uma vez que há distinção de público nos usos. A Tabela 7 demonstra o total de peças nos vestiários de funcionários, por sexo e andar: 


\begin{tabular}{lccc|cccc} 
& \multicolumn{3}{c|}{ FEMININO } & \multicolumn{4}{c}{ MASCULINO } \\
& lavatório & bacia & chuveiro & lavatório & bacia & mictório & chuveiro \\
\hline TÉRREO & 3 & 4 & 2 & 3 & 3 & 3 & 2 \\
\hline 10 ANDAR & 0 & 0 & 0 & 0 & 0 & 0 & 0 \\
\hline 20 ANDAR & 0 & 0 & 0 & 0 & 0 & 0 & 0 \\
\hline \multicolumn{1}{r}{ total } & $\mathbf{3}$ & $\mathbf{4}$ & $\mathbf{2}$ & $\mathbf{3}$ & $\mathbf{3}$ & $\mathbf{3}$ & $\mathbf{2}$
\end{tabular}

Tabela 7 - Distribuição de peças sanitárias destinadas aos funcionários.

\subsubsection{Mobiliário}

Serão analisados balcões, bilheteria, mesas, telefones e bebedouros.

A bilheteria na entrada, no $1^{\circ}$ andar, é geralmente o primeiro mobiliário que o visitante tem contato. Sua altura é $1,12 \mathrm{~m}$, portanto está acima da medida máxima permitida para uso de pessoas em cadeira de rodas e baixa estatura ${ }^{339}$.

A altura dos balcões utilizados nos guarda-volumes, a 1,10m do piso, e na recepção, a 0,95m do piso, também estão além do máximo permitido, que seria $0,90 \mathrm{~m}^{340}$.

O balcão de pagamento da loja de presentes também é mais alto, pois tem $1,16 \mathrm{~m}$ de altura do piso ${ }^{341}$. Na loja há também prateleiras e mobiliários expondo os produtos à venda. De forma geral esses móveis têm altura $0,90 \mathrm{~m}$, adequados para o

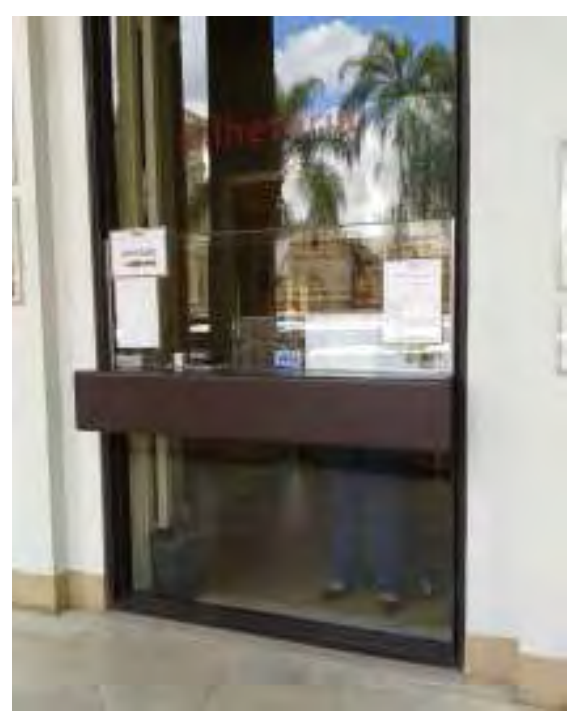

Figura 322 - Bilheteria. 2011.

\footnotetext{
${ }^{339}$ Não atende ao disposto na ABNT NBR 9050/2004 - item 9.5.5.1.

${ }^{340}$ Não atende ao disposto na ABNT NBR 9050/2004 - item 9.5.2.1.

${ }^{341}$ Não atende ao disposto na ABNT NBR 9050/2004 - item 9.5.2.1.
} 
alcance manual ${ }^{342}$. Algumas das prateleiras são altas e estão fora do alcance, manual e visual, da maioria das pessoas.

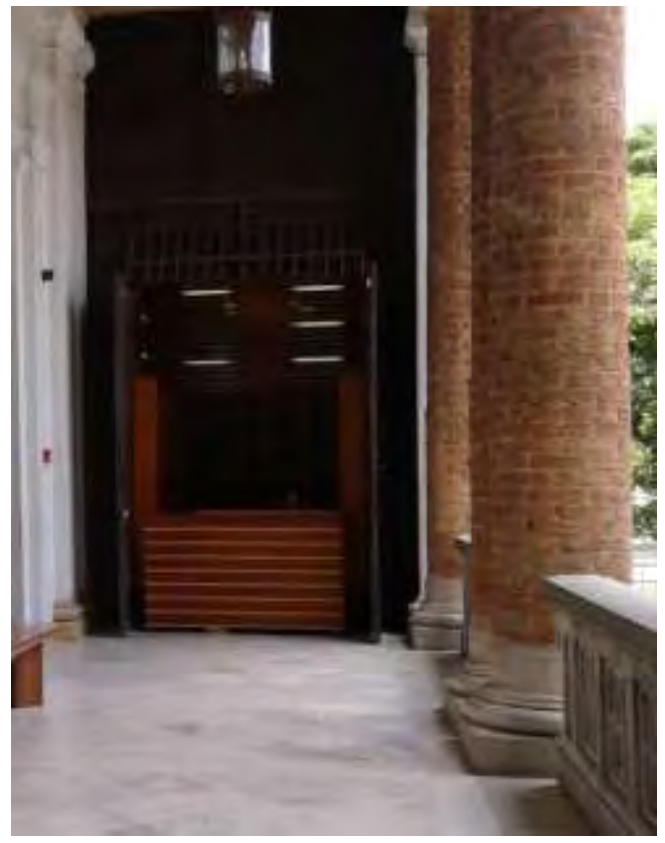

Figura 323 - Guarda-volumes. 2011.

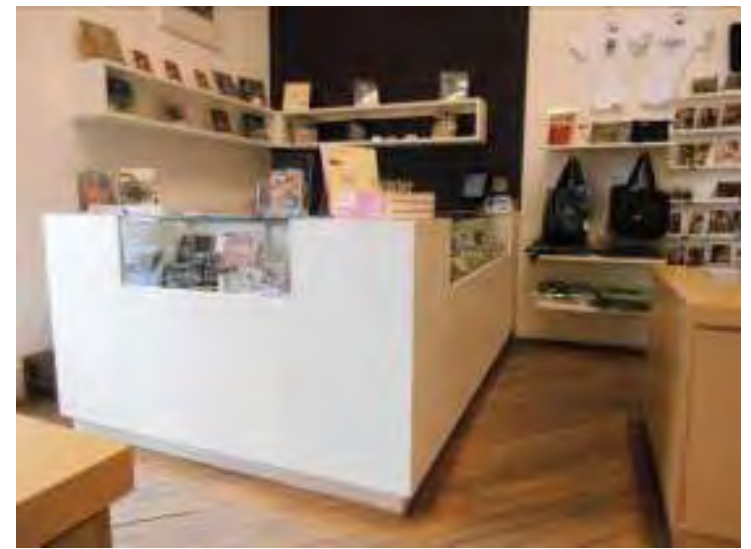

Figura 325 - Balcão de pagamento da loja. 2011.

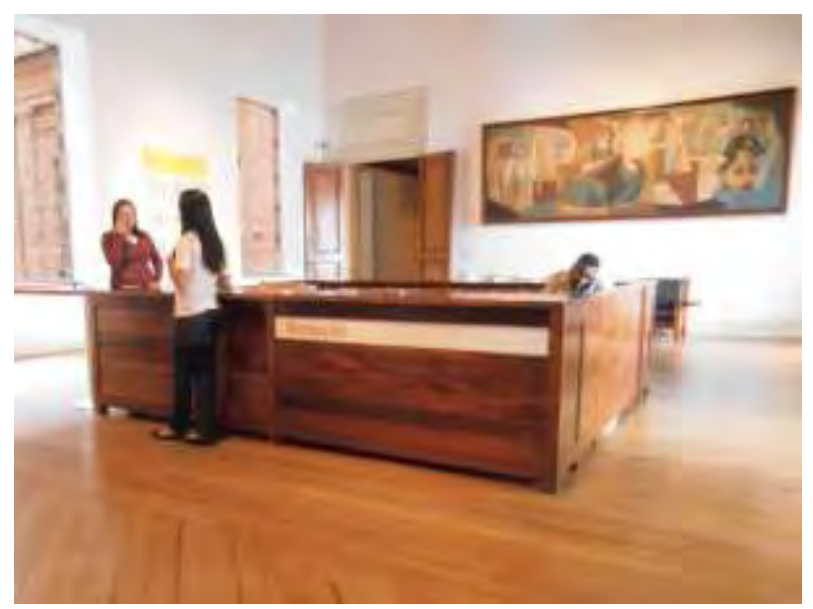

Figura 324 - Balcão da recepção. 2011.

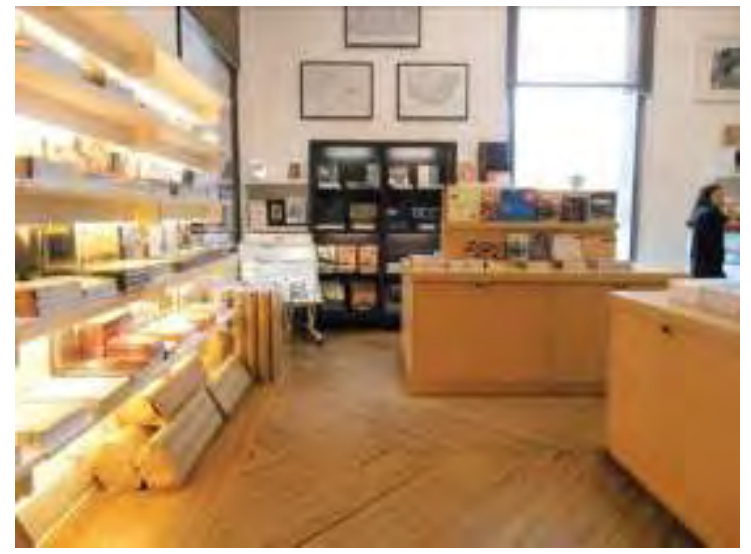

Figura 326 - Estantes e expositores de produtos. 2011.

$\mathrm{Na}$ entrada de serviço, no térreo, o balcão é muito alto ${ }^{343}$. Diferente do balcão, no mesmo andar, utilizado pela equipe do educativo na saída da visita, que

${ }^{342}$ Atende ao disposto na ABNT NBR 9050/2004 - item 4.6.2.

${ }^{343}$ Não atende ao disposto na ABNT NBR 9050/2004 - item 9.5.2.1. 
tem altura inclusiva, e possibilidade de aproximação ${ }^{344}$.

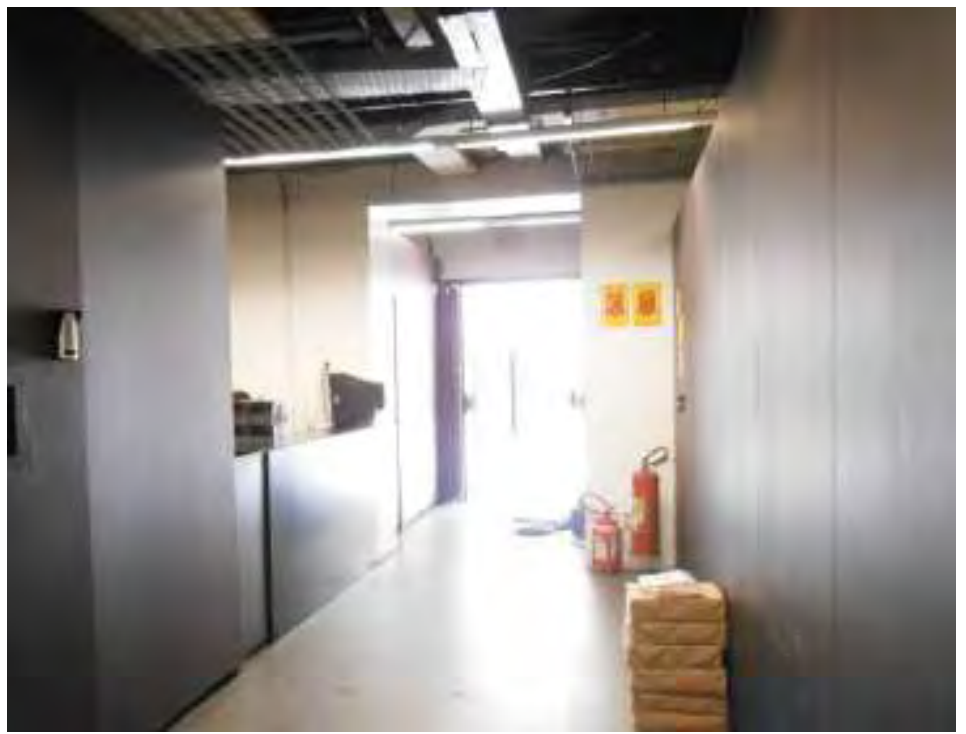

Figura 327 - Balcão da entrada de serviço. 2011.

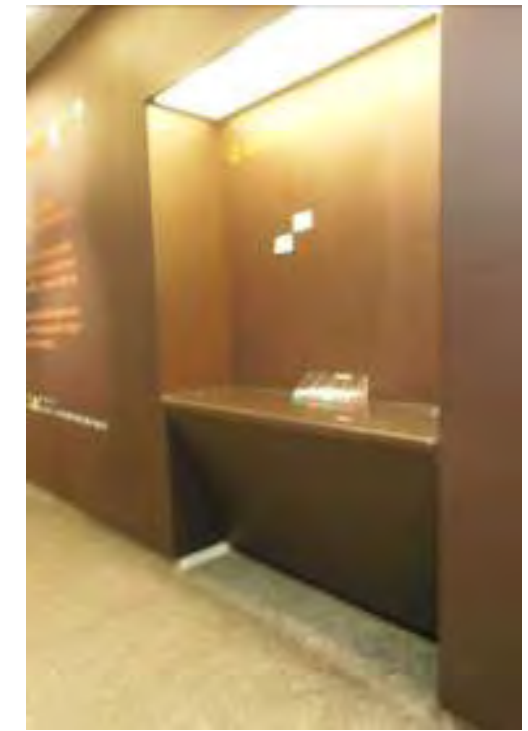

Figura 328 - Balcão utilizado pelo educativo. 2011.

Na cafeteria há diversos mobiliários a serem analisados. O balcão de pagamento está acima da altura máxima ${ }^{345}$. $\mathrm{O}$ balcão de autosserviço tem altura e espaço de circulação adequados para a utilização de uma pessoa em cadeira de rodas $^{346}$. Sobre as mesas de refeição, apenas uma pode ser considerada acessível, dentro dos parâmetros normatizados, entre as 25 mesas existentes, portanto não há $5 \%$ de mesas acessíveis ${ }^{347}$. Essa mesa, que fica no salão externo, acomoda 10 pessoas e possui espaço livre necessário para aproximação ${ }^{348}$. As demais mesas não possuem menos do que 0,73 de espaço livre inferior ${ }^{349}$ ou pé de apoio inadequado para aproximação de pessoa usuária de cadeira de rodas ${ }^{350}$. Fica assim,

\footnotetext{
${ }^{344}$ Atende ao disposto na ABNT NBR 9050/2004 - item 9.5.2.1.

${ }^{345}$ Não atende ao disposto na ABNT NBR 9050/2004 - item 9.5.2.1.

${ }^{346}$ Atende ao disposto na ABNT NBR 9050/2004 - item 9.5.3.4.

${ }^{347}$ Não atende ao disposto na ABNT NBR 9050/2004 - item 8.2.3.

${ }^{348}$ Atende ao disposto na ABNT NBR 9050/2004 - itens 9.3.3.1 e 9.3.3.2.

${ }^{349}$ Não atende ao disposto na ABNT NBR 9050/2004 - item 9.3.3.1.

${ }^{350}$ Não atende ao disposto na ABNT NBR 9050/2004 - item 9.3.3.2.
} 
prejudicado o serviço, pois se estiver chovendo, por exemplo, não haverá mesa adequada do lado de dentro. O espaço tem um sofá que permite acomodar pessoas obesas atendendo a quantidade mínima ${ }^{351}$.
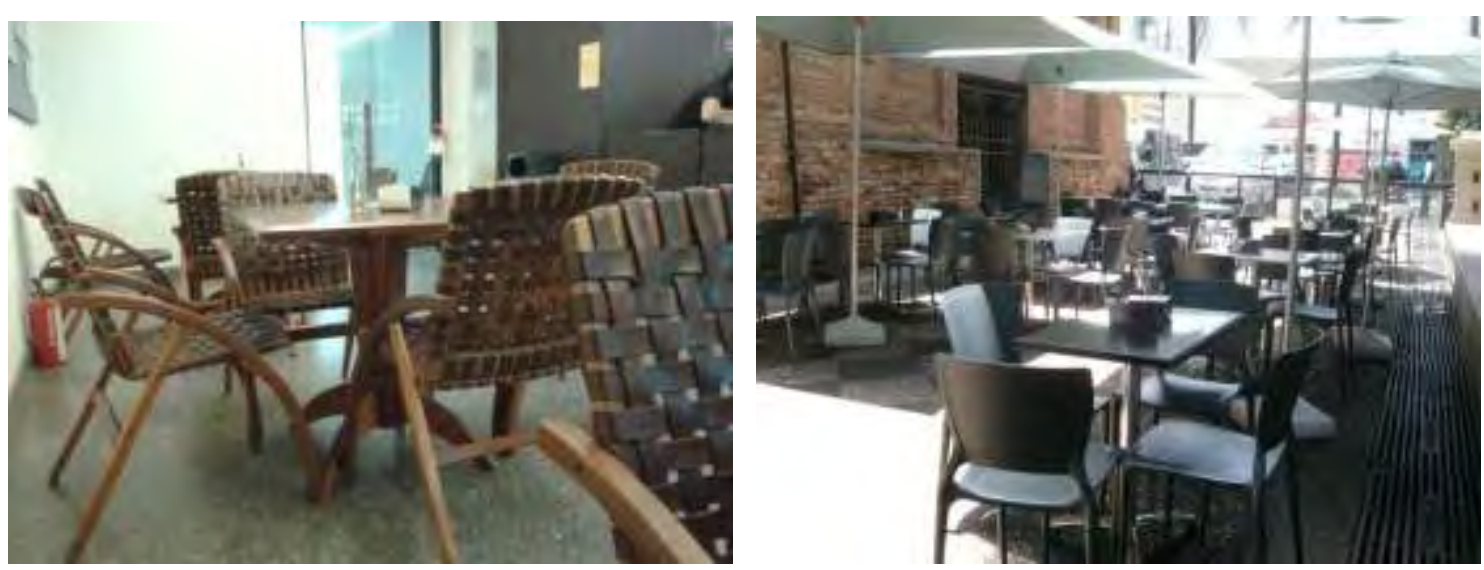

Figura 329 e 330 - Mesas da cafeteria. 2011.

É também no pavimento térreo que estão os bebedouros e telefones para o público. Nos dois conjuntos, não há bebedouros acessíveis, apenas um bebedouro para pessoas em pé e outro para crianças; este último muito baixo para permitir a aproximação de usuários de cadeira de rodas. Os telefones estão corretos, pois possui um em altura para pessoas em pé, outro para usuários de cadeira de rodas ${ }^{352}$ e um TDD (Telecommunication device for the deaf), aparelho com teclado ${ }^{353}$, próximo ao terceiro aparelho.

\footnotetext{
${ }^{351}$ Atende ao disposto no art. 1ํ da Lei municipal no $12.658 / 1998$.

${ }^{352}$ Atende ao disposto na ABNT NBR 9050/2004 - item 9.2.5.

${ }^{353}$ Atende ao disposto na ABNT NBR 9050/2004 - item 9.2.3.
} 


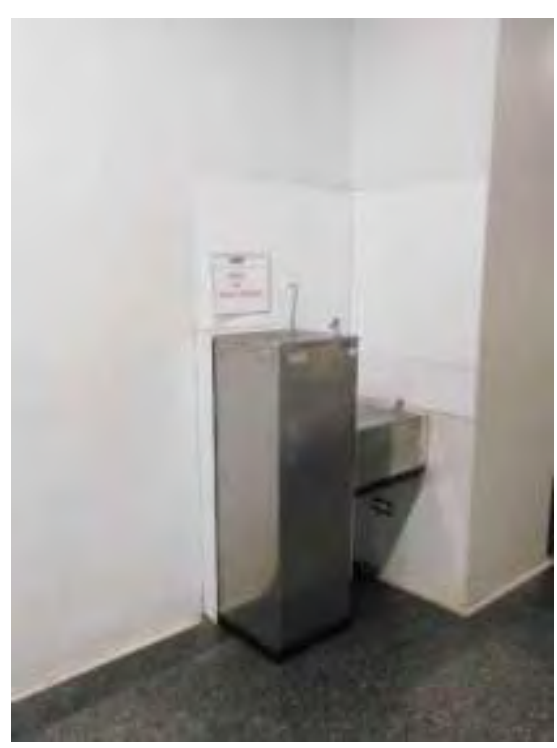

Figura 331 - Bebedouros. 2011.

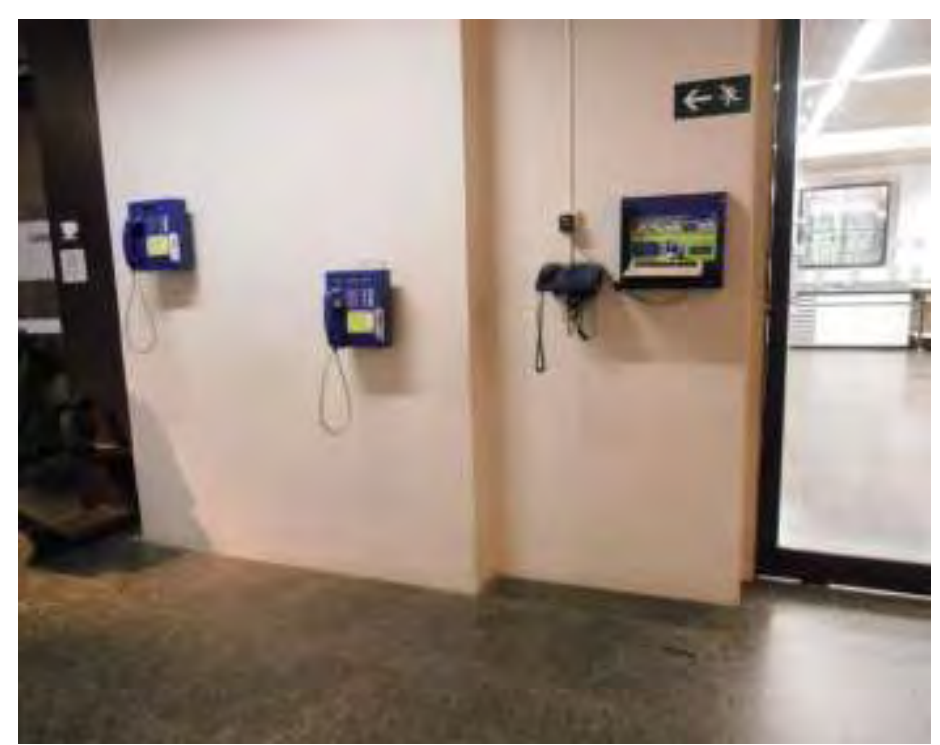

Figura 332 - Telefones. 2011.

No último andar, onde há diversas salas de exposições, o visitante pode pegar um mapa em um dos totens para orientar seu percurso. Esses totens garantem o alcance manual adequado ${ }^{354}$.

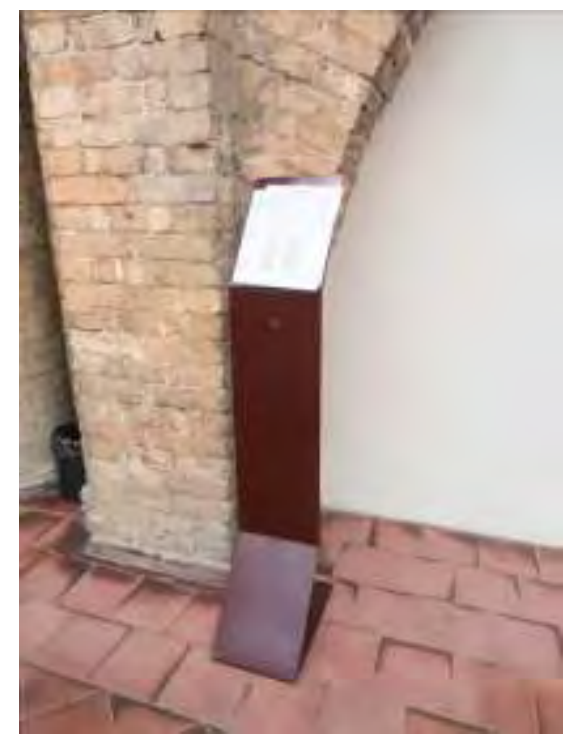

Figura 333 - Totem. 2011.

${ }^{354}$ Atende ao disposto na ABNT NBR 9050/2004 - item 4.6.2. 


\subsubsection{Sinalização e comunicação}

Relativa à sinalização ambiental há o uso de pictogramas internacionais que buscam facilitar a comunicação dos espaços e serviços. A entrada acessível está corretamente sinalizada com 0 $S I A^{355}$.

A bilheteria está identificada, porém, há dificuldade de leitura e percepção ${ }^{356}$, pois o texto do adesivo, sobre o fundo de vidro transparente, se confunde com o fundo. O reflexo também prejudica. Os guarda-volumes não estão identificados.

De forma geral há boa sinalização ambiental, direcionando aos principais serviços e ambientes, principalmente em pontos de mudança de direção. Essa sinalização utiliza símbolos de circulação ${ }^{357}$. Há adequado contraste entre fundo e texto ou símbolo ${ }^{358}$, porém o tamanho da letra e dos símbolos permite a

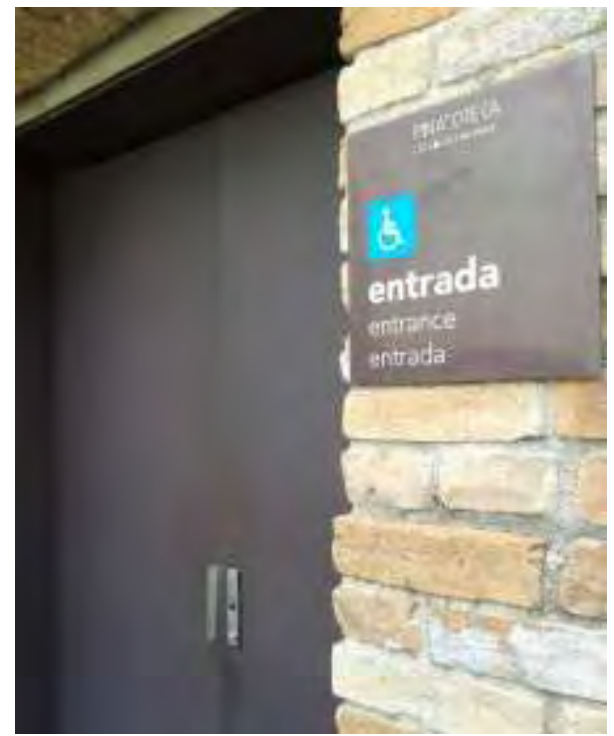

Figura 335 - Identificação da entrada acessível. 2011.

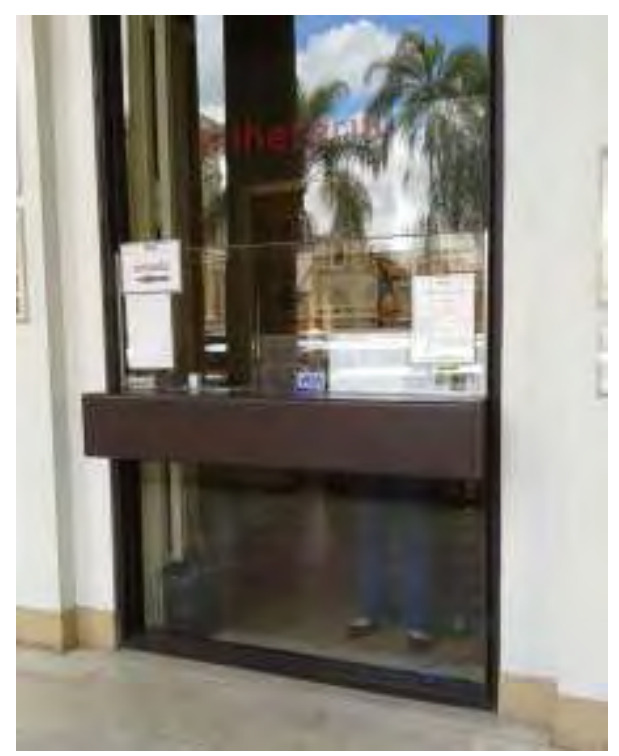

Figura 334 - Sinalização da bilheteria. 2011.

\footnotetext{
${ }^{355}$ Atende ao disposto na ABNT NBR 9050/2004 - item 5.4.1.3.

${ }^{356}$ Não atende ao disposto na ABNT NBR 9050/2004 - item 5.5.2.2.

${ }^{357}$ Atende ao disposto na ABNT NBR 9050/2004 - item 5.4.4.3.

${ }^{358}$ Atende ao disposto na ABNT NBR 9050/2004 - item 5.5.2.1.
} 
leitura da informação apenas de perto, especialmente por quem tem baixa visão ${ }^{359}$. A sinalização de sanitários, na entrada dos mesmos, tem bom tamanho e permite a identificação de longe.

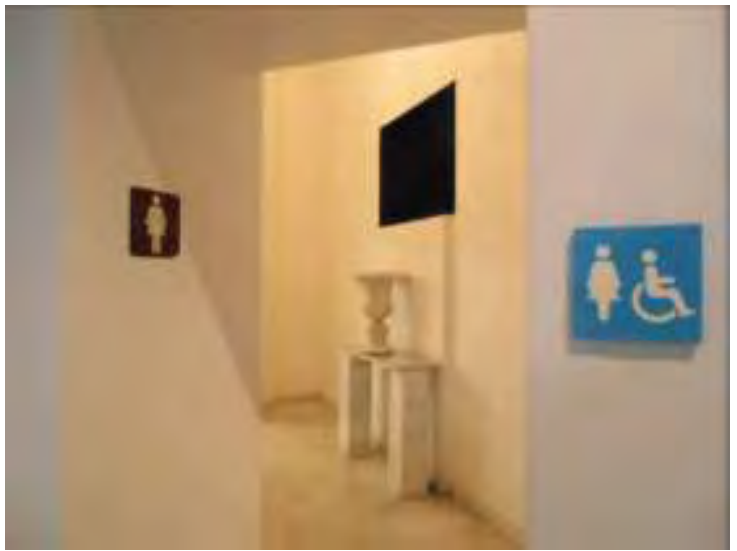

Figura 336 - Sinalização da entrada do sanitário. 2011.

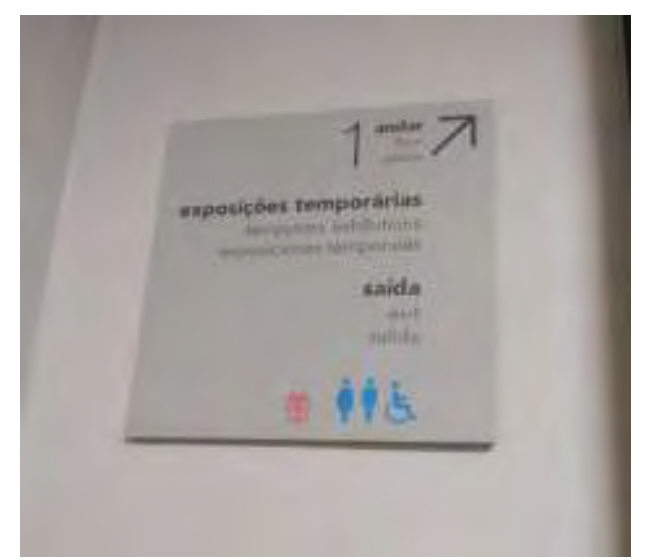

Figura 337 e 338 - Sinalização ambiental com símbolos de circulação e de sanitários. 2011.
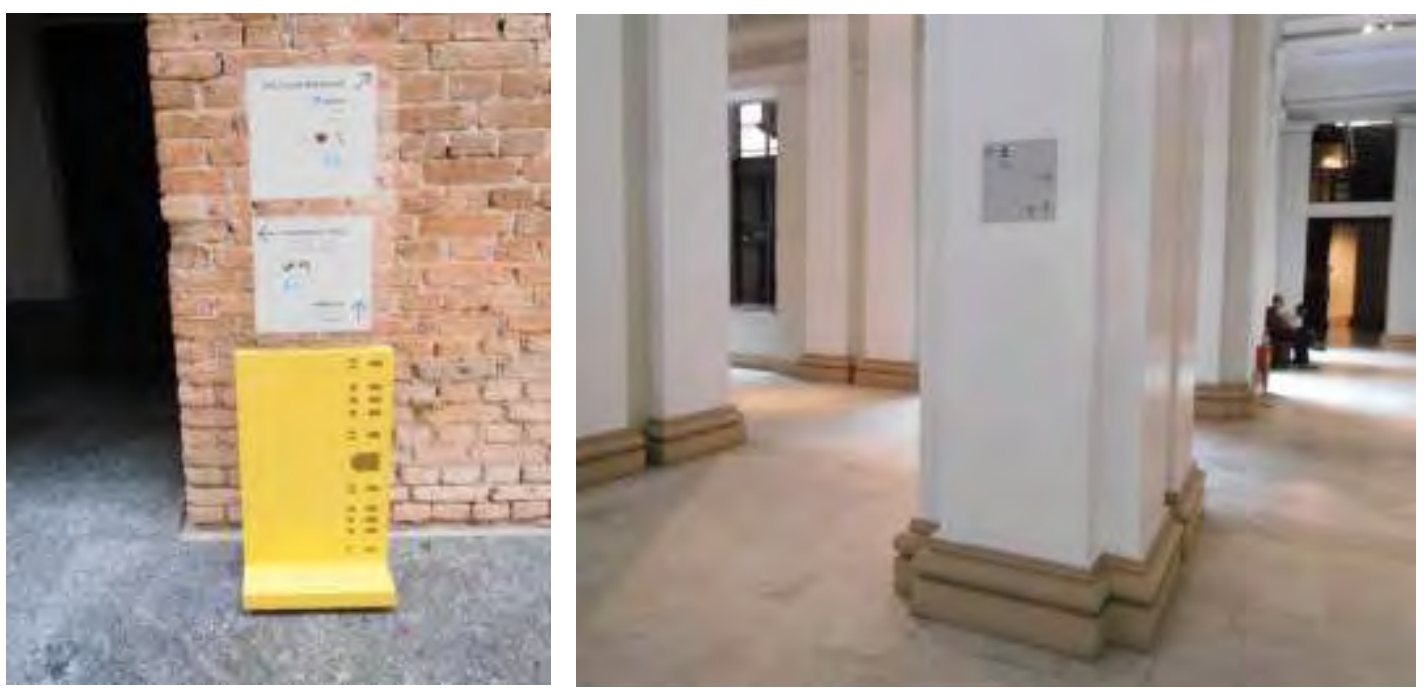

Figura 339 e 340 - Exemplos de sinalização ambiental. 2011.

${ }^{359}$ Não atende ao disposto na ABNT NBR 9050/2004 - item 5.5.4. 
As salas de exposições são, geralmente, identificadas com bom contraste. Como, para cada sala é utilizada uma cor de identificação, associada ao mapa visual entregue na entrada, algumas cores garantem melhor contraste em relação ao texto de cor branca, do que outras.
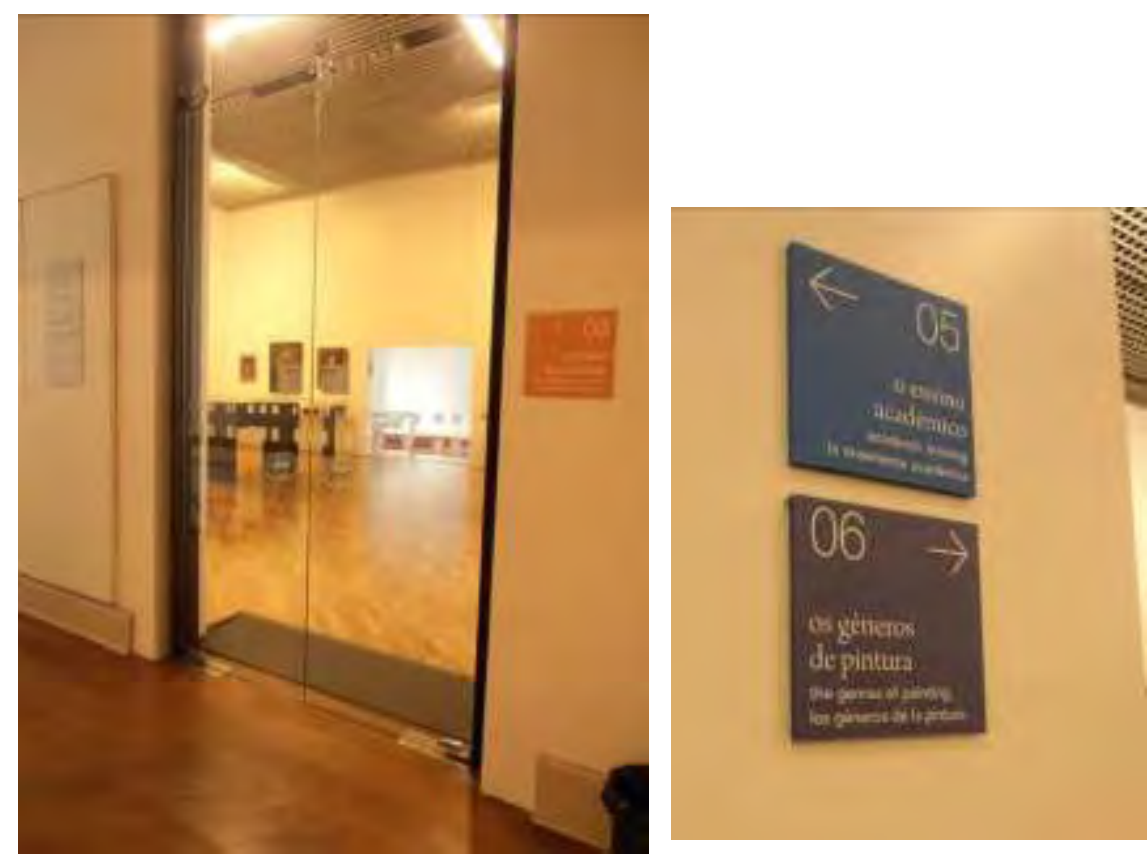

Figura 341 e 342 - Sinalização das salas. 2011.

Não há na sinalização ambiental, correspondente em braile ou relevo, com exceção da área da Galeria Tátil, que tem o mapa tátil e o piso tátil direcional. Salas de exposições, sanitários e lanchonete, por exemplo, não têm sinalização em braile que os identifiquem ${ }^{360}$. Também não há braile nos corrimãos identificando os andares $^{361}$ nem faixa contrastante nos degraus das escadas ${ }^{362}$.

Próxima à porta dos elevadores, há sinalização indicativa dos principais serviços e ambientes em cada um dos andares, facilitando a orientação e a definição por rotas.

\footnotetext{
${ }^{360}$ Não atende ao disposto na ABNT NBR 9050/2004 - item 5.10.

${ }^{361}$ Não atende ao disposto na ABNT NBR 9050/2004 - item 5.15.1.2.

${ }^{362}$ Não atende ao disposto na ABNT NBR 9050/2004 - item 5.13.
} 
Somente o Elevador 2 possui piso tátil de alerta, e apenas na saída no $2^{ }$andar, onde interliga com 0 piso tátil direcional que percorre a Galeria Tátil de Esculturas Brasileiras. Não há piso tátil de alerta nesse elevador nos outros andares; e o Elevador 1 não tem piso tátil de alerta

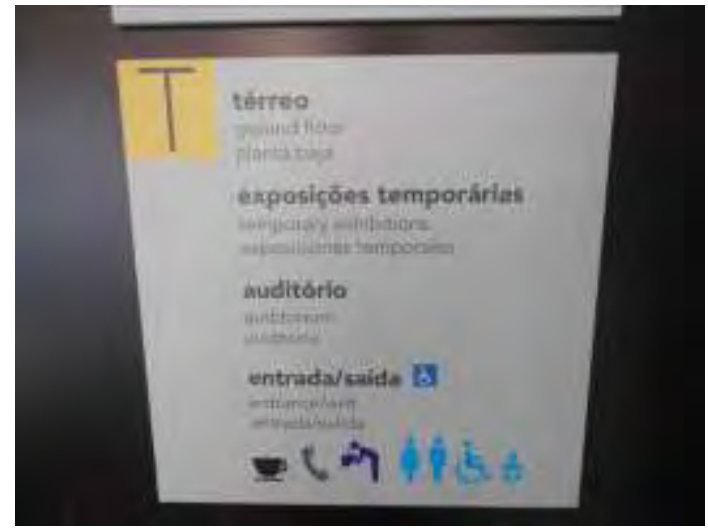

Figura 343 - Sinalização dos pontos de interesse em cada andar. 2011. em nenhum dos três andares ${ }^{363}$.

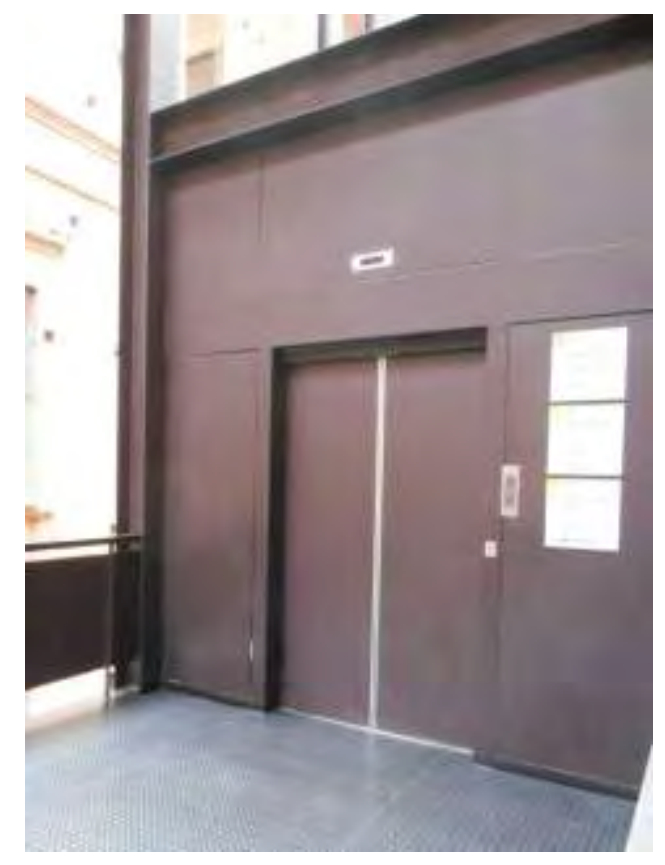

Figura 344 - Elevador sem piso tátil de alerta. 2011.

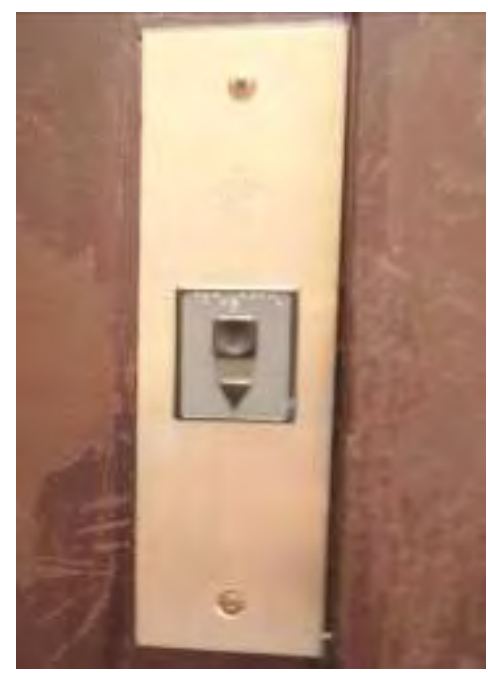

Figura 345 - Botoeira de piso com indicação em braile e relevo. 2011.

Há braile nas botoeiras de chamada de piso e do painel interno, para os andares, chamadas de emergência e operação. Indica de forma visual e sonora o pavimento de parada, assim como quando um andar é acionado ${ }^{364}$. Indica sonoramente quando as portas abrem.

\footnotetext{
${ }^{363}$ Não atende ao disposto na ABNT NBR 9050/2004 - item 5.14.1.2.

${ }^{364}$ Atende ao disposto na ABNT NBR NM 313/2007 - item 5.4.3 e 5.4.4.
} 


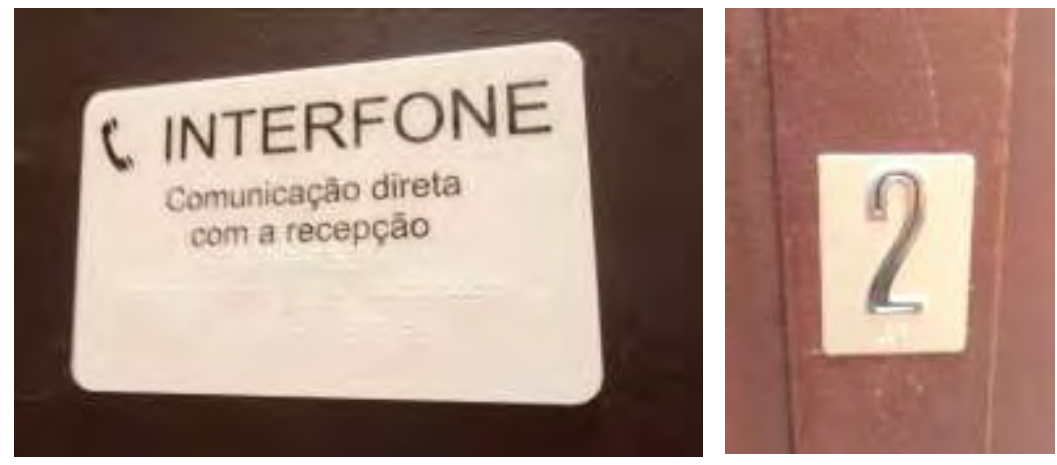

Figura 346 e 347 - Sinalização do Elevador 2 em fonte ampliada e braile. 2011.

Somente no $2^{\circ}$ andar há, em algumas situações, sinalização com piso tátil de alerta nas situações de risco, porém, não em todas as necessárias. Nos outros andares não há pisos táteis de alerta em degraus, elevadores e em barreiras suspensas, como extintores e telefones ${ }^{365}$. Alguns extintores estão posicionados no piso ou em nichos, o que evita que causem riscos de choque.

Figura 348 - Ausência de sinalização tátil de alerta. 2011.

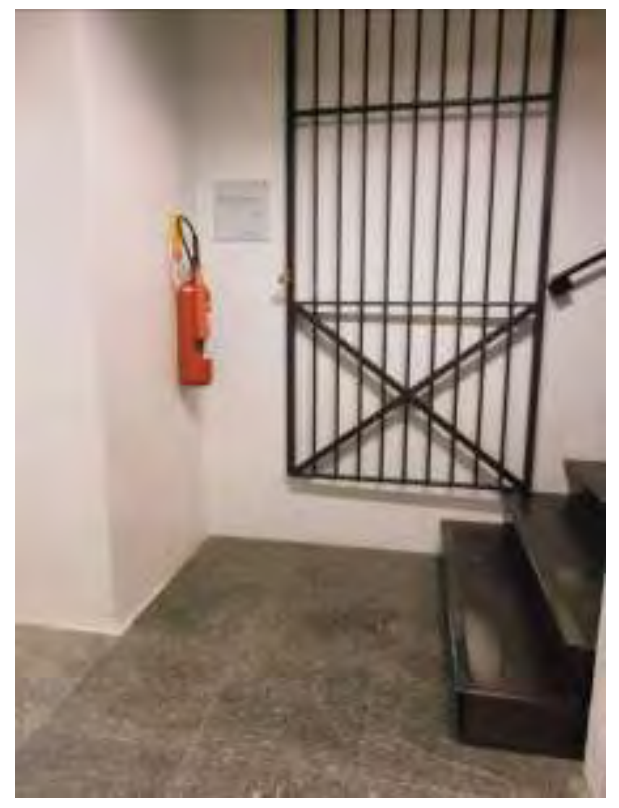

${ }^{365}$ Não atende ao disposto na ABNT NBR 9050/2004 - item 5.14.1.2. 

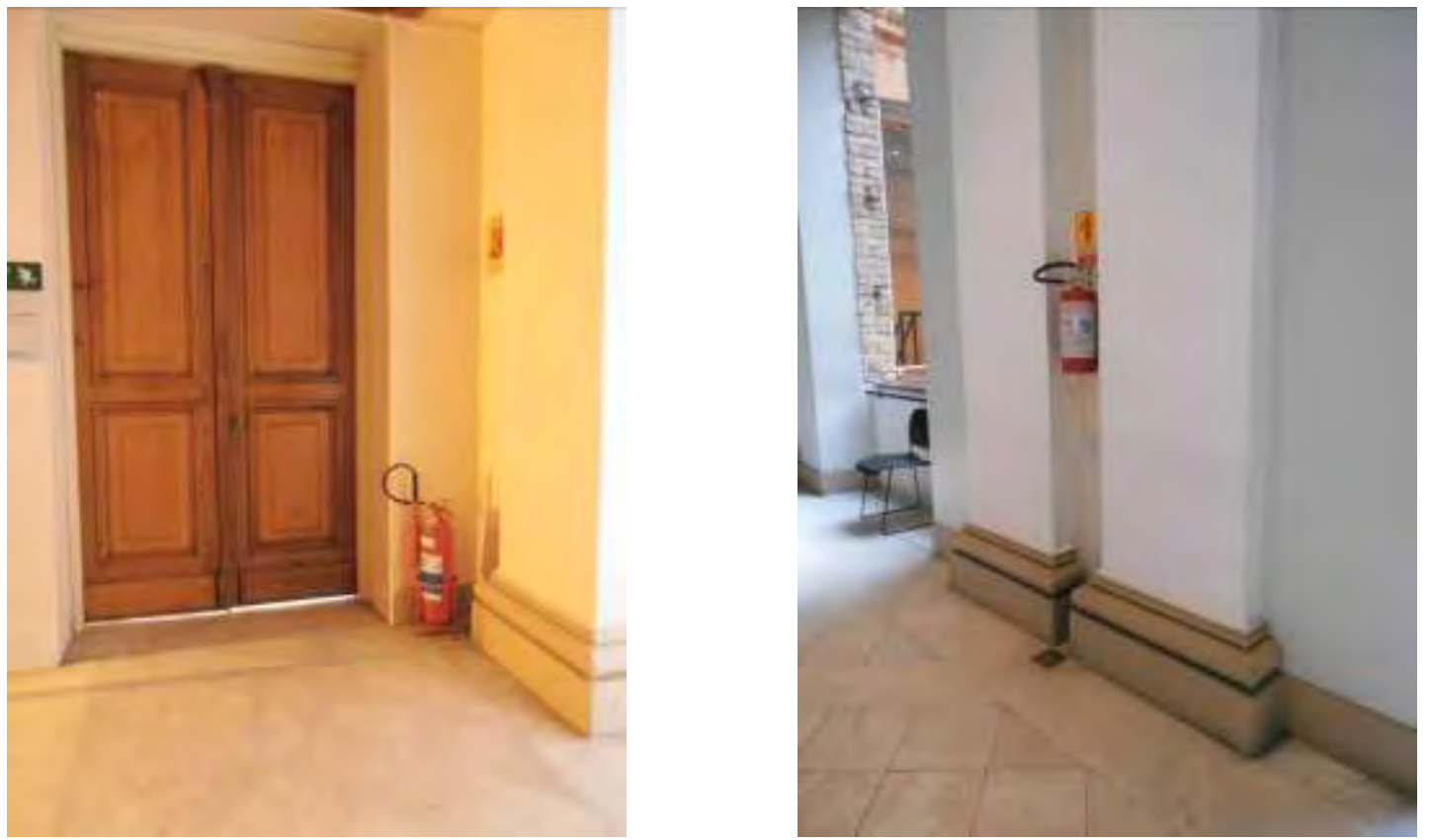

Figura 349 e 350 - Extintores que não precisam de sinalização. 2011.

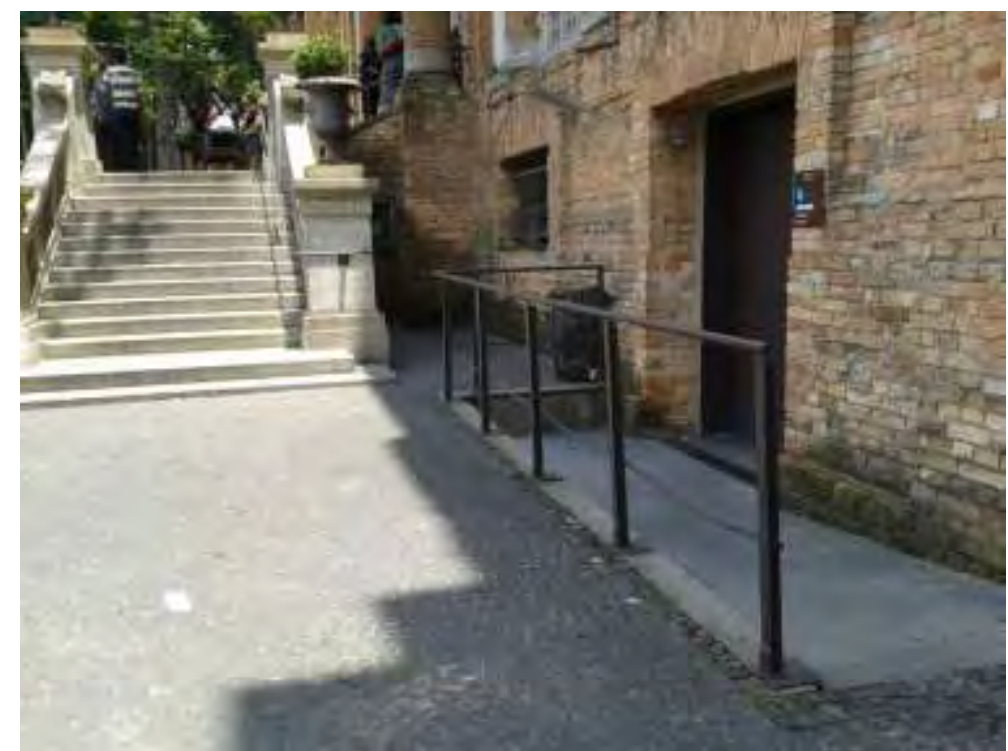

Figura 351 - Ausência de piso tátil de alerta na rampa e na escada e de faixa contrastante nos degraus. 2011. 


\subsection{Análise com base no Desenho Universal}

Os quadros a seguir demonstram a necessidade de melhora em todos os princípios do Desenho Universal.

\begin{tabular}{|c|c|c|}
\hline $\begin{array}{l}\text { PRINCÍPIO 1: } \\
\text { Uso equitativo }\end{array}$ & \multicolumn{2}{|l|}{ É útil e utilizável por pessoas com habilidades diversas } \\
\hline \multirow[t]{2}{*}{$1 a$} & $\begin{array}{l}\text { Fornece os mesmos meios de utilização para todos os } \\
\text { usuários: idêntico - quando possível -, ou equivalente. }\end{array}$ & $\mathbf{x}$ \\
\hline & \multicolumn{2}{|c|}{$\begin{array}{l}\text { Exige que usuários que não podem fazer uso da escada percorram } \\
120 m \text { a mais que os demais, para chegar ao ponto de início do museu. }\end{array}$} \\
\hline \multirow[t]{2}{*}{$1 \mathrm{~b}$} & Não segrega ou estigmatiza qualquer usuário. & $x$ \\
\hline & \multicolumn{2}{|l|}{ Entradas separadas. } \\
\hline \multirow[t]{2}{*}{ 1c } & $\begin{array}{l}\text { Elementos relacionados à privacidade, proteção e } \\
\text { segurança estão igualmente disponíveis para todos os } \\
\text { usuários. }\end{array}$ & $\mathbf{x}$ \\
\hline & \multicolumn{2}{|c|}{$\begin{array}{l}\text { Não há equipamentos para a retirada de usuários com deficiência em } \\
\text { casos de emergência. }\end{array}$} \\
\hline 1d & Tem design atraente para todos os usuários. & $\sqrt{ }$ \\
\hline \multicolumn{3}{|c|}{ Espaços amplos e iluminados facilitam o deslocamento. } \\
\hline
\end{tabular}

\begin{tabular}{|r|l|c|}
\hline $\begin{array}{l}\text { PRINCÍPIO 2: } \\
\text { Uso flexível }\end{array}$ & $\begin{array}{l}\text { Acomoda uma ampla variedade de preferências individuais e } \\
\text { habilidades }\end{array}$ & $\sqrt{ }$ \\
\hline 2a & Proporciona escolha dos métodos de utilização. & $\sqrt{ }$ \\
\hline 2b & Permite uso e acesso por pessoas canhotas ou destras. & Xá recursos sensoriais e visitas guiadas. \\
\hline & Não há elementos que prejudiquem. & Facilita a exatidão e precisão do usuário. \\
\hline 2c & $\begin{array}{l}\text { Rampas muito inclinadas e escadas sem corrimão adequado dificultam } \\
\text { a precisão. }\end{array}$ \\
\hline 2d & É adaptável ao ritmo do usuário. \\
& $\begin{array}{l}\text { O espaço pode ser percorrido no tempo necessário e há bancos de } \\
\text { descanso. }\end{array}$ \\
\hline
\end{tabular}




\begin{tabular}{|c|c|c|}
\hline $\begin{array}{l}\text { PRINCÍPIO 3: } \\
\text { Uso simples e } \\
\text { intuitivo }\end{array}$ & \multicolumn{2}{|c|}{$\begin{array}{l}\text { O uso é fácil de compreender, independente da experiência do } \\
\text { usuário, seus conhecimentos, habilidades de linguagem ou nível } \\
\text { de concentração }\end{array}$} \\
\hline \multirow[t]{2}{*}{$3 \mathbf{a}$} & Elimina a complexidade desnecessária. & $\mathbf{X}$ \\
\hline & \multicolumn{2}{|l|}{$\begin{array}{l}\text { Pode ser difícil se orientar no espaço pela similaridade de seus } \\
\text { corredores. }\end{array}$} \\
\hline \multirow[t]{2}{*}{$3 b$} & É coerente com as expectativas do usuário e intuição. & $\mathbf{X}$ \\
\hline & \multicolumn{2}{|c|}{$\begin{array}{l}\text { Orientação por planta (folheto disponível na entrada) pode ser de difícil } \\
\text { compreensão para a maioria das pessoas. }\end{array}$} \\
\hline \multirow[t]{2}{*}{$3 c$} & $\begin{array}{l}\text { Atende a uma gama variada de níveis de alfabetização e } \\
\text { de aprendizado de idiomas. }\end{array}$ & $\sqrt{ }$ \\
\hline & \multicolumn{2}{|c|}{$\begin{array}{l}\text { Sinalização com pictogramas, três idiomas e cores de identificação de } \\
\text { salas. }\end{array}$} \\
\hline \multirow[t]{2}{*}{ 3d } & Hierarquiza a informação de acordo com a importância. & $\sqrt{ }$ \\
\hline & Identifica os pontos principais de visitação. & \\
\hline \multirow[t]{2}{*}{$3 e$} & $\begin{array}{l}\text { Fornece alerta ou retorno eficaz durante e após a } \\
\text { conclusão da tarefa. }\end{array}$ & $\sqrt{ }$ \\
\hline & O elevador emite os alertas necessários. & \\
\hline
\end{tabular}

\begin{tabular}{|c|c|c|}
\hline $\begin{array}{l}\text { PRINCÍPIO 4: } \\
\text { Informação } \\
\text { fácil e } \\
\text { perceptível }\end{array}$ & $\begin{array}{l}\text { Comunica eficazmente a informação necessária ao usu } \\
\text { independentemente das condições do ambiente ou de s } \\
\text { habilidades sensoriais }\end{array}$ & \\
\hline $4 a$ & $\begin{array}{l}\text { Usa diferentes modos de comunicação (visual, sonora, } \\
\text { tátil) para apresentar a informação essencial. }\end{array}$ & $\mathbf{X}$ \\
\hline & Ambientes não têm sinalização tátil. & \\
\hline 4b & $\begin{array}{l}\text { Proporciona contraste adequado entre as informações } \\
\text { essenciais e seu entorno. }\end{array}$ & $\sqrt{ }$ \\
\hline & Bom contraste na sinalização ambiental. & \\
\hline $4 c$ & Maximiza a legibilidade da informação essencial. & $\mathrm{X}$ \\
\hline & Uso de fontes pequenas para a sinalização direcional. & \\
\hline 4d & $\begin{array}{l}\text { Oferece compatibilidade com uma variedade de técnicas } \\
\text { ou dispositivos utilizados por pessoas com limitações } \\
\text { sensoriais. }\end{array}$ & $\mathbf{X}$ \\
\hline & Apenas à uma parte do acervo. & \\
\hline
\end{tabular}




\begin{tabular}{|c|c|c|}
\hline $\begin{array}{l}\text { PRINCÍPIO 5: } \\
\text { Tolerância ao } \\
\text { erro }\end{array}$ & $\begin{array}{l}\text { Minimiza perigos e consequências adversas de ações } \\
\text { involuntárias ou imprevistas }\end{array}$ & \\
\hline $5 a$ & $\begin{array}{l}\text { Organiza os elementos para minimizar riscos e erros: os } \\
\text { elementos mais utilizados ficam mais acessíveis; os } \\
\text { elementos perigosos são eliminados, isolados ou } \\
\text { protegidos. }\end{array}$ & $\mathbf{X}$ \\
\hline & Elementos suspensos não estão sinalizados com piso tátil & \\
\hline $5 b$ & Fornece alertas de perigos e erros. & $\mathbf{x}$ \\
\hline & Situações de risco não são sinalizadas com piso tátil de ale & \\
\hline $5 c$ & Fornece recursos à prova de falhas. & $\mathrm{X}$ \\
\hline & $\begin{array}{l}\text { Interrupção do corrimão antes do fim da escada pode ocas } \\
\text { acidentes. }\end{array}$ & \\
\hline $5 d$ & $\begin{array}{l}\text { Desencoraja ações inconscientes em tarefas que } \\
\text { requerem vigilância. }\end{array}$ & $\mathbf{X}$ \\
\hline & Rampas muito inclinadas. & \\
\hline
\end{tabular}

\begin{tabular}{|c|c|c|}
\hline $\begin{array}{l}\text { PRINCíPIO 6: } \\
\text { Baixo esforço } \\
\text { físico }\end{array}$ & \multicolumn{2}{|l|}{$\begin{array}{l}\text { Pode ser usado eficientemente, confortavelmente e com um } \\
\text { mínimo de fadiga. }\end{array}$} \\
\hline $6 a$ & Permite ao usuário manter uma posição corporal neutra. & $\mathbf{X}$ \\
\hline & Rampas muito inclinadas. & \\
\hline \multirow[t]{2}{*}{$6 b$} & Exige razoável força de operação. & $\mathbf{X}$ \\
\hline & Rampas muito inclinadas, piso irregular na entrada e portas & das. \\
\hline \multirow[t]{2}{*}{$6 c$} & Minimiza ações repetitivas. & $\sqrt{ }$ \\
\hline & Não exige ações repetitivas. & \\
\hline \multirow[t]{2}{*}{$6 d$} & Minimiza o esforço físico contínuo & $\sqrt{ }$ \\
\hline & Há bancos de descanso nas salas expositivas. & \\
\hline \multirow[t]{2}{*}{$6 e$} & $\begin{array}{l}\text { Permite o uso com apenas uma das mãos e sem } \\
\text { necessitar de habilidade. }\end{array}$ & $\mathbf{X}$ \\
\hline & $\begin{array}{l}\text { Percorrer piso irregular da entrada e vencer desnível da cal } \\
\text { habilidade para manobrar a cadeira de rodas. }\end{array}$ & exige \\
\hline
\end{tabular}




\begin{tabular}{|c|c|c|}
\hline $\begin{array}{l}\text { PRINCÍPIO 7: } \\
\text { Dimensão e } \\
\text { espaço para } \\
\text { aproximação e } \\
\text { uso }\end{array}$ & $\begin{array}{l}\text { Tamanho e espaço apropriado para aproximação, alca } \\
\text { manipulação e uso, independentemente do tamanho, } \\
\text { mobilidade do usuário. }\end{array}$ & \\
\hline $7 a$ & $\begin{array}{l}\text { Fornece uma linha clara de visão dos elementos } \\
\text { importantes para qualquer usuário, sentado ou em pé. }\end{array}$ & $\sqrt{ }$ \\
\hline & Elementos expostos têm bom alcance visual. & \\
\hline $7 b$ & $\begin{array}{l}\text { Alcance confortável a todos os componentes para } \\
\text { pessoas sentadas ou em pé. }\end{array}$ & $\mathbf{X}$ \\
\hline & Dificuldades no uso de bebedouros e balcões. & \\
\hline 7d & $\begin{array}{l}\text { Proporciona espaço adequado para o uso de espaços e } \\
\text { dispositivos de apoio ou de ajuda pessoal. }\end{array}$ & $\mathbf{X}$ \\
\hline & Sanitários pequenos sem acesso independente e portas & \\
\hline
\end{tabular}

\subsection{0. Ótica do usuário}

A seguir são apresentadas as principais considerações de algumas pessoas com deficiência, sobre o local visitado, registradas utilizando-se a técnica de grupo focal.

\subsubsection{Pessoa usuária de cadeira de rodas (PCR)}

Desde a entrada relatou ter tido bastante facilidade, nesta que foi a sua primeira visita à Pinacoteca. Foi de carro ao local, e após estacionar, rapidamente um funcionário da equipe de segurança foi ajudá-lo.

Utilizou a entrada lateral, como denominou, e achou os espaços bem organizados para a pessoa em cadeira de rodas. Gostou que o elevador fosse grande e com apoio nas laterais. Relatou ainda que, durante a visita, a cada 10 metros alguma pessoa oferecia ajuda, segundo suas palavras. 
Perguntado se teve problemas na circulação do piso externo trepidante, informou que para ele não apresentava dificuldade, pois em situações como essa empinava a cadeira para amenizar a trepidação. No entanto, ressalto que essa necessidade de adaptação do usuário ao ambiente, e não o contrário, não é adequado. Ele mesmo relatou que por ser jovem e ter força consegue tem maior facilidade nas adversidades.

Não considerou um problema fazer uma entrada distinta dos demais visitantes. E finalizou dizendo que, entre os três locais visitados, a Pinacoteca seria um local que recomendaria a visita.

\subsubsection{Pessoa idosa (PI)}

A pessoa idosa relatou bastante dificuldade e complicação no seu acesso. Viu as escadas no acesso e informou ao segurança que pretendia conhecer a Pinacoteca e queria acessibilidade. Pelo rádio o funcionário falou com outro segurança, o que a deixou constrangida, como se fosse suspeita. Foi orientada a ir pela entrada de trás, da qual ela não foi informada, mas trata-se da entrada de funcionários.

Precisou fazer um longo percurso no sol até a entrada, e precisou se identificar, com RG, ter sua imagem registrada no computador e guardar a sacola que carregava. A pessoa que veio recebê-la informou que seria mais adequado guardar suas coisas para não carregar peso. Essa pessoa mostrou a entrada com rampa, que ela percebeu ser junto à entrada das escadas e que poderia ter entrado por ali.

Disse que o funcionário da segurança deveria ter questionado se ela tinha 
dificuldade para subir as escadas e, em caso positivo, orientar para a entrada da rampa. Achou que a sinalização com o SIA utilizada na entrada acessível, que traz o desenho da cadeira de rodas, não facilita a orientação de que idosos e gestantes, por exemplo, também podem usar essa entrada.

Depois que entrou encontrou um espaço que considerou acessível, e destacou os corrimãos no grande elevador. Por fim, disse que os funcionários precisam ser capacitados para ajudar o cadeirante, o idoso, o surdo etc.

\subsubsection{Pessoa com deficiência visual (PDV)}

O visitante PDV teve dificuldades para chegar ao local, ao ser conduzido por um funcionário-aprendiz do Metrô que não conhecia a Pinacoteca e a saída mais adequada. O funcionário iria deixá-lo no saguão central da estação, quando o próprio visitante questionou quanto a sua localização e o local onde ele pretendia deixá-lo. Na estação da Luz existe uma saída em frente à Pinacoteca, e desde o seu interior há orientação visual para esta saída denominada 'Pinacoteca', no entanto o funcionário conhecia o prédio apenas como 'museu', conforme relato do visitante.

Foi a segunda vez que esteve na Pinacoteca, e percebeu que houve avanço na acessibilidade em relação à sua primeira visita. Desde a entrada foi oferecido por um funcionário da Pinacoteca o audioguia para uso na Galeria Tátil de Esculturas Brasileiras. No início do roteiro, percebeu que o aparelho estava com problemas na execução das faixas. No entanto, antes de receber o aparelho o funcionário informou que havia testado e que estava em ordem, o que fez com que o visitante considerasse uma falha de atendimento. Na saída recebeu dois materiais em braile e relevo para levar para casa: um informativo sobre a história da 
Pinacoteca e da Galeria Tátil e outro sobre as obras da Galeria Tátil, inclusive com contorno em relevo das esculturas. O visitante alertou que esse material deveria ser entregue no começo, pois inicia dizendo "seja bem-vindo à Galeria Tátil" e termina com um "vamos lá?", o que deixa claro ter sido elaborado para ser material de apoio à visita e não posterior. No entanto, acredita que esse material é dispensável durante a visita, por conta do audioguia e da acessibilidade no local.

O visitante PDV notou que a Galeria Tátil foi pensada para todos: para pessoas em cadeira de rodas, anões, cegos, idosos, etc. Disse ainda que, na Pinacoteca a acessibilidade se limita ao segundo piso, e qualquer outro espaço que a pessoa cega for visitar tem que ir com alguém.

\subsubsection{Pessoa com deficiência auditiva (PS)}

Para a pessoa surda (PS) a dificuldade não foi no acesso físico, mas no acesso à informação. Como não sabia onde era a bilheteria, perguntou ao segurança que não soube se comunicar com ela. Na bilheteria tentou fazer mímica e gesto, para facilitar para a pessoa entender, já que esta não sabia língua de sinais e teve que recorrer ao seu acompanhante para comprar o ingresso. Neste momento descobriu que pessoas com deficiência não precisam pagar a entrada para a visitação.

Dentro da Pinacoteca tentou se orientar no espaço e procurou algo que mostrasse o que era para que lado. Considerou a comunicação visual terrível. O sistema de informação utilizado com apoio de mapa foi muito difícil de entender e ficou perdida.

Algumas pessoas dentro da Pinacoteca conseguiram passar as 
informações solicitadas. Por exemplo, perguntou a um segurança onde era a cafeteria, em língua de sinais e gestos. Ele respondeu com mímica e indicou com precisão como chegar sem precisar descer com ela.

No entanto, ela relata que na cafeteria teve um péssimo atendimento. Por mais que se esforçasse, utilizando mímica, ninguém a entendia lá. Foi necessário pegar o cardápio para mostrar o que queria. Na hora de pagar a conta, a atendente falou com a visitante sem que ela tivesse como entender. A atendente mostrou 0 visor do caixa com um valor mais alto e outro mais baixo, e então apontou novamente para o mais alto. Sem entender o porquê dos dois valores pagou, então, o mais alto. Depois o acompanhante explicou a ela que a diferença entre os dois valores, mostrado pela atendente, era relativa à taxa de serviço. Como não entendeu, pagou a taxa de serviço, a qual não queria pagar.

Por ser formada em artes, teve facilidade para contextualizar o que estava exposto, mesmo sem ter tanta informação. Ela explica que, normalmente as obras têm um texto em português, e que o entendimento pode ficar prejudicado, considerando que os surdos têm a língua de sinais como primeira língua e nem sempre boa compreensão da língua portuguesa. Deveria ter um vídeo em língua de sinais ou alguém que soubesse Libras; algo para garantir a comunicação.

Considerou a Pinacoteca um espaço visualmente mais bem disposto, para o surdo, pois a estrutura, a arquitetura, o desenho são mais interessantes. E entre os três locais visitados, preferiu a Pinacoteca, apesar de todos os problemas.

Concluiu que, durante a visita, tentou se fazer entender pelas pessoas, mas que deveria ser o contrário. 


\subsection{Análise da relação entre preservação e acessibilidade}

A reforma de 1998 garantiu um dos principais elementos para garantir o deslocamento vertical de pessoas com deficiência e mobilidade reduzida. Esse momento de grande transformação do edifício trouxe, além dos elevadores, os sanitários e as rampas na entrada.

Não cabe aqui listar todas as adições, supressões e sobreposições feitas ao longo da vida do edifício, em relação à estrutura existente hoje, mas sim aquelas que deram base para a condição de acessibilidade atual.

\subsection{1. $\quad$ Adições}

Neste ponto podemos destacar os elevadores e passarelas. Essas adições permitiram o deslocamento entre os andares e a redução de percursos, uma vez que é possível atravessar de uma área para a outra de forma mais direta. As passarelas facilitam também a visualização dos espaços, o que melhora a compreensão e a definição do deslocamento a ser feito.

O acréscimo do elevador e das passarelas nos pátios retangulares só foi possível com a colocação de cobertura, protegendo assim, essas áreas das intempéries. Antes, apenas o pátio octogonal era coberto.

Esses acréscimos foram e são vitais para garantir a acessibilidade da Pinacoteca, apesar de não terem sido feitos pensando exclusivamente nisso. 0 objetivo era melhorar a circulação de visitantes e o transporte de obras. 

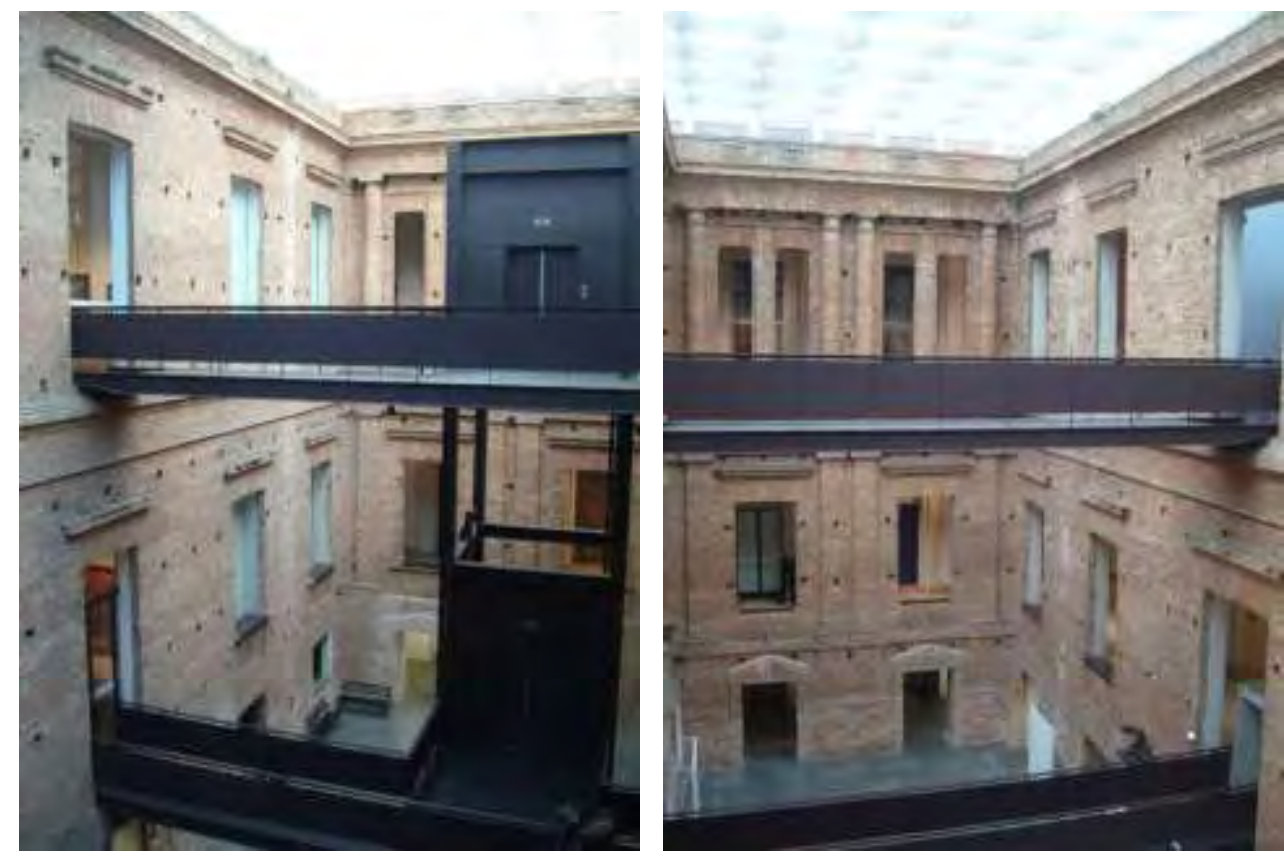

Figura 352 e 353 - Novos elementos: elevador, passarelas e cobertura. 2009.

Os corrimãos, nas quatro escadas internas, foram acrescidos provavelmente também na reforma de 1998. Importantes para o deslocamento seguro, os corrimãos apresentam problemas, que devem ser corrigidos para garantir a acessibilidade plena. A escada de entrada também recebeu corrimão de um dos lados, porém essa adição foi mais recente ${ }^{366}$.

Os sanitários próximos ao pátio octogonal existiam anteriormente à reforma. O vestiário de funcionários e os conjuntos próximos à fachada da Av. Tiradentes, ambos no térreo, são posteriores. Justamente esses não possuem nenhuma bacia acessível. Mesmo assim, os boxes acessíveis nos demais conjuntos são apenas $0,10 \mathrm{~m}$ mais largos e a bacia sanitária é a mesma, e não alteada como deveria ser. De acréscimos é possível citar as barras.

\footnotetext{
${ }^{366}$ Lopes em sua tese de doutorado mostra que essa escada não tinha ainda corrimão em 2005.
} 


\subsubsection{Supressões}

Todas as janelas da fachada foram retiradas e substituídas por outras, ou por um vedo escuro, ou por um pano único de vidro, nos ambientes que havia a necessidade de iluminação. Segundo, o arquiteto Paulo Mendes da Rocha, a tectônica de um edifício como o da Pinacoteca está nas formas e molduras de suas aberturas e deixá-las aparentemente vazadas é a melhor solução ${ }^{367}$. Isso beneficiou o isolamento externo das salas de exposição para uma melhor climatização do ambiente.

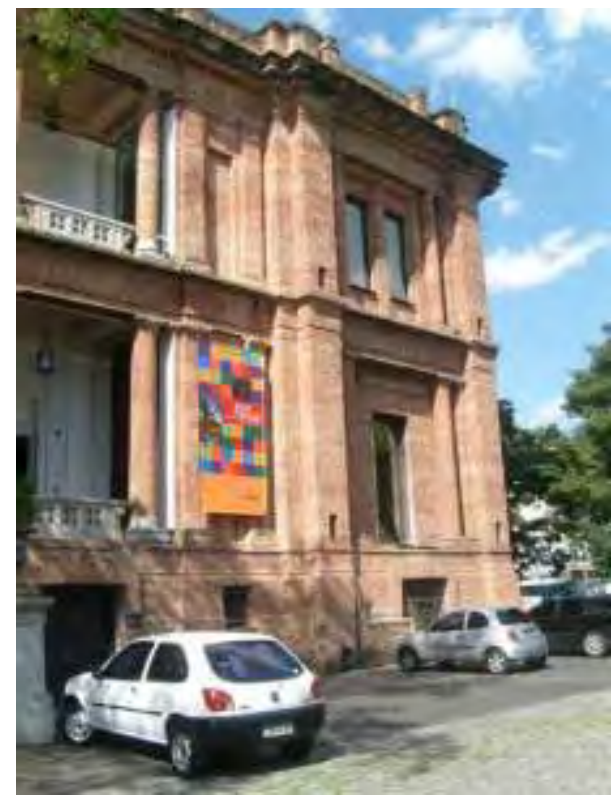

Figura 354 - Supressão das janelas. 2011.

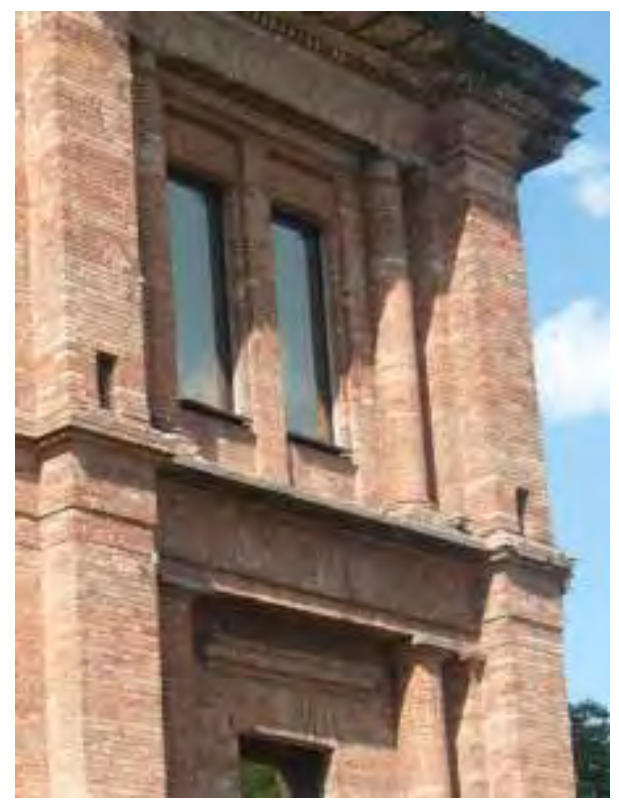

Figura 355 - Detalhe das janelas. 2011.

Dentro deste contexto, duas janelas do térreo, na fachada da nova entrada, foram também eliminadas para criar as portas de acesso da entrada acessível. Consequentemente, foi necessária a supressão de parte da alvenaria (peitoril) e do piso externo em frente à nova porta de acesso, e a criação da rampa, pois o piso interno, no térreo, tem uma diferença de $0,30 \mathrm{~m}$ de desnível em relação ao externo.

${ }^{367}$ RESGATE Histórico. Finestra Brasil, São Paulo, v.7, n.25, p.16-18, abr./jun, 2001. 
Com a colocação das coberturas nos pátios retangulares, as janelas voltadas para eles perderam a razão e também foram suprimidas. Esses vãos abertos a essa nova circulação, permitem identificar mais facilmente rotas, o que também contribui para a acessibilidade.

Houve a supressão também dos parapeitos das janelas que são hoje 0 acesso às passarelas.

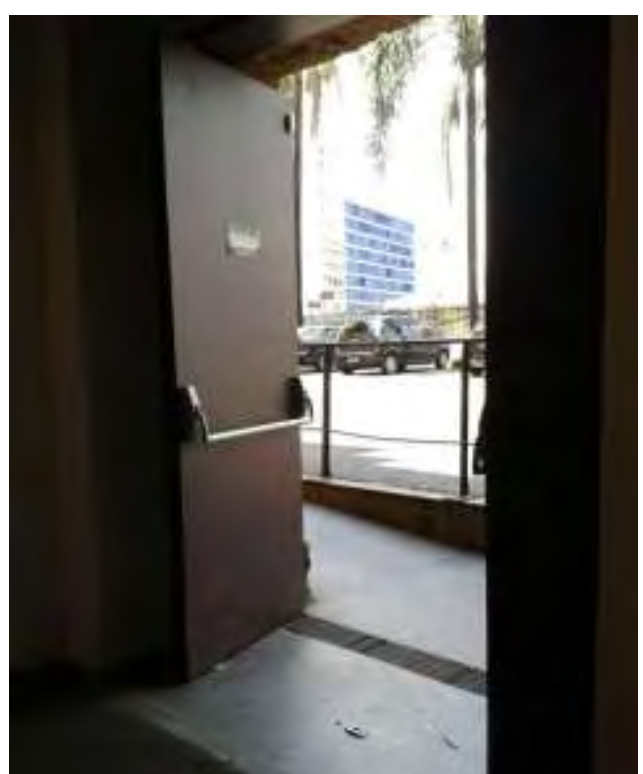

Figura 356 - Local de supressão de uma janela. 2011.

Nas salas expositivas as portas

originais foram retiradas na nova reforma. Outras já haviam sido modificadas durante o período que a Faculdade Belas Artes coabitava o edifício. Novas portas procuram melhorar o isolamento térmico da sala, ao mesmo tempo em que facilitam a visualização interna, convidando a entrar. O que poderia ter sido um momento para a melhora da acessibilidade resultou na manutenção do problema.

\subsubsection{Sobreposições}

Em 2011, foram retirados os pisos acarpetados, das salas de exposições do $2^{\circ}$ andar. Segundo o arquiteto Flávio Pires, responsável pela manutenção do edifício, a retirada do carpete teve dois motivadores: péssimo estado de conservação após muitos anos de uso e propagação de ruído de passos nas salas de exposições localizada no andar inferior. Esses problemas foram resolvidos com a retirada do carpete e sobreposição do piso original por piso laminado, criando um 
desnível em relação à circulação. Para garantir o acesso, rampas metálicas foram colocadas em todos os acessos, inclusive nas saídas para as varandas.

No auditório, também são rampas metálicas sobrepostas ao piso do palco que garantem a rota acessível, entre este e a circulação externa. No entanto, como o auditório não é original, assim como o palco, neste caso não se caracteriza como um elemento novo sobreposto à estrutura existente, dentro do que foi proposto aqui para esta análise.

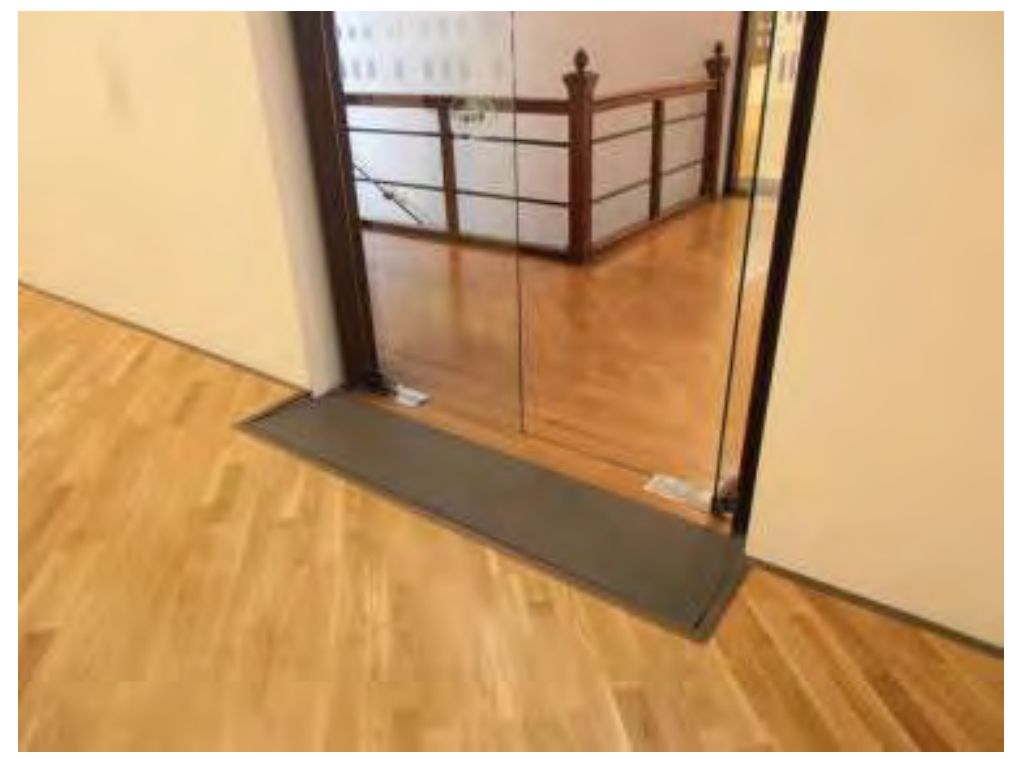

Figura 357 - Piso de madeira e rampa metálica, sobrepostos ao piso original. 2011.

\subsection{Conclusões e recomendações de adequação}

A mudança do eixo de circulação do edifício, definição primordial do projeto do Arq. Paulo Mendes da Rocha e equipe, apesar das críticas por mexer de forma tão marcante em como o edifício é percorrido e visto, tornou-se uma mudança relevante para a acessibilidade presente no edifício, permitindo menores deslocamentos.

Estes elementos, por ser facilmente distinguíveis da estrutura original, respeitam as premissas, analisadas e descritas no Capítulo 1, de intervenção em 
bens culturais imóveis. Claro, que o elevador poderia ter sido posicionado no pátio de forma a não serem necessárias as passarelas, com sua saída diretamente no pavimento. No entanto, a análise das decisões projetuais do autor não é o foco desta dissertação.

Sem as passarelas não haveria a possibilidade de gozar de visuais e transições que hoje o edifício dispõe e permitem melhor leitura do próprio, que ainda assim, detém suas dificuldades por conta da simetria e repetições dos espaços, que tornam o reconhecimento e a orientação uma atividade exigente ao visitante. Problema que pode ser resolvido com a melhora da sinalização ambiental.

Em essência, as mudanças não vieram em razão da acessibilidade, mas a acessibilidade vem em consequência das mudanças, associadas a adequações pontuais especificas, como a rampa no acesso e o banheiro, que porventura apresentam problemas. Ou seja, os pontos feitos a propósito não atendem adequadamente as necessidades atuais. E lembremos que a acessibilidade não é estável e depende de constante avaliação e revisão, antes que se diga que o momento em que foram feitos justifica-se suas inadequações. Explica, contudo, não justifica a permanência dessa condição.

O fato é que houve alguma preocupação com a acessibilidade na época da reforma. Provavelmente por imposição legal, pois é do ano de 1993 a lei municipal n 11.345 que, integra a ABNT 9050 ao Código de Obras e Edificação do Município de São Paulo e exige adequações à acessibilidade nos locais de reunião para mais de 100 pessoas. O próprio Código de Obras, Lei municipal $\mathrm{n}^{\circ}$ 11.228/1992, já exigia como parâmetro de desempenho da edificação que fossem asseguradas "[...] condições de acesso, circulação e uso por pessoas idosas ou portadoras de deficiências [...]". 
Mas não foram necessariamente feitas a contento, mesmo, em relação às leis e normas à época. Uma hipótese é que algumas incorreções advêm de desconhecimento de normas, ou de descaso com a precisão dos parâmetros, imaginando, por exemplo, que qualquer rampa é suficiente. Na verdade não é possível determinar a raiz do problema, pois não foi possível ter acesso, a tempo desta dissertação, aos projetos de reforma, para uma análise mais veraz.

Pode e deve haver evolução na acessibilidade física e comunicacional da Pinacoteca, dentro do que foi analisado no item 4.9, sem, contudo, que isso seja invasivo ao edifício. A seguir, destaco alguns pontos.

Do passeio, precisam melhorar o tipo de piso e o desnível existente para o acesso de veículos. Essa interrupção da calçada não se justifica de forma alguma e prejudica o acesso. O tipo de piso externo também deve ser repensado, criando no mínimo, uma faixa de circulação de $0,90 \mathrm{~m}$ em piso plano, estável e regular, do portão até os acessos. A interligação com o Parque da Luz deve ser garantida sem desníveis e em piso adequado. O próprio Parque da Luz precisa melhorar e muito os deslocamentos, com regularização do piso.

Para melhorar a condição de circulação de pessoas com deficiência visual é possível dispor de pisos táteis colados, em placas ou em relevos, assim como as placas utilizadas no $2^{\circ}$ andar, para identificar as demais situações de risco, e garantir o deslocamento seguro, associados à sinalização dos ambientes, adequada a esse público. No acesso, no novo percurso, proposto em piso regular, será possível identificar rota em contraste com o piso trepidante. Mas, mais adequado será aproveitar-se deste momento de alteração e instalar piso tátil direcional do portão à entrada, assim como piso tátil de alerta no início da escada, que sem a trepidação do piso atual, poderá ser percebido. 
A instalação de corrimão em altura correta e que chegue até o piso do andar se torna essencial para todos, uma vez que essas escadas estão integradas à circulação regular de visitantes e funcionários, ademais, por serem utilizadas como rotas de fuga. Como há rota acessível garantida por elevador poderíamos imaginar que as escadas estão dispensadas de qualquer adequação. Todavia, uma vez que elas já dispõem de corrimão contemporâneo, a troca por outro, com mesmo desenho e algumas correções necessárias, não causa qualquer trauma à preservação do edifício. E sendo as escadas espelhadas, ter pelo menos o corrimão junto à parede garantindo apoio adequado será suficiente, dentro do contexto da preservação. Pois, quem precisar utilizar o apoio do lado do corrimão original poderá se direcionar para a escada na fachada oposta e utilizar esta circulação.

É quase indispensável dizer que os sanitários considerados acessíveis estão muito aquém das condições adequadas para garantir o uso com conforto, privacidade, segurança e esforço razoável. Os boxes sanitários podem ser corrigidos, no entanto ainda assim faltaria sanitário acessível com entrada independente do coletivo, para as pessoas que necessitam de apoio de acompanhante. Para isso, deve-se estudar os espaços e as condições técnicas para encontrar esse local necessário. E no vestiário de funcionários, adequar pelo menos um conjunto de peças dentro da características normatizadas.

O auditório, além dos pormenores, como corrimãos, sinalização de palco e degraus, também pode melhorar a condição de distribuição e sinalização dos espaços para cadeiras de rodas, na fileira do fundo, utilizando longarinas com menor quantidade de assentos, para dispor os quatro espaços reservados com acompanhante, quantidade mínima exigida. E, claro, substituir alguns assentos por outros mais adequados às pessoas obesas. 
Quanto às portas novas que tem folhas de 0,75 de largura, indicaria sua substituição por portas de correr de abertura automática, como as da entrada do museu, dada a necessidade de climatização do ambiente. Além de adequar o vão de passagem evita o esforço para abertura. Nesse contexto, as portas que permanecem originais seriam mantidas e suas folhas, abertas durante o horário de funcionamento.

Outras correções devem ser feitas, como sinalização das vagas reservadas, mobiliários e sinalização ambiental, sem qualquer prejuízo para o patrimônio.

E sobre a entrada separada e o longo percurso para se chegar ao mesmo ponto de início, esta seria a demanda mais invasiva. Acredito necessitar de uma discussão mais extensa para verificar a validade de nova proposta de acesso. Por conta do grande desnível até o piso de acesso, seria necessária a instalação de plataforma vertical e a retirada de parte do guarda-corpo da varanda. Essa alteração na estrutura original é justificável? É a melhor solução? Hoje, talvez não, uma vez que a plataforma, submetida às intempéries, não seria tão eficaz para justificar a alteração na ambiência e na estrutura original. Não quer dizer que isso não possa ser reavaliado daqui a algum tempo, inserido em uma mudança de juízo de valor, novo contexto e tecnologia, e ser considerado como opção válida e mais adequada. Ou até mesmo na mudança da posição do elevador do pátio.

Se pensado sobre isso na reforma de 1998, o Elevador 1 poderia ter sido instalado no primeiro pátio retangular, diminuindo para $50 \mathrm{~m}$ o deslocamento da entrada alternativa até o ponto inicial. Ou seja, dentro do limite previsto em norma. Isso demonstra que a acessibilidade das pessoas com deficiência não era o real foco. E também que, a concepção com base no desenho universal, inclusive em 
uma reforma, pode garantir melhores soluções.

A seguir, apresento resumidamente 0 que foi exposto aqui, complementando esta análise com quatro tabelas que apresentam as inadequações, prioridade de adequação, dificuldade de adequação e impacto para a preservação: 
ATENDIMENTO ÀS LEIS E NORMAS DE ACESSIBILIDADE

\begin{tabular}{|c|c|c|}
\hline & SITUAÇÃO & OBSERVAÇÃO \\
\hline Passeio & & $\begin{array}{l}\text { piso irregular / interrupção de } \\
\text { percurso longitudinal }\end{array}$ \\
\hline Circulação externa & & piso trepidante \\
\hline Estacionamento & & $\begin{array}{l}\text { vagas sem sinalização / não há vagas } \\
\text { de idosos }\end{array}$ \\
\hline Entradas e saídas & & $\begin{array}{l}\text { percurso de } 120 \mathrm{~m} \text { até o ponto inicial } \\
\text { interno / rampa muito inclinada }\end{array}$ \\
\hline Circulação interna & & $\begin{array}{l}\text { rampas muito inclinadas / portas } \\
\text { estreitas e pesadas / inadequações } \\
\text { nos corrimãos }\end{array}$ \\
\hline Infraestrutura expositiva & & $\begin{array}{l}\text { boa circulação e expositores } \\
\text { adequados }\end{array}$ \\
\hline Locais de reunião & & $\begin{array}{l}\text { ausência de demarcação e de } \\
\text { assento para pessoa obesa }\end{array}$ \\
\hline Locais de refeição & & circulação adequada \\
\hline Outras áreas & & circulação adequada na loja \\
\hline Instalações sanitárias & & $\begin{array}{l}\text { sem espaço para manobra e } \\
\text { transferência / sem lavatório interno }\end{array}$ \\
\hline Mobiliário & & $\begin{array}{l}\text { inadequações nas mesas de refeição, } \\
\text { bebedouros e balcões }\end{array}$ \\
\hline Sinalização e comunicação & & $\begin{array}{l}\text { tamanho inadequado para leitura à } \\
\text { distância / sem piso tátil de alerta / } \\
\text { sem indicação em braile nas salas }\end{array}$ \\
\hline
\end{tabular}

LEGENDA

GRAVE

MÉDIO

BOM 


\section{PRIORIDADE DE ADEQUAÇÃO}

\begin{tabular}{|c|c|c|}
\hline & SITUAÇÃO & OBSERVAÇÃO \\
\hline Passeio & & $\begin{array}{l}\text { desnível no acesso de veículos } \\
\text { interrompe a continuidade da calçada }\end{array}$ \\
\hline Circulação externa & & $\begin{array}{l}\text { piso trepidante e ausência de } \\
\text { interligação com o Parque da Luz são } \\
\text { prejudiciais }\end{array}$ \\
\hline Estacionamento & & $\begin{array}{l}\text { os funcionários podem suprir as } \\
\text { inadequações de sinalização até as } \\
\text { correções }\end{array}$ \\
\hline Entradas e saídas & & $\begin{array}{l}\text { correção da rampa até definições } \\
\text { após estudo sobre o acesso distinto }\end{array}$ \\
\hline Circulação interna & & $\begin{array}{l}\text { troca dos corrimão para garantir a } \\
\text { segurança / rota está garantida pelo } \\
\text { elevador / rampa de saída da } \\
\text { passarela }\end{array}$ \\
\hline Infraestrutura expositiva & & correções pontuais e novos recursos \\
\hline Locais de reunião & & $\begin{array}{l}\text { sinalização das áreas reservadas e } \\
\text { acréscimo de cadeiras de obeso }\end{array}$ \\
\hline Locais de refeição & & falta cardápio braile \\
\hline Outras áreas & - & não há necessidade de adequação \\
\hline Instalações sanitárias & & $\begin{array}{l}\text { não há mesas para refeição e } \\
\text { assentos para pessoas obesas }\end{array}$ \\
\hline Mobiliário & & $\begin{array}{l}\text { não há mesas de refeição no } \\
\text { ambiente interno, balcões e } \\
\text { bebedouros acessíveis }\end{array}$ \\
\hline Sinalização e comunicação & & $\begin{array}{l}\text { dificuldade de orientabilidade e } \\
\text { ausência de sinalização tátil }\end{array}$ \\
\hline
\end{tabular}

\section{LEGENDA}

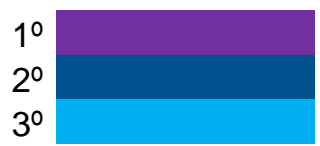




\section{DIFICULDADE ADEQUAÇÃO}

\begin{tabular}{|c|c|c|}
\hline & SITUAÇÃO & OBSERVAÇÃO \\
\hline Passeio & & $\begin{array}{l}\text { interromperá o acesso durante a } \\
\text { execução }\end{array}$ \\
\hline Circulação externa & & $\begin{array}{l}\text { rota em piso regular e nivelamento } \\
\text { com a áreas adjacentes }\end{array}$ \\
\hline Estacionamento & & $\begin{array}{l}\text { pintura do piso para demarcação das } \\
\text { vagas }\end{array}$ \\
\hline Entradas e saídas & & $\begin{array}{l}\text { exigi-se grandes transformações } \\
\text { para melhorar as condições de } \\
\text { acesso }\end{array}$ \\
\hline Circulação interna & & correção das rampas das passarelas \\
\hline Infraestrutura expositiva & & correções pequenas \\
\hline Locais de reunião & & $\begin{array}{l}\text { mudança de mobiliário e instalação } \\
\text { de corrimão, só dependem da } \\
\text { confecção/ compra dos mesmos }\end{array}$ \\
\hline Locais de refeição & & confecção de cardápio \\
\hline Outras áreas & - & não há necessidade de adequação \\
\hline Instalações sanitárias & & $\begin{array}{l}\text { diminuição das peças sanitárias } \\
\text { comuns para comportar característica } \\
\text { de boxe acessível / local para } \\
\text { sanitário com entrada independente }\end{array}$ \\
\hline Mobiliário & & $\begin{array}{l}\text { troca de mobiliários por um com } \\
\text { desenho adequado }\end{array}$ \\
\hline Sinalização e comunicação & & $\begin{array}{l}\text { o estudo de nova sinalização deve } \\
\text { ser feito com bastante rigor }\end{array}$ \\
\hline
\end{tabular}

LEGENDA

COMPLEXO

MÉDIO

SIMPLES

IMPACTO PARA A PRESERVAÇÃO 


\begin{tabular}{|c|c|c|}
\hline & SITUAÇÃO & OBSERVAÇÃO \\
\hline Passeio & & $\begin{array}{l}\text { calçada da Av. Tiradentes não é mais } \\
\text { em mosaico português }\end{array}$ \\
\hline Circulação externa & & $\begin{array}{l}\text { ainda permanecerão áreas com piso } \\
\text { original }\end{array}$ \\
\hline Estacionamento & & não há impacto \\
\hline Entradas e saídas & & $\begin{array}{l}\text { se considerar a mudança de acesso, } \\
\text { pela entrada principal, por plataforma } \\
\text { e retirada de guarda-corpo }\end{array}$ \\
\hline Circulação interna & & $\begin{array}{l}\text { corrimão, rampas e portas fazem } \\
\text { parte das adições da reforma de } 1998\end{array}$ \\
\hline Infraestrutura expositiva & & $\begin{array}{l}\text { melhoras para a exposição não } \\
\text { geram impacto na estrutura original }\end{array}$ \\
\hline Locais de reunião & & auditório não é original \\
\hline Locais de refeição & & cardápio em braile \\
\hline Outras áreas & - & não há necessidade de adequação \\
\hline Instalações sanitárias & & $\begin{array}{l}\text { novo banheiro trará a maior distinção } \\
\text { nesse quesito }\end{array}$ \\
\hline Mobiliário & & não são mobiliários originais \\
\hline Sinalização e comunicação & & $\begin{array}{l}\text { piso tátil e melhora da sinalização } \\
\text { ambiental não trazem impactos }\end{array}$ \\
\hline
\end{tabular}

\title{
LEGENDA
}

\author{
SEVERA \\ SATISFATÓRIA \\ ISENTA
}




\section{CONCLUSÕES FINAIS}

A tarefa de eleger determinadas edificações como bens culturais imóveis, antes restrita a especialistas, vem sendo cada vez mais reivindicada pela população. Esse poder da população, de definir quais os representantes de sua história e identidade, vem sendo amplamente reconhecido pelos órgãos do patrimônio, ao lado de definições de caráter erudito. Está claro, conforme preconizado por Riegl (2006) que é a relação com a sociedade que emprega valor e reconhecimento à definição do nosso patrimônio histórico. Assim como é a sociedade que aponta os limites e possibilidades desejáveis para o seu patrimônio.

Brandi (2005) define que a restauração é um ato crítico-cultural do presente, onde as diretrizes e ações devem estar baseadas no reconhecimento do valor, no conhecimento técnico, e também nas exigências de cada sociedade. O que foi válido no passado como diretriz não necessariamente permanece. E os anseios de uma sociedade não necessariamente podem ser transpostos para outra. Sempre objetivando a manutenção dos valores para a sociedade futura, a forma de preservar e restaurar um bem cultural imóvel pode sofrer modificações ao longo das gerações e com o desenvolvimento tecnológico.

A visão de congelamento já não cabe mais. Esta sociedade exige a atualização do seu patrimônio aos novos conhecimentos e necessidades, de forma respeitosa à dúplice percepção e materialidade. E de forma crescente, as pessoas com deficiência estão cada vez mais inseridas na sociedade, buscando seu direito de igualdade. Podemos reconhecer que de forma paralela, o valor do bem cultural não é inerente a ele e sim à relação que a sociedade estabelece com ele. Da mesma 
forma, as limitações da pessoa com deficiência não são dela e sim do ambiente. As limitações do ambiente têm condição de ser corrigidas.

E sobre limitações, podemos considerar que hoje a sociedade brasileira tem dois grandes limites, dentro do recorte aqui proposto, a ser trabalhados: ausência de orientações de adequação à acessibilidade para edifícios históricos e despreparo dos profissionais a respeito do Desenho Universal, dos parâmetros de acessibilidade e das necessidades de um público diverso.

O trabalho aqui desenvolvido expôs a viabilidade teórica e prática de aliar acessibilidade à preservação. $\mathrm{Na}$ adequação o respeito deve ser mútuo e a análise feita em profundidade, antes de qualquer proposição. Exige-se sensibilidade para perceber os elementos a ser preservados, assim como as necessidades de um público amplo. E humildade para notar que determinadas soluções podem não mais atender à demanda presente e, assim sendo, exigem revisão constante.

Quanto à primeira limitação, apesar da ampla legislação para proteção dos direitos das pessoas com deficiência, infelizmente, no que se refere ao tema acessibilidade e preservação, ainda prevalece o sentido de exceção, apoiado pela lei e pelo mito. Para avançar nesse ponto, novas orientações devem ser elaboradas com clareza e ter preceitos realmente pró-acesso. Devem estar destacados conceitos de inclusão, autonomia, mobilidade e segurança, lado a lado com distinguibilidade, reversibilidade, mínima intervenção, ambiência e compatibilidade físico-química. Cada órgão de preservação, em sua esfera de atuação, é um promotor nato da mudança, de três maneiras: orientando, cobrando e refinando. Com esse objetivo, deve redigir orientações e diretrizes e thes dar ampla visibilidade. Também, ao receber propostas de intervenção, deve exigir adequações de 
acessibilidade, mesmo quando não propostas inicialmente. E para apurar a qualidade dos projetos, deve conhecer tecnicamente as normas de acessibilidade para avaliar se há efetividade no que é proposto; lembrando que uma solução de acessibilidade inadequada é, também, um ataque ao patrimônio a ser preservado. Para que isso seja possível, os técnicos dos órgãos de preservação precisam ser sensibilizados sobre a importância de considerar a diversidade humana e capacitados em normas técnicas de acessibilidade. Com isso tudo, será possível dispor de exemplos que atendam tanto à preservação quanto à acessibilidade, e que devem ser compilados em publicação que servirá de orientação aos profissionais em novas intervenções.

E sobre a segunda limitação, posso afirmar devido aos objetos de estudo analisados e à minha trajetória profissional, que os preceitos do Desenho Universal e os parâmetros técnicos contidos nas normas de acessibilidade são, de maneira massiva, desconhecidos pelos profissionais da área da construção.

Ao olharmos para as faculdades, de forma geral, a visão atual não é promissora, apesar de o Desenho Universal já ser uma exigência na formação profissional $^{368}$. O ensino da temática está centrado muito mais no interesse do professor do que em premissa contida no projeto pedagógico. E, ainda assim, os professores, se não sensibilizados e capacitados adequadamente, têm a tendência a abordar o assunto entre "a rampa e o banheiro", o que já se mostrou extremamente limitado. É necessário que o Desenho Universal seja discutido e exercitado em sala de aula, pelas várias disciplinas: projeto, planejamento urbano, ergonomia,

\footnotetext{
${ }^{368}$ Segundo o Decreto federal 5.296/04, "caberá ao Poder Público promover a inclusão de conteúdos temáticos referentes ao desenho universal nas diretrizes curriculares da educação profissional e tecnológica e do ensino superior dos cursos de Engenharia, Arquitetura e correlatos".
} 
segurança, conforto etc. Isso, de fato, é tema para uma discussão mais extensa ${ }^{369}$, que não cabe aqui abordar.

Mais uma vez, faltam sensibilização e capacitação de coordenadores, professores e estudantes - os últimos são os que mais têm se mostrado conscientes e interessados, mesmo sem referenciais que lhes deem suporte. É evidente que algumas faculdades têm trilhado caminho oposto ao que foi apresentado aqui, mas são poucos, face à quantidade de profissionais que se formam todos os anos, e ao fato de que acessibilidade é premissa de qualquer projeto.

Em relação aos estudos de caso, ficou demonstrado que a acessibilidade deve estar presente em diversas etapas e envolver diversos agentes: projeto, execução, manutenção e gerenciamento do uso. A falta de um desses momentos pode prejudicar o sistema todo. $\mathrm{E}$ isso é válido para todas as adequações e propostas para atender à acessibilidade, não só em edifícios tombados. Um projeto adequado é invalidado por uma execução sem atenção aos detalhes como, por exemplo, a altura da barra de apoio junto à bacia ser alterada por falta de rigor. Como no dia a dia da edificação novas demandas surgem, novos elementos são inseridos. E o desconhecimento por parte do gestor das necessidades do público com deficiência pode acarretar prejuízo involuntário. Se projeto, execução e manutenção acontecerem corretamente, mas não houver atividades que visem a diversidade de usuários, estará fadado ao insucesso e a não apropriação popular. A acessibilidade trabalha de forma sistêmica e contínua e, assim, deve ser encarada por todas as partes envolvidas em sua efetivação.

\footnotetext{
369 Para mais informações sobre o ensino do Desenho Universal no Brasil e no mundo ver: CAMBIAGHI, S. S. Desenho Universal: métodos e técnicas para arquitetos e urbanistas. $2^{\mathrm{a}}$ ed. rev. São Paulo: Editora Senac São Paulo, 2011.
} 
Acredito que nem tanto a área construída, a inserção no lote, o gabarito e o uso original foram preponderantes a uma maior facilidade de adequação dos bens culturais imóveis estudados. Revelador e condicionador foi, sim, o aproveitamento oportuno de intervenções físicas de requalificação da edificação para eliminar barreiras. No que se refere a isso, o resultado foi tanto mais adequado e próximo das necessidades dos usuários quanto mais as soluções de acessibilidade estavam incorporadas no processo como um todo. Isso pode ser verificado no CCBB que teve boa aceitação do usuário apesar de seus erros. A exceção foi a usuária surda, que se sentiu prejudicada nos três ambientes visitados, por falta de adequações no que se refere, principalmente, ao gerenciamento do uso.

No caso da Casa das Rosas, onde as necessidades de acesso foram ventiladas cerca de um mês antes da inauguração da mostra, que deu origem ao pouco de acessibilidade que o local tem hoje, conclui-se que é fundamental tratar o assunto desde o início e não ao final do processo projetual, como algo acessório e imposto.

A ausência de preceitos do Desenho Universal na concepção da proposta da Pinacoteca fez com que não fosse pensada uma condição melhor de acesso dentro da intervenção ocorrida, no que se refere ao longo percurso da entrada alternativa até o ponto inicial do museu.

Todos os estudos de caso apresentaram problemas e incorreções, e todos necessitam responder aos seus visitantes quais medidas serão tomadas e em quanto tempo. É um absurdo, da parte dos gestores e dos órgãos de preservação, que a Casa das Rosas, ou qualquer outro local, permaneça três anos sem uma forma de acesso seguro. Ou que um espaço passe quase dez anos sem considerar 
rever suas instalações sanitárias, após a mudança de parâmetros de uma norma técnica, como ocorre na Pinacoteca. Essas situações demonstram a falta de comprometimento e respeito às necessidades do usuário. As questões de comunicação também se mostraram bastante subestimadas. De forma geral, acredito que esse tema é desconsiderado nas edificações, resultando em sinalização ambiental e atendimento deficitários. Uma boa sinalização ambiental garantirá orientabilidade e, consequentemente, a autonomia.

Uma rota acessível interligando todos os usos e serviços, na adaptação de um edifício existente é o suficiente para garantir a acessibilidade mínima, quando não há a possibilidade de adequação integral. Em um edifício de interesse histórico, onde o mínimo de intervenção é uma das diretrizes a ser cumpridas, não será a impossibilidade que determinará a adequação para criar apenas uma rota e, sim, o respeito ao seu aspecto original. Não esquecendo que isso é válido não só para os visitantes, mas também para os funcionários.

Contudo, quando se trata da rota para um cego (e não estou me referindo à rota tátil direcional), para garantir seu uso com autonomia e segurança, seria necessária a demarcação de qualquer desnível e situação de risco com piso tátil de alerta. Enquanto um usuário de cadeira de rodas pode ver o espaço como um todo e, com a ajuda da sinalização ambiental determinar seu percurso pela rota acessível, um cego poderá circular por qualquer lugar da edificação histórica, mesmo com a existência de degraus. Dado isso, o risco existente nos desníveis é relevante. E no caso do cego seria inviável determinar uma única rota acessível, a não ser que se colocasse linha tátil direcional para todos os percursos, o que não seria nem um pouco eficaz - porém estaria determinada a rota segura, sem precisar adequar 
outras. E claro, levando em consideração que ele permaneceria somente nesta rota pré-determinada, o que fere o direito de escolha e é antinatural.

Com tudo isso exposto, e levando em consideração que hoje já temos recursos no mercado, considero que o piso tátil de alerta e direcional, quando se mostrar necessário, deve ser aplicado na edificação e em seu entorno. Isso garante maior autonomia e segurança da pessoa com deficiência visual. Neste caso, os pisos táteis por elementos são os que irão garantir o mínimo de interferência, inclusive da percepção espacial que se quer preservar, sem que isso signifique prejuízo na percepção do usuário com deficiência visual. Esses pisos táteis colados (por placas ou por elementos) podem ser removidos se necessário, respeitando a reversibilidade da intervenção em um edifício histórico.

Pode-se notar, ainda, com toda essa experiência, que o uso da lista de verificação com base no Desenho Universal é um recurso importante e válido. No entanto, da forma como foi aplicado no presente trabalho, utilizando-se a citada referência, demonstrou-se muito heterogêneo para o objetivo. Tornou-se demasiado complicado avaliar pontos tão distintos da edificação, sem uma divisão mais clara, como por exemplo, utilizar uma lista de verificação para cada item: acesso, circulação interna, serviços etc. Apesar de que a inadequação em um ponto invalida a adequação de outro, já que o objetivo é alcançar o Desenho Universal. Para atender tal reflexão será necessário desenvolver outro modelo de verificação com base no Desenho Universal, mais adequado para edificações.

Talvez para a análise de um objeto utilitário, que não tenha tantas vertentes, esse modelo seja válido. Para uma edificação e seu entorno, nem tanto. Mas sua utilização não deixou de demonstrar que o Desenho Universal está longe 
de ser atendido nas edificações em questão. Essa situação não decorre de serem bens culturais tombados: a diversidade humana ainda não é plenamente considerada na prática dos projetistas.

As tabelas de valor, ao final de cada estudo de caso, essas sim provaram ser uma boa ferramenta para resumir os problemas e matizar as ações a ser tomadas. São mais orientativas e facilitam as tomadas de decisão. Esse tipo de instrumento deve ser aplicado na avaliação, resultando em posterior cronograma de adequação, conforme as condições específicas de cada local em análise. O cronograma irá demonstrar ao público que algo está sendo feito em prol da melhora das condições de acesso e uso do espaço.

A técnica de grupo focal, para conhecer a opinião dos usuários, mostrouse eficaz para o tempo disponível e para o objetivo proposto. Apesar de ser mais cansativo para os participantes do que uma entrevista individual, a discussão em grupo trouxe benefícios, enriquecendo as observações de todos. Os próprios participantes, ao longo da discussão, observaram haver semelhanças e diferenças nos problemas e facilidades que os espaços proporcionam a cada uma de suas deficiências. Perceberam, também, que apesar de as adequações para atender restrições de mobilidade serem, aparentemente, as mais impactantes para um edifício histórico preservado, foram as alterações mais recorrentes nos locais visitados.

As demandas de sinalização e comunicação - que são importantes para todos mas vitais às pessoas surdas e cegas -, foram as que menos puderam ser observadas, mesmo sendo as menos invasivas ao patrimônio. E, por fim, consideraram a comunicação e o atendimento elementos essenciais, entre tudo que 
foi discutido, até mesmo para suprir problemas temporariamente.

Devemos estar atentos ao alerta de Sarraf (2008, p. 104):

Mesmo com a aderência à 'responsabilidade social', os museus realizam raras ações de acessibilidade para a população de pessoas com deficiência. Nesse sentido, as poucas instituições que possuem programas de atendimento às pessoas com deficiência são consideradas de ótimas qualidade, sem que o público em questão acumule experiências para analisar criticamente as ofertas.

A consideração aos programas de atendimento, feita por Sarraf, aplica-se claramente às condições de acesso e uso do espaço em si. Não podemos achar suficiente o pouco realizado, dentro de um universo escasso. Isso se mostrou realmente inadequado e insatisfatório. Ainda mais, por se tratar de bens culturais imóveis, muito pode ser feito sem qualquer alteração aos elementos essenciais preservados, conforme demonstrado. E ficou claro que a falta de conhecimento e rigor foram as maiores barreiras à promoção da verdadeira inclusão, visando o acolhimento do usuário.

O presente trabalho buscou contribuir com o debate entre os campos de preservação e acessibilidade, para que sejam desenvolvidas diretrizes oficiais mais adequadas e eficazes à conquista dos direitos humanos. Convém frisar que a acessibilidade e o Desenho Universal são conquistas de todos, pois atendem à diversidade humana na qual estamos todos inseridos. Acessibilidade não é mérito, é direito. O momento é, cada vez mais, de empoderamento das pessoas com deficiência, garantido por seus direitos e apoiado em recursos que a tecnologia dispõe. Não se pode retroceder nesses dois pontos. O espaço está tomado por todos que desejam fazer uso dele, e cabe aos gestores, arquitetos e engenheiros determinar a melhor forma técnica de garantir o acesso pleno, livre de riscos e de dependência. 
O respeito ao edifício deve existir, mas o respeito inerente ao direito de ir e vir deve prevalecer. Ambos precisam caminhar juntos nas decisões, durante propostas de reformas e restauros. Isso só fortalece ainda mais o bem imóvel tombado, garantindo cada vez mais relevância para a comunidade, de forma atual e acolhedora, que resulte em uso amplo e irrestrito. 


\section{REFERÊNCIAS BIBLIOGRÁFICAS}

ASSOCIAÇÃO BRASILEIRA DE NORMAS TÉCNICAS. Histórico ABNT: 65 anos. Rio de Janeiro, 2006. Disponível em:

<http://www.abnt.org.br/downloads/conheca_abnt/historicoabnt.pdf>. Acesso em: 11 maio 2011.

ASSOCIAÇÃO BRASILEIRA DE NORMAS TÉCNICAS. NBR 10520: informação e documentação: citações em documentos: apresentação. Rio de Janeiro, 2002.

ASSOCIAÇÃO BRASILEIRA DE NORMAS TÉCNICAS. NBR 6023: informação e documentação: referências: elaboração. Rio de Janeiro, 2002.

ASSOCIAÇÃO BRASILEIRA DE NORMAS TÉCNICAS. NBR 9050: adequação das edificações e do mobiliário urbano à pessoa deficiente. Rio de Janeiro, 1984.

ASSOCIAÇÃO BRASILEIRA DE NORMAS TÉCNICAS. NBR 9050: Acessibilidade de pessoas portadoras de deficiências a edificações, espaços, mobiliários e equipamentos urbanos. Rio de Janeiro, 1994.

ASSOCIAÇÃO BRASILEIRA DE NORMAS TÉCNICAS. NBR 9050: Acessibilidade a edificações, mobiliário, espaços e equipamentos urbanos. Rio de Janeiro, 2004.

ASSOCIAÇÃO BRASILEIRA DE NORMAS TÉCNICAS. NBR 13994: Elevadores para transporte de pessoa portadora de deficiência. Rio de Janeiro, 2000.

ASSOCIAÇÃO BRASILEIRA DE NORMAS TÉCNICAS. NBR 15599: Acessibilidade - Comunicação na prestação de serviços. Rio de Janeiro, 2008. 
ASSOCIAÇÃO BRASILEIRA DE NORMAS TÉCNICAS. NBR NM 313: Elevadores de passageiros - Requisitos de segurança para construção e instalação Requisitos particulares para a acessibilidade das pessoas, incluindo pessoas com deficiência. Rio de Janeiro, 2007.

BARTH, Alberto. Laudo técnico. São Paulo, 08 de maio 1987. Disponível em: <http://www.planoauditoria.com.br>. Acesso: 21 de abril 2009

BOITO, C. Os Restauradores. Tradução de Beatriz Mugayar Kühl e Paulo Mugayar Kühl. 2ª ${ }^{a}$ ed. Cotia: Ateliê Editorial, 2002. 63 p.

BRANDI, Cesare. Teoria da Restauração. Tradução de Beatriz Mugayar Kühl. 2ª . ed. Cotia: São Paulo, Ateliê, 2004.

BRASIL. Constituição (1988). Constituição da República Federativa do Brasil. Brasília, DF: $1988 . \quad$ Senado, Disponível em: <http://www.planalto.gov.br/ccivil_03/Constituicao/Constitui\%C3\%A7ao.htm>. Acesso em: 05 maio 2011.

BRASIL. Coordenadoria Nacional para Integração da Pessoa Portadora de Deficiência. Acessibilidade. Brasília: Secretaria Especial dos Direitos Humanos, 2005. $60 \mathrm{p}$.

BRASIL. Decreto Legislativo $n^{\circ} 186$ de 9 de julho de 2008. Aprova o texto da Convenção sobre os Direitos das Pessoas com Deficiência e de seu Protocolo Facultativo, assinados em Nova lorque, em 30 de março de 2007. Diário Oficial da União, Brasília, DF, 10 jul. 2010. Seção 1, p. 1.

BRASIL. Decreto no 5.296 de 2 de dezembro de 2004. Regulamenta as Leis nos 10.048, de 8 de novembro de 2000, que dá prioridade de atendimento às pessoas que especifica, e 10.098, de 19 de dezembro de 2000, que estabelece normas gerais e critérios básicos para a promoção da acessibilidade das pessoas portadoras de deficiência ou com mobilidade reduzida, e dá outras providências. Disponível em: 
<http://www.mj.gov.br/sedh/ct/CORDE/dpdh/sicorde/dec5296.asp> Acesso em: 11 de jul. de 2008.

BRASIL. Decreto-lei no 25, de 30 de novembro de 1937. Organiza a proteção do patrimônio histórico e artístico nacional. Diário Oficial da Republica Federativa do Brasil, Brasília, DF, 1 de dezembro de 1937. Disponível em: <http://portal.iphan.gov.br>. Acesso em: 11 de jul. 2008.

BRASIL. Instituto do Patrimônio Histórico e Artístico Nacional - IPHAN. Cartas Patrimoniais. Brasília: IPHAN, 1995.

BRASIL. Instituto do Patrimônio Histórico e Artístico Nacional. Instrução Normativa no 1 de 25 de Novembro de 2003. Dispõe sobre a acessibilidade aos bens culturais imóveis acautelados em nível federal, e outras categorias, conforme especifica. Disponível em: <http://portal.iphan.gov.br:8080/portal/baixaFcdAnexo.do?id=355>. Acesso em: 12 de jul. 2008.

BRASIL. IPHAN. Edital de Notificação do Tombamento do Conjunto Artístico e Paisagístico do Bairro da Luz. Diário Oficial [da] República Federativa do Brasil, Poder Executivo, Brasília, DF, 28 dez. 2011. Seção 3, p. 23. Disponível em: < http://www.in.gov.br/imprensa/visualiza/index.jsp?jornal=3\&pagina=23\&data=28/12/2 011 >. Acesso em: 10 jan. 2012

BRASIL. IPHAN. Edital de Notificação do Tombamento Provisório do Conjunto Histórico do Bairro da Luz. Diário Oficial da União, Poder Executivo, Brasília, DF, 03 ago. 2000. Seção 3, p. 14. Disponível em: $<$ http://www.in.gov.br/imprensa/visualiza/index.jsp?jornal=3\&pagina=54\&data=03/08/ 2000>. Acesso em: 10 jan. 2012

BRASIL. IPHAN. Portaria no 420, de 22 de dezembro de 2010. Dispõe sobre os procedimentos a serem observados para a concessão de autorização para realização de intervenções em bens edificados tombados e nas respectivas áreas de entorno. Diário Oficial [da] República Federativa do Brasil, Poder Executivo, Brasília, DF, 24 dez. 2010. Seção 1, p. 9. Disponível em: 
<http://portal.iphan.gov.br/portal/baixaFcdAnexo.do?id=1703>. Acesso em: 20 set. 2011.

BRASIL. Lei $\mathrm{n}^{\circ} \mathbf{1 0 . 7 4 1}$, de $1^{\circ}$ de outubro de 2003. Dispõe sobre o Estatuto do Idoso e dá outras providências. Diário Oficial da União, Brasília, DF, 03 out. 2003. Seção 1, p. 1.

BRASIL. Ministério da Cultura. Política nacional de museus. Brasília: MinC, 2007.

BRASIL. Ministério da Educação e do Desporto. Portaria no 1.770, de 21 de dezembro de 1994. Fixa as diretrizes curriculares e o conteúdo mínimo do curso de graduação em Arquitetura e Urbanismo. Diário Oficial da União, Brasília, DF, 23 dez 1994. Seção 1, p. 58.

BRASIL. Ministério da Educação. Resolução no 2, de 17 de junho de 2010. Institui as Diretrizes Curriculares Nacionais do curso de graduação em Arquitetura e Urbanismo, alterando dispositivos da Resolução CNE/CES nº 6/2006. Diário Oficial da União, Brasília, DF, 18 jun 2010b. Seção 1, p. 37-38.

BRASIL. Ministério da Educação. Resolução n 6, de 2 de fevereiro de 2006. Institui as Diretrizes Curriculares Nacionais do curso de graduação em Arquitetura e Urbanismo e dá outras providências. Diário Oficial da União, Brasília, DF, 03 fev 2006. Seção 1, p. 36.

BRASIL. Secretaria de Direitos Humanos. Secretaria Nacional de Promoção dos Direitos da Pessoa com Deficiência História do Movimento Político das Pessoas com Deficiência no Brasil. Brasília: [s.n.], 2010c. 473 p.

BRASIL. Secretaria Especial dos Direitos Humanos. Convenção sobre os Direitos das Pessoas com Deficiência. Brasília, 2007b. 47 p.

CALDEIRA, V.; FANUCCI, F.; FERRAZ, M.; SANTOS, C. R. Museu Rodin Bahia. In. - Francisco Fanucci, Marcelo Ferraz: Brasil Arquitetura. São Paulo: Cosac Naify, 2005. p. 98-105. 
CAMBIAGHI, Silvana Serafino. Desenho universal: métodos e técnicas para arquitetos e urbanistas. São Paulo: Editora Senac São Paulo, 2007.

CAMBIAGHI, Silvana Serafino. Desenho universal: métodos e técnicas para arquitetos e urbanistas. $2^{a}$ ed. rev. São Paulo: Editora Senac São Paulo, 2011.

CAMBIAGHI, Silvana Serafino. Desenho universal: métodos e técnicas de ensino na graduação de arquitetos e urbanistas. 2004. 291 f. 18 pranchas. Dissertação (Mestrado em Arquitetura e Urbanismo) - Faculdade de Arquitetura e Urbanismo, Universidade de São Paulo, São Paulo, 2004.

CARBONARA, Giovanni. Adeguamento del patrimonio storico ed archeologico. In: Curso Progettare per tutti senza barriere architettoniche. Curso de pós-graduação - 10 $0^{\mathrm{a}}$ edição. Roma, 2002. Disponível em: < http://www.progettarepertutti.org/formazione/lez08_carbonara.pdf>. Acesso em: 11 set. 2011.

CHING, Francis D. K. Dicionário Visual de Arquitetura. Tradução Julio Fischer. São Paulo: Martins Fontes, 2006. 319 p.

CHOAY, Françoise. A alegoria do patrimônio. São Paulo: Estação Liberdade: Editora UNESP, 2001.

CICHINELLI, Gisele. Projetos precisam prever integração de soluções especiais para estabelecer rotas acessíveis em edifícios. Revista AU, São Paulo, ed. 214, p.64-68, jan.2012. Disponível em: <http://www.revistaau.com.br/arquiteturaurbanismo/214/artigo244684-1.asp>. Acesso em: 01 fev. 2012.

COHEN, Regina. Sobre o Teatro Municipal. [mensagem pessoal]. Mensagem recebida por<contato@elisaprado.com.br> em 23 fev. 2012.

CUNHA, C. R. A atualidade do pensamento de Cesare Brandi. Vitruvius, São Paulo, agosto 2004. Disponível em:< http://www.vitruvius.com.br/revistas/read/resenhasonline/03.032/3181>. Acesso em: 
04 de mar 2011.

Alois Riegl e o culto moderno dos monumentos. Vitruvius, São Paulo, jun $2006 . \quad$ Disponível em: <http://www.vitruvius.com.br/revistas/read/resenhasonline/05.054/3138>. Acesso em 20 de mar 2011.

CURY, Isabelle (Org). Cartas Patrimoniais, Rio de Janeiro: IPHAN, 1999. 408 p. (Coleção Edições do Patrimônio).

DIAS, Isabella Corrêa. Acessibilidade ambiental em bens tombados pelo patrimônio histórico: conflitos e consensos. 2007. Monografia (Especialização em Arquitetura e Urbanismo), Universidade Federal de Minas Gerais, 2007.

DOURADO, Guilherme Mazza. Pinacoteca do Estado entra em nova fase. In. Revista PROJETO, n. 139, p. 97, mar. 1991.

FARIAS, N. \& BUCHALLA, C. M. A Classificação Internacional de Funcionalidade, Incapacidade e Saúde: Conceitos, Usos e Perspectivas. Revista Brasileira Epidemiologia. v. 8, n. 2, p. 187-193, jun. 2005. Disponível em: $<$ http://www.scielosp.org/scielo.php?pid=S1415790X2005000200011\&script=sci_pdf\&tlng=pt>. Acesso em: 23 maio 2011.

FEIJÓ, Alexsandro Rahbani Aragão. O direito constitucional da acessibilidade das pessoas portadoras de deficiência ou com mobilidade reduzida. Buscalegis, 2009.

Disponível

em:

$<$ http://www.buscalegis.ufsc.br/revistas/index.php/buscalegis/article/view/32588/3179 8>. Acesso em: 18 de jul. De 2010.

FERNÁNDEZ, Jesús de Benito; MILÁ, Javier García. Manual Para un Entorno Accesible. Madrid, Centro Español de Documentación sobre Discapacidad, 2005. 
FOGOS e papel picado na inauguração do calçadão. Folha de S. Paulo, São Paulo, 17 dez. 1976. Caderno Local, p.12. Disponível em: <http://acervo.folha.com.br/fsp/1976/12/17/2/4328864>. Acesso em: 02 fev. 2012.

GABRIELY, Alexandre Oliveira. Edifícios Públicos Tombados e a Acessibilidade para pessoas com deficiência: um olhar multidisciplinar. 2007. 115 f. Dissertação (Mestrado em Distúrbios do Desenvolvimento), Universidade Presbiteriana Mackenzie, São Paulo, 2007.

GALLO, Haroldo. Júlio Prestes e Pinacoteca: um paradoxo nas intervenções em dois edifícios históricos. In. Revista PROJETODESIGN, ed. 252, fev. 2001. Disponível em: <http://www.arcoweb.com.br/artigos/haroldo-gallo-julio-prestes-2803-2001.html>. Acesso em: 22 jan. 2012.

GERENTE, Melissa M. Introduzindo diretrizes de projeto para a acessibilidade em sítios históricos a partir do estudo de São Francisco do Sul. Florianópolis, 6 de abril de 2005. 165 p. Dissertação (Mestrado em Arquitetura e Urbanismo) Programa de Pós-graduação, UFSC, 2005. Disponível em: $<$ <ttp://arq.ufsc.br/petarq/wp-content/uploads/2008/02/abergo-27.pdf>. Acesso em: 26 de jul. 2009

GOVERNO DO ESTADO DE SÃO PAULO. Resolução 57, de 22-10-85. Diário Oficial do Estado. Poder Executivo, Seção I, 24.10.1985, pg 14. Disponível em: <http://www.imprensaoficial.com.br>. Acesso: 03 de jun. 2009

GUGEL, M. A. Pessoas com Deficiência e o Direito ao Trabalho. Florianópolis, Obra Jurídica, 2007.

A pessoa com deficiência e sua relação com a história da humanidade. Associação Nacional dos Membros do Ministério Público de Defesa dos Direitos dos Idosos e Pessoas com Deficiência. Disponível em: <http://www.ampid.org.br/Artigos/PD_Historia.php>. Acesso em: 05 maio 2011. 
HENRIQUES, Andrea Santini; MELO, Cristiana Malfacini. Acessibilidade como parte da responsabilidade social. [S.I.], Inmetro, 2006. Disponível em: $<$ http://www.inmetro.gov.br/producaointelectual/obras_intelectuais/207_obralntelectu al.pdf>. Acesso em: 18 de jul. de 2010.

JORDAN, Katia F. (Org.). De Villa Catharino a Museu Rodin Bahia 1912-2006: um palacete baiano e sua história. Salvador: Solisluna Design, 2006.

JUNCÀ UBIERNA, José Antonio. Accesibilidad y Patrimonio Cultural. A la búsqueda de un equilibrio compatible. In Boletín del Real Patronato Sobre Discapacidad. n. 64, p. 4-11. Disponível em: <http://www.cedd.net>. Acesso em: 26 de jul. 2009.

KATINSKY, Júlio Roberto. Pesquisa acadêmica na FAUUSP. São Paulo: Universidade de São Paulo, Faculdade de Arquitetura e Urbanismo, 2005.

KÜHL, B. M. Arquitetura do ferro e arquitetura ferroviária em São Paulo: reflexões sobre a sua preservação. Cotia: Ateliê Editorial, 1998. 436 p.

. História e Ética na Conservação e na Restauração de Monumentos Históricos. Revista CPC, v.1, n. 1, p. 16-40, nov. 2005/ abr. 2006.

A restauração de monumentos históricos na França após a Revolução. Revista CPC, 1, n. 3, 2006.

Notas sobre a Carta de Veneza. Anais do Museu Paulista, São Paulo, v. 18, n. 2, p. 287-320, jun-dez 2010.

LARAIA, M. I. F. A pessoa com deficiência. In: A pessoa com deficiência e o direito ao trabalho. 2009. cap. 1. f. 21-51. Dissertação (Mestrado em Direito) Pontifícia Universidade Católica de São Paulo, São Paulo, 2009. Disponível em: $<$ http://www.sapientia.pucsp.br/tde_busca/arquivo.php?codArquivo=10579>. Acesso em: 03 maio 2011.

LEMOS, Carlos Alberto Cerqueira. Alvenaria Burguesa: breve história da 
arquitetura residencial de tijolos em São Paulo a partir do ciclo econômico liderado pelo café. São Paulo: Nobel, 1989. 206 p.

, Carlos Alberto Cerqueira. O Eclestismo em São Paulo. In: FABRIS, Annateresa. Ecletismo na Arquitetura Brasileira. São Paulo: Nobel, 1987.

LOPES, Maria Elisabete. Metodologia de análise e implementação de acessibilidade para pessoas com mobilidade reduzida e dificuldade de locomoção. 2005. 494 f. Tese (Doutorado em Arquitetura e Urbanismo) - Faculdade de Arquitetura e Urbanismo, Universidade São Paulo, São Paulo, 2005. 2v.

MARQUES, L. P. Retraçando as concepções de deficiência mental. In: 0 professor de alunos com deficiência mental: concepções e prática pedagógica. 2000. cap. 3. f. 37-52. Tese (Doutorado em Educação). Universidade Estadual de Campinas, $\quad$ Campinas, $2000 . \quad$ Disponível em: <http://www.bibliotecadigital.unicamp.br/document/?code=vtls000200019>. Acesso em: 07 maio 2011.

MARTÍN Enrique $S$. et al. Accesibilidad y patrimonio. Yacimientos arqueológicos, cascos históricos, jardines y monumentos. Castilla y León: Consejería de Cultura y Turismo, 2007. 281 p.

MINISTERO PER I BENI E LE ATTIVITÀ CULTURALI. Linee Guida per il superamento delle barriere architettoniche nei luoghi d'interesse culturale.. Itália: Gangemi Editore, 2008. 177 p.

MIRANDA, Marcos Paulo de Souza \& NOVAIS, Andrea Lanna Mendes. Direito de acessibilidade aos bens culturais. Disponível em: <http://www.vitruvius.com.br/minhacidade/mc259/mc259.asp>. Acesso em: 19 de jul. 2009.

MORAES, Miguel Correia de. Acessibilidade no Brasil: Análise da NBR 9050. 2007. 173 f. Dissertação (Mestrado em Arquitetura e Urbanismo) - Universidade Federal de Santa Catarina, Florianópolis, 2007. 
OLIVEIRA, Aíla Seguin Dias Aguiar de. Acessibilidade espacial em centro cultural: Estudo de casos. 2006. 214 f. Dissertação (Mestrado em Arquitetura e Urbanismo), Universidade Federal de Santa Catarina, Florianópolis, 2006.

OMS - ORGANIZAÇÃO MUNDIAL DA SAÚDE. CIF: Classificação Internacional de Funcionalidade, Incapacidade e Saúde. Tradução de Cassia Maria Buchalla. São Paulo: Edusp, 2003. 325 p.

ORGANIZAÇÕES DAS NAÇÕES UNIDAS. Declaração dos Direitos das Pessoas Deficientes. Resolução aprovada pela Assembléia Geral da Organização das Nações Unidas em 09/12/75. Disponível em: http://www.mj.gov.br/sedh/ct/corde/dpdh/sicorde/decl_pessoa_def.asp. Acesso em: 12 de jul. 2008.

ORGANIZAÇÕES DAS NAÇÕES UNIDAS. Declaração dos Direitos das Pessoas Deficientes. Resolução aprovada pela Assembleia Geral da Organização das Nações Unidas em 09/12/75. Disponível em: http://www.mj.gov.br/sedh/ct/corde/dpdh/sicorde/decl_pessoa_def.asp. Acesso em: 12 de jul. 2008.

ORNSTEIN, Sheila Walbe; BRUNA, Gilda Collet; ROMËRO, Marcelo. Ambiente construído \& comportamento: a avaliação pós-ocupação e a qualidade ambiental. São Paulo: Nobel / FAUUSP / FUPAM, 1995. p. 216.

ORNSTEIN, Sheila. Avaliação Pós-ocupação (APO) do ambiente construído. São Paulo, Studio Nobel, EdUSP, 1992.

PAIVA, Ellayne Kelly Gama de. Acessibilidade e preservação em sítios históricos: $O$ caso de São Luís do Maranhão. 2009. 177 f. Dissertação (Mestrado em Arquitetura e Urbanismo) - Universidade de Brasília, Brasília, 2009.

PICCELI, Angélica Fátima Baldin. O gerenciamento para a acessibilidade ambiental de pessoas com mobilidade reduzida. 2009. 365 p. Dissertação 
(Mestrado em Arquitetura) - Universidade Federal de Minas Gerais, Belo Horizonte, 2009.

PINHEIRO, M. L. B. William Morris e a SPAB. In: Rotunda no. 3, 2004, pp. 22-32. Disponível em: <http://www.iar.unicamp.br/rotunda/rotunda03.pdf>. Acesso em: 07 maio 2011.

PLANO AUDITORIA. O Desafio do Restauro: 1987 - 1991. Disponível em: <http://www.planoauditoria.com.br>. Acesso: 20 de abril 2009.

PORTELA, Carine. Agência de Cultura, Revista AU, São Paulo, n. 96, p. 46-53, jun./jul. 2001.

PRADO, A. R. A.; LOPES, M. E.; ORNSTEIN, S. W. (org.). Desenho Universal: Caminhos da Acessibilidade no Brasil. São Paulo, Annablume, 2010.

PRADO, Adriana R. A. (Coord.). Município acessível ao cidadão. Fundação Prefeito Faria Lima - CEPAM. Unidade de Políticas Públicas - UPP. São Paulo, 2001. 276 p.

PREISER, W. F. E.; OSTROFF, E. Universal design handbook. Nova lorque: McGraw-Hill, 2001.

. Universal design handbook. 2 th ed. Nova lorque: McGraw-Hill, 2011.

RESGATE Histórico. Revista Finestra Brasil, São Paulo, v.7, n.25, p.16-18, abr./jun, 2001.

RESOURCE: THE COUNCIL FOR MUSEUMS, ARCHIVES AND LIBRARIES. Acessibilidade/Resource: The Council for Museums, Archives and Libraries; [tradução Maurício O. Santos e Patrícia Souza]. São Paulo, Editora da Universidade de São Paulo : [Fundação] Vitae, 2005.

RIEGL, A. O culto moderno dos monumentos: sua essência e sua gênese. 
Tradução Elaine Ribeiro Peixoto e Albertina Vicentine. Goiânia: UCG, 2006. 121 p.

RODRIGUES, Marly. O Condephaat: as práticas definem a política. In: Imagens do Passado - a instituição do patrimônio em São Paulo, 1967-1987. São Paulo: Ed. Unesp; Imesp; CONDEPHAAT, Fapesp, 2000. 182 p.

RODRIGUES, Marly. Patrimônio cultural paulista - CONDEPHAAT bens tombados 1968-1998. São Paulo: Imprensa Oficial do Estado, 1998.

RUA São Bento virou laboratório. Folha de S. Paulo, São Paulo, 12 mar. 1976. Caderno Local, p.10. Disponível em: <http://acervo.folha.com.br/fsp/1976/03/12/2>. Acesso em: 02 fev. 2012.

RUIZ, Antonio Espinosa \& CARRATALÁ, Diana Guijarro. La accesibilidad al Patrimonio Cultural. Disponível em: <http://www.interpretaciondelpatrimonio.com/documentos.htm>. Acesso em: $27 \mathrm{de}$ jul. 2009.

RUSKIN, J. A lâmpada da memória. Tradução Maria Lucia Bressan Pinheiro. Cotia: Ateliê Editorial, 2008. 88 p.

SANTOS, Cecília Rodrigues dos. Espelhos da Cidade. In Revista Projeto. São Paulo: Arco, n.148, p. 36-41, dez, 1991.

SANTOS, Maria Almeida Santos. Acessibilidade em Museus. 2009. 223 f. Dissertação (Mestrado em Museologia) - Faculdade de Letras da Universidade do Porto, Porto, 2009.

SÃO PAULO (ESTADO). Comunicado Secretaria de Cultura - Condephaat. Relativo à Ata no 1610 da sessão ordinária de 14 fev. 2011. Diário Oficial [do] Estado de São Paulo, Poder Executivo, São Paulo, SP, 24 fev. 2011. Seção 1, v. 121, n. 37, p. 39. Disponível em: <http://www.imprensaoficial.com.br>. Acesso em: 10 jan. 2012. 
SÃO PAULO (ESTADO). Comunicado Secretaria de Cultura - Condephaat. Relativo à Ata o 1649 da sessão ordinária de 07 nov. 2011. Diário Oficial [do] Estado de São Paulo, Poder Executivo, São Paulo, SP, 12 nov. 2011. Seção 1, v. 121, n. 214, p. 106. Disponível em: <http://www.imprensaoficial.com.br>. Acesso em: 10 jan. 2012.

SÃO PAULO (ESTADO). Resolução SC - 40, de 02 de setembro de 2004. Tombamento como bem cultural de interesse artístico, urbanístico, arquitetônico, histórico e turístico o edifício que instala o Centro Cultural Banco do Brasil de São Paulo. Diário Oficial [do] Estado de São Paulo - Poder Executivo, São Paulo, SP, 14 set. 2004. Seção I, p. 75.

SÃO PAULO (MUNICÍPIO). Ata da 494a reunião extraordinária do Conpresp. Relativo ao Processo Administrativo no 2009-0.344.111-6 sobre Construção de rampa de acessibilidade para a Casa das Rosas. Diário Oficial da Cidade de São Paulo, São Paulo, SP, 09 dez. 2011. Número 228, p. 17. Disponível em: <http://www.imprensaoficial.com.br>. Acesso em: 10 jan. 2012.

SÃO PAULO (MUNICÍPIO). Despacho Secretaria de Cultura - Conpresp. Relativo ao Processo Administrativo no 2007-0.150.708-6 do Evento CAD Brasil 2007 - Casa Artes e Design Brasil. Diário Oficial da Cidade de São Paulo, São Paulo, SP, 13 jul. 2007. Número 127, p. 27. Disponível em: <http://www.imprensaoficial.com.br>. Acesso em: 10 jan. 2012.

SÃO PAULO (MUNICÍPIO). Despacho SEMPLA.CTLU/246/2007. Relativo ao Processo Administrativo do Evento CAD Brasil 2007 - Casa Artes e Design Brasil. Diário Oficial da Cidade de São Paulo, São Paulo, SP, 11 jul. 2007. Número 125, p. 27. Disponível em: <http://www.imprensaoficial.com.br>. Acesso em: 10 jan. 2012.

SÃO PAULO (MUNICÍPIO). Lei no 12.349, de 6 de junho de 1997. Estabelece programa de melhorias para a área central da cidade, cria incentivos e formas para sua implantação. Diário Oficial da Cidade de São Paulo, São Paulo, SP, 07 jun. 1997, p. 1. 
SARRAF. Viviane P. Reabilitação do museu: políticas de inclusão cultural por meio da acessibilidade. 2008. 180 f. Dissertação (Mestrado em Ciência da Informação) - Escola de Comunicação e Artes, Universidade de São Paulo, São Paulo, 2008.

SASSAKI, Romeu K. Nada sobre nós, sem nós: Da integração à inclusão - Parte 1. In. Revista Nacional de Reabilitação, ano X, n. 57, jul./ago. 2007, p. 8-16.

Nada sobre nós, sem nós: Da integração à inclusão - Parte 2. In. Revista Nacional de Reabilitação, ano X, n. 58, set./out. 2007, p.20-30.

SECRETARIA [ESTADUAL] DE CULTURA. CONDEPHAAT. Listagem de bens tombados. Disponível em: <http://www.cultura.sp.gov.br>. Acesso em: 10 de jul. 2009.

SECRETARIA MUNICIPAL DE CULTURA. CONPRESP. Resoluções. Disponível em:

<http://www.prefeitura.sp.gov.br/cidade/secretarias/cultura/conpresp/legislacao/resolu coes/index.php?p=1137>. Acesso em: 10 de jul. 2009.

SECRETARIA não dá acesso a deficientes. Folha de S. Paulo, São Paulo, 13 maio 1997. Caderno $3, \quad$ p. $6 . \quad$ Disponível em: <http://acervo.folha.com.br/fsp/1997/05/13/264/285410>. Acesso em: 18 set. 2011.

SECRETÁRIOS visitam o Municipal e anunciam mudança no orçamento. Folha de S. Paulo, São Paulo, 11 fev. 1988. Caderno llustrada, p. A38. Disponível em: <http://acervo.folha.com.br/fsp/1988/02/11/21/4111595>. Acesso em: 24 set. 2011.

SEGAWA, Hugo. A atividade bancária e sua arquitetura. Revista Projeto, São Paulo, n. 67, p. 50-54, set. 1984.

SEMINÁRIO INTERNACIONAL - NUTAU (1996: São Paulo). Insumos metodológicos para aplicação da avaliação pós-ocupação (APO) do ambiente construído, com ênfase em populações específicas como idosos e os 
deficientes físicos e nos aspectos da arquitetura e do desenho urbano relacionados à segurança contra crimes. São Paulo, NUTAU/USP, 1996.

SERRA, Geraldo G. Pesquisa em Arquitetura Urbanismo: guia prático para o trabalho de pesquisadores em pós-graduação. São Paulo, Edusp, Mandarim, 2006.

SILVA, O. M. A Epopéia Ignorada: A Pessoa Deficiente na História do Mundo de Ontem e de Hoje. São Paulo: CEDAS, 1986. 470 p.

TEATRO municipal do Rio é reinaugurado nesta quinta. Portal R7, [S.I.], 27 maio 2010. Disponível em: <http://noticias.r7.com/cidades/noticias/theatro-municipal-dorio-e-reinaugurado-nesta-quinta-20100527.html>. Acesso em: 29 set. 2011.

TEHZY, S. K. SIMPLESMENTE IGREJA: um olhar sobre inclusão de pessoas com deficiência em busca de contribuições para uma práxis comunitária inclusiva. São Leopoldo, 2008. Dissertação (Mestrado em Teologia) - Escola Superior de Teologia, de São Leopoldo, RS, 2008.

THE CITY OF CALGARY. Universal Design Handbook: Building Accessible and Inclusive Environments. Calgary, [s.n.], 2010. Disponível em: <http://calgary.ca/cns>. Acesso em: 02 de jul. de 2010.

TOJAL, Amanda Pinto da Fonseca. Políticas públicas culturais de inclusão de públicos especiais em museus. 2007. 322 f. Tese (Doutorado em Ciência da Informação) - Escola de Comunicação e Artes, Universidade São Paulo, São Paulo, 2007.

TOLEDO, Benedito Lima de. Álbum iconográfico da Avenida Paulista. São Paulo: Editora Ex Libris: João Fortes Engenharia, 1987. p. 162-165.

UBIERNA, José Antonio Juncà. Accesibilidad universal al patrimônio cultural: Fundamentos, critérios y pautas. Madrid: Centro Español de Documentación sobre Discapacidad, 2011. $145 \mathrm{p}$. 
UNESCO. Convenção para a proteção do património mundial, cultural e natural. Conferência Geral da Organização das Nações Unidas para Educação, a Ciência e a Cultura, reunida em Paris, de 17 de outubro a 21 de novembro de 1972. Disponível em: <http://unesdoc.unesco.org/images/0013/001333/133369por.pdf>. Acesso em: 11 de jul. de 2008.

UNIVERSIDADE DE SÃO PAULO. Sistema Integrado de Bibliotecas. Grupo DiTeses. Diretrizes para apresentação de dissertações e teses da USP. São Paulo: SIBi-USP, 2004. 110 p.

VESPUCCI, A.C.; CICCACIO, A. M. Portas abertas. Revista Urbs, São Paulo, v.4, n.21, p.50-53, abr./maio, 2001.

VIOLLET-LE-DUC, Eugène Emmanuel. Restauração. Tradução Beatriz Mugayar Kühl. 3ª ed. Cotia: Ateliê Editorial, 2007. 76 p.

ZEISEL, J. Focused Interviews. In. Inquiry by design: tools for environment-behavior research. USA: Cambridge University Press, 1997. p. 137156. 